States at Work 


\section{Africa-Europe Group for Interdisciplinary Studies}

Series Editors

Gregor Dobler, University of Freiburg, Germany Elísio Macamo, Basel University, Switzerland

\section{Editorial Board}

William Beinart, University of Oxford, UK Filip De Boeck, Catholic University Leuven, Belgium Patrick Chabal, King's College London, UK Paul Nugent, Edinburgh University, UK Nic van de Walle, Cornell University, Ithaca, USA

VOLUME 12

The titles published in this series are listed at brill.com/agis 


\title{
States at Work
}

\section{Dynamics of African Bureaucracies}

\author{
Edited by \\ Thomas Bierschenk \\ Jean-Pierre Olivier de Sardan
}

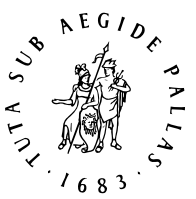

B R I L L

2014 
This is an open access title distributed under the terms of the CC BY-NC 4.0 license, which permits any non-commercial use, distribution, and reproduction in any medium, provided the original author(s) and source are credited. Further information and the complete license text can be found at https://creativecommons.org/licenses/ by-nc/4.0/

The terms of the Cc license apply only to the original material. The use of material from other sources (indicated by a reference) such as diagrams, illustrations, photos and text samples may require further permission from the respective copyright holder.

An electronic version of this book is freely available, thanks to the support of libraries working with Knowledge Unlatched. More information about the initiative can be found at www .knowledgeunlatched.org.

Cover illustration: City Hall offices, Lubumbashi, DR Congo, 2007 @Guy Tillim. Courtesy of Stevenson, Cape Town and Johannesburg.

Library of Congress Cataloging-in-Publication Data

States at work : dynamics of African bureaucracies / edited by Thomas Bierschenk, Jean-Pierre Olivier de Sardan.

pages $\mathrm{cm}$. - (Africa-Europe Group for Interdisciplinary Studies ; volume 12)

Includes index.

ISBN 978-90-04-26478-6 (pbk. : alk. paper) — ISBN 978-9o-04-26496-o (e-book) 1. Public administration-Africa. 2. Bureaucracy-Africa. 3. Africa-Politics and government-19604. Africa-Economic policy. 5. Economic development-Africa. 6. State, The. I. Bierschenk, Thomas. II. Olivier de Sardan, Jean-Pierre. III. Series: African-Europe Group for Interdisciplinary Studies (Series) ; v. 12.

$$
\begin{aligned}
& \text { JQ1875.S } 732014 \\
& \text { 351.6-dc23 }
\end{aligned}
$$

2013046380

This publication has been typeset in the multilingual "Brill" typeface. With over 5,100 characters covering Latin, IPA, Greek, and Cyrillic, this typeface is especially suitable for use in the humanities. For more information, please see www.brill.com/brill-typeface.

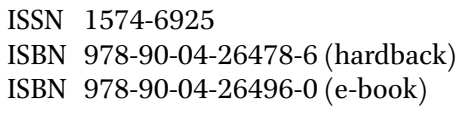

Copyright 2014 by the Authors. Published by Koninklijke Brill NV, Leiden, The Netherlands. Koninklijke Brill NV incorporates the imprints Brill, Brill Nijhoff, Global Oriental and Hotei Publishing.

All rights reserved. No part of this publication may be reproduced, translated, stored in a retrieval system, or transmitted in any form or by any means, electronic, mechanical, photocopying, recording or otherwise, without prior written permission from the publisher.

Authorization to photocopy items for internal or personal use is granted by Koninklijke Brill NV provided that the appropriate fees are paid directly to The Copyright Clearance Center, 222 Rosewood Drive, Suite 910, Danvers, MA 01923, USA.

Fees are subject to change.

This book is printed on acid-free paper. 


\section{CONTENTS}

What others say about States at Work ...................................................... viii

Acknowledgements .................................................................................. ix

About the Authors …............................................................................ xi

\section{PART ONE}

AFRICAN BUREAUCRACIES IN COMPARATIVE PERSPECTIVE

Studying the Dynamics of African Bureaucracies. An Introduction to States at Work

Thomas Bierschenk and Jean-Pierre Olivier de Sardan

Ethnographies of Public Services in Africa: An Emerging Research

Paradigm

Thomas Bierschenk and Jean-Pierre Olivier de Sardan

PART TWO

\section{BUREAUCRATS AT WORK}

Seeing like a State Agent: The Ethnography of Reform in Senegal's Forestry Services

Giorgio Blundo

Factionalism and Staff Success in a Nigerian University:

A Departmental Case Study

Chris Willott

Working in Neopatrimonial Settings: Public Sector Staff

Perceptions in Tanzania and Uganda

Ole Therkildsen

"We make do and keep going!" Inventive Practices and Ordered Informality in the Functioning of the District Courts in Niamey and Zinder (Niger) 
"I take an oath to the state, not the government":

Career Trajectories and Professional Ethics of Ghanaian Public Servants

Carola Lentz

"We must run while others walk": African Civil Servants, State Ideologies and Bureaucratic Practices in Tanzania, from the 1950 os to the 1970 s 205 Andreas Eckert

Sedimentation, Fragmentation and Normative Double-Binds in (West) African Public Services 221 Thomas Bierschenk

PART THREE

\section{BUREAUCRACIES AT WORK}

The Politics of Reform: A Case Study of Bureaucracy at the Ministry of Basic Education in Cameroon Hélène Charton

Building State Capacities? The Case of the Poverty Reduction Unit in Mali Isaline Bergamaschi

A Breeding Ground for Revenue Reliability? Cameroonian Veterinary Agents and Tax Officials in the Face of Reform 301 José-María Muñoz

Old-school Bureaucrats and Technocrats in Malawi: Civil Service Reform in Practice Gerhard Anders

Teachers' Unions and the Selective Appropriation of Public Service Reforms in Benin 
The State that Works: A 'Pockets of Effectiveness' Perspective on Nigeria and Beyond

Michael Roll

The Delivery State in Africa. Interface Bureaucrats, Professional Cultures and the Bureaucratic Mode of Governance 399 Jean-Pierre Olivier de Sardan 


\section{WHAT OTHERS SAY ABOUT STATES AT WORK}

This is a major breakthrough in scholarly understandings of the African state. Masterly analytic chapters by the two editors unravel the complex interactions of norms and institutions that shape how the bureaucracies that constitute states in Africa in fact deliver (or don't) goods and services. They thus manage simultaneously to trace out some specifically African patters of state functioning, while demystifying and brilliantly undercutting essentialist arguments about African "culture" or "tradition." The whole is enriched with a number of specific case studies, drawing broadly across countries and public services. The strong case made by the editors, and illustrated by the case studies, of the importance of empirical ethnographic approaches to understanding the state in its complex realities is a methodological lesson that should be taught in graduate programs not only in anthropology, but in political science and related disciplines.

Leonardo A. Villalón, Professor of Political science and African Studies, University of Florida

This is an exemplary collection in the best tradition of ethnographic inquiry: theoretically astute, empirically rich, and capable of challenging pre-conceptions. It makes outstanding use of the comparative method to de-exoticize African bureaucrats and bureaucracies, while tracing the elements that have formed them. Recommended for readers interested in understanding states-in-practice in any corner of the globe, and especially important for experts bearing blueprints for state reform.

Tania Murray Li, Professor of Anthropology, University of Toronto

While African states have attracted all kinds of labels over the last fifteen years, little scholarly attention has been paid to the actual working of African state agencies. This fresh and theoretically informed contribution, based on close empirical inspection, is a landmark behind which the discourse on the state in Africa should not fall back again.

Klaus Schlichte, Professor of Political Science at the University of Bremen

This book constitutes a landmark in its efforts to rescue African states and public bureaucracies from a tendency to homogenize, pathologize and, above all, generalize on the basis of limited evidence. It squarely addresses larger theoretical questions about bureaucracies in general, as well as the contribution anthropology can make to our understanding of actual states in Africa. The critique of some current academic fashions is provocative and will spark a debate. The plea for more empiricallygrounded reflections about how officials negotiate formal rules, and how bureaucracies are affected by donor-driven civil service reform, is taken up in the main body of the book. It represents a weighty contribution to a strangely neglected topic.

Paul Nugent, Professor of Comparative African History, Director of the Centre of African Studies, University of Edinburgh 


\section{ACKNOWLEDGEMENTS}

The editors thank the Volkswagen Foundation for the financial support to the States at Work 2005-2013 project (www.ifeas.uni-mainz.de/91 .php), under its funding initiative 'Knowledge for tomorrow. Cooperative research projects in Sub-Saharan Africa'.

We are grateful to the Johannes-Gutenberg-Universität at Mainz, Germany, which made the preparation of this book possible through its budgetary support, and to LASDEL, Niamey, Niger, which hosted the final conference of the States at Work project in 2009.

Special mention should be made of Mahaman Tidjani Alou, then director of LASDEL, who has co-directed the project and edited the proceedings of this conference.

We would also like to extend our thanks to Sarah Fichtner, who was in charge of the administrative coordination of the project, a task that transformed her into a specialist in intercultural accounting, and to our long-time copy-editor Susan Cox, who has again been very competent in rendering over-complex French-German writing habits into, we hope, intelligible English. She copy-edited several chapters of this book and translated Chabi Imorou's and Hamani's chapters from the French. Amanda Hammar was a competent resource in some tricky style questions. Our thanks also go to Elena Hofferberth and Alessa Wilhelm who corrected several versions of the book manuscript and assisted with the formatting. 
Thomas Bierschenk and Jean-Pierre Olivier de Sardan - 978-90-04-26496-0 Downloaded from Brill.com@4/26/2023 02:08:21PM via free access 


\section{ABOUT THE AUTHORS}

Gerhard Anders ( $\mathrm{PhD}$ 2005) is a lecturer at the Centre of African Studies, University of Edinburgh, United Kingdom. His research focuses on the anthropology of emergent regimes of global order in the fields of criminal justice and development. He has published on legal anthropology, international criminal justice, good governance and corruption, including the co-edited volume (with M. Nuijten) Corruption and the Secret of Law (Ashgate, 2009) and the monograph In the Shadow of Good Governance: An Ethnography of Civil Service Reform in Africa (Brill, 2010).

Isaline Bergamaschi (PhD, Institut d'Études Politiques de Paris, 2011) is an assistant professor at the Department of Political Science at the Universidad de los Andes, Bogotá (Colombia) since 2012. Her main research interests lie in the sociology and political economy of international development and cooperation. Her doctoral thesis focused on the case of Mali, her current research project is on the Organisation for Economic Cooperation and Development's Development Assistance Committee (OECD/ DAC). For more details, see: http://c-politica.uniandes.edu.co/cv.php/162/ index.php.

Thomas Bierschenk is professor of anthropology and modern African studies at the Johannes Gutenberg University of Mainz, Germany. His research focuses on politics, the state and development in West and Central Africa. His most recent English-language publications include: 50 Years of Independence in Africa, Africa Spectrum 45 (3) (2010), Hamburg: GIGA (ed. with Eva Spies); Democratisation without development: Benin 1989-20o9, International Journal of Politics, Culture, and Society 22 (3) (2009): 337-357; and The every-day functioning of an African public service: Informalization, privatization and corruption in Benin's legal system, Journal of Legal Pluralism and Unofficial Law 57 (2008): 101-139. For more details, see http:// www.ifeas.uni-mainz.de/171.php.

Giorgio Blundo is professor (directeur d'études) of social and political anthropology at the École des Hautes Études en Sciences Sociales (EHESS) in Marseilles. A former president of the Euro-African Association for the Anthropology of Social Change and Development (APAD), he 
has conducted research in West Africa studying local powers, factionalism, the state and corruption. He co-authored with J.-P. Olivier de Sardan, Everyday Corruption and the State: Citizens and Public Officials in Africa (Zed Books, 2006), and, edited with P.-Y. Le Meur, The Governance of Daily Life in Africa: Ethnographic Explorations of Public and Collective Services (Brill, 2009). He is currently carrying out two research projects in the perspective of an anthropology of public services delivery and governance: the ethnography of forest services in Niger and Senegal, and the study of the transnational brokers of good governance policies in Senegal.

Azizou Chabi Imorou (Dr. phil., Gutenberg University Mainz, 2009) is a researcher at the Laboratory for Research on Social Dynamics and Local Development (LASDEL, Benin, www.lasdel.net) and lecturer at the University of Parakou in Benin. He is interested in topics such as public policy, African public services, governance, local elections, and African parliaments.

Hélène Charton is a full time researcher currently at the Centre National de la Recherche Scientifique (CNRS, France), working for the research unit LAM (Les Afriques dans le monde) at the University of Bordeaux (France). Her research deals with international education policies in Africa, from a historical and public policy perspective.

Andreas Eckert is professor of African history at Humboldt University, Berlin. His research and writing focuses on the history of Africa in the 19th and 2oth centuries, the history of colonialism, and the history of global labour. He is the author of numerous books and articles, between 2005 and 2011 he served as editor of the Journal of African History (published by Cambridge University Press) and he is currently working on a general history of Africa since 1850. Since October 2009, he has been director of the International Research Institute on Work and Human Life Cycle in Global History, funded by the German Federal Ministry of Science and Research. He is also chairman of the German Association of Social Historians. For more details see: http://www.asaf.hu-berlin.de/afrika/geschichte/ mitarbeiter $/ 1681578$.

Oumarou Hamani (doctorate, École des Hautes Etudes en Sciences Sociales/EHESS, 2011) is an anthropologist and researcher at the Laboratory for Research on Social Dynamics and Local Development (LASDEL) 
in Niamey, Niger. His research interests focus on the delivery of public services and on elections, the legal professions, decentralization and migration. He is a founding member of the network of young researchers working on Africa (Nyra).

Carola Lentz is professor of social anthropology at the Department of Anthropology and African Studies of Johannes Gutenberg University, Mainz, Germany. Since 1987, she has been conducting research on labour migration, ethnicity, the history of chieftaincy, land rights and the politics of belonging in Northern Ghana and Burkina Faso. Her current research project explores the changing career strategies and home ties of the members of an emerging middle class in Northern Ghana. She also supervises a group of junior researchers who have been studying the 2010 African independence celebrations in nine different countries. She is author of Ethnicity and the Making of History in Northern Ghana (Edinburgh University Press, 2006), Land, Mobility and Belonging in West Africa (Indiana University Press, 2013) as well as other monographs and numerous journal publications, and she has edited, inter alia, Land and the Politics of Belonging in West Africa (Brill, 2006). She has been President of the German Anthropological Association since autumn 2011.

José-María Muñoz is lecturer in international development at the University of Edinburgh's Centre of African Studies. From 2010 to 2012, he held a postdoctoral fellowship with Emory University's Program in Development Studies. He has conducted extensive fieldwork in Cameroon on topics ranging from cross-border trade, repertoires of finance, rural livelihoods, and Muslim identities to non-governmental organizations, corporate social responsibility, public contracts, and taxation. He has published articles in the African Studies Review, the Law \& Society Review, and Politique Africaine.

Jean-Pierre Olivier de Sardan lives and works in Niger, and is among the founders of LASDEL, Laboratory for Research on Social Dynamics and Local Development, in Niamey (www.lasdel.net). He is also professor of anthropology at the Ecole des Hautes Etudes en Sciences Sociales in Marseilles and emeritus director of research at the Centre National de la Recherche Scientifique (CNRS, France). Since 1965, he has authored numerous articles and books, including: Les sociétés songhay-zarma (Niger, Mali) (Karthala, 1984) Karthala, 1984; Les pouvoirs au village: le Bénin rural entre 
démocratisation et décentralisation (edited with T. Bierschenk) (Karthala, 1998) Karthala, 1998; Courtiers en développement. Les villages africains en quête de projets (edited with T. Bierschenk et J.P. Chauveau) (Karthala, 200o) Karthala, 2000; Anthropology and Development (Zed Books, 2005) Zed Books, 2005 and, with G. Blundo, Everyday Corruption and the State. Citizens and Public Officials in Africa (Zed Books, 20o6) Zed Books, 2006. His last book (La rigueur du qualitatif. Les contraintes empiriques de l'interprétation socio-anthropologique, Louvain-La-Neuve, AcademiaBruylant, 2008, to be translated into English) deals with methodological and epistemological issues, concerning the policy of fieldwork and the empirical constraints of anthropological interpretations.

Michael Roll is a PhD student and university fellow in the Department of Sociology at the University of Wisconsin-Madison. Before returning to university he worked for the Friedrich-Ebert-Stiftung (FES) for seven years. He was their resident representative in Nigeria until 2009. Michael holds degrees in social anthropology and sociology from Stellenbosch University and Bielefeld University, respectively. His research interests include comparative sociology and politics, development, institutional transformation and democratisation. He is the editor of the forthcoming book The Politics of Public Sector Performance: 'Pockets of Effectiveness' in Developing Countries (Routledge).

Ole Therkildsen is a senior researcher at the Danish Institute for International Studies, Copenhagen. His research is mainly on East and Southern Africa where he has worked on and off as an advisor, consultant and researcher since 1980 . He has published on public sector reforms, service provision, taxation, and the political economy of production.

Chris Willott is senior teaching fellow in global health at University College, London. His research analyses the functioning of the contemporary Nigerian state, in particular its higher education system. 
PART ONE

AFRICAN BUREAUCRACIES IN COMPARATIVE PERSPECTIVE 
Thomas Bierschenk and Jean-Pierre Olivier de Sardan - 978-90-04-26496-0 Downloaded from Brill.com@4/26/2023 02:08:21PM via free access 


\title{
STUDYING THE DYNAMICS OF AFRICAN BUREAUCRACIES. AN INTRODUCTION TO STATES AT WORK
}

\author{
Thomas Bierschenk and Jean-Pierre Olivier de Sardan
}

\section{State Theories and Empirical Research on Statehood ${ }^{1}$}

This book aims to contribute to the academic debates on processes of state-building in Africa and, among development practitioners, on the role of the state in development, by underpinning these debates with a much firmer empirical grounding than is often the case in the existing literature. It analyses the 'real' workings of states and public bureaucracies in different African countries. A second, related objective is to define the public services of the Global South, and in particular Africa, as a legitimate and productive object of anthropological enquiry. We argue that an anthropological contribution to the study of the state needs to be based on the discipline's defining strength, i.e. ethnography, on a recognition that African states, like other states, are made up of bureaucracies and public employees, and that their basic, banal, routinized day-to-day functioning, practices and strategies warrant the interest of anthropologists as much as warlords, smugglers and witchdoctors. A third objective is to develop a more intensive dialogue in the context of the study of the state between anthropology and other disciplines, and show that anthropologists, in particular, need to engage the sociology of organization and bureaucracy in the North, while the latter would profit from taking the results of the ethnographies of states in the Global South into account.

${ }^{1}$ We would like to thank all members of the States at Work project (see below) and the participants of the various panels organized by the project in Leiden in 2007, Leipzig in 2009, Niamey in 2009 and Uppsala in 2011 for many fruitful discussions. We also thank the authors of this book, and, in particular, Gerhard Anders, Isaline Bergamaschi, Hélène Charton, Carola Lentz, Ole Therkildsen and Chris Willott for their many comments on previous version of this introduction and the second chapter. The same thanks go to Jan Beek, Nora Brandecker, Gregor Dobler, Julia Eckert, Amanda Hammar, Mirco Göpfert, Nikolaus Schareika and Klaus Schlichte. It goes without saying that we are responsible for the remaining deficiencies of these two texts. 
Despite the abundant academic literature on African states, little empirical attention has been devoted to actual 'state apparatuses' (in the sense of Althusser 1970/1976). ${ }^{2}$ Recent anthropological investigations of the state describe how the 'idea' of the state spreads in the social fabric or explore the state's margins or interstices. As for political science, it is rich in studies that highlight the dysfunctions of African public services, but mainly emphasizes deviations from the official norms inspired by Western bureaucratic models. These deviations are frequently explained in terms of concepts such as clientelism and neopatrimonialism, and often with a culturalist bent (this is further developed in the next chapter). ${ }^{3}$

Breaking with these approaches, this book focuses on the daily functioning of state services: how public servants spend their time, how teachers are being trained and socialized into their jobs, how judges, policemen and teachers define their role in society, how they see their future and how they negotiate all of the conflicting demands made of them, by their clients, their relatives and superiors and the outside agencies that have increasingly defined a role for themselves in disciplining African public servants according to their own norms. Our book shares this focus with a number of studies that have been published over the past decade. Indeed, although African states and bureaucracies were a long-neglected field of research, despite some programmatic calls for more research, various empirical studies have been undertaken on this subject in recent years, many of which adopt the same perspective as the authors of this book (see Bierschenk and Olivier de Sardan, chapter Research paradigm, in this volume).

In this book, we explore the mundane practices of state-making from three key, inter-related points of entry: first, the ethnography of public servants (bureaucratic cultures and practical norms, operational routines in offices, career patterns and modes of appointment etc.); second, the delivery of public services and goods (how bureaucrats themselves perceive and deliver the goods and services for which their departments have responsibility and how they construct their everyday relationships with service users); and third, the accumulation of public administration

2 Althusser, however, was only interested in these apparatuses in terms of their domination and legitimation functions, and did not adopt an empirical and ethnographic perspective.

3 This and the following paragraph are inspired by the call for papers for a thematic workshop at the European Conference for African Studies at Uppsala in 2011 which was organized by the two authors and Giorgio Blundo. 
reforms (how the different bureaucratic corps react to the 'good governance' discourse and new public management policies; the consequences of these reforms for the daily working of state bureaucracies and for the civil servants' identities and modes of accountability; the space that exists for bottom-up micro-reforms that build on local innovations or informal arrangements).

Throughout the book, we adopt a broad definition of public service that covers the totality of public sector employment, e.g. persons employed by state administrations or state agencies to provide a public service. In our definition, the public service not only includes the civil service in the narrower sense of the term (e.g. employees of central administrations) but also public services like teaching, the police, healthcare professionals etc., and, moreover, independently of the institutional arrangements under which they are employed (e.g. tenure vs. contract). ${ }^{4}$

\section{States at Work: Two Meanings of a Metaphor}

This book addresses the question of what states do when they are working. The use of the metaphor 'work' has two dimensions that require explanation. In using this term, we originally wanted to highlight the always incomplete nature of state formation processes and the 'cobbled together' (bricolé or gebastelt) nature of 'state', that is its heterogeneity. This idea translates metaphorically into English as 'states at work', through a play on the familiar 'men at work' signs used on roads in many Anglophone countries.

The metaphor refers to a building site, but a particular type, one that is more often found in Africa than, say, in Germany or France. Any observer will know that in many places in Africa, construction sites in particular for private homes may exist for many years. To the untrained eye, they may even look like abandoned sites. However, closer inspection usually reveals that there are, in fact, people on the site. The initial temptation is to assume that they are squatters, however, in most cases, they are the owners. And suddenly, out of the blue, a truck arrives with sand and cement, a room is added to the half-finished building, a wall goes up, or make-shift

4 The 'public service' vs. 'civil service' definition problem is discussed in Evans (2008: 33f.). Public services in the modern sense were established in Prussia and France in the 18th century, and in France they were the basis for Napoleonic reforms that transformed the royal service into the civil service. The term 'civil service' itself was first used in BritishIndia (Osborne 1994). The United States' law on civil service examinations was passed in 1883 , however, it did not cover 90 per cent of all federal public servants until 1990 (Raadschelders and Rutgers 1996). 
windows are replaced with glass ones. Of course, these particular trajectories of African building sites have to do with two hard economic facts of many African economies: there are very few investment opportunities outside construction, and the banking and credit sector works very badly. So people have to wait until they get their hands on some money before they start building, and then they have to wait again until they can set a little money aside before they continue construction. And while the years go by, the family grows, relatives move in, some parts of the building have to be rented out and the original plan for the building does not make sense any more. Hence, a room is added here, a toilet there; what was planned as a guest room is turned into a dressmaker's shop; many rooms are left unpainted for the time being; and what was once planned as a bungalow becomes a three-storey house. And, again, more often than not, the first floor might be already inhabited while the second awaits finishing and the third barely has half of its walls. So the house is very different to the way it was originally conceived and looks like an unfinished, apparently perpetual building site where construction, repair, abandonment and re-purposing proceed simultaneously, with the inhabitants not always agreeing on what to use the building for, the different parts of the site apparently having had completely different architects, some from the inhabitants of the site, some from outside the site; and these different architects often disagree both with each other and with (some of) the inhabitants about what the buildings should be used for and how it should be used.

This metaphor helps us to think the state as a site of contention, not only between competing actors and competing organizations, but also between competing normative ideas. Max Weber's ideal type of bureaucracy (see below) functions as one, but only one of these blueprints; another one was recently proposed by the New Public Management school (see below). These masterplans come in different variants and forms; they not only compete with, but also inform each other. The metaphor has the advantage that it helps us to see that there are not just actors, practices, processes and negotiation, but there are also structures, institutions and materiality. Once a part of the building has been erected, it stands there; it can, of course, be put to a different use to that intended by the builder, however its particular shape favours certain uses and creates disadvantages - costs - for others. And if it is decided to tear it down because the owner's plans have changed, that requires efforts and resources-all of which promotes routines, compromises, make-shift solutions and bricolage.

Thus, the metaphor of states and public services as the construction sites of overlapping projects led by different actors refers to both the incompleteness of state-building processes and the heterogeneity and (always) improvised nature of statehood. We proceed from the premise that the 
processes of state formation in Africa were not completed once and for all with the establishment of the colonial states, with the achievement of the independence of these countries, or with the recent emergence of democratic regimes. If one considers, from a Weberian perspective, the institutionalization of (a monopoly of) violence, the local anchoring of central power and the self-limitation of the rulers qua codification of the law as the core of the development of the modern Western-type state, state-building processes are never-ending. However, this characteristic does not set contemporary African states apart from others: incompletion, fragility and reversibility are universal features of state- building processes. Statehood in Europe has in fact been described as a building site (Tzermias 2011). ${ }^{5}$ Hence, we only wish to point out a relative difference of stateness between Africa and Europe, inasmuch as the building-site character of the state in many African examples is particularly striking. The state is a vanishing point of macro-historical processes everywherea vanishing point that by its very nature is never attained and processes that can always be deflected and (at least partly) reversed.

There is also a second dimension to the work metaphor, which is inspired by the 19th century German sociologist and social historian Lorenz von Stein. To explain this, a short review of the history of European thinking on the state is in order. In contemporary debates on states in Africa, it is frequently forgotten that even the most general theories of the state arose in specific local and historical contexts. ${ }^{6}$ These general theories, which emerge from particular historical conditions, have created different traditions of thinking about the state which, in turn, colour the general attitudes and empirical approaches of present-day social scientists to states and statehood. For even when doing purely empirical work on the state, researchers write from a particular philosophical position. In this sense, their writing is localized. In fact, to extend an idea presented in Fardon (1990), their writing is doubly localized: by the position from which they write, and by the empirical data on which they write. We argue that the current debates on statehood in Africa also need to be

5 The metaphor of a 'building site' has been variously used for describing a political, social, cultural or intellectual project and its often incomplete and incoherent implementation. In contemporary African studies, it has been deployed by Leimdorfer and Marie (2003) to refer to urban civil societies 'in the making'.

6 Forgotten, for example by Sharma and Gupta (2006). Their chapter on 'theoretical genealogies' contains texts by Weber, Foucault, Gramsci and others which are entirely stripped of historical references and information about the production conditions of the texts presented and the specific analytical interests of their authors. Cf. Bierschenk (2009). 
read against the background of these very different philosophical positions from which authors write, and that it is better to make one's position clear. Our own perspective is localized in an empirical tradition (à la von Stein) and focuses on actors' practices, it is informed by a typological perspective (à la Weber), and it assumes a non-normative position towards the state as an institution with potentialities for development, the defense of civil freedoms and the weak against the poor, social promotion and service delivery, as well as for repression, clientelism and bureaucratic mismanagement.

\section{The Historical Contexts of Theories of the State}

Modern Western political theory was built on the concept of the state: the state was viewed by European political philosophers as a necessary solution for creating order in modern societies (Bartelson 2001). However, Western state philosophy is not a unified and homogeneous body of thinking. Two major traditions may be distinguished (Waldmann 2005): marked by the experience of the English Civil War, philosophers like Hobbes and Locke saw the state as an institution that was necessary to protect the citizens against internal discord and armed conflict. In this function, it was no more than an unavoidable phenomenon, a necessary evil. This corresponds to a particular 'genetic constellation' of state, civil society and the rule of law, by which the state faces barriers to its actions that are erected by the citizens and that it cannot ignore at will. Wolfgang Reinhard (2005) has termed this as "states-before-the-law" (Staaten vor dem Recht). Through the American Revolution, this tradition of consensus and voluntary association against the state gained global importance. In recent debates on the state in Africa, both the mistrust of the international finance institutions towards the state as expressed in the so-called Washington Consensus as well as James Scott's (1998) fundamental critique of the state need to be read as a reflection of this particular, American, philosophical tradition. In fact, it is in the fundamental mistrust of the state that very opposed ideological positions like neo-liberalism and erudite anarchism à la Scott find common ground. These approaches generalize a specific US-American historical experience of a weak state, which often fails at the imposition of justice: in the American experience, justice is, more often than not, created by private actors in the absence of a state (Gumpert 2010: 162-173).

The historical experience of the continental powers of France, Prussia/ Germany and Spain was different: strong absolutist regimes developed 
here that ruled through authoritarian laws. Only at a later moment in history, when states had firmly established the monopolies of violence and taxation, did they concede rights to civil society, which they controlled and disciplined. This gradually led to a self-binding of the state by the rule of law, including, in particular, the banning of state arbitrariness. This may be termed "states-in-law" (Staaten im Recht).

Consequently, continental European philosophers had a much more positive image of the state than their Anglo-Saxon counterparts. This is most striking in the case of Hegel (1821/1972) who saw in the state, and especially in its Prussian variant, the contradictions of modern societies harmoniously resolved (aufgehoben). For him, the state-as 'concrete reality' -is reasonable (vernünftig) per se. Against the historical background of the Prussian bureaucracy, Hegel also recognized the importance of loyal civil servants for the state. However, in line with his anthropomorphisizing view of history-the state was for him conceivable only as embodied in one person-, he was more interested in public servants and their value orientations as members of the 'general estate' (allgemeiner Stand, which for him also included teachers, doctors and lawyers) than in the organization of public services as such. The latter were of no particular philosophical interest to him. ${ }^{7}$

In other words, the representations of the state proposed by philosophers and social scientists are always rooted to a greater or lesser extent in a particular context that constitutes a kind of latent reference point. This reference point may be constructed on the basis of second-order analysis of empirical studies, but it is also not infrequently based on implicit experience, common-sense knowledge and largely shared stereotypes which are characteristic of a specific space-time and act as an 'infrastructure' for the theories of state (for an example, see Hegel's [1840/1986: 152-163] highly stereotyped and negative image of Africa).

The Hegelian state-fixated and totalizing idealism, however, did not remain unchallenged, not even in Germany. It was Lorenz von Stein

7 Hegel's appreciation of the Prussian bureaucracy should not be misinterpreted as condoning the absolutist tendencies of the Prussian state of his time, of which he was quite critical. Cf. Avineri (1972). While Hegel could be seen as the theoretician of the continental European, and more particularly Prussian, pathway to modern statehood, it should not be overlooked that some parts of continental Europa were sites of alternative trajectories, which resembled the Anglo-Saxon model more, e.g. Switzerland and, to a certain extent, the Netherlands (Kappel, Tobler and Waldmann 2005). 
$(1943)^{8}$ who observed that Hegel's notion of the state was limited to symbolic acts-like a coronation ceremony-in which state actors expressed an authoritative idea of the state, or to government decrees in which (to adopt modern terminology) a policy was formulated. However, these state acts (von Stein calls them "deeds") only become effective if they are implemented, for which von Stein used the term "work". This work of the state is done by the public service (in von Stein's terminology: the administration). In other words, in contradiction of Hegel's idealistic theory of state, von Stein pleaded for an empirical study of the public service, as it is the public service- the state "at work" (der arbeitende Staat) - in its empirically existing form that is the real power centre of the state. ${ }^{9}$

\section{Max Weber and the Ideal-Type of Bureaucracy}

Von Stein's focus on the real state is not only a critique of Hegel, but also an anticipated, and very necessary, complement to the ideal type of the bureaucracy which Max Weber (1921/1972, cf. Treiber 2007) presented decades later. In a way, Weber rather shared Hegel's admiration for the technical efficiency of 'bureaucratic rule'. In his ideal type-which was also inspired by Prussia where this ideal type form appeared for him in the 'purest' form - the bureaucracy presents as a well-functioning, effective machinery of domination.

For Weber, bureaucratic rule appeared in its purest form in Western Europe and in particular in Prussia, and in the guise of public bureaucracies. However, bureaucracies are also found outside administration in the narrow sense of the term, for example in the military and universities. They also exist outside the state in large-scale capitalist enterprises, the churches and in political parties. Measured against the ideal type, historical and contemporary 'real' types can be identified. Historically, proto-forms of bureaucracy existed, for example, in Egypt (where the New Kingdom is "the historical model of all later bureaucracies", p. 54), the Roman Principate of the Roman Catholic Church, and Classical China. These proto-forms were always threatened by mediating tendencies, e.g. the tendency for officials to either have direct recourse to tributaries or for the ruler to transfer the power to tax

8 This short work is a collection of von Stein's central arguments which were first published in his eight volumes of 'Verwaltungslehre' (first edition 1865) and then condensed from 1870 in his three-volume 'Handbook of Public Administration'.

9 Although his writings were more programmatic than empirical, von Stein is considered today as one of the founders of empirical policy studies (Staats- und Verwaltungswissenschaften). He did not really undertake empirical research on the state in the proper sense himself (Seibel 2008; cf. also Derlien 2008). 
to individuals with the resulting phenomenon of the purchase of office. A developed bureaucracy can always regress to these forms of prebendal and feudal administration (p. 54f.).

Weber was particularly interested in the comparison of these protobureaucracies (of the "traditional" or "patrimonial" type) with modern bureaucracy. Much of his reflection on the forms of domination or legitimacy concerned not so much the relationship between political authorities (kings, lords, despots, democratic governments) with their populations but rather the relationship of the former with their administrative bodies. Of particular interest to him were those factors which, in different historical contexts, might explain the obedience of these administrative bodies to the political authorities (cf. Bruhns 2011).

But he was also interested in contemporary variants of bureaucratic rules which diverge from the ideal type, like those constituted by the USAmerican principle of the election of public officials. In other words, 'real' bureaucracy, according to Weber, can develop along specific trajectories which cannot be predicted from the ideal-type.

Furthermore, the 'chance for the existence' of bureaucracies is predicated on a series of social conditions. In the case of modern bureaucracy (Weber 1921/1972: 54ff.), these are a money economy, the availability of continuous revenue via a stable system of taxation, and, in its more highly developed form, the existence of a capitalist market economy and the "conceptual separation of the 'state', as an abstract bearer of sovereign prerogatives and the creator of legal norms, from all personal authority of individuals" (p. 66). Bureaucratization and state formation are mutually linked: "it was left to the complete depersonalization of administrative management by bureaucracy and the rational systematization of law to realize the separation of the public and the private sphere fully and in principle" (p. 67). At a later historical stage, social welfare policies and, to an extent, mass democracy were strong accelerators of bureaucratization.

However, Weber did not share Hegel's optimism about progress which the latter had projected on the state: in the face of the alienation that is produced by the bureaucracy as an extreme form of Western rationalism, his work is pervaded by a deep melancholy.

Weber was fascinated by the pervasive tendency of bureaucracy in modern societies and the "ever-increasing importance of experts and specialized knowledge" (p. 69) ${ }^{10}$ Bureaucracy, as he saw it, is the typical form of domination in modern societies (their "fate", p. 63); as a consequence, the bureaucratic state is the most accomplished form of state. The success of bureaucratic domination stems from its "technical superiority" (pp. $5^{6}$ et al.): "precision, speed, unambiguity, knowledge of the files, continuity,

10 Translations from Weber are by Thomas Bierschenk. 
discretion, unity, strict subordination, reduction of friction and of material and personal costs - these are elevated to the optimum point in the strictly bureaucratic administration" (p. 62). Once bureaucratic rule is established, it stays in place and cannot be challenged, neither by the ruler, nor the ruled, nor the bureaucrats themselves: The "objective indispensability of the once-existing apparatus... makes 'revolution', in the sense of the forceful creation of entirely new formations of authority, more and more impossible" (p. 63).

Weber established a set of defining characteristics of bureaucratic rule (pp. 49ff.):11 the delineation of an official jurisdictional area by a bureaucratic agency; rule-based office management and execution of tasks, in particular the application of coercive means, "without regard for persons" (p. 58) (in fact, "the more it is 'dehumanized', the more completely it succeeds in eliminating love, hatred and all purely personal, irrational and emotional elements that evade calculation, the more perfectly bureaucracy develops", p. 58); office hierarchy, monocratic rule and channels of appeal based on written documentation (Schriftförmigkeit); separation of the bureau from the private domicile of the official, of public from private monies and equipment; recruitment and promotion based on general rules concerning specialized training (expert knowledge); a fixed monetary salary and old-age pension; promotion according to fixed career lines, based on seniority and/or examinations; full-time activity, life tenure (at least in public bureaucracies) secured against arbitrary dismissal (which is the material base for the "independence" of the bureaucrat); office holding as an abstract vocation (Beruf) as distinct from loyalty to a particular ruler.

Bureaucracy as a particular social form also requires a particular type of social actor, the official (Beamter) (pp. 53ff.) The particular "personality type of the professional expert" differs from that of the "cultivated man" of earlier epochs (pp. 67ff.). The Beamten owe their position to having successfully passed a technical exam, and they consider their professional activity not as a social position (or a job) but as a vocation. They form a specific status group striving for social esteem who tend to identify their interests with those of the public. This makes the bureaucracy into "an ethical class, one that embodies and exemplifies a model of ethical conduct based on the spirit of public service" (Osborne 1994: 302). Bureaucratic vocation creates a particular bureaucratic persona, for it

11 However, these characteristics fit the middle and lower ranks of bureaucracies better than the higher ones (Weber 1921/1972: 53). 
"presupposes an ethical formation... on the part of the bureaucrat... as opposed to a more or less blind obedience to rules and orders" (ibid.: 309). Only on this ethical basis can the bureaucrat exercise discretion, a necessary complement to the application of his expertise. Therefore, working in a government office is not just a job but the participation in an "order of life" (Lebensordnung). At the same time, job security and social esteem allow relatively low wages.

What Weber does here is to define "structural principles" that are different from "all of the types existing in the real world" (Weber 1921/1972: $69 \mathrm{ff}$.$) , where these organizational principles are, in fact, fluid and overlap.$ “Their 'pure types', after all, shall be considered as border cases which are of special and indispensable analytical value, and bracket historical reality which almost always appears in mixed forms" (ibid.). In other words, bureaucracy as a social form as defined by Weber is an ideal type, an analytical category, not something to be found in reality as such. If it refers to empirical phenomena, it mainly refers to the world-view of (Prussian) bureaucrats themselves (Hilbert 1987). In any case, it is not the direct result of empirical research on actual practices of state actors as called for by Lorenz von Stein. For although the 'interpretive' (sinnverstehend) process advocated by Weber provides a label for the defence of qualitative approaches and the need to take the 'point of view of the actor' into account, it was always hypothetical for Weber and he never applied it himself on the basis of empirical studies (cf. Olivier de Sardan 2008: chapter 'emique').

It is important to underline this point, for a widespread misunderstanding of Weber's methodology exists: his concepts are ideal types, e.g. they are analytical categories which in his understanding are clearly not real objects, but yard-sticks with which to 'profile' real objects. Weber himself speaks of a "chance of a specific type of behaviour" which his ideal-types indicate: in other words, the ideal-type of bureaucracy only connotes the "chance of its own existence". The empirical punch-line is that there are different gradients of the existence of bureaucracies and states, ranging from the hypothetical extremes of complete non-existence to complete existence. Hence, to claim that a given bureaucracy, say an African bureaucracy, does not conform to Weber's ideal type of bureaucracy, is a sociological banality, and would certainly not come as a surprise to Weber himself. The particular, empirical, features of a given bureaucracy cannot be used to 'disprove' the Weberian model - a model can only be critiqued with another model. As Weber says: "It does not provide any difficulty for sociology to acknowledge the parallel validity of different, 
mutually contradicting orders within the same circle of people. For even the individual can direct his actions according to contradictory principles. For sociology, there is no absolute alternative between the validity (Geltung) and the non-validity (Nicht-Geltung) of a particular order. Instead, fluid transitions exist between both cases, and, as noted, contradictory orders can exist in parallel to each other, each ... to the degree that action (das Handeln) is indeed oriented to them." (Weber 1921/1972: 16f.). In other words, the 'existence' of a state is predicated on the existence of certain types of social behaviour-when these practices cease to exist, the 'state' likewise ceases to exist (ibid.: 13).

\section{A Post-Weberian Perspective on the State}

To sum up, even a cursory glance at the history of political thinking in the 'West' reveals a wide range of positions: from state scepticism to state idealism to approaches that are more interested in the empirical reality of states. Inspired by Abrams's (1977/1988) critique of neo-Marxist theories of the state, these distinctions have recently been reformulated by Migdal and Schlichte (2005) as the difference between state-idea and statepractices, that is between the "image of the state" and the "practices of the state" (pp. 14-15) and between "seeing the state" and "doing the state". "The state", they write, "is a field of power marked by the use and threat of violence and shaped by 1) the image of a coherent, controlling organization in a territory, which is a representation of the people bounded by that territory, and 2) the actual practices involving those staffing its multiple parts and those they engage in their roles as state officials" (p. 15).

On the one hand, a global image exists today of the modern state "as singular, supreme rule-maker, as separate or bounded, and as a representation... as the dominant and single centre of authority" (p. 16). But the idea of the state does not need to match actual current state practices. On the contrary, the image of a coherent and autonomous state can certainly coexist with practices which leave much space to various social groups in fields that are 'properly' attributed to the state (e.g. ranging from security services to education). In addition, "while some state actors themselves may employ practices that strengthen the image of the state, others may employ those that weaken the image" (p. 19).

Therefore, within what is commonly referred to as 'the state', there exists a tension between the homogenising idea of the state-which may be shared by opposite normative perspectives, statist and anti-statistand heterogeneous state practices. From the perspective of this book, the 'state' should be seen not as an entity but as a bundle of practices 
and processes in a field of complex powers (for a similar perspective, see Schuppert 2010). And such processes can run in different directions with diverse effects. For example, they can move in the direction of strengthening the image of the state, or in the direction of weakening the state image. In other words, they can manifest as processes (and practices) of 'étatisation' or of 'dé-étatisation'. From this perspective, 'the state' is the result of social closure and compromise in the battle of conflicting interests.

The methodological conclusion-which informs the contributions to this book - is to aim to produce ethnographies of the state and thereby concentrate on 'doing the state' or on state-making (and un-making) practices. The focus is not on a bounded research object- 'the state' as a clearly definable unit of analysis - but on ethnographic investigations of the properties of the phenomena, processes and practices connected to state institutions, state authority and the state provision of services and goods, that is their 'stateness' or state quality.

This is not to suggest that the object of the 'state' is so continually fluid in its endlessly reshaping composition that it cannot be empirically investigated. The question of what constitutes the state can instead be reformulated as the question about the conditions, under which-historically and geographically specific - temporary condensations of these practices and the stabilization of certain patterns and meanings take place.

Many authors have highlighted the fact that the role of the state has undergone considerable changes in the last 40 years. In reference to the Global North, some authors speak of a 'golden age' of the national democratic capitalist welfare state-roughly during the period between the end of the Second World War and the 1970s-which has unravelled since. It is less obvious whether there is an overarching tendency in this unravelling. Some authors claim an increasing hegemony of a "neoliberal project" (Comaroff and Comaroff 2001, Chalfin 2010). ${ }^{12}$ However, empirical research on the transformation of the state in Europe (Zürn and Leibfried 2005; Derlien and Peters 2008, 2009) points instead to 'asymmetrical change', e.g. transformations which go in very different directions, depending on which dimension of statehood is being envisaged. While nation-states continue to cling to tax revenues and the monopoly of the use of force,

12 The interest in the 'neoliberal project' can become an obsession among some anthropologists, e.g. when the journal Cultural Anthropology decides to devote one issue per year (out of four) exclusively to this topic (http://www.culanth.org/?q=node/2 [11.2.2013]). For a nuanced and empirically grounded approach see the discussion between Wacquant, Hilgers, and others in Social Anthropology 20 and 21 (2012 and 2013). See also Olivier de Sardan (2011a) and the other contributions in Politique Africaine no. 123 on Chalfin's (2010) book. 
the rule of law appears to be moving, at least partly and depending on the sector of law in question, into the international arena. The welfare dimension of the state, by contrast, is headed in every direction, including privatization, internationalization, supra-nationalization, and defence of the national status quo, again depending on the sector and country in question. As for the democratic legitimacy of political processes, how it will be ensured in such an incoherent situation remains unclear.

Nevertheless, many authors agree that the state is no longer the only carrier of effective government (if it ever was), and that it is increasingly confronted with other actors, with which it is in overlapping and complex relations of conflict, negotiation, alliance, compromise, avoidance, etc. (Hagmann and Péclard 2010, Eckert, Behrends and Dafinger 2012). Various key terms have been proposed in order to account for these changes, for example the 'pluralization of governance' and 'fragmentation' (or 'overlapping') of sovereignty (Randeria 2007, Benda-Beckmann, BendaBeckmann and Eckert 2009). With regard to Africa, most authors writing today on politics and the state assume, in one form or another and using various terminologies, a plurality of power centres within and adjacent to, and partially intertwined with the state. In the Africanist debate, the concepts used range from 'polycephaly' (Bierschenk and Olivier de Sardan 2003, orig. in French 1997) and 'para-sovereignty' (Parastaatlichkeit) (Trotha and Rösel 1999) to 'twilight institutions' (Lund 2007), 'heterarchy' (Bellagamba and Klute 2008) and different 'modes of governance' (Olivier de Sardan 2011b). Other authors have described the delegation of state functions to private actors (Hibou 2004). Therefore, in many cases several actors are quite frequently involved in the delivery of public services in Africa today: state administrations, international actors such as NGOs and international donor organizations, community-based organizations, and private companies (Blundo and Le Meur 2009; for a similar perspective beyond Africa, see Tendler 1997).

While these observations-which are confirmed by the contributions to this book - relativize the role of the state in regulation and public service delivery, they also confirm that state agencies remain strong, although not exclusive, actors in these fields.

\section{Anthropology and the Modern State in AfricA}

The primary objective of this book is to provide new knowledge on state apparatuses and their actors in Africa. However, the ethnographic scrutiny 
of state phenomena, which we advocate in this book, also claims to make an original contribution to research on the state in general as well as to the discipline of anthropology.

\section{A Contribution to Studies of the State}

Studies on modern forms of the state are the preserve of political science, the sociology of organizations and administrative science. It is through its method that anthropology can contribute added value. Admittedly, this discipline no longer has a monopoly on fieldwork carried out in its natural setting; qualitative methods are increasingly employed by sociologists and political scientists, even if only by a very small minority. However, these methods owe their existence largely to anthropology, even if it could be argued that participant observation was a parallel invention by anthropology and qualitative sociology, e.g. the Chicago school (itself largely influenced by anthropological inquiry). The approach used by most contributors to this book has been to apply the fieldwork practices routinely used by anthropologists to topics that originate in the political sciences and the sociology of organizations, and to do this in an African context, which is rarely the focus of such perspectives. Such an approach has yet to become established, despite the fact that it opens up new lines of questioning and new forms of knowledge, especially when it systematically takes actors' viewpoints into account, observes their actual practices and undertakes in-depth case studies or analyses of interactions in situ.

We also argue that the studies we have conducted in an African context can make a positive contribution to studies undertaken in other contexts and on other continents. To put it a little differently, the findings presented in the following chapters can, to a certain extent and in certain respects, be 'exported' elsewhere from Africa, or 'translated' into other contexts and initiate a dialogue with research on the state in the countries of the North.

Why is this so? Fundamentally and paradoxically because African states are both similar to European states and, at the same time, different.

One of the premises of the studies assembled in this book is precisely that practices in Africa and in Europe do not differ in nature. Many Africa specialists think the opposite, and claim incompatibility between the state of western origin and 'African culture' (for a critique of such claims, see Olivier de Sardan 2010). Whatever the argumentations of these believers in the irreducible specificity of Africa, they are all based on the sameand admittedly well-founded-observation, namely, the existence of 
significant divergences between the 'imported' state (Badie 1992), supposedly of the Weberian kind, on the one hand, and the real African state, in which the practices of public employees are far removed from the public norms, on the other.

However, irrespective of their location, all practices in all modern states display both permanent and multi-faceted disparities between the official model, which state actors are supposed to follow, and actual behaviour. This is a common feature of all organizations, be they public or private. In Africa as in Europe, all public bureaucracies are permeated by tensions between prescribed and real conduct, between official and practical norms, between organizational charts and professional cultures, and between public policies and their implementation. Bureaucracies are, without exception, subject to a host of contradictory directives. Competing rationales, overlapping power structures, shifting alliances and different conflicts clash endlessly.

This does not mean, of course, that the substance, scale, style and nature of these tensions, directives, rationales, alliances and conflicts are identical in Africa and Europe. Quite the reverse: the contexts in which they occur are different, as are the issues and strategies. The codes, points of reference, forms of non-verbal communication and social norms diverge.

However, the investigation of African and non-African forms of statehood using the same analytical concepts and the same methods enables interesting comparisons. Certain forms of behaviour in the context of the state that are less pronounced in Europe, and hence barely discernible, assume such proportions in Africa that they could not, as it were, escape the attention of either citizens or researchers. The many kinds of corrupt transactions are a significant case in point, another being the role of personal connections within the working environment (Blundo and Olivier de Sardan, with Bako-Arifari and Tidjani Alou 2006). These practices are universal in African states, and are not difficult to spot for those who look closely enough. Hence it is relatively easier for a researcher to access them in Africa. They are also present in Europe, of course, but much better hidden or disguised. Therefore, it is clearly in the interests of researchers working on European bureaucracies to familiarize themselves with the findings of anthropologists studying African bureaucracies. The specificity of the practices engaged in by public employees in Africa highlights forms of behaviour that are more difficult to detect in Europe, either because they occur on a smaller scale or because they take a different form. 
The informality of practices is another example. This is omnipresent in Africa in the area of the economy and is a favourite object of anthropological investigation; it is difficult to conduct investigations on informal practices other than by ethnographic surveys. However, informality does not only exist outside the state, it is also firmly entrenched in state mechanisms themselves (cf. Olivier de Sardan, Bierschenk, this volume) and can be enlisted (as in the contributions to this book) in the analysis of the informal processes internal to the public services in all their diversity. This approach is in stark contrast to the culturalist analyses of those African specialists who interpret every informal practice as the outcome of an 'African world view'. The approach can no doubt be used to advantage in Northern countries, too, and enables interesting comparisons to be made between North and South, as well as East and West. The close resemblance between post-colonial and post-communist countries is striking in this respect, in this area as in others (Bayart 1996, 2004, Hibou 2011).

The entanglement of multiple rationales in heterogeneous public arenas provides a final example for the comparative study of African and non-African statehood, and one that is highlighted in the studies featured in this volume. Public action brings together not only public servants and service users, all with their own rationales, objectives and strategies, but also chiefs, patrons, development projects, priests, ministers and imams, development agents, NGOs, experts and consultants, bilateral cooperative ventures, international organizations, etc. Here, too, our perspective is different from those of the culturalist Africanists, who promote a single rationale (more often than not, of the neo-patrimonial kind). In this respect, also, our approach can bear fruit in non-African contexts, by underlining the multiplicity of 'strategic groups' (Evers and Schiel 1988; Bierschenk and Olivier de Sardan 1997) that intervene not only in the bureaucracies themselves but also in the environments with which they interact, the diversity of modes of governance delivering or co-delivering services (Olivier de Sardan, this volume) and the multiplicity of logics and strategies that individual public agents follow, in both the Global North and the Global South.

\section{A Contribution to Anthropology}

However, this comparative venture concerning the modern state, to which we are seeking to contribute, also entails a plea for a new relationship between anthropology and the other social sciences, as well as for innovations within anthropology itself. 
For reasons that are both historical and institutional, anthropology is inclined to be self-referential and inward-looking. In celebrating the uniqueness of its method, its approach and objects, especially when the latter are perceived-by Europeans-as 'exotic', and in adopting a culturalist stance, it all too often forgets that other social sciences have dealt with the same objects or conducted the same kind of research in different areas.

In this book, we have attempted to correct this trajectory, as far as possible, by engaging in a wide-ranging dialogue with history, sociology and political science, not only when they deal with the state, its machinery and its practices in an African context (which, sadly, is all too infrequently), but also when they deal with these objects in a European or American context (which is the norm) (Bierschenk and Olivier de Sardan, Research Paradigm, this volume).

Oddly, and one need only glance through the bibliographies of the anthropological works currently in favour to conclude that, when it comes to other disciplines, anthropology is more inclined to align itself with philosophy, especially political philosophy, than with its closest disciplinary (and empirically-oriented) neighbours. It is as though many anthropologists preferred the ethereal realms of highly generalized, speculative forms of interpretation to empirically grounded and methodically controlled forms of comparativism applied to specific historical configurations. One sometimes gets the feeling that as anthropology has increasingly shied away from the essentialization of its traditional objects of study (e.g. 'primitive cultures'), it has become prone to essentializing certain general concepts - like 'neopatrimonialism' or 'neoliberalism' - which are considered not as emerging from actors' practices, but as having a reality of their own (Carrier 1992).

There is obviously no question of banning all dialogue with philosophy but instead of promoting, as a matter of priority, a different kind of dialogue, a dialogue with the empirical social sciences which investigate the same objects in the Northern hemisphere as contemporary anthropology in the South. This would involve a triple dialogue: anthropology's dialogue with history, sociology and political science; dialogue between Africanist and non-Africanist researchers; and dialogue between researchers from the North and the South. It would also mean the delineation of an agenda for anthropology generally (and not only the anthropology of the state): in the vast majority of cases, anthropology now studies social processes and empirical objects that are typical of the contemporary world, everywhere, and it should draw the methodological consequences from this. 
The anthropology of the contemporary world-of which the anthropology of the state is a part-is increasingly faced with the challenge of analysing 'transversal objects'. By this term, which we borrow from the historian Espagne (2012), we understand relatively bounded empirical phenomena which are a result of transfer processes that took place in the past in the context of European imperialism and colonization. Modern state bureaucracies, which are under investigation in this book, are a prime example of transversal objects. In the classical phase of ethnographically-based anthropology, when Malinowski analysed the social functions of an exotic institution like the Kula ring, or Evans-Pritchard the social embedding of Azande witchcraft beliefs, researchers, all of them western ethnographers, were faced with empirical phenomena which were, a priori, unknown to them, and of which they had to make sense. Today, in the presence of transversal objects, the boundaries between the known and the unknown are drawn differently, and ethnographers are no longer exclusively Westerners. In fact, they belong to a globalized body of experts who are confronted with a set of institutions and organizations that are spread throughout the world, and who are (or should be) in constant dialogue with other experts from other disciplines and professions.

While the temptation in some academic circles in the political or administrative sciences is to view these institutions in the South from the confines of a (ethnocentric) Northern conceptual framework and from a universalistic perspective (similar to the way in which, for example, many comparative political studies rely on quantitative data), in contrast, the temptation for many anthropologists working in Southern countries, is to exoticize or essentialize these objects from a particularistic perspective. We argue that the study of transversal objects requires systematic "reciprocal comparison" (Austen 2007: 10 and passim). What is needed, therefore, is the development of a 'symmetrical' social science that consigns the both epistemic and methodological 'great divide' (Latour 1983) between 'Them' and 'Us', South and North, Africa and Europe to history, and at the same time allows for the relativity of particular 'Northern' perspectives.

At the same time, however, this implies the adoption of a different approach to the making of comparisons. Traditional anthropological comparativism was concerned with closed systems (cultures and societies)which should be considered as passé. Contemporary anthropological comparativism, more often than not, is quick at establishing direct if fragile connections between anecdotal local observations and theories of the global. We are advocating a third type of comparativism, which spreads progressively outwards from a solid empirical base: (a) an intensive, 
multi-site comparativism pursued in the field (for an appropriate methodology, see Bierschenk and Olivier de Sardan 1997); (b) a comparativism based on regional and thematic affinities, comparing similar institutions in historically related local and national contexts (such as bureaucracies in Africa, to take the present volume as an example); (c) a wider level of comparison involving similar processes in very different historical or spatial contexts (such as the police in Benin and in Germany).

An important methodological consequence needs to be stressed here. As soon as anthropology begins to take an interest in modern societies or the modernity of societies, in Africa as elsewhere, it is to its advantage to develop teamwork in research, thereby enabling the optimum implementation of these three levels of comparativism. This, of course, means breaking the strongly individual mould of the discipline.

The studies collected in this book are a step in this direction.

\section{Presentation of THE Book}

This book grew out of an international comparative research project entitled "States at Work: Public Services and Civil Servants in West Africa: Education and Justice in Benin, Ghana, Mali and Niger", which was funded through a programme of the Volkswagen Foundation (see above, acknowledgments). This programme investigated two key sectors, education and justice, in four West African countries: Benin, Ghana, Mali and Niger. The focus was on ethnographic enquiry within an interdisciplinary approach combining social anthropology, sociology, political science and law. ${ }^{13}$

13 On a research policy level, and against the background of existing research networks, the objectives of the project were to: promote young (mainly African) researchers at PhD level; contribute to the development of West African centres of excellence; develop interdisciplinary cooperation between West African scholars of different countries, in particular between Anglophone and Francophone countries, on the basis of joint empirical research; and strengthen existing cooperative relations between German and African researchers at different levels (senior staff, $\mathrm{PhD}$ and MA students). The project was co-ordinated by a German-African tandem (Bierschenk/Mainz and Tidjani Alou/ Niamey). Institutionally, the project operated as a network of the Laboratoire d'études et de recherches sur les dynamiques sociales et le développement local (LASDEL; www.lasdel .net/) in Niger and Benin, the Department of Anthropology and African Studies of the Johannes Gutenberg University of Mainz, the Department of Sociology of the University of Legon (Accra, Ghana) and the University of Mali, Bamako. On the staff level, and including the coordinators, it comprised nine senior researchers from Benin, Ghana, Germany, Mali and Niger (six anthropologists, one jurist, one political scientist, one sociologist), one 
While this book includes contributors from outside the project team (see below), it should be acknowledged that our view on public services and state practices has been heavily influenced by the empirical research carried out, or supervised, in the context of this project. Therefore, a short reflection on the particular location of our own empirical work is in order. For academics who express views on Africa always do so on the basis of limited empirical experience. They generalize according to the small corner of Africa with which they are familiar to a greater or lesser extent. In fact, nowhere does the temptation to succumb to such continent-wide generalizations appear to be as strong as it is for Africa (Keller 1991). ${ }^{14}$

Therefore, we consider it important to refer explicitly to the empirical basis of our statements. Like any empirical sample, ours was limited-in three important respects: first, it incorporated four relatively small, poor states all located in West Africa which, however, also function relatively well in the context of Africa. At the time of our research, none of them could be described as a 'failed' state - in fact, in international donor discourse, Ghana, Benin and Niger are, and Mali until recently was, viewed as quite respectable African democracies. Second, we were primarily interested in the interface bureaucrats, that is the officials who have direct contact with the citizens, mainly on a local level, and the organizations in which they work. (Lentz's contribution is an exception here.) Third and, finally, we only focused on two selected state sectors, e.g. the justice system (understood here in a wider sociological sense that includes, along with the judiciary, the police and gendarmerie) and primary education.

The reasons for the selection of these two state sectors were partly practical: other sectors like health, customs and public service delivery at local level had already been studied by some members of our team (Jaffré and Olivier de Sardan 2003; Blundo and Olivier de Sardan, with Bako-Arifari and Tidjani Alou 2006; Blundo and Le Meur 2009; see also Bierschenk and Olivier de Sardan, Research Paradigm, this volume). However, there

post-doctoral researcher (anthropologist, Benin), four $\mathrm{PhD}$ students (one anthropologist two sociologists, one jurist) from the same four countries, five associated PhD students with fourth-party funding from Germany (3) and Benin (2) (all anthropologists), and about 30 MA students from all five countries.

14 In fact, "one has to ask, what is Africa? Is it Botswana or Guinea-Bissau? Is it Swaziland or the Democratic Republic of Congo? Of course it is all of them. But they won't develop in remotely similar ways. In fact, there should actually be a moratorium on the use of the word Africa in book titles related to development. Just that one modification would force well-intentioned thinkers ... to investigate more deeply and see what might actually work in a particular case, rather than what ought to work for everyone" (Keating 2009). 
were also systematic reasons for our selection. While the reputation and the image of the state are staged through daily practices in both sectors, primary school education and the justice/police system represent two very different fields of state action. In most African countries, the primary school sector is probably the biggest single apparatus of the state-up to $50 \%$ of all public sector employees are primary school teachers, and if an African citizen in a rural area comes into contact with the state, statistically speaking, this is most likely to happen in the school environment. Since the late colonial era, the educational system has been a top priority of African governments, and it was and continues to be assigned a central role in the building of state and nation, and in the economic development process. At the same time, the teaching profession is, at present, a particularly hotly contested site for establishing the boundary between the public and the private, the state and civil society (Bierschenk 2007).

The justice sector, on the other hand, involves a far smaller group of apparatuses, in which the development function of state action assumes a less prominent role than the claims for sovereignty and the monopoly of violence.

Hence, it was our intention to study two different areas of state action. When we embarked on the research we were not aware of just how different these areas actually were and, at the same time, of how similar some of the actors' practices would nonetheless prove to be. However, the broader theme of the construction of the state and the theoretical and empirical perspectives adopted here exceed the sectoral (education and justice/police) and geographical (Benin, Ghana, Mali, Niger) limits of the States at Work programme. Hence, we decided to extend this book to include other researchers who were working from a similar perspective on other state sectors and other African countries. In other words, this books presents contributions from the States at Work project (Bierschenk, Chabi Imorou, Hamani, Lentz, Olivier de Sardan) and other researchers, most of whom (with the exception of Roll and Therkildsen) participated in one of the panels organised by the project between 2007 and 2011.

The authors of this book originate from different European (Denmark, France, Germany, Italy, United Kingdom) and African (Benin, Niger) countries, wrote the original versions of their paper in different languages and work at the confluences of several social sciences (anthropology, history, political sciences, management sciences). A majority, however, are anthropologists, which undoubtedly explains the general prevalence of a qualitative approach (with the exception of Therkildsen whose research is of the survey type). The conditions in which the empirical studies were 
carried out also differ considerably: in some cases, teamwork was involved (Roll), in others, individual studies were carried out in the context of larger research programmes (Blundo, Chabi Imorou, Hamani, Lentz), while other contributions issued from individual doctoral or postdoctoral projects (Anders, Bergamaschi, Charton, Muñoz, Willott).

The first part of this book includes this introduction and an overview of the relevant literature, in which the editors describe the emergence of a research paradigm for the ethnographic study of states, bureaucracies and bureaucrats at work, in Africa and beyond.

The second and third part of the book take up the theoretical perspectives of the two introductory papers and develop them further based on empirical examples. The African states under consideration in these sections are not 'failed states' (like Somalia or the Democratic Republic of the Congo), a category frequently and erroneously interpreted as the archetype of the African state (Englebert 2009; for a critique, see Bierschenk 2010). They do not concern areas of "limited statehood" (in the sense of Risse 2011). Neither are they 'success stories' like Botswana, Rwanda and South Africa. They more closely resemble the modal type of African states, and this undoubtedly lends greater validity to the comparative lessons drawn from their study. The different chapters deal with both Frenchspeaking (Benin, Cameroon, Mali, Niger, Senegal) and English-speaking (Ghana, Malawi, Nigeria, Tanzania, Uganda) countries. With the exception of Cameroon in Central Africa and Tanzania and Uganda in East Africa, the book focuses for the most part on West Africa. The particular state sectors examined in the book are varied: primary (Charton, Chabi Imorou) and university (Willott) education, the administration of livestock breeding (Muñoz) and natural resources (Blundo), and the judiciary (Hamani). Not all chapters focus on particular sectors of state activity; some adopt a more cross-sectional perspective, for example Bergamaschi on the role of external actors, Lentz on the particular outlook of higher civil servants, Roll on 'pockets of effectiveness' in the Nigerian public service and Therkildsen on public sector hiring and promotion. Several of the authors (Anders, Blundo, Chabi Imorou, Charton, Muñoz) chose the issue of reform as their main subject, or as their point of entry into wider analyses of bureaucratic practices.

While all contributions analyse bureaucratic practices, we have grouped them into two sections, the first taking bureaucrats as an entry point, the second bureaucracies. The first section is introduced by a contribution by Giorgio Blundo on the professional practices of Senegalese foresters, which develops several themes taken up later on by other authors of this 
book. Beyond their formal structures, the forestry service in Senegal-like higher education (Willott) and the judiciary (Hamani) - is marked by a strong degree of 'informal privatization', but also new hybridized ways of 'doing' the administrative service and managing the relations of foresters with the public. Like other bureaucratic services of the postcolonial state (see, in particular, Charton on education in Cameroon, Anders on the civil service in Malawi, Muñoz on tax authorities in Cameroon), the Senegalese forestry service has been reshaped by major reforms, partly initiated by international donors. This has created 'two-speed' bureaucracies, by which a 'traditional' service, relying solely on the state budget, underfunded and therefore condemned to inactivity and/or petty corruption, co-exists with 'projects', which offer their employees much better working conditions and income (see Roll, this volume, on 'pockets of effectiveness'). At the same time, the different reforms reinforce the dilemma that the foresters must navigate between protecting the environment, for which they have recourse to repression and sanctions, and new 'participatory' and developmental professional roles in line with recent international aid fashions.

Willott is interested in factionalism and patronage as strategies for manipulating promotions in Nigerian higher education. Faction politics are played out there in a complex interplay of formal and informal rules. However, official regulations still play an important role, as unofficial practices can only be used to a certain degree before the official rules act to rein them in. Understanding staff success and failure is, therefore, dependent on an understanding of both formal and informal processes, and particularly the way these processes intersect.

Therkildsen, likewise, focuses on hiring, firing, transfer, demotion and promotion practices, this time in the public sector in Tanzania and Uganda and using a survey type of approach. He is interested in how such practices influence organizational performance and staff motivation. Very much in line with the results of Willott's study, he concludes that the neopatrimonalism paradigm, which is widely adapted to characterize African public services, does not provide an adequate analytical basis for understanding politics and administration, as it tends to overlook the often significant variation in organizational capacity within public sectors, the uncertainty that characterizes relations in neopatrimonial settings, and the particular types of hypocrisy that this generates.

These results are corroborated by Hamani's study of the Niger judiciary. His point of departure is the startling fact that while African public 
services show many obvious deficiencies, they do seem to meet (some of) the needs of citizens. This raises the question as to how these services 'really' function-largely, as he shows, through the practical inventiveness (débrouillardise) of public services which generate numerous informal reforms on the local level. In other words, far from expressing administrative inefficiency, the practical norms of public servants contribute, at least in some cases, to making service delivery workable, and making the state work (a theme developed further by Olivier de Sardan).

Lentz deals with the persistence of a surprisingly high commitment to public service among contemporary Ghanaian higher civil servants. Her chapter investigates the images of a worthy public servant and a wellfunctioning bureaucracy developed by senior Ghanaian bureaucrats. Analysing her informants' views on changing professional trajectories, the role of merit, seniority and patronage in public service careers, and on professional ethics, she highlights the role that a rigorous Catholic education, certain ethnic stereotypes of 'hard work' and 'honesty', and membership in close-knit, regional-ethnic elite peer groups play in the professional commitment of higher public servants.

Eckert's paper looks at the historical roots of this moral commitment. He shows that the work of civil servants in early independent Tanzania was very much defined as 'work for the nation', and that this self-image went along with notions of discipline and a strong sense of the connections between political issues and administrative duties. However, this development orientation was coupled with a view that because these objectives were considered to be so important and humane and because there appeared to be so little time to implement them, they had to be imposed from above, if necessary. This fostered a form of arrogant and authoritarian paternalism vis-à-vis fellow citizens on the part of a bureaucratic power elite that saw itself as the avant-garde of state and nation building.

This section on bureaucrats is concluded by a more general chapter by Bierschenk which shows that, by a process that may be called sedimentation, historical trajectories - colonial and post-colonial—have resulted in heterogeneous and fragmented bureaucracies which, for the public servants working in them, are complex normative universes shot through with numerous double binds. The chapter concludes that the 'ordered informality' of bureaucratic processes is at least as much produced inside the state apparatuses themselves as it is an expression of cultural logics of an African environment, and that the search for the uniform logics of 
'the' African states is a futile one. The chapter ends with a reflection on how to theorize macro-change and difference as the accumulated product of numerous micro-processes.

The second section on bureaucracies is introduced by a chapter by Charton which examines the dynamics generated by the implementation of the so-called competency-based approach within the Cameroonian educational system, and shows how a development aid technology is challenged by internal bureaucratic dynamics. Far from producing the expected change, the reform was turned into a very normative, hierarchical and administrative exercise by the bureaucratic agents. Consequently, the main effect of the reform has been to strengthen bureaucratic dynamics through the distribution of new symbolic and material resources.

Bergamaschi examines the ability of international organizations to shape and reform African administrations. Based on a detailed study of the technical unit installed to implement the Poverty Reduction Strategy in Mali, she argues that such targeted capacity-building initiatives have limited impact as they have to deal with pre-existing institutional features, social relations and competing interests which are created by the unit itself. However, international support has made unexpected contributions to the process of state formation in Africa as it contributes to the extension of bureaucratic power.

Muñoz, in turn, explores the contours of two decades of administrative reform in Cameroon by taking a close look at a governmental programme which, informed by objectives such as the introduction of performancebased management and the fight against corruption, has since 2000 attempted to improve the 'reliability' of the cattle sector as a source of state revenue. The cooperation between two administrative agencies in Adamaoua Province meant a realignment of their respective professional cultures and spheres of influence, which was only achieved gradually through a pragmatic reformulation of the programme's goals. This chapter serves as a reminder of the patchiness of public authority in regions and domains of activity where uncoordinated state action is pervasive.

Anders, like Blundo, uses the issue of reform as a point of entry into the study of civil servants in Malawi. While these reforms are seen by their promoters as key to transforming African state bureaucracies into efficient, transparent and accountable service providers, ethnographic evidence points instead to a widening of existing fissures in the civil service as an unintended consequence of reform. Due to the establishment of new agencies, which were supposed to function as motors of reform, 
two types of institutions competed, i.e. the 'enclaves', which were mainly staffed by a younger generation of technocrats (see also Blundo and Roll), and the line ministries led by old-school bureaucrats. The reform measures also fuelled a latent conflict between the bureaucratic elite and the rank and file of junior civil servants, which was often expressed in the idiom of ethnic and regional difference.

Trade union activity is often decried in the donor literature as a main impediment to reform. However, as demonstrated in Chabi Imorou's chapter, it may also serve as a filter of reform proposals. As the numerous reforms initiated by outside actors often lack synergy and present significant internal contradictions, it comes as no surprise that the sectors affected (in his case, primary education in Benin) experience few of the intended changes, or even witness the completion of any action that is undertaken. If these reforms do work, to a certain extent, it is because they are selectively appropriated by public actors, including trade unions, to make them more workable (see also the contribution by Hamani to this volume).

Striking a more positive note and inverting the frequently found deficiency-focused perspective on African public services, Roll explores the often overlooked phenomenon of 'pockets of effectiveness' in a weak governance state like Nigeria. These pockets emerge as a result of the interactions of political interests, the functions of a public organization and specific leadership and management styles. He concludes that, under certain conditions, factors that are normally seen as detrimental to state effectiveness, such as the personalization of the bureaucracy and political interference, can even contribute to building pockets of effectiveness.

This section, and the book, concludes with a chapter by Olivier de Sardan which (like Bierschenk's chapter) is based on both the contributions to this book and other topical studies in which the author has been involved for the last 20 years, including the States at Work programme. The chapter takes a special interest in the function of the delivery of public or collective goods and services by the state through the bureaucracy, the implementation of policies and the functioning of the local state'. The author uses the concept of practical norms to empirically investigate the informal, tacit and latent regulations that underpin the actions of public actors and do not conform to the bureaucratic, professional and formal norms. Far from going back to a 'traditional African culture', they are integrated into modern professional cultures, which are partly common to all officials, on the one hand, but also partly specific to each 
professional body, on the other, and are integrated into a bureaucratic mode of governance, prompted to mix or collaborate with other modes of local governance.

All of the contributions call for a new perspective on the 'real' state in developing countries which is based on detailed empirical analysis and grounded theory rather than stereotypical assumptions and hasty generalizations. States in Africa, as everywhere, are complex, dynamic, ambivalent institutions composed of varied professional mechanisms and bodies that deliver services while also exerting authority or domination. Their fabrics are interwoven and layered with heterogeneous practices and representations, with actors 'doing the state' and 'seeing the state'.

\section{REFERENCES}

Abrams, Philip. 1988 [orig. 1977]. Notes on the difficulty of studying the state. Journal of Historical Sociology 1 (1): $58-89$.

Althusser, Louis. 1971. Ideology and ideological state apparatuses. In Althusser, Louis. Lenin and Philosophy, and Other Essays. London, New Left Books, 127-188.

Austen, Gareth. 2007. Reciprocal comparison and African history: tackling conceptual eurocentrism in the study of Africa's economic past. African Studies Review 5o (3): $1-28$.

Avineri, Shlomo. 1972. Hegel's Theory of the Modern State. Cambridge, Cambridge University Press.

Badie, Bertrand. 1992. L'État importé. L'occidentalisation de l'ordre politique. Paris, Fayard.

Bartelson, Jens. 2001. The Critique of the State. Cambridge, Cambridge University Press.

Bayart, Jean-François. 1996. L'historicité de l'État importé. In Bayart, Jean-François, ed. La greffe de l'État. Les trajectoires du politique 2. Paris, Karthala, 11-39.

. 2004. Le gouvernement du monde. Paris, Fayard.

Bellagamba, Alice and Georg Klute, eds. 2008. Beside the State. Emerging Forms of Power in Contemporary Africa. Köln, Köppe.

Benda-Beckmann, Franz von, Keebet von Benda-Beckmann and Julia Eckert, eds. 2009. Rules of Law and Laws of Ruling. On the Governance of Law. Farnham, Surrey, Ashgate.

Bierschenk, Thomas. 2007. L'éducation de base en Afrique de l'Ouest francophone. Bien privé, bien public, bien global. In Bierschenk, Thomas et al., eds. Une anthropologie entre rigueur et engagement. Essais autour de l'œuvre de Jean-Pierre Olivier de Sardan. Paris, APAD-Karthala, $251-276$.

- 2009. Review of: Sharma, Aradhana, and Akhil Gupta, eds. 2006. The anthropology of the state: a reader. Oxford, Blackwell. Zeitschrift für Ethnologie 134 (1): 154-158.

- 2010. Review of: Pierre Englebert. 2009. Africa. Unity, sovereignty and sorrow. Boulder, Co. \& London, Lynne Rinner. Africa Spectrum 45 (3): 161-165, available at: http:// hup.sub.uni-hamburg.de/giga/afsp/article/view/382/380, accessed on: May 1, 2013.

Bierschenk, Thomas and Jean-Pierre Olivier de Sardan. 1997. ECRIS: Rapid collective inquiry for the identification of conflicts and strategic groups. Human Organization 56 (2): $238-244$.

- 2003. Powers in the village: rural Benin between democratisation and decentralisation. Africa 73 (2): 145-173.

Blundo, Giorgio and Pierre-Yves Le Meur. 20og. The Governance of Daily Life in Africa. Ethnographic explorations of public and collective services. Leiden, Brill. 
Blundo, Giorgio and Jean-Pierre Olivier de Sardan, with N. Bako-Arifari and M. Tidjani Alou. 2006. Everyday Corruption and the State. Citizens and Public Officials in Africa. London, Zed.

Bruhns, Hinnerk. 2011. Weber's patrimonial domination and its interpretation. In Bach, Daniel and Mamadou Gazibo, eds. The Neopatrimonial State in Africa and Beyond, London, Routledge, 9-24.

Carrier, James G. 1992. Occidentalism: the world turned upside down. American Ethnologist 19 (2): 195-203.

Chalfin, Brenda. 2010. Neoliberal Frontiers. An Ethnography of Sovereignty in West Africa. Chicago, University of Chicago Press.

Comaroff, Jean and John L. Comaroff, eds. 2001. Millenian Capitalism and the Culture of Neoliberalism. Durham, Duke University Press.

Derlien, Hans-Ulrich. 2008. Introduction: The state at work. In Derlien, Hans-Ulrich and B. Guy Peters, eds. The State at Work. Volume 1: Public Sector Employment in Ten Western Countries. Cheltenham, UK, Edward Elgar, 1-18.

Derlien, Hans-Ulrich and B. Guy Peters, eds. 2008. The State at Work. Volume 1: Public Sector Employment in Ten Western Countries. Cheltenham, UK, Edward Elgar.

- 2009. The State At Work, Volume 2: Comparative Public Service Systems. Cheltenham, UK, Edward Elgar.

Eckert, Julia, Andrea Behrends and Andreas Dafinger. 2012. Governance—and the state: an anthropological approach. Ethnoscripts (1): 14-34.

Englebert, Pierre. 2009. Africa. Unity, Sovereignty and Sorrow. Boulder, Co. \& London, Lynne Rienner Publishers.

Espagne, Michel. 2012. Comparison and transfer: a question of method. In Middell, Matthias and Lluís Roura Aulinas, eds. Transnational Challenges to National History Writing. London, Palgrave Macmillan, 36-53.

Evans, Anne. 2008. Civil Service and Administrative Reform: Thematic Paper (Background Paper to Public Sector Reform: What Works and Why? An IEG Evaluation of World Bank Support) (IEG Working Paper 2008/8). Washington, D.C., The World Bank.

Evers, Hans-Dieter, and Tilman Schiel. 1988. Strategische Gruppen. Vergleichende Studien zu Staat, Bürokratie und Klassenbildung in der Dritten Welt. Berlin, Reimer.

Fardon, Richard. 1990. Localizing strategies: the regionalization of ethnographic accounts (general introduction). In Fardon, Richard, ed. Localizing Strategies: Regional Traditions of Ethnographic Writing. Edinburgh, Scottish Academic Press and Washington, Smithonian Institution Press, $1-35$.

Gumpert, Hans Ulrich. 2010. California Grafitti. Bilder vom westlichen Ende der Welt. München, Hanser.

Hagmann, Tobias and Didier Péclard. 2010. Negotiating statehood. Dynamics of power and domination in Africa. Development and Change 41 (4): 539-562.

Hegel, Georg Friedrich. 1972 [orig. 1821]. Grundlinien der Philosophie des Rechts oder Naturrecht und Staatswissenschaft im Grundrisse. Frankfurt, Ullstein.

— 1986 [orig. 1840]. Vorlesungen über die Philosophie der Geschichte (Werke. Bd. 12). Stuttgart, Reclam.

Hibou, Béatrice, ed. 2004. Privatizing the State. New York, Columbia University Press.

-

Hilbert, Richard A. 1987. Bureaucracy as belief, rationalization as repair: Max Weber in a post-functionalist age. Sociological Theory 5 (1): 70-86.

Jaffré, Yannick and Jean-Pierre Olivier de Sardan, eds. 2003. Une médecine inhospitalière. Les difficiles relations entre soignants et soignés dans cinq capitales d'Afrique de l'Ouest. Paris, Karthala.

Kappel, Rolf, Hans Werner Tobler and Peter Waldmann, eds. 2005. Rechtsstaatlichkeit im Zeitalter der Globalisierung. Freiburg, Rombach.

Keating, Michael. 2009. Review of Fantu Cheru's 'Africa's Development in the 21st Century: Re-shaping the Research Agenda' (Uppsala: Nordic Africa Institute 2008). Pambazuka 
News. Pan-African Voices for Freedom and Justice (No. 460 of December 3, 2009), available at: http://pambazuka.org/en/category/books/6o699, accessed on: 1 May 2013.

Keller, Edmond J. 1991. Political change and political research in Africa: agenda for the 1990s. Issue. A Journal of Opinion 20 (1): 49-53.

Latour, Bruno. 1983. Comment redistribuer le Grand Partage? Revue de Synthèse 3 (110): $203-236$.

Leimdorfer, François and Alain Marie. 2003. L'Afrique des citadins. Sociétés civiles en chantier (Abidjan, Dakar). Paris, Karthala.

Lund, Christian. 2007. Twilight institutions: an introduction. In Lund, Christian, ed. Twilight Institutions: Public Authority and Local Politics in Africa. Oxford, Blackwell, 1-12.

Migdal, Joel S. and Klaus Schlichte. 2005. Rethinking the state. In Schlichte, Klaus, ed. The Dynamics of States: The Formation and Crises of State Domination. Aldershot, Ashgate, $1-40$.

Olivier de Sardan, Jean-Pierre. 2008. La rigueur du qualitatif. Les contraintes empiriques de l'interprétation socio-anthropologique. Louvain-La-Neuve, Bruylant-Academia.

— 2010. Le culturalisme traditionaliste africaniste. Analyse d'une idéologie scientifique. Cahiers d'Études Africaines (198-199-200): 419-453.

- 2011a. Autour d'un livre: Brenda Chalfin, Neoliberal Frontiers. An Ethnography of Sovereignty in West Africa, Chicago, University of Chicago Press 2010. Le point de vue de Jean-Pierre Olivier de Sardan. Politique Africaine (123): 141-146.

— 2011b. The eight modes of local governance in West Africa. IDS Bulletin 42 (2): $22-31$.

Osborne, Thomas. 1994. Bureaucracy as a vocation. Governmentality and administration in nineteenth century Britain. Journal of Historical Sociology 7 (3): 289-313.

Raadschelders, Jos C.N. and Mark R. Rutgers. 1996. The evolution of civil service systems. In Bekke, Hans A.G., James L. Perry and Theo A.J. Toonen, eds. Civil Service Systems in Comparative Perspective. Bloomington, In., Indiana University Press, 67-99.

Randeria, Shalini. 2007. The State of globalization, legal plurality, overlapping sovereignties and ambiguous alliances between civil society and the cunning state in India. Theory, Culture \& Society 24 (1): 1-33.

Reinhard, Wolfgang. 2005. Rechtsstaat und Staatsgewalt: Historische Reflexionen. In Kappel, Rolf, Hans Werner Tobler and Peter Waldmann, eds. Rechtsstaatlichkeit im Zeitalter der Globalisierung. Freiburg, Rombach, 33-48.

Risse, Thomas, ed. 2011. Governance without a State? Policies and Politics in Areas of Limited Statehood. New York, Columbia University Press.

Schuppert, Gunnar Folke. 2010. Staat als Prozess. Eine staatstheoretische Skizze in sieben Aufzügen. Frankfurt, Campus.

Scott, James C. 1998. Seeing Like a State. How Certain Schemes to Improve the Human Condition Have Failed. New Haven, Ct., Yale University Press.

Seibel, Wolfgang. 2008. Zur Ideengeschichte des arbeitenden Staates. Contribution to the Kolloquium aus Anlass des 8o. Geburtstags von Gerhard Lehmbruch, University of Konstanz (April 18, 2008), available at: www.uni-konstanz.de/FuF/Verwiss/.../files/ SeibelIdeengeschichte.pdf, accessed on: May 1, 2013.

Sharma, Aradhana and Akhil Gupta, eds. 2006. The Anthropology of the State: A Reader. Oxford, Blackwell.

Stein, Lorenz von. 1943. Verwaltungslehre und Verwaltungsrecht (Deutsches Rechtsdenken. 11). Frankfurt, Klostermann.

Tendler, Judith. 1997. Good Government in the Tropics. Baltimore, John Hopkins University Press.

Treiber, Hubert. 2007. Moderner Staat und moderne Bürokratie bei Max Weber. In Anter, Andreas and Stefan Breuer, eds. Max Weber's Staatssoziologie. Positionen und Perspektiven. Baden-Baden, Nomos, 121-156.

Trotha, Trutz von and Jakob Rösel. 1999. Nous n'avons pas besoin d'État. Dezentralisierung und Demokratisierung zwischen neoliberaler Modernisierungsforderung, 
Parastaatlichkeit und politischem Diskurs. In Rösel, Jakob and Trutz von Trotha, eds. Dezentralisierung, Demokratisierung und die lokale Repräsentation des Staates. Köln, Köppe, $7-36$.

Tzermias, Nico. 2011. Die Erfindung der italienischen Nation. Der Einheitsstaat ist auch 150 Jahre nach seiner Gründung eine Baustelle geblieben. Neue Züricher Zeitung, no. 64 of March 17, 2011.

Waldmann, Peter. 2005. Staatsentwicklung und Rechtsstaatlichkeit: Zwischenbilanz des Diskussionsstandes. In Tobler, Hans Werner, Rolf Kappel and Peter Waldmann, eds. Rechtsstaatlichkeit im Zeitalter der Globalisierung. Freiburg, Rombach, 529-556.

Weber, Max. 1972 [orig. 1921]. Wesen, Voraussetzungen und Entfaltung der bürokratischen Herrschaft. In Weber, Max, ed. Wirtschaft und Gesellschaft. Studienausgabe. Tübingen, Mohr (Siebeck), 551-579.

Zürn, Michael and Stephan Leibfried, eds. 2005. Transformations of the State? Cambridge, Cambridge University Press. 
Thomas Bierschenk and Jean-Pierre Olivier de Sardan - 978-90-04-26496-0 Downloaded from Brill.com@4/26/2023 02:08:21PM via free access 


\title{
ETHNOGRAPHIES OF PUBLIC SERVICES IN AFRICA: AN EMERGING RESEARCH PARADIGM
}

\author{
Thomas Bierschenk and Jean-Pierre Olivier de Sardan
}

The Study of Public Services in Africa: An Invisible College?

This book is at the heart of a new and rapidly growing field, in which conventional anthropological methods (qualitative approaches, fieldwork, participant observation, interviews, etc.) are used to investigate topics usually taken up by political science, the administrative sciences or management studies.

Empirical studies of public services and 'the state at work' (von Stein, see Bierschenk and Olivier de Sardan, introduction) have, of course, been carried out for a long time. They mainly concern the Global North, where they are a focus of the political and administrative sciences and sociology rather than social anthropology. The situation with respect to the Global South, and especially Africa, is different: a comparably rich research tradition does not exist there. At the same time, however, in recent years, anthropological and ethnographic approaches have gained a special importance in the study of public services in Africa.

This chapter is about what we have learned from the literature, and how it has influenced our perspectives. We do not aim to provide a comprehensive literature review; instead, we describe the emergence of a particular research paradigm in which this book participates. The process involved could also be referred to as the formation of an invisible college of researchers who share important theoretical references and empirical perspectives on public services in Africa.

\section{Studies of Public Services, Public Policies and Public Servants IN THE GLOBAL NORTH}

Public services, public policies and public servants have been extensively studied in countries of the Global North. 
The Sociology of Organization and Bureaucracy, Administrative Sciences, Public Policy Studies

In fact, specialized academic disciplines like the sociology of organization and bureaucracy, the administrative sciences, and public policy studies, developed for that very purpose since the second half of the 2oth century. Here, we would like to draw attention to three works that have had a particular influence on us, directly or indirectly. Inspired by an already very productive American sociology of organizations (Simon 1957, 1978, March and Simon 1958, Cohen, March and Olsen 1972, see also March and Olsen 1984, 1989), Crozier (Crozier 1963, Crozier and Friedberg 1977) was one of the driving forces behind the introduction of an actor-centred approach into the study of bureaucracy in France. He showed that a formal organizational structure never completely limits actors who retain room for manoeuvre and strategic games in line with their own interests and situational definitions. Hence, the so-called 'dysfunctions' of a bureaucracy must be interpreted as the result of these strategies and games. In the absence of progressive reforms, these dysfunctions become an essential element of the system's equilibrium, resulting in deep, recurrent crises.

Second, Lipsky (1980) focused on 'street-level bureaucrats', e.g. those public servants who deal directly with the public. As the demand for their services is not fixed but tends to increase with supply, street-level bureaucrats face a chronic lack of resources, one of the reasons for the high level of employee dissatisfaction and frequent burn-out among them. Their relation to their superiors is marked by ambiguity and contradictory goals, the difficulty in measuring performance and, therefore, low accountability. As for their clients, these are mostly involuntary and consequently do not serve as primary reference groups. Against this background, the work of street-level bureaucrats is characterized by broad discretionary scope and huge autonomy from and resources for resisting organizational control. In particular, street-level bureaucrats develop strategies for rationing services, e.g. through favouritism and/or stereotyping, strategies which invariably lead to discrimination. The important conclusion drawn by Lipsky was that street level bureaucrats are not simply policy implementers but policy makers. Policy is not what is written in policy papers and organizational regulations but what street-level bureaucrats do: they, and not the administrators and politicians, make the everyday decisions about what really constitutes policy in the field. Bureaucrats have greater margins for manoeuvre than officially prescribed by the rules and they make extensive use of them. 
Third, in a study aptly sub-titled "How great expectations in Washington are dashed in Oakland; or why it is amazing that federal programs work at all", Pressman and Wildavsky (1973) argued that full implementation of a policy is extremely unlikely. The chances of implementation decrease with the rise in the number of actors involved and in the decision points that have to be successfully navigated. Therefore, the most likely outcome of a complex policy is partial or selective implementation, the unpacking of policy packages, re-purposing and other actor strategies which convert the end result into something very different to what the policy-makers had in mind. ${ }^{1}$ In other words, any empirical study of the translation of a policy into practice is likely to discover what has been described as the "implementation gap" (Lane 2009: 47 et seq.) in recent policy studies. ${ }^{2}$

Among other works that have influenced us, especially in relation to the areas of justice and education which were at the core of our research, we need to mention the highly ethnographic - and historically informedresearch carried out in France and Germany on the police ${ }^{3}$, teachers ${ }^{4}$ and justice. For example, the empirical sociology of justice has developed important ideas like the difference between the 'formal' and 'informal programme' of judges when they take decisions (Lautmann 1972), Blankenburg's (1995) observation that law and the apparatus of justice are not just 'there', working according to their formal programme, but are resources which actors first have to mobilize (for which not all social actors are equally well equipped), and the 'funnel model' as a mechanism for keeping the justice system working despite constant overload (cf. Rehbinder 2000).

\section{'Northern' Anthropology of Organizations, Bureaucracy and Public Policy}

While the aforementioned studies essentially originate from the fields of political science, the sociology of organizations and policy analysis, it should not be forgotten that an-admittedly minority-field within anthropology has also shown an interest in bureaucracy for a long time.

1 This idea was applied by Bierschenk (1988) and Olivier de Sardan (1988) to development projects in Africa and has recently been adopted and refined by Mosse (2004).

2 For the present state of implementation research, cf. Saetren (2005), Robichau and Lynn Jr. (2009).

3 Feest and Blankenburg (1972), Monjardet $(1987,1994,1996)$, Chesshyre (1989), Young (1991), Reichertz and Schröer (1992), Soeffner (1992), Behr (1999), Bouillon (2008), Elguezabal (2008).

4 Neboisa (196o), Ozouf (1967), Schefer (1969), Gauthier, Guignon and Guillot (1986), Prinz von Hohenzollern and Liedtke (1989), Ozouf and Ozouf (1992), Terhart (1993). 
In fact, from as early as the late 1920s, certain anthropologists turned their backs on 'primitive societies' to carry out research on organizations in 'developed' countries, in particular in the USA (Schwartzman 1993). William L. Warner (1941) and Eliot Chapple (1953) were pioneers in this field; Chapple was also the founding president of the Society for Applied Anthropology (later presided over by Margaret Mead), which published the journal 'Human Organization', originally called 'Applied Anthropology'. The famous (and controversial) 'Hawthorne studies' triggered the implementation of various ethnographic studies in industrial and bureaucratic work environments prior to the Second World War. Chapple (1943) also developed the concept of 'anthropological engineering' as a variant of social engineering (Bennett 1996). In the 1950s, these approaches were radicalized by the 'action anthropology' of Sol Tax (1975). In the UK, from the late 1950s, the American Hawthorne Studies inspired ethnographic research in English factories, which has become known as the "Manchester shop floor studies" (Emmert and Morgan 1987). However, mainstream anthropological circles considered these studies as too close to the theories of management and concerned with human relations within companies.

Hence, the world of work in the countries of the North only received "sporadic attention" (Schwartzman 1993: 27) up to around the 1980s when it began to attract the interest of American anthropologists with the development of research on organizations, public services, offices, hospitals, schools, companies, etc. (cf. for example, Van Maanen 1973, 1979). However, as noted by Bate (1997: 1150), this anthropology of organizations was often marked by a predilection for colourful and marginal topics: "Organizational' often turns out to be yet another marginal group: football hooligans, Greenham Common protestors, divorce court personnel, cocktail waitresses, Olympic organizing committees, funeral directors, girls scouts, dance companies, or LA punks. I mean where are the ethnographies of the health services or modern ethnographies of the shop floor?".

Nonetheless, numerous ethnographies of the 'shop floor' or the health services and other state agencies have been produced since then (and some before, for example Van Maanen 1973 on the police), and the public services in the North are now the subject of numerous publications of an anthropological (or qualitative sociological) nature. Of greatest appeal for our approach are those that develop emic perspectives and accord a central focus to the representations and practices of actors (Van Maanen 1973, 1979, Richman 1983), and those that focus on the informal face of organizations and the dialectic between formal rules and practical organizational 
cultures (Britan and Cohen 1980: 14-21). While some of these studies are neo-Marxist in orientation (Burawoy 1979, Nash 1981), others focus on the mechanisms of power (Heyman 1995, 2004). Others are inspired by the cognitive sciences (Spradley and Mann 1975) and others, again, originate from ethno-methodology (Haines 1990, Cicourel 1968). Finally, others take their inspiration from actor networks and the sociology of translation as promoted by Callon and Latour (Riles 2006, Rottenburg 2009). ${ }^{5}$

Nevertheless, due to their enormous conceptual and empirical heterogeneity, these studies did not prompt the emergence of a specific scientific field. In any event, as attested by various comparative collections (in addition to the pioneering work of Britan and Cohen 1980, see Gellner and Hirsch 2001), the vast majority of these studies concerned the Global North. Until recently, organizations in Africa remained marginal to anthropological research and received little interest. ${ }^{6}$

\section{How and by Whom Research was Done on Public Services In Africa, AND How Anthropology BecAme Involved}

A huge number of publications have been produced about the state in Africa from the 1970 s to the present day. Most of them originate from the political sciences and try to characterize the specificity of 'the African state' and African politics ${ }^{7}$ in one way or another. Nevertheless, the pungent question asked by Copans in 2001 remains fully relevant, that is whether African states are "states without civil servants?". Empirical studies about administrations, state professions, service delivery, public policy implementation, and street level bureaucrats are spectacularly lacking for Africa. Africa obviously does not have the rich tradition that Europe has in research on bureaucracy and organization, to which we referred above. Instead, in the case of Africa, we find a small and heterogeneous body of studies by various disciplines on the history of the public services, the

5 The frequently quoted study by Herzfeld (1992), the title of which highlights one of the ideal-type properties of bureaucracy ("the social production of indifference"), presents very few ethnographic data on Greek bureaucracy.

${ }^{6}$ However, some interesting recent work in the anthropology of Southern organizations and bureaucracies exists, e.g. Fuller and Bénéï (2000), Fuller and Harriss (2000), Hull (2003), Nuijten (2003), Eckert (2004, 2011); for an older study, see Conkling (1984).

7 Cf. Lonsdale (1981), Médard (1982, 1991), Rothchild and Chazan (1988), Darbon (1990), Badie (1992), Fatton (1992), Hydén and Bratton (1992), Bayart (1993), Bayart, Ellis and Hibou (1998), Reno (1998), Boone (2003), Hydén (2006), Jourde (2009), Nugent (2010). 
administrations of development and underdevelopment, the elites, and public service reforms.

\section{Historical Studies on African Public Services}

Of particular importance to the authors of this book are the existing historical studies of African colonial administrations as this is where we locate the genesis of the specific operating modes of contemporary African state administrations and their articulation of formal and practical norms (Bierschenk, Olivier de Sardan, this volume). Notwithstanding the punctual existence of patrimonial bureaucracy in pre-colonial states like Danxome and Buganda, the modern bureaucratic state was introduced during the colonial period in sub-Saharan Africa. This modern colonial state was not simply a copy of the European bureaucratic state. Rather, it combined bureaucratic modes of operation with despotic and intermediate ones (Spittler 1981, Olivier de Sardan 1984, Trotha 1994, Young 1994). ${ }^{8}$ At the same time it largely lacked the elements of citizenship and the legal form (Rechtsförmigkeit) of administration that had marked authoritarian modes of government such as Napoleonic France and Prussia, even in the 19th century. Naturally the colonial state also delivered-albeit limited and selective-public goods and services: mainly infrastructure, but also education and vocational training, health services, animal health, etc. However, due to the special conditions of colonial domination, these public goods were delivered in a special form, wrapped, so to speak, in practices of patronage, privilegism, corruption, contempt of anonymous customers - practices that differed significantly from the Weberian idealtype of bureaucracy (see Bierschenk and Olivier de Sardan, introduction, this volume) and established lifestyle routines of officials that remain virulent to the present day (Olivier de Sardan 2009). The possibilities for the uncontrolled exercise of power by colonial officials, who notably combined executive and judicative functions, were far greater than those enjoyed by their colleagues in European administrations, their privileges (official residence, cars, servants, etc.) were comprehensive and largely out of proportion to their often limited education. These privileges were scarcely merit-based, but primarily markers of social distinction. The

8 Spittler's (1981) epochal analysis of colonial administration in the French colonies of West Africa in the interwar period still awaits translation. For part of the argument, see Spittler $(1984,2004)$. Some categories of colonial public servants have been rather thoroughly studied, in particular teachers (Sabatier 1977a, 1977b, Jézéquel 2002, 2003, 2005). 
actual 'under-administration' of the colonies weakened both the possibilities of internal control of the subaltern African staff, and made it necessary to outsource many governance functions to informal-and unpaid - subcontractors, auxiliaries of the administration. Both the weak internal control and outsourcing of governance functions created a hotbed of small everyday corruption of officials (Cohen 1971, Lackner 1973, Lawrance, Osborn and Roberts 2006).

The central gateway of patrimonialism into the bureaucratic mode of government, however, was the institution of the chieftaincy. Chiefs were the street-level agents of colonial rule. Because of the underadministration already referred to, they were a necessary part of the colonial administration, which would not have been able to function without them. At the same time, however, they were held officially, as it were, to following a patrimonial logic. The practices instituted in this way still characterize African chieftaincies today and have infiltrated the public services (Blundo and Olivier de Sardan, with N. Bako-Arifari and M. Tidjani Alou 2006, Bayart 1993).

\section{Studies on African Elites}

There is very little information on the professional practices of African colonial bureaucrats in the period immediately leading up to independence and in the post-colonial period. ${ }^{9}$ The African officials of the postindependence period have been mainly studied under the label of 'African elites' (Behrends and Pauli 2012). These studies were particularly popular in the 196os and 1970s; however the topic has also remained of interest to the present day (although the concept of 'elite' is increasingly replaced by that of 'middle class'). Due to the political-economic structure of many African countries, the social groups referred to as elites were overwhelmingly products of modern, Western-style education, and, in the French colonies, consisted almost exclusively of (higher) officials, whereas in the British colonies they also included members of the free professions, in particular lawyers as well as teachers and nurses employed by the missions. Up to the 1980 s, the vast majority of secondary and university graduates went into government service. However, the studies on the African-educated elites pursued a different interest from that on which this book is based, and must therefore be regarded as a largely separated research tradition.

\footnotetext{
9 Some information can be found in Cooper (1996). For Ghana, see Lentz in this volume, for East Africa, Eckert.
} 
These studies were less concerned with the working conditions and professional practices of officials than with their social and political role in the modernization process. The main interest was in the question as to whether the Western-style educated elites would play a central role in the modernization of the newly independent states. Their lifestyles and values were seen as modern and as representative of the newly independent Africa. Issues of class formation came into focus at a later stage (do we observe increasing self-recruitment and class closure or continued high social mobility?) along with topics like urban-rural relations, clientelism, neo-patrimonialism and ethnic mobilization.

The moral connotations of the elite literature are striking; both extreme idealizations and condemnations of African elites can be found (Cohen 1981; for a more balanced view, see Werbner 2004). In the 1980s the optimistic view of the role of elites was reversed, and political science authors, in particular, highlighted the problematic role of elites and 'big men' in 'neo-patrimonial' political systems (Médard 1992) and the "reciprocal assimilation" of different categories of elites (Bayart 1993). The criticism was directed against corrupt political elites, tyrannical dictatorships and the economic self-interest of those in power, which were deemed as threatening the development of independent African states. However, the elites were not investigated 'at work', nor in their relations with administrative bodies. Leonard (1987, see below) is a rare and early exception of an author who attempted to integrate an organizational perspective with insights from these elite studies. In this book, Lentz's chapter and, to a certain extent, Eckert's show how a perspective on elites can be fruitfully interlinked with a perspective on public bureaucracies (see also Budniok 2012).

Early Administration Studies in Africa:

The Bureaucracy of Underdevelopment and Development

In the 196os and early 1970s, we also witnessed the beginnings of an African administrative science, mainly in the Anglophone regions of the continent. However, it remained embryonic, and had difficulties in shedding its normative orientations. In fact, a large part of the literature consisted of textbooks for use in the classroom at African universities and intended for the transmission of basic concepts from the administrative sciences to African administrators (cf. Adu 1964, Harris 1965, Blunt 1983, Koehn 1990). If African bureaucracies were studied empirically, more often than not it was from a deficiency perspective: the focus was on what 
African bureaucracies were not as compared with an idealized notion of Western bureaucracy (e.g. Oyugi 1985).10

However, a limited number of more empirically grounded works on the 'bureaucracy of underdevelopment' also existed which followed the lead given by Riggs (1964) and Kasfir (1969) in comparative administration studies. In terms of their orientation, these works fall into two camps (Leonard 1987: 905): on the one hand were the 'universalists' who held that the basic principles of organizational behaviour were the same everywhere, and, on the other hand, there were the 'environmentalists' who held that African administrative systems could only be understood through reference to their cultural and political environment (e.g. Price 1975, Hydén 1984). At their most extreme, the universalists would plead for the turn-key import of Western-style management techniques into African bureaucracies. The more extreme environmentalists, on the other hand, saw African public services as essentially unreformable. This led some of them (Bates 1981) to conclude that the only way forward was to reduce state activities to a minimum: public services were not the pre-condition for, but the main barrier to development and had to be replaced, wherever possible, with market mechanisms. This position-later labelled the Washington consensus - was gradually espoused by the World Bank in the 1980 os following the so-called Berg report (World Bank 1981).

Adopting a more nuanced position, which integrated 'universalist' and 'environmentalist' perspectives, and which is compatible with the approaches favoured in this book in many respects, Leonard (1987) pleaded for taking the realities of African public services as well as their social environment into account when proposing reforms from the outside rather than the wholesale import of Western-style management systems. The improvement of existing systems, he argued, was a more promising approach than wholesale replacement. ${ }^{11}$ In this, he argued against the structural amnesia

10 The irony here is that this is a contribution to a book which is very critical of overefficient and over-powering bureaucracy in the West and tends to blame it for all the evils of the modern world, including the impending nuclear holocaust. Oyugi argues the opposite case, however: i.e. that an inefficient and powerless bureaucracy is not a good thing either.

11 The dominant form of development intervention is 'starting from a clean slate', whereas Leonard argues that it might be more productive "to swim with the current of indigenous morality" (p. 904), a position recently labelled as "going with the grain in African development" (for a similar argument, see already Bierschenk and Elwert 1988). Obviously, the problem is what exactly is meant by "the grain" (or "the current"): traditionalist-culturalist visions (Kelsall 2008) can coexist with much more complex and nuanced ones (Booth 2013). 
of the development discourse and for the use of the chequered history of European administrations as an inspiration. A direct influence can be traced from this approach to the focus on 'pockets of effectiveness' as discussed by Roll (this volume; see also Roll [forthcoming]).

These early empirically-oriented administration studies are not only interesting because the structuring of the debate does not appear to have changed that much since the 1970 s and 1980 . They also gave some interesting methodological leads: at best, we have quantitative studies in which, for example, the Nigerian ombudsman system was compared, in its personnel inputs and its outputs, i.e. in terms of complaints settled, with other such systems in the world (Ayeni 1987).

In any case, this small tradition of organizational studies largely dried up in the late 1970 os and early 1980 s. It is possible to cite three reasons for this: the Marxist paradigm, which became increasingly hegemonic in development sociology, generated more interest in theories of the state than in their empirical analysis, ${ }^{12}$ the nationalist one-party systems which dominated Africa at the time rendered access difficult for researchers; and the increasingly severe economic crises that hit the continent made the undertaking of research at many African universities an increasingly unrealistic ambition.

\section{Recent Studies Carried Out in the Context of Civil Service Reforms}

In the 1990s, the anti-statist Washington Consensus was nuanced by an emphasis on 'good governance'. Consequently, various attempts were made at implementing public sector reforms in practically all African countries, all of which were essentially donor-driven. The first round of reforms, which was still inspired by the structural adjustment policies imposed on almost all African countries by the IMF since the 1980s, had led to a considerable downsizing of a supposedly overgrown civil service. With the new emphasis on good governance, attempts were made to reform supposedly 'Weberian', if imperfect, bureaucracies in accordance with the norms of New Public Management. The principles of tenure and career appointments, promotions based on qualifications, knowledge and seniority as well as that of a unified national civil service were to be

\footnotetext{
12 For an example, see the book by Godin (1986) on the "logic of the African state" which is entirely based on Beninese official government pronouncements (e.g., the idea which the Marxist-Leninist regime had of itself) rather than on an empirical investigation of how the Beninese state functioned.
} 
replaced with performance-based pay linked to specific results specified in agreement or quasi-contracts, fixed-term contracts, in particular for top officials, flexible procedures for recruitment and remuneration, the decentralization of management functions, and the unification of private and public labour regimes.

Today, even their promoters generally acknowledge that these reforms have failed (Evans 2008, World Bank 2008). However, this has not stopped the international promotion of the New Public Management package (McCourt and Minogue 2001). Although New Public Management claims to be inspired by a coherent 'neo-liberal' ideology, the techniques developed are a stack of disparate prescriptions and axioms arising from the world of Western private enterprise, American economics departments and circles of international experts (Bezes 2008). It is equally surprising how little the reformers know about the public services that they wish to reform, starting from the basic question as to whether these bureaucracies may be called 'Weberian' at all—which is, after all, the point of departure of all New Public Management reforms. Most contributions written about public service reforms in Africa over the last 20 years as reports or publications in academic journals have adopted a normative point of view, or rely on non-reliable empirical material like surveys. In many cases, even the statistics are dubious. More often than not, they are also based on poor conceptual approaches, stereotypes about culture, or very aggregate and highly disputable categories.

In other words, the reformers are at a loss to understand the organizational processes concealed behind the perceived deficiencies in the African public service. Bad reform policy is rarely acknowledged and the admission of "weak diagnostic work on the civil service" is even rarer (World Bank 200: xvi). Civil service reform turns out to be a highly ideological enterprise with only a slim empirical basis. It is not at all an example of evidence-based policy, in which the exact identification of problems leads to tailor-made proposals for reform. Instead, it is an attempt at the full-scale transposition of organizational models. These models had been developed elsewhere as a solution to specific problems found elsewhere. Leaving aside the open question as to just how successful New Public Management reforms have been in other parts of the world, it can be argued for the African context that the reforms are a case of solutions looking for problems (Naudet 1999). Bezes (2008: 20) rightly concludes that "New Public Management is often ill-suited to the institutional contexts it is supposed to reform and generates considerable adverse effects in the course of its implementation". Moreover, with regard to Africa in 
particular, it fosters "the development of bureaucratic enclaves in symbiosis with the international consultants but who leave the remainder of the administrative system intact" (ibid.).

This unsatisfactory situation has recently led to calls by political and administrative scientists for a more empirically grounded and more theoretically relevant study of African bureaucracies (Darbon 1985, Copans 2001). While only a few political and administrative scientists (Rzafindrakoto and Roubaud 2001) have responded to this challenge, it is taken up by the authors of this book, most of them anthropologists. The paradoxes of reform in particular are dealt with by several of the authors (Anders, Bierschenk, Chabi Imorou, Charton, Hamani, Muñoz), while Bergamaschi examines the ambiguous role of outside intervention in the reform process.

\section{Anthropology and African Public Services}

Within anthropology, up to the early 1990s, the few studies dealing directly and, more often, indirectly with African administrations or, more generally, the administrations in countries of the South, focused on the colonial state and its post-colonial extension in the early years of independence. It was only from the 1980s, and particularly from the 1990s, that a larger number of studies emerged, very often from the new anthropology of development, that approached various aspects of the state and public services from an empirical perspective and along the same lines as the work undertaken for this book.

In post-evolutionist anthropology, starting with Malinowski and Boas, the state was not initially an explicit topic. The great merit of this anthropology was to have shown, instead, that - contrary to what the European state theorists believed-political order is possible without the state. This anthropological discovery was made by Evans-Pritchard in southern Sudan (Evans-Pritchard 1940, see also Fortes and Evans-Pritchard 1940) and Edmond Leach (1954) in the highlands of Burma (see also Middleton and Tait 1958). Therefore, while not an explicit object of research, the state was always present as a major philosophical issue in the background of this early political-anthropological research. In this philosophical and indirect sense it may be said, therefore, that the state was the midwife of modern political anthropology. However, in line with the original-19th century - division of work between sociology and anthropology (see the introduction to Wolf 1982), most anthropologists, in continental Europe at least, remained much more interested in 'traditional' forms of politics. As 
George Balandier (1951) expressed it in his thundering critique, they were "fleeing the present".

Since the 1930s, however, British anthropology had extended its range of interest from 'traditional societies' to more contemporary topics based on a mixture of practical concerns (of colonial rule) and academic interests (Asad 1973, Parkin 1990). (As we have already pointed out, a similar shift towards the modern world took place in North American anthropology, albeit directed towards US society.) This growing concern with social change in the colonies was accompanied by a shift of attention from the Pacific to Africa, and from economic to political anthropology. The shift was indicated by the establishment of the International Institute of African Languages and Cultures (now known as the International Africa Institute) in 1926, and by Malinowski's growing interest, in his post-Trobriand phase, in issues like "practical anthropology" (Malinowski 1929), "culture contact" and "culture change" (Malinowski 1938, 1945). In the wake of this movement, and with the object of scientifically accompanying the modernization of colonial rule, the Rhodes Livingstone Institute was founded in Northern Rhodesia (today's Zambia) in 1938 for the purpose of studying social change in the colony. This was followed by the foundation of the East African Institute for Social Research (EAISR) in Kampala in 1950. In other words, anthropologists in both the RLI and the EAISR tried to work out a scientific base for public policies.

However, these 'modernist' British anthropologists were not interested in the (modern) state as such, but studied around the state, at its margins. ${ }^{13}$ When they were interested in modern forms of politics - as was the case with the Manchester school, whose shop floor studies have already been referred to above-, it was mainly on the local level and with a focus on the articulation between traditional and modern forms of politics (Evens and Handelman 2006). The transformation of the chieftaincy and its conflictive relationship with modern government structures was a favoured subject (Mair 1936, Gluckman 1948, Fallers 1955, 1956, Southwold 1960). This is also true of French Africanist research, in any case the studies developed under the influence of George Balandier (1951), who drew a

13 The question of the origin of the state remained a topic tackled by evolutionist anthropologists like Elman Service (1962), Robert L. Carneiro (1967) and Lawrence Krader (1968). For an overview of this field, see Wright (1977). There were also anthropologists like Nadel (1942), Goody (1971), Terray $(1974,1988)$ and Southall (1988) who were interested in pre-modern states. This sometimes led to a search for the 'survival' of certain of their traits in modern times and their colonial or pre-colonial origins. 
large part of his inspiration from the Manchester School. In the course of this research, political anthropology developed important concepts like clientelism, networks, political arenas, etc., which were later adopted by sociology and political science. Anthropology also developed particular competence in the study of the informal side of politics (Olivier de Sardan, this volume).

Ethnographic accounts of African public services, on the other hand, were rare. One exception is Eames's (1986) highly personal, ethnographic account of encounters in the Nigerian bureaucracy, in which she developed a notion of neo-patrimonialism, independent of Médard's (1982) famous conceptualization which the latter had adopted from Eisenstadt (1973) (see also Therkildsen, Willott, in this volume). Another early example of an ethnographic approach to African public services is found in the work of Cohen (1980), who identified the different 'patterns' characteristic of the Nigerian bureaucracy and demonstrated their links with the former colonial state.

Indirectly influenced by the Manchester School, the anthropology of development constituted another door to the empirical study of the state and public services in Africa. Anxious to break away from the culturalisttraditionalist tropism of main-stream continental anthropology, some researchers took the interventions associated with development as their main points of access to the study of African modernity. They were thus reacting to the omnipresence of development discourses among public actors, the controlling of the rural population by development projects and a growing demand for expertise in the social sciences by the development institutions. Hence, a new research paradigm emerged, in particular in African studies, that considered the development projects as arenas, in which different strategic groups confronted each other (Bierschenk and Elwert 1988), analysed the interfaces between two worlds which mobilized very different types of knowledge (Long 1989, Long and Long 1992), and applied a deliberately non-normative, non-culturalist and empirical perspective (Olivier de Sardan 2005a). While the old anthropology of development was centred on 'culture contact' (Malinowski 1945, Herskovits 1958, Bastide 1973), this new anthropology of development was characterized by an approach centred on the 'entanglement of social logics', which included both the development institutions and the target populations as objects of study. It differed markedly from other types of anthropology of development that were emerging at the same time and were based either on a 'deconstructionist' or normative approach (Bierschenk 2008a). 
The new anthropology of development, which mostly concerned African contexts and initially focused on development projects as the archetypal form of development mechanism in the period 1970-80, gradually expanded to encompass the entire palette of development interventions, from the 'brokers' to the agents of development and development bureaucracies, and from NGOs and decentralized cooperation to decentralization and public policies. ${ }^{14}$

However, in the face of the continued tendency of aid flows (particularly since the Paris Declaration in 2005) to pass through the states and their machinery, the overlaps between development interventions and state interventions, the growing adoption of a policy approach by donors, and the entanglement of state and development bureaucracies, the anthropology of development in Africa expanded quite naturally and has gradually transformed into an anthropology of public spaces and public action, which adopts both public policy interventions and the interventions by development institutions as the same object of study (Olivier de Sardan 2005 b). After all, development policies are merely a particular form of public policy that are designed, managed and financed from outside a country but implemented within it with the direct or indirect support and instrumental use (and sometimes resistance) of national public actors (Bergamaschi, this volume).

From the 1990s, an increasing number of empirical studies emerging from the anthropology of development were carried out on African administrations. In other words, the classical methods of anthropology (qualitative approaches, fieldwork, participant observation, interviews, etc.), which were used in the context of development studies, are now used to investigate topics that are usually the concern of political science, the administrative sciences and management sciences. Some of this

14 On brokers, see Bierschenk, Chauveau and Olivier de Sardan (2000), Lewis and Mosse (2006); on development agents, see Long (1989), Olivier de Sardan and Paquot (1989), Arce (1993), Mongbo (1995); on development bureaucracies, see Quarles van Ufford, Kruyt and Downing (1988), Harrison (2003), Rottenburg (2009); on NGOs and decentralized cooperation, see Jacob and Lavigne Delville (1994), Marie (2005); on decentralization and public policies, see Laurent (1995), Blundo (1998), Mosse (2004, 2005), Fay, Koné and Quiminal (2006). This progressive expansion is mirrored by the content of the APAD Bulletin (EuroAfrican Association for the Anthropology of Change and Development, Ed. Lit, Münster), which is representative of a considerable proportion of this new anthropology of development in various respects. While the history of APAD is relatively well documented, the parallel and partly overlapping history of the EIDOS network in development anthropology still needs to be recorded in writing. 
recent anthropological research has focused on specific areas of public action and the state like health, education, the judiciary, the police and others. ${ }^{15}$ Other studies also based on ethnographic fieldwork present, instead, cross-sectional analyses of the 'everyday' life of African administrations and states. ${ }^{16}$ This book is a direct extension of these recent studies and benefits from their findings.

This emerging anthropology of public policies and state bureaucracies is based on theoretical and methodological perspectives which are similar to those that marked the 'entanglement of social logics' paradigm in the anthropology of development: i.e. the focus on the diversity of actors' rationales, the non-normative perspective, the primacy accorded to empirical investigation, the use of multi-site team-based research.

There is another advance that is also worth highlighting. Following some of its precursors, the European anthropology of development had become interested in, among other things, the gap between a development project on paper, i.e. the way in which it presented itself in its documentation, its planning and methods, on the one hand, and the actual development project as it unfolded 'for real' and on the ground, on the other. In other words, it demonstrated the divergences between the objectives of a development project and its actual implementation. One of the most interesting mechanisms it discovered in this context was the "hijacking' of development projects under the impact of different logics and multiple actor strategies (Bierschenk 1988, Olivier de Sardan 1988, Smith 2003). The emerging anthropology of public action has likewise taken the policy-implementation gap as one of its main topics of interest.

15 Apart from the chapters of this book, on health, see, for example, Gobatto (1999), Jaffré and Olivier de Sardan (2003), Jaffré, with Diallo, Vasseur et al. (2009), Koerling (2011), Kroeker 2012; on education, see Bierschenk (2007), Chabi Imorou (2010a, 2010b), Fichtner (2010, 2012), Tama (2011), Willott (2011), see also recent works on the special role of teachers in producing and disseminating the state idea, e.g. Bénéï (200o), Wilson (2001); on the judiciary, see Tidjani Alou (2001, 2006), Bierschenk (2008b), Hamani (2011), Tchantipo (2012), Budniok (2012); on the police, see Beek and Göpfert (2011, 2013), Beek (2012), Göpfert (2012, 2013), Badou (2013), Bierschenk (2013); on the customs authorities, see BakoArifari (2001, 2006), Chalfin (2010); on the water and forest authorities: Blundo (2011); on collective infrastructure, see Jaglin (2005), Tidjani Alou (2009), Baron and Peyroux (2011), Beckedorf (2012); on local public tenders, see Blundo (2001, 2006); on the local state and decentralization, see Olivier de Sardan and Tidjani Alou (2009), Hahonou (2010), Olivier de Sardan (2011), Hilgers (2012).

16 Cf. for example: Oppen and Rottenburg (1995), Blundo and Olivier de Sardan et al. (2006), Smith (2006), Blundo and Le Meur (2009), Anders (2010), Hagmann and Péclard (2010). 
The importance of the divergences between the official norms and the behaviour of public actors is, in effect, a frequently highlighted characteristic of African bureaucracies and is particularly evident in the case of the 'interface' or 'street-level' bureaucracies. However, this is nothing more than a particular instance of the universal divergences that can be observed between all kinds of social prescriptions and actor behaviours (Olivier de Sardan, this volume).

Concerning Africa, the social sciences, in general, and anthropology, in particular, remained particularly reticent when it came to investigating the unexpected effects of state intervention. It is true that the creative or adaptive practices of actors developed in response to the constraints imposed on them, their tactics and strategies, their ruses and disputes, and their non-conformist, deviant, or marginal behaviours, have been studied nonetheless by anthropologists, but such a perspective was largely restricted to the domain of informality (Meagher 2010), in other words outside bureaucracies or formal organizations. The emerging research paradigm advocated in this book involves studying informality inside the state as well as the gaps between public policies and their implementation or between official norms and actual behaviour.

\section{Anthropology of Public Bureaucracies or Anthropology OF THE STATE?}

While anthropologists have been working on state-phenomena one way or another for a long time without calling it an 'anthropology of the state' (apart from the evolutionist anthropologists, see footnote 13 ), ${ }^{17}$ articles and

17 There are two books that used the term 'anthropology of the state' in their titles at a relatively early stage, however they both use this term differently to the way it is used here. Fallers (1974) is an attempt to show what anthropology can contribute to the comparative perspective on nation-building, which had become the interest of the new discipline of comparative politics, indicated by names like Shils, Almond, Verba and (the early) Geertz. The interest of this book for the perspective pursued here lies less on a thematic than on a methodological level: First, in his definition of anthropology as "science of the everyday, the ordinary" (p. 10) by which the anthropology "take(s) note of matters... that to other social scientists may seem trivial" (p. 11), second, in his refutation of the common assumption that anthropological methods are particular suited to "traditional" (in the sense of "custom-bound") societies while those of the political scientist and the sociologist are more appropriate to "modern" societies" (p. 17), and, finally, in his plea for the interdisciplinary cooperation of anthropologists with what he calls "comparative macro-sociology" (in his case largely inspired by Weber) (p. 15ff.): "One cannot", he writes, "study an elephant armed only with a microscope" (p. 20). Abélès's (1990) book likewise is 
books in which the terms 'anthropology' or 'ethnography' are combined with that of 'state' have become somewhat more common since shortly before the turn of the millennium; these started with articles (Gupta 1995, Masquelier 2001, Trouillot 2001, Ferguson and Gupta 2002) and were followed by several edited volumes (Hansen and Stepputat 2001, Das and Poole 2004, Krohn-Hansen and Nustadt 2005) and a topical reader (Sharma and Gupta 2006). We share an interest in establishing and defining a new field for anthropology with these authors. However, the research stream of which this book is an expression differs from the theoretical orientations and methodological approaches adopted in many of these texts. In particular, these studies do not all share our empirical focus. While we are interested in state apparatuses and their actors, their practices and their emic point of view, most of the recent literature on the 'anthropology of the state' prefers to stay in the 'margins' of, or 'beside', the state (Das and Poole 2004, Bellagamba and Klute 2008). Thus, it follows a classical reflex of anthropology which has always favoured the periphery. This has resulted in interesting work which draws attention to the governmental and non-governmental continuum as well as formal and informal political structures. The state (with a varying presence and reach) exists within this continuum as one of several actors, in addition to and/or in interaction or confrontation with a range of other political actors (Bierschenk and Olivier de Sardan 1997, 2003). However, to subsume all these actors under the heading of 'state' renders the notion of the state co-existent with all political forces, if not society itself.

In other words, starting from the valuable insight that the borders of the state are contested, some authors appear to conclude that there are no borders at all, and that an anthropology of the state in a stricter sense (as attempted in this book) might as well be replaced by an anthropology of governing processes in general. We argue that in such an approach the notion of the state becomes a totalizing concept by which, in the final analysis, it is impossible to think the 'outside' of the state, or the 'nonstate'. Used in this broad and overextended fashion, the concept of the state is not a tool for empirical analysis, as the authors in this book try to employ it, but, to paraphrase Martin (2002) and his search for OPNI, 'objets politiques non identifiés', it becomes instead a UTO, i.e. an 'unidentified theoretical object'.

not on the state, but is an introduction to (and plea for) political anthropology 'at home' (in this case, France), with examples drawn from the author's own research interests, e.g. elections, local politics, rituals and political language. 
The theoretical referents for these totalizing approaches are, of course, mainly Foucault (2007) and his concepts of bio-power and governmentality, and sometimes also Gramsci (1971) with his notions of hegemony and the integral state. These were authors who were less interested in the state as an ensemble of concrete actors, institutions and practices, however loosely articulated, but instead in broad macro-historical processes with a clear focus on Europe. Foucault's totalizing concept of power is particularly resistant to operationalization for empirical research. One of the effects of the predominant reference to Foucault found in some of the recent 'anthropology of the state' literature has also been to reduce the notion of the state to its political, regulatory and disciplinary practices as opposed to other functions like service delivery. This gives the impression that, in some works, the excessive referencing of Foucault and other master-thinkers, taken out of time and place, does not connote a critical and productive use of theoretical categories for empirical analysis (Bierschenk 2009). Instead, it serves the function of labelling as a strategy of academic identity politics. This becomes particularly obvious when the reference to Foucault is paralleled by an occasionally obsessive attempt to 'disprove' Weber, within a frame of reference in which Weber is presented as an 'affirmative', Foucault as a 'critical' thinker. This strategy is often based on an ignorance of Weber's original texts, and can only be explained by the very selective and biased reception of Weber in the US where his oeuvre is often reduced to Parsonian functional sociology (Cohen, Hazelrigg and Pope 1975; on Weber, see Bierschenk and Olivier de Sardan, Introduction, this volume). The differences between Foucault and Weber are also more often than not overstated in this form of academic identity politics, whereas in fact they share many perspectives. ${ }^{18}$

As far back as 1952, Kroeber and Kluckhohn (p. 146f.) criticized an overly philosophical, essentializing tradition in (US) anthropology and

18 For both, the empirical referents are late capitalism and the advanced liberal societies of Europe (not of the Global South); for both, state power is part of a wider regime of power; for both the macro-historical process of state-formation is perceived as being embedded in larger processes of disciplining and social control; for both, regimes of rules are largely actor-less; for both, consent (Weber: legitimation, Foucault: fashioning of subjectivities) is a central problem of domination; and both see the rule of the expert as a signature of modernity. As we have already pointed out (Introduction, this volume), Weber was very critical of modern bureaucratized capitalism (an "iron cage") but, unlike Marx, he saw its dominance as inevitable (thus again resembling Foucault). It could also be argued that, without more precise operationalization, Foucault's concept of governmentality is of limited use for empirical analysis as it conflates three pre-existing concepts which had been well established in sociology or psychology ('domination', 'social control' and the 'super-ego' of Freud) in one rather diffuse complex. 
argued for the study of social behaviour ('customs') which were seen as "variable, particular, plural, and empirical". It is remarkable how much an important strand of contemporary anthropology continues to shy away from empirical engagements but instead aims to produce an often second-hand philosophy. In any case, among the social sciences today, anthropology is probably the one that refers the most to the philosophical fashions of the moment: Agamben and Butler today, Foucault, Deleuze, Gramsci yesterday or the day before yesterday, and Wittgenstein the day before that. We interpret this as a strategy for defending the discursive authority of a discipline which, in the aftermath of decolonization, has lost its 'natural' object and a unifying theory (Asad 1973). In the case of the anthropology of the state, this dissolution of anthropology into a more or less speculative social theory is all the more remarkable as it shows no interest in, or is simply unaware of, major achievements in the empirical sociology of organization and bureaucracy in the Global North (to which we referred above). This ignorance appears to us to be largely the effect of a peculiar, North American disciplinary constellation. It has, however, the unfortunate effect of creating within some of 'the anthropology of the state' literature a tendency to re-invent the wheel and to present certain truisms of organizational sociology as more innovative findings than they really are: i.e. that organizations are not regulated exclusively on the basis of their formal rules, but that informal state actions are always based on a combination of formal and informal practices; that there is a difference between policy formulation and implantation, or between the formulation of law and the application of law; that state agents interpret new rules in the light of their professional experiences and corporate interests; etc. In our view, this ignorance of empirical organizational and professional sociology leads to a tendency to exoticize states of the South by comparing actual practices in the South with an idealized notion of how things work in the North.

\section{Conclusions: ToWARdS AN ETHNOGRAPHY OF MOdern States} IN AFrICA

Over the last two decades, an interest has progressively emerged in more empirically grounded analyses of statehood in Africa, in ethnographic studies of state actors, state institutions, state professions and state-making and unmaking processes, and in investigations of the many logics underlying these practices and interactions. Both the growing attendance at 
panels we organized on such topics at international conferences between 2007 and 2011 and the increasing number of doctoral theses compiled and defended by African and European scholars on these themes testify to this emerging research paradigm.

This chapter has attempted to localize this emerging paradigm within academic debates and the achievements of social science. The objective of this book is to respond to the call made by Lorenz von Stein to empirically study the state at work, from a neo-Weberian perspective and using ethnographic methods (Bierschenk and Olivier de Sardan, Introduction, this volume). Irrespective of the undeniably changing configurations of governance, law and the state, we believe - to paraphrase Karl Marxthat people have spent too much time essentializing or deconstructing the state in Africa and beyond in search for an evanescent entity, and that it is time to study it empirically. What we are interested in are the apparatuses of states, the practices of public bureaucrats and their emic perceptions, and the implementation of public policies. We are not interested in finding out 'how the state sees' (à la Scott 1998), but how public bureaucrats see their world, how they are perceived by the citizens to which they deliver services (Blundo, this volume), and how they deal on a routine basis with their hierarchy, their colleagues, other non-state institutions, and the users of public services.

\section{REFERENCES}

Abélès, Marc. 1990. Anthropologie de l'État. Paris, Armand Colin.

Adu, Amishadai L. 1964. The Civil Service in New African States. London, Allen \& Unwin.

Anders, Gerhard. 2010. In the Shadow of Good Governance. An Ethnography of Civil Service Reform in Africa. Leiden, Brill.

Arce, Alberto. 1993. Negotiating Agricultural Development: Entanglements of Bureaucrats and Rural Producers in Western Mexico (Wageningen Studies in Sociology 34), Wageningen, Agricultural University.

Asad, Talal, ed. 1973. Anthropology and the Colonial Encounter. London, Ithaca Press.

Ayeni, Victor. 1987. Nigeria's bureaucratized ombudsman system: an insight into the problem of bureaucratization in a developing country. Public Administration and Development 7 (3): 309-324.

Badie, Bertrand. 1992. L'État importé. L'occidentalisation de l'ordre politique. Paris, Fayard.

Badou, Agnes O. 2013. Socialisation professionnelle et gestion des carrières des agents de sécurité publique au Bénin. Dr. phil. dissertation, Department of Anthropology and African Studies of the Johannes Gutenberg University, Mainz.

Bako-Arifari, Nassirou. 2001. La corruption au port de Cotonou: douaniers et intermédiaires. Politique Africaine (83): $38-58$.

- 2006. "We don't eat the papers": corruption in transport, customs and the civil forces. In Blundo, Giorgio and Jean-Pierre Olivier de Sardan, eds. Everyday Corruption and the State. Citizens and Public Officials in Africa. London, Zed, 177-224. 
Balandier, Georges. 1951. La situation coloniale: approche théorique. Cahiers Internationaux de Sociologie 11: 44-79.

Baron, Catherine and Élisabeth Peyroux. 2011. Services urbains et néoliberalisme. Approches théoriques et enjeux de développement. Regards croisés sur deux terrains contrastés (Burkina Faso, Afrique du Sud). Cahiers d'Études Africaines 51 (202-203): 369-393.

Bastide, Roger. 1973. Applied Anthropology. London, Croom Helm.

Bate, S.P. 1997. Whatever happened to organizational anthropology? A review of the field of organizational ethnography and anthropological studies. Human Relations 50 (9): $1147-1175$.

Bates, Robert H. 1981. Markets and States in Tropical Africa. Berkeley, Ca., University of California Press.

Bayart, Jean-François. 1993. The State in Africa. The Politics of the Belly. New York, Longman.

Bayart, Jean-François, Stephen Ellis and Béatrice Hibou, eds. 1998. The Criminalization of the State in Africa. London, IAK \& James Currey.

Beckedorf, Anne-Sophie. 2012. Political Waters. Governmental Water Management and Neoliberal Reforms in Khartoum/Sudan. Münster, LIT.

Beek, Jan. 2012. 'There should be no open doors in the police': Criminal investigations in northern Ghana as boundary work. The Journal of Modern African Studies 50 (4): $55^{1-572 .}$

Beek, Jan and Mirco Göpfert. 2011. 'Ground work' und 'paper work': Feldzugang bei Polizeiorganisationen in Westafrika. Zeitschrift für Ethnologie 136: 189-214.

- 2013. Police violence in West Africa: Perpetrators' and ethnographers' dilemmas. Ethnography 14 (4): 477-50.

Behr, Rafael. 1999. Cop Culture. Der Alltag des Gewaltmonopols. Opladen, Leske \& Budrich.

Behrends, Andrea and Julia Pauli. 2012. Zwischen Charisma und Korruption. Kontinuitäten und Brüche in der Auseinandersetzung mit Eliten in Afrika. In Bierschenk, Thomas and Eva Spies, eds. 5o Jahre Unabhängigkeit in Afrika. Kontinuitäten, Brüche, Perspektiven. Köln, Köppe, 301-320.

Bellagamba, Alice and Georg Klute, eds. 2008. Beside the State. Emerging Forms of Power in Contemporary Africa. Köln, Köppe.

Bénéï, Véronique. 200o. Teaching nationalism in Maharashtra schools. In Fuller, C.J. and Véronique Bénéï, eds. The Everyday State and Society in Modern India. New Delhi, Social Science Press, 194-221.

Bennett, John W. 1996. Applied and action anthropology: Ideological and conceptual aspects. Current Anthropology 37 (1): 23-53.

Bezes, Philippe. 2008. Construire des bureaucraties wéberiennes à l'ère du New Public Management? Critique internationale 35 (2): 9-29.

Bierschenk, Thomas. 1988. Development projects as arenas of negotiation of strategic groups. A case study from Benin. Sociologia Ruralis 28 (2-3): 146-16o.

- 2007. L'éducation de base en Afrique de l'Ouest francophone. Bien privé, bien public, bien global. In Bierschenk, Thomas, et al., eds. Une anthropologie entre rigueur et engagement. Essais autour de l'œuvre de Jean-Pierre Olivier de Sardan. Paris, APAD-Karthala, $251^{-276 .}$

- 2008a. Anthropology and development. A historicizing and localizing approach. Working Papers of the Department of Anthropology and African Studies of the Johannes Gutenberg University Mainz, 87, available at: http://www.ifeas.uni-mainz.de/working papers/AP87a.pdf.

- 2008b. The every-day functioning of an African public service: informalization, privatization and corruption in Benin's legal system. Journal of Legal Pluralism and Unofficial Law (57): 101-139.

- 2009. Review of: Sharma, Aradhana, and Akhil Gupta, eds. 2006. The Anthropology of the State: A reader. Oxford: Blackwell. Zeitschrift für Ethnologie 134 (1): 154-158. 
— - ed. 2013. La Justice et la police dans la République du Bénin. Un résumé de rapports de recherches étudiantes effectuées dans le cadre du séminaire «La justice et la police dans la République du Bénin ». Working Papers of the Department of Anthropology and African Studies of the Johannes Gutenberg University, Mainz, 121b, available at: http://www. ifeas.uni-mainz.de/workingpapers/AP121b.pdf.

Bierschenk, Thomas, Jean-Pierre Chauveau and Jean-Pierre Olivier de Sardan, eds. 2000. Courtiers en développement. Les villages africains en quête de projets Paris, Karthala \& APAD.

Bierschenk, Thomas and Georg Elwert, eds. 1988. Aid and Development (Sociologia Ruralis vol. 28, no. 2-3) Assen, Van Borcum.

Bierschenk, Thomas and Jean-Pierre Olivier de Sardan. 1997. Local powers and a distant State in rural Central African Republic. Journal of Modern African Studies 35: 441-468.

- 2003. Powers in the village: Rural Benin between democratisation and decentralisation. Africa 73 (2): 145-173.

Blankenburg, Erhard. 1995. Mobilisierung des Rechts. Eine Einführung in die Rechtssoziologie. Heidelberg, Springer.

Blundo, Giorgio. 1998. Decentralization, Participation and Corruption in Senegal. Contribution to The fourteenth International Congress of Anthropological and Ethnographical Sciences, 26 July-1 August, Williamsburg, Va.

- 2001. Négocier l'État au quotidien: intermédiaires, courtiers et rabatteurs dans les interstices de l'administration sénegalaise. Autrepart 20: $75^{-90}$.

- 2006. Dealing with the local state. The informal privatization of street-level bureaucracies in Senegal. Development and Change 37 (4): 799-819.

- 2011. Une administration à deux vitesses. Projets de développement et construction de l'État au Sahel. Cahiers d'Études Africaines 50 (202-203): 427-452.

Blundo, Giorgio and Pierre-Yves Le Meur. 2009. The Governance of Daily Life in Africa. Ethnographic Explorations of Public and Collective Services. Leiden, Brill.

Blundo, Giorgio and Jean-Pierre Olivier de Sardan, with N. Bako-Arifari and M. Tidjani Alou. 2006. Everyday Corruption and the State. Citizens and Public Officials in Africa. London, Zed.

Blunt, Peter. 1983. Organizational Theory and Behaviour. An African Perspective. London, Longman.

Boone, Catherine. 2003. Political Topographies of the African State: Territorial Authority and Institutional Choice. Cambridge, Cambridge University Press.

Booth, David and Diana Cammack. 2013. Governance for Development in Africa. Joining Collective Action Problems. London, Zed.

Bouillon, Florence. 2008. Le squatteur, le policier, le juge et le préfet: Procédures en actes et en classements ad hoc. Contribution to the conference on L'Etat au prisme du contrôle des déviances: Plaidoyer pour une approche ethnographique, Berlin, Centre Marc Bloch, 12-15 novembre 2008.

Britan, Gerald M. and Ronald Cohen, eds. 1980. Hierarchy and Society: Anthropological Perspectives on Bureaucracy Philadelphia, Pa., Institute for the Study of Human Issues.

Budniok, Jan. 2012. The Politics of Integrity. Becoming and Being a Judge in Ghana. Dr. phil. dissertation, Department of Anthropology and African Studies of the Johannes Gutenberg University, Mainz.

Burawoy, Michael. 1979. Manufacturing Consent. Chicago, III., Chicago University Press.

Carneiro, Robert L. 1967. The Evolution of Society. Selections from Herbert Spencer's Principles of Sociology. Chicago, III., Chicago University Press.

Chapple, Eliot. 1943. Anthropological engineering: Its use to administrators. Applied Anthropology 2 (2): 23-32.

- 1953. Applied anthropology in industry. In Kroeber, Alfred L., ed. Anthropology Today. Chicago, III., Chicago University Press, 819-831.

Chabi Imorou, Azizou. 2010a. L'action politico-syndicale des enseignants au Bénin (19452008). Approche socio-historique. Working Papers of the Department of Anthropology 
and African Studies of the Johannes Gutenberg University Mainz, 111, available at: http:// www.ifeas.uni-mainz.de/92.php.

—. 2010b. Le Bénin à l'epreuve du syndicalisme enseignant. Les revendications des 'dévalorisés' et la construction de l'Etat (1945-2008). Dr. phil. dissertation, Department of Anthropology and African Studies of the Johannes Gutenberg University, Mainz.

Chalfin, Brenda. 2010. Neoliberal Frontiers. An Ethnography of Sovereignty in West Africa. Chicago, University of Chicago Press.

Chesshyre, Robert. 1989. The Force. Inside the Police. London, Sidgwick \& Jackson.

Cicourel, Aaron V. 1968. The Social Organization of Juvenile Justice. New York, Wiley.

Cohen, Abner. 1981. The Politics of Elite Culture. Explorations in the Dramaturgy of Power in a Modern African Society. Berkeley, Ca., University of California Press.

Cohen, Jere, Lawrence E. Hazelrigg and Whitney Pope. 1975. De-Parsonizing Weber: A critique of Parson's interpretation of Weber's sociology. American Sociological Review 40 (2): 229-241.

Cohen, Michael D., March, James G. and Johan P. Olsen. 1972. A garbage can model of organizational choice. Administrative Science Quarterly 17: 1-15.

Cohen, Ronald. 1980. The blessed job in Nigeria. In Britan, Gerald M. and Ronald Cohen, eds. Hierarchy and Society: Anthropological Perspectives on Bureaucracy. Philadelphia, Pa., Institute for the Study of Human Issues: $73-88$.

Cohen, William B. 1971. Rulers of Empire. The French Colonial Service in Africa, 1880-1960. Stanford, Ca., Hoover Institution Press.

Conkling, Robert. 1984. Power and change in an Indonesian government office. American Ethnologist 11: 259-274.

Cooper, Frederick. 1996. Decolonization and African Society: The Labor Question in French and British Africa. Cambridge, Cambridge University Press.

Copans, Jean. 2001. Afrique noire: un État sans fonctionnaires? Autrepart (20): 11-27.

Crozier, Michel. 1963. Le phénomène bureaucratique. Essai sur les tendances bureaucratiques des systèmes d'organisation modernes et sur leur relations en France avec le système social et culturel. Paris, Seuil.

Crozier, Michel and Erhard Friedberg, eds. 1977. L'acteur et le système Paris, Le Seuil.

Darbon, Dominique. 1985. Pour une socio-anthropologie administrative. Revue francaise d'administration publique 35: 457-468.

- 1990. L'État prédateur. Politique Africaine (39): 37-45.

Das, Veena and Deborah Poole, eds. 2004. Anthropology in the Margins of the State. London, James Currey.

Eames, Elizabeth. 1986. Navigating Nigerian bureaucracies, or 'Why can't you beg?' She demanded. In Perman, Lauri, ed. Work in Modern Society. Dubuque, IA, Kendall/Hunt, 166-172.

Eckert, Julia. 2004. Urban governance and emergent forms of legal pluralism in Mumbai. Journal of Legal Pluralism 50: 29-60.

- 2011. Work in progress: The State at work in urban India. In Schareika, Nikolaus, Eva Spies and Pierre-Yves Le Meur, eds. Aufdem Boden der Tatsachen. Festschrift für Thomas Bierschenk. Köln, Köppe, 435-447.

Eisenstadt, Samuel N. 1973. Traditional Patrimonialism and Modern Neopatrimonialism. Beverly Hills \& London, Sage Publications.

Elguezabal, Eleonora. 2008. Nos clients, les fraudeurs: les ambiguïtés du métier de contrôleur de métro. Contribution to the conference: L'Etat au prisme du contrôle des déviances: Plaidoyer pour une approche ethnographique. Berlin, Centre Marc Bloch, 12-15 November 2008.

Elwert, Georg and Thomas Bierschenk. 1988. Development aid as intervention in dynamic systems. Sociologia Ruralis 28 (2-3): 99-112.

Emmert, Isabel and David Morgan. 1982. Max Gluckman and the Manchester shop-floor ethnographies. In Frankenberg, Ronald, ed. Custom and Conflict in British Society. Manchester, Manchester University Press, 140-165. 
Evans-Pritchard, Edward E. 1940. The Nuer. A Description of the Modes of Livelihood and Political Institutions of a Nilotic People. Oxford, Oxford University Press.

Evans, Anne. 2008. Civil Service and Administrative Reform: Thematic Paper (Background Paper to Public Sector Reform: What Works and Why? An IEG Evaluation of World Bank Support) (IEG Working Paper 2008/8). Washington, D.C., The World Bank.

Evens, Terry M.S. and Don Handelman. 2006. The Manchester School. Practice and Ethnographic Praxis in Anthropology. Oxford, Berghahn.

Fallers, Lloyd A. 1955. The predicament of the modern African chief: an instance from Uganda. American Anthropologist 57: 290-305.

- 1956. Bantu Bureaucracy. A Study of Integration and Conflict in the Political Institutions of an East African People. Cambridge, Heffer.

- 1974. The Social Anthropology of the Nation-State. Chicago, III., Aldine.

Fatton, Robert. 1992. Predatory Rule: State and Civil Society in Africa. Boulder, Co., Lynn Rienner.

Fay, Claude, Félix Y. Koné and Catherine Quiminal, eds. 2006. Décentralisation et pouvoirs en Afrique. Paris, IRD Editions.

Feest, Johannes and Erhard Blankenburg. 1972. Die Definitionsmacht der Polizei. Strategien der Strafverfolgung und soziale Selektion. Düsseldorf, Bertelsmann Universitätsverlag.

Ferguson, James and Akhil Gupta. 2002. Spatializing states: Towards an ethnography of neoliberal governmentality. American Ethnologist 29 (4): 981-1002.

Fichtner, Sarah. 2010. A laboratory for education reform or a battlefield of donor intervention? Local debates on primary education and the New Study Programmes in Benin. International Journal of Educational Development 30: 518-524.

- 2012. The NGOisation of Education. Case Studies from Benin. Köln, Köppe.

Fortes, Meyer and Edward E. Evans-Pritchard, eds. 1940. African Political Systems. London, International African Institute.

Foucault, Michel. 2007. Governmentality. In Burchell, C., C. Gordon and Peter Miller, eds. The Foucault Effect. Studies in Governmentality. Chicago, III., University of Chicago, 87-104.

Fuller, Chris J. and Véronique Benéi, eds. 200o. The Everyday State in Modern India. New Delhi, Social Science Press.

Fuller, Chris J. and John Harriss. 2000. For an anthropology of the modern Indian State. In Fuller, C.J. and V. Bénéï, eds. The Everyday State in Modern India. New Delhi, Social Science Press, $1-30$.

Gauthier, Nicole, Guignon, Catherine and Maurice-Antoine Guillot. 1986. Les Instits. Enquête sur l'école primaire. Paris, Le Seuil.

Gellner, David N. and Eric Hirsch, eds. 2001. Inside Organizations. Anthropologists at Work. Oxford, Berg.

Gluckman, Max. 1948. The village headman in British Central Africa. Africa 19: 89-106.

Gobatto, Isabelle. 1999. Être médecin au Burkina Faso: dissection sociologique d'une transplantation professionnelle. Paris, L'Harmattan.

Godin, Francine. 1986. Benin 1972-1982. La logique de l'État africaine. Paris, L'Harmattan.

Goody, Jack. 1971. Technology, Tradition and the State in Africa. London, Cambridge University Press.

Göpfert, Mirco. 2012. Security in Niamey. An anthropological perspective on policing and an act of terrorism in Niamey. Journal of Modern African Studies 50 (1): 53-74.

- 2013. Bureaucratic aesthetics. Report writing in the Nigérien gendarmerie. American Ethnologist 40 (2): 324-334.

Gramsci, Antonio. 1971 [orig. about 1930]. Selections from the Prison Notebooks. New York, International Publishers.

Gupta, Akhil. 1995. Blurred boundaries: The discourse of corruption, the culture of politics and the imagined state. American Ethnologist 22 (2): 375-402.

Hagmann, Tobias and Didier Péclard. 2010. Negotiating statehood. Dynamics of power and domination in Africa. Development and Change 41 (4): 539-562. 
Hahonou, Eric K. 2010. Démocratie et culture politique en Afrique. En attendant la décentralisation au Niger. Saarbrücken, Editions Universitaires Européennes.

Haines, David W. 1990. Conformity in the face of ambiguity: A bureaucratic dilemma. Semiotica $78(3-4): 249-269$.

Hamani, Oumarou. 2011. Les modes de régulation de l'appareil judiciaire nigérien, Thèse de doctorat, Ecole des Hautes Etudes en Sciences Sociales, Paris/Marseille.

Hansen, Thomas Blom and Finn Stepputat, eds. 2001. States of Imagination: Ethnographic Explorations of the Postcolonial State. Durham, Duke University Press.

Harris, Richard L. 1965. The role of the civil servant in West Africa. Public Administration Review 25 (4): 308-313.

Harrison, Elizabeth. 2003. The monolithic development machine? In Ufford, Philip Quarles van and Ananta Kumar Giri, ed. A Moral Critique of Development. In Search of Global Responsiblities. London, New York, Routledge, 101-117.

Herskovits, Melville J. 1958. Acculturation: The Study of Culture Contact. Gloucester, Mass., Smith.

Herzfeld, Michael. 1992. The Social Production of Indifference. Exploring the Symbolic Roots of Western Bureaucracy. Chicago, Ill., University of Chicago Press.

Heyman, Josiah McC. 1995. Putting power in the anthropology of bureaucracy: the immigration and naturalization service at the Mexiko-United States border. Current Anthropology 36 (2): 261-287.

- 2004. The anthropology of power-wielding bureaucracies. Human Organization 63 (4): 487-500.

Hilgers, Mathieu. 2012. Contribution à une anthropologie des villes secondaires. Cahiers d'Études Africaines (205): 29-55.

Hull, Matthew S. 2003. The file. Agency, authority and autography in an Islamabad bureaucracy. Language and Communication 23: 287-314.

Hydén, Göran. 1984. No Shortcut to Progress. African Development Management in Perspective. London, Heinemann.

- 2006. African Politics in Comparative Perspective. Cambridge, Cambridge University Press.

Hydén, Göran and Michael Bratton, eds. 1992. Governance and Politics in Africa. Boulder, Co., Lynne Rienner.

Jacob, Jean-Pierre and Philippe Lavigne Delville, eds. 1994. Les association paysannes en Afrique. Organisation et dynamiques. Paris, APAD \& Karthala \& IUED.

Jaffré, Yannick, with Yveline Diallo, Patricia Vasseur, et al. 2009. La bataille des femmes. Analyse anthropologique de la mortalité maternelle dans quelques services d'obstétrique d'Afrique de l'Ouest. Paris, Éditions Faustroll.

Jaffré, Yannick and Jean-Pierre Olivier de Sardan, eds. 2003. Une médecine inhospitalière. Les difficiles relations entre soignants et soignés dans cinq capitales d'Afrique de l'Ouest Paris, Karthala.

Jaglin, Sylvy. 2005. Services d'eau en Afrique subsaharienne: la fragmentation urbaine en question. Paris, Editions CNRS.

Jézéquel, Jean-Hervé. 2002. 'Les mangeurs de craie'. Socio-histoire d'une catégorie lettrée à l'époque coloniale. Les instituteurs diplômés de l'École normale William Ponty. Thèse de doctorat, École des Hautes Études en Sciences Sociales, Paris.

- 2003. 'Les enfants du hasard'. Les voies d'accès à l'école à l'epoque coloniale. Le cas des diplômés de l'Ecole normale William Ponty. Cahiers de la Recherche sur l'Éducation des Savoirs 2: 173-200.

- 2005. Les enseignants comme élite politique en AOF (1930-1945). Des 'meneurs de galopins' dans l'arène politique. Cahiers d'Études Africaines 45 (178): 519-543.

Jourde, Cédric. 2009. Les grilles d'analyse de la politique africaine: la problématique de l'Etat. In Gazibo, Mamoudou and Céline Thiriot, eds. Le politique en Afrique. Etats des débats et pistes de recherche. Paris, Karthala.

Kasfir, Nelson. 1969. Development administration in Africa. The balance between politics and administration. Canadian Journal of African Studies 3 (1): 94-103. 
Kelsall, Tim. 2008. Going with the Grain in African Development? (Power and Politics in Africa Programme Discussion Paper 1). London, DFID.

Koehn, Peter H. 1990. Public Policy and Administration in Africa: Lessons from Nigeria. Boulder, Co., Westview.

Koerling, Gabriella. 2011. In Search of the State. An Ethnography of Public Service Provision (Uppsala Studies in Cultural Anthropology. 51). Uppsala, University of Uppsala.

Krader, Lawrence. 1968. Formation of the State. Englewood Cliffs, NJ, Prentice Hall.

Kroeber, Alfred L. and Clyde Kluckhohn. 1952. Culture. A Critical Review of Concepts and Definitions. New York, Vintage.

Kroeker, Lena. 2012. From global policies to local practices: Behavioural advice for the prevention of mother-to-child transmission of HIV. Sociologus 62 (1): 47-71.

Krohn-Hansen, Christian and Knut Nustadt, eds. 2005. State Formation: Anthropological Perspectives London, Pluto Press.

Lackner, Helen. 1973. Colonial administration and social anthropology: Eastern Nigeria, 1920 -1940. In Asad, Talal, ed. Anthropology and the Colonial Encounter. London, Ithaca Press, 123-151.

Lane, Jan-Erik. 2009. State Management: An Enquiry into Models of Public Administration. London, Routledge.

Laurent, Pierre-Joseph. 1995. Les pouvoirs politiques locaux et la décentralisation au Burkina Faso (Cahiers du CIDEP. 26). Louvain-la-Neuve \& Paris, L'Harmattan \& Academia.

Lautmann, Rüdiger. 1972. Justiz-Die stille Gewalt. Teilnehmende Beobachtung und entscheidungssoziologische Analyse. Frankfurt/Main, Athenäum Fischer.

Lawrance, Benjamin Nicholas, Emily Lynn Osborn and Richard L. Roberts, eds. 2006. Intermediaries, Interpreters and Clerks: African Employees in the Making of Colonial Africa Madison, Wi., University of Wisconsin Press.

Leach, Edmund R. 1954. Political Systems of Highland Burma. A Study of Kachin Social Structure. London, Athlone.

Leonard, David K. 1987. The political realities of African management. World Development 15: 899-910.

Lewis, David and David Mosse, eds. 2006. Development Brokers and Translators. The Ethnography of Aid and Agencies. Bloomfield, Ct., Kumarian.

Lipsky, Michael. 1980. Street-Level Bureaucracy. Dilemmas of the Individual in Public Services. New York, Russel Sage Foundation.

Long, Norman, ed. 1989. Encounters at the Interface. A Perspective on Social Discontinuities in Rural Development. Wageningen, Agricultural University.

Long, Norman and Ann Long, eds. 1992. Battlefields of Knowledge. The Interlocking of Theory and Practice in Social Research and Development. London, Routledge.

Lonsdale, John. 1981. States and social processes in Africa: a historiographical survey. African Studies Review 24 (2/3): 139-225.

Mair, Lucy P. 1936. Chieftainship in modern Africa. Africa 9 (3): 305-316.

Malinowski, Bronislaw. 1929. Practical anthropology. Africa 2: 22-38.

- 1938. Introductory essay on the anthropology of changing African cultures. In International Institute of African Languages and Cultures, ed. Methods of Study of Culture Contact in Africa (Memorandum 15). London, Oxford University Press: vii-xxxvii.

- 1945. The Dynamics of Cultural Change. An Inquiry into Race Relations in Africa. New Haven, Ct., Yale University Press.

March, James G. and Johan P. Olsen. 1984. The new institutionalism: organizational factors in political life. The American Political Science Review 78: 734-749.

- 1989. Rediscovering Institutions. The Organizational Basis of Politics. New York, Free Press.

March, James G. and Herbert Simon. 1958. Organisations. New York, Wiley.

Marie, Alain. 2005. La coopération décentralisée et ses paradoxes. Paris, Karthala.

Martin, Denis-Constant, ed. 2002. Sur la piste des OPNI (Objets Politiques Non Identifiés). Paris, Karthala. 
Masquelier, Adeline. 2001. Behind the dispensary's prosperous facade: Imagining the state in rural Niger. Public Culture 13 (2): 267-291.

McCourt, Willy and Martin Minogue. 2001. The Internationalization of Public Management: Reinventing the Third World State. Cheltenham (UK), Edward Elgar.

Meagher, Kate. 2010. Identity Economics: Social Networks and the Informal Economy in Nigeria. Woodbridge, Suffolk, James Currey.

Médard, Jean-François. 1982. The underdeveloped state in tropical Africa: political clientelism or neo-patrimonialism? In Clapham, Christopher, ed. Private Patronage and Political Power. London, Pinter: 162-192.

- 1991. L'État néo-patrimonial en Afrique noire. In Médard, Jean-François, ed. États d'Afrique noire. Formation, mécanismes et crise. Paris, Karthala: 323-353.

—. 1992. Le big man en Afrique. Esquisse d'analyse du politicien entrepreneur. L'annee sociologique 42.

Middleton, David and David Tait, eds. 1958. Tribes without Rulers London, Routledge \& Kegan.

Mongbo, Roch L. 1995. The Appropriation and Dismembering of Development Intervention. Policy, Discourse and Practice in the Field of Rural Development in Benin. Ph.D. dissertation, Wageningen, Agricultural University.

Monjardet, Dominique. 1987. Compétence et qualification comme principe d'analyse de l'action policière. Sociologie du Travail 29 (1): 47-58.

- 1994. La culture professionnelle des policiers. Revue francaise de sociologie 35 (3): 393-411.

-1996. Ce que fait la police. Sociologie de la force publique. Paris, La Découverte.

Mosse, David. 2004. Is good policy unimplementable? Reflections on the ethnography of aid policy and practice. Development and Change 35 (4): 639-671.

- 2005. Cultivating Development. An Ethnography of Aid Policy and Practice. London, Pluto.

Nadel, Siegfried F. 1942. A Black Byzantium. The Kingdom of Nupe in Nigeria. Oxford, Oxford University Press.

Nash, June. 1981. Ethnographic aspects of the capitalist system. Annual Review of Anthropology 10: $393-423$.

Naudet, Jean-David. 1999. Trouver des problèmes aux solutions. Vingt ans d'aide au Sahel. Paris, OECD.

Neboisa, Marianne. 1960. Die Lehrerin im Dorfe. Eine Untersuchung ihrer Arbeits- und Lebenswirklichkeit. Bad Heilbrunn, Klinkhardt.

Nugent, Paul. 2010. States and social contracts in Africa. New Left Review (63): 35-68.

Nuijten, Monique. 2003. Power, Community and the State. The Political Anthropology of Organisation in Mexico. London, Pluto Press.

Olivier de Sardan, Jean-Pierre. 1984. Les sociétés songhay-zarma (Niger-Mali). Chefs, guerriers, esclaves, paysans... Paris, Karthala.

- 1988. Peasant logics and development project logics. Sociologia Ruralis $28(2-3)$ : 216-226.

- 2005a. Anthropology and Development. Understanding Contemporary Social Change. London, Zed.

- 2005b. Classic ethnology and the socio-anthropology of public spaces in Africa. Africa Spectrum 40 (3): 485-497.

. 2009. State bureaucracy and governance in West francophone Africa. Empirical diagnosis, historical perspective. In Blundo, Giorgio and Pierre Yves Le Meur, eds. The Governance of Daily Life in Africa. Ethnographic Explorations of Public and Collective Services. Leiden, Brill, 39-71.

- 2011. Local powers and the co-delivery of public goods in Niger. IDS Bulletin 42 (2): $32-42$.

Olivier de Sardan, Jean-Pierre and Elisabeth Paquot, eds. 1989. D'un savoir à l'autre. Paris, La Documentation Francaise/GRET. 
Olivier de Sardan, Jean-Pierre and Mahaman Tidjani Alou, eds. 2009. Les pouvoirs locaux au Niger. Tome 1: A la veille de la décentralisation Paris, CODESRIA-Karthala.

Oppen, Achim von and Richard Rottenburg, eds. 1995. Organisationswandel in Afrika: Kollektive Praxis und kulturelle Aneignung (Studien des Forschungsschwerpunkts Moderner Orient. 2). Berlin, Das Arabische Buch.

Oyugi, Walter Ouma. 1985. Zivile Bürokratie in Afrika nach der Unabhängigkeit: Eine kritische Analyse von Rollenausübung. In Diamond, Stanley and Wolf-Dieter Narr, eds. Bürokratie als Schicksal? Opladen, Westdeutscher Verlag, 197-215.

Ozouf, Jacques. 1967. Nous, les maîtres d'école. Autobiographies d'instituteurs de la Belle Époque. Paris, Juillard.

Ozouf, Jacques and Mona Ozouf. 1992. La République des instituteurs. Paris, Gallimard \& Le Seuil.

Parkin, David. 1990. Eastern Africa: the view from the office and the voice from the field. In Fardon, Richard, ed. Localizing Strategies: Regional Traditions of Ethnographic Writing. Edinburgh \& Washington, D.C., Scottish Academic Press \& Smithonian Institution Press, $182-203$.

Pressman, Jeffrey L. and Aaron Wildavsky. 1973 [third ed. 1984]. Implementation. How Great Expectations in Washington Are Dashed in Oakland; Or Why It Is Amazing That Federal Programs Work At All, This Being a Saga of the Economic Development Administration as Told by Two Sympathetic Observers Who Seek to Build Morals on a Foundation of Ruined Hopes. The Oakland Project. Berkeley, Ca., University of California Press.

Price, Robert M. 1975. Society and Bureaucracy in Contemporary Ghana. Berkeley, Ca., University of California Press.

Prinz von Hohenzollern, Johann Georg and Max Liedtke, eds. 1989. Schreiber, Magister, Lehrer. Zur Geschichte und Funktion eines Berufsstandes. Bad Heilbrunn, Klinkhardt.

Quarles van Ufford, Philip, P. Dirk Kruyt and Theodore Downing, eds. 1988. The Hidden Crisis in Development: Development Bureaucracies. Amsterdam, Free University Press.

Rehbinder, Manfred. 20oo. Rechtssoziologie. München, Beck.

Reichertz, Jo and Norbert Schröer, eds. 1992. Polizei vor Ort. Studien zur empirischen Polizeiforschung. Stuttgart, Enke.

Reno, William. 1998. Warlord Politics and African States. Boulder, Lynne Rienner.

Richman, Joel. 1983. Traffic Wardens. An Ethnography of Street Administration. Manchester, Manchester University Press.

Riggs, Fred W. 1964. Administration in Developing Countries. The Theory of Prismatic Society. Boston, Ma., Houghton Mifflin.

Riles, Annelise. 2006. Documents: Artifacts of Modern Knowledge. Ann Arbor, Mi., University of Michigan Press.

Robichau, Robbie and Laurence Lynn Jr. 2009. The implementation of public policy: Still the missing link. The Policy Studies Journal 37: 21-36.

Roll, Michael, ed. (forthcoming). The Politics of Public Sector Performance: Pockets of Effectiveness in Developing Countries. London: Routledge.

Rothchild, Donald and Naomi Chazan, eds. 1988. The Precarious Balance. State and Society in Africa. Boulder, Co., Lynne Rienner.

Rottenburg, Richard. 2009. Far-Fetched Facts. A Parable of Development Aid. Boston, Ma., MIT Press.

Rzafindrakoto, Mireille and François Roubaud. 2001. Vingt ans de réforme de la fonction publique à Madagascar. Autrepart 20: 43-6o.

Sabatier, Peggy R. 1977a. Educating a Colonial Elite. The William Ponty school and its graduates. Ph.D. dissertation, University of Chicago, III.

—. 1977b. 'Elite education' in French West Africa. The era of limits, 1903-1945. International Journal of African Historical Studies 11 (2): 247-266.

Saetren, Harald. 2005. Facts and myths about research on public policy implementation: out-of-fashion, allegedly dead, but still very much alive and relevant. The Policy Studies Journal 33 (4): 559-582. 
Schefer, Gerwin. 1969. Das Gesellschaftsbild des Gymnasiallehrers. Eine Bewußtseinsanalyse des deutschen Studienrats. Frankfurt/ Main, Suhrkamp.

Schwartzman, Helen. 1993. Ethnography in Organizations. Newbury Park, Sage.

Scott, James C. 1998. Seeing Like a State. How Certain Schemes to Improve the Human Condition Have Failed. New Haven, Ct., Yale University Press.

Service, Elman R. 1962. Primitive Social Organization. An Evolutionary Perspective. New York, Random House.

Sharma, Aradhana and Akhil Gupta, eds. 2006. The Anthropology of the State: A Reader Oxford, Blackwell.

Simon, Herbert A. 1957. Models of Man: Social and Rational. New-York, Wiley.

- 1978. Rationality as process and as product of thought. American Economic Review $68(2): 1-16$.

Smith, Daniel J. 2003. Patronage, per-diems and the workshop mentality: the practice of family planning programs in Southeastern Nigeria. World Development 31 (4): 703-715.

- 2006. A Culture of Corruption: Everyday Deception and Popular Discontent in Nigeria. Princeton, NJ, Princeton University Press.

Soeffner, Hans-Georg. 1992. Wahrheit und Entscheidung. Polizeiliche und juridische Wahrheitsfindung. In Reichertz, Jo and Norbert Schröer, eds. Polizei vor Ort. Studien zur empirischen Polizeiforschung. Stuttgart, Ferdinand Enke, 205-221.

Southall, Aidan. 1988. The segmentary state in Africa and Asia. Comparative Studies in Society and History 30 (1): 52-88.

Southwold, Martin. 1960. Bureaucracy and Chieftainship in Buganda (East African Studies. 14). London, Kegan Paul.

Spittler, Gerd. 1981. Verwaltung in einem afrikanischen Bauernstaat. Das koloniale Französisch-Westafrika 1919-39. Wiesbaden, Steiner.

- 1984. Peasants, the administration and rural development. Sociologia Ruralis 24: 7-29.

- 2004. Administrative despotism in peasant societies. In Jenkins, Bill and Edward C. Page, eds. The Foundations of Bureaucracy in Economic and Social Thoughts, Vol. 1. Cheltenham/Northampton, 339-350.

Spradley, James P. and Brenda E. Mann. 1975. The Cocktail Waitress. Women's Work in a Man's Place. New York, Wiley.

Tama, Clarisse. 2011. Les enseignants de l'école primaire au Bénin. Transformations d'un groupe professionnel. Dr. phil. dissertation, Department of Anthropology and African Studies of the Johannes Gutenberg University, Mainz.

Tax, Sol. 1975. Action anthropology. Current Anthropology 16 (4): 514-517.

Tchantipo, Sai Sotima. 2013. Normes officielles, normes pratiques et stratégies des acteurs dans le service public de justice au Bénin. Dr. phil. dissertation, Department of Anthropology and African Studies of the Johannes Gutenberg University, Mainz.

Terhart, Ewald. 1993. Lehrerbiographien. In König, E. et al., ed. Bilanz qualitativer Forschung. Weinheim, Deutscher Studien Verlag, 225-264.

Terray, Emmanuel. 1974. Long-distance exchange and the formation of the state: The case of the Abron Kingdom of Gyaman. Economy and Society 3 (3): 315-345.

— 1988. Le debat politique dans les royaumes de l'Afrique de l'Ouest. Enjeux et formes. Revue française de science politique 38 (5): 720-731.

Tidjani Alou, Mahaman. 2001. La justice au plus offrant. Les infortunes du système judiciaire en Afrique (autour du cas du Niger). Politique Africaine (83): 59-78.

- 2006. Corruption in the legal system. In Blundo, Giorgio and Jean-Pierre Olivier de Sardan, eds. Everyday Corruption and the State. Citizens and Public Officials in Africa. London, Zed, $137^{-176 .}$

- 2009. Public goods and the management of collective infrastructure: The case of the drinking- water supply systems in the Maradi region of Niger. In Blundo, Giorgio and Pierre-Yves Le Meur, eds. The Governance of Daily Life in Africa. Ethnographic explorations of public and collective services. Leiden, Brill, 317-339. 
Trotha, Trutz von. 1994. Koloniale Herrschaft. Zur soziologischen Theorie der Staatsentstehung am Beispiel des Schutzgebietes Togo. Tübingen, Mohr.

Trouillot, Michel-Rolph. 2001. The anthropology of the state in the age of globalization. Close encounters of the deceptive kind. Current Anthropology 41 (1): 125-138.

Van Maanen, John. 1973. Observations on the making of policemen. Human Organization 32: 407-418.

-1979. Reclaiming qualitative methods for organisational research. Administrative Science Quarterly 24: 520-526.

Warner, William L. and Josiah O. Low. 1941. The Social System of the Modern Factory. New Haven, Ct., Yale University Press.

Werbner, Richard P. 2004. Reasonable Radicals and Citizenship in Botswana. Bloomington, In., Indiana University Press.

Willott, Chris. 2011. 'Get to the bridge and I will help you to cross'. Merit, personal connections and money in the access to Nigerian higher education. Africa Spectrum 46 (1): $85^{-108 .}$

Wilson, Fiona. 2001. In the name of the state? Schools and teachers in an Andean province. In Hansen, Thomas B. and Finn Stepputat, eds. States of Imagination. Ethnographic Explorations of the Postcolonial State. Durham, NC, Duke University Press, 313-342.

Wolf, Eric R. 1982. Europe and the People Without History. Berkeley, Ca., University of California Press.

World Bank. 1981. Accelerated Development in Sub-Saharan Africa: An Agenda for Action. Washington, DC, World Bank.

. 2008. Public Sector Reform: What Works and Why. An Independent Evaluation Group Evaluation of World Bank Support. Washington, D.C., World Bank.

Wright, Henry T. 1977. Recent research on the origin of the state. Annual Review of Anthropology 6: 379-394.

Young, Crawford. 1994. The African Colonial State in Comparative Perspective. New Haven, Ct., Yale University Press.

Young, Malcolm. 1991. An Inside Job. Policing and Police Culture in Britain. Oxford, Clarendon Press. 
Thomas Bierschenk and Jean-Pierre Olivier de Sardan - 978-90-04-26496-0 Downloaded from Brill.com@4/26/2023 02:08:21PM via free access 
PART TWO

BUREAUCRATS AT WORK 
Thomas Bierschenk and Jean-Pierre Olivier de Sardan - 978-90-04-26496-0 Downloaded from Brill.com@4/26/2023 02:08:21PM via free access 


\title{
SEEING LIKE A STATE AGENT: \\ THE ETHNOGRAPHY OF REFORM IN SENEGAL'S FORESTRY SERVICES
}

\author{
Giorgio Blundo
}

13 April 2005, Ngor Diarama Hotel, Dakar, Validation Forum of the Forest Action Plan: The director of Senegalese Forestry Department takes the floor welcoming a new stage in environmental policy in Senegal: from now on, the rural population and the municipalities will be given new responsibilities in the area of forest management and the forestry service must support them. 'Participation' and 'local management' are the buzzwords of the several workshops that take place in the afternoon. However, during the breaks, another issue is the object of a considerable behind-the-scenes gossip among the foresters: after endless negotiations, the Senegalese government has finally enacted a law reforming their status. They are now a full paramilitary body and, as a result, they lose their voting rights but double their salaries. At lunch, tempers flare. A Senegalese forestry expert working for a German project is against this reform, which he considers to be in contradiction with the new participative credo popularized by the decentralization reform. A regional inspector retorts that those who do not agree with 'militarization' need only resign from office. Moreover, who would be so foolish as to refuse a salary increase? To hell with the civil rights we are going to lose! At least the other military bodies will finally respect us!

The first day, most of foresters were in uniform. The second day, the majority wore civilian clothes.

This account sets the scene for this chapter, which focuses on the recent evolution and daily functioning of the forestry services in Senegal. This extract from my field notes refers to the internal debates that inflamed passions among the foresters, who had been confronted with two recent and apparently contradictory reforms: decentralization and militarization. These reforms appeared to aggravate the dilemma between a role involving the protection of environmental resources using repression and penalties (echoing the colonial forestry policy) and a new 'participative' role, which would transform the forestry agents into technical advisers of the producers and the local elected representatives. In my view, these two reforms, one of which has been imposed on the forestry services and the other desired by them for a long time, provide a good starting point for analysing how the state is 'seen' and 'done' by a specific segment of its bureaucracies (Migdal and Schlichte 2005). 
It is indeed timely to reverse the perspective presented by James Scott in Seeing like a State (1998): instead of considering the state as a unified source of intentions, policies and coherent plans that is capable of making a shifting and complex social world 'legible', I seek, first, to render the state itself legible by observing it through the concrete practices of its officials. Second, I enquire whether civil servants 'see' in the same way as the state.

The question here is not merely one of filling an empirical gap. A comprehensive anthropology of the state cannot confine itself to describing the ways in which the idea of the state is embedded in local societies and the expectations, representations and fantasies associated with it (Gupta 1995, Hansen and Stepputat 2001, Masquelier 2001), or exploring the state's margins or interstices (Das and Poole 2004) — both of which are among the favourite themes of contemporary political anthropology. The inquiry 'around the state' must be complemented by an inquiry into the 'core of the state' that focuses on the daily functioning of state apparatuses and describes the mundane practices of state-making.

\section{THE ETHNOGRAPHY OF THE 'BUREAUCRATS IN UNIFORM'}

Against this background, in 2005 I embarked on a comparative study of the forestry departments in my two principal research areas, i.e. Niger and Senegal. ${ }^{1}$ The forestry service offers a fruitful point of access for an ethnographic exploration of the everyday functioning of the state in Africa.

To begin with, the institution has a rich historical past. Founded in the 1930s, it was among the first colonial bodies and, for a long time, represented one of the rare manifestations of the state's presence in the countryside. For this reason, it is also one of the strongest sources of people's representations of the state.

Second, like customs officers, policemen and gendarmes, forestry agents belong to the huge proportion of African state employees whose main characteristic is that they are 'bureaucrats in uniform', i.e. "administrative

1 To date I have conducted ten research trips, initially in the framework of a research project financed by CIRAD, then on a study of the "local State" in collaboration with LASDEL (Niamey) and, ultimately, as head of the State Bureaucracies research stream of the Africa Power and Politics programme led by a consortium of research institutions headed by the Overseas Development Institute and funded by the UK Department for International Development (DFID) and Irish Aid. The ideas expressed here do not necessarily reflect the views of DFID, ODI or Irish Aid. 
agents who have the task of enforcing the law through the legal use of violence" (Blundo and Glasman, forthcoming). However, its work places the forestry department at the heart of the production of essential public goods and services in the environmental sector (reforestation, soil regeneration, combating desertification, the protection of forest reserves and national parks, the rational exploitation of forest resources to supply timber and charcoal for urban areas, etc.). Being caught in a dilemma between protecting environmental resources using suppression, law enforcement and sanctions and their new 'participative' role, which has been strengthened by recent decentralization reforms, forestry services represent simultaneously a suppressive state and a state as provider of services. "For this reason, they should not be studied only as violence specialists, but also as state agents. They represent some specific segments of the state and need to be analysed with the same perspectives and methods we adopt when studying the 'civilian' bureaucracies" (Blundo and Glasman, forthcoming).

Third, forestry services are a 'two speed' bureaucracy (Blundo 2011a): a 'traditional administration' financed by the single state budget and often condemned to inactivity coexists with an administration sustained by development aid that offers its agents both better working conditions and an additional income. This constitutes a crucial element of statutory difference within the service. Observing these dynamics provides insightful examples about the impact of international aid policies on state-building in Africa.

Finally, forestry services crystallize some of the tensions and contradictions that characterize contemporary African public administrations. Although they establish their legitimacy through a mastery of technical and scientific knowledge, this legitimacy is strongly contested by partisan, patronage and economic networks and lobbies. Moreover, they illustrate the informal privatization of public administrations. Forestry services are an important site of the production and reproduction of informality: in fact, the inadequacy of official norms as a guide for the behaviour of officials leads to the production of informal, practical norms to ensure the functioning of a service (Blundo 2012; see also Olivier de Sardan, this volume).

Although forestry agents are present across the national territories, they constitute a relatively manageable group for the researcher-totalling around 500 in Senegal and 770 in Niger. Due to the freezing of public appointments between 1990 and 2006, they are an ageing group and, in some significant respects, a bureaucratic example of 'face-to-face societies' 
as studied by classical works of anthropology. They were trained in the same establishments. Frequent transfers gave rise to recurrent interactions and exchanges; practically everyone knows everyone else. Hence, it is not very difficult to ascertain facts about delicate matters such as political appointments, internal conflicts and cases of corruption.

Instead of concentrating on a single site of observation, I opted to carry out a multi-site inquiry. The study of a state administration, which is, furthermore, a paramilitary corps, raises specific problems such as, obviously, those associated with obtaining official authorizations, but also problems regarding gaining access to the discourse of subordinates. The traditional obligation of confidentiality common to every administrative agent is strengthened here by the burden of the military hierarchy. In order to win the confidence of high-level officials, I began at the top by "studying up" (Nader 1974) the 'big family of foresters'. I then progressively observed work in offices and at checkpoints, studying the interactions with the administered from below. Finally, I "studied through" (Wedel, Shore, Feldman and Lathrop 2005) the processes of implementation, negotiation and entanglement of two reforms. The first, the militarization of the forestry department, was internal; the second, which was motivated by international donors, was national and involved the decentralization of natural resource management.

Doing the ethnography of a state administration also involves the attempt to understand its jargon, its working tools (legislative texts, administrative procedures, technical terminology), and its modes of acknowledgement and internal distinctions. For someone who had no training in the natural sciences and who had not done military service, the task was particularly laborious and the blunders frequent.

In this chapter, I will consider military reform as the main theme so as to shed light on some of the provisional results of my ethnographic work on the forestry department. This case study is limited to Senegal.

\section{IN SEARCH OF A LOST ESPRIT DE CORPS}

The coherence and unity of the state are merely an "ideological artefact" (Abrams 1988: 81). State institutions are profoundly fragmented, continuously reconfigured and often in conflict with one another. Many foresters hoped that militarization reform would reinforce a feeling of unity that had become weakened since independence. In fact, despite official discourses exalting the unity of the 'big family of foresters', collective rituals that marked this so-called solidarity and reaffirmed the department's 
values and common goals disappeared progressively in parallel to the rise of some internal distinctions.

The first-rather obvious-distinction is made between the heads of the services, the high-level officials (Ingénieurs des Eaux et Forêts [IEF] and Ingénieurs des travaux des Eaux et Forêts [ITEF]), the low-ranking officials (Agents techniques des Eaux et Forêts [ATEF]) and the local-level agents. The service heads have the power to sanction subordinates and, perhaps more significantly, redistribute financial and material resources and rewards. Moreover, an imbalance in favour of senior executives can be observed (170). Local-level agents are few in number (fewer than 300), sometimes poorly trained and lack material means for carrying out daily activities.

A second division concerns senior officers. There is an 'emic' difference in status between foresters educated in Western universities and those with degrees from Third World or socialist countries. Another difference currently in force is that between the IEF who entered the forestry administration directly thanks to holding a university degree and those who entered the administration as junior officers and were then promoted through civil service examinations. In the forest rangers' jargon, the former are referred to as 'direct foresters' and the latter as 'backpack foresters'.

A final distinction can be made between foresters who pursued their career within development projects and those who dedicated themselves to the traditional tasks of control and repression.

Thus, beyond the official picture of concord, the forestry services are permeated by internal conflicts, resentments and widespread frustration. Two factors appear to have undermined the unity between foresters decisively: internal struggles for the monopolization of 'profitable' jobs (or, in emic terms, 'juicy jobs') and what agents perceive as the opaque, arbitrary and unpredictable management of human resources and careers.

\section{An Informal Topography of Administrative Posts}

In accordance with the model of other paramilitary bureaucracies (customs, police, gendarmerie), the posts most sought after by foresters are posts that "provide access to a high level of transactions, whereby the holder has direct contact with users - that is, posts in the field as opposed to strictly administrative posts" (Blundo and Olivier de Sardan 2006: 89).

The appeal of a job is determined by its capacity to simultaneously engender three types of financial resources (Cantens 2009): public money (tax revenues and fines); private money, both legal (corresponding to $30 \%$ 
of the total of fines attributed to indicators and booking agents) and illegal (corresponding to the results of informal arrangements with users); and collective money (collected in each service in kitties or black boxes and redistributed according to different criteria). In Senegal, every forester knows the places where these three resources are most easily mobilized: i.e. mainly in the Kolda and Tambacounda regions, which are open for charcoal production, or at the checkpoints located at the crossroads of the busiest roads (Kaffrine, Gouloumbou, Bargny, etc.).

However, from the mid-1970s, a new category of 'profitable' posts opened up for foresters, adding good working conditions and opportunities for promotion to the economic interests associated with the development projects financed by international cooperation. The emergence of these 'functional bureaucratic enclaves' connected to the system of aid constitutes an important source of differentiation within the forestry department (for a further analysis of these dynamics, see Blundo 2011a).

Apart from the obvious pecuniary advantages, working on a project provides access to considerable work resources, greater autonomy, inservice training courses, study trips and scholarships for university training. The experience improves an employee's curriculum vitae and opens the door to the consultancy market thanks to contacts made. Moreover, it is also the best way of building or extending a network of clients through the probable redistribution of project resources. Finally, it is a factor that can accelerate careers. All former and current directors of Senegal's forestry department have participated in projects and been involved in them for most of their professional lives.

Control of project resources quickly became a power stake, so much so that, in 1985 , the Senegalese Minister of Nature Protection decided to divide the directorate of the forestry department into two sections by creating a new head in charge of 'reforestation and soil conservation' and hence centralize de facto all of the projects in the hands of a trustworthy individual. Although this measure only endured for five years, the project system generated internal conflicts around high-level appointments within the projects. The Minister and the head of the forestry department also disagreed about the control and appropriation of project resources: i.e. vehicles, petrol, public contracts that enable the establishment of arrangements with obliging suppliers.

Disagreements also arise between projects and decentralized forestry services. In the past, a reforestation project at the level of a Senegalese district could receive greater logistic resources than a regional inspectorate. 
Hence, the forestry administration worked at two speeds. The gap deepened between the 'traditional', shoddy services with no resources, which were reduced to forest policing and fighting forest fires, and the more valued 'projects' departments. In this context, agents who remained outside the project system became discouraged and were sometimes forced to search for forms of parallel or illicit remuneration. Rumours and suspicions grew within the service.

\section{Human Resources Management: Between Clientelist Logics and the Search for Efficiency ${ }^{2}$}

In a paramilitary administration in charge of law enforcement, agents are frequently transferred to other localities so as to prevent them from establishing collusive practices with the population. The shortage of staff and 'profitable' jobs makes appointments a real challenge.

Staff transfers are very frequent: 161 national transfers took place in

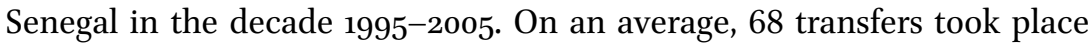
each year, however, with ministerial reshuffles or changes in direction, this figure could sometimes affect more than 100 agents, which is one fifth of the workforce.

The logics of appointments varied. Whereas the Director-General of the forestry department, the administrative authority, appoints the technical agents on the suggestion of regional inspectors, the Minister of the Environment, which is the supervisory political authority, decides on the appointment of leading and technical staff (engineers and technical engineers). The important or strategic jobs are distributed according to classic clientelist logics (classmates, trustworthy men, ethnicity, political militancy). For example, during the last decade, like the Director-General himself, the majority of those responsible for the national direction in Senegal came from the Canadian university branch.

Nevertheless, clientelism is not the only criterion that dictates appointments (on this point, see also Willott, this volume). On the one hand, a considerable number of agents remain excluded from patron-client networks and, under duress, agree to go where service calls them, even if the reasons for successive changes are not clear and discourage officials in the long term.

\footnotetext{
2 For a further analysis on this point, see Blundo $2011 \mathrm{~b}$.
} 
Let us take the example of Saliou, a technical agent who comes from Djibélor's first class ${ }^{3}$ of 1967 . He remained in his native city Ziguinchor, from 1968 to 1994 where he basically looked after reforestation. In 1994 he was sent to Kedougou and put in charge of departmental nurseries. However, after seven months, he was posted back to the departmental sector of Tambacounda. As an addition to the manpower, for five months, he carried out controls along with the head of the central brigade. He was then appointed head of the Missirah brigade but he only remained there for eight months, after which he was removed by Tambacounda's regional IREF (Inspecteur régional des Eaux et Forêts). He was then sent to Kouthiary. He thinks that someone wanted the Missirah appointment. He spent five years in Kouthiary under the orders of a young sector chief from Bala. He feels that if seniority were recognized in the service, he would not have had to endure this. However, it is simply a question of contacts, he adds. He was then appointed chef du contentieux (head of the litigation department) at the IREF in Tamba where he lasted no more than six months before being posted on to the Kidira brigade, $190 \mathrm{~km}$ away from Tambacounda: "I am like a football, as long as the player doesn't touch it, I don't move..."

On the other hand, appointments to jobs are also made with respect to agents' skills and experience. It is common for an experienced agent to be sent to a reputedly difficult zone to settle a running conflict or to repair damage caused by a predecessor.

Therefore, the directorate tries to juggle apparently contradictory requirements. It tries to satisfy clientelist pressure and ensure the proper functioning of the service.

Transfers can also conceal sanctions. Clientelism prevents direct sanctions. The only possible initiative consists of removing the dishonest or greedy agent under the pretext that 'he is inefficient'. Frequently, when several agents are transferred at the same time, two are actually being sanctioned while the others are 'whipping boys'. The concealment of sanctions responds to two logics. First, it spares the agent a certain stigmatization and, second, it also protects his chief from the suspicion of complicity. Patrons generally protect corrupt agents since both share bribes on the basis of a well-oiled system that also works for the police and customs. If agents know how to redistribute the fruits of their illicit activities, they can keep their jobs for years.

Sanctions can also strike agents with a reputation for being too rigid, disinclined to compromise and too frequently opposed to orders issued by

3 The École des Agents Techniques des Eaux et Forêts was created in Djibélor (Ziguinchor) in 1963 . 
the directorate that contravene professional ethics. I met several agents who had been punished for wishing to remain honest.

As a general rule, the jobs with the highest turnover are found in charcoal exploitation areas in Senegal. Agents are quickly shifted when it is known that they have been involved in rackets or have opposed a powerful charcoal producer, but also if their job is desired by another agent who has 'a long arm' (i.e. more influence).

On the other hand, some foresters remain in key posts for a long time, particularly the fund managers (gestionnaires des Caisses intermédiaires des recettes forestières). Hence, they ensure the department's stability and administrative memory in an environment in which administrative archives are neglected or non-existent.

Finally, appointments can also take account of agents' specific demands, however such cases are quite rare officially and limited to reasons modestly referred to as 'social': i.e. disease, the approach of retirement, aged or ill parents, excessive distance from the family etc. In reality, these cases are more common than people would like to admit. According to the Assistant Director of the Forestry Department in Senegal, during a recent national transfer concerning 96 ATEF, 30 persons asked for a transfer and their requests were accepted. Based on these same 'social criteria', if they are government employees and even if they are too numerous, agents' wives are systematically posted in the same district.

\section{Defending Foresters' Jurisdiction from External Pressure}

Since its establishment in French West Africa in the 1930s, the Corps des Eaux et Forêts essentially fulfilled its function of protecting environmental resources through suppression and sanctions. However, from the 1970 s onwards, the national forestry services progressively assumed tasks corresponding to those of a development administration and became the principal actor in ambitious reforestation schemes and forest and wildlife protection programmes. It has been the vehicle for the introduction of a succession of new approaches from state-supervised technocratic projects, in which the only form of participation was food-for-work, through projects centred on rural community development, with experiments in rapid rural appraisal, to the current phase in which the central focus is decentralization. Since the mid-199os, rural municipalities, particularly in Senegal, have been placed at the centre of natural resource management. The professional forester has since been called on to accompany 
and stimulate rural populations in making choices regarding the use of their environmental resources (Boutinot 2002).

However, the transfer of natural resources management to local councils and rural populations has yet to become effective. There are several reasons for this. Foresters appear to have blocked the transfer in order to avoid relinquishing their prerogatives of authority and control, invoking local technical incompetence and mismanagement by elected representatives as justifications (Boutinot 2005; Ribot 2008). According to these studies, foresters have formed an alliance with powerful logging interests and with de-concentrated state authorities (sub-Prefects, Prefects and Governors) so as to resist being reduced to mere advisory roles, which would also involve the loss of illicit economic rents linked to the exploitation of forest resources.

Despite an increasingly participative rhetoric that serves as a smokescreen, the feelings of the forestry department's agents waver between regret for an incomplete decentralization and the conviction that environmental protection should remain a competence reserved to the state.

The forestry service feels threatened by the redefinition of its skills, which is interpreted as a loss of authority and economic resources. Some agents even suspect lobbies of working toward the declassification of all state protected forests and fear the pure and simple disappearance of the forestry department in the short term. Consequently, for many, militarization represents a means of "keeping our administration in its place. It is a safety-valve to defend our field from external threats" (interview, AN 22/9/06). In the context of the strong politicization of the forestry department in the last decade and increasing external interventions in its daily functioning, "the uniform is a security for agents today".

\section{Interventionism and Registers of Accountability}

Indeed, the discretionary powers of agents in relation to the application of the Forest Code are strongly influenced by interventions from a variety of formal and informal institutions and actors. This modifies the logics of accountability to which they are subjected and leads to public action characterized by the hybridization of norms and informal administrative procedures (on the multiple accountabilities of the postcolonial African state, see Blundo 2012).

These interventions cancel or transform an administrative decision or a penalty applied in respect of the law. The authors of interventions can be religious or customary authorities, state or political authorities like 
prefects and governors, deputies, high-ranking officials or even forester colleagues.

In Senegal, the intervention of religious leaders appears to be more willingly tolerated or legitimized by agents who are themselves very often the disciples of marabouts. Authorities at the top of the brotherhood's hierarchy are sometimes invited to convince foresters to relax a penalty or annul it. The discourse of agents who share their co-citizens' religious experience presents the marabouts' mediation as legitimate in the framework of the patron-client relationships that link them to their disciples. Hence, they shift responsibility to the latter, who would take advantage of the religious leaders' honesty to engage in illicit activities.

The head of the $\mathrm{K}$ regional inspectorate showed me a letter dated 22 June 2008 with the letterhead of the general Caliph of Mourides and his signature, asking him very politely to be lenient with the drivers of two trucks fraudulently loaded with 60 bags of charcoal. Their only mistake, according to the Caliph, would have been their failure to declare that the goods were destined for the preparation of collective meals in a religious festival.

In reality, the pressure of marabouts can be very important and sometimes leads to physical threats:

One day, a marabout of the Mbacké family accompanied by 20 of his disciples came to hunt in a forest classified as a reserved zone. When questioned by the Assistant Regional Inspector of the Forestry Service, the marabout told him: 'You are very undisciplined. What gives you the right to come and disturb me in my work and tell me that I must not hunt here?' In the meantime, the disciples roughed up the Assistant Inspector and pelted him with blows. They also asked their marabout for permission to kill him. Consequently, the marabout added: 'Go tell your inspector to come prohibit me from hunting here. If he doesn't dare come, go tell his Director-General to come and do it, if he doesn't dare, go tell the minister to come, and if he doesn't dare come, go tell the President of the Republic to come. And you'll see that he too will not dare come. So I don't see how a subaltern like you can prevent me from hunting here. Besides, I was hunting for good game but there isn't enough here. I'm going to change my hunting ground'. After that, he got into his $4 \mathrm{X}_{4}$ vehicle, which got stuck in the sand. Instead of asking his disciples to get the vehicle out of the sand, he got down from the vehicle and asked the Assistant Inspector and his two agents to do it. The agents wanted to resist but when they looked at the disciples they understood that it was better to accept. So they did what was necessary to get the vehicle out of the sand (head of a forestry brigade in Northern Senegal).

More generally, there are no-go areas for foresters and other official law enforcers where the state has deliberately chosen not to interfere. A 
regional head of Diourbel told me that "to avoid problems" forestry service agents do not go into Touba, the holy city of Mouridism. The last administrative post is located in Mbacké and the person in charge is a fervent mourid whose only role, according to the higher officials of the service, is to accompany the Minister and the Director-General when they pay a visit to religious leaders.

These forms of interventionism share some common characteristics. First, interventions are not forcibly linked to the status of the offender but to the nature of his links with the author of the intervention: thus, a simple peasant or trader can win his case if he is the disciple of an influential marabout, or claims to be one, or if he is close to a member of parliament etc. Second, they highlight the disconcerting ease with which it is possible to enter into contact with the highest state representatives. The summit of the state is closer than one would imagine.

As demonstrated by my observations at the control station in Pont Noirot in August 2009, thanks to the use of mobile telephones, interventions have become increasingly rapid and practically instantaneous: having stopped a truck transporting precious wood without authorization, two forest agents negotiated the release of the driver along with his load directly on their cell phone with a person whose identity they were unwilling to reveal.

The final administrative decision after intervention, is the result of the mobilization of different forms of accountability (Lindberg 2009): upward accountability related to a patron-client relationship when a disciple invites the administrative mediation of a marabout or a governor is questioned as a son of the soil; downward accountability typical of a relationship of patronage when a marabout contacts the Minister or the Director-General; downward bureaucratic accountability when the minister exerts pressure on the administrative hierarchy.

However, if it cannot be ruled out that these interventions are motivated by the denunciation or correction of an offence by the forestry administration, it would appear to me that, instead, a large number tend to redress the effects of the normal application of the law, in other words to attenuate the effects of formal legality.

Finally, interventionism contributes to forging a professional culture amongst foresters that condemns rigor and values the capacities of negotiation and the notion of maslaa that is central in Wolof and other Sahelian societies: the constant search for a consensual solution aimed at establishing social peace. 


\section{IMPROVING THE EFFICIENCY OF FORESTRY SERVICES}

The reform of militarization also aimed at "strengthening discipline, order and efficiency in the application of police forestry tasks, hunting, controlling poaching, fighting bush fires and participating in defence committees". ${ }^{4}$ With militarization, the loss of civil rights was compensated by a considerable increase in the purchasing power of civil servants who saw their salaries practically double thanks to various allowances. This was supposed to motivate them further and thereby attain the goal of greater rigor in their operations.

\section{Informal Privatization of Forestry Services}

In practice, however, the allocation of resources continues to be highly skewed. Financial and material resources destined for the functioning of local forestry services are managed at the central level. They are unequally distributed over the national territory: the directorate prioritizes regions and sectors likely to produce significant financial resources and neglects regions that are 'dry' from the perspective of rent extraction, despite the fact that they suffer from serious environmental challenges. The most deprived services correspond to the decentralized level of the department (secteur), the district (brigade), the rural community (triage) and checkpoints. Field agents have no means of transport, little petrol and no money for maintenance and repairs. They buy their own uniforms from other military services and sometimes make their own stripes. Offices are neither equipped nor functional and checkpoints are mere shanties.

In this context of structural shortage, decentralized services resemble an archipelago of islands functioning in isolation (Copans 2001: 14); they have little formal contact with regional directorates and practically no relationship with the national directorate.

Under conditions of such structural penury, field officials acquire almost complete autonomy and their operations are effectively privatized. Members of local teams organize to equip themselves individually and collectively to ensure the minimal functioning of the service.

Agents like to evoke Wolof proverbs to describe their situation: "Yalla du tej buntu tej feneetr" ("God never closes a door and a window in a room at the same time", i.e. when the formal resources financed by the state are

\footnotetext{
4 According to the preamble to the Senegalese Forest Code, law n ${ }^{\circ} 2005^{-10}, 3$ August 2005, Republic of Senegal.
} 
lacking, the forestry agent always has the possibility of 'surviving' by other channels that could present themselves from elsewhere). Procedures differ, because "to each his manner of using his rat's head" ("ku nek yaa xam ni ngay tojee sa bopu kaña").

Thanks to the activities of the forestry police, agents can individually invest a part of the illicit gains obtained to buy themselves a motorcycle, a new uniform or office supplies. This informal privatization is not synonymous with predation and is not incompatible with providing a public service (cf. the case described by Bierschenk, this volume). In some cases corruption can ensure the survival of the public service. Other agents engage in activities that generate revenue in order to finance the brigade's activities (sale of decorative plants and fruit trees, chicken breeding).

Collectively, they can have recourse to local patrons (private operators, private firms, development projects) or dip into a 'kitty', a common fund financed by the legal proceeds of fines.

Irrespective of the source of financial resources, this situation prompts the agents to consider service equipment as private goods: a district head, whom I encountered in an office that had been freshly repainted and well-equipped told me proudly: "Everything here, even the forestry service stamps, belongs to me. I bought it all and I'll take it with me when I leave".

The de facto independence enjoyed by subaltern agents is important. One agent told me: "Here, I am the one who cuts the head, chops it, cooks it but also the one who eats it" ("Fii may dag bop, may fees, may tog te may lekk"). This autonomy increases their already significant discretionary powers. Combined with the informal privatization of the logistical resources of services, they determine a specific regime of activities on the field.

Forestry brigades, which often consist of a single agent, spread their activities across reforestation, forestry police, battling bush fires and the training and supervision of peasants. Although militarization did not lead to a significant increase in forestry police activities, it did not necessarily involve the conversion of forestry agents to a participative credo. Due to the lack of resources or petrol, agents tend not to go into the field unless they are sure that the 'hunt will be good' or if the cost of their trip is covered by a development project.

Sorties by the brigades most often result from denunciations made by a small network of local informants or they are limited to unannounced controls in places considered strategic, or, again, carried out at certain strategic periods corresponding to religious festivals like tabaski and korité, periods when clandestine users tend to be very active. 
In reality, the control and supervision operations are very sporadic, both on the level of protected natural spaces and at charcoal production sites. In this context, suppression takes precedence over prevention. Most agents prefer to hide in the bush and wait for offences to take place before intervening.

\section{Informal Arrangements, Simplification of Administrative Procedures and Practical Professional Norms}

A paramilitary body that can legitimately exercise control and suppression activities armed with important discretionary powers (evaluation of the offence and the penalty to be applied, a large range of fines etc.) governing economically and politically crucial resources, subjected to contradictory pressures but lacking the necessary means to act: all of these factors combined constitute an ideal ground for the growth of corruptible behaviours.

Several studies describe the corruption of the forest control system (Fall 2006, Djigo 2006). However, I would tend to qualify these conclusions. My research suggests the need to try to go beyond the classical reading of the dysfunctionality of African public administrations in terms of neopatrimonialism (see Therkildsen, this volume), clientelism and the 'capture' of bureaucracies by economic and/or political elites.

This does not involve the denial that there is an-often markedhiatus between the formal mission of the Eaux et Forêts service and the reality of its practices (in fact, the same disjunction applies to the majority of the public services of the same countries). The problem is that most of the cited works take a normative and externalist approach to the analysis of the malfunctioning of the service. This approach is normative to the extent that it focuses on the ways in which practices deviate from formal norms and leans on a non-critical faith in a vigorous civil society acting as a counter-power; it is externalist in that it takes no account of the internal logics governing the functioning of the service but instead adopts the point of view of external actors, whether donors or service users.

In contrast, I have attempted to approach this question by adopting the point of view of forestry service agents who are not reticent in providing examples of their own practices and, contrary to all expectations, do not solely adopt a stance that tends to justify or minimize the scale of these practices.

The forestry administration manages spaces and resources that involve significant economic stakes: hunting and the allocation of licenses, the timber trade, the collection of fruit and wild species. Charcoal production 
alone, "represents an annual turnover of 20 billion FCFA for the state" (Boutinot 2002). Even an agent at the bottom of the hierarchical ladder can achieve a living standard incommensurable with his basic salary if he knows how to manage his career smartly. For example, a former head of a district sector could finance a pilgrimage to Mecca, build one house in Saint-Louis and another in Touba, and send his children to Europe to study.

Indeed, the opportunities for enrichment, particularly in charcoal zones, are numerous. This is not the place to describe them in detail. It may be noted, however, that they are located in a continuity of practices characterized by blurred boundaries, ranging from 'tolls' required at each of Senegal's 13 official checkpoints for the control of transport licences to 'commissions' in cash or kind arising from mutually agreed arrangements between forestry agents and producers for evading the requirements of the Forest Code. Although it is by definition impossible to evaluate the scale of the illicit transactions, according to a senior official at the head of the forestry services, the number of transactions settled on a 'friendly' basis can be estimated at $80 \%$. According to a recent study, two fifths of the charcoal loads that arrive in Dakar are fraudulent in origin (Djigo 2006: 34). Thus, foresters trade in free transport licences, which, in principle, are limited in number and reserved for domestic use. It is also common knowledge that in case of the seizure of illegally produced charcoal, the latter is resold 'in auctions' to the same producer, in the name of another member of a forestry cooperative. Exceeding the tonnage has also become the rule: trucks are generally loaded with $45^{\circ}$ bags instead of the regulatory 300; moreover, hauliers use bags containing up to $80 \mathrm{~kg}$ instead of the standard $5^{0} \mathrm{~kg}$. Money is distributed at each checkpoint to ensure that agents turn a blind eye.

Several factors contribute to the corruptibility of forestry agents. To begin, when a forester decides to book an offender, he already knows that he risks being disowned by a superior as a result of a political, administrative or religious intervention and, moreover, the delegitimization of his action in the eyes of the population.

The cancellation of a statutory settlement also deprives the booking agent and the informer of the shares of the fines due to them by law, ${ }^{5}$

5 Article R.64 of law $\mathrm{N}^{\circ}$ 98/03, 8 January 1998 stipulates: "Three tenths of the income from fines, confiscations, repayments, damages-interests and constraints are attributed to forestry agents, to agents commissioned by the Forestry Service and, if necessary, to authorized agents of other services. The division is made on the basis of two tenths for 
which are paid as an incentive to honest behaviour. However, even if the fine is normally paid, the forestry agent knows that the probability that he will receive the entire share due to him is very low. At best, the service 'will have a kitty': the money contained in this common fund will be distributed among the brigade's agents so as to motivate agents who rarely 'go out'. This will reward the auxiliary staff, but also serve to finance working costs or social expenses. At worst, the shares will end up in a black box managed by the head of the service in the greatest secrecy.

Sporadic and irregular relations with hierarchical superiors also dictate the tone of actions of the field. In July 2009, the head of a sector in the Senegalese groundnut basin admitted: "Temptation is great. No one controls me", and then asked: "How can you explain that since my installation six months ago, no one, not even the IREF, has come to see me?".

Moreover, agents shelter behind the well-established justification that the bad example comes from above. According to a rumour going around the service in 2009, the outgoing Director of the Forestry Service granted special authorizations to his entourage to produce up to 85,00o hundredweight of charcoal and gave government contracts to 'relatives' for supplying very bad quality equipment to tree nurseries.

The problems that beset the charcoal sector and the entire management of forestry resources are systemic. Subaltern agents are only the last link in a chain of fraudulent transactions and irregularities that extends up to the supervisory authority. Furthermore, even programmes financed from outside and considered as 'success stories' are not immune from this system. The example of the Sustainable and Participative Energy Management programme (PROGEDE) financed by the World Bank is a case in point.

In short, much of the administrative action in the forestry sector follows informal arrangements with users. It is even possible to affirm that the forestry administration is an important site of the production and reproduction of informality as public action is instigated by actors immersed in a pluralism of norms: official norms (for example, the Forest Code and statutes dealing with the internal organization of the forestry service), social norms (general principles of conduct and behaviour in the social sphere which are codified to varying degrees), and 'practical'

the informer agent and one-tenth for the booking agent. Seven tenths are paid to the local group administering the forest, in which the offence was reported or to the state if the law has been breached in the state forest reserve." 
professional norms, which the official learns in the course of his professional socialization (for example, knowing how to spot a fraudulent load, knowing how to negotiate the sum of a fine, learning to handle traditional authorities etc.).

Different mixtures of these varieties of norms constitute the so-called "professional culture" (Olivier de Sardan 2001) of foresters. I would avoid treating this in a deterministic manner. The professional culture is not fixed and does not extend to the entire service. It is not fixed because it evolves with changes in environment policy, new approaches to development and the appointment of new staff. Moreover, rather than conceiving professional culture as a set of common traits that shapes the behaviour of every forestry administrative agent, it can be seen as a repertory of norms, values and registers of action for foresters to draw on in their daily actions and as responses to new situations created by reforms in their sector (reforms involving decentralization, militarization, development actions, the technical framework etc.). An integral part of foresters' culture consists in learning how to handle different types of authority, bargaining the sum of a legal penalty, respecting local codes of propriety, undoing and preventing sorcery and relying on intermediaries (political leaders, informants, religious authorities) for contact with the population.

\section{CONCLUSIONS: THE LIMITED IMPACT OF REFORM}

It is clear that as implementers of the Forest Code, forestry agents exert their discretionary powers under the influence of multiple pressures flowing from a variety of formal and informal interests and actors. This complicates the logics of accountability to which they are subject and results in forms of public goods provision being governed by hybridized norms and informal administrative procedures. Under these circumstances, the capacity of top-down reforms to deliver significant benefits would appear doubtful (see also Anders, Charton, Muñoz, this volume).

Restoring the prestige of the service, rediscovering the 'big forestry family', protecting the service from external pressures, strengthening order and discipline, ending abuses in the attribution of stripes, increasing the salaries of government employees: of all these-official or unofficialgoals, only the latter appears to have been successful to the extent that most of the agents encountered voluntarily spoke of a "militarization carried out merely to earn a living". And yet, the service needs something other than new recruits. In order to fully assume its role of protecting and regenerating natural resources, it requires a series of reforms. 
If top-down reforms have partially failed, the emergence of bottom-up micro-reforms can be observed occasionally (for the observation of a similar phenomenon in the Niger judiciary, see Hamani, this volume). There appears to be significant scope for local innovations, which, in fact, formalize some of the more constructive features of the informal habitus, or the way things work in reality. The leadership styles of heads of services (e.g. the regional inspector, sector head) play a preponderant role here. In the eyes of foresters, a good chief must know how to share technical and financial resources with his subalterns and be capable of 'communicating' and making them more responsible. He must know how to defend and protect the interests of subordinates and the service in general, take interest in their working conditions and listen to their demands, know how to resist a minister, and not be too politicized. In short, he must behave as a boss vis-à vis subalterns without himself being a client of hierarchical superiors.

Clearly, a hierarchical administration based on patron-client relationships is often better managed than a service, in which the chief intends to apply the criteria of 'good governance' literally. In the former case, agents are more motivated, the team more united and even ready to provide quality service. Internal relations in the services remain informal. In the Tambacounda regional inspectorate, for example, the chief took the initiative of formalizing the use of the legal or illicit shares collected by the agents when they booked offences. The agents decided to create a fund managed by the accountant. Part of the sum collected was redistributed on the basis of a unanimously accepted allocation system and the rest was used to finance urgent repairs, petrol consumption and unexpected social expenses. This is an example in which the formalization of an informal practice appears to have improved the functioning of the service, anticipated predatory behaviours and fostered internal solidarity.

In other regions situated outside the charcoal zone, I met young sector heads, who, even while privatizing their services entirely, simultaneously rejected the classical forestry professional culture and, above all, its form of internal patronage, corruption and repression of rural people. They undertook small reforms towards formalization of and tighter control on the informal arrangements with the population instituted by their predecessors. If, as foresters like to recall, "charcoal is black and hands get dirty", then the motor of the internal transformation of the forestry service could come from these very 'dry zones' which have long been discredited by the service. 


\section{REFERENCES}

Abrams, Philip. 1988. Notes on the difficulty of studying the state. Journal of Historical Sociology, 1(1): 58-89.

Blundo, Giorgio and Joël Glasman. (forthcoming). Introduction: Bureaucrats in Uniform. Sociologus. Journal for Empirical Social Anthropology.

Blundo, Giorgio and Jean-Pierre Olivier de Sardan, with N. Bako-Arifari and M. Tidjani Alou. 2006. Everyday Corruption and the State. Citizens and Public Officials in Africa. London, Zed.

Blundo, Giorgio. 2011a. Une administration à deux vitesses. Projets de développement et construction de l'Etat au Sahel. Cahiers d'Etudes Africaines, LI (2-3), 202-203: 427-452.

- 2011b. Comme un ballon de foot. La gestion quotidienne des ressources humaines dans les services forestiers en Afrique de l'Ouest. In Schareika, Nikolaus, Spies, Eva and Pierre-Yves Le Meur, eds. Auf dem Boden der Tatsachen. Festschrift für Thomas Bierschenk. Mainzer Beiträge zur Afrikaforschung 28. Köln, Köppe, 377-394.

- 2012. Le roi n'est pas un parent. Les multiples redevabilités au sein de l'État postcolonial en Afrique. In Haag, Pascale and Cyril Lemieux, dir. Faire des sciences sociales: Critiquer. Paris, Editions de l'Ecole des Hautes Etudes en Sciences Sociales (Cas de Figure), 59-86.

Boutinot, Laurence. 2002. La gestion décentralisée des ressources forestières au Sénégal: transfert de compétences et transfert de pouvoir. Bulletin de l'APAD 22: 27-45.

- 2005. La décentralisation de la gestion des ressources forestières au Sénégal: un processus contraint par le marché? Bulletin de l'APAD 26: 47-66.

Cantens, Thomas. 2009. Ettre chef dans les douanes camerounaises, entre idéal type, titular chief et big katika. Afrique Contemporaine 230 (2): 83-100.

Copans, Jean. 2001. Afrique noire: un État sans fonctionnaires? Autrepart 20: 11-26.

Das, Veena and Deborah Poole, eds. 2004. Anthropology in the Margins of the State. London, James Currey.

Djigo, Alpha Seybatou. 2006. Etude sur la surveillance, le suivi, et le controle de l'exploitation forestiere au Sénégal. Programme Agriculture/Gestion des Ressources Naturelles 'Wula Nafaa', September.

Fall, Abdou Salam, ed. 2006. Gouvernance et corruption dans le domaine des ressources naturelles et de l'environnement au Sénégal. Dakar, Forum Civil.

Gupta, Akhil. 1995. Blurred boundaries: the discourse of corruption, the culture of politics, and the imagined state. American Ethnologist 22 (2): 375-402.

Hansen, Thomas and Finn Stepputat, eds. 2001. States of Imagination: Ethnographic Explorations of the Postcolonial State. Durham, Duke University Press.

Lindberg, Staffan I. 2009. Accountability: The core concept and its subtypes. Africa Power and Politics Programme, Working Paper 1.

Masquelier, Adeline. 20o1. Behind the dispensary's prosperous facade: imagining the state in rural Niger. Public Culture 13 (2): 267-291.

Migdal, Joel and Klaus Schlichte. 2005. Rethinking the state, In K. Schlichte, ed. The Dynamics of States: The Formation and Crises of State Domination. Aldershot, Ashgate, $1-40$.

Nader, Laura. 1974. Up the anthropologist—perspectives from studying up. In Hymes, Dell, ed. Reinventing Anthropology. New York, Vintage, 284-311.

Olivier de Sardan, Jean-Pierre. 2001. La sage-femme et le douanier. Cultures professionnelles locales et culture bureaucratique privatisée en Afrique de l'Ouest. Autrepart 20: 61-73. 
Ribot, Jesse. 2008. La non-décentralisation démocratique au Sénégal: le non-transfert de l'autorité sur les forêts. Séries de documents de travail sur la représentativité, l'équité et l'environnement 23. Washington, WRI.

Scott, James. 1998. Seeing like a State. How Certain Schemes to Improve the Human Condition Have Failed. New Haven, Conn., Yale University Press.

Wedel, Janine, Shore, Cris, Feldman, Gregory and Stacy Lathrop. 2005. Toward an Anthropology of public policy. The Annals of the American Academy of Political and Social Science 600: $30-51$. 
Thomas Bierschenk and Jean-Pierre Olivier de Sardan - 978-90-04-26496-0 Downloaded from Brill.com@4/26/2023 02:08:21PM via free access 


\title{
FACTIONALISM AND STAFF SUCCESS IN A NIGERIAN UNIVERSITY: A DEPARTMENTAL CASE STUDY
}

\author{
Chris Willott
}

\section{INTRODUCTION}

In recent years a narrow group of approaches and themes has come to dominate analysis of the African state. ${ }^{1}$ From a methodological perspective, broad brush approaches that provide a homogenous vision of the African state shorn of empirical content have gained pre-eminence. These approaches tend to use the methodologies of the discipline of political science, and are often normative, in that they examine African states through the prism of Weberian logic and conclude that, because states do not conform to a rational-legal ideal, they must therefore be deficient. Thematically, corruption, patronage and informality dominate, and are held to be the characteristics that define all African public service bureaucracies. Taken together, these approaches and themes can be termed the neopatrimonial approach to the African state.

A key question arising from this dominance is, when one undertakes long-term, ethnographic analysis of African public institutions, to what extent are these themes actually apparent? To what extent do corruption and patronage, compared to the official rules, structure access to rewards? How do patron-client systems actually operate for those who are embedded in them? This chapter seeks to analyse these processes in the context of an institution in Nigeria's elite Federal university sector. In particular, I analyse the pervasiveness of one aspect of patron-client relationships, but one that has been relatively excluded from the dominant neopatrimonial approach: factionalism, defined as competition for resources between structurally and functionally similar groups of individuals.

This chapter argues that factionalism exerts a significant influence over the careers of academics in a Nigerian university. This conclusion supports the general neopatrimonial thesis: that it is personal connections

\footnotetext{
${ }^{1}$ I gratefully acknowledge the financial support of the ESRC for funding my research in Nigeria. I also thank Dibyesh Anand and Joe Devine for their helpful comments on an earlier draft of this chapter.
} 
rather than formal competence that exert a greater influence over access to rewards. Despite this, however, the influence of factionalism and other non-merit considerations are not absolute: merit still exerts an influence on both staff entry and promotion. Prospective academic staff who do not have the required qualification will not gain employment regardless of their personal or factional connections, and decisions about promotions that are not based on merit-either the promotion of unworthy candidates or the 'frustration' of meritorious ones-can only reach a certain level before the official rules act to rein them in. The neopatrimonial characterisation of Nigerian state institutions as operating wholly for the benefit of those working for them and their client groups (see for instance Chabal and Daloz, 2006; Joseph, 1987) has clear limits and must be tempered by an understanding of the micro-dynamics of individual institutions. Entry to and promotions within Nigerian higher education are not a power-politics-led free-for-all; they operate on the basis of clearly defined logics that combine emphasis on personal connections with merit. That the former often take precedence does not mean that the latter are nonexistent.

\section{SETTING AND Methods}

This chapter is based on nine months of ethnographic fieldwork carried out in a university in the Igbo-speaking region of south eastern Nigeria in 2007. In this chapter I will refer to the university where I carried out fieldwork as the University of South Eastern Nigeria (USEN). ${ }^{2}$ During the data collection process I became close to one of the two factions I describe, the anti-select club (ASC), which was generally made up of people who were sympathetic to my research and were happy to discuss their experiences, even those concerning relatively sensitive topics. By contrast, the members of the other faction, the select club, were much less open and I found it difficult to gain an 'insider' understanding of their views. It could be argued that, in becoming closely associated with the ASC, I suffered from what Olivier de Sardan (2003) terms encliquage-literally, becoming factionalised. Olivier de Sardan notes two particular difficulties engendered

2 Throughout this paper the name of the university, the department where I worked and all individuals are pseudonyms. In addition I have changed some details about individual members of staff in order to protect their identities. 
by this process - the tendency for the researcher to "become the echo of his adoptive clique and to adopt their points of view" and the way in which it can close off other cliques to him or her (ibid.: 49). In my case, the first of these problems may well have occurred, though it is difficult to say for certain. I have endeavoured to be as neutral as possible in my analysis of the factional struggle, though my closeness to the ASC means that I may have unwittingly given greater credence to their views than those of others. I acknowledge that there is therefore a potential bias in this work. In an effort to combat this during fieldwork, I also carried out research with staff outside my department and those who were not members of either faction.

During my time at USEN I also tried to get close to members of the select club, though this group were much less welcoming to me and, later in my fieldwork I became aware that some members were unhappy with my presence on campus as they believed I was 'asking too many questions'. This is because I was researching aspects of extra-legal practice in which they were involved. For this reason, I do not believe that the second problem of encliquage - closing off access to other groups-occurred in my research, because, regardless of my relationship with the ASC, I would have been denied access to the select club in any case. My isolation from this group was due to the sensitive nature of my research and the fear amongst select club members that I might discover their participation in extra-legal practice, rather than my closeness to the ASC.

\section{FACTIONALISM}

Factionalism refers to competition for power and prestige between "structurally and functionally similar groups" (Brumfiel, 1994: 4). It takes place in many different arenas-particularly political parties but also bureaucracies, chiefdoms, trades unions, employers' organizations and religious groups (Bayart, 1991) — of African social and political life. Nicholas's (1977: 57-58) classic definition incorporates five characteristics of factions: they engage in conflict; are political; are not corporate groups, meaning that they are "basically impermanent" (ibid.: $5^{8}$ ); their members are recruited by a leader; and members are recruited on diverse principles. I will use a combination of the definitions provided by Brumfiel and Nicholas in this chapter.

Few scholars of African politics and society examine factions in detail. Only one author of the broad neopatrimonial school, Jean-François 
Bayart, ${ }^{3}$ studies the primacy of factions in Africa, noting that they are "the very stuff of political life" (2009: 211). Within micro-empirical accounts of public service bureaucracies in Nigeria and elsewhere in West Africa, analysis of factions, their operation, impact and historical antecedents, is conspicuously absent. Smith (2001, 2005, 2006), who spent a number of years working in Nigerian universities, does not mention their existence in his numerous writings on patronage and corruption in Nigeria, while Olivier de Sardan (2009) touches on the subject very briefly, viewing factionalism as part of broader patterns of clientelism. Understanding of African states, and particularly interface bureaucracies - those arenas such as schools, hospitals, police stations, courts and, in my research, universities, where the individual 'meets' the state-would benefit greatly from further empirical research on factions and their functions. However, as Sandbrook (1972) argues, conducting research on factions can be a dangerous activity, which is a possible reason why so little empirical work on the phenomenon has been produced.

\section{Factionalism at the University of South Eastern Nigeria}

In USEN's social policy department, the department where I carried out my research, there are two broad groupings, and every member of academic staff bar one is closely allied to one of the two groups. ${ }^{4}$ One of the groups is semi-official and staff can become members. This group has a title, though in this chapter I use the pseudonym the select club. The opposing faction is unofficial, in that staff cannot officially join. It does not have a title, though for the purposes of clarity I term this group the anti-select club (ASC). The split exerts a large influence on departmental activity, and was acknowledged as existing by every staff member I spoke to. One senior member of staff described the departmental split as "a huge chasm", "bitter" and "fascistic" (interview, 3 September 2007). Faction membership is very much a zero-sum game: by being closely allied to one faction individuals will find it extremely difficult to become close

3 Jean-François Bayart's contribution to the study of African politics and society is broad and diverse and to label this work neopatrimonial is something of an oversimplification. Nonetheless some of his writing contains some strongly neopatrimonial arguments.

4 The social policy department was viewed by many other academics as the most 'corrupt' department in the university. The patterns of behaviour outlined here may therefore not be repeated across the university, though anecdotal evidence suggests that similar situations may be found in other departments, albeit to a lesser extent. 
to, or even have civil personal relationships with, members of the other camp.

The factionalism in the social policy department began in the 196os and 1970 s when the department was largely split along ideological lines, in that there was a 'liberal' group and a 'Marxist' group, each led by a charismatic member of senior staff. At the time all USEN social science departments were split along Cold War lines. During this period ideological differences did not prevent staff from enjoying each other's company socially: differences were to do with academic debate rather than personal animosity. However, the mid-1980s were a time of great upheaval in Nigerian universities (Anugwom, 2002), as in the country as a whole, as structural adjustment and the devaluation of the Naira brought increasing scarcity following the plentiful years of the late-1970s oil boom. Conditions for staff, including salaries, worsened considerably (ibid.) and some staff used this as a justification for participating in extra-legal practices in order to augment their wages. Departmental splits took on a different character around this time, the new cleavages being based more around beliefs on the acceptance of extra-legal practices and less on political ideology or national politics, though personnel remained broadly the same: those who had been in the liberal camp were those who were most likely to participate in extra-legal practice and those in the Marxist camp the least, though this was by no means absolute. It is not clear why members of the Marxist group were less likely to participate in extra-legal practice, though strength of ideology — which would be likely to be stronger amongst Marxists, a doctrine that tends to attract highly committed followers - over self-interest is a plausible explanation. Indeed, Nicholas (1977: 57) argues that political ideology forms a greater part of factional conflict for socialists than for conservatives. The division over the issue of 'moral standards' at USEN persisted while the political divide did not. Many of those who had formerly been in the Marxist camp retained their belief in socialist ideology but it no longer formed the basis of factional conflict.

The issue of morality in working practices remains a driving force behind the factional split, though the related issue of attitudes towards student success - the ex-Marxist faction (broadly) favouring advancement on the basis of merit and the ex-liberal faction being more heavily involved in 'sorting' - also plays a part. 'Sorting' is a Nigerian English term referring to the sale of grades for money. There are a number of other practices that academic staff who seek personal enrichment involve themselves in. 'Lobbying' refers to the sale of university places for money, 
while academic staff may also demand that students purchase handouts in order to pass courses and engage in exam malpractice in exchange for financial reward. ${ }^{5}$ As one lecturer put it, there are those who are "here to trade" and those who "want to contribute to the university realising its [official] objectives" (interview, 2 October 2007). In this environment academics inevitably gravitate towards others who share their views. One faction member said that he seeks to establish relationships with people with the same "value system relationship" as him, meaning a belief in hard work and upholding the stated values of the university. Often academics are 'brought in' to the university on the basis of their views on morality in working practices, depending on which faction is in control of each department at that point. Factional groups seek to 'replicate themselves' in the appointments they make, in order to increase their numerical strength and reinforce their power in the department.

In the next section I outline the histories, personnel and characteristics of the two main factions.

\section{Anti-Select Club}

The anti-select club can be viewed as the modern incarnation of the Marxist faction that began in the 1960s though, as noted above, it has undergone significant change since then. The inception of the current group in the social policy department occurred soon after the inauguration of the incumbent Vice Chancellor (VC) in 2005 when the select club went "over the heads of the department" to appoint a Head of Department (HoD) who would "give them leeway" to participate in extra-legal practice (interview, 3 October 2007). As a result of this, all lecturers who had not been involved in this endeavour - with the exception of the one non-affiliated member of staff in the department - were called for a meeting by the VC, and these staff members became a group. The ASC therefore owe their existence to a successful attempt by the select club to install their preferred candidate to the position of HoD.

The ASC is an informal group of academics, mainly in social policy but also in other departments in the social sciences faculty. During my research at USEN the ASC, like the select club, had a clear leader, though

5 These practices are by no means ubiquitous, and many academic staff do not participate in them. Additionally, there is usually an element of merit to these transactions. For instance, a student with a very low score on their entrance exams would not be offered a place to study, whatever their ability to pay. For more detail on these processes see Willott 2011. 
other very senior staff were also closely allied to the group. These academics, however, did not have an active role in the ASC at the time. The de facto leader of the ASC during my time at USEN was a charismatic Marxist scholar named Professor Arinze Omeife, who was also in a position of authority within the faculty. He also has a PhD from a prestigious American university and is an internationally-renowned scholar.

The vast majority of staff members associated with this group espoused an ideology that can be described as socialist or Marxist; as noted above, though the factional conflict no longer concerned this issue, a number of Marxist scholars remained committed to its ideology. This was a key aspect of the way the group presented itself. Many of the group were also heavily involved with the Academic Staff Union of Universities (ASUU). ${ }^{6}$ However, neither of these two characteristics were prerequisites for membership. ${ }^{7}$ A number of ASC members were not active members of ASUU, nor were they adherents to Marxist ideology. This situation has evolved since the origins of this group and illustrates the dynamic nature of the factional struggle at USEN.

In addition to a leftist ideology, many members of the ASC saw themselves as guardians of a long-established tradition of scholarship at USEN and within the social policy department. Faction members would often emphasise the 'traditions' and 'culture' of the department, and how those currently in control of the department-the select club-were moving the department away from its roots:

This particular department... has a culture rooted in hard work. So for you to move in from elsewhere and start academic work here... if you are not too careful in learning and understanding how we function, the tendency [is] that you might bring in some of the practices that are not known here (interview, 25 July 2007).

This individual alludes, through the phrase "some practices that are not known here", to extra-legal practices such as lobbying, sorting and selling handouts that members of the select club engage in. He suggests that those who favour hard work and academic culture are guardians of an old tradition in Nigerian higher education, while the newcomers he refers to are implicitly seen as part of a newer, inferior tradition based on personal

\footnotetext{
6 ASUU is the trade union for Nigerian academics. All academic staff are automatically ASUU members though many actively work against the union in university politics.

7 There was no formalised way of joining the ASC. I use the word membership here to refer to a sense of belonging to a like-minded group and participating in their activities.
} 
gain. The safeguarding of old traditions was presented as one of the ASC's main raisons d'être. Some non-ASC members, however, viewed this stance as more rhetorical than actual.

At the time of my research, the ASC were rather marginalised within the social policy department. They struggled to 'replicate' themselves by bringing in new members of staff who shared their views on extra-legal practice and scholarship. All new staff members recruited during my fieldwork were affiliated to the select club. ASC members also suffered in regularization - the process academics go through to become permanent members of the faculty-promotion and committee membership at the hands of the select club. The main function of the ASC at the time was therefore to forward the interests of its members, such as to ensure that they received regularizations and promotions on time, a function it was not able to fulfil particularly well. The ability of the group to influence the prevalence of extra-legal practice in the university and to encourage scholarship was also severely hampered by their lack of power within the department.

A second key function of the group was to link each individual with Prof. Omeife, a man who, as a senior academic, could have a significant impact on their current and future careers. This corresponds to assertions (such as by Bujra, 1973; Nicholas, 1977) that factions are more about the relationship between members and the leader than within the faction as a group. It also highlights the way in which factionalism can be viewed as a concept with close links to that of patron-clientism, which forms a central part of the neopatrimonial characterisation of the African state.

The two main functions outlined here would suggest that ASC members were rather more self-interested than their rhetorical commitment to socialism and scholarship might suggest, as individual success rather than ideological advancement was a key goal. A further piece of evidence pointing to the self-interest thesis is the actions of staff at a departmental board meeting I attended. A number of questions were raised at this meeting by ASC members and, despite the widespread existence of exam malpractice, poor facilities and lack of opportunities for research, all questions raised were directly linked to the factional struggle and to personal welfare. These included queries as to why certain members of staff (nonselect club members) were excluded from some responsibilities, particularly those that carried high remuneration, and other issues related to contracts and salaries. Furthermore, a key meeting place for ASC members in the social policy department was a discussion group on African 
politics, but this group appeared not to meet when Prof. Omeife was not on campus, illustrating that impressing the leader, rather than discussing African politics, was the real reason for the existence of the group. This evidence appears to point to a pattern of self-interest in the ASC, in which the faction could be seen as simply the best avenue through which individuals gain access to rewards in a potentially hostile environment.

Contrastingly, there is also evidence that ASC members did behave differently to their select club counterparts. Students noted that ASC members were less likely to award "unmerited favours" when it came to the allocation of marks and instead focused on the students' academic quality. By contrast, the select club were viewed as non- or even anti-intellectual by students and staff alike. My own observations also point to a qualitative difference in attitude to scholarship and meritocracy between the two groups, though this does not necessarily apply to all members.

There is, therefore, coherence in the way the ASC presents itself to outsiders: it exists in order to work against the select club's focus on material gain and instead emphasises hard work, meritocracy and a socialist political ideology. Internally, however, it does not possess this coherence as the group combines a logic of commitment to meritocracy with that of selfinterest. Some members were committed to both socialism and scholarship but also viewed the faction as an important vehicle for self-interest, while others had little commitment to either of the group's ideological raisons d'etre, but instead were simple opportunists, in that they would join any group if it assisted their climb up the social and academic hierarchy.

\section{Select Club}

The select club is a group of academic staff at USEN that, in contrast to the ASC, is a semi-official group of which staff can become members. It is much more organised than its opposite number. The club contains members from across the social science faculty and the university as a whole. The openly espoused goal of the select club is the acquisition of material wealth, and members see themselves as 'select' in these terms, not in terms of academic or intellectual prowess. During my time at USEN the select club was 'in control' of the social policy department, meaning that it had significant influence over decisions on such issues as allocation of resources, staff promotions and committee memberships. A number of factors contributed to this. First, the HoD at the time was a man who, while not a select club member, was nonetheless sympathetic to their aims. Second, the select club had close links with the Vice Chancellor-a position of unrivalled importance in Nigerian higher education-which 
substantially improved their ability to act independently. One non-select club member of staff commented that their association with the VC allowed them to "become liberated" from constraints on their action. Third, the de facto leader of the select club was a particularly powerful member of staff who had close ties with the VC independent of his position as leader of the select club. He had previously held important positions in national politics. As a result, the benefits accrued by members of the select club were likely to be derived from a combination of closeness to the faction and closeness to the leader. One respondent commented that one of the reasons certain select club members were able to secure promotions is because they were tied "to the apron strings" of their leader.

It was widely acknowledged that the glue holding the select club together was their individual and collective participation in extra-legal practice. One of the main functions of the club, therefore, was to protect members from external sanctions on their behaviour. As a result, it was widely believed that the select club in social policy operated on the basis of collective decision-making, in that decisions taken by individuals had to be agreed on by all members. As any extra-legal activity had been agreed by all members, each member therefore agreed to defend their colleagues against allegations of malpractice or wrongdoing. This mechanism provided a protection for all members as they knew that they would not be betrayed by a colleague, as betrayal would also implicate the accuser. This marked it out as being significantly different from the ASC, which had no such codes of behaviour, primarily because it was unnecessary: even if individual ASC members participated in extra-legal practice, there was no group decision to do so. Members who did do this were on their own. In addition, the select club members much more exclusionary than the ASC, specifically because of their participation in extra-legal activities.

Participation in extra-legal practice may not be the only thing holding the select club together and encouraging new members, however. The select club is an isusu group, a form of Igbo credit institution in which members make regular financial contributions and receive fixed amounts at periodic intervals. Isusu groups initially developed in order to provide young men with the resources they needed to get married (Nwabughuogu, 1984). The select club isusu group is intended to provide members with the capital to make large purchases such as cars or to begin building homes or businesses. This aspect of the select club, which has no connection to their participation in extra-legal practice, provides another explanation for their success. 
The select club performs similar functions to its opposite number, though with far greater success. It was able to 'bring in' staff to the social policy department who shared its ethos, and was also successful in supporting staff once they had joined the department. Its primary role was to act as protector of individuals and to ensure that they advanced up the academic ladder as quickly and efficiently as possible and gain membership of important departmental and faculty committees, both of which give greater power to the group. During my time at USEN the select club performed this function extremely effectively: of four promotions announced during my fieldwork, all were select club members. This is despite the fact that some of these promotions were to grades not yet achieved by other staff members who had considerably longer service at USEN. This is particularly noteworthy as Nigerian bureaucracies have a reputation for promoting people on the basis of "serving time" in an institution as opposed to merit (Cohen, 1980: 76), so one might therefore expect people with longer service to be promoted earlier. My research suggests that a number of those promoted were lacking in both time served and merit compared to some of their non-select club colleagues. Departmental committees, particularly lucrative and influential ones, were also dominated by the select club.

There is greater clarity to the logics that structure the existence of the select club. The central logic underlying their existence is that of individual and collective self-interest. The group does not seek to cloak this behind a different external portrayal; to the contrary, they are very open about their interest in material advancement. This logic was based on a belief that personal material advancement, even at the expense of the university, was justified and represented a legitimate goal. I would argue - though detailed examination of this issue is beyond the scope of this chapter-that this belief is a direct result of the alienation from the state felt by many Nigerian people, particularly in the south-eastern region (Tignor, 1979), a direct result of the type of rule imposed during the colonial era (for more detail on this issue see Ekeh, 1975; Willott, 2009).

\section{Non-Faction Members}

There was just one member of staff in the social policy department who was not a member of either of the two factions. Chigozie Emerenini had a broadly anti-colonial, though not avowedly Marxist, political stance, something which would have allied him more closely to the ASC, though he did not seem to fit in with this group's emphasis on hard work and 
scholarship. Chigozie had a difficult time gaining access to promotions or perks at USEN-it had taken him well over a year to get his position regularized - and appeared to be the most marginalised of all members of the department. However, Chigozie was fortunate that he had a strong patron, a senior ASC academic called Professor Isaac Okonkwor, someone who was able to ensure that he retained his position and eventually ensured his regularization.

This relationship illustrates the extent to which obligation is a key concept in understanding Nigerian state and society. When I first became aware of the relationship between the two men I was surprised, as I had regarded Chigozie's patron as a strong academic and Chigozie as much less so. I later learnt that Prof. Okonkwor's reason for assisting Chigozie was that he had 'inherited' the role of patron from a patron of his own who he felt obliged to help. Chigozie had been 'brought in' to the department on a temporary contract by a senior academic called Professor Uche Osoagwu. There is some debate over why Prof. Osoagwu chose to bring Chigozie in, with Chigozie himself remarking that Prof. Osoagwu had brought him in on merit and another academic commenting that Chigozie was "his townsman with a higher degree, that's all" (interview, 22 July 2007), suggesting that their community of origin was the most important factor. This interpretation is consistent with Young's work in a Zairean university, in which non-merit factors - in Young's research, ethnicity, in this case, patronage - can only operate among formally qualified but not outstanding candidates. He provides an example from his research:

[E]thnic preference, conscious or unconscious, can only arise when the relative qualifications of the contenders fall into a gray zone of ambiguity. For example, in Zaire, it would be unimaginable for a candidate armed with a dubious doctorate from Spain or Czechoslovakia to win support over a contender whose thesis, directed by a distinguished Belgian academic, had won a "grande distinction" from Louvain, whatever the respective ethnicity of the aspirants and the voters (Young, 1981: 153).

This suggests a system in which the individual concerned first has to achieve the required standard-in Chigozie's case a Master's degreebefore they can enter the 'gray zone of ambiguity' in which patronage exerts an influence. With no Master's degree, it would have been impossible for Chigozie's patron to accept him as a staff member in the department. Merit and patronage are therefore both required for success, and operate simultaneously (see also Therkildsen, this volume).

Prof. Osoagwu had been the Masters and $\mathrm{PhD}$ supervisor of Prof. Okonkwor, so when Prof. Osoagwu retired he "handed [Chigozie] over" 
to Prof. Okonkwor, who "has taken it upon himself to see about his social climbing” (interview, 3 September 2007). Prof. Okonkwor clearly felt an obligation to help his patron by taking responsibility for Chigozie, even though Chigozie did not have the characteristics of scholarship or Marxism that might otherwise have made him a good candidate for Prof. Okonkwor's patronage. Obligation to his patron therefore trumped Prof. Okonkwor's sense of loyalty to these more abstract concepts.

\section{Factionalism and Entry to USEN}

Academic staff recruitment at USEN is dependent on a combination of factors including qualifications and where they were obtained, connections, including those to factions, ethnicity, political ideology and beliefs about the way the university should run. Each member of staff will utilise a different combination of these "currencies" (Bierschenk, 2008) in order to gain entry. A combination of qualification and connections is necessary for all but the very best candidates, such as those with higher qualifications from British or US institutions. If an individual has both the qualifications required to begin an academic career-sometimes nothing more than an undergraduate degree - and people of influence-whether individuals or a faction - supporting his or her application, they are very likely to succeed. For those with one but not the other, gaining a position will be considerably more difficult. Andreski (1979) suggests that the limits to purely kin-based appointments are tiny, but my research suggests that unqualified academics, however well-connected, will not secure employment. At the opposite end of the spectrum, a senior academic with a doctorate from Oxbridge or a prestigious US university would be appointed regardless of other considerations. Young's (1981) concept of the 'gray zone of ambiguity' plays a part only amongst those who are formally qualified but not outstanding candidates.

A striking attribute of academic appointments to USEN is their informality. Very often an individual—sometimes a postgraduate or ex-student or non-academic member of staff-will be contacted by an academic because there is a vacancy in their department. If the person is qualified and influential people within the department are happy for them to join, they will enter the university. To get around administrative procedures related to advertisements and interviews, new academics will often receive temporary appointments initially, which are 'regularized' later. There is a general belief that recruitment is now much more based on connections than previously, a change that began during the financial 
crisis and subsequent era of austerity and structural adjustment during the 1980s and depends largely on the attitude of those in positions of authority in departments, faculties and the central university administration. A number of authors (such as Anugwom, 2002; Jega, 1995; Saint et al., 2003) support the view that staff appointments and promotions became more personalised and less meritocratic during this period, particularly as a result of military intervention in university management. As is the case for other aspects of the operation of USEN, there are also senior members of staff who work to the official rules and will only appoint others if they are adequately qualified.

During the Cold War period political ideology played a part in academic recruitment, especially in social science departments. A senior member of staff in the social policy department told me that in the 1980 s academic staff would be appointed on the basis of two criteria: whether they were, first, a good scholar, and second, a Marxist. This was partly because the $\mathrm{HoD}$ at the time wished to guide the department along ideological lines. However, the importance of political ideology in recruitment has declined markedly since the end of the Cold War. This may, however, be influenced by the fact that those in control of the social policy departmentand, by extension, appointments of academics - are the select club, who are far less ideologically-minded than their ASC counterparts. Individuals are now much more likely to be judged on their loyalty to a particular faction and how they believe the university, rather than the country as a whole, should be run.

Recruitment of particular individuals has the potential to intensify departmental conflict, as the case of Wilson Nnaji reveals. Wilson was lecturing at a different, much less prestigious university and was registered for his PhD at USEN, where he had also completed his BSc and Masters. He was approached by the social policy department at USEN to teach part-time. At the time the department was headed by a member of staff who was known to be hostile to the select club and a close associate of the ASC. During the period that Wilson was teaching part-time, two members of the select club were suspended for unethical practice. The circumstances of the suspension of one member of staff are unknown to me, but the second was suspended for asking a student for $£ 50,000$ (approximately $£ 200)$ to approve a PhD thesis. When Wilson entered the department he was given the courses of one of the suspended lecturers to teach. The attitude of other select club members in the department was that Wilson had "come to replace their friend" (interview, 30 August 2007), resulting 
in a large amount of hostility being directed towards Wilson. In addition, these people believed that, as Wilson had been brought into the department by the previous, ASC regime, he must be loyal to them.

Whatever the reasons behind Wilson's entry into USEN, he is now firmly associated with the ASC. This has had negative implications for his academic career. Wilson originally came in on a temporary contract and so had to go through regularization to get a formal academic post. However, soon after his original appointment the departmental leadership changed hands with the new select club leadership being much less sympathetic to Wilson than the previous one. Wilson's regularization was 'sat on' by a senior member of staff to ensure it was not completed. This staff member once described Wilson and a close friend of his to me as "insulting specimens". Eventually his regularization was only completed with the intervention of senior academic Prof. Arinze Omeife, the ASC leader.

\section{Factionalism and Promotion}

At USEN, as in all higher education systems, promotion up the academic ladder is dependent on a variety of official criteria. At USEN promotions are officially subject to the rules set out in the university's 'green book' and candidates for promotion must fill out an Academic Staff Appraisal Form (ASAF). Promotions are decided on the basis of length of service, academic qualifications, publications, teaching and professional experience and conference attendance (USEN, nd), and are on a points-based system. At USEN promotions are a site of extreme contestation between the two factions and are used by the powerful to advance the interests of those they favour and stifle the ambitions of those they are hostile to. There are clearly-set rules regarding promotions, but those in positions of influence nonetheless use numerous methods to either assist or thwart promotion efforts. During my time at USEN I came across a number of staff members who believed that their advance up the academic ladder had been 'frustrated', in some cases for many years. A key issue with regard to promotions at USEN is the huge scope for different interpretations of the criteria set out in ASAF.

The situation individuals are faced with when seeking promotion could be described as a classic double bind (cf. Bierschenk, this volume). Individuals find that they must meet the official criteria for promotion, but are also acutely aware that, without the support of a senior member of staff to ensure their application is not 'sat on' or frustrated, they are likely to 
be denied. Official criteria are used with great rigour in some situations, and great laxity in others, depending on the positions and interests of those involved.

Publications are a particularly contested site. According to ASAF, books, book chapters and journal articles each receive points depending on the quality of the publication. Journals are assessed on their impact factor. However, some in the social policy department have sought to manipulate this process in order to ensure that local journals owned by their members are categorised as high impact. In this case the journal's owner would then encourage his or her friends and fellow faction members to submit articles to this journal, which would then be published whatever their quality, a practice that is well known in Nigeria (Olukoju, 2002).

The remaining criteria in form ASAF are also subject to the interpretation of the reviewer, and are therefore open to decision-making on the basis of non-merit factors. There is considerable scope for reviewers to award more or fewer points in each category, and, as with publications, it is personal and factional connections that are often-though not always - the deciding factor.

As with most types of patronage at USEN, where there are winners - such as those who have poor-quality publications accepted to local journals and gain promotion on that basis-there are also losers. A useful case study of thwarted ambition is that of Professor Emenike Esonwanne. Prof. Esonwanne was a highly regarded scholar who had finished top in national examinations and had a long list of publications in both local and international journals. However, Prof. Esonwanne was viewed by many at USEN as a "radical", a perspective that was not well received by many, particularly those close to the locus of power. In Prof. Esonwanne's case, this meant he was politically left-wing and a strong trade unionist, something that brought him into conflict with "established interest" within the university (interview, 27 June 2007). He was close to, and had some ideological affinity with, some ASC members, but their marginalisation meant that they were unable to assist his promotion efforts.

A number of different methods were adopted to prevent Prof. Esonwanne gaining a variety of promotions. In an attempt to get promoted to the rank of Reader, many of his publications were not sent to the external assessor. For a later promotion attempt the faculty did not send any papers at all to the external assessor. His file and forms went missing within the department and he was accused of trying to send the assessor an additional paper in order to improve his chances. Deans of Prof. Esonwanne's 
faculty refused to sign forms that would have assisted his chances of promotion and assessment of his publications was manipulated.

Prof. Esonwanne was awarded enough points to be promoted to Reader, but not Professor, a title of great significance and one to which Prof. Esonwanne believed he was entitled. Eventually the university agreed with this and he gained his Professorship, having submitted his papers four times and after a wait of seventeen years from his original application. The final decision was made, according to Prof. Esonwanne, because the university was ashamed at the length of time it had taken to approve the Professorship. This suggestion is similar to evidence relating to extra-legal processes across USEN: rules may be manipulated up to a point - the moral boundary, beyond which it is viewed as unacceptable to go-but the formal written policy will, once the informality reaches a certain stage, act to rein it in. 8

This situation reflects the double bind at the heart of Nigerian higher education. Many people within the university wish to use it-in an archetypal prebendal manner (cf. Joseph, 1987) — to benefit themselves and their clients. However, these people are also aware of the necessity for the university to retain the image of an institution embodying the principles of higher education: scholarship, meritocracy, hard work. For this reason, and particularly because the university is in the Federal sector-where the country's educational elite come to study-unofficial practice can only go to a certain level before the norms of the university - an uneasy, changeable equilibrium between the formal and the informal-prevent it from going further. Prof. Esonwanne's case, however, and those of others who have had similar experiences, illustrates that there is considerable flexibility in this equilibrium. The role of merit may, at times, be very small indeed.

Another case study illustrates the negotiation between merit and nonmerit factors, and the importance of hierarchy in determining access to rewards. Daniel Nwabeke, who had difficulty advancing academically due to his position on the wrong side of the factional divide, was advised by a senior member of staff to eliminate bias by using academic means:

8 This type of moral boundary was in evidence in a number of areas at USEN, including the numbers of students who could be admitted to the university and pass courses on the basis of non-merit factors, and the allocation of rewards such as promotions and committee memberships for academic staff. 
[My colleague] said what you need now is to write and publish... if you publish and people want to [frustrate] you there is a limit to how far they can do it. If every year they see at least one or two more articles in your appraisal, over the years, they will transform the hatred they have for you to respect (interview, 30 August 2007).

I would cast doubt on the plausibility of this statement. It appears more likely that Daniel's attempts to get around his problems through using official channels would be frustrated by those who were averse to him achieving success. For top-rank academics in Nigeria, success through these formal mechanisms may be achievable, though first getting to the position of a strong academic may require either the use of personal connections, qualifications from a high-ranking foreign institution or both. For young, inexperienced academics battling against numerous enemies in their own institutions, it is highly unlikely. As a result, promotions are not always, or even usually, reserved for the most meritorious staff.

\section{Factionalism and Other Benefits}

$\mathrm{PhD}$ supervision is another important site of contestation between factions. A PhD is viewed as an important aspect of an academic career in Nigeria, both in terms of prestige and as an important criterion for promotion. However, actually receiving a $\mathrm{PhD}$ can be difficult if you are either a member of a group that is outside power in your department or you are assigned to a PhD supervisor with whom you have a conflict of interest.

Emeka Obi is a member of staff who has experienced difficulty in getting his PhD. Emeka is an ASC member who is currently registered for a $\mathrm{PhD}$ in social work but was informed by other members of staff in the department that he was not allowed to do this $\mathrm{PhD}$ as his Master's degree was in social policy and he must therefore repeat his Masters. Emeka later discovered that this rule had been 'cooked up' within the department to frustrate him. He informed me that $\mathrm{PhD}$ supervision is intensely political and that if the student is not liked or is not loyal to the supervisor's group, they simply will not get their PhD. Indeed, he told me that members of the select club in the department had said that they "wouldn't live to see [him] get [his] PhD from the department" (interview, 30 August 2007). Emeka is now searching for a scholarship to study for a PhD outside Nigeria.

USEN academics also have the opportunity to contribute to the academic life of the department and faculty through committees. Committee Chairmanships and memberships are also beneficial when seeking promotions - they appear on form ASAF that is used to assess suitability 
for promotion - and are used by some staff members to divert departmental funds to individuals. Committee membership is another arena in which those in charge of appointments can favour members of their faction. In the social policy department, non- and anti-select club members were excluded from influential committees with remits covering financial matters, appointments and promotions, all of which were used to advance the interests of the select club, who dominated these committees. During my time at USEN only one committee, the environmental committee, was headed by a non-select club member. The environmental committee's main remit concerns litter, an extremely marginal issue. When I related this fact to a non-select club academic, he commented that whoever allocated committee memberships was playing a joke at the ASC's expense by allocating them a committee concerning rubbish.

Another area that is influenced by patronage and factionalism is allocation of courses to academics. Heavily subscribed or "juicy" (Blundo, 2006: 86) courses were more likely to be allocated to select club members, who could use them to acquire wealth through selling handouts or through students 'sorting' them. ASC members were often unhappy with course allocation because it was not done on the basis of specialism but other factors. There appeared to be a concerted effort on the part of select club members to retain the courses they wanted to teach and foist others on non-select club members, regardless of their ability to teach these courses. A prominent ASC member told me that by forcing courses on unqualified members of staff, those in charge "want to humiliate you" (interview, 3 October 2007).

\section{CONCLUSION}

The careers of academics at USEN are critically influenced by their connections to factional groupings. In the social policy department during my fieldwork, those close to the select club and its leader found promotion, committee membership and the right to teach the juiciest, most lucrative courses relatively straightforward. By contrast, those who were either ASC members or non-factionalised found their working lives much more difficult, and even the most simple things - such as getting $\mathrm{PhD}$ supervision or one's post regularized-became a struggle. However, despite this conclusion, factionalism has boundaries and cannot be reduced to a mere power struggle between identical groups. There are two reasons for this conclusion. 
First, there are clear differences between the two factions. While it is clear that both groups' main function was to advance the fortunes of their members, there were both rhetorical and actual contrasts. Many, though not all, ASC members had a commitment to scholarship and were less likely to participate in extra-legal practice than members of the select club. Students viewed them as more likely to reward high-quality work as opposed to financial favours. Despite this, however, some ASC members were just as likely to engage in sorting and lobbying as members of the select club. There is, therefore, an ambiguity to the ASC that combines the logics of meritocracy with those of self-interest. The select club, by contrast, showed no such ambiguity, and were openly committed to material gain.

Second, there are moral boundaries at work within the factional struggle. The extent to which staff can be either unjustifiably rewarded or frustrated has clear limits, though these show a large degree of flexibility and are still dependent on the personalities and positions of the individuals involved. As the example of Prof. Esonwanne illustrates, this moral boundary may be a long way from the official rules, but it nonetheless still exists.

These conclusions illustrate patterns of behaviour that structure the careers of academic staff at USEN. Patronage and factionalism are the strongest influences over attainment, but these logics are entangled with those of merit. Entrance to the university for academics is dependent upon achievement of a minimum qualification. Once they have achieved this, they enter what Young (1981) terms the 'gray zone of ambiguity': the arena in which patronage and factionalism exert an influence. Very highly qualified candidates, such as those with doctorates from prestigious US or UK institutions, are likely to be admitted on merit alone, without the need for a personal or factional connection, while very poor candidates will not gain entry, whatever their personal or factional linkages. Once inside the university, the factional struggle exerts a greater influence, as noted above. However, even in these cases there are moral boundaries that prevent the rules from being stretched too far. In short, then, logics of merit and patronage are intertwined in the careers of academic staff at USEN, such that for all but the most outstanding candidates, both are required for success.

The complexity and ambiguity of the factional struggle and its impact on staff at USEN illustrates the necessity for long-term ethnographic work to understand the character of states - in Africa no more and no less than 
anywhere else. Reduction of the Nigerian state to simple slogans-prebendalism, neopatrimonialism - glosses over the intricacy of relationships and how they structure access to rewards. Only by understanding how these relationships work at the micro-level are we able to understand the dynamics of the African state and how it might better serve its people.

\section{REFERENCES}

Andreski, Stanislav. 1979. Kleptocracy as a system of government in Africa. In Ekpo M., ed. Bureaucratic Corruption in Sub-Saharan Africa: Toward a Search for Causes and Consequences. Washington DC, University Press of America, 275-290.

Anugwom, Edlyne E. 2002. Cogs in the wheel: academic trade unionism, government, and the crisis in tertiary education in Nigeria. African Studies Review, 45 (2): 141-155.

Bayart, Jean-François. 1991. L'Etat. In C. Coulon and D.-C. Martin, eds. Les Afriques politiques. Paris: Découvertes. In Young, T. ed. Readings in African Politics. Oxford, James Currey, 40-44.

- 2009. The State in Africa: the Politics of the Belly, second edition. New York, Longman.

Bierschenk, Thomas. 2008. The everyday functioning of an African public service: informalization, privatization and corruption in Benin's legal system. Journal of Legal Pluralism, 57, 101-139.

Blundo, Giorgio. 2006. Dealing with the local state: the informal privatization of streetlevel bureaucracies in Senegal. Development and Change, 37 (4): 799-819.

Brumfiel, Elizabeth M. 1994. Factional competition and political development in the New World: an introduction. In Brumfiel E.M. and J.W. Fox, eds. Factional Competition and Political Development in the New World. Cambridge, Cambridge University Press, 3-14.

Bujra, Janet M. 1973. The dynamics of political action: a new look at factionalism. American Anthropologist, 75 (1): 132-152.

Chabal, Patrick and Jean-Pascal Daloz. 20o6. Culture Troubles: Politics and the Interpretation of Meaning. London, Hurst and Company.

Cohen, Ronald. 1980. The blessed job in Nigeria. In Britan G.M. and R. Cohen, eds. Hierarchy and Society: Anthropological Perspectives on Bureaucracy. Philadelphia, Institute for the Study of Human Issues, 73-88.

Ekeh, Peter P. 1975. Colonialism and the two publics in Africa: a theoretical statement. Comparative Journal of Society and History, 17 (1): 91-112.

Jega, Attahiru. 1995. Universities and academic staff under military rule. Review of African Political Economy, 22 (64): 251-256.

Joseph, Richard A. 1987. Democracy and Prebendal Politics in Nigeria: The Rise and Fall of the Second Republic. Cambridge, Cambridge University Press.

Nicholas, Ralph W. 1977. Factions: a comparative analysis. In Schmidt, S.W., Gausti, L., Landé, C.H. and J.C. Scott, eds. Friends, Followers and Factions: A Reader in Political Clientelism. Berkeley, University of California Press, $55^{-73}$.

Nwabughuogu, Anthony I. 1984. The isusu: an institution for capital formation among the Ngwa Igbo; Its origin and development to 1951. Africa, 54 (4): 46-58.

Olivier de Sardan, Jean-Pierre. 2003. L'enquête socio-anthropologique de terrain: synthèse méthodologique et recommandations à usage des étudiants. Etudes et Travaux 13, LASDEL, Niamey.

- 2009. State bureaucracy and governance in francophone West Africa: an empirical diagnosis and historical perspective. In Blundo, G. and Le Meur, P.-Y., eds. The Governance of Daily Life in Africa. Leiden, Brill, 39-72. 
Olukoju, Ayodeji. 2002. The Crisis of Research and Academic Publishing in Nigerian Universities: The Twentieth Century and Beyond. Paper presented at the 28th Annual Spring Symposium, African Universities in the Twenty-First Century, University of Illinois/ CODESRIA, Dakar, Senegal, 25-27 April 2002.

Saint, William, Hartnett, Teresa A. and Erich Strassner. 2003. Higher education in Nigeria: a status report. Higher Education Policy, 16: 259-281.

Sandbrook, Richard. 1972. Patrons, clients, and factions: new dimensions of conflict analysis in Africa. Canadian Journal of Political Science, 5 (1): 104-119.

Smith, Daniel J. 2001. Kinship and corruption in contemporary Nigeria. Ethnos, 66 (3): 320-343.

. 2005. Legacies of Biafra: marriage, 'home people' and human reproduction among the Igbo of Nigeria. Africa, 75 (1): $30-45$.

- 2006. A Culture of Corruption: Everyday Deception and Popular Discontent in Nigeria. Princeton, Princeton University Press.

Tignor, Robert L. 1979. Colonial chiefs in chiefless societies. In Ekpo, M. ed. Bureaucratic Corruption in Sub-Saharan Africa: Toward a Search for Causes and Consequences. Washington D.C., University Press of America, 189-210.

University of South Eastern Nigeria, no date. Academic Staff Appraisal Form. University of South Eastern Nigeria.

Willott, Chris. 2009. Refashioning Neopatrimonialism in an Interface Bureaucracy: Nigerian Higher Education. Unpublished PhD thesis, University of Bath, UK.

- 2011. "Get to the bridge and I will help you to cross": Merit, personal connections and money in access to Nigerian higher education. Africa Spectrum, 46 (1): 85-108.

Young, M. Crawford. 1981. The African university: universalism, development, and ethnicity. Comparative Education Review, 25 (2): 145-163. 


\title{
WORKING IN NEOPATRIMONIAL SETTINGS: PUBLIC SECTOR STAFF PERCEPTIONS IN TANZANIA AND UGANDA
}

\author{
Ole Therkildsen
}

\section{INTRODUCTION $^{1}$}

The performance of organisations - their capacity to produce mandated outputs-exists to the extent that they possess and effectively manage external relationships and a sufficient range of human, financial, infrastructural, coercive and normative resources (Boesen and Therkildsen 2004). But there are often considerable differences in the performance of government organisations within and across countries. One explanation for these differences-especially among poorer countries-is that performance is influenced not only by 'intrastate' governance factors such as the extent of rule-based decision-making, the competency of public officials and 'correct' governmental procedures in a rather narrow sense, but also by how-and how efficiently - various sections of the state apparatus interact with societal groups (Moore, Leavy, and White 2003: 189). The relationship between state and societal actors is at the centre of this 'polity' approach (Houtzager 2003: 13).

Some observers claim that neopatrimonialism (NP) dominates this relationship in Africa. Chabal (2005: 21), for example, argues that, "[c]ontemporary politics in Africa is best understood as the exercise of neopatrimonial power." NP connotes "those hybrid political systems in which customs and patterns of patrimonialism coexist with, and suffuse, rational-legal institutions" (Bratton and van de Walle 1997: 62). Proponents of the neopatrimonial paradigm claim that "scholars of African politics have embraced the neopatrimonialism model" (ibid.: 63). It "has become the standard for understanding African politics" (Leonard and Straus 2003: 5).

1 This is a revised version of a paper presented at the conference, "The Artifices of Government. On the Appropriation, the Use and the Formation of States" held at the Max Planck Institute for Social Anthropology Halle/Saale, July 20-21, 2006.

Some of the empirical information used was collected through commissioned work for Danida and the governments of Tanzania and Uganda (see Therkildsen and Tidemand (2006). I alone am responsible for the opinions and assessments made here. 
While the concept of NP means widely different things to different scholars (Erdmann and Engel 2006, 2007), and claims of the dominance of the paradigm in studies on Africa are clearly exaggerated (Mkandawire 2001), it is certainly true that the paradigm has significant influence, and that this influence extends beyond academic circles. Thus, the World Bank states that " $[\mathrm{m}]$ eritocracy has not yet become established in many countries. Instead the state has often become a massive source of jobs, with recruitment based on connections rather than merit" (1997: 93). Interestingly, this resonates well with opinions expressed by the government in Tanzania. The new public service management and employment policy, for example, states:

For quite some time now, the public service has been viewed as a liability to the taxpayer rather than an asset. This is because low productivity, erosion of work ethics, indiscipline, blatant violation of rules, regulations and procedures, weak control and corruption have been observed as common features in the service (President's Office 1999: 10).

The Ugandan government also presents a very critical picture of its own public service: its staff are poorly managed, it lacks integrity and it uses limited resources inefficiently. "A disabling public service culture" is also lamented (Government of Uganda 2005: 8).

But how useful is the NP paradigm for understanding African bureaucracies? This chapter focuses on staff perceptions of the use of merit principles in staff management. It focuses specifically on hiring, firing, transfer, demotion and promotion practices in the public sector in Tanzania and Uganda and on how such practices influence organisational performance and staff motivation to work in such ostensibly neopatrimonial settings.

There are two main reasons for this focus. First, public servants are said to be at the centre of many patrimonial practices. Yet empirically grounded analyses of the motivations and performance of government staff at work are rare. Second, a central premise of human relations theory is that organisational capacity is strongly influenced by staff (Guest 1999). Although public servants are obviously not the only factor of importance for capacity, this simple premise is especially relevant for poor countries where public sector organisations are relatively labour-intensive. Moreover, conflicting or cumbersome bureaucratic rules, resource scarcity and contested relations with societal groups or individuals often make even simple administrative tasks demanding, so that staff efforts beyond the normal call of duty are required to get things done. Staff motivation and management are therefore central to capacity. 
The central argument of this chapter is that the NP paradigm applied to these issues-both on its own, and as it is currently used in studies on Africa-does not provide an adequate analytical basis for understanding politics and administration. Specifically, proponents of NP tend to: (a) ignore that legal-rational and patrimonial practices coexist and interact; (b) interpret all evidence of informality and poor performance to be a result of patrimonial practices, thereby ignoring other relevant factors identified by human relations and organisational theory; and (c) use the category 'patrimonial' as a label for practices that are actually quite different. As a result, analyses based on the paradigm tend to overlook the often significant variation in organisational capacity within public sectors; the uncertainty that characterises relations in neopatrimonial settings; and the particular types of hypocrisy that this generates.

The empirical basis for this study is a 2006 survey of public servants' perceptions of merit, motivation and staff management in their own workplaces and in the public sector in general. Twelve organisationsone pair of ministries, local governments and executive agencies respectively-were selected in Tanzania and Uganda. The selection was based on assessments of their relative performance (as being either above or below average in each category). Some 400 public servants (all university graduates, middle-level officers and working in headquarters) were interviewed in these twelve organisations. Around 100 of these officers also participated in a total of 24 focus group discussions (a separate group of younger and older staff in each case organisation). The information collected in this way offers a glimpse inside the 'black box' of bureaucracies in poor countries, which more macro-oriented approaches tend to ignore. As a consequence of this focus, less explicit attention is paid to the general macro-context in which public organisations operate.

The rest of the chapter is divided into seven sections. Following a very brief introduction to some of the main features of public service in Tanzania and Uganda, the concept of NP is presented and discussed, and the methods used to study it with respect to staff management are presented. Next, it is shown how variation in adherence to bureaucratic rule is clearly associated with variation in organisational performance. Some findings on employee perceptions of staff-related practices follow. The next section aims to point out that the legal foundation for legal-rational behaviour is often weak, and that it can be analytically and conceptually difficult to distinguish whether practices are driven by merit principles, patronage or clientelism. Finally, an analysis of staff acceptance and contestation of neopatrimonial practices is presented. The conclusion also 
briefly discusses the prospects for transformation and change of public organisations in neopatrimonial settings.

\section{The Public Service in Tanzania ANd Uganda}

Presidential power is a key feature of the political systems in both Tanzania and Uganda. The president is the head of state and effectively the leader of government, although the prime minister is the head of the cabinet. While Tanzania has held competitive presidential elections every five years since 1995 - and peacefully changed office holder two timesUganda has had three recent competitive presidential elections (in 2001, 2006 and 2011) with no change of office holder.

Although formal presidential powers are set out in the legislation they are reinforced by many informal mechanisms. In each country the most important informal channel goes through the ruling party, which is headed by the president. It is through this channel that he and the party have significant influence on who get what position in the public service and how particular public organisations are run.

In Tanzania presidential appointing power over the public services is extensive. It includes the provision that even appointing powers which are delegated to others can be claimed and exercised by the president should he so desire (Bana and McCourt 2005: 8). In Uganda, presidential powers vis-à-vis the public service are written into the constitution and are similarly wide-ranging. The Public Service Commissions in both countries are ostensibly independent, but the presidents appoint their members. Central control of a substantial segment of the staff in ministries therefore remains strong. However, the recent decentralisation reforms and the establishment of executive agencies in the two countries have given both local governments and executive agencies some autonomy in staff matters - more so in Uganda than in Tanzania.

The Ugandan public service had the reputation of being the best in Africa in the 196os, but it collapsed during the Amin era and the subsequent civil war. State capacity remained weak in strife-ridden Northern Uganda for decades. The National Resistance Army came to power in 1986. After that state capacity rose significantly until the late 1990s when problems of corruption, patronage and governance came to the fore (Barkan et al. 2004; Robinson 2006). Public perceptions of bribery in different public organisations, however, vary widely (Deininger and Mpuga 2005: 178). Since Independence, when over half the civil servants were Bangandas, 
the ethnic composition of the public service has remained politically sensitive, and the Movement has always had a rather ambivalent view of the public service: regarding it with suspicion while relying heavily on it to implement its policies. Museveni's own writings (1997) and the 2006 election manifesto exemplify this.

The Tanzanian public service has had a rather different performance reputation. It was feeble at Independence and was soon thereafter put in charge of state-led rural and industrial development. Its official mandates have outstripped its capacity ever since, with the push for the Millennium Development Goals (MDGs) being the most recent example among many. Nevertheless, political stability, some political support for public service reform, and donor funding for implementation have meant that Tanzania's public sector has been strengthened in recent years compared to other countries (Hydén, Court, and Mease 2004). Ethnically based recruitment is not common-at least not in the upper levels of the public service (Nyang'oro 2004). Nevertheless, there is widespread dissatisfaction with the performance of public organisations, and the delivery of services is generally believed by the public to be corrupt (President's Office 2005: 30).

A merit-based public service is the officially declared goal in both countries. Public service reform efforts have aimed to promote a performance culture in the public sector (Clarke and Wood 2001). Efficiency, effectiveness and accountability have been the buzzwords (Therkildsen 2001). Major changes in size, structure and pay have been implemented to achieve that (Rugumyamheto 2004; Mutahaba 2005).

Thus, the size of the public service has changed significantly in the last twenty years. ${ }^{2}$ Following fairly drastic reductions in the size of the services during the Structural Adjustment Programmes from the mid-1980s and onwards (most pronounced in Uganda) employment is now growing again partly due to internal political pressure (also especially in Uganda) and partly due to efforts to attain the MDGs. Security of employment, which was one of the privileges of public service in the past, is now coming under pressure. Moreover, career promotions are no longer supposed to be based on length of service, as in the past, but on merit and individual

2 Public service employment was 299,000 in Tanzania and 240,000 in Uganda in 1986. In 1998, the figures were 264,000 and 154,000 respectively. In 2004 they were 295,000 and 219,000. In Tanzania, the employment growth rate has been lower than the population growth rate (2.9 per cent) since 1998 (Therkildsen and Tidemand 2006). 
performance. Staff are ambivalent about these changes. A performanceoriented culture in the two bureaucracies is clearly not strongly rooted.

At the same time, a multitude of restructurings have taken place. Many ministries are restructured regularly. Staff have also been decentralised, so that local government in Tanzania and Uganda now employs 64 per cent and 87 per cent of public servants respectively. In addition, a number of executive agencies and other public agencies have been established during the last 10 years-especially in Uganda where they now employ some $5^{-10}$ per cent of the total staff.

African public servants are the best paid in the world relative to the average person (Schiavo-Campo 1999) —as are those formally employed in the private sector. Tanzania and Uganda are no exceptions but public servants here (as elsewhere) have many social obligations to extended families. The number of dependants that rely in whole or in part on a public servant income is often large. In our survey sample the family size of public servants (including dependants) was-on average-fifty per cent higher than the average family size in the capital. ${ }^{3}$

Overpaid compared to ordinary people or overburdened with social obligations? In any case, staff complain loudly (in interviews, rarely on the streets) about low salaries for three reasons. Firstly, present salary levels are significantly lower than thirty years ago, despite recent improvements. Moreover, public servants do not compare their situation with that of the average person on the street; they use pay levels in the upper league of the private sector as a yardstick instead-and feel dissatisfied as a consequence. Secondly, as part of the public sector reforms (which included substantial retrenchments), both governments promised much higher salaries to those who remained but then did not deliver. Pension improvements have not materialised either (Kiragu, Mukandala and Morin 2004). Finally, substantial wage decompressions have taken place, especially in Uganda. Here the pay difference between the salary of the president and that of the lowest paid employee is 51:1-without considering fringe benefits (Kiragu and Byaruhanga 2004: 4). Employees in executive agencies in Uganda earn some 27-6o per cent more than their occupational counterparts in central government (Ministry of Public Service 2005: 21). Indeed, massive pay differentials now exist in the public service, with the car drivers in some agencies earning 50 to 150 per cent more than economists

3 Data from the most recent population census (where a household is defined as those that eat together). 
working in the central ministries (Government of Uganda 2004: 140). Such differentials cause resentment. In both countries, but especially in Tanzania, equality (among bureaucrats themselves) remains a strong norm.

Interestingly, salary is not the most important legal source of income for public servants. Various allowances are equally or even much more important income generators for almost go per cent of the respondents in our survey. There may well be even bigger disparities between beneficiaries of allowances than there are in salaries although this is difficult to establish (Valentine 2004).

Finally, both Tanzania and Uganda have, at various times, been favourites of donor countries. Tanzania fell from grace in the early 1990s. Relations improved after that, but have now soured again following recent corruption scandals involving high-level politicians. Uganda was the darling of donors for some years in the 1990s. Now political developmentsthe war in the north, the political transition issue and corruption-worry them. Nevertheless, donors have been major funders of the two governments for years. Both countries are aid-dependent with total aid being 12 per cent of GNI for Tanzania in 2000, and of a similar magnitude for Uganda. Some $3^{-}-5^{0}$ per cent of the government budget is financed by donors. In both countries, but particularly in Tanzania, donors have funded major public sector reform activities, including retrenchments, restructuring of public organisations, decentralisation, pay reform, establishment of executive agencies and so on.

\section{Problems of Neopatrimonialism as an Analytical Concept}

NP has become the standard approach for analysing bureaucracy and politics in sub-Saharan Africa. Eisenstadt (1973) was the first to use the term. Médard (2002), among others, developed it for use in African contexts. Inspired by Max Weber they thought of it as an ideal-type concept against which to assess deviations. It is in this sense that it is used in the following.

The paradigm is based on two main propositions. 'Patrimonialism' means that a patron, who is culturally anchored in a social and political order, distributes gifts from own resources to followers to obtain and strengthen loyalty and support. Clients, on the other hand, obtain material benefits and protection. 'Neo' means that office-holders in legal-rational state institutions are patrons who use public funds to build their personal loyalty among clients so as to stay in power (Clapham 
1985: 47-49). In other words, a clear public/private boundary, so central to the notion of modern administration, is ambiguous and contested. That boundary may not exist at all in some cases.

In studies on Africa, however, the use of the NP paradigm often leads to very different positions. Some argue that the role of the state, especially the president (the 'Big Man'), is central, while others take a more society-centric view based on the proposition that the state in Africa has never been properly institutionalised. There are also differing views about distributional effects. Some claim that resource scarcity restricts the use of patrimonialism to try to establish intra-elite accommodation in new multi-ethnic and poorly integrated political systems. There are limited trickle-down effects. Others claim that the spoils of the state are more widely distributed in society (Therkildsen 2005).

Despite such differences, Africa is exceptional in the eyes of key proponents of the NP paradigm. "Although neopatrimonial practices can be found in all polities, it is the core feature of politics in Africa... Whereas personal relationships occur on the margins of all bureaucratic systems, they constitute the foundation and superstructure of political institutions in Africa" (Bratton and van de Walle (1997: 62-63); their emphasis). Chabal and Daloz (1999: 16) make a more extreme claim: in "most African countries, the state is no more than a décor, a pseudo-Western façade masking the realities of deeply personalised political relations. There may well appear to be a relative institutionalisation of the main state structures but such bodies are largely devoid of authority."

Such claims of African exceptionalism fit nicely with images of miserable conditions on the continent. Much of the paradigm's attraction lies, perhaps, herein. That neopatrimonialism is especially widespread in Africa and less important everywhere else is based on two arguments. One is cultural:

Neopatrimonialism originates in the African extended family, with the dominance of older males and strong interpersonal ties. It has been reinvented in the form of the 'big men' and personal political relationships that pervade post-colonial African political institutions, including government bureaucracies (Bratton 1994).

The other argument refers to the logic of capitalism and increasingly globalised markets. Competition promotes efficiency and effectiveness. Eventually, therefore, principles of rationality will extend to all areas, including that of the public sector. This has just not yet happened in Africa. 
The use of the NP paradigm to understand politics and administration in Africa is problematic for many reasons. ${ }^{4}$ Eight problems are especially relevant for the subsequent empirical study of staff issues in Tanzania and Uganda.

First, in many studies it is assumed - rather than empirically investigated - that patrimonial practices dominate politics and administration across African countries. This bias is most explicitly stated in the quote above from Chabal and Daloz and less pronounced in that from Bratton and van de Walle. Nevertheless, this skews the empirical analyses and precludes that legal-rational practices may be important too.

Second, legal-rational and patrimonial practices may be exercised simultaneously. Different state organisations play different roles in the political economy of the country. Islands of organisational capacity in public service can exist alongside poorly performing organisations within the same country, as Moore, Leavy and White (2003: 190) and Grindle (1997) point out. Some of these variations may be due to deliberate political decisions by rulers to pursue developmental and clientelistic policies at the same time. The United States is an example of this, as is Japan (Woodall 1996). Similar two-track strategies may be used in African countries. Consequently, some organisations (as well as units within them) may perform well, while others do not.

Third, proponents of NP regard patronage as a special feature of administration and politics in Africa. This ignores that patrimonial practices exist in hierarchical organisations all over the world-sometimes pervasively so-and not just in African countries. Thus, specific personal networks at the upper levels of organisational hierarchies continue to play a central role, even in rich countries, in both the private and the public sectors. It is, for example, estimated that there were some 4 million patronage appointments in state and local government in the United States during the early 1980s. Today, political appointees occupy some 3,000 of the most senior posts in government. ${ }^{5}$ The US extends this practice to the UN organisations as well. The Executive Director of UNICEF from 2005 to

\footnotetext{
4 See Erdmann and Engel $(2006,2007)$ for a critical review, which has also inspired some of the following points.

5 http://web.worldbank.org/WBSITE/EXTERNAL/TOPICS/EXTPUBLICSECTORANDGO VERNANCE/o,,contentMDK:20134011 pagePK:210058 piPK:210062 theSitePK:286305 isC URL:Y isCURL:Y,oo.html (accessed 1 February 2010).
} 
2010 Ann Veneman, for example, was positioned in the organisation by the Bush Administration, under which she had worked as the Secretary of State for Agriculture (she was earlier a director of Calgene, a major agro-business). ${ }^{6}$

Patronage being so widespread, its driving forces cannot be especially African. On the contrary, according to Theobald (1999: 496-497), it is rooted in certain features of all hierarchical organisations. Required merit qualifications become increasingly difficult to specify as the organisational hierarchy is ascended. ${ }^{7}$ Incumbency in such positions also yields highly valued rewards and exceptional opportunities, so that vague criteria of exclusion are needed to restrict access. In addition, occupants of higher positions often have to make controversial decisions that may subject them to public scrutiny or create conflicts and therefore they prefer trusted supporters around them. To strengthen this trustworthiness, the rewards of office are usually high. It should be added that an influential body of studies of organisations in rich countries, both private and public, has shown that cliques, factions and informal networks function within, and sometimes dominate, formal rules and regulations (March and Olsen 1989).

Fourth, NP ignores insights from human resources management and institutional theories (e.g. Guest 1999). These argue that organisational performance depends not only on compliance with merit principles in staff management but also on motivation of staff to work (monetary and non-monetary factors); on staff management (supervision, encouragement and sanctions, communication, etc.); and on context (relations to other organisations and organised groups, norms and values, etc.). There is no reason why such factors should not be important in African countries as well.

Fifth, the legal framework which regulates staff management in the public sector is often ambiguous, contradictory and complex. This is a common feature of many public services across the world, Tanzania and Uganda included (Therkildsen and Tidemand 2006). Some proponents of the centrality of patrimonialism in African politics and administration

6 On Veneman's qualifications for the UN position see Flanders (2005). Absurdly, the World Bank's (1997: 93) advice to poor countries - in the face of what it calls extensive 'political appointments' in industrial countries such as the United States-is that "countries with weak institutions and inadequate checks and balances are better off relying on more transparent and competitive mechanisms."

7 Peters (1995: 90-91) seeks to capture this through the concept of 'responsive merit'. 
may argue that this is the result of intentional decisions (or nondecisions) aimed at enabling the exercise of patrimonial power: disorder as a political instrument in the interpretation of Chabal and Daloz. A different interpretation of the causes of the problems of the legal framework is that they result from errors in legislative drafting, confusions about key terminology in the legislative process (sometimes a result of inexperienced and overworked legal staff), and unsolved conflicts about who should control staff. It is an analytical challenge to assess staff management practices in such situations.

Sixth, proponents of NP tend not to distinguish between various forms of patrimonialism such as patronage and clientelism (as Erdmann and Engel (2006: 20) also point out). In this study patronage is defined as the practice of using state resources to provide jobs and services for political supporters (groups rather than individuals). It is part of high-level politics aimed at gaining political support. ${ }^{8}$ Clientelism concerns individuals. Whereas 'traditional' clientelism involves direct dyadic relations between patron and client and tends to be durable over time, 'neopatrimonial' clientelism as used in this study involves the personal hierarchical networks of politicians and bureaucrats. Rather than being political in function, such networks aim primarily at using state resources for the economic support of network members. Networks may be based on ethnicity, common schooling, or service in the conscription army and sometimes help members or their dependants in the absence of social security arrangements. Patronage and clientelism may be difficult to distinguish empirically, but it is important to do so for analytical reasons as the two forms have different aims, may not be equally stable, and therefore have different impacts on state capacity and on the dynamics of politics and administration.

Seventh, some versions of NP tend to exaggerate the control and power of the president in politics and administration. Bratton and van de Walle (1997: 63), for example, describe 'presidentialism' as a system in which "one individual... resists delegating all but the most trivial decisionmaking powers."9 Van de Walle (2005: 20) exemplifies this by the claim that President Kenneth Kaunda of Zambia personally controlled some

8 Prebendalism is a specific form of patronage. It refers to the handing out of public offices to individuals in order for them to benefit from personal access to state resources. It is not specifically dealt with in this chapter.

9 Quoted from Erdmann and Engel (2006: 15). They point out that Bratton's and van de Walle's use of 'presidentialism' differs significantly from conventional political science usage (in which the term simply connotes that the president heads a democratic regime as opposed to a parliamentary democracy). 
$5^{0,000}$ jobs in and around the city of Lusaka in the late 1980s. This image of overwhelmingly centralised presidential power is not only based on an incorrect reading of the source, ${ }^{10}$ it is also highly unlikely to exist in practice because it is an organisational impossibility. No individual can personally control that number of persons, even with the help of the most efficient of bureaucracies.

Finally, NP assumes that narrowly defined self-interest motivates both patrons and clients. Patrons seek accumulation of personal power. Clients seek personal and family protection and economic advantages. This ignores other sources of staff motivation commonly recognised in studies of bureaucracies (Peters 1995: 102-107) such as conviction (i.e. 'doing good for my country'); professionalism ('doing things right'); or involvement in decision-making (i.e. as an employee in running the organisation; as a politically active citizen).

To clarify some of these problems, the concept of NP defined by Erdmann and Engel (2007: 105) is used as the starting point for the empirical analysis. NP is:

... a mixture of two, coexisting, partly interwoven, types of domination: namely, patrimonial and legal-rational bureaucratic domination... the distinction between the private and the public, at least formally, exists and is accepted, and public reference can be made to this distinction. Neopatrimonial rule takes place within the framework of, and with a claim to, legalrational bureaucracy and 'modern' stateness.

This means that the formal institutions of the state-and the formal legal frameworks for their operations - are not just mere façades as Chabal and Daloz regard them. They must be taken seriously. Not all official relations are privatised, nor do all public organisations operate on an informal basis. Therefore recruitment, promotions, demotions and dismissals of staff are not just decided based on patrimonial logics. On the other hand, evidence shows that such activities do not necessarily follow stated procedures, rules and laws either. Elements of patrimonial and legal-rational bureaucratic domination coexist. Erdmann and Engel (2006: 15) state that it is the former that penetrates and twists the logic, functions and effects of the latter. However, the empirical analyses below illustrate that the two

10 His source is Bates and Collier (1993: 391). They write that the UNIP party-not the president - filled over 40,00o local party positions in various committees and positionsnot jobs in the public sector. Even that claim appears exaggerated; it originates from a local newspaper. 
forms of practices penetrate-and may reinforce-each other under certain circumstances. It is therefore the mutual articulation of patrimonial and legal-rational practices-and the context specific relations between them-that are in focus in the analysis presented below.

\section{METHODS}

Most information on staff issues in the public sectors of Tanzania and Uganda was collected in five ways in early 2006: (a) questionnaire survey of perceptions of 400 public servants (around 35 from each of the twelve organisations selected) using mostly Likert Scale-based questions filled in by employees themselves in half to one hour sessions. (b) One to two-hour discussions in 24 focus groups (half junior staff; the other half senior staff) with some 100 of the 400 sampled staff members. The same questionnaire and focus group issues were used in both countries and in all organisations to facilitate comparisons. (c) Interviews with chief executives. (d) Interviews with a substantial number of well-informed people within and outside the public sector; and (e) secondary sources such as government and consultancy reports.

Organisations were selected from among local governments, ministries and executive agencies. Together these categories employ around 90 per cent of all staff working in the public sector, and each category has specific formal arrangements for staff management (although these arrangements differ between Tanzania and Uganda as explained earlier). The aim was to select one organisation performing above and one below average respectively in each category in each country (twelve cases in total) by using information from well-informed persons and available official assessments. However, upon closer scrutiny of additional material, including focus group discussions in all twelve organisations, it was decided that the information on performance was reliable for only nine organisations. Therefore, mainly information from these is used in the following. The details of the case organisation and identification can be found in Therkildsen and Tidemand (2006: appendix volume).

Some limitations of the survey should be noted. Only officers (graduates) working in headquarters - and, in particular, finance and administration staff but also other professional staff-were sampled. Front-line staff, for example, were not included. Their motivations may be quite differently constituted (Lipsky 1990). Lower-level staff are certainly lower paid than the employees included in this sample. Second, individuals that 
had failed to get a job in the selected organisations were not sampled. Their views on the recruitment process may differ from those of successful candidates. Third, the survey was done as part of ongoing work on public sector reforms in the two countries. This gave access to engage with staff, but may also have associated the interviewers with the authorities and may therefore have influenced respondents' answers. Fourth, the selected organisations are not representative of the public sector as a whole as the sample was purposely constructed to allow comparisons between organisations that perform above and below average. Finally, the analyses build on staff perceptions and opinions solicited through interviews.

Obviously, some scepticism about the validity of information obtained quickly and by outsiders unknown to staff is appropriate. Respondents may simply try to echo what researchers want to hear. Not surprisingly, some staff clearly preferred to talk about the application of merit in their workplace rather than about patrimonial practices. This was especially the case in Tanzania. Ugandan respondents seemed more frank. Moreover, people in organisations face formal expectations about performance and compliance with certain norms that they may not be able to meet. Therefore they sometimes respond hypocritically as is discussed below.

Consequently, the survey information should be interpreted with care but there are two reasons to have confidence in it. First, the focus group discussions generally supported the findings of the quantitative interviews and the limited information available from secondary sources. Second, several of the results are consistent with findings from the relatively few empirical studies of merit, work motivation and staff management in the public sector of poor countries (for example Grindle 1997; Tendler 1997; Owusu 2006; Rauch and Evans 2000; Court, Kristen and Weder 1999), and with the general findings in the human resources management literature (see literature review by Guest (1999)).

\section{Variation in Organisational Performance Across the Public Sector}

As argued above, performance variations across organisations of the same type may-in part-be caused by differences in the use of legalrational and patrimonial staff-related practices. ${ }^{11}$ To establish this

11 Since this chapter focuses on staff-related factors that affect organisational performance, other capacity relevant factors receive less attention. 
association empirically we compared assessments by staff from organisations performing above and below average with respect to issues of merit, work motivation, and staff management. We found the following.

First, staff in above average performing organisations consistently, and significantly, rated the merit quality of their organisation's recruitment practices (as well as the organisation's transfer, disciplinary and promotion practices) higher than staff from organisations performing below average. The quality rating is based on agreement/disagreement with questions such as "In this organisation, staff are hired on the basis of:... merit (ability and skills required for the job)... clear and transparent rules... tribal affiliation and home region... political connections... gender considerations ... social connections (who knows who)... corruption, bribery and back-door arrangements."

Second, we found significant association between staff statements about their own work motivation and organisational performance. This is based on ratings of replies to statements such as "I work in this organisation because I.... need salary/security/pension ... have no other options... can do something important for my country... it gives me prestige...improves my career possibilities" and of statements about future employment (actively trying to find a job in the private sector, with NGOs or donors etc.).

Third, assessments of the quality of staff management were associated significantly with organisational performance differences. Ratings were based on questions about the extent to which supervisors set clear targets and standards of work; do follow-up; encourage performance; improve office environment; help staff with personal problems; and reward and discipline staff fairly.

The broad conclusions are that differences in adherence to merit principles, in rule-related work motivation and in rule-related staff management practices do help to explain differences in organisational performance (undoubtedly these three factors interact, too)..$^{12}$ These conclusions are not surprising. They fit well with the results of similar analyses elsewhere (Grindle 1997; Tendler 1997). They are, however, remarkable in light of the generalisations about African politics and administration made by some proponents of NP.

12 Other factors than those related to staff may also help to explain performance differences (e.g. differences in access to funds and in competitive pressures). Nevertheless, even when such factors are considered, the staff-related factors identified here are significantly associated with performance as shown in Therkildsen and Tidemand (2006). 


\section{Employee Perceptions of Staff Management-Related Practices}

How do public servants themselves perceive staff-related practices in situations where legal frameworks do not provide a clear basis for decisionmaking and day-to-day administration, and where practices of patronage and clientelism may be common and explicitly acknowledged by the government (as illustrated in the introduction), by public servants (as shown below) and by the public (as indicated in numerous opinion polls (e.g. Bratton, Mattes and Gyimah-Boadi 2005)?

In the staff survey empirical information on this was obtained by focusing on staff perceptions of hiring, firing, transfer and promotion/demotion practices (HFTP) in their workplaces. The survey data indicate that:

- only slightly more than $5^{0}$ per cent had ever applied in writing for the positions they had held in the public service.

- a little less than 5o per cent had ever been transferred to another jobmost by order of the authorities, fewer by own request. It is unusual to have been transferred more than twice.

- some $5^{0}$ per cent had been promoted twice in their career on average.

- around 10 per cent had experienced a demotion for various reasons.

- Less than 5 per cent had experienced a disciplinary case.

The first thing to note is that HFTP events are relatively rare considering that the sampled staff had worked in the public sector for an average of 17 years. ${ }^{13}$ Moreover, the pattern of HFTP events is fairly similar across countries and organisations except for staff in Tanzania dealing with finances who are more frequently transferred than staff in other positions: handling money in the public service is a sensitive matter.

How do public servants perceive these HFTP events in their own workplaces? Public servants have a range of views as table 1 shows. It focuses on recruitment practices, which the literature normally regards as the most vulnerable to neopatrimonial practices. ${ }^{14}$

13 Aggregate statistics on such events do not exist. This is itself an interesting feature of staff administration in light of the expansion of statistical information on many other key issues of the public sector, especially finances. As a researcher it has always been much more difficult to get access to aggregated information on staff than to information on public finances.

${ }_{14}$ Public servants do not agree with this. They regard the processes of transfers and promotions as the most problematic. Thus, interviewees (in percentage of the whole sample) 
Table 1. Staff perceptions of recruitment practices in the workplace (percentage of respondents that 'agree'/'agree very much' that the factor is important)

Source: Survey data from Therkildsen and Tidemand (2006).

\begin{tabular}{lcccccc}
\hline & Tanzania & Uganda & \multicolumn{2}{c}{ Tanzania } & \multicolumn{2}{c}{ Uganda } \\
\hline $\begin{array}{l}\text { Organisation } \\
\text { Factor } \downarrow\end{array}$ & All & All & $\begin{array}{c}\text { Performance } \\
\text { above }\end{array}$ & $\begin{array}{c}\text { Performance } \\
\text { below }\end{array}$ & $\begin{array}{c}\text { Performance } \\
\text { above }\end{array}$ & $\begin{array}{c}\text { Performance } \\
\text { below }\end{array}$ \\
$\begin{array}{l}\text { Merit } \\
\text { Political }\end{array}$ & 80 & 83 & 94 & 68 & 82 & 77 \\
$\begin{array}{l}\text { connections } \\
\begin{array}{l}\text { Social } \\
\text { connections }\end{array}\end{array}$ & 6 & 29 & 6 & 8 & 23 & 46 \\
$\begin{array}{l}\text { Ethnic } \\
\text { connections }\end{array}$ & 9 & 16 & 8 & 19 & 16 & 38 \\
\hline
\end{tabular}

Merit-based recruitment is the dominant practice in the selected public organisations according to the respondents. This corresponds well with the finding that six out of ten recruitment cases comply with rules in Tanzania (President's Office 2005). That fewer than half of the staff had not applied for a job (see bullet points above) cannot in itself be construed as an indication of widespread patrimonial practice, since recruitment by application has only recently been introduced as a general rule. Previously all graduates were secured a job upon obtaining a degree. Many of the staff interviewed were recruited at that time.

Non-merit principles are, however, also used. There are remarkable differences in answers to questions about the importance of patronage ('political connections') and clientelism ('social connections' and 'ethnic connections') in the recruitment process: Uganda scores significantly higher than Tanzania in both categories. A similar difference exists when patronage and clientelism in organisations performing above and below average are compared. Although national differences in these figures should be interpreted with care ${ }^{15}$ there is little doubt that patrimonial pressures on public sector organisations are higher in Uganda than in Tanzania.

that 'disagree' and 'strongly disagree' that the HFTP process is 'fair and transparent' are as follows: recruitment (13); disciplinary action (15); transfers (21) and promotions (29). However, for reasons of space only recruitment is dealt with in some detail here.

${ }^{15}$ For example, Ugandan respondents appeared to be more open and frank in focus group discussions than the Tanzanian respondents. See also Peters (1995). 
It is also noteworthy that for the sample as whole, political, social and ethnic connections are mentioned with roughly the same frequency in Tanzania. Variation is larger in the Ugandan sample (table 1). Whilst political connections obviously involve political patronage, the focus group discussions and other interviews revealed three types of 'social/ethnic connections'. One is constituted, in both countries, by secondary school/ university-based networks. These can be actively used to get a new job (and to get promotions, transfers or to handle disciplinary cases). Peerbased relations and pursuit of mutual economic benefits are probably as characteristic of these networks as hierarchical patron-client relations. Another type of network was established during service in the conscription army in Tanzania (now abolished) - and the national resistance army in Uganda in the 1980 s and early $1990{ }^{16}{ }^{16}$ In Tanzania these networks seem to serve the same purpose as the school-based networks, whereas political patronage is clearly more dominant in the Ugandan version of the army network. The third type of network is based on ethnicity. Where relations in the school/army networks are intra-governmental with public servants and/or politicians as members, the third type involves relationships with prominent persons (elders, businessmen, religious leaders, etc.) outside the public sector. The aim of this third type of network may be to gain political or economic support - or both. Sometimes, however, it is analytically difficult to distinguish the political and social motivations in these networks, although the implications of conflating them are, obviously, significant for understandings of staffing-related practices.

Nevertheless, 'social and ethnic connections' seem to be as important in recruitment as 'political connections' are. The former may, or may not, involve patron-client relations aimed at gaining political support. Only a context-specific assessment may determine this (and we did not do that). Van de Walle (2005: 21), who defines patronage as "the practice of using state resources to provide jobs and services for political clientele", is therefore on uncertain ground when he makes the following generalisation: "Hiring a member of one's ethnic group to a senior position in the

16 The conscription army in Tanzania, which also included women, was compulsory for all university graduates after Independence. It was abolished due to economic crisis and donor pressure in the late 1980 s. Its role remains poorly researched, although it was regarded as a central element in state building for decades after Independence. Museveni (1997) describes some of the prominent persons in networks originating in the Ugandan resistance army. Members in this network are more closely linked to the political hierarchy than those in the Tanzanian network. 
customs office is an example of patronage." In any case, all three types of networks aim at obtaining economic benefits and protection for members and their families. And all three types of networks seem fairly stable although they are obviously not intergenerational as 'traditional' clientelistic relations are. Several networks may exist simultaneously within an organisation, and this may lead to unstable and conflictual relations (see next section).

Table 1 is based on staff's general perceptions about the situation in their places of work - not on their assessments of specific recruitment events. The conclusions that can be drawn are therefore general ones: (a) merit-principles, as understood by staff, are often used in recruitment but clearly more so in organisations that perform above average; and (b) patrimonial practices are also used, and more so in Uganda than in Tanzania.

\section{Acceptance and Contestation of Patronage and Clientelism AMONG STAFF}

Patrimonial and legal-rational practices occur in all public organisations in Tanzania and Uganda as indicated in table 1 and vividly expressed in the focus group discussions. However, Chabal and Daloz argue that the former practices totally dominate, while Bratton and van de Walle state that the former 'suffuse' the latter. Erdmann and Engel (2007: 105) propose that the two systems operate simultaneously and coexist but that "the patrimonial penetrates the legal-rational system and twists its logic, functions and output, but does not take exclusive control over the legalrational logic. That is, informal politics invade formal institutions."

In all three formulations-domination, suffusion and penetrationpatrimonial practices are deemed to pervade all activities. The coexistence of legal-rational islands in neopatrimonial systems is ruled out, as are contestations about these practices. Also ruled out is that patrimonial practices may interact (and sometimes strengthen) the use of legal-rational practices. And finally, the large variation, insecurity and hypocrisy resulting from such coexistence and interactions are ignored.

\section{Coexistence}

On the one hand the case studies show that patrimonial pressures to influence recruitment "are everywhere" as one executive agency personnel officer in Uganda said. Sometimes this includes high-level outside pressures 
on specific organisations as well. Two of the six Ugandan organisations, for instance, had received recent phone calls from 'State House'17 to request that specific individuals be considered for a job. In both cases the vacancy was at the lower end of the hierarchy. ${ }^{18}$ In one organisation the request was rejected, according to our sources; in the other it was complied with. Staff involved in recruitment processes in local government in Tanzania also talked about how they often received "piles of written pleas" aimed at influencing their decisions. Here we were not told of any 'State House' attempts at influencing staff recruitment.

On the other hand, merit-based principles also featured strongly in our discussions with staff and in the survey results. One personnel officer, for example, recorded all steps in the recruitment process in his organisation and volunteered to let us look through the recruitment files. ${ }^{19}$ Moreover, during many focus group discussions, staff and superiors talked about the use of merit-based principles as if they are an accepted norm in their workplace and a well established routine (e.g. "in this world of globalisation..." one respondent working in local government in Tanzania told us, “... we must accept the merit principles [in order] to survive.") The growth in the numbers of universities and students in both countries illustrates a rapidly increasing demand for better formal qualifications. Particularly in Uganda, many staff members in the sampled organisations were enrolled for further studies to improve their qualifications for a better job. Indeed, the opportunities for further education offered by the workplace are a significant incentive in the eyes of staff. All this would not make sense if recruitment and promotions were only done according to patrimonial practices.

Thus, legal-rational and patrimonial practices coexist within organisations in both countries. We cannot establish the extent to which officials follow formal workplace rules and obligations, and how many officials do so, but the typical situation is that compliant and non-compliant colleagues work in the same organisations, and are keenly aware of that. Moreover, formal bureaucratic behaviour seemed much more routinised

17 'State House', the official residence of the president of Uganda, is a big building. We do not know if the calls were from conmen (or women) or from 'genuine' inhabitants of that house. Clearly our respondents did not believe that these were phony calls.

18 And may therefore have been motivated as much by the prospect of securing a paid job for economic reasons as by political patronage.

19 This executive agency has started to do consultancies in a growing market for professional recruitment services in Uganda. 
in some units (departments, sections, desks) than in others within almost every one of the case organisations.

\section{Interactions}

Interactions between bureaucratic and patrimonial behaviour are clearly influenced by this coexistence. However, some of the well-known and expected findings from the case studies also turned out to have unexpected implications.

It is, for example, well known that patrimonial practices can undermine bureaucratic behaviour, especially in organisations with low bureaucratic capacity. For where patrimonial practices dominate there can be few incentives for officials and politicians to comply with or enforce rules, the argument goes. That is the situation most often described in the literature (e.g. van de Walle 2005: 26).

Paradoxically, the coexistence of bureaucratic and patrimonial behaviour can also strengthen the resolve to comply with rules as the following examples illustrate. First, weak enforcement of bureaucratic practices can lead to a (often unmet) staff demand for discipline in the workplace. It was a fairly general complaint, especially among younger staff, that superiors failed to supervise; and that work plans and targets were too vague or unrealistic to be taken seriously. There were complaints of too much idle time and frustrations at having nothing much to do. Others have registered similar staff demands for strengthened bureaucratic practices (Keele Consortium 2005). It is part of the same picture that an opposite view was expressed by many older staff and women with family obligations: they saw the slack discipline as a clear advantage as it allowed them to tend to their private business or family affairs. It is this lack of discipline that makes employment in the public sector attractive even for staff that could get better paid jobs in the private sector (see also Cohen and Wheeler (1997).

Second, several respondents explained how recruitment in the workplace was done in a rigid and highly regulated manner to avoid subjective assessment of applicant qualifications that may give rise to accusations of wrongdoing and bias. Thus, as a rule for the entire public sector in both countries, most advertisements specify only requirements that can be objectively assessed (typically about age, years of experience, educational qualifications). Similarly, job interviews in some organisations are conducted in a highly regulated manner. The panel prepares questions for applicants that only probe technical competencies- not attitudes to 
work and target groups, team efforts, social skills, past achievements and failures, etc. . No additional or follow-up questions are allowed. In this way all applicants are faced with exactly the same questions. The entire recruitment process is aimed at excluding any subjective assessments to avoid patrimonial practices.

But could bureaucratic rules be a façade behind which patrimonial practices are exercised, as Chabal and Daloz claim? That cannot be ruled out. In Tanzania, for example, a Programme Implementation Unit offered positions with donor-funded salaries well above ordinary public service levels (see also Therkildsen 2004). Elaborate procedures for recruitment to these top positions were agreed with the donors to secure adherence to merit principles. These required an inter-ministerial interviewing panel to provide a priority list of candidates from which the Permanent Secretary (PS) could choose. He appointed three of the five positions to candidates identified as the most qualified by the panel, while two were given to persons lower down on the list. Donors complained but the priority list was confidential. The PS assured them that the recruitment had followed all the agreed procedures. But as often happens in such cases, information was eventually leaked, and the panel's priority list became known. Two years later, when the PS was transferred to another post, the two officers in question were sacked immediately.

The problem with the Chabal-Daloz position is not that it is entirely wrong, but that it is very often difficult to generalise as this example shows. And paradoxically, patrimonial practices carried out behind a bureaucratic façade may sometimes strengthen personal relationships and adherence to bureaucratic rules. For example, in a large public service commission in Uganda in charge of central recruitment of many public servants, candidates for positions were called for interview in Kampala and entitled to reimbursement of various expenses for transport, etc. However, the administrative unit in charge of processing the reimbursements systematically delayed and obstructed the process. Management did not attempt to clean out the known culprits for 'human reasons' as a supervisor told us but also for fear of reprisals: "life is cheap here." Instead, management assigned a trusted employee from another department to keep the money in a drawer in his office, and to make the payment to applicants from there. To comply with legal-rational practice a personal and trusted relationship between a superior and that individual had to be relied upon. However, such relations burden the good performers because supervisors often overloaded them (or such employees volunteer to do tasks beyond their job assignments). While these efforts may sometimes be rewarded in 
cash or kind, the only sure reward is more work. Consequently, in many organisations overworked good performers can be found side by side with colleagues that do not do much-or have little to do.

We encountered several other examples of such personal ties between trusted individual employees and their superiors. Typically, the literature focuses on ostensibly patrimonial networks. The person-based performance-oriented networks (i.e. individuals who help to fulfil the official mandates of the organisation) receive less attention.

Finally, the coexistence of legal-rational and patrimonial practices sometime provides decision-makers with useful choices. In Uganda, for example, a reform of pay structures in 2003/04 resulted in the consolidation of lunch allowances for health staff into their salaries. This did not change actual pay much (allowances were now taxable). Health staff were still paid higher - up to 85 per cent - than other professionals on the same salary scale. Nevertheless, doctors and nurses were aggrieved and organised pay negotiations directly with president Museveni. He agreed that health staff be paid a lunch allowance again —on top of the one they now received as part of their consolidated salary - and contrary to technical advice. It is a good example of patronage in action with the president trying to buy support from a vocal and influential interest group. In other cases when Ugandan government staff demanded pay increases, no access to the president was granted and they had to negotiate through 'normal channels'.

There is an interesting twist to this example. The government is now, with reference to the example above, proposing to 'distance' the president from pay decisions in the future (Ministry of Public Service 2005: 19-20, 27-28). This is unlikely to deter him from using pay policy for patronage purposes in the future. But it does make the motives for the president's future involvement in pay decisions more transparent.

\section{Variation, Insecurity and Hypocrisy}

The coexistence and interaction of legal-rational and patrimonial behaviour across the public sector and within each of its organisations makes for a messy (working) life for many public employees: which practice to follow and which to avoid is often far from clear-cut.

For public servants are faced with many ambiguous choices. They work in organisations where both legal-rational and patrimonial practices are typically used simultaneously. Even where the former practices dominate in their workplace, their organisation often operates in a context 
where external patrimonial pressures can be strong. These are key features of working in a neopatrimonial setting.

Moreover, staff choices not only depend on individual preferences and on the consequences of alternative actions in light of these preferences: choice-based decisions. They also depend on the social appropriateness of these actions in the specific context: norm-based decisions. These are the two basic parameters of individual and organisational decision-making according to March (1994).

These two perspectives-the political science perspective on neopatrimonialism and the organisational studies perspective on decisionmaking — can be combined. An individual or an organisation may act on the basis of choice-based decisions (seeking to anticipate the future effect of current actions evaluated in terms of preferences) in mixed legalrational and patrimonial settings. However, the ambiguities are many, both with respect to reading the setting and then to calculating the actions that best fulfil preferences, and the capacity for such rational decision-making is limited. Likewise, an individual or an organisation may act on the basis of norm-based decisions (seeking appropriate action based on an understanding of the context and the rules that apply to it such that individual or organisational identity is preserved or enhanced). But this approach is also fraught with difficulties as situations, rules and identities are all likely to be ambiguous. The most likely outcomes of decision-making and action in neopatrimonial settings are therefore performance variation, insecurity and hypocrisy.

Neopatrimonial settings fuel variation in organisational performance across the public sector as documented earlier. Comparatively wellperforming public organisations exist - contrary to many predictionsbut so do poorly performing ones. This is a logical consequence of the ambiguities outlined above. When public organisations are weakly institutionalised and the legal framework for decision-making is conflictual, vague, or poorly externally enforced, there is a larger scope for internal organisational decisions and actions and more space for management and staff to influence how these are made. There is little doubt that individuals at the top of the organisation can have considerable influence on the extent to which bureaucratic or patrimonial behaviour is practiced. Executives in the better-performing organisations clearly made a positive difference (and employees often admired them for this). In fact, the poor institutionalisation of bureaucratic rules may leave executives and staff with more room for manoeuvre to improve effectiveness and efficiency than would otherwise be the case. Nevertheless, this room for manoeuvre 
should not be exaggerated. In one of the poorer performing organisations staff explained how a new executive had tried to enforce working hours: "... for one year he struggled, then he gave up ... now we are comfortable with him." The variation is both temporal and cross-organisational.

Neopatrimonialism also fuels insecurity (Erdmann and Engel 2006: 19). A client needs a patron for protection or for improving livelihood in situations where prospects are uncertain. In return the provider expects political support or a return of favour at some future time. Insecurity is increased if patrimonial practices become widespread because it then becomes more difficult to fulfil mutual obligations.

Moreover, patrimonial practices blur hierarchical authority relationships within organisations and in dealings with other organisations. It means that an employee can challenge the instructions of a superior with open or subtle reference to powerful political or social connections. One of the major problems in the new open staff appraisal systems that both Tanzania and Uganda introduced recently is precisely that supervisors are reluctant to exercise their authority. They fear the reactions of subordinates who now have access to the evaluation result. Previously it was confidential and made without a face-to-face meeting between supervisor and employee. Even the officially lowest-ranking employee can turn out to be an opponent who must be treated with caution. Where politicians are closer to the decision-making processes the adherence to bureaucratic rules seems to be especially under pressure as is often the case in local government.

Thus, insecurity is generated by the difficulties of individuals and organisations to find out what constitute appropriate norms or procedures in the situation they find themselves in. For what indeed is appropriate when both legal-rational and patrimonial practices are exercised simultaneously; or when they coexist both internally and externally? Moreover, each situation highlights a different set of relationships so that it becomes difficult to live up to important relationships and cultural expectations. This is a key feature of norm-based decision-making (March 1994: 63). ${ }^{20}$

Not surprisingly, therefore, we found widely varying staff assessments of their situation. At one extreme was a group of young employees in a poorly performing local council who frankly stated that since they were

20 Thus, Bratton, Mattes and Gyimah-Boadi (2005: 200) are wrong when they write that people in Africa "are buffeted by conflicting values... and respond to these tensions by adopting multiple, shifting identities." This is a general phenomenon. 
paid 'tokens' contrary to government promises of pay improvements in the 1990s, they were justified in seeking compensation through corrupt practices when given the chance. At the other extreme were supervisors who preferred to work with staff from other ethnic groups, because this helped to clarify and amplify the formal, non-personal, hierarchical relationship between them. Other executives emphasised (and actually practised) that 'in the interest of the nation' it is the duty of the workplace to provide its staff with further education-even if they would not return to their workplace upon completing a course. In between these outlier cases, there were numerous examples of fence sitting. Although many interviewees stressed their desire to contribute to better organisational performance through improved bureaucratic behaviour, they were clearly more loyal to each other as colleagues than to their organisation and its official mandate. Hence firing is an exceedingly rare event in both countries (disregarding retrenchments that are typically done to reduce costs not to sanction wrongdoers or non-performers and which are often pushed by donors). "You know, we don't fire staff in this country" as a ministry official in Uganda remarked. In fact, pension and death (often due to HIV/AIDS) remain the two most common ways of leaving public service except where specific staff, such as medical personnel, have access to foreign labour markets.

Hypocrisy is the third outcome of decision-making and action in neopatrimonial settings although it is a generic phenomenon. ${ }^{21}$ It is "a way of handling severely conflicting values, and this is exactly what organisations imbued with hypocrisy do" in all societies. Hypocrisy makes it possible for people "to talk and make decisions about high values, even if they do not act in accordance with such values themselves" as Brunsson (2002: xii and xvii) argues on the basis of his studies of local government in Sweden. Thus, an organisation (or an individual) is hypocritical when what it says, what it decides and what it does are inconsistent. The lack of conventionally assumed casual relations between talk, decision and action challenge traditional decision theory and traditional administrative wisdom. For hypocrisy may help to solve a true dilemma of how to respond to a situation with contradictory but compulsory demands that exceed capacity. It can therefore be useful in dealing with (and diffusing) conflicting demands within an organisation and between that organisation

21 Riggs (1964: 201) refers to 'double talk', but argues that this is characteristic of societies in transition to modernity. 
and society. In this way it may enhance the legitimacy of those who exercise it. When exercised without skill, hypocrisy can, of course, also have the opposite result.

Although hypocrisy is not a particularly African phenomenon, neopatrimonial settings bring specific dilemmas to the fore. Most of our respondents, for example, would claim that recruitment follows merit principles in their workplaces, but some would also, when explicitly asked, readily admit that non-compliance with such principles is common (see table 1). Asked about what to do about non-performing colleagues most answers were consistent with standard bureaucratic behaviour: they should be disciplined. That disciplinary action is rare was explained with reference to the need to understand the particular (often family) situation of the individuals involved. Or we were told that non-action against wrongdoers and non-performers was indeed a problem in the past, but that things are changing now ("It is a process, you know"). Or the blame for non-action was put on others ("a few unfortunate individuals" or on the lack of externally provided tools/budgets/training etc.) Hypocritical conduct is an art rather than a science, of course, but it is one that is useful to master for staff and organisations faced with conflicting (and often impossible) performance demands in neopatrimonial settings.

\section{CONCLUSIONS}

To claim that African states are neopatrimonial, as many analysts do, may often tell us little about how politics and administration actually work there. This chapter focuses on employee perceptions of staff issues in the public sector in Tanzania and Uganda-such as hiring and firing, staff motivation and management. It is inspired by human resources literature and by institutionalism. From these perspectives the chapter provides a critical look at the use of the neopatrimonial paradigm for studies of organisational level human resource management in African countries.

A main problem with the NP paradigm is that it takes as given precisely that which should be empirically investigated: namely, in specific settings, the actual impacts on politics, administration and organisational capacity of the coexistence and interactions of legal-rational and patrimonial practices in and around organisations.

Moreover, to interpret all evidence of informality and poor performance as results of patrimonial practices - as is fairly common in studies on Africa using the NP paradigm - is clearly a biased understanding. 
Patrimonial practices are just one reason (albeit an often important one) among many for non-compliance with legal rules and regulations. These other reasons are well known from organisational studies: lack of capacity to follow rules due to underfunding, poor skills and incompetent management; ambiguous, complex, conflicting or non-existent legal frameworks; etc. Likewise, narrow self-interest is not the only motivational factor. Nationalism, sense of duty, professional pride and desire to influence decision-making, for example, may also induce people to work to enhance organisational mandates.

A third problem with the NP paradigm, related to the above, is that the category 'patrimonial' actually merges widely different practices under this heading. Not all patrimonial practices are politically motivated although this is a typical assumption among NP proponents. In poor countries, economically motivated clientelism is widespread and public sector staff-not just politicians-are often involved in it. For such staff have substantial social obligations (being among the best paid groups in their countries) and they are strategically placed to engage in clientelism so as to help members of their social or ethnic networks. Patronage, by contrast, is politically motivated and focuses on groups rather than individuals.

If these problems are addressed, the NP paradigm may help to improve the understanding of the complex interactions between legal-rational and various forms of patrimonial practices in specific public sector organisations. However, this does not necessarily provide more clear-cut and general answers about their impacts on politics, administration and capacity. Not only is there variation in impacts between countries; impacts also vary across public sector organisations within countries. Moreover, the coexistence of and interactions between legal-rational and patrimonial practices generate uncertainty because norms that are regarded as appropriate bases for action may differ depending on the specific situation. Neopatrimonial settings also generate hypocrisy in organisations when the gap between organisational means and official ends is large.

However, hypocrisy is far from being a phenomenon specific to organisations in Africa. Donors and many analysts also engage in this activity. Some of their views on patrimonialism are remarkable. In spite of the recognition that the West's historical experience is distinctive and unique there is an implicit notion that this experience provides African countries with a ready-to-use model of the 'modern' state. The recipe is that market-conforming economic policies and liberal democratic governance reforms are mutually supportive and jointly represent the best way 
towards development. Quantitative regression analyses of governance and economic growth are increasingly used to back up such claims. Kaufmann (2004: 86) of the World Bank argues that even poor countries can improve their governance (which includes getting rid of patrimonial practices) because there is little evidence to support the claim that poor governance in Africa is attributable to its poverty. The optimistic message is that a de-patrimonialised state is realistic. This claim seems just as problematic as the general claim by Chabal and Daloz that the African state is merely a pseudo-Western façade.

It is more likely that the coexistence of and interactions between legal-rational and patrimonial practices may produce different types of changes, perhaps even transformations, in both patrimonial and legalrational directions depending on the specific context. Some of the possibilities are outlined in this chapter. However, where patrimonial pressures are strong, such changes/transformations will be unstable (reversible), certainly in the short term. But even where legal-rational practices may prevail (in organisations or larger parts of the public service), certain key transactions through the structures of formal organisations may remain personalised as experiences from our own part of the world indicate (Peters 1995: 48-51; Theobald 1999). After all, the legal-rational form of authority identified by Weber is an ideal type. And so it remains for most countries, also for some in the North.

\section{REFERENCES}

Bana, Benson \& Willy McCourt. 2005. Institutions and Governance: Public Staff Management in Tanzania. Manchester, Institute for Development Policy and Management.

Barkan, Joel D., Kayunga, Saillie Simba, Njunga, Ng'ethe \& Jack Titsworth. 2004. The political economy of Uganda: The Art of Managing a Donor-Financed Neo-Patrimonial State (two versions). Kampala: World Bank.

Bates, Robert H. \& Paul Collier. 1993. The politics and economics of policy reforms in Zambia. In Bates, Robert H. \& Anne O. Krueger, eds. Political and Economic Interactions in Economic Policy Reform. Oxford, Blackwell, 387-443.

Boesen, Nils \& Ole Therkildsen. 2004. Between Naivety and Cynicism: A Pragmatic Approach to Donor Support for Public Sector Capacity Development. Copenhagen, Ministry of Foreign Affairs, Denmark.

Bratton, Michael. 1994. Civil society and political transition in Africa. IDR Reports, 11 (6).

Bratton, Michael, Mattes, Robert \& Emmanuel Gyimah-Boadi. 2005. Public Opinion, Democracy and Market Reform in Africa. Cambridge, Cambridge University Press.

Bratton, Michael \& Nicholas van de Walle. 1997. Democratic Experiments in Africa: Regime Transitions in Comparative Perspective. Cambridge, Cambridge University Press.

Brunsson, Nils. 2002. The Organization of Hypocrisy: Talk, Decisions and Actions in Organizations. 2nd ed. Oslo, Abstrakt Forlag. 
Chabal, Patrick. 2005. Power in Africa reconsidered. In Engel, Ulf \& Gorm Rye Olsen, eds. The African Exception. Aldershot, Ashgate, 17-34.

Chabal, Patrick \& Jean-Pascal Daloz. 1999. Africa Works: Disorder as Political Instrument. Oxford, James Currey.

Clapham, Christopher. 1985. Third World Politics: An Introduction. London, Croom Helm.

Clarke, Jeremy \& David Wood. 20o1. New public management and development: the case of public service reform in Tanzania and Uganda. In McCourt, William \& Martin Minogue, eds. The Internationalisation of Public Management: Reinventing the Third World State. Cheltenham, Eward Elgar.

Cohen, John M. \& John R. Wheeler. 1997. Training and retention in African public sectors: capacity-building lessons from Kenya. In Grindle, Merilee S., ed. Getting Good Government: Capacity Building in the Public Sectors of Developing Countries. Boston, Harvard Institute for International Development, ${ }^{125}-156$.

Court, Julius, Kristen, Petra \& Beatrice Weder. 1999. Bureaucratic Structure and Performance: First Africa Survey Results. Helsinki, Wider.

Deininger, Klaus \& Paul Mpuga. 2005. Does greater accountability improve the quality of public service delivery? Evidence from Uganda. World Development, 33 (1): 171-191.

Eisenstadt, Shmuel N. 1973. Traditional Patrimonialism and Modern Neo-Patrimonialism. London: Sage.

Erdmann, Gero, and Ulf Engel. 2006. Neopatrimonialism Revisited-Beyond a Catch-All Concept. Hamburg, German Institute of Global and Area Studies.

Erdmann, Gero, and Ulf Engel. 2007. Neopatrimonialism reconsidered: critical review and elaboration of an elusive concept. Commonwealth \& Comparative Politics, 45 (1): 95-119.

Flanders, Laura. 2005. Review of Bushwomen: tales of a cynical species. London Review of Books.

Government of Uganda. 2005. Public Service Reform Programme: Strategic Framework (2005/6-2009/10). Kampala, Government of Uganda.

Government of Uganda. 2004. Poverty Eradication Action Plan, 2004/5-2007/8. Kampala, Ministry of Finance, Planning and Economic Development.

Grindle, Merilee S. 1997. Divergent cultures?: when public organizations perform well in developing countries. World Development, 25 (4): 481-495.

Guest, David E. 1999. Human resource management and performance. a review and research agenda. In Schuler, Randall S. \& Susan E. Jackson, eds. Strategic Human Resource Management. Oxford, Blackwell, 177-190.

Houtzager, Peter. 2003. Introduction: from polycentrism to the polity. In Houtzager, Peter \& Mick Moore, eds. Changing Paths: International Development and the New Politics of Inclusion. Ann Arbor, University of Michigan Press.

Hydén, Göran, Court,Julius \& Kenneth Mease. 2004. Making Sense of Governance: Empirical Evidence from 16 Developing Countries. Boulder, Lynne Rienner.

Kaufmann, Daniel. 2004. Human Rights, Governance, and Development. Washington D.C., World Bank.

Keele Consortium. 2005. Stakeholder Consultations on Development of Human Resources for Health Policy in Uganda. Kampala, Ministry of Health.

Kiragu, Kithinji \& Charles Byaruhanga. 2004. Uganda Public Service Reform Gainers and Loosers, 2001-2004. Kampala, PriceWaterhouseCoopers.

Kiragu, Kithinji, Mukandala, R.S. \& Denyse Morin. 2004. Reform pay policy: techniques, sequencing and politics. In Levy, Brian \& Sahr J. Kpundeh eds. Building State Capacity in Africa: New Approaches, Emerging Lessons. Washington, The World Bank, 109-148.

Leonard, David K. \& Scott Straus. 2003. Africa's Stalled Development: International Causes \& Cures. Boulder, Lynne Rienner Publishers.

Lipsky, Michael. 1990. Street-Level Bureaucracy: Dilemmas of the Individual in Public Service. New York, Russel Sage Foundation. 
March, James G. 1994. A Primer on Decision Making: How Decisions Happen. New York, The Free Press.

March, James G. \& Johan Olsen. 1989. Rediscovering Institutions: The Organizational Basis of Politics. New York, The Free Press.

Medárd, Jean-François. 2002. Corruption in the neo-patrimonial states of sub-saharan Africa. In Heidenheimer, Arnold J. \& Michael Johnston, eds. Political Corruption: Concepts and Contexts. New Brunswick, Transaction Publishers.

Ministry of Public Service. 2005. Revised Public Service Pay Reform Strategy. Kampala, Government of Uganda.

Mkandawire, Thandika. 2001. Thinking about development states in Africa. Cambridge Journal of Economics, 25: 289-313.

Moore, Mick with, Jennifer Leavy \& Howard White. 2003. Polity qualities: how governance affects poverty. In Houtzager, Peter \& Mick Moore, eds. Changing Paths: International Development and the New Politics of Inclusion. Ann Arbor, University of Michigan Press, 167-203.

Museveni, Yoweri Katuga. 1997. Sowing the Mustard Seed: The Struggle for Freedom and Democracy in Uganda. London, Macmillan.

Mutahaba, Gelasa. 2005. Pay Reform and Corruption in Tanzania's Public Service. Paper read at seminar on potential for public service pay reform to eradicate corruption among civil servants in Tanzania, 26 May 2005, Dar es Salaam.

Nyang'oro, Julius E. 2004. Ethnic Structure, Inequality and Governance of the Public Sector in Tanzania. Geneva, UNRISD.

Owusu, Francis. 2006. Differences in the performance of public organisations in Ghana: implications for public-sector reform policy. Development Policy Review, 24 (6): 693-705.

Peters, B. Guy. 1995. The Politics of Bureaucracy. Fourth edition. White Plains, N.Y., Longman.

President's Office. 1999. Public Service Management and Employment Policy. Dar es Salaam: Civil Service Department.

- 2005. State of the Public Service Report 2004. Dar es Salaam, President's Office, Public Service Management.

Rauch, James E. \& Peter B. Evans. 2000. Bureaucratic structure and bureaucratic performance in less developed countries. Journal of Public Economics, 75: 49-71.

Riggs, Fred W. 1964. Administration in Developing Countries: The Theory of Prismatic Society Boston, Houghton Mifflin Company.

Robinson, Mark. 2006. The Political Economy of Governance Reforms in Uganda. Brighton, IDS-Sussex.

Rugumyamheto, Joseph. 2004. Innovative Approaches to Reforming Public Services in Tanzania. Public Administration and Development, 24: 437-446.

Schiavo-Campo, Salvatore. 1999. Government Employment and Pay: the Global and Regional Evidence. Public Administration and Development, 18: 457-478.

Tendler, Judith. 1997. Good Government in the Tropics. Baltimore, The John Hopkins University Press.

Theobald, Robin. 1999. So what is really the problem about corruption? Third World Quarterly, 20 (3): 491-502.

Therkildsen, Ole. 2001. Efficiency, Accountability and Implementation: Public Sector Reform in East and Southern Africa. Geneva, UNRISD.

- 2004. Autonomous tax administration in sub-saharan Africa: the case of the Uganda Revenue Authority. Forum for Development Studies, 31 (1): 59-88.

- 2005. Understanding public management through neopatrimonialism: a paradigm for all African seasons? In Engel, Ulf \& Gorm Rye Olsen, eds. The African exception. Aldershot, Ashgate. 
Therkildsen, Ole \& Per Tidemand. 2006. Staff Management and Organizational Performance in Tanzania and Uganda: Public Servant Perspectives. Copenhagen, Danida and the Danish Institute for International Studies.

Valentine, Ted. 2004. Budget Analysis to Facilitate Pay Reform. Dar es Salaam, The United Republic of Tanzania. Public Service Reform Programme.

Walle, Nicolas van de. 2005. Overcoming Stagnation in Aid-Dependent Countries. New York, Center for Global Development.

Woodall, Brian. 1996. Japan under Construction: Corruption, Politics and Public Works. Berkeley, University of California Press.

World Bank. 1997. The State in a Changing World. World Development Report, Oxford University Press. 


\title{
“WE MAKE DO AND KEEP GOING!” INVENTIVE PRACTICES AND ORDERED INFORMALITY IN THE FUNCTIONING OF THE DISTRICT COURTS IN NIAMEY AND ZINDER (NIGER)
}

\author{
Oumarou Hamani \\ Introduction: How to Manage a Public Service in Chronic Need \\ OF RESOURCES?
}

If you insist that you need this and that to work, they will end up saying that you do not do your work!

This statement by a Vice President of the Higher District Court of Niamey, Niger's most important court in terms of the volume of cases processed, is indicative of the functioning of its jurisdiction and of the judicial system in general. It reflects the scale of dysfunction within the courts. Nonetheless, the courts continue to more or less meet the needs of service users. How do they manage to do this? Taking the concept of 'practical inventiveness' (débrouillardise) as its starting point, this chapter explores the mechanisms by which these services function. These inventive practices are often overlooked in the research carried out on African public administrative systems. An ethnography of the operation of two district courts in Niger will not only provide insights into the state's everyday functioning 'from below' but will also demonstrate that practical norms and ordered informality (see Olivier de Sardan in this volume) are not always negative and can contribute, in some cases, to making the state work. ${ }^{1}$

To ensure the production and delivery of public services in a context of state weakness, civil servants rely on a wide range of practices which are, themselves, based on equally diverse logics. They face organizational constraints in the decisions they make: they must deal with problems, and build strategic relations with local political authorities whose support they depend on for the completion of certain tasks. This constant quest

\footnotetext{
1 The term "ordered informality" is inspired by Evans-Pritchards (1940, repr. 1987: 296) analysis of the working of segmentary societies. See also Olivier de Sardan (in this volume). Special thanks to Susan Cox for translation into English.
} 
for resources to facilitate the running of the courts shapes the magistrates' image of the state.

These practices are often out of step with what is set forth in the official documents; however, they sometimes produce unexpectedly positive results which are currently of interest to both the development community and social science researchers (Jütting et al. 2007). If these practices help to strengthen the production and delivery of public services by the state, particularly in local contexts, the potential offered by the analysis of their emergence and embedding in public administration practices is considerable. In the context of the judicial system, such an analysis raises the question of the 'independence' of the judicial system and the capacity of the state to control a service that relies-at least in part-on non-state resources in order to function.

Addressing the concept of practical inventiveness is to bring to light certain practices-sometimes hovering on the limits of legality-which facilitate the functioning of the judicial system on a daily basis. It also means re-examining the level of commitment among magistrates in relation to the state they serve (Lentz in this volume). Contrary to the claims of Das and Poole (2004), this is not limited to the "margins of the state". This consideration concerns the very heart of the judicial structure; it endeavours to give substance to the concept of 'practical norms' as put forward by Olivier de Sardan (in this volume). There is a significant discrepancy between the inventive practices referred to here and the official functioning and the formulated policies of the state. However, far from impeding the operations of state justice, much like the oil that lubricates an engine, these practices sometimes act as a catalyst for functionality. 'Practical inventiveness' adds to the notion of the plurality of norms already recognized as existing in public administrations. In an analysis of this plurality of norms in the implementation of public policy, Chauveau, Le Pape and Olivier de Sardan (2001: 150) maintain that 'unofficial' norms develop as a result of an incapacity on the part of the state to formulate rules and regulations and ensure their acceptance (see also Olivier de Sardan 2009; Titeca and De Herdt 2010). I will argue here that the emergence of unofficial rules could also arise as a result of the state's incapacity to provide sufficient resources to its administrations.

In the sphere of justice, unofficial practices raise a very specific question: to what extent does the emergence of informal practices affect the independence of the judicial system? The literature on the subject of judicial independence (in francophone Africa) focuses on political interference in the treatment of court cases (Badara Fall 2003; Du Bois de 
Gaudusson 1990). This perspective, however, is limited, failing as it does to take into account a number of covert forms of dependence in the justice system, involving manifestations of 'powers' other than political power. In the everyday functioning of the judicial system, indeed, magistrates have dealings with a range of institutional non-state actors, with whom they must negotiate in order to obtain some of the resources needed for the system to function. In the context of the courts, these negotiations also contribute to the informal privatization of the judicial service in the form of corruption (Blundo and Olivier de Sardan 2007), predation (Trefon 2009), "every-man-for-himselfism" and "cronyism" (Olivier de Sardan 2004). These negotiations are a double-edged sword; on the one hand, they present fertile ground for the emergence of corruption or clientelism (Titeca and De Herdt 2010). On the other hand, they may contribute to the operation of public services. In this text, I am particularly interested in the ways in which magistrates adjust their professional practice according to the scarcity of resources.

In other words, the purpose of this chapter is to analyze the interactions between magistrates and members of the public from a perspective of "palliative delivery" (see Olivier de Sardan in this volume), within the bureaucratic mode of functioning. This perspective is complementary to the analysis of Tidjani Alou (2001: 64) who, with reference to the insufficient budgets allocated to the judicial system in Niger, remarks that "the judicial administrations find it impossible to function normally. This has an impact on the execution of the public judicial service, a process that is often compromised or diverted from its primary objectives..." (for similar perspectives see Blundo 2003b and Bierschenk 2008). ${ }^{2}$

While I am interested in the negotiations between state officials and their environment and the 'transactions' surrounding access to the public judicial service-practices that are situated in the context of the wider debate about the links between the state and the non-state sphere (Lund 2007; Baker 2010) - this paper focuses on the mechanisms by which the resources mobilized from outside the system by state officials are reinvested in the judicial system and the state. I am also interested in how

2 This approach is also inspired by Gobatto and Lafaye (2005), who, in their work on the healthcare sector, carried out an analysis of the arrangements, adjustments and negotiations employed by healthcare practitioners to incorporate or circumvent the constraints they face in the care given to pregnant women, particularly in the context of preventing mother-to-child transmission of HIV (PMTCT). In this case, the constraints were analyzed as the drivers of new practices rather than insurmountable obstacles. 
magistrates view and/or legitimize these negotiations. How does the concept of 'practical inventiveness' influence the magistrates' perception of the state?

Based on these questions, the analysis is structured in four parts. The first discusses the background and context of the study. The second highlights the weakness of the public judicial service in Niger. The third deals with the manifestations of inventive practices in the observed courts, and the fourth is dedicated to an analysis of the discourse of the judges on their relationship with the state. ${ }^{3}$

\section{The Organization of the Judicial System: the Courts of Niamey AND ZINDER}

The judicial system in Niger is based on the French model. In order of importance (from bottom to top), there are the tribunaux d'instance (Magistrate Courts) at the departmental level, the tribunaux de grande instance (Higher District Courts) whose jurisdiction is regional in scope, two cours d'appel (Courts of Appeal), each with a jurisdiction of four District Courts and 15 Magistrate Courts. At the top of the judicial hierarchy, there are the cour de Cassation (Courts of Cassation), the cour d'Etat (the national courts), the cour des comptes (Courts of Audit), and one cour constitutionnelle (Constitutional Court). The District Courts of Zinder and Niamey, the subject of this study, are connected to the Courts of Appeal of Zinder and Niamey respectively. To quote Raynal (1990: 7), Niger's judicial system is characterized by a "unity of judicial and administrative measures, a unity of modern and customary law jurisdictions, a unity of civil and commercial jurisdictions". Once trained, the same judge may cover all specializations and assume a variety of judicial and administrative functions.

3 Fieldwork was carried out in Zinder between 2006 and 2008. The data were collected on the basis of a qualitative methodology combining interviews and observations. The observation of practices at the margin of state law is clearly problematic, both epistemologically and ethically. The resulting dilemma can be summed up in the following question: How does one observe that which is by nature hidden (Blundo 2003a), and how does one write about it? I adopted an approach based on the observation of work practices, the analysis of professional careers, and the comments of informants about their work conditions, their perception of the state, their expectations etc. 


\section{Magistrates and Prosecutors}

From a functional point of view, the magistrates may be divided into two categories. First, there are the magistrats du parquet, i.e. prosecutors, comprising both prosecutors and deputy prosecutors. Hierarchically, they are subject to the authority of the Ministry of Justice. Second, there are the magistrats du siège, the independent judges whose functions combine instruction and judgment. Some judges are assigned to special courts/jurisdictions, such as juvenile courts, customs courts, and civil and commercial courts. In principle, while assigned to a special court, a judge should not be involved in other cases. This embargo ceases once they have left their assigned jurisdiction.

The Higher District Court of Zinder has six magistrates, two of whom are prosecutors and four who act as judges. ${ }^{4}$ None of these are women. In addition to the President of the court, Zinder's district court judges include a juvenile court judge, an investigating judge, and a civil and customary judge. Outside of the city of Zinder, the Higher District Court has five Regional Courts under its jurisdiction (Matamey, Magaria, Mirriah, Tanout, Gouré), all of which come under the authority of a single magistrate. Between 2002 and 2004, the Public Prosecutor's Office at the Higher District Court of Zinder registered an average of 300 cases each year, inclusive of all offences.

The Higher District Court of Niamey has 25magistrates in total, i.e. four times more than its counterpart in Zinder. Of these, 15 are judges and ten are prosecutors. On average, this court completes around 60 hearings per week, giving a monthly average of 240 cases. Each judge hears an average of 16 cases per month.

\section{Ordered Informality 1: Court Clerks, Secretaries and Others}

The support staff in the courts of Niamey and Zinder can be divided into two categories based on their status. The first of these is the permanent staff, composed of clerks and secretaries, who are permanent public service employees. Zinder Higher District Court has six permanent support staff, e.g. three clerks (greffiers) and three secretaries. Only three of these six staff members hold qualifications and the bulk of the clerking and

\footnotetext{
4 The number of staff changed between 2007 and 2009. In 2009, there were a total of
} nine magistrates in Zinder's District Court, seven of whom were judges. 
secretarial work falls to them. This kind of disparity in the distribution of work among administrative support staff is commonplace in Zinder Higher District Court:

They (the clerks and secretaries, $\mathrm{OH}$ ) are in great demand by different judges. Some tasks are regularly deferred or delayed...judges must wait until one case is completed before soliciting the services of the official for another. This means that work drags on (President of the Court, February 2007).

Niamey Higher District Court has more permanent support staff at its disposal than its counterpart in Zinder. In 2008, there were 17 permanent members of staff, composed of clerks and secretaries to the clerks, representing about $46 \%$ of its total support staff.

From an administrative point of view, the head clerk (greffier-en-chef) single-handedly manages the court operations and is responsible for the entire support staff. Given the huge volume of cases dealt with in Niamey, several departments report to the head clerk: the secretariat of the offices of the clerks and prosecutors and the offices of the civil, social and correctional clerks. Each office collates the different records and carefully guards the legal files in metal filing cabinets. To quote A., greffier (clerk) at the Office of the Civil Clerk, Niamey Higher District Court, whom I interviewed in February 2008, the clerks see themselves as the "court's memory".

The second group of support staff comprises the subsidiary staff that do not, however, form a homogenous category. They are composed of volunteers, national civic service workers and, in Niamey, trainees (stagiaires). ${ }^{5}$ Volunteers are individuals who hope to eventually gain paid work within the system. National civic service workers are young university graduates who are employed in the civil service as part of a policy to combat youth unemployment among young graduates. Trainees are unpaid pupils or students who pass a few months at the court to "learn the bureaucratic routines" under the supervision of one of the employees. While the volunteers and trainees are unpaid, the national civic service workers receive a salary of FCFA 50,00o (about $76 €$ ) per month. Niamey Higher District Court has a large number of subsidiary workers relative to its official staff: according to a survey carried out in 2008, the former comprise over $5^{0}$ percent of the support staff. They often have little or no training in the tasks assigned to them and are left to learn on the job; they gain their

5 In other sectors of the state, for example health and education, there are also contract workers (previously referred to as "volunteers"), who are paid by the state. 
knowledge and experience of professional procedures through contact with official staff.

The subsidiary workers-in particular the volunteers-are not under any obligation to produce results. They are not subject to any official terms and conditions, and receive no pay because they are not formally recruited. Nor are they included in the official organizational chart of the judicial administration. However, when it comes to the completion of tasks, these statutory differences have no impact because "due to a lack of personnel, the subsidiary workers perform the work of the official staff" (Ms M.H.R, Clerk, Higher District Court Niamey, February 2008).

Just as there is a discrepancy in their treatment, there is also a discrepancy in the way in which these two categories of workers-permanent and subsidiary - are recruited to the courts. The subsidiary workers enter the judicial administration through various channels, often at the margins of official practice. Many of them begin as trainees or national civic service workers employed for two years on a renewable basis. The case of M.M. provides an insight into the manner of recruitment of the subsidiary workers.

Ms M.M. began in 1998 as a secretary-volunteer in the Ministry of Justice while 'awaiting' more steady work. Fobbed off with empty promises of promotion until 2008, her status evolved to that of 'permanent trainee' (stagiaire-titulaire). She held a vacant position in the Ministry of Justice and hoped to be made permanent. In 2005, she was 'assigned' (M.M.'s own phrasing) to Niamey Higher District Court, specifically to the Chief Clerk of the Court. At the time, she says, she had taken a break from the internship to return to her studies. During this period, there was a recruitment drive, and somebody else was given the job that had been promised to her. However, due to a shortage of personnel, the Director of Administrative and Financial Affairs assigned her to Niamey Higher District Court on the basis of a favourable reference from the president and prosecutor of this court. When we met in 2008 she was still waiting to be made permanent.

Subsidiary workers aspire to the more legitimate status of the permanent staff. To achieve this, they must 'have experience'. Often the process of gaining work experience takes several years, during which they are heavily involved with court procedure. M.M. described the range of tasks assigned to her as follows:

When I was working with the outgoing head clerk, I sometimes worked on call. When you work at the public prosecutor's office.... it's Niger's secret, you are bound to observe professional secrecy. We are not sworn in, but everyone is there to do a job. When the head clerk, our boss, asks us to do 
something, we obey... we help him to find files as we know how the files are organized... During the ten years I've worked here, I have never received anything. I come to work every day for love of the work and love of my country. If you're out of work, you forget all you've learned so it's important to come to work regularly. I have no support, and no wage.

It is worth examining the trajectory of this volunteer, a former secretary at the office of the public prosecutor in Niamey Higher District Court in greater detail. Over the course of her career, her status has evolved in a twilight zone (Lund 2007) - there is a discrepancy between her actual status as a trainee, and the process that led to her being made available to the higher district court. Her career trajectory is similar to that of a permanent employee. From the Ministry of Justice, she was 'assigned'based on a reference from the President and the prosecutor-to the head clerk of Niamey Higher District Court where she had to provide off-duty cover for the secretariat. Her status is ambiguous, alternating between formal and informal. In fact, as a subsidiary worker, she performs tasks officially intended for completion by permanent staff. Given that she does not receive any official payment, she is not a state employee, however she is at the heart of the administrative machinery of Niamey Higher District Court. We may call this a more or less ordered informality which prevails here. This ambiguity is characteristic of the functioning of most of the courts observed in the course of my research. The actual work done dissolves the statutory divisions that separate the permanent and subsidiary staff.

Moreover, M.M. is diligent in her work at the court in order 'not to forget what she has learned' at school, she claims. This work is unpaid. She finds it satisfying because it enables her to use what she learned at school and to consolidate this learning through everyday professional application. However, the fact that she is not officially remunerated by the state makes her prone to corruption. On this subject and in reference to the judicial system in Benin, Bierschenk (2008) emphasizes the role of the 'minor personnel' of the courts as a key component of corruption.

The assessments by the permanent staff of the work carried out by these subsidiary workers differ. One prosecutor mentions the ambivalent contribution made by volunteers in the administration of the office of the prosecutor in Niamey.

They are not a high-quality staff: they hinder as much as help (I.B., First Deputy Prosecutor, Niamey District Court, November 2008). 
This discourse reflects the ambivalent attitude of the court authorities towards subsidiary workers whom they view as both a support, or 'those who help', and as a hindrance, or 'those who ruin things'. Their skills often are not equal to the tasks with which they are entrusted and their work is marked by ambivalence. Although these volunteers are not sworn in, they have access to court records. They provide support to the secretaries and clerks in the drafting of correspondence, the transmission of files, the registration and filing of records, and the referral of users of the justice system. In this way, they may be seen as discharging some of the core duties of the permanent staff. Due to the numerous tasks that they carry out and that have rendered them essential to the service, the subsidiary workers have established themselves at the heart of the court. Thanks to this position, they have managed to create networks of internal and external relations that sometimes fall outside the context of the formal organization of work.

\section{Ordered Informality 2: Gendarmes, Policemen and Assessors}

Ordered informality also characterizes professional categories which are auxiliaries of the justice system like gendarmes, policemen and assessors. In Zinder, despite being under the authority of the Ministry of Defence and the Ministry of the Interior from an institutional perspective, two gendarmerie stations and one police station are regularly 'placed at the disposal of the justice system'. The services of the officers of the Criminal Investigation Department are sought for the purposes of preliminary enquiries into breaches of the law. Since they provide the minutes for these preliminary enquiries, the gendarmerie and the police are the first link in the penal chain. From an operational point of view, these officers report to the state prosecutor (procureur général) who is placed at the level of the Court of Appeal. However, in the implementation of their everyday duties, they have more dealings with the Public Prosecutor (procureur de la République) at the District Court level, to whom they submit their daily investigation reports.

Very often, the investigating officers do not adhere to their prerogatives in the execution of their duties. They regularly encroach on the remit of the prosecutors by dealing with cases at the police station or gendarmerie station "unbeknownst to the prosecutor's office", as reported by one public prosecutor whom we interviewed in Zinder. However, these encroachments are embedded in the judicial administration as some 
prosecutors 'prefer that certain cases be dealt with on the level of the police or gendarmerie stations'.

Another group which supports the justice system from the outside are the so-called assessors. To overcome the difficulties inherent in interpreting customs that are by their very nature uncodified, the law appoints two assessors to the judge of customary affairs. The customary affairs assessors, who were previously known as interpreters, are the judge's principal advisors in civil and customary law matters. They are called on to shed light on the customs of conflicting parties. ${ }^{6}$ The nomination of the customary assessors is beyond the control of the judges and is decided by the administrative or customary authorities. In the municipalities, it is the duty of the mayors to prepare an annual list of skilled assessors to assist the judges in customary affairs. The judges must accept the assessors assigned to them by the administrative authorities. The assessors can, however, be dismissed in the case of a complaint from a judge. They receive a monthly salary based on the number of cases they have been assigned. The assessors have a solely advisory function. However, in practice, when faced with a case that depends on the interpretation of Muslim custom, for example, a judge in a customary court will have little or no choice but to submit to the advice of the assessor if he is not familiar with Muslim law.

\section{LaCK of Resources as Discourse and ReALITy, AND the IDEALIZATION OF THE PAST}

\section{The Lack of Resources: Discourses and Realities}

According to the magistrates with whom we spoke, if there is a common, recurrent characteristic to be observed throughout the courts, it is 'work overload' and the 'wretchedness of the judicial system' (see also Du Bois de Gaudusson 1990: 10). Two types of discourse emerge with reference to the resources available to the judicial system. One of these treats the lack of resources as the key to the functioning of the judicial system; the other idealizes the past.

In relation to the lack of resources, the younger magistrates highlight the ongoing imbalance between the increasing demands on the judicial

${ }^{6}$ Loi 2004-050 du 22 juillet 2004 fixant l'organisation et la compétence des juridictions en République du Niger: 2029. 
system, on the one hand, and the insufficient resources provided to meet this demand, on the other. The pressure the magistrates are under is evident from the following accounts:

You know, the difficulties experienced in public administration are exactly the same. It's a question of not having enough resources, the offices are not equipped with information technology. There's also a lack of human resources because there isn't enough magistrates... Niamey Higher District Court should function as a collegial service, if there were enough officers; there should be three judges with a deciding rule as opposed to one.... There's also a shortage of support staff, of secretaries and clerks. For the most part, these roles are filled by volunteers. We have to make do in this way! (M.I.S., Deputy Prosecutor, Niamey Higher District Court, 2006).

For example, in the past five months, we've received nothing at all! In the meantime, we manage as best we can.... We should receive quarterly allocations of operational funding, the sum of which is unfixed. In the past year, I've only received two instalments of funding! (ODA, President of Zinder Higher District Court, 2007).

The lack of resources has come to represent the norm in the operation of the justice system. This deficiency is felt on many different levels: in the shortage of personnel as compared to the volume of work, the shortage of working materials in the courts, the insufficient levels of funding etc. According to the rules regarding the allocation of funding, the courts are entitled to receive quarterly allocations of funding from the central administration to facilitate their operations. In actual fact, as described by the President of Zinder Higher District Court, the courts often have to make do with receiving the designated funding once every six months. Moreover, the allocated sum is not dictated by the needs of the court, but by the resources available (Interview with the Director of Administrative and Financial Affairs at the Ministry of Justice, 2009). Furthermore, as Department of Justice officials report, the courts regularly suffer due to the under-funding of the budget allocated to the Ministry of Justice, which, in the best-case scenario, still only receives 'a quarter of the amount envisaged by the budgetary legislation.' The total funding allocated to the courts is insufficient, irregular and unstable.

\section{"Previously, we had Resources": Idealizing the Past}

Older magistrates refer regularly to the past when discussing the current state of the judicial system. In fact, many older magistrates, who have either retired or hold a position in the judicial hierarchy, never fail to refer to the former glory of this state sector. 
Twenty years ago, we never had these problems with resources; we were able to function with no difficulty. At the time, there was respect for the judicial service. President Kountché loved justice, and this ensured that the magistrates had a real commitment to their work (M.B., Advisor to the Constitutional Court, May 2008).

The period M.B. speaks of refers to Kountché's period in office (19741987), which is generally remembered as a time of plenty. This highranking magistrate associates the 'respect' afforded the judicial system with the resources allocated to it by the state. The judicial system was not neglected; on the contrary, it enjoyed preferential treatment from the regime in power at the time. This may appear contradictory in the context of a military dictatorship. However, another magistrate interviewed in Niamey reiterates M.B.'s statement:

I have spoken with many magistrates...they told me that magistrates were better equipped with vehicles, for example the R4s which enabled them to make work-related journeys. Each magistrate had a house or a rental property... One time, the President attended a swearing-in ceremony to greet the new magistrates. At that time Bondieré was President of the Appeal Court and he asked him (the President, $\mathrm{OH}$ ) to take off his kepi. ${ }^{7}$ When the swearing-in ceremony was over, the president greeted them, and asked them 'Are there any problems?' Sissoko, the President of the Supreme Court, replied 'Sir, we do have some problems. We do not have any means of transport, nor the minimum housing requirements.' So the President went to the Ministry of Finance and told them to see that these requirements were fulfilled. At that time, when Kountché gave orders they were obeyed to the letter!' (Interview with G.S., Magistrate at Niamey Higher District Court, former Under-Secretary General of the Independent Magistrates' Association of Niger (Syndicat autonome des magistrats du Niger), August 2007).

The idea that working conditions were significantly better in the past can be contextualized by analyzing the relationship between the development of the budget allocated to the justice system and the increase in the operating costs of the courts. The budget allocated to the judicial system has never exceeded one percent of overall national expenditure-this includes the period under Kountché referred to by the former magistrates. During this period, in fact, the percentage of the national budget allocated to the judicial service was on average 0.42 percent, which is considerably lower than that allocated during the periods before ( 0.82 percent) and

7 Every person entering into a courtroom is obliged to remove his hat, as a sign of respect to the judicial authority. This symbolic display of power may still be seen at hearings held in Niger's courtrooms today. 
after Kountché's period in power ( 0.61 percent). Hence it is difficult to support the argument of the magistrates who maintain that this sector of the state was prioritized in the context of the evolution of the budget allocated to the justice system.

This idea that justice received special treatment also warrants some qualification. Under Kountché's authoritarian regime the costs incurred by the operation of this sector were low: Niger only had 48 magistrates in 1988. The 1990s saw a marked departure from this situation. First, there was an increase in the number of magistrates. Up to 1990, the low number of magistrates meant that the annual judicial budget could cover their salaries. From 1990, the situation changed dramatically due to a policy for the recruitment of huge numbers of new magistrates. Fifty-five magistrates were trained and appointed to the judiciary during two recruitment sessions (in 1989 and 1990), bringing the total number in the country to 103. This meant that the judicial system required a lot more state funding. However, the budget allocated to the judicial system remained the same as it was during the period $1985^{-1986}$ when there were barely 30 magistrates.

We must also bear in mind the expansion in the total number of judicial districts initiated in 2002 with the support of the European Union. Until 1994, Niger had 37 jurisdictions, encompassing all levels. From 2004, the 'legal realm' was expanded to include 43 jurisdictions. The creation of new jurisdictions was also a factor in the increased demand for operational funding for the judicial system; however state resources were already in short supply and were, therefore, unable to meet this increased demand.

These changes came on top of the institutional changes of the 1990s and were marked by the appearance of the very first Union (syndicat) for the representation of magistrates, which publicly highlighted the difficult working conditions faced by the judiciary. The early $1990 \mathrm{~s}$ saw the progressive distancing of the state from the justice sector, a development that coincided with the emergence of inventive practices by the sector's personnel so that they could do their work. The testimony of G.S., a magistrate in Niamey Higher District Court at the time, provides an insight into the way the judiciary were left to invent methods to 'make do' when faced with this systemic insecurity:

We began the trade union fight based on material issues because the system was antiquated from the point of view of equipment, buildings and the prisons, which were undersized and crumbling. We started with these issues, but also with simple problems to do with our everyday operations. At the time, the judges themselves were drawn into these issues, as judges in 
Niamey were forced to buy paper personally or to ask friends for it. Institutions like the postal service, as it is related to our sector, provided us with reams of paper as we have friends there. On occasion the Ministry for Justice would send us two reams. This was not enough for even the prosecutor's office. Imagine that at that time there were 13 judges in the court, and they received only one ream of paper between them. This was in 1992-1993 (G.S., August 2007).

Having been circumvented for a long time, the justice system was now increasingly used as a channel for regulating conflicts. With the judicialization of social relations (the frequent use of the law in settling disputes), a phenomenon that emerged with the advent of democracy and has been reinforced by the influence of human rights organizations, the judicial system increasingly faced 'demands for justice'. These demands grew not only in terms of the number of cases, but also in terms of the complexity of the cases assigned to the magistrates. The number of civil and commercial cases dealt with between 1987 and 1989 by Niamey Court of First Instance was 283 (Raynal 1990): this figure had grown to over 442 in 2006, i.e. almost double that of $1989 .{ }^{8}$ Judicial administration being 'paperbased', the increase in the number of official files was accompanied by an increased need for storage facilities and office equipment in the courts.

From the 1990s onwards, the magistrates were caught in a bind: they had to manage with the meagre resources provided by the state while attempting to meet the increasing demands on the judicial system. To contend with this challenge, they had to learn to adapt, applying the inventive practices referred to earlier. I will now examine some concrete examples of this concept.

\section{InVentive Practices as Local TaILORING of the JUDiCiAL ADMINISTRATION}

In the judicial system, inventive practices express themselves in various forms. These include decision-making based on work constraints, the establishment of strategic relations in order to 'deal with problems', the extension of official working hours and the creation of an informal mail delivery system.

8 Statistics collected by the Civil Registry Office of Niamey Higher District Court, December 2006. 


\section{Reinventing the Internal Organization of Work}

In Zinder Higher District Court, the dearth of magistrates has resulted in the emergence of new methods for the internal organization of work. Criminal trials, which would normally be dealt with by the President, are delegated to the sole court judge (juge au tribunal), who happens to be a juvenile judge. Hence, although he is not technically authorized to deal with cases other than those concerning minors, this judge must take on all criminal cases not dealt with by the President of the court.

On his own [the President of the Court], he cannot manage all the cases (A.I. juvenile judge, Zinder Higher District Court, 16 February 2007).

The President of the court should deal with criminal, administrative and customary appeal cases. Aside from these judicial functions, the President must also deal with administrative requests, for example the numerous applications for certificates of nationality, of which over 2,00o were processed by Zinder Higher District Court in the six months from October 2006 to March 2007. In response to this deluge of demands, the President chose to delegate many administrative tasks to other judges, the court judge and the investigating judge (juge d'instruction).

Depending on the internal organization of hearings, the court tries criminal cases on two days of the week, Tuesdays and Thursdays. Customary law appeals, and civil and commercial cases are heard on Wednesdays and Fridays respectively. However, as noted by the President of the Higher District Court: "younger judges are reluctant to deal with civil or commercial cases as these present the most difficulty". Hence, if the President complied with the official distribution of tasks, he would have hearings all four working days of the week (Tuesdays, Wednesdays, Thursdays and Fridays). One can imagine the pace at which he would have to work to prepare for the hearings alone. Therefore, it would be rather difficult for him to find sufficient time for the administrative element of his duties.

While it does not lead to a completely dysfunctional state in the courts, the lack of magistrates affects the planning of work. Through the delegation of tasks, the court ensures that the public's judicial requirements are met on a daily basis. A similar approach may also be observed among the clerks of the court who are not limited to specific tasks. They can be called on by any of the magistrates as and when the need arises. For example, as he has no clerk assigned to his staff, the investigating judge must constantly send for the clerk officially assigned to civil and customary matters. The President of the court does not regard this makeshift administrative approach as a weakness but as a local solution. 
The judge holds both a judicial and a political mandate (Commaille and Kaluszynski 2007: 14). The judicial mandate of the judge is well known. The political mandate, on the other hand, is a complex one. In the courts, the judge is instrumental in implementing the judicial policy (extending or alleviating sentences) developed by the Ministry of Justice. There are two elements to this policy. There is a broad-ranging judicial policy, which is difficult to apply to a range of cases as it fails to take regional specificities into account. Furthermore, this policy is rarely based on field data:

Today, normally, a division (e.g. the Judicial Affairs and Seals Division, $\mathrm{OH}$ ) should be able to record statistics of the cases processed over the course of the year. But it is not possible to do this, and it is unclear how many court cases are ruled on each year, and which cases are the most common: theft, rape, embezzlement, murder? The division ought to provide these analyses to help direct penal policy... if it is made clear that the courts are harsher on a particular crime, there is usually a decrease in this type of offence. At the moment, penal policy suggests that the courts should treat crimes more severely.... But unfortunately... we have not been able to provide these statistics (Interview with A.D., Magistrate and former Division Head at the Central Administration of the Ministry for Justice, November 2006).

For its part, the General Assembly of Magistrates which is supposed to meet once a year on the level of the jurisdiction of a Court of Appeal, also sets out a 'court policy' which is more closely aligned with everyday reality. In the case of recurring offences, the heads of the courts instruct magistrates in the General Assembly with regard to the severity of their sentencing. In practice, magistrates defer more often to the resolutions reached by the General Assembly than to the directives originating from the political authorities. Indeed, the district courts enjoy relative autonomy in assessing the appropriateness of 'state judicial policy' within their jurisdiction. In certain situations, the priorities of the courts differ from those outlined in government policy and the heads of the courts reallocate the limited resources to what they consider to be priorities in their courts.

I myself believe that whatever the resources at our disposal, it is of the utmost importance to ensure that the mail service functions. Because if the mail isn't delivered, there is no way of ensuring that hearings will take place. If you go the court in Niamey, to the hearings for traffic violation cases, you will see cases that are 15 to 20 years old. They are scheduled and then rescheduled because the mail does not reach the intended recipients. Even if it means taking it from the funding for supplies and even if the allocated budget for supplies is only FCFA 100,000, I myself always try to put aside FCFA 20,000 to 25,000 to ensure that the mail is delivered. That is why it 
takes at least a month to give notice to those required to attend a criminal case, be it an expert witness, a civil claimant or the defendant, if they are based somewhere outside the constituency of the court (G.S., former President of Arlit Higher District Court, August 2007).

The use of the first person singular 'I' and the insistence conveyed by the repeated use of 'myself' reveals the personal nature of the management of the courts. As the actor primarily responsible for the 'judicial firm', the President of the court acts as the policy developer within his jurisdiction and the arbiter of its implementation. If, from a functional point of view, these initiatives help the courts to operate, in the name of 'innovation', it must also be noted that this operation depends very much on the personality of the head of the court. These initiatives are not rooted in any permanent framework capable of ensuring regularity in a public judicial service. The court functions solely according to an 'irregular regularity'. The irregularity stems from the personal factor, from the high turnover of magistrates at the head of the courts and also from the irregularity of the funding allocated by the central judicial administration.

\section{Short-Circuiting Letters Rogatory}

Informal procedures are employed also by the investigating judges to sidestep the administrative burdens involved in executing letters rogatory (commissions rogatoires). These practices may be seen in situations in which the settlement of a dispute is a matter of urgency. A magistrate shared his personal experience with us:

In N'Guigmi (a town situated in the far east of Niger on the border with Chad, $\mathrm{OH}$ ), I encountered many problems with witnesses, particularly in cases concerning the theft of livestock as this is a major problem in that region. Sometimes the witnesses, and the victims, are from Chad, and the object of the dispute, that is to say the animal, would invariably be found in Niger; the thief would also be found in Niger, hence, it was necessary for the victims and the witnesses to travel... the law required a long and complicated process. There is the possibility of issuing a summons but summonses go through the Ministry of Justice, which refers it to its colleagues at the Ministry of Foreign Affairs, which in turn must refer it to its counterpart in the country in question, who must refer it to his colleague, the Ministry of Justice of the country in question. In this way, a simple summons can take years. The procedure specified by law is arduous and slow. Therefore, there are times when we operate informally, that is to say that the victims and witnesses are located in a foreign country, and if there is more than one person from a given foreign country implicated in the case, they are told to bring their colleagues with them. This method does not 
work with the perpetrators of a crime: somebody who knows he has broken the law will not come forward as he knows that he will invariably be tried and sentenced. But witnesses or victims often come willingly because a witness wishes to present his version of the facts and the victim is seeking justice for the injury done to him, whether in one country or another. So we operate informally because if we follow the legally prescribed route, the case may even fall by the wayside (Investigating Judge, Zinder Higher District Court, February 2007).

The execution of a letter rogatory, which is signed in the framework of judicial cooperation agreements, is not systematic. It is always subject to review by the judicial authorities of the country in question. Clearly, the judicial authorities responsible are not inclined to implement such letters rogatoryas they do not give rise to any reimbursement of the costs incurred by the relevant courts in these cases.

In order to avoid the 'long and complicated procedure' required by these letters rogatory, conflicting parties living on two sides of a border are directly summonsed by an investigating judge. A kind of 'cross-border' ruling takes place in the case of certain crimes, which evades the administrative channels of the Ministry of Justice and the Ministry for Foreign Affairs in the relevant countries (Niger and Chad in the case in point).

\section{Orders of Remand in Custody}

Orders of remand in custody (ordres de mise en détention), which are standard practice in the prosecutor's office are acknowledged by magistrates as an obstruction of the law, however they are tolerated. They involve the interaction of the Public Prosecutor (procureur de la République) and the criminal investigation department (which is composed of both gendarmerie and police officers). Orders of remand in custody arise in cases in which accused parties are referred to the prosecutor outside of the hours of service (4pm on normal days, and $1 \mathrm{pm}$ on Friday). Referred at the time of the deposition, the 'accused parties' are placed at the disposal of the prison governor pending the provision of a legal detention order. Considered as a "service requirement" by one magistrate (I.M., Magistrate at Zinder Higher District Court, interview on 13 December 2009), orders of remand in custody are a "practice that we must put up with. The police frequently come to the depositions. And we can't just turn suspects loose..." (M.W., Court Auditor, interview on 23 February 2007).

Magistrates believe that the orders of remand in custody are the result of the delayed transfer of reports by the criminal investigation department. The law specifies that after a 48 -hour period in police custody, 
offenders must be referred to the prosecutor. However, it is often only at the deposition that police hand offenders over to the courts. This situation presents the prosecutor with a dilemma: he must either prolong the term of custody (which would be illegal) or let the accused go (and run the risk that the person could abscond). An illegal practice involving the holding of suspects in provisional detention, orders of remand in custody directly contravene a decision by the judicial authorities for their abolition (according to the President of the Appeal Court of Zinder, a circular was issued to put an end to Orders of remand in custody).

\section{Alternating Roles of Police Officers}

In Zinder Higher District Court, alternating roles are a regular feature of working life among the auxiliary staff. Thus, for example, the police officers who work as security staff to the Public Prosecutor are often assigned supplementary tasks that do not fall within the scope of their duties. During my fieldwork in 2007, I was very often informed of the absence of the police officer from his post, and this happened repeatedly throughout my stay. His regular presence at the Higher District Court enabled him to create a parallel network of relationships, which gave him a certain symbolic status in the eyes of the litigants and also put him in touch with the magistrates and clerks. This police officer was also called on to act as a courier, particularly for the collection and delivery of mail on behalf of private transport companies. He was also involved in the daily administrative functioning of the Zinder court.

Law enforcement officers are also involved in judicial procedures. They are required to deliver summonses to those involved in trials. In principle, this relieves the bailiffs of the task. A deputy prosecutor justifies the use of law enforcement officers in the justice system as follows:

This way is effective. When people are summonsed by the police, they will come. But this is not lawful because people panic. Sometimes it's even the complainants who are most upset! You see, it's a dilemma! (O.B., Deputy Prosecutor, Zinder Higher District Court, January 2007).

Hence, law enforcement officers, whose official task is to protect the prosecutor, are also entrusted with new responsibilities in the name of the 'efficacy' of the service. 


\section{Litigants and Defendants Helping to Make the State Work}

In the provinces, land and inheritance conflicts account for the majority of legal disputes. To make a decision on such cases, the judge is required to move to the location in question to familiarize himself with the characteristics of the disputed property. In reality, getting the judge to these locations is easier said than done.

In these cases (moving to assess sites), we ask for help from the parties involved, especially in cases of land disputes. Without these contributions, we wouldn't be able to carry out the work. In the same way, in cases of people seeking certificates of citizenship, we require that people bring their own paper to photocopy the printed documents. Then we can give them one copy and the court can keep the second in its archives. We are aware that this is problematic but we have no choice as we don't have a photocopier (ODA, President of Zinder Higher District Court, March 2007).

The contributions required from users of the justice system are either 'inkind' or financial. They account for a key part of the non-state resources mobilized and reinvested in the operation of the justice system. Hence, in addition to the officials, the users of the justice system participate in 'making the state work'. Reliance on litigants and defendants is one of the strategic options taken by magistrates when faced with the 'absence' of the state. To deal with certain emergencies, such as repairing the District Court's only vehicle, the court officials dip into the material placed under seal for the resources they require. (The material placed under seal refers to any material or financial object confiscated in the course of a legal dispute and bearing the seal of the court or the bailiff who affixed the seal.) This is an infringement of the law, which forbids all use of material under seal placed at the disposal of the justice system.

\section{Getting on with Local Administrative Authorities}

The relationship between judicial professionals and local administrative authorities can vary according to the community, but also according to the level of the material constraints faced by the magistrates on a daily basis. In his account of his experience as a judge in a secondary town in the region of Tahoua (in the north of Niger), R.O. stresses:

In Bouza ... at the level of these jurisdictions, land disputes are very common, and the majority of the time, it is necessary to travel to the location involved. You have no car, so you are forced to go to the administrative authority in order to obtain a vehicle from another department so that you can carry out your duties. And this is much easier when you have a good 
relationship with the administrative authority in question. Because if you don't get on with the departmental prefect or his subordinates, when you request a vehicle to travel to the site in question, he'll tell you that there is no vehicle (Deputy General, Zinder Court of Appeal, February 2007).

For the judges, 'getting on' with the local administrative authority appears to be the contextual norm in courts located in the provinces far from the central administration. This reflects a dimension of power relations between the administrative authorities with the power to assign vehicles to all departments and the magistrate who does not have the resources necessary to carry out his job. It is worth noting that in the provinces, technical services, beyond those of the judicial system, are placed within the administrative jurisdiction of the Prefect or the Governor. Based on the local administrative hierarchy, the heads of the services are required to comply with the orders of the administrative authority.

\section{Exceeding the Official Hours of Work}

In the name of the 'efficacy' of the service, judicial professionals (magistrates and clerks) do not always adhere to the official timetable of the service. Their works spills over into their free time (in the evenings and at weekends). This failure to observe the regular hours of service is common practice in public services in Niger. According to the new civil service timetables introduced in 2007 , the working day ends at $4 \mathrm{pm}$ on Mondays to Thursdays and at $1 \mathrm{pm}$ on Fridays. These guidelines are rarely adhered to by the magistrates, who regularly remain at work until after $8 \mathrm{pm}$. They dedicate a proportion of their personal time to state work. According to the President of Zinder Higher District Court, this practice of unpaid overtime is commonplace. Without actually complaining of his situation, he stated that he 'often works until 8pm, although the working day ends at $4 \mathrm{pm}$.' The same phenomenon may be observed among the clerks, notably at the office of the clerk of civil and commercial affairs Niamey Higher District Court.

We should really have at least four clerks here but there are only two of us, as you can see. The magistrates are equally overwhelmed with their workload. We have practically no private life. Sometimes we are even in the office until 3pm on Sundays!

Q: These extra hours are not considered working hours?

R: No! [but] there's the efficiency of the work to be considered. For example, if you miss a beat in the processing of one hearing, when the documents begin to accumulate, it's over, you can't catch up. As I have some free time 
I might as well update them (M. civil clerk, Niamey Higher District Court, 2007).

Two clerks carry out the work normally assigned to four. In other words, they must dedicate twice as much time to their work. This means sacrificing some of their personal time in order to 'make progress' on the pending files.

\section{An Informal Postal Delivery System}

The delivery of mail is an example of the ordered informality of the functioning of the judicial system. Since the state stopped providing the courts with postage stamps, the magistrates make use of the public transport courier service to communicate with each other. These couriers make many stopovers before arriving at their destination. The judges sometimes use their influence to 'impose' the duty of delivery on public transport workers. For their part, the workers volunteer to 'be of service', wishing both to help and to create a good relationship with the judge. The use of the transport workers has become commonplace in the country's provinces. Magistrates are aware that the documents may get lost sometimes, however they believe that this is the only option available to them for sending and receiving mail.

The magistrates do not evade the question as to the risks presented by this form of communication. They discuss it but, in their view, they 'have no alternative'. Gayakoye (2005), at the time a judge in the judicial sector of Arlit, describes the scale of the risks involved in this informal postal delivery system in the journal of the Independent Union of the Magistrates of Niger (Syndicat autonome des magistrats du Niger, SAMAN):

Instead of being sent via the postal service, summonses, notifications, documents, and appeal and assize files are transported across the country by brave citizens. These letters are transferred from hand to hand at each vehicle's terminus until they reach their destination... Sometimes, the last bearer forgets the letter and passes by its destination and does not remember it until he has reached Sokoto (Nigeria) or Malanville (Benin) (Gayakoye 2005: 17).

The use of public transport vehicles has mixed results. On the one hand, it is a local palliative solution that facilitates correspondences not only between jurisdictions, but also between judges and defendants in the absence of both a reliable postal service and a supply of stamps in 
the courts. On the other hand, as the magistrates are all too aware, these inventive practices constitute a real threat to the independence of the judicial system:

Q: Surely if you negotiate a service, that negotiation implies a chain of...

R: An element of our independence is lost in this way. You can't negotiate with a certain service in order to make photocopies for your service. If an employee or head of this service has a problem tomorrow, he will come to you with it and you'll be obliged to treat him with leniency. The favour must be returned (I.L., investigating judge at Zinder District Court, February 2007)

\section{Judges And the State: An Ambivalent Relationship}

The magistrates' discourse reflects the way they perceive the state. They construct an image of the state regarding 'what the state does' against the backdrop of the failure of the state to honour its obligations. With this image in mind, they define their relationship with the state and their place within the state's structure. For the magistrates, there are two dimensions to this representation of the state.

The state is judged with reference to its ability to provide the resources necessary for the functioning of the judicial system. This dimension became evident when the magistrates spoke of their working conditions. They have a negative perception of the state. Their discourse reveals a distance between them and the state:

Q: As a judge, as a man of the law, what place do you see yourself as occupying within the structure of the state?

R: In my opinion, we should look to the Constitution to answer that question. There are three powers: the executive power, legislative power and judicial power and, honestly, even if something is recorded as official policy, it does not mean it is respected. The judicial system may be seen as the poor relative, because I cannot compare myself to a member of parliament or a minister today.... A minister drives around in a black car [an official recognition of his status, $\mathrm{OH}$ ], embossed with the crest of the Republic. Where is the judge's vehicle? Not all magistrates have one, by a long shot. The Head of court and the President of the court and some others may have vehicles. But go and ask them how they manage to pay for the fuel, and ask also whether among all these magistrates any one of them receives allowances for accommodation, electricity etc. I pay my own electricity and water bills. Ministers and deputies do not have to shoulder these expenses themselves. In reality, 
the three powers are not equal although the Constitution has conferred us with the same powers. In reality this is not the case. In reality, Ministers have more resources (E.M., judge, Niamey Higher District Court, November 2007).

E.M.'s testimonial expresses a sense of abandonment by the state stemming from the lack of resources allocated to the judges to facilitate the fulfilment of their duties. With reference to primary teachers in Benin, Bierschenk speaks of a 'breach of moral contract by the state' (Bierschenk 2009; see also Bierschenk in this volume). In the case of judges in Niger, their complaints are not followed by an 'exit' from the service (one strategy often chosen by teachers). In the courts they display a kind of resiliencethe magistrates do not resort to suffering or complaining about the lack of resources. Instead, they attempt to work within a hostile environment and within the limitations they face in the performance of their duties, mobilizing networks outside of the state in order to 'make the state work' (an alternative strategy also adopted by other public servants). Far from giving in, the magistrates overcome the difficult conditions in which they are forced to work, sometimes by mobilizing personal resources:

When I need to travel for work, I take my own car to go and assess a situation... If I take my own car for a case, I must pay for my own petrol. The state will not pay my expenses to go to see a house or field which is the subject of a lawsuit... The state really ought to provide me with the means to exercise my duties. It does not do that very often, which can give rise to certain situations, and then people say that the judge is causing problems! I have a laptop computer of my own and a printer, and I paid for them out of my own pocket. The state gives me nothing for this and I pay for the ink. I often provide copies myself for the litigants and defendants! (E.M., judge at Niamey District Court, November 2007).

These excerpts of interviews carried out in Niamey reveal the frustration experienced by this judge. He points out the discrepancy between the principle of the tripartite separation of powers as outlined by the Constitution and the discrimination experienced by the judicial sector. A discourse of this nature with its tone of 'protest' is indicative of the general ambivalence of the position which this judge believes he occupies in the machinery of the state. While asserting his status as a 'representative of judicial power', a constitutive power of the state, he also feels aggrieved and against the background of comparing his actual status to that of a minister (executive power) or of member of parliament (legislative power), accuses "the state" to do not perform its duties. 
It is worth noting that in this type of discourse, popular within the courts, there is a semantic confusion between the concept of the state and that of executive power. In claiming that "the state really ought to provide me with the means to exercise my duties", E.M. is referring to the executive power which draws up the budget and distributes resources among the services of the state. 'The state' he evokes is here reduced to the government, whose mission is to mobilize resources and ensure that certain policies are implemented, in this case, judicial policy.

The feeling of outsider status expressed by magistrates with regard to the state is explicitly present in the frequently recurring phrase that 'the state has failed us, we're trying to do something about it.' This sentiment is roughly equivalent to the idea of substituting for the state. The magistrates justify their own actions. They understand their actions as a way of supplementing the state whose deficiencies need to be compensated for.

Q: How do you feel when you are dealing with these specialists [judicial experts]?

R: I don't feel culpable in any real sense as this is not our fault. We don't need a registered psychiatrist to tell us that this is not our fault; somewhere along the way the state has failed but we're trying as best we can to make do (investigating judge, Zinder Higher District Court, February 2007).

At the same time, the judges clearly also see themselves as representatives of the state:

Q: When you say that you are doing this for the state, that the state should provide you with resources, what exactly do you mean by the word state?

$\mathrm{R}$ : To define the state, you must refer to the Constitution; there are three powers which constitute the state. The state is the sum total of them. We represent the state to a certain extent (E.M., judge, Niamey Higher District Court).

The end of the interview summed up all of the ambivalence and complexity that characterizes E.M's representation of the state, and particularly his place in relation to the state. The judge uses two distinct registers to express his links to the state. He considers himself sometimes as exterior to the state when speaking of the resources he needs to do his job properly, but sometimes he is one with the state, of which he considers himself a representative and an enforcer of the law. The concept of the state is not fixed in the minds of the judges; it is ambivalent and varies according to the register being used. 


\section{Conclusion: Circumventing the Rule of LAW in the InTerest OF JUDICIAL EFFICIENCY}

'Practical inventiveness' appears to be an interpretive key that can be used to unlock the general question of the discrepancy between practice and regulation. This discrepancy has been analyzed in studies on the delivery of goods and public services by public administrations in SubSaharan African states (Bierschenk 2008; Olivier de Sardan 2004; Blundo 2003b; Darbon 2001). These studies focused on the misappropriation of public funds by state officials for their personal ends, which contributes to the weakening of the state. However, the results of my study show that the reality is rather more ambivalent. Without disregarding corruption, I conclude that certain conduct may contribute to the alleviation of the state's shortcomings and allow the public service to function despite its limitations. Officials refer to "palliative norms" in order to make the state work. This recalls Blundo's (2011: 438; and this volume) research on the water and forestry services of Senegal and Niger where the water and forestry officials "buy their own uniforms and sometimes even make their own trimmings", e.g. the very symbols of their state functions. Hence, the analysis of 'inventive practices' reveals the blurred boundaries between the formal and informal, between the state and non-state. The lack of formal state resources can be compensated by a range of informal non-state resources, which civil servants may mobilize to carry out their duties.

First, non-state resources originate in part from the personal initiative of the magistrates, who dip into their own salaries to equip themselves with materials for work or to fund their travel in the case of land disputes. Second, the resources mobilized by the magistrates also originate from a variety of private actors. The magistrates sometimes obtain photocopies, office supplies and vehicles for field trips from development aid projects. They also negotiate office supplies from local businesses while waiting for the release of their allocated funding. Private transport services are also called on to ensure the conveyance of mail between the courts and the central administration at the Ministry of Justice. Third, also the people involved in court proceedings pay for the provision of certain judicial services, such as the issuing of civil status documents or trips made by judges in the case of land property disputes.

While these practices render the boundary between state and non-state porous and fluid, formal boundaries within the state are also constantly breached. For resources for judicial purposes, more often than not, have 
to be obtained from the administrative authorities (governors, prefects) who enjoy considerable powers in the provinces. Their ability to control the vehicles of the technical services makes them actors with whom the magistrates must cooperate. The functional relationships established in this way are informal and are not regulated by official documents; in fact, they run counter to the official norm of the separation of constitutional powers. But they involve local initiatives by magistrates and local administrative, by which they assure a minimum public service.

The judicial system operates thanks to a combination of public resources allocated by the central state and 'private' resources which the magistrates are able to negotiate not only with external actors, but also, so to speak, with themselves. This combination generates new dynamics in the judicial system's relationship with its social environment. It decompartmentalizes the justice system and, in such a context, the capacity of the judicial system to function resides in the scope and depth of the network which its managers negotiate, and above all, in their willingness to serve the state and to place its needs before their own (Bierschenk in this volume). These numerous forms of 'support' admittedly enable the courts to function, however they also highlight the structural dependence of the judicial administration on its external environment.

In conclusion, inventive practices redefine the vertical relationships between the magistrates and the state. From the very moment that state officials develop and mobilize extra-professional networks to access resources, they distance themselves from the centralized state, which can no longer control them. State resources cease to constitute the sole means of regulating judicial operations. Non-state means of regulation are put in place, which are linked to the networks constructed by the state offcials. In appealing to actors outside of the state structure for resources, the state officials participate in the creation and reinforcement of a system of rules separate from that of the state itself. Sociability, affinity, solidarity and reciprocity become the framework of 'practical' action in place of the 'official' framework supported by impersonal rules which-according to Weber (see Bierschenk and Olivier de Sardan in their introduction to this volume) - are supposed to govern the functioning of public administrations. These palliative delivery modes of functioning reinforce the plurality of norms. This in turn contributes to the limitation of the central state's capacity to control the conduct of its civil servants. 


\section{REFERENCES}

Badara Fall, Alioune. 2003. Le juge, le justiciable et les pouvoirs publics: pour une appréciation concrète de la place du juge dans les systèmes politiques en Afrique. Afrilex, 3: 1-27, available at: http://afrilex.u-bordeaux4.fr/le-juge-le-justiciable-et-les.html, accessed on: February 2, 2013.

Baker, Bruce. 2010. Linking state and non-state security and justice. Development Policy Review, 28 (5): 597-616.

Bierschenk, Thomas. 2008. The everyday functioning of an African public service: informalization and corruption in Benin's legal system. Journal of Legal Pluralism, 57: 101-139.

- 2009. State at work in West Africa: sedimentation, fragmentation and normative double-binds. In: Etats en chantier en Afrique au Sud du Sahara/States at work in SubSaharan Africa. Proceedings of the Conference/Actes du colloque, Niamey 7-9 December 2009. Niamey, Buco-Edit, 13-41.

Blundo, Giorgio. 2003a. Décrire le caché, autour du cas de la corruption. In Blundo, Giorgio and Jean-Pierre Olivier de Sardan, eds. Pratiques de la description. Paris, Editions de l'EHESS, $75^{-111 .}$

— 2003 b. Négocier l'Etat au quotidien: agents d'affaires, courtiers et rabatteurs dans les interstices de l'administration sénégalaise. In Lebeau,Yann et al., eds. Etats et acteurs émergents en Afrique. Paris, Karthala, 153-173.

- 2011. Une administration à deux vitesses. Projets de développement et construction de l'Etat au Sahel. Cahiers d'études africaines, 202-203: 427-452.

Blundo, Giorgio and Jean-Pierre Olivier de Sardan with Bako Arifari, Nassirou and Mahaman Tidjani Alou, eds. 2007. Everyday Corruption and the state. Citizens and Public Offcials. New York, Zed Books.

Chauveau, Jean-Pierre, Le Pape, Marc and Jean-Pierre Olivier de Sardan. 2001. La pluralité des normes et leurs dynamiques en Afrique. Implications pour les politiques publiques. In Winter, Gérard, ed. Inégalités et politiques publiques en Afrique. Pluralité des normes et jeux d'acteurs. Paris, Karthala, 145-162.

Commaille, Jacques and Martine Kaluszynski. 2007. La fonction politique de la justice. Paris, La Découverte/PACTE.

Darbon, Dominique. 2001. De l'introuvable à l'innommable: fonctionnaires et professionnels de l'action publique dans les Afriques. Autrepart, 20: 27-42.

Das, Veena and Deborah Poole. 2004. Anthropology in the Margins of the state. Oxford, James Currey Publishers.

Du Bois de Gaudusson, Jean. 1990. Le statut de la justice dans les états d'Afrique francophone. Afrique contemporaine, 156: 6-12.

Evans-Pritchard, Edward E. 1940 (repr. 1987). The Nuer of the Southern Sudan. In Fortes, Meyer and Edward E. Evans-Pritchard, eds. African Political Systems. London, KPI, 272-296.

Gayakoye, Sabi A. 2005. La justice de la débrouillardise. La Revue du SAMAN, 4: 17.

Gobatto, Isabelle and Françoise Lafaye. 2005. Petits arrangements avec la contrainte, les professionnels de santé face à la prévention de la transmission mère-enfant du VIH à Abidjan (Côte d'Ivoire). Sciences sociales et santé, 1 (23): 79-105.

Jütting, Johannes and Dennis Drechsler with Bartsch, Sebastian and Indra de Soysa. eds. 2007. Informal Institutions, How Social Norms Help or Hinder Development. Development Centre Studies, OCDE.

Lund, Christian. 2007. Twilight Institutions: Public Authority and Local Politics in Africa. Oxford, Blackwell.

- 2004. Etat, bureaucratie et gouvernance en Afrique de l'Ouest francophone. Politique africaine, 96: 139-162.

Olivier de Sardan, Jean-Pierre. 2009. State bureaucracy and governance in francophone West Africa: an empirical diagnosis and historical perspective. In Blundo, Giorgio and 
Pierre-Yves Le Meur, eds. The Governance of Daily Life in Africa. Ethnographic Explorations of Public and Collective Services. Leiden, Brill, 39-71.

Raynal, Maryse. 1990. Les institutions judiciaires au Niger. Ministère français de la coopération et du développement.

Tidjani Alou, Mahaman. 2001. La justice au plus offrant, les infortunes du système judiciaire en Afrique de l'Ouest (autour du cas du Niger). Politique africaine, 83: 59-78.

Titeca, Kristof and Tom De Herdt. 2010. Regulation, cross-border trade and practical norms in West Nile, North-Western Uganda. Africa, 8o (4): 573-594.

Trefon, Théodore. 2009. Public service in a failed state: looking beyond predation in the Democratic Republic of Congo. Review of African Political Economy, 119: 9-21. 
Thomas Bierschenk and Jean-Pierre Olivier de Sardan - 978-90-04-26496-0 Downloaded from Brill.com@4/26/2023 02:08:21PM via free access 


\title{
"I TAKE AN OATH TO THE STATE, NOT THE GOVERNMENT": CAREER TRAJECTORIES AND PROFESSIONAL ETHICS OF GHANAIAN PUBLIC SERVANTS ${ }^{1}$
}

\author{
Carola Lentz
}

\section{INTRODUCTION}

Emmanuel Zuwera, a retired career diplomat, entered the Ghanaian Civil Service in 1969. Serving in the Ministry of Foreign Affairs since 1971, he was posted to a variety of embassies in Africa and Europe, with intermittent periods back in Accra, and eventually rose to the rank of a Minister, the highest administrative grade in the Foreign Service. Zuwera has worked under governments of different ideological orientations. When I first interviewed him in 1989, he commented on the challenges that the repeated regime changes had presented for his career, and insisted that

a civil servant is supposed to loyally serve every regime that comes in. This is what I was taught. And because you are not supposed to be biased in your political thinking, it doesn't matter whether it is a socialist or a conservative government. $^{2}$

In a more recent interview after his retirement, Zuwera told me one of the stories that must have circulated among his colleagues at the time. During the early days of the Provisional National Defence Council (PNDC)

1 A first draft of this paper was presented in the seminar series of the Department of Anthropology and African Studies, Mainz University; for a more detailed version, see Lentz (2010). I thank my colleagues at the department, and particularly Thomas Bierschenk, for their helpful comments. Research for this paper, conducted in 2006-07, was made possible by the VolkswagenStiftung-funded project 'States at Work'; earlier field work in the Upper West Region was financed by grants by the Deutsche Forschungsgemeinschaft. A sabbatical year (2008-09) at the W.E.B. Du Bois Institute for African and African American Research and the Committee on African Studies, Harvard University, provided the opportunity to analyse my interviews and write up the findings. I am grateful to the Fulbright Foundation for supporting my stay in Cambridge with a travel fellowship. Thanks also go to the Institute of African Studies at the University of Ghana to which I was affiliated as a research associate, and to my many Dagara colleagues, friends, and adopted family who have supported me during my many years of research in Ghana. Because I have not yet been able to get an authorisation from all my interview partners for the quotes used in this text, I have decided to anonymise their names.

2 Interview with Emmanuel Zuwera, Bonn-Meckenheim, 2 Aug. 1989. 
government under Jerry Rawlings, Zuwera related, one of the Foreign Service directors was removed from office because in his welcome address to the young men who had just been sent to his department, he told them "that their loyalty was to the state and not to any government". This candid avowal of the classical professional ethics of the civil service effectively cost the outspoken diplomat his job. ${ }^{3}$ Zuwera fully subscribed to the director's understanding of the duties of a worthy civil servant and to the idea of a moral contract sealed between the state and the officer. 'The rule of the civil servant', he explained, 'is that we should be neutral so that we are able to give our best to our governments.... I serve the state... We take an oath to the state, we don't take an oath to the government'. ${ }^{4}$

Political neutrality, professionalism, and commitment to the welfare of the nation: these are the basic pillars of the professional ethics that all Ghanaian civil and public servants whom I interviewed endorse. They differ in their motivations to join the public service and their career trajectories, but unanimously share this Weberian ideal-type image of a worthy bureaucrat and well-functioning public institutions. They believe that the state is distinct from the current government. And many told me stories like Zuwera's tale of the heroic director who suffered the consequences for upholding these ideals, or of related conflicts they themselves had faced when confronting 'nepotism'. While admitting that it was sometimes necessary to mobilise their 'networks' in order to enter the public service, they were adamant that ideally only a high standard of qualification, 'hard work' and dedicated service towards the common good should determine public service careers.

In this chapter, I explore such normative statements and narratives that feature role models or castigate discrimination and patronage. I argue that these ideals and stories create moral boundaries and support an 'esprit de corps' of dedicated public servants. Such "boundary work" (Lamont 1992: 1-14) often invokes stereotypical images of opportunistic or corrupt politicians, or of less qualified and uncommitted civil servants, against which the interviewees set off the group of highly motivated, competent and honest administrators to which they aspire to belong. These stereotypes, in turn, are often associated with ethnic and religious distinctions, and I will discuss how such particularist identities are mobilised in the construction of an universalist ethos of public service.

3 Interview with Emmanuel Zuwera, Accra, 13 Feb. 2007.

4 Interview 13 Feb. 2007. 
My discussion is based on a case study of thirteen public servants from Ghana's Upper West Region who have entered government service between the late 1960s and the late 1990s, and, in the case of my older interviewees, have risen to top positions in the civil or public service. The chapter explores how my interviewees' career trajectories and work experiences in the public service have changed over the decades, and how these changes, in turn, have influenced their images of the state, public service and the ideal administrator. Most of these men, with whom I conducted in-depth biographical interviews in 2006 and 2007, sometimes following up on initial encounters in the late 1980s, were among the first educated members of their extended families. My sample is biased in that I am dealing not with street-level bureaucrats, but members of the upper echelons of the public service, with successful career-makers, not 'losers', and with people from a specific region. Northern Ghana, and the Upper West in particular, is, until today, generally regarded as an economically and politically marginalised region. This regional background plays an important role for my interviewees' careers in and perceptions of the public service. 'Marginalised' people who believe that they have to work very hard to gain entry into an institution tend to identify strongly with the latter's ideals and official norms. An analysis of their experiences and 'boundary work' can thus throw a particularly interesting light on broader questions of the construction of professional ethics in the public service.

By focussing on the administrators and their perspectives, like all the other authors of this book I hope to contribute to the renewed sociology of (African) bureaucracy that Jean Copans (2001) has recently called for in an article whose title provocatively suggests that former studies have treated 'the African state' as if it worked without bureaucrats. There are only few, mainly historical, studies on African administrators, and virtually none ask how professional ethics are generated, disseminated and upheld. ${ }^{5}$ One may object that it is naïve, if not misleading, to study what public servants say about professional ethics and official norms because the institutional framework in which they work is so thoroughly structured by neopatrimonial logics that no administrator can escape its dictates. One could

5 Robert Price (1975) has conducted a survey among Ghanaian civil servants in the late 1960 s that I will discuss below; for examples of historical research on African administrative careers, see Eckert (2007 and this volume) and Lawrance et al. (2006). Haruna's (2008) discussion of public service ethics in Ghana develops a "transcultural" normative model of how the administration's integrity should be based on a traditional "community ethos", but is not based on any empirical study of public servants. 
thus contend that my interviewees simply put up a façade of universalist ethics to camouflage their 'real' actions, that are in fact guided by particularistic interests and clientelist ties. However, this is, on all accounts, a far too simplistic approach. On the one hand, as Jean-Pierre Olivier de Sardan (2004, 2008 and in this volume) has convincingly argued, it is not sufficient to simply point to the difference between official norms and observed behaviour, and then explain away the latter with broad, generalising concepts such as neopatrimonialism and clientelism. Rather, we need to engage in a detailed analysis of the "practical norms" that do in fact guide the pragmatics of administrators' day-to-day conduct of business. On the other hand - and this is the focus of this chapter — we should also pay more attention to the "official norms" as phenomena sui generis, and analyse how public administrators produce, defend, or modify them.

As Ayee (2001: 1) contends in his analysis of the recent civil service reforms in Ghana, "the motivation and involvement of civil servants themselves" are particularly relevant "in a bureaucratic system that is too weak to impose central top-down reform". In other words: the less coercive power a state bureaucracy commands in imposing a specific work discipline on its members, the more its efficiency depends on how reliably administrators perform their role, as well as how willing and able they are to improvise and innovate in the interest of attaining organisational goals. This, in turn, requires bureaucrats who are not only well trained, but also committed to serving the public interest. The ways in which they have come to identify with and adopt official norms, and how such norms affect their own and their colleagues' actions thus matters. And, I would argue, this is particularly true for public servants who, like most of my interviewees, occupy top positions in their institutions and control, or at least attempt to influence, the actions of often numerous colleagues and subordinates.

In what follows, I will first briefly sketch some aspects of the changing institutional context in which my interlocutors' careers developed, and give an overview of the educational background of the public servants whom I interviewed. I will then discuss their experiences and views with respect to two major themes: firstly, the motivation to join the public service and the factors they identify as determining their own and other public servants' career trajectories; secondly, their ideas about the state, their own role and their professional ethics. Finally, I will look at the ideological and social resources that they mobilise in their quest for a dignified professional life. 


\section{The Ghanaian Public Service: Some Facts and Figures}

Up until the Second World War, the civil service of the Gold Coast Colony and the Ashanti and Northern Territories Protectorates was a rather small institution. In 1931, there were altogether 866 senior posts, and just about 20 of them occupied by Africans. Even in 1948, when the total number of senior appointments rose to somewhere between 1,300 and 1,400, only 98 of them were held by Africans (Greenstreet 1963). The Africanisation of the civil service gained momentum after the election of Kwame Nkrumah as Prime Minister in 1951. Between $195^{2}$ and 1960, the ranks of the senior civil service (posts paying over $£ 680$ per annum) swelled from 1,970 to 3,515 posts, and the percentage of Africans among these civil servants rose from $31 \%$ to nearly $79 \%$. In absolute numbers, the increase of Africans employed in the upper ranks of the civil service was even more impressive, from 620 African civil servants in 1952 to 2,766 in 1960 (Greenstreet 1963). ${ }^{6}$

Initially, it was not easy to find enough qualified African personnel to staff senior civil service positions. Only from the mid-196os onwards did Ghana produce her own university graduates (Daniel 1997-98). Before, degrees had to be awarded by external examiners from the University of London; students interested in subjects other than those of the liberal arts had to venture abroad, mainly to Britain or, in a few cases, to the US or Canada. Senior public servants had to be recruited either among these Ghanaians who had studied abroad or, more often, among graduates of teacher training colleges who were then trained on the job or at the Ghana Institute of Management and Public Administration.

Until well into the 1980 , the public service continued to grow, particularly in the junior ranks, but also with regard to senior positions. For Ghana's university graduates this meant secure career opportunities. In the early 1960 s, more than $80 \%$ of the secondary school leavers went into teaching or "clerical duties", mainly in the public sector, and thus found some form of government employment (Foster 1965: 284-90). Among university graduates, this trend must have been just as pronounced. Job security, quasi automatic promotion, relatively high salaries with numerous fringe benefits such as access to government bungalows, good health care

\footnotetext{
6 For more details on the development of the Ghanaian public service, see Lentz (2010: $6-8)$.
} 
and easy credit, as well as the prestige that went along with a senior position in the public service made the latter an attractive option for many young university leavers.

The "good days of the civil service", as Ayee (2001: 2-3) refers to this period, lasted from the late 1950 s until the mid-1970s, when, due to repeated political upheavals and a massive and prolonged economic crisis, the Ghanaian public service faced increasing problems. The structural problems that Ayee enumerates include logistical shortcomings, i.e. overcentralisation and excessive 'red tape'; substantial overstaffing and uncontrolled recruitment at the junior level, while senior grades lacked qualified personnel due to the increasing 'brain drain'; grossly inadequate wages and narrow increment levels; and, consequently, low work morale and lack of incentives to deliver competent service. Particularly senior public servants faced a dramatic decline in salaries. In 1984, the real salary earned by a high-ranking administrative officer dropped to $10 \%$ of the 1977 income, and even five years later, during economic recovery, would only reach $43 \%$ of the 1977 level. In short, from the late 1970 onwards, it became much less attractive for well-trained and high aspiring Ghanaians to work as public administrators. On the other hand, however, increasing general unemployment and job competition in other sectors of the economy still made the public service an important option for many university graduates.

First attempts to restructure the civil service were initiated in the late 1960 s and mid-1970s, but political instability and successive regime changes seriously hampered the implementation of the suggested reforms. Renewed reform initiatives followed during the early years of the Rawlings regime, but it was only towards the late 1980s, in the context of the Structural Adjustment Programme, that public sector reforms were seriously tackled. The first initiative was the Civil Service Reform Programme (1987-1993) that aimed at an overall improvement of the effectiveness and quality of public service delivery, but ended up concentrating mainly on the downsizing of the staff and a reform of the salary structure (Ayee 2001: 22-23). Figures are notoriously unreliable, but by the end of the 1990s, altogether 50,000 staff had been retrenched from the civil service and the Education Service, and the civil service was cut down to approximately 91,000 employees (Ayee 2001: 10-12, 25). Because the first reform initiative was unable to achieve its farther reaching goals, a new programme was set up in 1995, namely the Civil Service Performance Improvement Programme, that aimed at reorganising salary structures and improving service delivery by reforming the guidelines for career progression and 
training. It involved senior staff in the reform effort, and introduced instruments of self-appraisal, management by objectives, surveys among beneficiaries of the services, and other measures in the vein of New Public Management programmes. In 1996, 'reform' was made a continual exercise by establishing a Civil Service Reform Coordinating Unit and a Committee on Administrative Reforms.

Robert Price's survey among Ghanaian civil servants in the late 1960s revealed that job security was one of the major incentives for embarking on a public service career, and that promotion worked quasi automatically mainly along lines of seniority, resulting in a "practically age-graded" civil service (1975: 188). The dominance of "high security careers, shaped by length of service and seniority" (Ayee 2001: 31) continued until well into the 1990s. It is only in recent years that the efforts to re-orient civil service careers towards higher remuneration coupled with performancebased evaluation have begun to be felt on the ground, and that the new philosophy of 'meritocracy' and customer orientation gradually has taken hold among some of the senior staff (Ayee 2001: 37-38). This trend was clearly noticeable in the emphasis that some of my interviewees laid on service delivery, efficiency and achievement while lamenting that their reform enthusiasm was hampered by entrenched structures of promotion by seniority and by the role 'networks' and patronage played in recruitment and postings. How the retrenchment exercise and changes in career opportunities are reflected in my interviewees' cases is the question to which I now shall turn.

\section{Public Servants From the UpPer West Region AND THE 'NORTHERN FACTOR'}

My interviews with public servants are part of a more comprehensive study of several generations of educated men who hail from the former Lawra District (now subdivided into the Jirapa, Lawra, Nandom and Lambussie Districts) and work in a wide variety of professions. ${ }^{7}$ My first

\footnotetext{
7 I follow here Karl Mannheim's (1952) definition of generations as communities whose members have been "born within the same historical and cultural region" and participate in "the common destiny of this historical and social unit" (ibid.: 303). Departing from a genealogical as well as a biological understanding of 'naturally' succeeding generations, Mannheim suggests that generations crystallise around the historical experiences of a particular group, garnered mainly during their youth, which distinguish it from other groups. In my case study, the primary factor distinguishing elite generations is the various phases
} 
biographical interviews in the late 1980 os focused on members of the earliest generation of the educated elite, nearly all of whom have since then passed away. ${ }^{8}$ These 'pioneers' went to the area's first colonial and missionary schools that were opened from 1935 onwards. They worked as teachers, nurses and clerks for the colonial administration, and generally remained within the region.

The second generation of highly educated men whom I interviewed in the late 1980s, and then again more recently, can be described as 'achievers'. They entered school after the Second World War and profited from the expanding higher educational opportunities as well as the backing of their teachers and sometimes also their families. Many of them studied in the newly opened Ghanaian universities or abroad, and they usually found employment outside their home region. Their careers were the most upwardly mobile, and they entered a much broader range of professions than their predecessors, namely the public administration, institutions of secondary and tertiary education, the medical and legal professions, senior positions in the army, and the Catholic church. ${ }^{9}$

Many members of the third generation of highly educated men, who graduated from secondary school after the mid-1970s, have educated parents and were born and raised in the cities. But due to the general economic and political crises of the late 1970 and 1980 s, they generally faced more difficulties in accessing high-quality education and have been confronted with growing competition on the job market. Their perspectives differed markedly from those of the second generation, and most of them expressed a clear sense of belonging to a different, younger generation that faced new challenges. In order to succeed in their professional lives, they have to rely more heavily on vertical patronage and become adept in making broader national and international contacts. These factors have become even more important for the emerging careers of a fourth generation of highly educated Upper Westerners who have graduated from university in recent years and encounter considerable difficulties in entering the job market.

in which the educational infrastructure developed in North-Western Ghana, where schools were generally established much later than in the South.

8 For some results, see Lentz (2006: 199-209, 228-233). For a study on educated women from Lawra District, see Behrends (2000a, 200ob); on the trajectories of first-generation educated men from Southern Ghana, see Miescher (2005).

9 For a discussion of the second generation of educated men from Lawra District, see Lentz (1994); specifically on home ties and the role of funerals as arena of elite selfrepresentation, see Lentz (2009). See also Behrends and Lentz (2012). 
The educational and professional trajectories of 'second-generation' public servants from the old Lawra District who entered government service before the mid-1980s and whose careers I discuss in this chapter are relatively smooth and straightforward. Careers were facilitated by the high quality of secondary school education in the North, the increasing intake of the universities and, finally, the growing or at least steady demand for university-trained personnel in the public service. While some of these early public service entrants put in a stint of teaching between secondary school and university, most continued more or less straight into university after passing their GCE (General Certificate of Education) A-level exams. All studied liberal arts or social science subjects. This actually implied that they had few professional choices besides joining the civil service or embarking on a teaching career. Some of my older interviewees also studied law, but only after they had already joined the public service. ${ }^{10}$ The transition from university to public service was usually uninterrupted, and most were recruited into the public service as soon as they received their bachelor degrees. Those who had to perform national service ${ }^{11}$ after graduation usually served in the public sector institutions that later recruited them. None of them was older than twenty-eight, and by the time they retire, members of this generation of public servants have usually worked for more than thirty years in the public sector.

For later entrants into the public service, access to employment and regular promotions have been more difficult. Many of them also faced difficulties in organising their university education - a fact that is reflected in the higher age at which they eventually joined the public sector, namely in their early or even late thirties. Four of my six 'third-generation' interviewees had to resit some of their A-level exams or sought alternative ways of accessing tertiary education. All had to work extremely hard to 'make it' against all odds, and even those who gained immediate entry into university were faced with the disruptive developments of student strikes, task force exercises and university closures, particularly in the early 1980 s and again in 1988. Members of this 'third generation' have had to struggle with the fact that the civil service in particular, but also

10 For an overview of the sample and more details on my interviewees' career trajectories, see Lentz (2010: 9-14).

11 The National Service scheme was established in 1973, and confirmed in 1982, and obliges all able-bodied Ghanaians between the ages of eighteen and forty to work for one or two years, depending on the candidates' educational status, for the common good in a variety of employments, mainly in the public sector. 
other public sector institutions, were recruiting less new personnel while the expansion of tertiary education establishments has swollen the ranks of employment-seeking graduates. While some younger entrants were aided by the personal networks that they were able to build up during their national service, others went through a period of unemployment. Furthermore, an increasing number of this new generation of university graduates no longer aims exclusively at a public service career, but sees employment in the public sector as just one phase in their trajectory. Such considerations reflect, in turn, the trend that the public service no longer offers secure and relatively well-paid employment for large groups of university graduates.

While most of the changes in civil service career trajectories discussed so far are probably also typical for many of my interviewees' colleagues, regardless of their regional origins, the problems in accessing highquality secondary education are more specifically a Northern problem. In many respects, the highly educated men and women from the Upper West Region were 'late-comers' in the national arena. Unlike the coastal elite, they had no access to secondary school education before the 1950s, and unlike their Southern peers, no Northerner studied abroad before the newly independent Ghanaian universities opened their doors. Thus, when the civil service was expanded and 'africanised' in the 1950s and early 1960s, very few Northerners were available for recruitment for the senior ranks. This situation gradually changed when Tamale Government Secondary School, the first Northern secondary school to offer A-level courses, produced its first batch of sixth form graduates in 196o. Thus, when the first Ghanaian post-independence institutions of tertiary education were established, Northern students were ready to participate in these new opportunities; and from the mid- or late 1960 s onwards, they could enter the senior grades of the public service.

However, university graduates from the North were very few. More generally, secondary school and university graduates from the Upper West, and more generally the North, were indeed "the fortunate few" (Clignet and Foster 1966). That they were often very successful in their studies and later careers is not as unusual as it may seem at first glance. As Foster (1980: 219) has pointed out, children from regions with underdeveloped educational infrastructure had to overcome so many obstacles that they tended to be highly motivated and successful students. Or, in other words, the high selectivity of the educational system results in a larger percentage of 'high achievers' than is normal in situations with less restrictions to enrolment. 
High academic achievement alone, however, did not suffice for Northern graduates to enter the public service. Encouragement from friends and family and role models were also important factors. A central role in this respect was played by Abayifaa Karbo, from the Lawra chief's house, and later himself the paramount chief of Lawra. Born in 1927, he was among the first graduates of the Tamale Senior Boys School (later to become Tamale Government Secondary School), continued to the newly opened Tamale Teacher Training College and later returned to Lawra to teach. In the early 1950s, Karbo was drawn into politics, and represented the Lawra-Nandom constituency in the Ghanaian parliament until 1965 when he was detained, as a member of the opposition to Nkrumah. While in Parliament, Karbo studied law, and was called to the bar-the first lawyer from North-Western Ghana. After his release from prison in 1966, he served as a member of the Political Committee of the National Liberation Council government (1966-69). In 1969, he was appointed member, and soon afterwards chairman, of the Public Services Commission, an office that he held until 1977. It was in this capacity that Karbo was instrumental to the recruitment of Northerners into the public service. Not only did he actively propagate information about opportunities to work in the civil service and, during recruitment interviews, ensured that Northerners were given a fair chance, but his very presence in this high-ranking office served as a source of encouragement for the younger generation of educated Northerners.

It is interesting, however, that a public service career apparently appealed exclusively to graduates from Catholic families who had gone through Catholic secondary schools. Due to the colonial educational policies, students in government-run institutions were usually recruited from chiefly families, and until well into the 1970s, this resulted in a bifurcated educational system - government and Catholic — and two groups of graduates who generally pursued different careers. ${ }^{12}$ Catholics became priests, teachers or public servants; government school graduates often studied law or medicine, or they went into the army. ${ }^{13}$ One of the reasons why Catholics went into the public service rather than, for instance, into the

12 See Lentz (2006: 133-137, 171-174) for more details on the government versus Catholic school divide, and the different educational goals.

13 That some of the Catholics studied at government-run schools for their sixth form was simply due to the fact that until the late 1970s none of the Catholic secondary schools in the North offered A-level exams. But even then, most of their secondary school training had been in the hands of priests and teachers approved of by the Catholic mission. 
medical field, may have been that in those early years Catholic schools generally offered a good liberal arts and language, but no strong science education. Studying liberal arts or social sciences were their best available options, and this qualified for a teaching or a public service career. This does not explain, however, why not more Catholics went into law, for instance, or why none of the government school graduates with a chiefly background applied for the civil service. It is likely that the Catholic schools also imbued their graduates with a specific creed of rendering service to the common good that resonated well with a public service career. The educated chiefly offspring, on the other hand, tended to subscribe to a leadership ideology that was not quite as service-oriented. Be that as it may, the Catholic background plays an important role for my interviewees' understanding of their role and duties as public servants, and for their perspective on worthiness, 'hard work' and honesty.

\section{"All ALONG, I WANTED TO BE AN ADMINISTRATOR": Organisational Commitment and Career Motivation}

A survey among more than four hundred Ghanaian civil servants that Robert Price (1975) conducted in 1968-69, found that more than two thirds would accept a job outside the public service, if it offered better income, and only $9 \%$ would recommend an intelligent young man to become a civil servant. Asked what they 'liked' about the civil service, more than $70 \%$ stated that they were attracted by the 'security' of a civil service career. Price (1975: 183) concluded that "Ghanaian civil servants ... are overwhelmingly committed to the civil service in an instrumental sense; only a small portion manifest a commitment based on an identification with the goals which the organization could and allegedly does seek, such as the development of Ghana and public service, or on satisfactions that are intrinsic to the role they are called on to perform". However, these findings need to be taken with a grain of salt, for Price's survey questions were at best rather naïve, if not outright biased. Moreover, his methodology did not allow him to capture the peculiar mixture of motivations that may well have characterised his respondents' attitudes, nor was he able to acknowledge that motivations may change in the course of a professional career. As I will show below, in-depth biographical interviews can yield more nuanced results.

The security of civil service careers also figured prominently in my interviewees' considerations why they sought employment in the public 
service. This was true for both the older and the younger generation. But security was only one among several factors, and particularly the older generation invariably mentioned that they also had been attracted, for instance, by the "respect" which the Ghanaian public once accorded her public servants. As Peter Tangviel who entered the civil service in 1972 narrated, "What attracted me into the civil service was the respect that the civil servants had at the time, particularly the administrative officer class." 14 He was not quite as impressed by the salaries paid to the officers, particularly when measured "against the responsibilities that one has to meet", both in terms of his work load and the expectations that his wider rural family had for material support. But, he explained,

I stayed on despite that bad salary because initially, for the first ten years, the situation... looked quite promising, the job was quite secure, and one was very optimistic that the economy would expand and you could have better opportunities or make it better still within the civil service. It happened not to have been it, after the tenth year. But then after ten years, getting out into a new place, you'd probably most likely go and meet your former colleagues and you will be a subordinate to them. So that was one thing that kept me back in the civil service all this while. The other one, too, of course is the general attitude of one not being sure of what the future holds for you.

Despite the fact that the conditions of service and salary levels improved in recent years, Tangviel would still not recommend his children and other young people to join the civil service; he would rather see them work in a private enterprise with higher remuneration. His pragmatic considerations of job security, income levels and lack of opportunities to change his career mid-way did not prevent Tangviel, however, from speaking quite enthusiastically about the challenges of his work in the ministry and the personal satisfaction he derived from honesty, integrity and loyal service.

Ivan Dometang's reflections make particularly clear that Price's survey method misses out on the important temporal dynamics of career motivations. Dometang remembered that his initial motivation of joining the public service in 1978 after his university studies was "just finding a job", and since many of his peers had joined the civil service, "we also just followed". ${ }^{15}$ However, as Dometang explained, "I wanted to do something

\footnotetext{
14 Interview with Peter Tangviel, 10 Feb. 2007, Accra.
}

15 Interview with Ivan Dometang, 12 Feb. 2007, Accra. 
different, I didn't want to go where most of my people were", namely the administrative officers' class. He decided to apply for the Internal Revenue Service, underwent the obligatory in-service training, and worked as tax administrators in various regions until he finally rose to become the Head of Operations of the collection of direct taxes in the entire country. He described vividly how he soon developed a strong interest in his work, and how "exciting", "interesting" and "very engaging" his tasks have been all along. Raising taxes was providing the basis for the country's development, he believed, and thus his work was of utmost importance.

For the younger generation, the security of a public service career seems to have lost nothing of its attraction. Ignacio Zaabaar, for instance, who finally secured employment with the Ghana Highways Authority after an extended period of unemployment, compared his peers' opportunities with the career trajectories of the older generation and found that for the latter,

it was much easier for them to find a job.... the opportunities were there, much more than we have now... Because the private sector is not too stable, everybody wants a stable job, [like in the public service] where when you are taken, it is very difficult for you to lose your job.... So that is why there is... that competition, the jobs are not enough for us.... It is becoming more and more difficult by the day. ${ }^{16}$

At the same time, Ignacio Zaabaar, like Tangviel and Dometang, developed a strong intrinsic motivation, and derived satisfaction from "seeing after my duties". "There is no way", he proudly stated, "I will be given a task, and it will be half done. I must be very concentrated to do it completely, to the satisfaction of whoever has given me the assignment".

Without any prompting from my side, most interviewees expressed such a strong commitment to their work. John Tangsege, for instance, who joined the police service in 1968 and later rose to become the director of the Bureau of National Investigation and Inspector General of Police, explained that as a young man he was attracted by the "respect" that police officers enjoyed "at that time" and by their "many privileges". At the same time, he enjoyed telling me about the excitement of intelligence work and the unique opportunities "of seeing many different people and different directions" and acquiring "an all-round knowledge of nearly everything" that the police service provided. ${ }^{17}$ Charles Zaabaar, for his

16 Interview with Ignacio Zaabaar, 2 Feb. 2007, Accra.

17 Interviews with John Tangsege, 24 and 30 Jan. 2007, Accra. 
part, could have chosen a career as a lawyer outside the public service, but decided to join the Prison Service, where he had been posted during his national service. His superior had advised him that he "would have a future in Prison Service", and could rise fast to the top ranks, and Zaabaar indeed made himself a name in the institution by building up its legal department, and finally became the service's director general, not least due to the professionalism of his job performance.

More generally, even if my interviewees entered the public service because of down-to-earth considerations such as the availability of employment, job security, income levels and status, this does not mean that they did not also develop an intrinsic interest in their work. They were all proud of their professionalism, and although some would, with hindsight, not "travel the same road" again, all of them found satisfaction in performing their tasks with commitment and "excellence". Furthermore, many expressed a sense of "serving the nation" and contributing to the public good through their professional work. Such nationalist commitment, however, did not preclude a pragmatic interest in earning a decent income, or as Emmanuel Zuwera expressed it, tongue in cheek, "in serving your country, you also earn some money".

There was only one member of the younger generation who expressed a decidedly instrumentalist attitude towards his work in the public service. For Alexander Kuuyaa, a quantity surveyor who worked with private firms before joining the Ghana Health Service, his current employment was helping him to acquire the know-how and establish the contacts that he would later need to set up his own property investment and construction enterprise. He explicitly criticised the older generation of civil servants who were "always looking at job security" and had joined the civil service because they were "risk averse". ${ }^{18}$ Alexander had always made it a point during his secondary school and university days to establish friendships with peers beyond the narrow circles of the Dagara community, and thus exposed himself to other perspectives on making a career and earning one's living. He felt that it was important to overcome the "inferiority complex" that was typical of many Northerners. Whether Alexander will serve as a role model for future generations of Dagara graduates is an open question, but he is certainly typical of the "business" orientation that some of my youngest interviewees outside the civil service expressed. At the same time, he fully subscribed to the ethics of professionalism, and

18 Interview with Alexander Kuuyaa, 6 Feb. 2007, Accra. 
"hard work" and "excellence" that my other public-servant interviewees held in high esteem.

\section{"Godfathers", "Friends" and "Untouchables": The Role of Patronage in Public Service Careers}

Max Weber described bureaucracies as professional "machines" that achieve "technical superiority" (1978: 974-7). Bureaucracies need "experts and specialised knowledge" (1978: 1002), and the recruitment of personnel is therefore regulated by meritocratic principles and certified educational achievements ("Fachprüfungswesen") (1978: 999). Similarly, promotion within the service follows, in principle, universalist rules, namely a fixed career trajectory ("Laufbahn") through which the entrant moves according to work experience, measured in terms of seniority, and intellectual qualification, determined through a system of examinations (1978: 963). Patronage or the purchase and use of public offices as a prebend are, in Weber's eyes, characteristic of a feudal administration and "tend to loosen the bureaucratic mechanism" (1978: 967).

The Ghanaian public service's official norms correspond quite neatly to Weber's ideal-typical description, and it was these norms that my interviewees had in mind when discussing their own and their colleagues' professional trajectories. But they also developed 'unofficial' normative ideas about the (il)legitimacy of patronage and 'friendship' in public service careers that adapted these official norms to local realities of ethnic and political clientelism. In this section, I will first discuss my interviewees' personal experiences of recruitment and promotion, and then explore their views on the changing role of patronage, networks and ethnicity.

Speaking about their own careers, all of my interviewees, across the generations, emphasised "hard work", "intelligence" and "excellence" as decisive factors that allowed them to enter into, and progress in, the public service. Most of my older interviewees prided themselves on not having relied on a "godfather" or "friend" in order to obtain employment in the public service. "Sacrificial and hard work", loyalty and "intelligence" were, according to John Tangsege, the qualities that had made his career in the Police Service possible. Ivan Dometang, for his part, believed that his successful career in the Internal Revenue Service was "earned by merit". ${ }^{19}$

19 Interview with Ivan Dometang, 12 Feb. 2007, Accra. 
At the same time, Dometang felt that in addition to being hard-working and dedicated, "luck also has gone my way". In a similar vein, Charles Zaabaar declared that he was "accidentally" drawn into the Prison Service, and that he was "lucky" and even did not quite "know what happened" that he eventually rose to the position of the service's director general. All interviewees indeed believed that their professional success was owed to a combination of 'hard work' and 'luck'. 'Luck' could mean, for instance, that a sympathetic superior 'discovered' the interviewee's exceptional abilities; or it could refer to the fact that someone had to face few competitors when applying for a position. The idea that success depended on both 'merit' and 'luck' was reflected in the language that my interviewees employed: they combined an 'active' register ("I struggled hard", "I was anxious to learn", "I took advantage" etc.) with 'passive' constructions such as "I was nominated", "I was sent", or "I was asked". 'Luck', in any case, was not the same as protection or patronage; it rather explained the fact that others who had been similarly hard-working were not as successful as my interviewees. It was a metaphor that summarised the fact that it is never sufficient to be highly qualified and dedicated, but that one also needs opportunities and to be at the right place at the right time. ${ }^{20}$

All interviewees agreed, however, that the combination of opportunities and qualifications that could 'move' someone 'up the career ladder' did not suffice to bring a public servant to the very top positions in their respective institutions. In order to be appointed ambassador, for instance, from among the higher ranks of career diplomats, "you need a little bit of patronage, you need somebody powerful to help you get up", Emmanuel Zuwera explained. This 'patron' does not necessarily have to be from one's own ethnic group, he continued, "you just need a mentor, somebody who likes you and thinks you are a very hard-working officer, and who is in the position to guide you and take you along".

When considering the different factors that played into top-level appointments, Charles Zaabaar, who had been ousted from his position as director general of the Prison Service, felt that his regional background had played an important role for his dismissal. Networks based on ethnicity could have kept him in office, Zaabaar believed, but of equal importance for arriving at, and remaining in, top positions in the public service

20 More generally on the conditions of 'success', see Gladwell (2008). For an extended discussion of the motif of 'luck' in the Dagara educated elite's biographical narratives, see Lentz (2008). 
were party-political alliances and the ability to "survive intrigues" by knowing "the ins and the outs of the office", having "informants" in the relevant ministries and maintaining good contacts with the media. ${ }^{21}$ In other words, a 'godfather' alone was not sufficient; horizontal networks, based on 'old boys' associations, shared ethnicity or other linkages of friendship were just as important.

The older generation asserted that ethnicity could play a role for passing the bottleneck to very senior appointments, but they insisted that ethnic background had not mattered for their recruitment into the public service and for regular promotion. Interviewees from the younger generation, on the other hand, mentioned more often that ethnic background and, more generally, patronage played an important role in gaining access to the public service (like in Nigeria, cf. Willot in this volume). They attributed their own or their peers' failure to enter a specific segment of the public service or to be promoted as rapidly as they thought they deserved to the increasing competition for public sector employment and their lack of a 'pivot', a 'godfather' or some other useful 'connection'. But just like their predecessors, the younger public servants explained their professional success by a combination of hard work, determination and 'luck'. John Mwinyele's thoughts on "godfathers" are a case in point:

some of us are basically here on the basis of merit [but others had a godfather who supported them] ... a godfather means you come in, maybe you have one of your bosses there who you are pet to, and then he keeps moving you, putting you where you want to be. Some of us didn't come in with that kind of background. We just came in, and by virtue of the discharge of our responsibilities, we are where we are.... I don't owe anything to anybody ... I'm working hard to justify myself and where I should be. ${ }^{22}$

Mwinyele and other interviewees thus drew a boundary between 'we', the morally upright who did not rely on patronage, and 'the others' who did. Placing oneself in the group of the incorruptible ones stabilises selfesteem and, in the long run, enhances job satisfaction as well as security. All interviewees argued, however, that competition for public service positions had increased, and thus made patronage and protection ever more important. John Mwinyele, for instance, felt that incidences of "tribalism" in the public sector were on the increase. Jessi Bonaventure Beyaa, too, asserted that "ethnicity, old-boyism, influence of maybe your parents,

21 Interview with Charles Zaabaar, 19 Jan. 2007, Accra.

22 Interview with John Mwinyele, 29 Jan. 2007, Accra. 
political alliance or leaning would play a role in jobs right now" and that much depended on "the networks, associations, clubs that you belong to". ${ }^{23}$ At the recruitment stage, 'godfathers' and 'friends' were needed, my interviewees explained, in order to receive information about job opportunities that were sometimes not publicly advertised, and to make sure that the selection committee did not 'overlook' a qualified candidate or conduct the recruitment interview in an unfair manner. Furthermore, patronage was often necessary in order to 'follow up' and make sure that the successful interview eventually resulted in actual employment. Promotion within the service then usually followed "the normal channel", as Ignacio Zaabaar put it. But a 'godfather' could help to be selected for some special training, including well-remunerated international courses, or to be awarded a study leave or other extras. And, as mentioned above, some sort of protection was regarded as necessary for passing the bottleneck to the superior positions in the respective service.

Interestingly, my interviewees invariably presented the increasing necessity for younger Northerners to rely on some form of patronage as an unfortunate, but basically legitimate reaction to the dominant and illegitimate nepotism by non-Northerners. The justification was tied to the status of Northerners as a disadvantaged minority. "I'll call it nepotism", Ignacio Zaabaar explained with regard to the general trend in public service recruitment and promotion. Access to "bottleneck positions" should definitely be based on merit, but in reality, "there is always a lot of lobbying",

because everybody wants to help his brother, so when we all have the same qualification and he [the employer] now has a choice, he'll definitely choose the brother. So for us who are from up there [Northern Ghana],... we are a minority, so when you come to nepotism, we are at a disadvantage. ${ }^{24}$

By the same logic, my older interlocutors who had risen to top positions in their respective services did not hesitate to admit that they acted as "patrons" and protectors of younger entrants from the North. Charles Zaabaar, for instance, related how he responded when he was questioned as to why he should have endorsed the employment of so many Northerners in the Prison Service:

23 Interview with Paul Beyaa, 16 and 20 Nov. 2006, Wa.

24 Interview with Ignacio Zaabaar, 2 Feb. 2007, Accra. 
I told them that the Constitution said 'equitable distribution of positions in the public service'. It's there, among the 'directive principles of state policy'. So, I said, look, if there are ten regions, and we have recruited a hundred people, then every region should have ten. So if I am bringing four or five people from each Northern region, from any of the regions from the North, I have not even complied with the Constitution. That one, they keep quiet. Of course, some definitely grumbled, he is filling the place with Northerners. $^{25}$

Other interviewees, too, reported that they actively intervened to help highly qualified Northerners to be placed according to their merits. They all believed that some amount of patronage and protection was necessary in order to implement meritocratic principles of recruitment and promotion according to achievement. Yet patronage that promoted candidates who did not have the necessary qualifications, on the other hand, was regarded as illegitimate.

On a more general level, one could argue that bureaucratic norms indeed need to be upheld through personal intervention when the institutionalised checks and balances are not strongly rooted. My interviewees' statements regarding the legitimacy or illegitimacy of protection and networks reflect ongoing debates among peers and colleagues, both within and outside the public service. Sometimes, their judgments are made explicit, but much is also said in more indirect ways through narrative strategies and semantic choices. They construct boundaries, by the use of 'we' and 'they', between deserving bureaucrats and reformers on the one hand and scroungers, nepotists and unqualified protegées on the other. They narrate stories of morally upright martyrs and victims who put up with condescending criticism of their naiveté and sacrifice by more adept winners. They employ a variety of terms and metaphors with different connotations, sometimes with a note of irony, for supportive networks that mark different degrees of legitimacy. The 'godfather', for instance, reminds of problematic Mafia networks, the 'untouchable' of the Indian caste system; reliance on 'friends' is certainly more acceptable than 'favouritism', 'old-boyism' and 'nepotism'. And they oscillate between the optimistic hope that their personal behaviour might serve as an example and the pessimistic resignation that 'nepotism' is a 'disease' that spreads and that it is very difficult to avoid 'being infected', or, as

25 Interview with Charles Zaabaar, 19 Jan. 2007, Accra. The relevant section of the 1992 Ghanaian Constitution is $\S 35,6 \mathrm{c}$. 
Sebastian Debuur put it, "personal conviction doesn't matter, you have to reckon these forces". ${ }^{26}$

\section{'HARD WorK', ExCELlence AND COMMITMENT to THE NATION: Images of A Worthy Public Servant}

The discussion on patronage and meritocratic principles feeds directly into my interviewees' image of a worthy bureaucrat. Some of my interlocutors spoke eloquently and at length about the ideal public servant; others presented their ideas more implicitly in the form of stories and examples. Again, the norms they subscribed to did not differ much across the generations. This is in itself an interesting finding because it means that despite the increasingly difficult conditions of recruitment and promotion, my interviewees did not adopt a cynical view of what it meant, or should mean, to be a public servant.

My interviewees' image of the worthy bureaucrat was closely tied to their view that the ideal state should serve as an effective agency to promote the public good, uplift the poor and bring about regionally equitable development. They distinguished between 'the state' and incumbent governments, and while governments were dominated by party politics, inevitably partisan and catered to special interests, the state should, at least to a certain extent, be politically neutral. The major figure against which the ideal public servant was set off was, therefore, the politician, and in many interviews, the conflict-ridden relations between public servants and political appointees were an important topic. Politicians, my interviewees elaborated, want to be re-elected and therefore need to act in accordance with short-term considerations aimed at securing the voters' favour. Civil servants, on the other hand, should consider the longterm effects of their actions for the public good, and have to implement sometimes unpopular measures that will, nevertheless, in the long run help to increase state income, distribute benefits more equitably according to impartial rules, or in other ways serve the nation's interests.

It is useful to keep in mind here that I am not dealing with "street-level bureaucrats" (Lipsky 1980) at the interface of bureaucracies and popular clients, but mainly with high-ranking officials whose relevant partners in professional interactions are, on the one hand, their subordinates in their

26 Interview with Sebastian Debuur, 13 Nov. 1989, Wa. 
respective departments and, on the other, ministers or other political appointees and politicians. It is against this background that their critique of the irresponsible behaviour of politicians, but not the state as such, needs to be understood. My interviewees would complain about salaries that did not adequately compensate their professional efforts or about the lack of sophisticated equipment to support them in their duties. But they did not express any feeling that the state to whom they had pledged their loyal service had not honoured its side of this contract and failed them, and that they could therefore legitimately withdraw from their obligations. On the contrary, the sense of a moral contract which both sides needed to respect, and indeed did respect, was dominant (see Bierschenk in this volume). This is an important difference compared to lower ranking state employees who may well complain that the state has broken this moral contract by neither acknowledging their services with an adequate remuneration nor providing them with the sufficient means to fulfil their professional duties.

Most interviewees insisted that their moral contract was with the state and the constitution to which they pledged an oath, not the government. Reflecting about the difficulties, but also advantages of steadfastly declining to do the politicians' bidding, John Tangsege, for instance, asserted that

the politicians want you to do what is not right. If you are somebody who is frank and truthful, they can't even sack you because what you have done is the truth, they can't send you away. They will want you to do what they want, and not what you want and what is right.... But the moment they realise that this man, he calls a spade a spade... if you tell them the truth and they find out it's the truth, they will receive it. ${ }^{27}$

Ivan Dometang was not quite as optimistic that the politicians would eventually change their mind about what was right. He was discouraged that they remained reluctant to support his work of raising state revenue, because they feared for their own popularity. Politicians feel, he explained,

that talking about taxation would diminish their political support... But if they kept on talking about it, the people would begin to know that it's not something to be hated, it's part of the civil responsibilities. But we haven't

27 Interview with John Tangsege, 30 Jan. 2007, Accra. 
succeeded in getting that round.... and when you go so firmly about some tax issues, they call and say that you have to be careful, that kind of thing. ${ }^{28}$

In all these narratives, my interviewees presented themselves as "state men", as Ivan Dometang put it, that is as professionals who were working for the public good in a non-partisan way. They felt frustrated that politicians, as well as media or other public voices, usually did not recognise, much less praise their service, but they compensated this by taking pride in their work and holding fast to the conviction that they contributed towards the wellbeing and progress of the nation. As Dometang explained,

I'm only being a good citizen, I'm trying to be a state man. I'm prepared to do my professional work.... My job is to be a state man. People want to be a politician to come up. But I want to end up with the state as a state man... of course a politician is committed to the state, but in the partisan way. But for me, it's just on the public service. Trying to serve in the public service dutifully, to record that you really contributed to the nation... A state man who is prepared, whoever is the government in power, I am there to contribute for the nation and not for one particular government. That is the kind of person I would call really a state man. His interest is in serving the nation and that is all.

With his rejection of party politics, Dometang even went a step further than Zuwera and Daanikuu, who had both stood as party candidates for elections. While distinguishing between their professional role as civil servants and their personal political convictions, Zuwera and Daanikuu were convinced that certain developmental problems, and more specifically regional inequality, could only be addressed by politics. But Ivan Dometang, like a few other interviewees, did not even want to become involved in politics, but rather wished to devote all his energy to his work as a public servant.

Political neutrality was only one of the criteria that distinguished a worthy public servant in the eyes of my interviewees, albeit an important one. Other elements that defined worthiness were professionalism and expertise, commitment and dedication to one's work, rule-bound and even-handed discharge of one's professional duties, and, finally, a spirit of service to the nation. "Qualification first" was John Mwinyele's succinct answer when I asked him what defined a good public servant. All interviewees agreed that a high educational standard and the necessary, job-related expertise were of utmost importance. Some pointed to further

28 Interview with Ivan Dometang, 12 Feb. 2007, Accra. 
qualities that a public servants should have: politeness, fairness and the ability to work collegially in a team.

Public servants should strive for "hard work and excellence", many of my interviewees believed. When asked what advice he would give to a new member of the civil service, Peter Tangviel elaborated with the following little speech:

Approach your work with commitment, be loyal to your political boss of the day. Be honest and sincere with him, open about what you are doing and what you are saying, and be as hard-working as possible. Accommodate both your superiors and your subordinates and guide your subordinates as much as possible to do what they are expected to do. Put in your best, so that at the end of each day when you are going home, you are convinced that you have earned the day's wage. That is what I'll tell anybody joining the civil service at any rank. ${ }^{29}$

In addition to commitment, a good public servant was defined by the "impartial discharge of our responsibilities", as John Mwinyele put it. He told me how as director of personnel he had to learn from a senior and more experienced colleague how to deal firmly, but also politely, with particularist expectations of family relations or friends. And he used the popular image of the government as "elephant meat" to explain how important it is to distinguish between private and public property and to drive this distinction home to all public servants:

In our Ghanaian parlance they say the government is an elephant meat. An elephant meat, in their local dialect means that it's so big that one man can't eat it all. So several people eat it. So they look at it from the other side: government is the big elephant, and so everybody accesses it in different ways, in whatever manner. So if I can pick [sic] this copier home to my house and own it, even though it is for government, then I have picked my part of the elephant. Somebody will use the offices to extort monies, you know. Government allocation is there for a purpose, they misappropriate it.... So there needs to be a radical change in our attitude in the civil service, in general. ${ }^{30}$

Mwinyele firmly believed in the value of training in order to effect a change in attitudes. Not all of my interviewees were as optimistic. Ivan Dometang felt that serving as a role model himself was certainly important, but insisted that it was also necessary to be "very smart and checking". And later in our interview he added that in the field of tax collection,

29 Interview with Peter Tangviel, 10 Feb. 2007, Accra.

30 Interview with John Mwinyele, 29 Jan. 2007, Accra. 
computerisation and certain institutional designs also went a long way in making the personal appropriation of public funds more difficult. ${ }^{31}$

Personal integrity, my interviewees agreed, is the indispensable foundation both for controlling the behaviour of one's subordinates and dealing with the illegitimate expectations of one's superiors. One of the driving forces that motivates a good civil servant to remain steadfast and dutybound despite various temptations or lack of respect is his conviction that only in this way will he serve the nation. All of my interviewees felt that the basic aim of their work was "to help the country", as Matthias Kuusob put it. Or, as John Tangsege explained, whenever he found that "governments want their work to be done" but what they want "is not necessarily the right thing", he would ask the simple question of whom his work served:

Does it offend more people, do people derive pleasure from what you have carried out? Or only few people derive pleasure? You are supposed to maximise felicity for the majority of the people. ${ }^{32}$

All of my interlocutors took pride in describing how their particular duties contributed to the common good-by increasing the state revenue, securing societal peace and safety, improving Ghana's international relations, developing her infrastructure or increasing agricultural production. And contributing to the public good by rendering competent and impartial service and being dedicated to development, not pursuing personal enrichment, was the most important element of what constituted a worthy bureaucrat.

\section{Religious AND Ethnic Sources of Professional Ethics}

Which role did these public servants' Northern background play for their professionalism and commitment? First, the personal convictions that informed their professional ethics are rooted in the interviewees' individual upbringing and beliefs. Secondly, the Northern public servants are influenced by their membership in a collective 'sub-culture', formed both among the regional peer groups of highly educated men and women from the North and, regardless of regional origin, among the higher ranks within the bureaucratic institutions. These peer groups are particularly

31 Interview with Ivan Dometang, 12 Feb. 2007, Accra.

32 Interviews with John Tangsege, 30 Jan. 2007, Accra. 
important in order to insulate the bureaucrats against particularist expectations of their extended rural and urban kin and of other persons from the home area or ethnic group.

With respect to the individual resources that support personal integrity, my interviewees' religious background was of utmost importance. All of them regarded their strict Catholic upbringing as crucial for the formation of their ideas of a meritorious life. It is most likely that in a different historical setting, and in other parts of Ghana, Protestant churches could work in a similar way, and it would be worthwhile exploring in which way a Muslim upbringing affects a public service career. In the Upper West Region, however, with the exception of the area around Wa, the Catholic church has been, since the 1930s, the dominant Christian denomination. Since most public servants are Catholic school graduates, they have been impregnated with these schools' ideals and norms. Furthermore, the fathers' of four of my interviewees were catechists, providing for an even more direct influence of Catholicism on their sons' moral upbringing. Ivan Dometang, for instance, narrated how his catechist father was at first shocked that his son wanted to enter the Internal Revenue Service and deal with other people's monies because he felt that it would be very difficult to resist the temptations to pocket some of these resources for personal ends. It was Dometang's firm resolution to disprove his father's fears that kept him disciplined, despite the fact that not many people would praise him for such steadfastness, but rather think that he was being naïve. That such considerations did not make him falter was, Dometang believed, due to his upbringing and his faith in God: "I have the fear of God in me. And I'm a very timid person,... and the fear of God is the beginning of wisdom".

In a similar manner, John Tangsege, another catechist's son, regarded his "good conscience" as the most important orientation for constantly interrogating his actions, both within and outside his profession. When I asked him where he learnt such an attitude, he pointed to his Catholic upbringing:

The Catholics have pumped in a lot of discipline in my mind. If you are doing anything wrong.... If you lie down to sleep, it [your conscience] says: 'no, it's not right'. So that's the conscience and the way you are brought up.... I told you, my father was a catechist and the moment you told a lie about your sister, my mother or my father would beat you. So we got used to speaking the truth, nothing but the truth. It is the Christian principles that I inherited from the Church. 
Most of my interviewees regarded these Christian principles as intimately connected with the Dagara 'ethnic' character of "hard work" and "honesty". The greater part of the Dagara are indeed Catholics, ${ }^{33}$ and my interlocutors felt that the church has left an important imprint on the way the Dagara act and perceive the world. John Mwinyele, for instance, who was brought up by educated white-collar parents outside the rural context, claimed not to know much about "Dagara culture", but was still convinced that he was socialised according to the Dagara principles of "honesty" and "uprightness":

Catholicism has actually dominated and it has schooled us in a certain manner.... I think that tradition is still trickling down to some of us where you can't do a wrong. It's extremely difficult to do the wrong, yes, I think culture has inculcated this pattern of behaviour in the Dagaare man.

Peter Tangviel sketched the same ethnic psychology, but wished that the Dagara would become more enterprising and interested in material progress. He felt that their sense of humility and honesty was standing in their way, and he included himself among those whose careers had been characterised by these commendable principles that did not quite fit with the dominant ways of 'making it' in Ghana. But even Tangviel would not, of course, want this progress to be achieved by illegitimate means.

That my interviewees talked about "the Dagara character" in very similar terms reflects not only a similar upbringing, but also the fact that they do indeed exchange such ideas in meetings among Dagara educated men and women in Accra and other Ghanaian cities. All of my interlocutors are involved in one or more of the ethno-political associations that Dagara migrants have created since the mid-1970s (Lentz 1995), and they also meet in church or informal get-togethers. These social networks are usually grouped according to generations, but at certain festive occasions, such as marriages or funerals, Dagara from the Upper West meet across distinctions of gender and age, and often also social position. But it is particularly in the more elitist social circles that the public servants' careers and life styles are evaluated and compared with those from other ethnic groups. It is at such occasions that stories and comments regarding what is considered legitimate or illegitimate behaviour, regarding ethnic traditions,

33 On the history of Catholicism in the Upper West Region which started with the coming of the White Father's mission to Jirapa in 1929, see Lentz (2006: 153-74). 
necessary reforms and commendable lives circulate and constitute a relatively close-knit tapestry of social control-a phenomenon that Richard Werbner (2004) has highlighted in his study of the Kalanga bureaucratic and managerial elites' contribution to the public good in Botswana. Such exchanges among the elite also establish norms regarding the amount of support that one's rural relatives can legitimately expect, and where to draw the boundary with regard to favouritism. Robert Price (1975) contended that Ghanaian bureaucrats were victims of their extended family's particularist expectations and would compromise their professional ethics because they found it much more important to maintain their good name in their rural home communities. This was probably already a problematic assumption at the time Price conducted his research during the late 1960 s. It is most certainly too simplistic now, some forty years later. One of the factors that allows public servants to insulate themselves, to a certain degree, against their relatives' demands is precisely elite sociability. That honour and shame are ascribed not only by one's 'home' community, but also, or even mainly, by one's peers allows precisely the compartmentalisation of roles - the public servant distinguished from the kinsman - that Price sees as the prerequisite of an efficient bureaucracy.

This insulation is also supported by an inner-bureaucratic 'esprit de corps' to which my interviewees referred when they distinguished between 'we', the reform-oriented and dedicated public servants, and the politicians or corrupt officials. It is further strengthened by cross-ethnic associations such as the Free Masons or other lodges to whom many of my interviewees belonged and that partly overlap with ethno-regional networks. All of these networks serve to stabilise professional ethics and promote a spirit of 'excellence' and 'service' by creating a moral community in the eyes of which the public servants want to be regarded as worthy and deserving. They constitute arenas in which standards of legitimate patronage, aspirations to material wealth, engagement in political activism and many other aspects of professional life are constantly negotiated and re-evaluated.

That in such discussions my interviewees tended to subscribe to rather strict norms of meritocracy and 'hard work', finally, also reflects a specific 'Northern' perspective. Because they had to struggle so hard to pursue their education and achieve entry into the public service, they fiercely defend the universalist norms of a meritocratic order. It remains to be seen whether the younger generation of Dagara that has grown up in an urban, multiethnic environment with educational privileges provided by 
the professional positions of their parents will develop a different outlook. The recent public service reforms, in any case, have apparently not transformed the dominant professional ethics, on the contrary, they have reinforced my interviewees' images of a dedicated public servant.

\section{REFERENCES}

Ayee, Joseph R.A. 2001. Civil service reform in Ghana: a case study of contemporary reform problems in Africa. African Journal of Political Science, 6 (1): 1-41.

Behrends, Andrea. 2002a. 'Pogminga' - the 'proper Dagara woman': an encounter between Christian thought and Dagara concepts. Journal of Religion in Africa, 32: 231-53.

- 2002b. Drahtseilakte. Frauen aus Nordghana zwischen Bildung, Beruf und gesellschaftlichen Konventionen. Frankfurt/Main, Brandes \& Apsel.

Behrends, Andrea and Carola Lentz. 2012. Education, careers and home ties: the ethnography of an emerging middle class from Northern Ghana. Zeitschrift für Ethnologie, 137 (2): 139-64.

Clignet, Rémi and Philip Foster. 1966. The Fortunate Few: A Study of Secondary Schools and Students in the Ivory Coast. Evanston, Northwestern University Press.

Copans, Jean. 2001. Afrique noire. Un État sans fonctionnaires? Autrepart, 20: 11-20.

Daniel, G.F. 1997-98. The universities in Ghana. In: The Commonwealth Universities Handbook 1997-98, 1, 649-56.

Eckert, Andreas. 2007. Herrschen und Verwalten. Afrikanische Bürokraten, staatliche Ordnung und Politik in Tanzania, 1920-1970. Munich, Oldenbourg.

Foster, Philip J. 1965. Education and Social Change in Ghana. Chicago, Chicago University Press.

- 1980. Education and social inequality in sub-saharan Africa. Journal of Modern African Studies, 18: 201-236.

Gladwell, Malcolm. 2008. Outliers: The Story of Success. New York, Little, Brown and Company.

Greenstreet, D.K. 1963. The development of the Ghanaian public service. Journal of Management Studies (Legon), 2 (2): 23-29.

Haruna, Peter Fuseini. 2008. Recovering integrity in Ghana's governance: a transcultural study in public service ethics. Public Integrity, 10 (2): 113-132.

Lamont, Michèle. 1992. Money, Morals and Manners: The Culture of the French and American Upper Middle Class. Chicago, University of Chicago Press.

Lawrance, Benjamin N., Osborn, Emily Lynn and Richard L. Roberts, eds. 20o6. Intermediaries, Interpreters, and Clerks: African Employees in the Making of Colonial Africa. Madison, University of Wisconsin Press.

Lentz, Carola. 1994. Home, death and leadership: discourses of an educated elite from northwestern Ghana. Social Anthropology, 2: 149-69.

- 1995. 'Unity for development': youth associations in north-western Ghana. Africa, 65: 395-429.

- 2006. Ethnicity and the Making of History in Northern Ghana. Edinburgh, Edinburgh University Press.

- 2008. Hard work, determination and luck: biographical narratives of a Ghanaian elite. Ghana Studies, 11: 47-76 (published in 2010).

. 2009. Constructing ethnicity: elite biographies and funerals in Ghana. In Rosenthal, Gabriele and Artur Bogner, eds. Ethnicity, Belonging and Biography: Ethnographical and Biographical Perspectives. Berlin, Lit, 181-202. 
- 2010. 'I take an oath to the state, not the government'. Career trajectories and professional ethics of Ghanaian public servants. Working Papers of the Department of Anthropology and African Studies of the Johannes Gutenberg University Mainz, 119, available at: http://www.ifeas.uni-mainz.de/workingpapers/AP119.pdf.

Lipsky, Michael. 1980. Street-level Bureaucracy: Dilemmas of the Individual in Public Services. New York, Russell Sage Foundation.

Mannheim, Karl. [Mannheim] 1952. The problem of generations. In Kecskemeti, Paul, ed. Essays on the Sociology of Knowledge by Karl Mannheim. New York, Routledge, $276-322$.

Miescher, Stephan F. 2005. Making Men in Ghana. Bloomington, Indiana University Press.

Olivier de Sardan, Jean-Pierre. 2004. Etat, bureaucratie et gouvernance en Afrique de l'Ouest francophone. Politique africaine, 96: 139-62.

- 2008. A la recherche des normes pratiques de la gouvernance réelle en Afrique. Afrique. Pouvoir et politique, Discussion Paper 5, London, Overseas Development Institute.

Price, Robert M. 1975. Society and Bureaucracy in Contemporary Ghana. Berkeley, University of California Press.

Weber, Max. 1978 [orig. 1922] Bureaucracy. In Roth, Guenther and Claus Wittich, eds. Max Weber, Economy and Society. Berkeley, University of California Press, 956-1005.

Werbner, Richard P. 2004. Reasonable Radicals and Citizenship in Botswana. Bloomington, Indiana University Press. 


\section{"WE MUST RUN WHILE OTHERS WALK": \\ AFRICAN CIVIL SERVANTS, STATE IDEOLOGIES AND BUREAUCRATIC PRACTICES IN TANZANIA, FROM THE 1950S TO THE $1970 \mathrm{~S}$}

\section{Andreas Eckert}

\section{Civil Servants and the Making of Independent Tanzania}

This paper attempts to shed some light on the crucial importance of higher civil servants in the making of independent Tanzania. It looks at the larger political context, the strong amalgamation of (party) politics and administration, the attitudes of higher civil servants towards general aspects of society, economy and politics, and more specifically, at their ideas about work. The latter aspect, however, is difficult to analyse, as related source material is fairly limited. The work of civil servants in early independent Tanzania was very much defined as 'work for the nation', and this definition went along with ideas of discipline, a strong connection between political issues and administrative duties, and the idea of having little time to fulfil the goals that had been set.

The development of an arguably specific Tanzanian policy making strategy has been the subject of a large number of studies. In his influential book, Göran Hydén (1979) refers to a "we must run while others walk"-strategy, using a famous quote from Tanzania's first president Julius Nyerere. In many speeches, and especially in the famous Arusha Declaration (see below), Nyerere stressed Tanzania's poverty and the hard work needed to develop the country, which implied that substantial effort was necessary. "By adopting the notion that 'we must run while others walk', the impression of a revolutionary atmosphere... [was] created", which aimed "partly at holding expectations back, partly at enforcing the need for discipline and restraint" (Hydén 1979: 5). This strategy was intended to create a sense of participation in the socialist transformation of society, as part of the effort to reinforce moral incentives (Jennings 2003).$^{2}$

\footnotetext{
1 See Lentz (in this volume) for the persistence of this perception among contemporary Ghanaian higher civil servants.

2 The formula 'running while others walk' is still used in articles referring to development issues in Africa. See for instance Mkandawire (2011).
} 
Four elements characterized the strategy (Skoog 200o: 111; Hydén 1979: 6). First of all, Tanzanian politicians, above all Nyerere, created an atmosphere of urgency in which everything was to be done at once. Secondly, in order to provide this sense of rapid advancement, policy decisions were announced under dramatized circumstances. The results sought after through these policy measures were declared so important that they should be achieved at any cost. The ends justified even the harshest means. Thirdly, policy makers claimed to carry out a radical break with the past associated with colonial rule. Finally, and as a consequence, employees in the public sector constantly had to work in an atmosphere of high expectations, promises and anxieties. In this context, civil servants took on an ambivalent role: on the one hand they were key figures within the 'we must run while others walk'-strategy and in most cases were convinced by their mission to bring progress to a supposedly backward peasantry; on the other hand, civil servants became a symbol for laziness and arrogance, especially when - as happened so often-promises were not fulfilled or specific measures were pushed through arbitrarily or even with violence.

Why are African civil servants important in order to understand the history of Tanzania between the 1950s and the 1970s? The importance of the African state employees in Tanzania hails from the fact that although they constituted a small group, they became the champions of political modernization and later important protagonists of anti-colonial nationalism, before going on to inherit state power at the end of colonial rule (Eckert 2006). It is instructive to see that before 1963 a considerable number of Tanganyikan cabinet members had worked at some point for the colonial administration (Who's Who in East Africa 1964; Nye 1965: 32). Survey research done in the 1960 clearly demonstrates that the rulers of independent Tanzania were overwhelmingly salaried administrators. A team from a private research firm found that more than half of the members of the elite in 1967 were "higher civil servants" (McGowan and Bolland 1971). According to Feierman (1990: 240), the salaried class with its roots in the colonial administrative service, "was so powerful in the early years of independence that it was able to prevent the emergence of alternative nodes of power, whether among the traders [...] or among the trade unions." These African employees belonged to the first individuals who-at colonial schools and in the workplace-were familiarized with the values of the colonizers. In their new positions they spread what they had learned. Moreover this group was at the centre of British attempts to discipline in schools and administrations, and to regulate time, space, clothing and food_character training, as the British called it (Eckert 2007b). 
On the eve of independence, a senior administrative job represented one of the greatest opportunities. In May 1960, the newspaper Mwafrika published a letter to the editor written by a clerk from Tabora, in which he proposed that clerks be promoted to higher administrative posts while women should take over the poorly paid clerk jobs:

These days we see that many Africans who do not come from among the clerks ... are taken to study in Europe, and others are given high positions here in Tanganyika without going to Europe to study. The thing which distresses us, for our part as clerks, is that it is our brothers who are not clerks [that] will get the benefit of important positions like Field Officers, Labour Inspectors, Co-operative Officers, Public Relations Officer and so on... Clerks are people who have special knowledge of work in offices, and therefore ought to be thought of for higher positions and to leave the clerks' jobs for women (Quoted in Feierman 1990: 238).

As Feierman adds, "the clerk's proposal became, to some degree, a reality" (Ibid.). In fact, after independence, male employees soon made a career in the party and state bureaucracy and occupied important political positions (Bienen 1967; Tordoff 1967).

What was the situation of Tanzania at the moment of independence in December 1961? In his 'Independence message to TANU' Nyerere declared that

this day has dawned because of the people of Tanganyika have worked together in unity... All the time that TANU has been campaigning for Uhuru we have based our struggle on our belief in the equality and dignity of all mankind and on the Declaration of Human Rights... Yet we know that on 9th December we shall not have achieved these objects. Poverty, ignorance, and disease must be overcome before we can really establish in this country the sort of society we have been dreaming of. These obstacles are not small ones, they are more difficult to overcome than any alien government. From now on we are fighting not man but nature (Nyerere 1966: 138f.).

But as Iliffe (1979: 576) so aptly commented on this message, "it was more complicated than that".

In the two decades following independence, Tanzania's government under Nyerere pursued a policy that was much celebrated by international observers for its commitment to "self-reliance" (Jennings 2007a). The government was also celebrated, at least in some corners, for its efforts to create and practice a specific 'African Socialism'. Nyerere himself became a world figure, a spokesman for the 'poorest of the poor', demanding a new international economic order that aimed to give a greater share of the world's wealth to those who suffer, and ensure that the non-aligned 
countries acted as a kind of trade union, merging some of their individual interests to campaign on a common programme (Eckert 2011). Nyerere's long-term vision was in many ways a familiar one to Western socialists. A perspective close to Fabian socialism, in which the state owns most of the means of production, equalizes income and provides a wide range of social services (Coulson 1982: 2, 327). Tanzania became a major target for development aid. Western governments did not wish to be seen as offering all their aid to avowedly right-wing regimes; as such 'socialist' Tanzania was a useful corrective (Jennings 2007b). Moreover, the government successfully obtained substantial support from non-Western camps, most notably from China, which funded the TAZARA railway connecting Tanzania and Zambia (Monson 2008). Nyerere's numerous writings earned him much respect and admiration among Western intellectuals. However, the supposedly promising Tanzanian path was full of paradoxes: restricted freedom of expression, political prisoners, the increasing power of state bureaucrats, and many economic failures; among other aspects, these stand for the dark side of post-independence Tanzanian development (Brennan 2005; Burton 2007). The first decade after independence was also characterized by massive conflicts between an urban youth that viewed itself as a part of modern global culture, and a state launching "decency campaigns" banning cultural forms such as soul music, miniskirts, wigs, and bell-bottoms (Ivaska 2011).

\section{The Africanization of the Civil Service}

Since the late colonial period, the Africanization of the civil service featured very prominently among the central aims of the nationalist party TANU (Aminzade 2001). In October 1960, in a speech at the Legislative Council, Nyerere offered his vision of affirmative action:

First, it will remain the policy of the Government that every vacancy arising in the civil service should, if possible, be filled by an appointment made locally and that recourse should only be had to recruitment from outside of East Africa if no suitable candidate (of any race) can be found locally [...] Secondly, within this policy, in the case of new appointments to the service, it is Government's intention that African candidates of Tanganyika should have prior claim to consideration. Thirdly, only if no suitable, qualified Tanganyika African candidate is available should other candidates be considered (Nyerere 1966: 100).

The pace of Africanisation soon accelerated. In 1962, short-term prime minister, Rachidi Kawawa, appointed a 'Commission for Africanisation' 
Table 1. Africanisation of civil service, $1961-1970^{3}$

\begin{tabular}{lcccc}
\hline Year & Total & Africans & Others & $\begin{array}{c}\text { African } \\
\text { share (in \%) }\end{array}$ \\
\hline 1961 & 4452 & 1170 & 3282 & 26.1 \\
1962 & 4723 & 1821 & 2902 & 38.5 \\
1963 & 5049 & 2467 & 2580 & 48.9 \\
1964 & 5389 & 3083 & 2306 & 57.2 \\
1965 & 5962 & 3851 & 2011 & 66.2 \\
1966 & 6262 & 4364 & 1898 & 69.7 \\
1967 & 6754 & 4937 & 1817 & 73.1 \\
1968 & 7827 & 6208 & 1619 & 79.3 \\
1969 & 7474 & 6123 & 1351 & 81.9 \\
1970 & 9419 & 8042 & 1377 & 85.6 \\
\hline
\end{tabular}

that was given the task of reviewing "every cadre and grade in the Civil Service with a view to ensuring that a satisfactory plan for complete Africanisation exists" (Government of Tanganyika 1963: 1). Tanzanians with a secondary school education or university degree were not allowed to work in the private sector; all had to become members of the state bureaucracy. During the 196os, both the number of administrative posts and the involvement of Africans considerably rose.

The Africanisation of the civil service went along with the amalgamation of government, administration and party. Shortly after independence, Nyerere sent around a circular letter to all government branches in which he explained the relationship between the public, civil servants and politicians. He stressed that on the one hand, civil servants had no business being in the political arena, and on the other hand, that politicians had no right to intervene in the affairs of civil servants. "I would remind you", Nyerere wrote, "that policy is decided by the central government and not by local party representatives. Political party organizations are not concerned with the execution or implementation of policy" (quoted in Bienen 1967: 125). Here Nyerere was speaking as a representative of a classic bureaucratic ethos and wrote in favour of the norm of a neutral, apolitical civil service, sheltered from the interventions of politicians. A similar attitude was shared by many African civil servants around independence: they were convinced that civil servants should have sufficient educational qualifications; positions within the civil service should have

\footnotetext{
3 Sabot 1979: 210; Government of Tanzania 1969: 27.
} 
clearly distinguished areas of competence; and that office and person should be separated.

A few months after independence, however, TANU began to link local state structures and local party structures. For instance, regional commissioners also had to be TANU's regional party secretaries. From 1964, TANU began recruiting civil servants for the posts of commissioners. This effort was associated with the hope that civil servants, with their administrative and leadership experiences, could strengthen TANU's competence at the regional and district level. In August 1964, Nyerere underlined this point:

Responsibility cannot be entrusted to people for sentimental reasons, or left with them once they have failed because they are nice people [...] these are circumstances which call for the use of every person who can be obtained and whose skill or experience contributes in any way to movement in the desired direction. (Nyerere 1966: 309).

A month earlier, Rachidi Kawawa had stated:

We want civil servants to join TANU so that they can help us in our struggle against poverty, disease and ignorance [...] Civil servants are the most educated people in our country. We cannot afford to leave them aside in important discussions concerning the country of which they are a part [...] It would be sheer hypocrisy to refuse government employees the permission to become a politician and at the same time to rely on them to prepare political speeches to be delivered by ministers (The Nationalist, 1.7.1964).

Nyerere, who a few years ago had clearly argued that strict distinctions be made between civil servants and politicians, had apparently changed his view:

$[\ldots]$ there would be no need to continue with the present artificial distinction between politicians and civil servants-a distinction desirable only in the context of a multi-party system where the continuity of public administration must not be thrown out of gear at every switch from one 'party' government to another. For, once you begin to think in terms of a single national movement instead of a number of rival factional parties, it becomes absurd to exclude a whole group of the most intelligent and able members of the community from participation in the discussion of policy simply because they happen to be civil servants. In a political movement which is identified with the nation, participation in political affairs must be recognized as the right of every citizen, in no matter what capacity he may have chosen to serve his country [...] (Nyerere 1966: 309).

Some Government representatives saw the need to substantiate their parting from bureaucratic ideals with references to African traditions and the specific situation of a young African state. Amon Nsekela, state secretary in the Ministry of Industries, stated at a seminar for civil servants: 
In Tanganyika and the United Republic we are faced with problems, traditions and ways of life peculiar to our countries; it is obviously expedient to adapt our civil service to meet those conditions and control them. We can do this by retaining what is best to the past and adapting it to the future [...] It would only be odd if we persevered with a civil service tradition alien to our heritage [...] There is a vast difference between countries with longestablished civil services and the new developing countries like our own, which have to build up their administrative systems from scratch [...] We have complete freedom of choice, and we are under no obligation whatsoever to copy any other country (Mbioni, 10.9.1964).

Interestingly enough, in many regions a distance could be felt between welltrained former state employees now in political positions on the one hand, and long-serving party members on the other. One (anonymous) government member used drastic words to describe the possibility of civil servants becoming TANU members: "No, it's not a good thing. There has been no change in the civil servants. These people simply can't change their colours. They don't trust politicians and they feel our ideas are no good unless we have a B.A. or something else" (Quoted in Hopkins 1971: 115).

This conflict is nicely captured in the following quote from The Civil Service Magazine (November/December 1965):

In the sense that Tanzania is a one-party state and will be for a long time to come, this is all right. And the result has been to create a lot of confidence among those who are civil servants. Politicians were under the impression that civil servants were holdovers from the old colonial regime; their ideas were suspected. Politicians were saying: 'We fought for the country and the civil servants didn't.' It was a fact that civil servants were alienated, even though they fully supported the party as did all thinking people. Now civil servants are accepted [...] Since the change, in fact, civil servants may be a real threat to the career of politicians. The problem is to try to allay their suspicions and overthrow the idea that civil servants didn't fight for the country's independence.

Local government reforms provide a good example of the problems resulting from introducing new administrative forms and personnel. As already mentioned, the political ambitions of the TANU administration centred on the achievement of rapid progress. This would ensure the stability and continued popularity of the government. Pursuant to this strategy, decisions were made without the sufficient involvement of local authorities. Sometimes they were not even involved at all; whether or not they were involved, local authorities were left with the task of implementation. Thus the government under Nyerere continued the colonial policy of centralised authoritarianism. Unlike the British, however, the post-independence government did not rely on supposedly 'traditional' authorities and chiefs 
to implement their concepts. The dependence of newly created rural local authorities upon the administrative support and assistance of the central government was an essential feature of the local government system during the 196os. From December 1962 to July 1965 the supervision of local government was transferred to a separate Ministry of Local Government. The Ministry recruited a corps of local government officers to perform field inspections under the control of regional commissioners. The majority of these officers, however, neither had the relevant qualifications, nor any understanding of local government problems. They made no significant impact in enhancing administrative capacity. Thus after three years the cadre was abolished and the staff absorbed into the general administration (Eckert 2007a).

\section{The Arusha Declaration, Ujamaa and Civil Servants}

Most state employees who occupied higher administrative posts after independence, shared Nyerere's main goals. They wanted to fight poverty and illness, they wanted to avoid those forms of exploitation which were connected with the spread of large individual fortunes. The national goals of Tanzania as mainly defined by Nyerere were so important and humane that it seemed imperative to carry them through, if necessary, from above (Eckert 2007b).

Between 1961 and 1965, Nyerere and the TANU leadership recognised that their freedom was limited by the structural dependence of the economy and the shortage of trained Tanzanians. This situation began to lower the aspirations of those who thought that independence meant immediate prosperity, or even control of the economy (Pratt 1976: Ch.7; Coulson 1982: Ch.16). As part of the process of transition, in January 1962, only one month after the triumphant handing-over of power, Nyerere resigned as Prime Minister, "... to act as a bridge between the people and the new government by demonstrating in practical terms the importance of the Party" (Nyerere 1966: 157). Most observers agree in retrospect that this was "a shrewd tactical move in the nature of reculer pour mieux sauter" (Sadleir 1999: 252). Rashidi Kawawa became Prime Minister. Nyerere spent some time reflecting and writing. He then began to travel widely within the country, explaining to enthusiastic audiences that independence was only the first step to full liberation, which could be achieved by self-help and hard work. He was becoming more and more the Mwal$i m u$, the far-seeing moral teacher, who knows what is right for his subjects 
and is never wrong (Coulson 1982: 136; Hatch 1972: 180ff.; Eckert 2011). Not surprisingly, some years later the cynical quote that "it is hard to build up socialism in a country where there is only one socialist" was attributed to him (Ansprenger 1999: 90).

By 1967, the government of Tanzania was experiencing a severe crisis of political legitimacy. The peasants had benefited very little, if at all, from the economic growth that had taken place since independence so that widespread disillusion and discouragement seemed almost inevitable (Pratt 1976: 227). Tanzania's economy was in a state of crisis. The Arusha Declaration can thus be seen as a reaction to a difficult situation, which Nyerere used to introduce policies that fitted his own philosophy. Although the declaration was amended by the National Executive Committee of TANU, which discussed and approved it a week before its publication on 5 February 1967 , the draft was written by Nyerere and the idea and strategies were largely his (Nyerere 1968: 231-250). He had tied up a carefully balanced package. The declaration claimed that building a socialist state was TANU's central aim and emphasized the role of agriculture and rural development. It formulated five 'leadership conditions', which included a whole series of limitations on the freedom of state employees to benefit personally from their positions. The declaration became extremely popular all over the country. Everywhere Nyerere was the hero and the villains were the politicians and civil servants who had been growing fat at the expense of the masses. The publication of the Arusha Declaration was soon followed by the nationalisation of key sectors in business, industry and banking. ${ }^{4}$

When explaining his political programme to students of the University of Dar es Salaam, Nyerere once again referred to what he assumed were "traditional African values". He urged

a full acceptance of our African-ness and a belief that in our past there is much that is useful for our future... We have to reactivate the philosophy of co-operation in production and sharing in distribution, which was an essential part of traditional African society (Nyerere 1968: 316, 325).

The Arusha Declaration must, incidentally, be seen alongside two other essays Nyerere wrote the same year. Education for Self-Reliance (Nyerere 1968: 267-290) was an attempt to reform the educational system so that

4 On the Arusha Declaration see the good summary by Coulson 1982: Ch. 19, which I paraphrase here. 
it would provide useful training for the mass population and not just the few who would proceed to secondary education or university. In this area, Nyerere could claim considerable success. When he stepped down from the presidency in 1985 , he declared that 91 per cent of the adult population was literate (Stöger-Eising 2000: 133).

Socialism and Rural Development (Nyerere 1968: 337-366), the second essay, was "a dream of an ideal world" (Coulson 1982: 240). In this paper the idea of Ujamaa is married to the idea of villagization in the concept of an Ujamaa village. This was a small group of politically committed farmers who worked together on a communal farm, using their savings to purchase equipment that would benefit the group. The efforts to implement this "dream" between 1967 and 1976, without any doubt, represent one of the darkest chapters in Nyerere's career as a politician, and sometimes proved demonstrative of the flagrant contradiction between his writings and his policies (Schneider 2007). Moreover, during this process Nyerere became more of a paternalistic "know-all mwalimu" (Scott 1998; Spalding 1996). Yet, as Schneider (2004: 346) has aptly observed,

when discussions move beyond a treatment of the goals and ideals of Ujamaa, and toward its coercive realities, Nyerere typically recedes into the background of a stage that is taken over by anonymous 'officials', as well as 'policies' and 'campaigns' without authors or initiators. The effect is a tendency for Nyerere to emerge from these narratives as a tragically failing hero, whose attractive and hopeful visions for rural development were derailed or subverted in implementation.

Numerous authors have directed our attention to the gulf between Nyerere's ideological project of a classless African society and realities in post-independence Tanzania. Two terms are particularly important here. Kabwela (urban poor) was the common denominator of urban nationalist frustrations: despite working hard and (somewhat) honestly, kabwela found themselves exploited by rack-renting landlords, cheating shopkeepers and abusive employers. The popular discursive antonym to kabwela was naizesheni, or naizi for short. Naizesheni referred to those urban Africans who with relatively little effort came to enjoy the lion's share of the fruits of independence by inheriting privileges from the departing colonialists. The term clearly derives from 'nationalization' and less directly from 'Africanization', both processes remained in the public eye during the early years of independence. The term naizi generally stood for civil servants and politicians as they apparently profited most from independence (Brennan 2006). 
On the other hand, many civil servants shared the peasants' impatience and expressed their concern that the majority of the people was ignorant about the central aims and tasks of nation-building. The following statements from higher civil servants may illustrate this:

The greatest need is for a citizen to understand his country's problems and contribute to their solution. But unfortunately, only a few do this.

His greatest responsibility is to know what is expected of him by his country, to do the things for the sake of his country. But there are very few who do this. In every person there is an element of self-interest. What is needed is that one must understand his obligations.

All of them should be as the president. That is, each should regard every problem of the country as their own problem - to feel the problem as the president does. (Quoted in Hopkins 1971: 106).

Civil servants were unclear about what Ujamaa or African socialism really meant. Some waited for an official council to fix a definition. Others regarded Ujamaa as a continuation of traditional cultures and practices, the transferral of communal obligations into modern society:

We have clearly told the world we want African socialism and that it is not copying the East or the West. Now we are awaiting a committee which will tell us exactly what this means.

I don't like the word 'African'. Socialism is the same in every country, but we're trying to find out what it means in this country. We're supposed to have a commission sometime to examine this idea.

Africans have had their culture, have had certain obligations among themselves, for example, helping each other so that everybody lives. It is the translation of this culture into the framework of modern life or modern way of living which is African socialism. It is not communism, and although it has not been defined, Africans have had this socialism for some time (Quoted in Hopkins 1971: 99).

But what role were civil servants expected to take on in a one party state? The government assigned two tasks to them: on the one hand, the classic task of ensuring the functioning of state and administration. Moreover, they were urged to contribute to the modernization of society and to promote projects that helped improve the economic and social situation of the people (Tanzania Central Establishment Division 1965). Joseph A. Namata, the Head of Civil Service in Tanzania, stated in 1966:

Here the civil servant is expected to be committed to development for the masses [...] In our conditions, it is essential that good civil servants understand the politics of the country, the objectives of the party, and they share the basic philosophy of the nation [...] Once a policy decision has been made, and a particular project is adopted, the civil servant in the field 
can-with the concurrence and cooperation of his Area Commissionerwork directly with the people [...] The civil servants [...] can brief their Party colleagues, and have it known that they are available for questioning [...] However, there still must be a distinction between the work of a senior civil servant and the politician. The decisions on policy have to be made by ministers. The good Tanzanian civil servant thus recognizes two things; firstly that the ministers and other political officers are responsible for policy, and secondly that his role is to help the politician to achieve the national objectives by the full use of his brains, training, and experience (Namata 1966).

At least in retrospect, some civil servants were critical about the influence of the party on administrative issues and about the political functions of civil servants. Francis Damien, who in the 196os was a member of the Ministry of Education's staff, stated: "Civil servants are no policy makers. Politicians make policy and it is our duty to see that it is carried out. Therefore, my duty as a civil servant is to carry out whether I like it or not" (Interview with Francis Damian, 11 August 1999).

\section{Conclusion: The Golden Age of the Civil Service}

"Duty, discipline and hard work are the key to success", Martin Kivumbi stated in an interview I conducted with him in August 1999. During the 196os, Kivumbi worked as an economist for the Tanzanian Ministry of Finance and later moved to the Ministry of Foreign Affairs. "A good citizen does his work, pays his taxes, and causes little trouble", he added. These statements provide a small hint about the way civil servants understood their work during the first one and a half decades after independence. In general, however, we still know very little about the work ethos and work practices of African civil servants in the early independence period in Tanzania and elsewhere in Africa. In the context of nation-building in a one-party system, civil servants were assigned the task of working for the nation and helping the party push through their projects. Civil servants were regarded as having profited the most from independence by the masses. Many civil servants insisted on training, professionalism, experience and knowledge as important elements of their job (directed against party members in important positions without these qualifications), but at the same time this self-perception made them vulnerable to arrogance and accusations of being know-it-alls.

In the late 1970 and early 1980 s, Tanzania underwent the most dramatic economic crisis since independence. This was a result of a number 
of coinciding factors, such as the evidently disastrous economic outcomes of forced villagization (total agricultural output declined drastically), soaring oil prices, the collapse of world commodity prices, severe and extensive droughts, as well as the costly war with Uganda in 1978/1979. In 1981, a hurriedly conceived National Economic Survival Program failed to secure the necessary support from external sources that were demanding a reduction in state intervention in the economy. The government under Nyerere resisted these pressures at first, but finally capitulated as the economic crisis deepened. The first structural adjustment program was reluctantly adopted by Nyerere in 1982. The economic performance of Tanzania remains mixed; it is still one of the poorest countries south of the Sahara.

In many ways and despite all the contradictions, the 1960s and early 1970s represented the 'golden age' of civil service in Tanzania. Since then, working for the state has become much less attractive. At the end of colonial rule a career as a civil servant meant training, social security and social prestige, whereas today the civil service often stands for want, insecurity and personal dependence. Public servants are often associated with corruption, while they regard themselves as underpaid and undervalued (Heilman and Ndumbara 2002; Therkildsen 2010). Today, those who attempt to make a career or money in Tanzania, only rarely work for the state.

\section{REFERENCES}

Aminzade, Ronald 2001. The politics of race and nation. Citizenship and Africanization in Tanganyika. In Davis, Diane E., ed. Political Power and Social Theory, Vol. 14. Amsterdam, Elsevier Science, 53-90.

Ansprenger, Franz. 1999. Politische Geschichte Afrikas im 20. Jahrhundert. München, C.H. Beck.

Bienen, Henry. 1967. Tanzania. Party Transformation and Economic Development. Princeton, Princeton University Press.

Brennan, James. 2005. The short history of political opposition and multi-party democracy in Tanganyika 1958-1964. In Maddox, Gregory \& James Giblin, eds. In Search of a Nation. Histories of Authority and Dissidence in Tanzania. Oxford, James Currey, 250-276.

- 2006. Blood enemies. Exploitation and urban citizenship in the nationalist political thought of Tanzania, 1958-1975. JAH, 47 (3): 1-25.

Burton, Andrew. 2007. The heaven of piece purged: tackling the undesirable and unproductive poor in Dar es Salaam, c.1950s-1980s. IJAHS, 40 (1): 119-151.

Coulson, Andrew. 1982. Tanzania. A Political Economy. Oxford, Clarendon Press.

Eckert, Andreas. 2006. Cultural commuters: African employees in late colonial Tanzania. In Lawrance, Benjamin N. et al., eds. Intermediaries, Interpreters, and Clerks. African Employees in the Making of Colonial Africa. Madison/Wisc., University of Wisconsin Press, 248-269.

. 2007a. Useful instruments of participation? Local government and cooperatives in Tanzania, 1940 s to 1970s. IJAHS, 40 (1): 97-118. 
_ 2007b: Herrschen und Verwalten. Afrikanische Bürokraten, Staat und Politik in Tanzania, 1920-1970. München, Oldenbourg.

- 2011. Julius Nyerere, Tanzanian elites, and the project of African socialism. In Dülffer, Jost \& Marc Frey, eds. Trajectories of Decolonization. Elites and the Transformation from the Colonial to the Postcolonial. New York, PalgraveMacMillan, 216-240.

Feierman, Steven. 1990. Peasant Intellectuals. History and Anthropology in Tanzania. Madison/Wisc., University of Wisconsin Press.

Government of Tanganyika. 1963. Report of the Africanisation Commission 1962. Dar es Salaam, Government Printer.

—. 1969. Annual Manpower Report to the President 1969. Dar es Salaam, Government Printer.

Hatch, John. 1972. Tanzania. A Profile. London, Praeger.

Heilman, Bruce \& Laurean Ndumbara. 2002. Corruption, politics, and societal values in Tanzania. An evaluation of the Mkapa administration's anti-corruption efforts. African Journal of Political Sciences, 7 (2): 1-19.

Hopkins, Raymond F. 1971. Political Role in a New State. Tanzania's First Decade. New Haven \& London, Yale University Press.

Hydén, Göran. 1979. Beyond Ujamaa in Tanzania. Underdevelopment and an Uncaptured Peasantry. Berkeley, University of California Press.

Iliffe, John. 1979. A Modern History of Tanganyika. Cambridge, Cambridge University Press.

Ivaska, Andrew. 2011. Cultured States: Youth, Gender, and Modern Style in 196os Dar es Salaam. Durham/NC, Duke University Press.

Jennings, Michael. 2003. We must run while others walk: popular participation and development crisis in Tanzania, 1961-1969. JMAS, 41: 163-187.

- 2007. 'A very real war'. Popular participation in development in Tanzania during the 1950 and 196os. IJAHS, 40 (1): 71-95.

- 2007. Surrogates of the State. NGOs, Development, and Ujamaa in Tanzania. Bloomfield, CT, Kumarian Press.

Mbioni 1964: The Monthly Newsletter of Kivukoni College. Vol 1.

Mkandawire, Thandika. 2011. Running while others walk: knowledge and the challenge of Africa's development. Africa Development, 36 (2): 1-36.

McGowan, Patrick J. \& Patrick Bolland. 1971. The Political and Social Elite of Tanzania. An Analysis of Social Background Factors. New York, Program of African Studies, Syracruse University.

Monson, Jamie. 2008. Africa's Freedom Railway: How a Chinese Development Project Changes Lives and Livelihoods in Tanzania. Bloomington, Indiana University Press.

Namata, Joseph A. 1966. The role of the civil service in a one-party state. The Civil Service Magazine, July/August, no pagination.

Nye, Joseph S. 1965. Pan-Africanism and East African Integration. Cambridge/Ma, Harvard University Press.

Nyerere, Julius. 1966. Freedom and Unity. A Selection from Writings and Speeches 1952-1965. Dar es Salaam, Oxford University Press.

—. 1968. Freedom and Socialism. A Selection from Writings and Speeches 1956-1967. Dar es Salaam, Oxford University Press.

Pratt, Cranford. 1976. The Critical Phase in Tanzania 1945-1968. Nyerere and the Emergence of a Socialist Strategy. Cambridge, Cambridge University Press.

Sabot, Richard H. 1979. Economic Development and Urban Migration: Tanzania 1900-1971. Oxford, Oxford University Press.

Sadleir, Randal. 1999. Tanzania. Journey to Republic. London \& New York, Radcliffe Press. Schneider, Leander. 2004. Freedom and unfreedom in rural development. Julius Nyerere, Ujamaa Vijijini, and villagization. CJAS, 38 (2): 344-393.

. 2007. High on modernity? Explaining the failures of Tanzanian villagization. African Studies, 66 (1): 9-38. 
Scott, James. 1998. Seeing like a State. How Certain Schemes to Improve the Human Condition Have Failed. New Haven \& London, Yale University Press.

Skoog, Gun Eriksson. 2000. The Soft Budget Constraint. The Emergence, Persistence and Logic of an Institution. Dordrecht, Kluwer Academic Publishers.

Spalding, Nancy. 1996. The Tanzanian present and Ujamaa: a study in contradictions. Third World Quarterly, 17 (1): 89-108.

Stöger-Eising, Viktoria. 2000. Ujamaa revisited. Indigenous and European influences in Nyerere's social and political thought. Africa, 70 (1): 118-143.

Tanzania Central Establishment Division. 1965. Professional Careers Guidebook. Dar es Salaam, Central Establishment Division.

Therkildsen, Ole. 2010. Working in neopatrimonial settings: perceptions of public sector staff in Tanzania and Uganda. Working Papers of the Department of Anthropology and African Studies of the Johannes Gutenberg University Mainz, 117, available at: http://www .ifeas.uni-mainz.de/Dateien/AP117.pdf.

Tordoff, William. 1967. Government and Politics in Tanzania. Nairobi, East African Publishing House.

Who's Who in East Africa 1964. Nairobi, Marco Surveys. 
Thomas Bierschenk and Jean-Pierre Olivier de Sardan - 978-90-04-26496-0 Downloaded from Brill.com@4/26/2023 02:08:21PM via free access 


\title{
SEDIMENTATION, FRAGMENTATION AND NORMATIVE DOUBLE-BINDS IN (WEST) AFRICAN PUBLIC SERVICES ${ }^{1}$
}

\author{
Thomas Bierschenk
}

The Kouandé gendarmerie brigade was established in 1962 . When we visited it in March 2009, it was manned by five gendarmes, of whom only four were present as one was on a training course in Porto-Novo. It is the only police force in an area of 4,500 square kilometres (almost twice as large as the Grand Duchy of Luxemburg which has an area of $2.600 \mathrm{~km} / 2$ ) and with a population of almost 100,000 people. The outermost frontiers of the commune are $100 \mathrm{~km}$ from the municipal centre. Apart from the road linking the town of Kouandé to Natitingou some $5^{0} \mathrm{~km}$ away, where the regional gendarmerie headquarters are located, there are no other tarmac roads.

The brigade registers between one and five cases per week, which are documented by official reports, and there had been 123 official written communications with the commander of the gendarmerie company in Natitingou since the beginning of 2009. In fact, it appears that these official documents relate mainly to more serious crimes and misdemeanours in flagrante. A good deal of the work of the gendarmerie is informal and actually involves the dispensing of justice; there is a preference for 'amicable arrangements' (reglements à l'amiable), as they are called. These settlements, which are moderated by the gendarmes, often include cases which, like financial debts, would be considered as warranting the resort to civil, and not penal, justice in other places. In making these judicial settlements, the gendarmerie is in competition with other regulatory instances, such as the ward heads (chefs de quartier) and the conciliation tribunal.

The gendarmerie has one Nissan pick-up vehicle which is broken. To find spare parts, the brigade chief himself had to go to the city of Lama Kara in Togo, about $200 \mathrm{~km}$ away, by bush taxi. The car will be repaired locally using the gendarmes' own resources as the officially stipulated procedure, e.g. towing the car to the repair shops of the gendarmerie in Natitingou $\left(5^{\circ} \mathrm{km}\right)$ or Parakou $(100 \mathrm{~km})$, would be very awkward. In theory, the brigade has an annual budget for petrol of 12,000 CFA francs, which equals around EUR 18. However, this money never arrives. (In fact, it would be interesting to find out where this money is actually used in the hierarchy.) If it did arrive, it would buy about 35 litres of gas oil, which would enable the

1 A first version of this chapter was read as a key-note paper at the conference 'States at Work in Sub-Saharan Africa', LASDEL, Niamey, 7.-12. December 2009 and published in 2010 as Working Paper No. 113 of the Department of Anthropology and African Studies of the Johannes Gutenberg University Mainz (http://www.ifeas.uni-mainz.de/92.php). 
pick-up to travel around $300 \mathrm{~km}$. For their official missions, the gendarmes use their own private motor-bikes. They also do this when they have to transport arrested persons to the Natitingou prison, and when they evacuate victims of mob justice to other gendarmerie posts to bring them to safety. In the former cases, the arrested person is handcuffed and put on the back-seat of the motor-bike, behind a gendarme. A second gendarme will be seated behind the detainee, or may follow the first on his own-motorbike. There is no telephone and the in-service radio-station has been broken for two years. As is the case in all Benin administrations, the gendarmes use their private mobile phones for all communications, including those carried out with the hierarchical chief. The brigade also boasts an old typewriter, however paper and everything else must be bought locally by the gendarmes themselves. The brigade chief comments that they are "doing the work of the state" but "the state doesn't send us anything".

He sees the present situation, in which, as he says, they "endure" (nous souffrons), as the result of a long process of deterioration, which accelerated after what Beninese refer to as the 'democratic renewal' of 1990. Their predecessors (les anciens) still had work equipment, he says, and there were 15 staff "under the revolution", e.g. at the time of the Marxist-Leninist regime which lasted from 1974 to 1989 . At the same time, he continues, democratization has translated into a loss of respect, both the respect that people have for the police and the respect of subordinates for their superiors. In other words, their work has become more complex as they cannot rely on the old means of repression, and, at the same time, their working conditions have deteriorated.

In order to maintain a minimum of service, the brigade needs the help of what one of the gendarmes calls "well-disposed people" (gens de la bonne volonté). However, their number is limited as there are no big businessmen in Kouandé who would be capable of "giving a helping hand" ( faire des gestes), as exist in bigger centres and, in particular, in border posts. The town hall recently gave them a computer, and one of the small Igbo merchants has given them a car tyre. This was the point at which, without any prompting by us, the chief began to talk about corruption. (From the author's field notes, March 2009)

\section{The Objective: Bringing the State Back into ANTHROPOLOGICAL RESEARCH}

This chapter-like most other contributions to this book-makes the case for the anthropological or, to be more precise, ethnographic study of statehood, which is severely lacking in the case of Africa. In concrete terms, it summarizes the findings of an international research programme carried out by a team of African, French and German researchers in four countries of West Africa (Benin, Ghana, Mali, Niger), which are occasionally 
supplemented by evidence from other parts of the continent. It will be obvious to the attentive reader, however, that this chapter has a distinctly 'Beninese' bias. ${ }^{2}$

In line with the general objective of the project and this book, this chapter addresses the question as to what states - in particular states in West Africa-do when they are 'at work' (Bierschenk and Olivier de Sardan, Introduction, this volume). It concentrates on a few selected findings of the research project and argues that, by a process which I will refer to as sedimentation, historical trajectories - colonial and post-colonial-have resulted in the emergence of heterogeneous and fragmented bureaucracies which, from the perspective of the public servants working in them, are complex normative universes shot through with numerous double binds. I conclude that the 'ordered informality' ${ }^{3}$ of bureaucratic processes is at least as much a product arising within the state apparatuses themselves as it is an expression of the cultural logics of an African environment, and that any quest for the uniform logics of the African state will ultimately prove fruitless. Macro-differences between public services around the globe should not, therefore, be essentialized but understood as the accumulated products of numerous micro-processes.

2 For a more detailed description of the project, see Bierschenk and Olivier de Sardan (Introduction, this volume) and the project homepage (http://www.ifeas.uni-mainz .de/277.php). As is inevitable in this type of collaborative work, many ideas-some of which are presented here-were developed in countless discussions among the project's researchers over the years and cannot always be attributed to a particular author. The perspective which I try to develop is strongly influenced by my previous work on politics and the state in Benin (Bierschenk, Thioléron and Bako-Arifari 2002, Bierschenk 2006, 2009a, 2011), in particular my own fieldwork on Benin's justice (Bierschenk 2008) and education (Bierschenk 2009b) sector, as well by relevant PhD theses, which I have either supervised directly (Chabi Imorou 2010, Fichtner 2012, Tama 2011, Tchantipo 2012, Badou 2013) or which I inspected as a member of the respective PhD committees (Hahonou 2006, Hamani 2011, Yessoufou 2011, Budniok 2012), or which are currently being compiled in Mainz (Jan Beek, Mirco Göpfert). The work of master students, whose research on the education (Brandecker 2007a, 2007b, Hällmeyer 2007, Voss 2007, Wetzig 2007) and justice (Bierschenk 2010) sectors in Benin I followed, was also a source of inspiration. Many of the examples I cite are taken from these texts; however, so as no to overload the present contribution, I have kept the references to a minimum. I would also like to thank the participants in the different panels organized by the project between 2007 and 2011 for many inspiring discussions.

3 This term of 'ordered informality' is adapted from Evans-Pritchard's (1940: 296) description of segmentary societies as 'ordered anarchies'-e.g. social configurations which, despite outer appearances, are regulated by routines and practices that are not always immediately obvious. The term 'ordered informality' is also used in this book by Olivier de Sardan and Hamani. 


\section{Historicity: The Sedimentation of Colonial AND Post-ColOnial EXPERIENCES}

Like all societal phenomena, statehood is path-dependent. ${ }^{4}$

\section{Colonial Rule: The Projection of a Despotic Model of State}

In the case of Africa, the colonial experience assumes a special significance in this context (Bierschenk and Olivier de Sardan, Research paradigm, this volume). With the establishment of colonial rule, a European form of statehood was projected onto African societies. What was involved here, however, was not simply a matter of 'the' European state. The colonial administration had few of the attributes required for African states today and in relation to which they are found to be deficient. The colonial state apparatus was at a remove from society; some authors have even described it as autistic (Spittler 1981). It was not at all accountable to its subjects and scarcely accountable to the European metropolitan public. Its main function was that of exploitation and political control, its preferred method the use or threat of physical violence. The colonial state engaged in little division of powers; executive, legislative and judicial powers largely coincided in this state. The lower one penetrated into the hierarchy, the more true this was; office and officer increasingly overlapped here. At the same time, due to its low level of human and fiscal resources, on the one hand, and the special problems of control it encountered in a peasant society with little market integration, on the other, this repressive colonial state was weak in terms of regulation and policy. As a result, at local level, it always relied on middle men who were difficult to control and whose practices were experienced by the population as largely arbitrary. Bureaucratic characteristics of the Weberian ideal type (Bierschenk and Olivier de Sardan, Introduction, this volume) were only found at the higher levels of the administration. The people who displayed these characteristics had a privileged world view, however; as expatriates, they expected an all-inclusive package with official residences, personnel and foreign allowances.

This very specific model of statehood was adopted in toto, as it were, at independence in Africa. Initially, only the European staff was replaced by African nationals at varying speeds. The fact that the African staff often

4 The following historic review is more broadly developed in Thomas Bierschenk and Eva Spies (2012). 
lacked the necessary qualifications for the work to be carried out was a result of the highly selective colonial educational policy. Hence, the real winners in the decolonialization process were the few well-educated Africans. This bureaucratic elite became the real power elite, saw itself as the avant-garde of the state and nation-building processes and developed an "arrogant paternalism" (Eckert, this volume) vis-à-vis their fellow citizens.

\section{The Fiscal Crisis of African States (After 1973)}

This historical legacy - a despotic model of state, small, poorly-trained elites who were ill-prepared for independence and prone to factionalismwas in itself a particularly difficult one, even when compared to those of post-colonial states in other parts of the world (Nugent 2004: $5^{8-71}$, Young 1994). After all, many African states were structurally bankrupt when they embarked on independence, not least because of high, and internationally uncompetitive, labour costs, a product of late-colonial development policy (Cooper 1996). After independence, further historical experiences accumulated. The safeguarding of the power position of the 'politicalbureaucratic' class quickly emerged as a matter of priority over the task of development (Bates 2008) while the state-centred economic development model soon revealed its limits. The model finally shattered in the early 1970 under the influence of the oil crisis, heralding two decades of economic decline, which, in most states, led to high debt and structural adjustment under the auspices of the International Monetary Fund in the 1980 . This deepening fiscal crisis of African states resulted in the increasing dilapidation of state apparatuses.

\section{African Countries as Objects of Experimentation Under the Post-Colonial Development Regime}

No other continent has been such an intensive focus of developmentpolicy intervention and social-policy experiments in the post-colonial period as Africa (Cooper 1997). The paradigms of intervention followed each other in increasingly rapid succession, the speed of which accelerated after 1990, in particular: the funding of infrastructure projects, the Basic Needs approach, Structural Adjustment, the fight against poverty, Good Governance, decentralization, participation, Millennium Development Goals - to name only a few of the adopted paradigms.

Within African countries, these paradigms translated into cascades of reforms, in particular after 1990. These reforms present a number of 
common features: they are externally driven, imposed from above, with only rhetorical nods towards 'participation', they are often contradictory and/or redundant, and highly selective. In any case, they place government employees, who are at once the agents and the objects of reform, in an ambiguous position. Learning to navigate numerous and contradicting reforms has become part of the professional skills of African public servants (Charton, Muñoz, this volume).

To begin, the paradigms of development were not generally created on the basis of internal political debates in the African post-colonial states themselves: apart from short spells of African socialism in some countries, in terms of their own development, post-colonial African governments and African populations have had no "discursive sovereignty" (Nganang 2012). On the contrary, development paradigms are almost always generated from outside. They do not, therefore, represent tailor-made responses to the specific problems of African states but, to paraphrase Naudet (1999), the importation of 'solutions looking for problems'. One of the consequences of this is the generalizaton of political irresponsibility: African governments can attribute failures and responsibility for the general course of action adopted to the donors, and vice versa (van de Walle 2001).

The reforms often incorporated a strong utopian element, hinging on the hope that 'if only' such and such reform were implemented, things would change profoundly (for examples from the education sector, see Bierschenk 2007). In the long term, this continuity of the rhetorical elements of development paradigms squares awkwardly with the contradictory approaches adopted by donors to African states as bureaucratic institutions. These approaches ranged from policies inspired by modernization theory, which viewed the state as a main vector of development (from the 1950s to the 1970s), to outright anti-state policies in the area of structural adjustment programmes (in the 1980s and early 1990s), augmented by a participation ideology, and, lately, a partial rehabilitation of the state under the banner of capacity development and institutionbuilding inspired by principles of New Public Management. However, even in the short term, and within specific public policy areas, the contradictions are striking (Charton, Muñoz, this volume).

Hence, it is reasonable to doubt whether donor-led reforms render public policies more coherent and more efficient; in fact, they appear to increase institutional complexity (Anders, Charton, this volume). This complexification is increased by a parallel tendency, which has been referred to as the "multiplication of units syndrome" (Bergamaschi, this 
volume). Governments and donors alike tend to respond to new challenges by doing their work through 'projects' - involving the creation of new institutions parallel to the existing ones. Examples of this practice are legion: from the creation of user committees around each little development project, to the predilection for Cellules de la moralisation de la vie politique, which replicate the internal control mechanisms of government departments in the fight against corruption, and special units in ministries which are solely occupied with the coordination of donor organizations. At best, 'islands of efficiency' are created which, however, are dependent on external funding (Roll, this volume). At worst, these projects and special units tie up the human and financial resources of national bureaucracies for months if not years into the future, and deflect the energies of the officials working there from all other tasks.

\section{The Resilience of a Politicized and Under-Resourced Prefectural Bureaucratic Model}

However, reforms do not-and, in fact, cannot—-take effect on a clean slate. They are interventions in dynamic systems (Elwert and Bierschenk 1988). On the ground, reforms encounter bureaucratic structures, rationalities and personnel - the legacy, so to speak, of previous reforms - which they try to reform, in turn, but which are at the same time the means by and contexts in which these reforms have to be implemented. Three aspects of these local bureaucratic configurations seem to be of particular relevance in this respect: state bureaucracies are dramatically underresourced, in terms of personnel and equipment; they have been heavily politicized since the 196os; and they reveal the authoritarian ethos of a command administration which itself is a colonial legacy.

\section{Under-Resourcing}

Despite statements frequently presented to the contrary, the public sector in African states is not 'inflated' (Goldsmith 1999). Correlated with the size of its population, Benin has only just over one third of the number of police officers found in Germany and only $40 \%$ of the number employed in France, and only five percent of the number of judges and state prosecutors in Germany. Following the economic crises of the late 1970 and early 1980s, salaries decreased, dramatically in some cases, and the number of public service employees, which had risen continuously up to then, decreased. (Both trends have recently been reversed.) Even more dramatic, however, was the decline in working resources: today, many 
local officials have de facto no budget whatsoever at their disposal. As we have seen in the ethnographic example presented at the beginning of this text, if local officals want to maintain a minimal state service, they must use private resources,. This is the other face of the creeping privatization of public services, which, more often than not, is viewed exclusively from the perspective of corruption. If the payment of a regular salary that is sufficient to cover living costs and access to an office and the necessary working resources constitute the minimum requirements for the existence of a state bureaucracy (according to Max Weber, see Bierschenk and Olivier de Sardan, Introduction, this volume), it follows that state bureaucracies do not exist in many parts of rural West Africa. The state is clearly unravelling at these edges; it is "dissolving", as Jean-Pierre Olivier de Sardan (2000) put it.

However, not all areas of the state bureaucracies have been equally affected by this decline. Some have managed to withstand the crisis better than others: in particular, the higher levels of the bureaucracy have been less severely affected by the crisis than the small interface officials (Lentz, Therkildsen, this volume).

\section{Politicization and Weakening of Internal Controls}

The state apparatuses were also weakened from within, however: the internal sanction and control mechanisms were systematically hollowed out in the course of their Africanization. A transfer to the suivi et évaluation department of any ministry today effectively means being politically side-lined (mis au placard). The motives behind this weakening process were political: they allowed the heads of state to implement a clientelist personnel policy. In the long term, this undermined the legitimacy of administrative sanctions which are usually understood as simply politically motivated, thereby eroding the control capacities of the leadership.

\section{A Prefectural Bureaucratic Model}

Ministries are organized according to a rigid hierarchical pattern and a very high level of centralized decision making. For example, in the education ministries, before any decision reaches the teachers, it has gone down through all the levels of the administrative ladder, while any information from the schools goes up the same ladder, feeding into increasingly synthetic reports on each level. An example are the subjects for the examinations taken at the end of primary school (certificat d'études primaries/CEP) in Cameroon: while teachers propose these subjects, they are revised at harmonized at each administrative level, validated by the central examination bureau and then transmitted downwards to the teachers. 
As Hélène Charton (this volume) shows for Cameroonian primary education system, this leads to paradoxical results of reforms: educational reforms like the competency-based approach are implemented in a system called formation en cascade which corresponds to this prefectural model of a command bureaucracy. As in the training-and-visit system of agricultural extension, the idea is that the top echelons of the education administration are trained in the new principles first, and that they then pass on their new knowledge to the inferior levels. The effect is that the top echelon, e.g. school inspectors, who do not teach, receive far more training than the people who are ultimately supposed to implement the reform, i.e. the teachers: whereas the former were trained in up to 30 days of seminars (with all the perks in terms of per diems attached to these seminars, cf. Smith 2003), teachers received only one or two days of training on average. Furthermore, the principle of the reform itselfputting the learner at the centre of the educational exercise-is contradicted by the authoritarian form of these training sessions, in which knowledge is dispensed ex cathedra.

In other words, reforms are distinctly top-down in nature, and are barely discussed with the stakeholders; if discussions and 'participation' take place they are highly ritualized. As a consequence, educational reforms are as much reforms implemented without the input of teachers as security sector reforms are reforms without the input of policemen and gendarmes. In this respect, many administrative reforms in Africa can, indeed, be studied as examples of how not to implement reforms. Instead of increasing the efficiency of public service delivery, more often than not, they provide opportunities for staging a technocratic and legal-rational discourse with the outside (Muñoz, this volume).

\section{The Simultaneity of the Non-Simultaneous}

As a result, African bureaucracies are very heterogeneous, if not fragmented, building sites, a point which we develop in the introduction to this book. Instead of buildings that are based on a more or less coherent plan and which are more or less efficiently used, they resemble landscapes of disjointed vestiges of reform. The 'products' of these reforms have deposited like sediments in the African bureaucracies we studied: the effects of a particular reform do not usually displace the results of the previous one-at least not completely. Instead, each institutional reform and each round of development policy intervention leaves behind an institutional legacy which slots into the group of existing institutional arrangements. Nicolas van de Walle (2001) has captured this dynamic in the notion of "the partial reform syndrome". However, he wrongly attributes this 
phenomenon exclusively to the interests of African elites who, for selfish reasons, boycott well-meant reform attempts by the donors; he fails to see how this partial reform syndrome is a result also of the dynamic of the development regime and the resulting donor competition.

Over $5^{0}$ years of development policy have not led to the homogenization of these institutional arrangements; instead they became increasingly complex. If one considers the individual elements of the bureaucraciespersonnel, official rules, practical norms, discourses - they paint a picture of the accretions of time that have accumulated, side by side, on top of each other, or in other twisted configurations. ${ }^{5}$

The simultaneity of the non-simultaneous is, of course, an attribute of all bureaucracies - which, after all, as organizational sociology has shown, are merely loosely coupled systems, at best (Weick 1976; for an application of this idea, see also Titeca and De Herdt 2010). However, sedimentation and the resulting heterogeneity appear to be particularly prominent features of the African bureaucracies we studied. Public bureaucracies in Africa can unite elements of an ancient colonial state with the very latest trends in administrative reform: for example, forestry officials are still very influenced by the repressive paramilitary, colonial operating style but at the same time support the principles of participative community forestry (Blundo, this volume); teachers teach in an authoritarian style that goes back to the 1950s but are expected to profess to the latest pedagogical fashions such as pupil-centred teaching, which, as everyone knows, is impossible to practice in the reality of an African school (Chabi Imorou, this volume); Benin's penal law originates in part from the 19th century, however its commercial law was recently modernized.

\section{Dimensions of HETEROgeneity in AFrican BUREAUCRACIES}

In fact, the multiplication and fragmentation of public authorities (as well as their increasing competition with non-public authorities) has been of increasing concern to scholars of politics in Africa (Bierschenk and Olivier de Sardan, Introduction, this volume). To describe this phenomenon, Jean Copans (2001: 14) proposed the allusive metaphor of "administrative archipelagos": i.e. African public services as a collection of peninsulas

5 This process of 'piling up' resembles mechanisms of local political arenas which were analysed in Bierschenk and Olivier de Sardan (2003). 
and islands which are connected to and isolated from each other to varying degrees. In some sectors of political science, this is not a new idea: Schmitter (1985: 33) sees the modern state as "an amorphous complex of agencies with ill-defined boundaries, performing a great variety of not very distinctive functions".

At least seven interconnected dimensions of this structural heterogeneity can be identified for the African bureaucracies we studied:

\section{Different Colonial Histories and Institutional Lagging}

Obvious differences arise due to the variations in the colonial pre-histories. For the sample of countries we studied, this relates, first, to the different institutional set-ups of former Anglophone and Francophone colonies. However, these differences do not affect all state sectors to the same extent; the colonial heritage is far more visible in some than in others. Thus, the justice sector in Ghana is clearly influenced by the British traditions while those in Benin, Niger and Mali are influenced by the French one. Similar differences also exist in the education sector: the normative model of the teacher as a state official is clearly inspired by the French system, and from the beginning of the colonial era to the present day, corporatist policies relating to teachers have always largely evolved around the objective that the various categories of non-functionary and non-tenured teachers be integrated in the country's civil service.

However, if the influence of the metropolitan model remains strong, it is often a model that was already replaced in the metropolitan country some time ago. For example, in the post- 1960 decade, the Dahomean educational system resembled different elements of the French model of the 1930s and 1940. Some central elements of this old French model even lingered in Dahomey (then re-named Benin) until the 1970s, while French reforms of the 1970s were adopted in Benin only 25 years later, if not later. This phenomenon, which may be termed 'institutional lagging', is widespread in African public services (but not, of course, unknown elsewhere): while the organizational model of the metropolitan country has evolved long since, organizational configurations found in the ex-colony today may still contain elements that were copied in colonial times. In this sense, African public bureaucracies could be described as still only partly decolonized.

It needs to be added that, in general, national structures in the education sector across African countries have converged to a greater extent than in the justice sector. Whereas the justice sector presents a 
professional culture with strong national characteristics, the language of the educational sector today is becoming increasingly international (Bierschenk 2007).

\section{The Differentiating Effects of Development Interventions}

Another dimension of the heterogeneity, often within the same sector but also between sectors, arises from the influence of development policy interventions. These often create "two-speed bureaucracies" (bureaucraties à deux vitesses) (Chauveau, Le Pape and Olivier de Sardan 2001; see also Blundo, this volume): a state bureaucracy which is completely underresourced and condemned to inactivity is faced with a 'project bureaucracy' with far better working conditions and higher salaries. The creation of parastatal agencies for the fulfilment of public tasks has a similarly differentiating effect (Therkildsen, this volume).

\section{Competition between State Ministries and Services Intensified by Donor Intervention}

Reforms, often implemented under pressure of donors, may also increase the competition between services. A well-known example from the Francophone countries is the competition between ministries of finance, strengthened and supported by the international finance institutions, and the planning ministries, which the international finance institutions associate with old-fashioned planning ideology and hence attempt to marginalize, but which, in turn, are often supported by the UNDP and bilateral donors critical of Structural Adjustment Programmes. Another example from Cameroon is cited by Muñoz (this volume). Here, the taxation of the livestock sector had been the task of agents of the Ministry of Livestock, Fisheries and Animal Husbandry (MINEPIA). Over the years, the latter developed routines involving collusive arrangements with taxpayers, interspersed with practices of unofficial exaction. Under a reform programme, which is intended to increase the efficiency of internal revenue mobilization and mirrors a string of other similar projects in neighbouring countries encouraged by donors, the agents of the ministry are now obliged to cooperate with officials from the Ministry of Economy and Finance (MINEFI) —an institution with not only a quite different political culture, but one which is also part of a different politico-ethnic network: while MINEPIA is considered to be within the Northern bloc islamo-peul, MINEFI is considered a Beti ministry, whose staff originate mainly from the southern part of the country. Hence, tax reform became a stage on 
which conflicts between local representatives of the state were played out (for a similar fragmenting effect of reform, see Anders, this volume).

\section{Islands of Efficiency and Inefficiency}

Different state bureaucracies vary significantly in their efficiency (not only but also) because of differences in their material resources. Just as 'islands of inefficiency' can be found in otherwise seemingly well-functioning state apparatuses, 'islands of efficiency' (or 'pockets of effectiveness') can be found, even within the state bureaucracies which were generally characterized by a low level of productivity in the countries we researched (Roll, this volume). ${ }^{6}$ As a general trend, our empirical studies suggest that the higher echelons of the public service function at a level that is closer to international professional norms than the lower echelons (Lentz, this volume). This is obvious, for example, in the judiciary and, judging from impressionistic evidence, it may also apply to institutions like central banks and finance ministries, at least in part. However, this concerns a point at which our sample (mainly lower-rank interface officials) shows its limits and where further empirical clarification is required.

\section{Differences in Working Conditions between Different Categories of Personnel}

The working conditions of different categories of public sector employees can vary significantly. Overall, the vertical spread of salaries is far more extreme in Africa than elsewhere. Whereas the ratio between the lowest and highest salaries paid in the German public services is around 1 to 9 and the World Bank recommends a ratio of 13 to 1 (Lentz, this volume), in Benin the corresponding ratio is 16 to 1 . In Uganda it appears to be 50 to 1 (Therkildsen, this volume). These figures only refer to the basic salaries of the employees, however, and therefore conceal a far higher spread in real terms: first, the privatization of public tasks, e.g. in primary school education as a result of the introduction of various contract teacher models, has led to the reduction of the salaries paid for lower-ranking roles which no longer feature in the public service salary tables. Second, various allowances and the differential possibilities for acquiring additional

6 These structural pockets of effectiveness need to be analytically distinguished from temporary 'islands of efficiency' which are created by the infusion of development aid resources, see above. 
income carry far greater weight in Africa than in Europe. In some African countries these amount to more than the basic salary. The spread of these allowances is even wider than that of basic income: for example, a high ranking official from the Beninese primary education ministry on an official mission to a rural area, for which he does not actually incur any accommodation or food costs as he will be lodged and fed by the teachers he visits, receives a daily per diem that may be twice the monthly salary of a community teacher. As we shall see, these material differences between the higher and lower ranks correlate with differences in the normative relationships with the state.

\section{Growing Internal Heterogeneity of Professional Groups}

These general differences between higher and lower ranks of public servants are thwarted, however, by the extensive and growing internal heterogeneity of the individual professional groups. This heterogeneity also is a sedimented product of bureaucratic history. Different eras leave behind different categories of personnel with the result that the internal composition of a professional group becomes increasingly differentiated: 'On ne sait plus qui est qui' is the view expressed in relation to the many categories of teachers who can end up working together today at one and the same school in Benin: i.e. teachers with civil-servant status, contract teachers, community teachers and unofficially employed assistants. The situation among police officers is quite similar. One feature of this differentiation is the very unequal salaries paid for the same work. Thus, for example, employees in public agencies or development projects in Uganda earn up to $60 \%$ more than their professional colleagues in the central government apparatus; some drivers in these agencies earn between 50 and $150 \%$ more than economists working in the ministries (Therkildsen, this volume). Remarkable differences also exist in the availability of working resources - for example IT equipment - within one and the same public bureaucracy, e.g. between schools, courts, ministries and ministerial departments .

To conclude this point: my claim is not that European bureaucracies are homogenous formations while African bureaucracies, in contrast, are heterogeneous ensembles. All bureaucracies are characterized by sedimentation and structural heterogeneity. The difference between European and African bureaucracies lies in their specific combination of heterogeneous elements and in the resulting degree of heterogeneity, which, overall, appears to be greater in Africa. 


\section{Co-Productions of Public Services}

The notion of what constitutes a public good or service is an historically rooted one (Bierschenk and Olivier de Sardan, Introduction, this volume). Therefore, whether a public service is delivered by a public authority, private commercial actors, or private non-profit associations varies over space and time. A good example is education: the fact that Europeans view primary school education as a public task today is, in historical terms, a comparatively recent product of 19th century history associated with the rise of the modern nation-state. And even the fact that education is viewed as a public responsibility does not say who should be running schools: the government or private, for-profit or non-profit, actors or both. In fact, many 'public' services, beyond education, are co-produced by state agencies together with private actors. Furthermore, it is possible that a particular public service is not rendered by the category of actor or institution foreseen in the official organigrams. In our research programme, this confusion of roles and functions concerned, in particular, teaching (by public and private schools, different categories of teachers from public servants over community teachers to private homework teachers), security (by the police, the gendarmerie, private security forces, village chiefs and many others) and the justice sector, especially at local level (firstinstance courts, conciliation tribunals, the different police forces, village chiefs and many others).

Co-production of public services by public and private actors is not, again, a purely African phenomenon; it is a feature of all public services. Nevertheless, it also appears to be particularly marked in Africa. However, there are no clear tendencies across the board, either in the direction of increasing privatization, nor increasing statism, and differences between countries and sectors have always been considerable. While education was delivered predominantly, if not exclusively by private actorsmainly Christian missions - in the African colonies up to 1906, it became a decidedly state affair in the French colonies after that date-with the paradoxical effect that educational parameters in the British colonies, which continued to rely heavily on missions, have been much better todate than in the Francophone countries.

However, the public-private divide cannot simply be projected onto different types of organizations. For example, even in theoretically free educational systems, strong private elements persist within the public system whereby some of the costs of running schools (mainly equipment) are borne by parents, the use of private homework tutors is very widespread 
and, even in public schools, some of the staff are private employees: they are privately sub-contracted by school directors who feel overburdened by their administrative tasks. This widespread practice is illegal but tolerated and is also found in other public services like the police and gendarmerie, courts and the customs service (Blundo and Olivier de Sardan, with BakoArifari and Tidjani Alou 2006). On the other hand, private schools, in all our sample countries, remain publicly regulated. The same is true of the production of security: the work of public police forces - the police in the strict sense of the word as well as gendarmerie and forestry servicesalways depends on the cooperation of private actors, and vice versa (Beek 2008).

In other words, the co-production of public services rests on complex, and shifting configurations of actors, and boundaries are not stable; these "delivery configurations" (Olivier de Sardan, this volume) are the object of continuous 'work' by the actors. The Good Governance ideology recently en vogue, which is based on the idea of a harmonious balance between the three sectors of the state, the market and non-profit associations, has certainly been a factor behind the push in the direction of increasing the 'private' element in education. One particularly fascinating phenomenon has been the 'disciplining' of the state-in this case, the education system - by private international NGOs which try to channel the public education sector in the direction of strict criteria of budgetary discipline, accountability, community participation and modern educational principles (Fichtner 2012). However, the results are far from unidirectional, and more often than not more complex than the blueprints drawn up abroad, with local political and bureaucratic logics often gaining the upper hand over attempts at modernization from the exterior (Anders, Bergamaschi, Chabi Imorou, Muñoz, this volume). Far from the harmonious picture of good governance ideologies, the public-private boundaries remain highly charged sites of conflict and creative strategies.

Therefore, it would certainly be wrong to assume that the role of the state is a generally diminishing one-in Benin and Mali, for example, we observe instead tendencies to for the re-enlargement of the role of the state in education by bringing community school under stronger government control (Félix Koné, private communication) and by putting formerly privately paid community teachers on the government payroll (Benin). Incidentally, this means that the internal brain drain is not unidirectional either: while working for an international NGO is in many respectssalaries, working conditions-more attractive than working for the state, and international NGOs in the education sector heavily rely on the work 
of (retired) school inspectors as local consultants, since the beginning of colonization, the corporatist interests of private actors in education in the Francophone countries have always been focused on the overriding objective of attaining the status of a government functionary.

\section{The Public Service as a Complex Normative Universe}

For the officials who work in these bureaucracies this heterogeneity means that they act in professional contexts marked by enormous normative pluralism (Chauveau, Le Pape and Olivier de Sardan 2001).

Modern bureaucracy not only has a technical side but also an ethical one. Hence, when the modern civil service was developed in the 19th century-the British civil service having been invented in colonial India - it was not merely a matter of creating institutional innovations to replace the patrimonial bureaucracy that had dominated up to then with its abuse of privileges, corruption and high dependency on politics. The creation of an "appropriate bureaucratic persona" and the "fashioning of an appropriate administrative subjectivity" were equally important. The modern civil servant was the product of a "codification of an ethical type that bears particular competence to rule", he became the bearer of a "ruling habitus" (Osborne 1994: 290). Therefore, the civil service entrance examination and corresponding preparation were not exclusively focussed on knowledge, but were primarily seen as character training: "The aim was not, in a negative sense, to create a bureaucracy, but to motivate officials for public service" (p. 306). Ideas about the radical non-ethic character of the modern bureaucracy, as often ascribed to Max Weber, are, therefore, misleading - both as regards bureaucracy and as regards Max Weber, who spoke of the office as "life order" (Lebensordnung): "Bureaucracy... presupposes an ethical formation on the part of the bureaucrat, a bureaucratic vocation, as opposed to a more or less blind obedience to rules and orders" (p. 309). An ethical understanding of bureaucratic office is, therefore, the necessary complement to the power of discretion of the bureaucrat and, specifically, the condition for the restriction of bureaucratic tendencies in the negative sense.

Contrary to prevailing clichés, this ideal image of the bureaucrat also exists in Africa and it comes into play there. It is taught in the teacher training institutes and police schools, its formulations-for example the ethical code of the customs officer or the "ten commandments of the good policeman" - can be read in many state offices. This ideal image was 
repeatedly referred to without prompting by our informants. The extent to which this image of the correct and responsible official is part of the external representation of many state authorities is in fact very striking (see also Lentz, this volume).

In their professional practice, officials must, however, act in complex normative universes, for which this ideal image can only be one template among many. These moral universes are characterized by an intense double tension. First, a tension between the different official norms themselves. These are often contradictory, in part obsolete and frequently simply not applicable. Extensive areas of educational practice, for example, are either not controlled by texts or the texts that exist are contradictory. The permanent intervention of many uncoordinated donors and the resulting stop-go policy, for example in the area of human resources policy, further exacerbate the problem. Moreover, these norms change constantly-as a result of reforms-sometimes from one year to the next.

The inadequacy of the official rules and regulations, which are often illadapted to reality, necessitates the production of informal norms which actually enable the minimal functioning of the apparatuses (Olivier de Sardan, Hamani, this volume)—albeit, in a negative feedback loop, intensifying its functional problems. As a result, the officials navigate in a context that appears to be fundamentally unpredictable and they frequently deplore this absence de vision prospective. They become masters in the selective application of contradictory norms of varying origin, of "organisation improviste" and "bricolage". This is aptly expressed in the saying familiar to every street-level bureaucrat in Benin: "c'est le terrain qui commande".

Therefore a second source of tension exists between these official norms - which, as underlined, are contradictory in themselves and constantly changing - and the practical norms. Again, this too is not a purely African phenomenon. No bureaucracy functions in accordance with the Weberian ideal type (which is, first, an ideal type and, second, limited to the formal aspects of the functioning of a bureaucracy). A bureaucracy is not a machine but a configuration of social processes. As the sociology of organizations has shown in recent decades, all formal organizations require informal rules and practices in addition to formal ones to be able to function. Most individual characteristics that are frequently cited as typical of African organizations can be found, therefore, in Western bureaucracies. For example, the German civil service has been described by leading organizational sociologists as a "patronage bureaucracy" (Bosetzky 1971, 1974). In addition to all of the meritocratic criteria (which are also effective), promotion in the German civil service is largely based on "promotional relationships among the employees" and on the "instrumentalization of 
the employees by external organizations", hence largely on the patronage of parties and interest groups (Bosetzky 1974: 431). Indeed, Bosetzky (p. 433) concludes that "a completely objective system of promotion liberated from all micropolitics, formalized and mathematicized" would involve considerable losses of efficiency for the public administration and actually cause its collapse into subsystems as the administration is reliant on "a high degree of group cohesion".

Officials in the countries we studied are given little preparation during their training on how to deal with these tensions. Instead, they are taught an ideal image of their future profession. They only learn to do deal with reality during the phase of informal professional socialization which they undergo in the early years of their career. This leads to a conclusion that may not be immediately obvious: the internal motivation of the bureaucrats is even more important in African bureaucracies than in those with greater top-down control, for example the German civil service!

In fact, one recurrent theme emerging from our interviews with African officials was the notion of a moral contractual relationship which binds them to the state. More senior officials describe this moral relationship as largely intact: "we work for the nation", they say, and they consider that meritocratic principles for hiring and promotion are in fact operational (Lentz, see also Willott, this volume). In the opinion of the lower ranks, the interface bureaucrats, however, the state has contravened the terms of this contract: "l'Etat nous a laissé", they say. This situation can be seen as a typical double-bind situation: low level bureaucrats are exposed to paralyzing, because contradictory, messages. Officially, their superiors insist on an ideal of behaviour, but, so to speak, with a wink, letting it be known that they, too, realize that this ideal cannot be followed. In certain circumstances, however, they may actually find it convenient to insist on the ideal being followed to the letter. This possibility of switching between official and practical norms - for example in the decisions over promotions and transfers between different posts-is an important basis of power within an organization together with the more or less deliberate creation of informational opacity (see also Therkildsen, this volume). Subordinates react to this double-bind by pretending, again with a wink, to be following official rules. The result is widespread hypocrisy: the state pretends to pay its officials and give them an operating budget and the officials pretend to work (see also the notion of 'double speak' in Olivier de Sardan 2009).

A wide range of the behaviours we observed among the street-level bureaucrats can, therefore, be understood as compensation strategies developed in response to this moral double-bind. Most of these strategies 
basically involve the principle of limiting professional commitment. The limiting of professional commitment means, first, that entry into a profession is very often based on highly random conditions. Many officials told us that they applied for different careers and that they became what they now are simply because they passed one exam and not another. Even when they have embarked on a particular career path, they keep a close eye out for alternatives; exit options are permanently scrutinized. This process of scanning for exit options can take different forms. It can mean the search for professional alternatives within or outside the relevant professional field. The low-level bureaucrats interviewed by us displayed an astonishingly firm belief in the professional significance of knowledge and its sanctioning by qualifications. Therefore, many officials spend a great deal of their spare time pursuing further training activities: police officers and gendarmes study law to gain access to the entrance examinations for qualification for the position of commissioner; teachers enrol for sociology courses for the same reason; contract teachers apply for work with the customs authorities; teachers in Ghana train to become lawyers; etc. This culture of qualifications (culture de diplôme) alone can be interpreted as empirical proof of the strong embedding of meritocratic principles at local level (see also Willott, this volume). Another strategy involves secondary employment. For example, the majority of younger teachers appear to be employed outside of their official hours of work as tutors. In other words, officials often only have limited investment in what they are actually doing, and are permanently on the lookout for exit options. They are "doing the state, en attendant" (Bierschenk 20ogb).

\section{Some General Conclusions}

These observations suggest three general conclusions for the understanding of statehood in Africa:

\section{The Production of Informality within the Bureaucratic Apparatuses}

The enormous emphasis on informal norms and practices in African bureaucracies is often interpreted as an adaptation to local social contexts, as the displacement of bureaucratic norms by social ones. In its most simplistic formulation, it is considered the expression of an 'African mentality' (cf. Olivier de Sardan 2010). We believe that such an interpretation misses the fact that the informal norms are largely produced within the apparatuses themselves. It is less culture, than history and organization 
that explain the characteristic features of African states. The immediate context in which this extensive production of informal norms takes place is the lack of steering capacity at the top level of African bureaucracies; another factor is the constant interventions by numerous uncoordinated donor organizations. Furthermore, all factors-bad management, bad functioning, constant interfering from the outside-are linked in a feedback loop and mutually reinforce their effects. In this situation, the production of informal norms is the functional equivalence to reforms which neither local leadership nor foreign donors are able to implement (Hamani, this volume).

These feedback loops render the informality that characterizes African bureaucracies collusive: a considerable degree of hypocrisy can be found in African bureaucracies-as, indeed, in all bureaucracies and modern organizations where it has been described as "the practice of incorporating different organizational structures, processes and ideologies for internal and external use" (Brunsson 2002). The management levels are aware that many formal rules are not implementable and that informal practices are required if the apparatus is to function at all. For example, school principals have significantly more tasks to fulfil than is officially admitted and yet they are still expected to complete a full teaching load. Many principals solve this problem by appointing private teaching assistants. Strictly speaking this is not allowed. Faced with this situation, management at the ministry officially insists on compliance with the official code but usually tolerates the practice in reality-in compliance with an informal code of conduct that characterizes many areas of life in Benin and is expressed in the saying "you must know when to close your eyes". All participants pretend to observe the official rules despite being fully aware that they cannot be implemented. In the emic discourse of public servants in Benin, this is referred to as navigation à vue. These informal practices should not necessarily — or primarily — be equated with corruption, but they can become the gateway to it. They fundamentally blur the boundaries between the state and non-state areas. And while the centrally regulated reforms go nowhere, the basis produces many small ad hoc reforms or réformes dérivées (Blundo, Hamani, this volume).

\section{African Statehood not Subject to a Uniform Logic}

Hence, the empirical research of statehood deconstructs the state fiction often presented by jurisprudence and the political sciences. It focuses on the heterogeneity, the incompleteness and 'omnipresence' 
of statehood-so that it is impossible to define, once and for all, where exactly the border between state and non-state lies. As a result of ethnographic research, this may not come as a surprise: within the ranks of the social and cultural sciences, anthropologists tend to side more with the splitters than the lumpers. Linear explanations are not allowed from this kind of perspective: it is difficult to ascribe a single cause or consequence to a given factor. Depending on the context and its position in a sequence, the same factor can have very different effects and the same phenomenon be triggered by different factors.

Thus, African statehood is not based on an 'essence' of its own; it has no inherent "grain" (Kelsall 2008); it does not represent the exotic 'completely other' as compared with western statehood. Just as African agriculture is characterized by high micro-variability, the characteristic feature of African bureaucracies is their enormous heterogeneity. Contrary to what some authors claim (see Bierschenk and Olivier de Sardan, Research paradigm, this volume), politics and statehood in Africa are not subject to any uniform moral matrix.

\section{Macro-Difference as the Result of Cumulated Micro-Differences}

The question arises, however, as to how we should understand differences between public services around the globe, in particular as regards their relative efficiency in the delivery of public goods and service. These differences undoubtedly exist and to a considerable extent. In an international comparison, African public bureaucracies are particularly unsuccessful at the production of public goods such as education, justice and social order. I argue that we should understand them as the accumulated outcome of many small differences. The difference between African and other, say European, bureaucracies does not, therefore, lie in the fact that they work on the basis of essentially different criteria. They function largely on the basis of the same elements, however with a different 'mixing ratio', and it is the accumulated effect of these many small differences that ultimately generates a different 'macro'-quality. As in a chemical process, macrodifference emerges, therefore, from the interaction of many different small factors and mechanisms. These, in turn, are only loosely linked and cannot be depicted by a single principle, for example neopatrimonialism (Therkildsen, this volume). Moreover, it is precisely this loose link that brings stability to the difference; the alteration of a single factor does not as a rule change the entire outcome. This overdetermination has an important implication for reformers: complex bureaucratic phenomena-like 
everyday corruption - cannot be addressed by one-factor measures, e.g. the raising of public salaries. In the complex bureaucratic systems of West Africa, such measures largely dissipate.

In other words: attributes of statehood that may appear to be 'typically African'-for example widespread everyday corruption of public officials - are overdetermined: they are not conditioned by a single factor but by a series of elements. These elements, and their complex, and shifting, articulations, are the objects of examination in this book.

\section{REFERENCES}

Badou, Agnes O. 2013. Socialisation professionnelle et gestion des carrières des agents de sécurité publique au Bénin. Dr. phil. dissertation, Department of Anthropology and African Studies, Johannes Gutenberg University Mainz.

Bates, Robert H. 2008. When Things Fell Apart. State Failure in Late-Century Africa. Cambridge, Cambridge University Press.

Beek, Jan. 2008. Friend of the Police. Polizei in Nord-Ghana (Upper West Region). Magisterarbeit, Department of Anthropology and African Studies, Johannes Gutenberg University Mainz.

Bierschenk, Thomas. 2006. The local appropriation of democracy in an African Middle Town: An analysis of the municipal elections in Parakou, Republic of Benin, 2002/03. Journal of Modern African Studies 44 (4): 543-572.

- 2007. L'éducation de base en Afrique de l'Ouest francophone. Bien privé, bien public, bien global. In Bierschenk, Thomas, Giorgio Blundo, Yannick Jaffré, et al., eds. Une anthropologie entre rigueur et engagement. Essais autour de l'œuvre de Jean-Pierre Olivier de Sardan. Paris, APAD-Karthala, 251-276.

- 2008. The every-day functioning of an African public service: informalization, privatization and corruption in Benin's legal system. Journal of Legal Pluralism and Unofficial Law (57): 101-139.

- 2009a. Democratization without development: Benin 1989-2009. International Journal of Politics, Culture and Society 22: 337-357.

- 20ogb. Doing The State, en attendant. Ethnographic Explorations among Primary School Teachers in the Republic of Benin (unpublished research report). Department of Anthropology and African Studies, Johannes Gutenberg University Mainz.

— - ed. 2010. La Justice et la Police dans la République du Bénin. Un résumé de rapports de recherches étudiantes. Working Papers of the Department of Anthropology and African Studies of the Johannes Gutenberg University Mainz, 121b, available at: http://www.ifeas .uni-mainz.de/workingpapers/AP121.pdf.

- 2011. Local political fields as negotiated orders. Non-representative participation and political violence in Parakou, Republic of Benin (1950-2005). In Jul-Larsen, Eyolf, PierreJoseph Laurent, Pierre Yves Le Meur, et al., eds. Une anthropologie entre pouvoirs et histoire. Conversations autour de l'oeuvre de Jean-Pierre Chauveau. Marseille, Paris, Uppsala, APAD, IRD, Karthala, 425-447.

Bierschenk, Thomas and Jean-Pierre Olivier de Sardan. 2003. Powers in the village: rural Benin between democratisation and decentralisation. Africa 73 (2): 145-173.

Bierschenk, Thomas and Eva Spies. 2012. Afrika seit 1960: Kontinuitäten, Brüche, Perspektiven. In Bierschenk, Thomas and Eva Spies, eds. 5o Jahre Unabhängigkeit in Afrika: Kontinuitäten, Brüche, Perspektiven (Mainzer Beiträge zur Afrikaforschung, 29). Köln, Köppe, 7-51. 
Bierschenk, Thomas, Elisabeth Thioléron and Nassirou Bako-Arifari. 2002. Institutionalising the PRSP Appproach in Benin. Ch. 2 of the ODI PRSP Institutionalisation Study. Mainz.

Blundo, Giorgio, Jean-Pierre Olivier de Sardan, with N. Bako-Arifari and M. Tidjani Alou. 2006. Everyday Corruption and the State. Citizens and Public Officials in Africa. London, Zed.

Bosetzky, Horst. 1971. Die kameradschaftliche Bürokratie und die Grenzen der wissenschaftlichen Untersuchung von Behörden. Die Verwaltung 4: 427-438.

—. 1974. "Dunkelfaktoren" bei Beförderungen im öffentlichen Dienst. Die Verwaltung (7): $315-337$.

Brandecker, Nora. 2007a. Der Wandel der bildungspolitischen Ansichten der Weltbank. Working Papers of the Department of Anthropology and African Studies of the Johannes Gutenberg University Mainz, 82, available at: http://www.ifeas.uni-mainz.de/ workingpapers/AP82.pdf.

— 2007 b. Dynamiken bildungspolitischer Reformprozesse in Benin. Ein Forschungsbericht über die Bildungsreform Les Nouveaux Programmes d'Etude (unpublished research report). Department of Anthropology and African Studies, Johannes Gutenberg University Mainz.

Brunsson, Nils. 2002. The Organization of Hypocrisy. Talk, Decisions and Actions in Organizations. Oslo, Abstrakt.

Budniok, Jan. 2012. The Politics of Integrity. Becoming and Being a Judge in Ghana. Dr. phil. dissertation, Department of Anthropology and African Studies, Johannes Gutenberg University Mainz.

Chabi Imorou, Azizou. 2010. Le Bénin à l'epreuve du syndicalisme enseignant. Les revendications des 'dévalorisés' et la construction de l'Etat (1945-2008). Dr. phil. dissertation, Department of Anthropology and African Studies of the Johannes Gutenberg University Mainz.

Chauveau, Jean-Pierre, Marc Le Pape and Jean-Pierre Olivier de Sardan. 2001. La pluralité des normes et leurs dynamiques en Afrique. In Winter, Gérard, Jean-Pierre Chauveau, Georges Courade, et al., eds. Inégalités et politiques publiques en Afrique. Paris, Karthala, $145^{-162 .}$

Cooper, Frederick. 1996. Decolonization and African Society: The Labor Question in French and British Africa. Cambridge, Cambridge University Press.

- 1997. Modernizing bureaucrats, backwards Africans and the development concept. In Cooper, Frederick and Randall Packard, eds. International Development and the Social Sciences. Essays on the History and Politics of Knowledge. Berkeley, Ca., University of California Press, 64-92.

Copans, Jean. 2001. Afrique noire: un État sans fonctionnaires? Autrepart 20: 11-27.

Elwert, Georg and Thomas Bierschenk. 1988. Development aid as intervention in dynamic systems. Sociologia Ruralis 28 (2-3): 99-112.

Evans-Pritchard, Edward E. 1940. The Nuer. A Description of the Modes of Livelihood and Political Institutions of a Nilotic People. Oxford, Oxford University Press.

Fichtner, Sarah. 2012. The NGOisation of Education. Case Studies from Benin (Mainzer Beiträge zur Afrikaforschung, 31). Köln, Köppe.

Goldsmith, Arthur A. 1999. Africa's overgrown state reconsidered: bureaucracy and economic growth. World Politics 51 (4): 520-546.

Hahonou, Eric K. 2006. En attendant la décentralisation au Niger. Dynamiques locales, clientélisme et culture politique. Thèse de doctorat. Marseille, Ecole des Hautes Etudes en Sciences Sociales.

Hällmeyer, Heide. 2007. Lehrerausbildung in Benin: Die Ecole normale d'instituteurs in Djougou (unpublished research report). Department of Anthropology and African Studies, Johannes Gutenberg University Mainz.

Hamani, Oumarou. 2011. Les modes de régulation de l'appareil judiciaire nigérien. Thèse de doctorat. Marseille, Ecole des Hautes Etudes en Sciences Sociales. 
Kelsall, Tim. 2008. Going with the Grain in African Development? (Power and politics in Africa programme discussion Paper. 1). London, DFID.

Naudet, Jean-David. 1999. Trouver des problèmes aux solutions. Vingt ans d'aide au Sahel. Paris, OECD.

Nganang, Patrice. 2012. Was heißt (schon) Unabhängigkeit? Autobiographie eines Konzeptes. In Bierschenk, Thomas and Eva Spies, eds. 5o Jahre Unabhängigkeit in Afrika. Kontinuitäten, Brüche, Perspektiven. Köln, Köppe, 555-569.

Nugent, Paul. 2004. Africa Since Independence. A Comparative History. Basingstoke \& New York, Palgrave Macmillan.

Olivier de Sardan, Jean-Pierre. 2000. Dramatique déliquescence des États en Afrique: L'espoir toujours repousse d'une démocratie authentique. Le Monde diplomatique. February 2000.

- 2009. State bureaucracy and governance in West francophone Africa. Empirical diagnosis, historical perspective. In Blundo, Giorgio and Pierre Yves Le Meur, eds. The Governance of Daily Life in Africa. Ethnographic Explorations of Public and Collective Services. Leiden, Brill, 39-71.

- 2010. Le culturalisme traditionaliste africaniste. Analyse d'une idéologie scientifique. Cahiers d'Études africaines (198-199-200): 419-453.

Osborne, Thomas. 1994. Bureaucracy as a vocation. Governmentality and administration in nineteenth century Britain. Journal of Historical Sociology 7 (3): 289-313.

Schmitter, Philippe C. 1985. Neo-corporatism and the State. In Grant, Wyn, ed. The Political Economy of Corporatism. New York, St. Martin's, 32-62.

Smith, Daniel J. 2003. Patronage, per-diems and the workshop mentality: The practice of family planning programs in Southeastern Nigeria. World Development 31 (4): 703-715.

Spittler, Gerd. 1981. Verwaltung in einem afrikanischen Bauernstaat. Das Koloniale Französisch-Westafrika 1919-39. Wiesbaden, Steiner.

Tama, Clarisse. 2011. Les enseignants de l'école primaire au Bénin. Transformations d'un groupe professionnel. Dr. phil. dissertation, Department of Anthropology and African Studies, Johannes Gutenberg University Mainz.

Tchantipo, Sai Sotima. 2012. Normes officielles, normes pratiques et stratégies des acteurs dans le service public de justice au Bénin. Dr. phil. dissertation, Department of Anthropology and African Studies, Johannes Gutenberg University Mainz.

Titeca, Kristof and Tom De Herdt. 2010. Real governance beyond the 'failed state': negotiating education in the DRC. African Affairs 110 (439): 213-231.

van de Walle, Nicolas. 2001. African Economies and the Politics of Permanent Crisis, 19791999. Cambridge, Cambridge University Press.

Voss, Katja. 2007. Grundschullehrerinnen in Benin: ein Beruf mit Perspektive? (unpublished reseach report). Department of Anthropology and African Studies, Johannes Gutenberg University Mainz.

Weick, Karl E. 1976. Educational organizations as loosely coupled systems. Administrative Science Quarterly 21: 1-19.

Wetzig, Salka-Lena. 2007. Die sozialistische Schulreform 'Ecole Nouvelle' in Benin (19751990) (unpublished reseach report). Department of Anthropology and African Studies, Johannes Gutenberg University Mainz.

Yessoufou, Akimi. 2011. Local Actors in Top-Down Implementation of Curricular Reform in Benin's Primary Education. Ph.D. thesis, The Institute of Social Studies, Erasmus University.

Young, Crawford. 1994. The African Colonial State in Comparative Perspective. New Haven, Ct., Yale University Press. 
Thomas Bierschenk and Jean-Pierre Olivier de Sardan - 978-90-04-26496-0 Downloaded from Brill.com@4/26/2023 02:08:21PM via free access 
PART THREE

BUREAUCRACIES AT WORK 
Thomas Bierschenk and Jean-Pierre Olivier de Sardan - 978-90-04-26496-0 Downloaded from Brill.com@4/26/2023 02:08:21PM via free access 


\section{THE POLITICS OF REFORM: A CASE STUDY OF BUREAUCRACY AT THE MINISTRY OF BASIC EDUCATION IN CAMEROON}

\section{Hélène Charton}

This chapter deals with reform processes in African bureaucracies taking place in an internationalized context. It examines the dynamics generated by the implementation of a specific reform, the competency-based approach (CBA) within the Cameroonian educational system. It thus provides an example of the political economy of reforms in countries of the global South. It also aims to capture the dynamics of change within a specific administrative segment as well as document each segment's capacity to reshape and redefine the programme itself through logics of change and resistance.

Over the past 20 years, education in Africa has become a major field of development experimentation. The achievement of the second Millennium Development Goal ('Ensure that, by 2015, children everywhere, boys and girls, will be able to complete a full course of primary schooling') prompted the implementation of educational reforms. Most of these programmes seek to provide quality education for all at limited costs. Hence, much consideration has been given to educational inputs (class size, teachers training, curricula, etc.). In fact, competency-based approach curricula are part of the quality education tool box designed by international institutions (mainly the World Bank) as a way of improving quality and access to basic education in African countries. This kind of reform, designed externally as a technical tool for resolving specific issues, epitomizes the nature of the set of reforms currently implemented in Africa. Although these processes require a high degree of external expertise and funding, the main agents of their implementation remain the local bureaucracy. It is precisely the interactions between the pre-existing administrative pattern and the new dynamics produced by the reform process that is under scrutiny in this chapter.

The issue of reform (de-)politicization has been raised by some authors. In his analysis of a World-Bank-sponsored project in Lesotho, James Ferguson highlights the way in which reforms enforce bureaucratic state power: 
The short answer to the question of what the "development" apparatus in Lesotho does, then, is found in the book's title: "it is an anti-politics machine", depoliticizing everything it touches, everywhere whisking political realities out of sight, all the while performing, almost unnoticed, its own pre-eminently political operation of expanding bureaucratic state power (Ferguson 1996: xv).

However, his analysis fails to account for local and individual responses to reforms and, more particularly, the way social actors are diverting reforms packages for their own benefit as underlined by Elwert and Bierschenk (1988) and Olivier de Sardan (1988). Far from enhancing bureaucratic power, reforms actually enforce individual positions within the bureaucratic system. Although reforms have been major issues in public policy analyses in Africa over the last 25 years, the process of reform itself has not attracted much attention (Chibber 2003; Lipsky 1980). Consequently, the specific role played by African public bureaucracies in these reforms has been neglected. The methodological debate between Dominique Darbon and Jean-Pierre Olivier de Sardan in the journal Politique africaine in 2004-which contrasted a theoretical state perspective as developed by political scientists with a more concrete analysis of 'states at work' based on their interrelations with users and citizens as developed by socioanthropologists-is indicative of the renewal of research perspectives on the state and bureaucracies in Africa (Darbon 2004; Olivier de Sardan 2004). The general assertion about the weak and uncertain capacities of African states to properly exercise their power (expressed in derogatory terms like 'soft', 'weak' and even 'failed' states) does not mean that states and their agents do not produce anything - in fact, this is the starting point of all of the contributions to this book. Recent studies in political science and social anthropology focus on the interaction between states and citizens through a close examination of certain actors, such as street-level bureaucrats (Lipsky 1980), and certain practices and modes of interaction, such as corruption (Blundo and Olivier de Sardan 2007). They have contributed to a reinterpretation of the role of bureaucracies in state-making and social change.

This paper is about bureaucratic state power and, more specifically, about the way in which international reform implementation processes contribute to strengthening such bureaucratic power, or, to put it more precisely, the power and status of particular actors in the bureaucracy. Our basic assumption is that reforms, such as the introduction of the CBA, are part of the international aid technology. However, the implementation of this externally derived technology is being challenged by internal bureaucratic dynamics, a process that feeds into conflicting perspectives 
on the reform process. From the point of view of their initiators, reforms are supposed to be a source of improvement and are presented as major instruments of change. However, from the point of view of bureaucrats in charge of their implementation, reform processes are perceived as a major means of rent-seeking. The ways in which the benefits of reform are captured and distributed within the bureaucratic apparatus transform the very objective of the reform.

In order to understand the CBA reform process, over the course of a four-week field study, approximately 6o interviews were conducted with a wide range of actors from the educational scene at international (international organisations and NGO representatives), national (education inspectors, heads of administrative services at the Ministry of Basic Education, representatives of parents' and teachers' associations and of teachers' unions), and regional and local levels (provincial and district inspectors, school heads, teachers, heads of teacher-training colleges, teachers and students in these institutions), and in school and district, departmental and provincial administration of three provinces (Central, Southern and English-speaking South Western province). ${ }^{1}$ This chapter will begin by outlining the national and international logics that have led to this specific reform process and that could appear contradictory or even conflicting. The following section explores the way in which the reform is currently being implemented in Cameroon with a view to gaining an understanding of the political economy of reforms in Africa. Indeed, this case study on the implementation of the CBA reform in Cameroon aims to demonstrate how internal bureaucratic dynamics have emptied an educational reform of its main pedagogical content and have turned it into a purely administrative exercise.

\section{REFORM AT THE JUNCTURE BETWEEN EXTERNAL AND INTERNAL DYNAMICS}

Since the mid-1990s, the government of Cameroon has been engaged in a stream of reforms aimed at reshaping and improving the country's educational system. This is the general context in which the CBA was introduced

\footnotetext{
1 This field study was carried out in the specific context of a research-action programme funded by the Agence française de développement on the implementation of the competency-based approach in Cameroon between October 2008 and February 2009. It was part of a comparative study conducted in five African countries: Cameroon, Senegal, Mali, Tunisia and Gabon.
} 
into the country. A reform of this nature manifests as a two-fold process: it relies very much on international expertise and engineering, however, at the same time, local bureaucracies play a major role in its implementation. Hence, we shall begin by analysing these internal and external, and sometimes conflicting, interactions.

\section{National Politics versus International Expertise: \\ The Cameroonian School System at a Crossroads}

Like many other African countries, Cameroon faced a major crisis in its education system in the early 1990s. While the country almost achieved universal primary school enrolment in the 1980s, gross enrolment rates dropped from around $96 \%$ in 1990 to $81 \%$ in 1995 (MEC 2003: 4). The impoverishment of people due to the economic crisis and aggravated by the devaluation of the CFA franc and the reductions in state expenditure under structural adjustment programmes, which incidentally led to the closure of teacher-training colleges, were among the causes of the crisis. In May 1995, the government convened a general assembly of education actors to resolve the crisis and establish new foundations for the school system, to be known as the 'New Cameroonian School' (Nouvelle école camerounaise).

This consultation at national level was part of a more general political process. From the beginning of the 1990s, opposition parties and civil society organizations had been putting significant pressure on the government to restore democracy to the country. A National Consultation was launched in 1993 (a year after the first multiparty elections) and led to the revision of the Constitution in 1996. ${ }^{2}$ Luc Sindjoun (1996) stresses that the ambiguities of this new constitution were exploited to legitimize President Biya's power. However, he also highlights the fact that much of the debate turned on ideas of national identity and the production of a common national reference system in the context of strong regional and ethnic antagonisms (most particularly in the English-speaking provinces).

In this political context, the reshaping of the national school system emerged as a major political tool that aimed both to solve the educational crisis and to foster national identity and unity. Basic education was made

2 January 19, 1996, Law revising the Constitution of 2 June, 1972 adopted by the National Assembly, December 23, 1995. 
compulsory under the revised Constitution. ${ }^{3}$ The new education law was passed in April 1998 and provided the legal framework for the enactment of the general principles set out by the national education convention. ${ }^{4}$ The rewriting of curricula and the harmonization of the English- and French-speaking educational sub-systems were also supposed to produce this common set of references.

This process occurred at a time when international donors were becoming most influential in the definition of education strategies in Africa as part of the implementation of Education for All policies (EFA). A number of international conferences on education (Jomtien 1990, Dakar 2000) and aid (Paris Declaration on Aid efficiency, Organisation of Economic Cooperation and Development, 2005) contributed to the setting of a general reform framework. New policy instruments were developed by international experts. In that context, as in many other African countries engaged in the same process, the achievement of universal education in Cameroon was seen as a technical challenge requiring both specific and standardized technical solutions.

Under the new international aid paradigm that emerged in the first decade of the new millennium, based on aid efficiency, donors were bound in technical and financial partnerships (TFP) under sector-wide approaches (SWAP) with a view to eradicating poverty (as defined in the Millennium Development Goals). These general objectives were operationalized and rationalized in Poverty Reduction Strategy Papers (PRSP). In the education sector, this kind of approach gave birth to a new generation of documents, such as Status Reports on the National Education Systems (Rapport d'Etat du Système Educatif National, RESEN) all of which were based on the same standardized model. ${ }^{5}$ In Cameroon, the Rapport d'Etat du Système Educatif National Camerounais, éléments de diagnostic pour la politique educative dans le contexte de l'Education pour tous et du DSRP6 (RESEN) was published in 2003 by a team of national and international

3 Cf. article 18 of the preamble to the Cameroonian Constitution: "The state shall guarantee the child's right to education. Primary education shall be compulsory. The organization and supervision of education at all levels shall be the bounden duty of the state." (http://www.icrc.org/ihl-nat.nsf/162d151af444ded44125673eoo508141/7e3eeo7f489d674dc12 56ae9002e3915/\$FILE/Constitution\%20Cameroon\%20-\%2oEN.pdf, accessed 15/02/2013).

4 Loi $N^{\circ}$ 98/004 du 14 avril 1998, portant orientation de l'Education au Cameroun: 3.

5 RESEN were conceived and developed as a specific diagnostic tool for African education systems by a team of economists from the World Bank.

6 Document stratégique de réduction de la pauvreté, Poverty Reduction Strategy Papers (PRSP) in English. 
experts coordinated by the World Bank and French bilateral development cooperation. As in most African countries, the Education Sector Strategy (Stratégie sectorielle d'éducation) was defined on this basis. The document was finalized and signed by all stakeholders (the government, donors and civil society representatives) in June 2006.

This was the general context in which various sets of reforms were launched. The competency-based approach was introduced in Cameroon in 2004 to enhance the quality of education in primary schools.

The competency-based approach (CBA) had been introduced in Frenchspeaking Africa during a 1998 meeting of the Conférence des Ministres de l'éducation ayant le français en partage (CONFEMEN). This educational reform was presented as a means of improving the quality of basic education in the context of Education for All programmes. At that time, most Western countries had changed their knowledge-based curricula into competency-based ones to respond better to the challenges of the modern labour market in the industrial world. However, the shift did not happen overnight in these countries. On the contrary, the reforms triggered numerous debates, resistance and adjustments (for France, see Ropé and Tanguy 1994). By way of contrast, in Africa, the CBA was transferred as a specific Western technology with no prior discussion. After the CONFEMEN meeting, the International Organisation of La Francophonie (IOF) launched a series of seminars to train African experts, both in West and Central Africa. A CBA pilot project was conducted in Cameroon between September 2003 and August 2004 by a national team of experts trained by the OIF. The CBA was then officially introduced in Cameroon at the end of 2004. It became a component of the education sector strategy, and most donors (the World Bank, UNICEF, Plan Cameroon, a subsection of the NGO Plan International, OIF etc.) started to fund and organise training sessions on the CBA.

The CBA belongs to the category of international standardized set of reforms described by Dominique Darbon (2003) in his analysis of 'projected administrations'. Designed externally by international experts, the CBA is presented as a transferable and replicable model that responds to the cost/efficiency concerns of donors. The way in which educational issues were set out as technical problems that could be solved with an appropriate set of reforms and tools is symptomatic of the capacity of development policy "to depoliticize whatever it touches" (Ferguson 1990: $\mathrm{xv})$. However, as we shall attempt to show in this chapter, technocratic reforms does not mean the end of politics. On the contrary, reforms produce their own political logics which are played out in bureaucratic and administrative processes. 


\section{A 'command' Administration}

The Ministry of Basic Education (MINEDUB) was created in 2004, following the division of the former Ministry of Education into four distinct ministries: the Ministry of Basic Education, the Ministry of Secondary Education, the Ministry of Higher Education and the Ministry of Technical and Professional Education. Officially, the MINEDUB, which is in charge of pre-primary and primary education and primary teacher training, was created in order to pay more attention to the specific needs of basic education in the context of Education for All programmes. In fact, this division diminished the size and power of a huge Ministry of Education while at the same time opening up new ministerial positions and extending the bureaucratic apparatus both at central and local levels. At a time when the Cameroonian educative system is exposed to intense international collaboration, this means, for example, that a person in each Ministry is responsible for the coordination with each donor programme (e.g. World Bank, Plan, UNICEF). This administrative reorganization contributed to the blurring of the connections between the various levels of education at the expense of an inclusive sectorial approach to education from pre-primary to university levels, which was praised by the international donors, and by multiplying the interlocutors and aid entry points, it expanded the opportunities for the capture and control of the resources released through international reforms.

Like other ministries, the Ministry of Basic Education's administration is organized on the basis of a prefectural model which replicates the national administrative network at all territorial levels. The Directorate of Primary and Pre-primary Education and Teacher Training (Direction de l'enseignement primaire maternel et normal) is in charge of administrative supervision while the Inspectorate-General for Education (Inspection générale des enseignements) is responsible for all educational issues. It has three subdivisions: Information and Communication Technologies (Technologies de l'information et des communications or TIC), Bilingualism, and Pre-Primary Education.

This general organization is roughly replicated at the regional and departmental levels, with a strong dichotomy between politico-administrative functions and educational work. Each of the 20 regional primary education delegates (délégués régionaux pour l'éducation de base) represents the minister's authority over the regional school systems. Effective educational supervision at the regional level is in the hands of the provincial co-ordination inspector (inspecteur provincial de coordination) and of three provincial educational inspectors (inspecteurs provinciaux 
Table 1. The prefectural organization of the Cameroonian education system

\begin{tabular}{|c|c|c|}
\hline Level & Position & Number \\
\hline National & $\begin{array}{l}\text { National inspectors for education (bilingualism; } \\
\text { information and communication technology; } \\
\text { pre-primary, primary, and teacher training) }\end{array}$ & 21 \\
\hline Region & $\begin{array}{l}\text { Regional inspectors for education and regional } \\
\text { inspectors for coordination }\end{array}$ & 80 \\
\hline Department & Education councillors & 116 \\
\hline District & District inspectors & 367 \\
\hline Schools & School principals & 13000 \\
\hline Schools & Teachers & 84765 \\
\hline
\end{tabular}

de pédagogie) for bilingualism, primary/pre-primary/teacher training and information \& communication technologies respectively. In the $5^{8}$ departments, two education councillors supervise the work of the 367 district inspectors (inspecteurs d'arrondissements), and the latter, in turn, supervise the school principals. Table 1 summarizes this administrative organization.

This highly centralized administrative structure shapes the nature of the work conducted by the Inspectorate-General for Education. Indeed, most of its tasks are organized along a rigid hierarchical pattern. Before any decision reaches the school teachers, it must descend through all of the levels on the administrative ladder. And any information originating in the schools must ascend through all of the educational levels. For example, school teachers are supposed to produce exam topics for the Primary School-Leaving Certificates (Certificats d'études primaries or CEP) awarded on completion of primary school education. The proposed subjects are revised and harmonized at each stage of the educational chain (head teacher, district, province) before they reach the MINEDUB's examination office which selects items for the examination.

This administrative structure produces paperwork at all levels. In fact, it would appear that the main activity of the school inspection administration is to produce, revise and compile reports. For example, routine reports written by the school principals are reviewed and compiled by the district inspectors who forward their reports to the department level, from where they are then sent on up the hierarchical chain. Since each level is responsible for the supervision of all levels below, this means that all field inspectors are supposed to conduct school inspections and supervise the administrative work of their colleagues at lower levels. However, as it emerged in the course of our interviews, school inspections are quite 
rare. For example, some national inspectors had not been on even one inspection tour in the course of the past year. All schools are visited twice or three times a year by the district inspectors, at the beginning and again at the end of the school year to supervise examination sessions. However, these inspections are merely administrative: their main object is to collect administrative information for the reports submitted to the hierarchy. There are very few contacts with teachers. Due to the lack of finance for transport, inspectors do not go out into the field as often as they should or would like to. Consequently, when they occur, these school visits take place in the most accessible or convenient locations, resulting in huge geographical discrepancies in the actual supervision of the school system. All of the inspectors interviewed complained about the administrative aspect of their work (mainly reviewing reports). According to them, inspection should be more practical and educational, i.e. they should be out in the field more often. These kinds of complaints could also be read as demands for greater visibility in terms of the exercise of power.

When they happen, school inspections mobilize the entire school community (principal, teachers, parents and district inspectors) who are supposed to accommodate, feed and entertain the inspection team (in some cases, national inspectors even receive livestock). This kind of unloading of material charges to the lower levels of the education chain (or civil society) has two consequences. First, it fosters personal relations within an administrative system which, according to the legal-rational logic, should be depersonalized. Second, it also reinforces the authoritative character of the system by publicizing the power of the administrative agent.

To some extent, the way the national system of educational inspection is organized shows important similarities with what Dominique Darbon (1994) describes as "command administration" in that it combines a high level of centralization with a powerful bureaucracy. In this kind of configuration, power and authority directly originate from the position held within the system rather than from skills and competencies, or even the capacity to perform the assigned tasks correctly.

All central services (including the Inspectorate-General for Education) of the Ministry of Basic Education, which is based in Yaoundé, are accommodated in an eight-storey building. The top flour is allocated to the Minister and direct collaborators. The General Secretary and the Direction for Primary Education are on the seventh floor. The sixth floor is occupied by the Inspectorate-General for Education. The size of the offices, the number of auxiliary staff posted in the waiting room and the quality of the equipment (size of the carpet and TV screen, video and audio equipment, 
quality of air conditioning) are directly related to an actor's rank in the ministry's hierarchy. This is a quite common situation in most Africanand indeed Western administrations-however, the level of the discrepancies in the quality of the resources provided to the administrative and educational services is striking.

In fact, the working conditions in the services of the InspectorateGeneral for Education are very poor. Five to six national inspectors share the same office and have no telephones or computers. The few cars controlled by the ministry are allocated to the heads of the general services; none are available for inspection tours. The same situation prevails at the provincial, departmental and divisional levels: most resources go to the administrative staff and very few are made available for actual educationrelated tasks.

This diversion of resources towards the administrative rather than educational functions and towards the higher ranks of the administrative structure is symptomatic of the morphology of a command administration. What is at play here is less the ability to perform a task than the capacity to exercise power and authority. In this kind of administrative structure, the position provides authority. And, in reality, administrative appointments do not always follow a clear rule. While-as in many African administrations - personal relations, kin and family networks play a key role in access to certain positions, the capacity to control access to resources is also important for agents to secure their authority and legitimacy. Therefore, at each level of the administrative structure, agents try and develop specific strategies for capturing material and symbolic capital that will strengthen their own authority while reducing the state's power and capacity to its bureaucracy. Such strategies appear particularly clear when reforms are being implemented.

\section{The Bureaucratization of an EducAtional REForm}

The CBA reform, which was devised at an international level and conducted by education actors under the responsibility of the Inspectorate-General for Education, offers a good example of the multilevel and multi-actor dynamics at play. International reforms usually inject new resources into an administrative system characterized by scarcity. Hence the reform process must be analyzed and interpreted as the result of combined internal (bureaucratic) and external (donor) logics. Like many other educational reforms, the CBA was introduced in Cameroon as a technical device 
aimed at solving educational issues. In the following section I will analyze the way in which a theoretically cost-efficient reform process is being circumvented by bureaucratic actors in order to capture and capitalize on the external resources generated by the reform and thereby divert the reform from its initial objectives. ${ }^{7}$

\section{The Anatomy of a Reform Process: The CBA in Cameroon}

The way the CBA reform began to be implemented in Cameroon from 2004 corresponds to the two main characteristics of the new international aid paradigm. First, it encourages a close partnership between technical and financial partners and state actors, and second, it promotes cost-efficient technologies. The cascade training scheme, through which the CBA reform was channelled, provides a good example of this type of technology.

The CBA was introduced and generalized in Africa in the mid-199os alongside reforms aimed at generating large-scale change in education. It actually appeared to offer a cost-efficient training scheme at a time when international aid resources and technical resources, in particular, were drastically reduced (Hayes 2000). The principle of this training scheme is that a handful of recipients receive direct training that they then pass on to others in the context of in-service teacher-training sessions. Based on the multiplying effect of this training approach, it is assumed that large scale educational reform could reach all teachers at minimum cost. The examination of the initial steps in the CBA implementation process in Cameroon tells another story, however.

All heads of central services, national education inspectors', and regional coordination inspectors attended a one-week seminar on the CBA in November 2004. The trainers were a group of four inspectors (the general inspector for education, two national inspectors and one regional inspector) who had benefited from first-hand training sessions on the CBA organized by the IOF for all French-speaking countries of central Africa. Trainees were identified for each country as national resource persons on the CBA. Following the national seminar, training sessions were supposed to be organized on a regional basis for regional, departmental and district

\footnotetext{
7 For a similar dynamic between donor logics and 'peasant logics', see Elwert and Bierschenk 1988 and Olivier de Sardan 1988.
} 
inspectors so that they could pass on their new knowledge about the CBA to teachers during the annual in-service training programme.

Alongside this national training scheme, the donors started to finance training sessions on the CBA. Ten training sessions were organized between 2006 and 2008, all of which were based on the same classical topdown model of cascade training. In 2006, the World Bank started a threeyear programme of workshops focusing on competencies and evaluation within its Sector Strategy Assistance Programme (Programme d'appui à la stratégie sectorielle, PASE). UNICEF and Plan Cameroon also held training sessions on the CBA during the same period. All were more or less organized on the basis of the same hierarchical pattern. When summing up the total number of days of training received on the CBA by each category of education actors, there is a striking discrepancy between the top and the bottom of the education chain.

Between 2006 and 2008, national inspectors spent 29 days in training sessions organized by donors. However, the district inspectors, who interact more closely with the school teachers, only received seven days of training; no teachers or principals attended any of these training sessions. In one of these training sessions, for example, it was the local head of UNICEF who insisted that local officers (at district and department levels) be part of the training scheme at some point while the Inspectorate-General for Education would have preferred to reserve it for the highest levels in the hierarchy. In fact, these training schemes follow administrative rather than educational logics as the level of training directly depends on the position held in the bureaucratic hierarchy. The fact that some education actors might be 'over-trained' in some regards clearly does not mean that the educational reform will be more effective (for a similar analysis from West Africa, see Yessoufou 2011).

The way in-service teacher training is planned in Cameroon makes it difficult for such comprehensive educational reform to effectively reach the "street-level" actors (Lipsky 1980) of any educational change: the teachers. At the beginning of each school year, in-service training sessions are organized at the district level for the school principals and some teachers (animateurs pédagogiques de niveau). They last for one to two days and are run by the district inspectors and other departmental and provincial staff when available. Various issues are discussed during these sessions. The CBA and its various aspects were one of the national themes chosen in 2008 , in order to disseminate the training received by the higher staff. For this purpose, weeks of training had to be compressed into three-hour 
sessions for dissemination to a limited group of teachers (principals and animateurs de niveau). In other words, the content of these sessions is more informative than formative, and the people attending these sessions received only second- or third-hand information. Because the length of training session is reduced as it reaches intermediate and local levels, there is a corresponding loss in content. The level and quality of information transmitted during these sessions depend on the capacity of the trainer to understand and reformulate what he or she learned from his or her own training. In fact, several teachers expressed doubts about the capacity of some principals and animateurs to share and transmit any new knowledge as they might not be able to understand it themselves.

In fact, when teachers were asked about the CBA four years after it was introduced in Cameroon, they made it clear that they had not been trained, and thus were not able to use this approach in their classrooms. They were 25 out of 32 to declare that they did not receive any training in the CBA before 2007 and 19 since 2007 .

\section{Widening the Gap: Teachers vs. Managers}

The principle underlying the entire process of reform implementation is the opposition between trainers and learners, linked with the bureaucratic polarization between administrative staff (inspectors) on one side and teaching staff on the other. The quantitative and qualitative deficiencies in the training of teachers, who are supposedly the main target group, demonstrate the limits of the reform. This actually raises the question of the capacity of the reform to meet its objectives, namely to produce significant educational change and improve the quality of education.

One issue frequently raised by the inspectors in the interviews was that teachers (especially the most senior among them) were not willing to change their practices because they did not see the point of these reforms which were very demanding and time-consuming. Interviews with the teachers reveal a different perspective. Most of the latter clearly see the benefits that the Cameroonian school system could yield from the CBA. However, their main problem is that they were not equipped to teach it properly, neither intellectually nor materially (in some urban areas, there are around 9o pupils per class). Moreover, teachers were not involved in the reform design. Their training, the reality of the school system and of teaching conditions had not been taken into consideration. In fact, the entire reform process from design to implementation is based on the administrative staff's representations of schools and of teachers. 
Consequently, what could be perceived by the administrative staff as reluctance to change might equally well be interpreted, from the teachers' point of view, as a form of resistance to the ways in which the reform is being implemented. In other words, the reform process itself is an obstacle to change. For example, during in-service sessions for the promotion of active teaching methods, teachers had to listen passively to their hierarchical superiors lecturing them about theory rather than practice.

None of these criticisms are actually new. The limited efficiency of cascade training has been demonstrated by several researchers (McDevitt 1998; Wedell 2005). As McDevitt stresses in his paper about Botswana:

One of the ironies of the situation, then, is that the cascade may succeed as a training mechanism, but fails in its primary goal as a means of disseminating ideas or of changing behaviour patterns. (...) Perhaps its failure lies within the metaphor of the cascade itself: if you're too far away from the source, you can easily avoid getting soaked (McDevitt 1998: 428).

This actually raises the question of the persistence of such dominant models in the field of education reform in countries of the South. There are various reasons why the criticism frequently expressed by researchers might not reach decision-making levels, one of them being, perhaps, that this kind of criticism is scarcely audible. There simply may not be any other training model available for such extensive reform programmes within the development machinery. In fact, most of the limits observed from the implementation of the CBA reforms through cascade training schemes echo criticisms of the World Bank's Training and Visit Extension system (Nijanyanupi 1976) that were formulated a long time ago.

This model of training was suggested by Daniel Benor, James Harrisson and Michael Baxter in a booklet entitled Agricultural Extension: The Training and Visit System (Benor et al. 1977), which was published by the World Bank in 1977. Up to the late 1990s, it had been implemented in over $5^{0}$ developing countries. It was progressively abandoned due to its high cost and lack of sustainability for national governments (Anderson et al. 2006; for a critique based on a West African example, see Lühe 1991). One of the main principles of this method was to rationalize methods of improving agriculture using locally available resources. The training schemes were slotted into the hierarchical command line of agricultural departments with five levels of officials above the farmers who were located at the bottom of the system. As pointed out by Nijanyanupi, this theoretically 'rational' structure in practice tended to divert resources by artificially feeding the bureaucratic structure. Equally problematic was the way information 
is actually being transmitted within this system. If a strict programme of training and visit at the bottom level was supposed to provide farmers with an intensive exposure to new methods, the way these methods were exposed are highly problematic. In fact, as Nijanyanupi stresses, the entire system was grounded in a categorical opposition between teachers and 'doers': "The teacher does not do and the doer cannot teach. In this system, knowledge is being passed on from one non-doer to another with the ultimate idea of influencing the doer" (Nijanyanupi, 1976). This author actually goes on to insist on the unbridgeable communication gap that is generated in this kind of system and hampers any possibility of change.

When the general features of the cascade training scheme in the Cameroonian education sector are considered, it appears that very little progress has been accomplished over the past three decades: indeed, the training models have actually deteriorated. Under the cascade system, few resources are allocated to the bottom level, the cornerstone of the training and visit extension system. Far from having been abandoned, it would appear that this model has had enduring effects. As far as the development technology is concerned, this corroborates the idea that development programmes are rather conservative:

This inability to learn from the past is primarily due to the fact that the development aid world has its own cognitive structures and its own communication channels. It pursues its own internal discourse, the central categories of which must be mastered. The reality which forms the frame of reference for the management and within which development projects are conceived (or implemented) is largely a derived reality, produced within this communication system itself (Bierschenk et al. 1991: 94).

Therefore, the achievement of the expected goals, e.g. changes in teaching practice in the case of educational reform like the CBA, matters less than the routinized exercise of the reform which in itself justifies the entire business of development.

\section{The Political Economy of the Reform Process: \\ The Limits to Coordination and Training}

The resources brought in by reforms opened up new accumulation and redistribution opportunities which could be used to foster the position of bureaucratic actors within the administration. Most training schemes aimed at disseminating the CBA were funded and organized by international donors. The strategies set up by bureaucratic actors and the ways in which these new resources are shared and distributed are critical to 
understanding the status and function of the reform from a bureaucratic perspective. The reform process is shot through with contradictory dynamics. On the one hand, international reforms belong to a specific cognitive order ruled by its own temporality (the project), its own set of replicable technologies and its own channels of communication. On the other hand, bureaucratic actors pursue their own agenda in the implementation process. Two further examples of these contradictory process and its consequences are developed below to illustrate the issue of reform planning and the individual uses of reform dividends.

Theoretically, the Inspectorate-General for Education is responsible for the coordination of all teaching activities, both internal and external. However, as far as the CBA is concerned, most training schemes and teaching programmes were carried out without any real effort at coordination. At a structural level, both technical and financial partners are represented in the Ministry by an official who is in charge of linking up donor projects to the Inspectorate-General for Education's agenda. However, in fact, most of these programmes were conducted independently both in terms of timing and content and thus led to conflicts and confusion.

In spring 2007, for example, some inspectors attended almost three consecutive weeks of training sessions on the CBA held by Plan Cameroon and the World Bank. However, the contents and approaches varied from one donor to another and, depending on the consultancy firm hired for training sessions or the teaching material used, caused much confusion in the minds of the so-called beneficiaries. Some activities were clearly redundant. In 2007, Plan Cameroon and UNICEF produced two sets of guidelines on the CBA, which turned up to be almost identical. It was only when the booklets were completed and ready to be sent out that the two organizations realized that the work had been duplicated and paid for twice. This lack of coordination and planning of the reform process raised major educational problems. Hachette Livre International, a private publishing house, published a complete set of school textbooks based on skills (in a series called Nouveaux champions). They were adopted as official text books in most Cameroonian primary schools in 2006, a time when new CBA curricula had not been officially adopted and when the training of teachers on this approach had scarcely begun. To make matters worse, the CBA approach was introduced alongside other educational approaches. For example, the French Académie des Sciences developed its scientific experimental programme known as 'La main à la pâte', LAMAP ('Hands On'), at a time when Cameroonian teachers were still trying out 
micro-science tool kits. These last programmes, which focused on the teaching of science, were not really competing with the CBA, which is far more inclusive, however from the teachers' point of view, and considering the way educational innovations are being implemented, the value and opportunity presented by this reform overload may be questioned. In fact, all of these programmes were introduced in Cameroon when teachers were only beginning to adjust to and master the previous educational reform called the Nouvelle Approche Pédagogique, NAP ('new pedagogical approach') which is based on active teaching methods and started at the end of the 1990s.

It is less the diversity of these pedagogical experiences that is problematic than the limited space provided for knowledge transfer under the current in-service training schemes whereby (some) teachers are only exposed to these new approaches once a year. In fact, this "piling up" (Darbon 2003: 13) of educational innovations sheds light on the political economy of reform. Far from being a Cameroonian specificity, the lack of coordination appears to be part of the general reform outlook and economy.

"The systematic sabotage of all efforts towards co-ordinating development planning" (Bierschenk et al. 1991: 4) raises the issue of who benefits from this reform overload. The more reforms there are, the greater the opportunities available to bureaucratic agents to reap individual benefits from them. However, this proliferation of reforms is also generated by donor agendas. Most projects are scheduled on a short-term basis (two to three years), which is also the length of staff contracts. The record of most international aid agencies is evaluated on the basis of their capacity to fund a certain amount of projects. Against this background, organizations are eager to answer as many demands originating from national governments as possible. On the other hand, government services are happy to multiply such demands as reform processes feed into the development of bureaucracies.

In addition, international reforms produce material and symbolic resources used by bureaucratic agents to foster their power and authority within the command line. Most training sessions funded by technical partners are organized in cosy beach hotels, and participants are granted per diems. One of the district inspectors interviewed was very forthright in his analysis of the situation:

When we talk about training, people think of the per diem. This is why at the central level people will try their best to keep the per diem up there. 
This is not based on any educational reason, but people think of the money first, the money they want to keep for themselves. ${ }^{8}$

In fact, interviewees tend to have more memories of the locations and the 'quality of service' offered during the training sessions than their content. However, the very same people often vehemently defend the intellectual value of such training courses.

The following excerpt from an interview conducted with a group of educational councillors (department) shows how access to training sessions also is a key instrument for building up and assessing their own authority and legitimacy within the system:

Q: Is the competency-based approach to curricula effective in Cameroonian primary schools?

A: It's starting. But we need to enforce it (twice). We ourselves are not sufficiently trained. The better we are trained, the better the information that will be passed to the teachers. Most teachers are familiar with the "New Pedagogical Approaches". But the competency-based approach is still a problem.

Q: How come?

A: Because, we, the resource persons (repeated three times), did not receive formal training that will enable us to supervise the teachers properly. It is our own curiosity that led us to teach ourselves some things but we did not receive any specific training.

Q: But you seem to have some knowledge of competency-based approaches. A: This is because, as intellectuals, we shouldn't talk nonsense about competency-based approaches. It is through our individual work that we were trained. We have bought and read books from abroad. We also have talked with colleagues who have been trained abroad.

The claim made by this intermediate section of the bureaucratic structure of being fully integral to the reform process highlights two issues. In their discourse, they clearly try to position themselves as key actors of the reform process between the teachers (compared to whom they are 'the intellectuals') and the armchair inspectors (who do not have any practical field-based knowledge). On a symbolic level, being part of the reform process through either training or self-teaching also means belonging to an epistemic community sharing the same language and representation of the universal value of reform as a means of progress and modernity. This specific knowledge produced by the reform appears as major symbolic source of authority and legitimacy.

8 For an analysis of the per diem mentality based on a Ugandan case, see Smith 2003. 
However, like any resource, the dividends of reform can be distributed and hence also appear as a way of fostering personal links within the administrative structure. For example, the criteria for selecting national inspectors as trainers in the CBA training schemes were not always very transparent. Some of them did not really have any direct experience with the CBA while some of the OIF-trained Cameroonian experts were deliberately excluded from these programmes. Various factors (including the place of origin of the people and personal relationships) appear to have played a greater role in these decisions than effective knowledge about and experience of the CBA. This further example shows how and to what extent the reform processes can be manipulated by bureaucratic actors for their own ends. It also highlights how international reforms are part of the political economy of African bureaucratic structures.

\section{CONCLUSION}

The description of the implementation process of the CBA in Cameroon illustrates the different uses and functions of reform in Africa. The competency-based approach, as many other educative reforms introduced in the broader context of Education for All programmes aimed at improving the quality of African educative systems. Far from producing the expected change, the reform was turned by bureaucratic agents into a very normative, hierarchical and administrative exercise. In fact, the main output of the reform, at this stage of implementation, has been to strengthen bureaucratic dynamics through the distribution of new symbolic and material resources.

International reforms such as the CBA, produced externally and diffused through international organizations, create a specific set of references and technologies which are supposed to trigger change and improvements in developing countries. Therefore they are infused with a kind of messianic aura of modernity and universality. As noted by many authors, the success of reform does not really need to matter as it is the reform itself that counts most. However, even if the reform does not produce the expected change in many cases, this does not mean than it does not produce anything. In fact the various resources brought in by reform processes are manipulated and diverted by bureaucratic actors in order to enforce their own position within the bureaucratic structure.

In developing countries and beyond, reform processes are a major field for the structuring of social and political relations. Not only do they sustain 
the development of bureaucracies (in terms of manpower and activities), they also organize power relations within a given administrative structure. The linking up of external and internal dynamics is, therefore, part of state construction processes in developing countries.

\section{REFERENCES}

Anderson, Jock R., Feder, Gershon and Sushma Ganguly. 2006. The Rise and Fall of Training and Visit Extension: An Asian Mini-Drama with an African Epilogue. Washington DC, The World Bank.

Benor, Daniel, Harrison, James Q. and Michael Baxter. 1977. Agricultural Extension. The Training and Visit System. Washington DC, The World Bank.

Bierschenk, Thomas, Elwert, Georg and Dirk Kohnert. 1991. The long-term effects of development aid: empirical studies in rural West Africa. Economics, 47 (1): 83-111, available at: http://mpra.ub.uni-muenchen.de/4217.

Blundo, Giorgio and Jean-Pierre Olivier de Sardan. eds. 2007. État et corruption en AfriqueUne anthropologie comparative des relations entre fonctionnaires et usagers (Bénin, Niger, Sénégal). Paris, Karthala.

Chibber, Vivek. 2003. Locked in Place: State-building and Late Industrialization in India. Princeton, N.J., Princeton University Press.

Darbon, Dominique. 1994. L'aventure ambigüe des administrations africaines de succession française dites francophones. Revue internationale de politique comparée, 1 (2): 201-222.

— 2003. Réformer ou reformer les administrations projetées des Afriques? Entre routine anti-politique et ingénierie politique contextuelle. Revue française d'administration publique, 105-106: 135-152.

. 2004. Pour une socio-anthropologie de l'administration en Afrique II. Retour méthodologique à propos d'un article de Jean-Pierre Olivier de Sardan. Politique africaine, (96): 163-176.

Elwert, Georg and Thomas Bierschenk. 1988. Development aid as intervention in dynamic systems. Sociologia Ruralis, 28 (2-3): 99-112.

Ferguson, James. 1990. The Antipolitics Machine. Development, Depoliticization and Bureaucratic Power in Lesotho. Minneapolis, University of Minnesota Press.

Hayes, David. 200o. Cascade training and teachers' professional development. English Language Teaching Journal, 54 (2): 135-45.

Lipsky, Michael. 1980. Streel-level Bureaucracy: Dilemmas of the Individual in Public Services. New York, Russell Sage Foundation.

Lühe, Nico von der. 1991. Transfer of technology or barter trade? The rural extension service in the Atlantic Province of Benin as a market for negotiating resources. Quarterly Journal of International Agriculture, 30 (3): 248-263.

McDevitt, Damien. 1998. How effective is the cascade as a method for disseminating ideas? A case study in Botswana. International Journal of Educational Development, 18 (5): 425-428.

Ministère de l'éducation du Cameroun (MEC). 2003. Rapport d'Etat du Système Educatif National Camerounais (RESEN), Yaoundé.

Nijanyanupi. 1979. The Benor System. Economic and Political Weekly, 14 (17): 761-763.

Olivier de Sardan, Jean-Pierre. 2004. Etat, bureaucratie et gouvernance en Afrique de l'Ouest francophone. Un diagnostic empirique, une perspective historique. Politique africaine, (96): 139-162.

- 1988. Peasant logics and development project logics. Sociologia Ruralis, $28(2-3)$ : 216-226. 
Ropé, Françoise and Lucie Tanguy, eds. 1994. Savoirs et compétences. De l'usage de ces notions dans l'école et l'entreprise. Paris, L'Harmattan.

Sindjoun, Luc. 1996. Identité nationale et 'révision constitutionnelle' du 18 janvier 1996: Comment constitutionnalise-t-on le 'nous' au Cameroun dans l'Etat post- unitaire? Polis 1, available at: http://www.polis.sciencespobordeaux.fr/volins/sindjoun.rtf.

Smith, Daniel J. 2003. Patronage, per-diems and the workshop mentality: the practice of family planning programs in South-eastern Nigeria. World Development, 31 (4): 703-715.

Wedell, Martin. 2005. Cascading training down into the classroom: the need for parallel planning. International Journal of Educational Development, 25 (6): 637-51.

Yessoufou, Akimi. 2011. Local Actors in Top-Down Implementation of Curricular Reform in Benin's Primary Education. PhD thesis, Rotterdam, Erasmus University. 
Thomas Bierschenk and Jean-Pierre Olivier de Sardan - 978-90-04-26496-0 Downloaded from Brill.com@4/26/2023 02:08:21PM via free access 


\title{
BUILDING STATE CAPACITIES? \\ THE CASE OF THE POVERTY REDUCTION UNIT IN MALI ${ }^{1}$
}

\author{
Isaline Bergamaschi
}

This chapter examines the ability of international organizations to shape and reform African administrations. In doing this, it highlights the practical implications of buzzwords such as ownership and capacity-building. It builds on the case-study of the technical unit (Cellule technique Cadre stratégique de lutte contre la pauvreté) established under the Poverty Reduction Strategy Paper (PRSP) in Mali, an aid-dependent country in West Africa. ${ }^{2}$ Until the coup d'état that took place in 2012 and the ensuing political instability, despite its poor economic performance, Mali was considered by the international community as a model of democracy, good governance and aid management in sub-Saharan Africa. However, empirical data collected over the course of six months of fieldwork and participant observation within the PRSP unit in Bamako in 2007-2008 tells another story.

This chapter primarily seeks to explain this paradox. I argue that targeted capacity-building initiatives - embodied by the PRSP unit-have limited impact, particularly when they have to deal with pre-existing institutional features, social relations and competing interests created by the unit itself. However, I also show that international support has made unexpected contributions to the process of state formation in Africa.

The chapter is divided into three main sections. The first section presents the theoretical framework used to interpret international initiatives

1 This article is based on six months of fieldwork in Bamako in 2007 and 2008 where I was able to conduct approximately 100 interviews with civil servants and representatives of aid organizations, and to carry out participant observation as an intern in the Malian PRSP technical unit. I would like to thank the staff of the PRSP unit, its coordinator and technical assistants for welcoming me among them. I would also like to thank Jeremy Gould and Philippe Bezes for their early advice on how to approach this topic and conduct fieldwork, and Jean-Pierre Olivier de Sardan and Thomas Bierschenk for their comments on a draft presented at the third European Conference on African Studies in Leipzig in 2009 and subsequent drafts. I thank Hélène Charton for proofreading the final draft of the text. I bear sole responsibility for any remaining errors.

2 There are approximately 40 bilateral and multilateral donors in Mali, the biggest of which are the European Commission, the World Bank and France, followed by the Netherlands, Japan, the United States, the African Development Bank, Canada and Germany. Aid accounts for a large share of the country's total budget. Between 1996 and 2005, aid represented an average of three-quarters of the country's Special Budget for investment and 27.6 per cent of the state's general budget (Bergamaschi 2008: 222-223).

(C) ISALINE BERGAMASCHI, 2014 | DOI: 10.1163/9789004264960_012

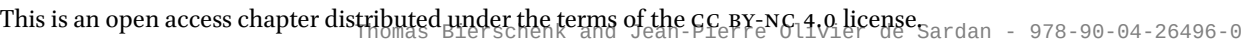


aimed at strengthening African states. It provides both an overview of donor approaches to state capacity-building and a critical overview of how the issue has been addressed in the academic literature. The second section explores the daily activities of Mali's PRSP unit and accounts for its failure to achieve its goals. The root causes of this failure, mainly the external and internal resistance to the unit's hegemonic ambitions, are identified. The third section presents some concluding remarks on capacity-building and state formation in Mali.

\section{INTERNATIONAL DONORS AND THE AFRICAN STATE: SHIFTING PARADIGMS}

The approach adopted by international donors towards African states over the past 50 years has been contradictory and shifting. Over time, it ranged from support for the developmental state (from the 1950s to the 1970s) to anti-state policies (diminution of resources, retreat from the main economic sectors, the privatization of parastatals) with structural adjustment programmes (SAPs) implemented in the 1980s and 1990s. A partial reassessment of the role of the state was carried out in the late 1990s together with the promotion of capacity-building strategies (Bezes 2007). This shift arose in response to the mitigated outcomes of SAPs, and the harsh criticisms they triggered at a time when the legitimacy of the international financial institutions (IFIs, e.g. the World Bank and the International Monetary Fund) was called into question. The Asian miracle highlighted the role of the state in development success stories and invited the World Bank to develop a new approach, which was presented in its 1997 annual report under the title "The state in a changing world" (World Bank 1997).

This reassessment was limited, however. First, an implicit defiance towards the state persisted at the World Bank and the IMF, particularly when it came to dealing with Africa. Second, the myth of the 'apolitical' norm prevailing in IFIs led to a technical conception of state reform, viewed and promoted as a set of measures to be uniformly implemented in developing countries (Miller-Adams 1999: 5-6, Peñafiel, 2008; see also Anders, Charton and Muñoz in this volume).

In the post-Washington consensus, a lack of "commitment" and "political will" on the part of recipient governments was identified as a major impediment to successful reform (Killick 1998). IFIs did not question the relevance and content of SAPs. Nor did they rehabilitate the idea of sovereignty, self-determination (Whitfield 2008) or indigenous policy-space as 
a means of development (Chang 2006). Instead, they blamed insufficient implementation for failure (Whitfield 2008), and thus promoted the idea of “ownership" (Johnson and Wasty 1993).

At the same time, the development paradigm also evolved with greater emphasis being placed on poverty reduction. While 'sound' macroeconomic and adjustment policies were pursued (through liberalization, privatization and trade openness), social safety nets based on human development policies were introduced with a focus on basic education and health, specific measures targeted the poorest alongside comprehensive state reform processes (Fine et al. 2001). Indeed, since the late 1990s, good governance has become a cornerstone of donor intervention (Hatcher 2009) and has hence led to the proliferation of conditionalities, triggers and benchmarks. In this new context, the scope of international intervention was broadened, shifting from the economic to the institutional arena as greater attention was being paid to the policy-making process in addition to policy content (Fraser 2008).

Reforming the state from within is increasingly been seen as a way of enhancing ownership and embedding poverty reduction strategies in developing countries. This functionalist approach is inspired by neoinstitutionalism: from this perspective, better institutions are necessary for the success of economic reforms (Campbell 1997; Stone and Wright 2007). Some authors have argued that the current aid agenda deals at least as much with state formation as with economic reform (Gould 2005; Peñafiel 2008). In the Western project of global governance (Williams 2006) state reform and poverty reduction should, therefore, be regarded as the two sides of the same coin.

These principles, which are at the heart of the new international aid system, have been enshrined in the Poverty Reduction Strategic Papers (1999), which were introduced by the World Bank as a condition for eligibility by developing countries for the Highly Indebted Poor Country Initiative (HIPC). PRSPs are pluri-annual plans geared towards the fulfilment of the Millennium Development Goals.

\section{The Paradoxes of Capacity-BuIlding in Mali: 'OWNERSHIP' AND FUSION}

In the era of ownership, the role of donors must accordingly shift from coercion to persuasion and influence, and the World Bank should "ensure that the process of policy reform is internalized in the country as quickly 
as possible" (Johnson and Wasty 1993). According to the IFIs, this describes a new, consensual 'partnership' with African governments.

In this context, capacity-building activities are crucial, to the extent that they can help to reform African states (Darbon 2003) by creating points of interaction and spaces for dialogue between donors and recipient governments. The dissemination of specific skills and capacities (stakeholder consultation, poverty monitoring, macroeconomic literacy and public expenditure tracking) among recipient states is seen as a lubricant in the poverty reduction process (Gould 2008: 91). In an empirical study of the World Bank describing attempts to constitute 'governance states' in Tanzania and Uganda, Graham Harrison argues that second generation institutional reforms and capacity-building projects aim to generate a specific form of state administration that is capable of pursuing reform, winning domestic political support and managing its relations with donors (Harrison 2004).

Capacity-building projects are hence intended to help governments develop autonomous decision-making, policy implementation and followup. However, if the recipient is formally given more control over the use of aid and a bigger role in the development process, its supposed lack of capacity serve to legitimize external intervention and the placement of technical assistants by donors in strategic positions at the heart of African administrations in the areas of planning, budgeting and spending processes (Gould 2005: 45; Bergamaschi 2008). Capacity-building, related units and technical assistance rest on this paradox and ambiguity. This is why some authors view capacity-building initiatives as technical transfers of knowledge as much as "political interventions designed to produce particular modern subjects" based on both coercion and inclusion, empowerment and discipline (Abrahamsen 2004: 1462-1463). Some African civil servants see technical assistance as a way for donors to keep an eye on public-spending process (Bergamaschi 2008: 232-233) and to become more closely involved in state governance (Gould 2005: 10).

In practice, capacity-building projects and units also meet pragmatic donor needs and interests. They give them the opportunity to choose their counterpart in the administration or on its periphery, to quickly establish functioning structures without increasing the government's tight national budget, to maintain control over the operations, and to shape national institutions according to their needs. As donors finance the PRSPs, they expect a clear idea of how the funds are spent. As one donor representative puts it: 
What donors want is a structure that can start working quickly, someone to talk to, someone who will answer the phone, answer their questions and follow up their programmes-not an administration that would be efficient for and accountable to the population (Interview, Bamako, 2007).

To a certain extent, implementation units are also aimed at rebuilding what was destroyed by structural adjustment programmes in the area of policy planning. These parallel implementation structures enable donors to fill in some of the perceived gaps and claim that they reinforce the state while bypassing the normal administration-which they generally consider as unreliable and underperforming.

The "cancerous proliferation" (Interview with Technical Assistant at the PRSP unit, Bamako, 2007) of such project units in downtown Bamako is largely encouraged by donors. In 2007 , their overall number was estimated roughly at 33 , and they were mainly concentrated in the areas of agriculture, decentralization, economics and finance. ${ }^{3}$ These units, which are often attached to a ministry but located in different buildings and composed mostly of civil servants with better working conditions, are ad hoc creations with limited life expectancy. Therefore, project aid persists despite donor commitments to supporting national administrations through programme and budget aid: old and new mechanisms coexist and often overlap, thus making the aid management framework more fragmented and confused (Whitfield 2008).

However, the proliferation of units should not be seen as unilaterally imposed by donors on passive, dependent recipients; instead, capacitybuilding projects are part of extraversion strategies and a source of rent for African elites, more specifically the highest ranks of civil servants in the public administration. ${ }^{4}$ Indeed, the multiplication of such units provides opportunities for additional financial and political resources. The post of head or coordinator of a unit is a good one, and can be assigned as a reward to a political supporter or a loyal civil servant. It is worth noting that in Mali, as is the case in Senegal, the aid market could be the second biggest provider of formal jobs after the civil service. ${ }^{5}$

3 This estimation is compiled on the basis of the data found on the website of the Malian Ministry of Foreign Affairs and International Cooperation: http://www.confedmali .gov.ml/contact.php.

4 This terminology is borrowed from Jean-François Bayart (2000).

5 This estimation about Senegal was referred to in a World Bank report (2006). 
Building on these elements of context and theoretical background, I shall now present my empirical material about the PRSP technical unit in Mali and its limited results.

\section{The PRSP Unit in Practice: Failed Institutionalization}

The government of Mali adopted its first PRSP in 2002 and second in 2006. The first PRSP was drafted by a light and informal structure composed of three people: a statistician and geographer, who was an advisor to the Ministry of Planning at the time, and two young economists educated in France. The United Nations Development Programme hired an international consultant to assist them on the grounds that drafting the PRSP required specific expertise.

To enable Mali's government to write and monitor the PRSP, the creation of a PRSP 'technical unit' was suggested; a move that reflected donors' preference for a new, special unit outside the administration. The unit, which is formally attached to the Ministry of Economics and Finance, is located in a separate building and enjoys relative autonomy. Its coordinator, a former official of the Ministry of Planning, is also a special advisor to the Minister of Economics and Finance.

Since its creation in 2001, the unit has been supported by donors, both financially (mostly by the European Union-EU) and through a technical assistance (TA) programme which allocated six technical assistants (TAs) in total, each of whom stayed at the unit for more than twelve months.

From the donors' perspective, the unit's goal is to make the PRSP the country's main development strategy. According to official documents, the unit should:

1. ensure the good functioning of PRSP institutional mechanisms and the coordination of all activities related to it;

2. reinforce the structures of the administration, civil society and the private sector for the implementation and follow-up of the PRSP and civil society participation;

3. follow-up the use of resources, and in particular HIPC resources;

4. develop an information system to inform public policy decisions, monitor and assess the implementation of the PRSP, in cooperation and partnership with other relevant institutions and national actors;

5. coordinate international aid efficiently based on the needs of the PRSP and structure the policy dialogue with donors on the implementation of the strategy.

The unit was viewed as an "island of effectiveness" (Roll, this volume), a kind of bubble protected from the rest of the administration, an 
institutional fix. The unit's office is located in the quartier du fleuve-the capital city's administrative district situated close to the river Niger-and has expanded to employ 30 people who enjoy much better working conditions than their counterparts in any average administrative service: airconditioning, cars and petrol vouchers, chauffeurs, a broadband internet connection and salaries comparable to those generally paid to local staff in donor agencies, i.e. XOF 1,000, ooo (around EUR 1,500) per month on average compared to approximately XOF 400,00o (600 Euro) for a civil servant of similar rank in the administration (Interview, Bamako, 2007).

The unit provides an interesting site for observing contemporary aid practices. Indeed, the unit is extensively penetrated by donors; its members appear to have internalized the logics of international involvement and policy dialogue better than civil servants in other parts of the administration. As one of them put it: "Donors are very involved, they have their say on everything, and that is a good thing, an asset for [our country]" (PRSP unit employee, interview, Bamako, 2007). This unit offers a perfect example of institutional entanglement (Whitfield 2008), and the merging of donor agencies and recipient administrations characteristic of contemporary aid practices (Harrison 2004).

The unit offers a setting for permanent interactions with donors which is considered as isolated from poor people. It is interesting to note that the unit's self-sufficiency is identified as a positive step, a sign of its independence and efficiency. As one employee from the unit put it:

The situation has improved a lot. For the first PRSP, the process was all brand new, and people had not grasped our role and rules. They thought that the unit was doing some charity work: old people, refugees and poor women would come and knock on our door, asking for direct support like financial aid or microcredit. And when we explained them that it was all about writing a general policy document, they were disappointed (Interview with employee of the unit, Bamako, 2007).

Instead, the unit's coordinator is said to be able to respond to all of the donors' demands, to convince them and find a relevant argument or data capable of demonstrating the efforts or progress being made (Interview with representative of a donor organisation, Bamako, 2007). He himself is mildly cynical of the donors' real desire and ability to help Mali (Interview with unit coordinator, Bamako, 2007), and constantly navigates between his minister and the development agencies, and between various domestic and international constraints. He wears both suits and traditional costumes, and while he masters the donor rhetoric very well, he also relies on popular expressions and images to boost the morale of his team. At a meeting held at the unit in 2007 , for example, he used prayers 
and blessings in Arabic and Bambara to incentivize his team to become involved in preparing for an upcoming Round Table with donors-an event chaired by the United Nations Development Programme (UNDP), at which the donors and recipient government would discuss policy issues and donors announce indicative future aid disbursements. As the meeting followed the celebration of the Islamic feast of 'id al-kabir, he had brought along two sheep to share with the team and asked its members to forgive his sins and misdeeds (in accordance with the Islamic tradition). He also called for unity and togetherness between the managers and drivers, the local and expatriate employees, and the Christians and Muslims within the unit: "We are all here for the same cause; we share the same house and objectives, the same interests (...). If we are united, then the devil will not approach us, and Holy God will support us". His greatest wish, he said, was to make the second-generation PRSP and the Round Table a success, "for the sake of the unit [and] the entire (...) society, and for the satisfaction of the international community!". Through its fascinating mise en scène, mixing local customs and international agendas, this speech conveyed the image of a wide consensus between all of the players involved in the poverty reduction strategy and within the unit, which is scarcely observed in practice.

As of autumn 2007, the unit's activities were mostly geared towards the preparation of the Round Table with donors. One of the main concerns was to convey the image of a responsible government to the international community so as to "sell Mali" (Meetings at the PRSP unit, Bamako, 2007) and thereby secure financial resources and aid predictability. The unit and its coordinator were in the frontline in the preparation of the event which can best be understood as a "public performance" (Scott 1985) that aimed to "instil trust in the capacity of the state to do what it is supposed to do" and an image of unity and rationality (Lund 2006b: 689-70o). The frenzied production of policy documents hastily validated by ministries in April and May $2008^{6}$ fuelled a process, according to which the

6 Initiative de mise en œuvre des Objectifs du Millénaire dans les 166 communes les plus vulnérables du Programme national de Sécurité Alimentaire, Plan d'Action d'accélération de la croissance économique du Mali, Plan décennal pour la réalisation des Objectifs du Millénaire pour le Développement (OMD) 2006-2015, Stratégie de croissance accélérée sur la période 2008-2012, and Plan de financement des Cadres Stratégiques pour la Croissance et la Réduction de la Pauvreté (CSCRP) et des Objectifs du Millénaire pour le Développement $(O M D)$ sur la période quinquennale 2008-2012, All of these documents and a report on the event are available on the Round Table website at www.tablerondemalizoo8.org/index .htm. 
government of Mali was supposed to show a political will, responsibility and commitment to reform. The process was supervised by the PRSP unit, however its staff was unable to keep up with all demands and had to hire two consultants to provide additional support (a senior French economist hired by the UNDP and a young Malian economist).

The mix of national and international actors in the unit is enhanced by the presence of six technical assistants (TAs). The main sectors selected for EU-funded capacity-building are: economics and statistics, methodological support, social statistics (health, education and water), public finance, logistics and management. The ambivalent logic of capacity-building at the juncture of control and dialogue is reflected in the words of one the programme's main designers at the European Commission delegation in Mali:

The introduction of the PRSP (...) has three implications: first, macroeconomic sustainability must be ensured. This is done through the IMF and PRSP annual reviews. We also have demands concerning the different sectors included in the PRSP. Finally, we need guarantees in the field of public finance management: we want clear signs of political commitment in favour of reform (European Commission delegation, interview, Bamako, 2007).

In addition to these EU-funded TAs, a French TA financed by the French embassy was posted to the unit in response to a demand from the Ambassador himself, who hoped to enhance the ability of his staff to monitor the PRSP implementation process and lead the policy dialogue with Malian administration (Interview, Paris, 2006 and Bamako, 2007). Hence, it would appear that these TAs may be considered as "transfer entrepreneurs", "importers" (Delpeuch 2008: 41) or "development brokers" (Bierschenk et al. 2000; Mosse and Lewis 2006; Fichtner 2012) as they are responsible for translating and enforcing international norms in different local contexts and act as facilitators between national and international arenas, actors and logics. Speaking about public policies in Mali, an aid agency representative asserted: “it's impossible to distinguish between 'Malian' or donor policies. We chew and digest everything together" (Interview, Bamako, 2007).

Three of the remaining TAs were Africans (but not Malians) and two others were French. This mix of nationalities often led to situations which were highly confusing to the observer. Indeed, during meetings at the unit, it was impossible to figure out who was who and who represented what as the unit's French TAs would speak on behalf of the Malian government. Similarly, some Malians (hired as local staff by international agencies) represented the donors and would blame Malian civil servants for their lack of proactiveness and assertiveness (Meeting at the PRSP unit, Bamako, 2007). This (con-)fusion was reinforced by the project (materialized in 
2012) to "locate the [government] secretariat for aid harmonization and efficiency together with the [donor] technical pool in the courtyard of the unit" (République du Mali 2008). The rationale was to nurture physical intimacy so as to bring people belonging to different institutions closer together and hence facilitate informal, daily and constant contact.

The question that arises here is whether this genuine fusion of actors, logics and practices was the result of capacity-building. Closer examination clearly reveals that the project was faced with significant limits and that the unit is not successful in fulfilling its various missions. The unit creates a space of "physical and metaphorical opportunities for engagement between actors" (Wilson 2006: 513) but it has failed to meet its officially stated objectives. The reasons for this failure are explored in the following section.

\section{DisAppointing Outcomes, Limited Results}

The unit is confronted with many limits and practical obstacles. Most interviewees appear to be disappointed and disillusioned about the unit's achievements. In the context of the domestic institutional arena, the main criticisms made of the unit are twofold. Some regret that it was set up as a separate entity from the administration, particularly because it is not in charge of a straightforward development project but of national strategy and planning. This, they say, impedes the unit's ability and legitimacy to coordinate all of the ministers involved (Interviews with Malian civil servants and donor representatives, Bamako, 2007). Civil servants also criticize it for its porosity and dependence on donors, which threaten its capacity for manoeuvre and sustainability:

The unit has become bigger and bigger, but with too many TAs (...) Very often, I see them taking the lead during meetings. I'm not a racist, but how come you see so many white faces in a unit that is supposed to be the site of 'country ownership'? How can you say that the PRSP is 'nationally owned'? We no longer master its conception (Interview with former employee of the Ministry of Planning, Bamako, 2007).

This statement reflects that in the institutional domain, "the eligibility for leadership often builds and depends on successful claims of autochthony and belonging" (Geschiere and Jackson 2006 quoted by Lund 2006b: 693).

From the perspective of the donors too, the unit has failed: in their view it does not follow any of the important issues for the country's development, it has not fostered sufficient political commitment to the PRSP and 
reform, and/or its team is not "up to the job" (Interviews, Bamako, 2007). Overall, it is felt that the results achieved by the unit are inadequate in relation to its initial mandate.

First, frustrations concerning the unit's work stem from the limits faced by the PRSP document itself. The PRSPs have been institutionalized and routinized into government priorities. However, it still is neither the government's nor donors' only reference and development strategy. The Mali government adopted the country's first PRSP in May 2002. Some civil servants involved in the PRSP process appreciated the fact that the drafting of the PRSP gave them the opportunity to debate and write the document themselves. However, World Bank and IMF supervision and donor involvement were strong (PRSP unit, interview, Bamako, 2007), and the content of the document is not very different from previous structural adjustment policy recommendations. The second PRSP (2006-2011) was adopted in December 2006. It focuses on three main areas: productive sectors and infrastructure, the pursuit of structural reforms and the strengthening of social sectors. It is akin to a catalogue of poverty-reduction targets. This can be traced back to the intervention of the supervisory ministries (Ministries of Health, Education etc.), which incorporated their priorities and strategies into the PRSP, the donors, who wanted to see their own priorities included in the document to make sure that they could later "align" on national policies (Interview with European Commission delegation, Bamako, 2008), and the rather disorganized participation of civil society. Moreover, the document displays weaknesses in terms of prioritization, operational character and budgeting strategy: little is said about how the proclaimed objectives shall be operationalized and fulfilled (Interviews with Malian civil servants and representatives of donor organizations, Bamako, 2007 and 2008). A sensible and lengthy process led to the adoption of the PRSP implementation joint assessment matrix, a complex and imperfect document that was criticized for its poor quality and not used as a result, pending further negotiations (Bergamaschi 2009).

The introduction of the PRSPs has also led to an interesting duplication of processes: President Amadou Toumani Touré refused to endorse the first PRSP because it was adopted at the end of his predecessor's mandate. For the 2007 election campaign, the President launched his own political program for economic and social development-Programme de développement économique et social-which is the only strategy to which he publicly refers to publicly and accounts for (Bergamaschi 2008). Gould (2005) noted that in many countries the PRSP is the cornerstone of a technocratic process, a tool for mobilizing aid flows which risks being 
deprived of national legitimacy and political support. However, the case of Mali case shows that it is fully connected to domestic politics.

As was the case in most sub-Saharan African countries (see Stewart and Wang 2003), civil society participation in the PRSP process materialized into formal and generally superficial discussions held in hotel rooms, assembling aid agencies and poorly representative Bamako-based organisations. The process is also believed to have had little impact on policy recommendations in Mali, especially concerning the country's macroeconomic framework and agricultural sector (Cissoko and Touré 2005).

In brief, the unit seems unable to fulfil most of its stated tasks in a satisfactory manner, thus failing to put an end to the rampant recruitment of consultants (both foreign and Malian) for the production of policy documents and reports and, hence, the privatization and extraversion of public policies. This failure is mostly due to the fact that it cannot have a strong impact on what other institutions and ministries do and how they do it (Interviews with Malian civil servants and representatives of donor organizations, Bamako, 2007 and 2008). Coordination between line policies, the monitoring of the implementation of the PRSP (results and performance) cannot be managed by the unit alone. Improving the national statistical and monitoring system is a very difficult task which requires the involvement of all the institutions in charge of public policies. But the unit's failure can also be traced to several factors, such as the unit's mandate, insufficient institutional backing, and a series of obstacles faced by TAs.

First, the unit's mandate is fundamentally ambiguous. Since its establishment, no consensus has been reached about what the unit should really invest in and achieve. The concept of 'capacity-building' is interpreted differently by the actors: while Malian civil servants insisted on training and the unit's material needs (cars, computers, oil coupons, etc.) in the early discussions, the EU promoted its own conception of how to improve poverty reduction methods and management through statistics and bureaucratic follow-up. Moreover, the unit has a cabinet-like structure: its coordinator is an advisor to the Minister of the Economy and Finance, to whom he is directly accountable, and therefore works on short-term, urgent political issues, an approach that is difficult to combine with long-term planning.

Second, some observers believe that the unit's national personnel are not adequately trained to cope with their assigned tasks (Interviews with employees of the unit and representatives of donor organizations, Bamako, 2007 and Paris, 2008). Several of its employees are graduates in 
law, economics and politics, and also received additional training abroad, for example in France, Germany and Côte d'Ivoire. Several of them are civil servants seconded from the Treasury or the Budget division and, hence, experts in public finance management or national accounting. According to some informants, this prevents them from seeing the bigger picture about development issues and strategy, a problem aggravated by the lack of a macroeconomist in the unit. An analysis of their CVs shows that many of the unit's employees were previously responsible for donor projects and the amount of training they have received in a number of fields is impressive; however most of them lack practical knowledge and experience of the national administration's procedures, formal and informal rules etc. They therefore lack both the capacity and legitimacy to coordinate different national institutions (Interviews with employees of the unit and TAs, Bamako, 2007 and 2008).

More importantly, the unit incites resistance, both externally (other institutions) and internally (against the TAs).

\section{United Against the Unit? Patterns of Resistance by INSTITUTIONAL ACTORS}

The unit is an increasingly powerful but contested actor. Its establishment has engendered confusion, potential for overlapping and resentment among national structures.

When PRSPs were introduced in Mali, the donors believed that none of the country's existing institutions had the capacity and necessary resources to manage them. This reflects the general distrust of African institutions by donors and is also an implicit acknowledgement that national administrations and development planning capacities were weakened in part as a result of SAPs. Despite their experience in the field of development planning, the IFIs were suspicious of the Ministry of Planning, which they associated with the socialist development phase (between 1962 and 1968 under President Keïta and, arguably also, during the subsequent military regime from 1968 to 1990). They insisted that the unit should be attached to the Ministry of Economics and Finance (Interview with Malian civil servant, Bamako, 2007), with whom they traditionally enjoyed privileged contact and have more in common. This was a turning point in a process involving the marginalisation of the Ministry of Planning in Mali. Hence, this initial choice should be understood as part of a wider competition between the UNDP (which has often been supportive of planning 
ministries in Sub-Saharan Africa) and the IFIs. This competition is both strategic (i.e. about leadership in the donor community) and ideological, since the UNDP has been very critical of IFI-driven SAPs. It is interesting to note that this competition is mirrored in national institutions, to the extent that each international agency has their particular clients within the government structure. ${ }^{7}$

The proactive attitude deployed by the coordinator of the PRSP technical unit in the implementation and monitoring of the PRSP was later interpreted as a threat by other institutions, which felt bypassed and relegated. The 'ministerial super-powers' allocated to the unit generated resentment and grievance among other institutions, namely the Ministry of Planning and other supervisory ministries which were protective of their special relationships and direct interactions with donors, and other structures such as the Observatoire du développement humain et durable (ODHD, a UN-sponsored human and sustainable development project responsible for the analysis of poverty reduction) and the presidential mission for aid management (Interviews with ODHD staff, Bamako, 2007). These institutions have adopted resistance techniques in response, for example failing to share information and respect the unit's deadlines, ignoring the PRSP framework when formulating their own sectoral policies, and not attending meetings. These are strong indications of their refusal to be coordinated or managed by the PRSP unit. These resistance techniques, which have been deployed extensively in the context of the implementation of the Paris Declaration on Aid Effectiveness (Organisation for Economic Cooperation and Development 2005) have undeniably affected the unit's ability to fulfil its role. This, in turn, confirms the instability and unpredictability of the institutions as they are fundamentally shaped by "certain social relationships for their continued reproduction" (Lund 2006b: 698). These social relationships have proven somewhat superior to the donor will to make the PRSP unit the overarching institution, and the considerable resources mobilized to achieve this goal. Capacity-building initiatives, in particular, have faced many challenges.

\section{TeChnical Assistance Beyond Myths}

In practice, the donor-supported TA programme generated power struggles and low integration with the unit. Furthermore, it emerged out that

\footnotetext{
7 A similar scenario was observed in Benin. See Bierschenk et al. 2002, 2003.
} 
the TAs were not the perfect missionaries of aid efficiency ${ }^{8}$ the donors had longed. Hence, their success in influencing the unit has remained limited.

It should be recalled that the TAs were appointed to the unit when the drafting of the second PRSP was well under way, which means that, for practical reasons, they could not fully influence the process from its inception. Also, the TA team felt they were victims of a kind of reticence by the unit's other employees (Interviews with TAs, Bamako, 2007). It appears that the other members of the unit members had hoped to retain some leverage over who would be in charge of building their capacities for draft and implementing the PRSP and how. When the call for tenders was launched, a team composed of former Malian ministers was dismissed by the European Commission delegation on the grounds that it might generate 'conflicts of interest' with the current government. In their view, local TAs risk getting "too integrated socially or committed politically" or becoming a 'big man's' protégé: "A technical assistant must be neutral. When conflicts emerge, he must not take a stand". Hence, the head of the European Commission delegation in Mali requested that a new assessment of all proposals be carried out; and the team proposed by Louis Berger, a Paris-based private consulting firm specialized in economics and development, was awarded the contract. Its 'international composition' (most of the proposed team's TAs had professional experiences in other developing countries) was supposed to give it the necessary 'distance' and 'comparative perspective'. Its 'neutrality' (towards domestic stakeholders and interests), racial 'diversity' and good 'representativeness' (the proposed team comprised a mix of French and African TAs) were also praised as features that would facilitate the team's integration into the PRSP unit in Mali (Louis Berger, interview, Paris, 2008).

This initial confrontation between the European delegation and the employees of the PRSP unit about the selected team had enduring consequences for the TA mission. Because former ministries were denied the right to contribute to PRSP-related activities, the unit was probably deprived of the political weight and backing it needed to fulfil its ambitious missions. Some long-lasting defiance between the unit agents and TAs was also created. Some employees considered that they had been deprived of an opportunity to exert increased sovereign control over the unit and the PRSP process, and viewed the TAs as 'spies' sent by the

8 The use of the term 'missionary' was inspired by Béatrice Hibou (1998) who refers to World Bank recommendations as "economic catechism". 
European Union; others felt that they had been denied an opportunity to gain some advantages or opportunities for the accumulation of resources that the management of the unit by local former ministries might have allowed (Interviews with employees of the unit and TAs, Bamako, 2007). As a result, one TA complained that when they arrived, "the atmosphere was awful" and was an obstacle to their successful settlement in the unit (Interview, Bamako, 2007).

If they had little power and say in the initial choice of TAs, the project's recipients still had significant nuisance power in terms of impeding them to do their job in good conditions. One African technical assistant appears to have succeeded in coping better with these strategies than others by using his knowledge of Bambara (the dominant language in the Bamako area) as a resource for cajoling the unit's most reluctant agents (Informal discussion with TA, Bamako, 2007).

Control and authority over TAs later became a stake in the power struggle between Malian public actors and international agencies. Whereas the unit coordinator thought that the unit was the ultimate beneficiary of TA, and that he could, therefore, design the TAs' work plan, the head of the European Commission delegation considered that it paid the TAs' salaries meant that the Commission to keep the TAs "at their disposal" (Interviews with TAs and donor representatives, Bamako, 2007). This prevented the TAs from carrying out their normal work for several weeks. In the most paradoxical and unforeseeable manner, the EU's initial fear of hiring a 'political' TA team (i.e. composed of former Malian ministers) appears to have increased the unit's politicization at the expense of its technical achievements.

Furthermore, it appears that the TAs placed in the PRSP unit were not the perfect, hoped-for missionaries of aid efficiency, a fact that can be explained, first, by their professional profiles. One of them is an economist and statistician from Cameroon. He is in his fifties and worked as a consultant at the World Bank headquarters in Washington D.C. for many years. Another technical assistant is an old-style French coopérant trained in electrical engineering, economics and econometrics. He spent 17 years in Côte d'Ivoire (the showcase of economic success in francophone West Africa at the time), mostly as a TA at the Ministry of Finance. After that, he completed shorter-term contracts in many African countries, mostly for the European Commission. The third technical assistant is a 40-year-old economist and statistician from Burkina Faso who is also head of a private consulting company based in Ouagadougou. The expert in public finance management is one of Benin's former treasury directors. The French-funded 
TA is a macroeconomist previously hired as a non-permanent official for French cooperation and the EU in African countries. The TAs recruited for the unit have first-hand experience of the PRSP, for it is a relatively recent policy instrument: for obvious reasons, the French TAs would not have experienced PRSPs at home and did not encounter them in the African countries they worked for previously either. The African TAs in the unit did not participate in the PRSP process in their home countries.

Furthermore, the TA's commitment to the aid efficiency model cannot be taken for granted. The former Benin treasury director has all of the necessary technical capacities and skills to assist in public finance management, however his own personal and professional references prompted him to compare Mali's financial situation that of Benin (even in a critical way for Mali) rather than with internationally-produced best practice (Interview, Bamako, 2007). Another TA is philosophical about his own positioning in the aid arena and rather critical of all aspects of the new aid rhetoric and buzzwords such as donor coordination, civil society participation, good governance, anti-corruption, results-based management etc. (Interviews and informal discussions, Bamako, 2007). In his opinion, this dogmatic toolbox sweeps industrialization, growth, economic development and the private sector aside, and differs from what he has experienced and from what he believes really works for development in other countries. He is also rather blasé about the succession of international aid fads and aware that the commitment shown by African civil servants to them is often superficial and instrumental. The TA who was most convinced by the IFI recommendations (the reduction of public services, the promotion of microcredit, the 'change in mentalities' required for development, etc.) only stayed at the unit for a short period of time, hence his impact was probably limited.

Overall, the room to manoeuvre and commitment of TAs varied greatly. The reluctance shown towards them at the beginning of their mission was clearly an early cause of discouragement. However, the TAs' degree of implication also varied on the basis of their contrasting personal profiles and professional prospects. One TA was eager to display a high level of professionalism. He was still in the middle of his career and therefore felt he had a lot to win (or lose) with this mission. As a result, he was very careful to please both the unit coordinator and the European Commission, in the hope that he would obtain other contracts of the kind in the future, perhaps with greater responsibility. As a result, he was willing to present concrete, quantified results (Interviews, Bamako, 2007). For another TA, the contract with the PRSP unit was the last long-term mission of his 
career. Also, due to his mandate, age and experience, he had to be careful to avoid presenting himself as a competitor to other unit members. To do this, he allegedly adopted a low profile posture, and may, therefore, have achieved less than he could or would have wanted to. Another expert had a position at the World Bank's headquarters; its mission at the unit was temporary and he could not stay in Bamako permanently. Indeed, he still had to make regular trips to Washington for professional or personal reasons. Another TA opted for a pragmatic approach and mobilized his expertise to achieve delimited, technical tasks.

Finally, it appears that TAs within the unit remained strangers within the organization: their integration and, hence their influence and control, were weak. The separation from the rest of the team was important, even from a purely physical point of view: the TAs had two different offices-which were larger and better-equipped than those of the Malian officials - and separate toilets, which were accessed using a special key. Language was also a barrier between TAs and Malian officials; the latter usually interacted in Bambara. Socialization patterns widened the gap: TAs tended to have lunch in expensive places that mostly attract expatriates, while the Malians would eat in surrounding African canteens. In the evenings, the unit employees were usually not free to attend social events as they had a family to care for after work so the TAs and local officials rarely met outside the unit. The TAs sometimes saw each other socially, in particular the Africans, who had moved to and settled in Bamako alone.

However, there were differences in the levels of integration of the TAs: the African TAs were better integrated to its social activities (i.e. marriages and burials). For example, they felt that contributing to the unit's informal but institutionalized system of money-collecting and solidarity was a duty they were expected to honour (Interview with African TA, Bamako, 2007). One of the French TAs would help his local driver in cases of financial hardship, however on a one-to-one (rather than collective) basis. The fact that the TA from Cameroon accepted to work part-time at the PRSP unit office and part-time at the office of the national division of statistics (a worse-resourced building than the PRSP unit) was greatly appreciated by Malian civil servants and probably enhanced his proximity with them (Interview, Bamako, 2007). On account of the extensive period of time he had spent on the continent, the older French TA was referred to as "an African" by some of the unit's employees. He was well accepted within the unit and connected to former Malian ministers and high-ranking civil servants. He was sensitive to and interested in development issues and Malian history. In contrast, another TA had fewer interactions with the 
unit employees and displayed little interest in Malian politics (Interview with TA, Bamako, 2007). One TA, in particular, was thought to have built substantial capacities and transferred knowledge and techniques to the unit staff and the wider administration. However, his training programme had limited impact because of its short-term character. One of his guest trainers (a European geographer) felt that the computer software he trained local civil servants to use was expensive, inaccessible (it involved frequent updates from a Europe-based hotline) and "way too complex" for what the Malian beneficiaries actually needed to do (e.g. compile quite simple statistical maps) and doubted that "the trainees will ever be able to make something out of it" (Interview, Bamako, 2007). This TA was himself worried about the sustainability and capitalization of his programs, which extended over a period of one year but were briefly interrupted by the renovation of the airport - a project hastily decided on by President Amadou Toumani Touré with no prior notice-and, more importantly, did not benefit from any clear follow-up mechanism after 2007-2008 (TA, interview, Bamako, 2007).

Ultimately, TAs were unable to exert much influence on the unit's activities or monitor them very closely. If, as one of them explained to me, the EU systematically wanted them to be their "ears and eyes in the administration", its representatives only "selects very technical, partial pieces of information on the basis of demands coming from the headquarters or the head of the delegation" (E-mail, 2008) and cannot fully control the unit and its TAs in practice. In the context of increasing decentralization and chronic lack of human resources, European staff is young and overwhelmed by the huge number of projects to be supervised (Interviews with officials within and outside the European delegation, Bamako, 2007). This possibility struck me when a European Commission official asked me about the unit's productivity - it appears that this person could not glean this information from personal observation or from the information provided by the TAs. One of them would sometimes complain of not having any contact with his funding agency (Interview, Bamako, 2007), another indication that the reporting by TAs to donor agencies is irregular and donor surveillance restrained. The latter is further restrained by TA's multiple accountability lines. Indeed, the TAs had to report to Louis Berger, the agency responsible for the execution of the project, every three months. However, this agency's priority is the disbursement of funds and satisfying the European Commission and the effective capacity transfer within the Malian administration is merely of secondary importance (Email from TA, 2008). 
As a result, and despite strong donor penetration, the unit's daily life and activity remains close to what prevails in the rest of the Malian administration. It follows rhythms dictated by social and religious events rather than donor agendas and schedules. Informal rules and hierarchies between officials are partially based on joking relationships, e.g. a set of institutionalized jokes and social obligations between particular groups common in West Africa (Canut and Smith 2006). Some interns with no clear formal status work at the unit; they survive on solidarity and redistribution or await permanent positions. The socialization patterns of the unit's employees are not highly globalized in terms of world views, professional habits and personal aspirations. They do not particularly look up to donor countries and their models. Dealing with their social constraints (distribution of wealth in their family and community) is a priority, and many complain about the pressures weighing on their salaries (Interviews with unit employees, Bamako, 2007). Like in many ministries, decisionmaking is centralized at the top. Several unit members prayed five times a day, and received social acquaintances seeking for advice or assistance. In other words, the unit never became the perfect super-performer detached from the social reality of Mali as envisaged by the donors.

\section{Donor-Driven CAPACITY-BuIlding ANd State Formation in Africa: CONCLUding REMARKS}

The case of the PRSP unit in Mali highlights the paradoxes and limits of donor-sponsored capacity-building. Indeed, the unit's hybrid status (as a separate entity located on the margins of the administration) was designed by donors to create a bureaucratic enclave that would enjoy better working conditions. However, ultimately, the project has proven counter-productive, particularly because it has affected its influence over other institutions involved in poverty reduction policies. Following several years of existence and the allocation of considerable resources, the unit's legitimacy and leadership are contested.

The EU-funded technical assistance programme set up within the unit has also faced many challenges; the TAs have failed to exert real control over the unit. Hence, this paper constitutes an invitation to put the power of international models into perspective, and, in particular, to demystify TA which is often accused of substitution or neo-colonial paternalism (e.g. by Ferguson 1990, Escobar 1995 and others). Far from being apolitical or able to unilaterally impose government methods serving a pre-defined 
global social order, development experts are 'learning elites' who draw on experience. In fact, their practice and leverage depend on the environment in which knowledge is co-produced and synthetized. Their real influence is subjected to genuine negotiation between actors (Wilson 2006: 502, 509, 513, 518). Hence the hegemony of aid agencies is better described as an object of permanent struggle than a secure and stable state of affairs (Mosse 2005: 7).

Our case study also illustrates that extraverted reform remains fundamentally superficial and ambivalent: if, at first glance, recipients display openness and willingness towards donor logics, at a deeper level, they are reluctant and partially reject the content of the reform through informal, creative practices, "weapons of the weak" 9 intended to bypass donor control or elude hegemonic regulation. As a result, the transformative dynamics of public administrations are "controversial and contentious" (Bezes 2007: 11) and affected by cultural contexts and pre-existing institutions that are able to instrumentalize foreign knowledge (Dezalay and Garth 2002a).

Finally, the PRSP unit in Mali is not conducive to state building per se-i.e. the "conscious effort at creating an apparatus of control", a rational, efficient state oriented towards poverty reduction and good public management, but indeed contributes to the process of state formation-a historical process composed of conflicts, negotiations and compromises between diverse groups whose self-serving actions and trade-offs constitute the "'vulgarization' of power" (Berman and Lonsdale 1992: 5). State formation is nurtured rather than contradicted by international capacitybuilding initiatives and their dual, fitful processes and "ever-changing agendas", which produce non-linear, unstable outcomes (Lund 2006b: 692). These, in turn, contribute to the extension of the bureaucratic power of African states. This particular point was first made by James Ferguson (1990) in his authoritative analysis of a World Bank's decentralization project in Lesotho. This chapter shows that, despite the international attempts at fostering the retreat of the state proclaimed since the 1980s, his conclusions remain true in the post-Washington era. The state thus formed through social relationships, mundane activities and negotiations

9 As demonstrated by Roberts (1996) for the cotton sector in Mali, 'weapons of the weak' and bypassing strategies were deployed under colonial rule. Reference can also be made to James Scott (1985) regarding resistance strategies deployed by subalterns in situations of domination. 
between a variety of local and external institutions (Lund 2006a: 674, 679; Lund 2006b: 686, 698) is best described as an "international state".10

It is difficult to assess the unit's legacy to the Malian institutional landscape and governmental practice, however a few key features stand out. For all its limits, the TA project marks an institutionalization of donor presence at the heart of policy-making arenas that is reminiscent of early post-colonial times. The unit enabled the government to show its commitment to reform and openness to donors. Managing aid relationships is an important part of the unit's job, and the capacities actually developed by its staff relate to aid management more than national planning or the promotion of public goods (Bergamaschi 2008). By doing this, the unit fuelled an aid system increasingly "geared toward ensuring its own self-perpetration" (Gould 2008: 8). International interventions are normalized, banalized and projected into the heart of African administrations through daily routines (Whitfield 2008) that blur the distinction between international and national actors. This co-production of public policies and government methods is not linear, however. The creation of the unit generated important debates about development, sovereignty, national capacities and donor interference amongst Malian bureaucrats. It also contributed to a shift in power relations in Mali: the power of the Ministry of Economics increased relatively while the Ministry of Planning has been further marginalized.

Moreover, capacity-building initiatives lead to imperfect outcomes because they are characterized by rigid procedures, short-term vision and objectives, and a restrictive and normative conception of the state (Campbell 1997; Darbon 2003; Bezes 2007). After a relative loss of donor interests and institutional backing, the unit has gained interest again and is recruiting more experts. In parallel, since 2010, donor funds are also directed towards the secretariat of aid harmonization and efficiency, another donor-initiated structure hosted by the Ministry of Economics and Finance and entitled to follow up the implementation of the Paris Declaration (Interview with international consultant, Paris, 2009). In 2012, both entities moved to a bigger building, in the more modern and expanding neighbourhood of Bamako called ACI 2000.

This multiplication of temporary, semi-institutional entities dilutes responsibility for action. The fragmentation of donor-sponsored capacity-

10 I borrow the expression coined by Yves Dezalay and Bryant Garth (Dezalay and Garth 2002b: 313) in reference to the US-led export of the rule of law to Latin American countries. 
building initiatives tends to destroy the possibility of institutional coherence and reform. It obscures the object referred to as 'administration' and hinders predictability in roles and conduct, and continuity of the state apparatus (Darbon 2003: 142). The contours of the state are also blurred and hard to identify. Institutions evolve in a "deluge of meaning" in which various actors and repertoires exist and compete for legitimacy as public authorities (Lund 2006a: 673; Lund 2006b: 692-693).

However, these permanent changes and instability may also be part of the division of bureaucratic labour that is characteristic of the modern state described by Weber (Bierschenk and Olivier de Sardan, Introduction, this volume). Indeed, the unit has generated debates but also contributions to clarify the role, resources and responsibilities of various public institutions. And the capacities built within the unit in recent years will be disseminated in a variety of settings (the administration, aid projects, donor agencies or NGOs) where its agents will get other positions, however the capitalization prospects remain uncertain. As such, ad hoc units, institutional changes and instability ought not to be primarily analysed as obstacles to state formation in sub-Saharan Africa per se, but as its very components and ingredients. Thus, reform presents as a constant feature and essence of African administrations, which appear to be more adaptable, flexible and open to change than is usually assumed by international donors and some academics.

\section{POST-SCRIPT: THE PRSP UNIT IN 2013}

Shortly after completing the final version of this chapter, I visited Bamako in June 2013 and interviewed former contacts in the Malian public administrations, at the PRSP Technical unit and in donor agencies. The context has consistently changed after a coup d'état in March 2012, the subsequent partition of the country and occupation of its Northern parts by Tuareg and Islamist insurgents, a French military intervention launched in early January 2013 and the preparation of the United Nations Multidimensional Integrated Stabilization Mission in Mali (Minusma) established by Security Council resolution 2100 of April 25, 2013, and officially launched on July 1. International aid had almost totally been suspended for a year, and Mali's status of model and "donor darling" had been badly affected. I was surprised, however, to find the unit in a rather good shape given those difficult circumstances.

As mentioned earlier, the unit moved to another building situated in the recently constructed, administrative neighbourhood called ACI 2000 
in July 2012. The new location has ensured the unit an increased isolation appreciated by some staff-since they now receive less visits from family and acquaintances than when the unit was located in the city centre-but has created major problems with the provision of electricity and chronic shortcuts impeding their productivity, too (interviews at the PRSP unit, Bamako, 2013). The unit now shares offices with the donor technical pool and a new instance in charge of aid harmonisation, the Secrétariat à l'harmonisation de l'aide (SHA).

Some continuity could be observed in the way unit members think of and negotiate sovereignty, and deal with international donors on a daily basis. Concerning the French military intervention, the head of the Sustainable Human Development division believed that for colonial reasons, "only France could answer" and that "we need to insert ourselves in globalizing processes, because we have no choice" (interviews at the PRSP technical unit, Bamako, 2013). The unit coordinator considered that "the international community has helped to protect Mali's sovereignty" by restoring Mali's "territorial integrity" and compelling the Mouvement national de libération de l'Azawad to abandon the idea of independence and negotiate with the central government. ${ }^{11}$ There is no doubt that they also trust in the government's well-proved abilities to deal with international constraints in a way able to preserve some interests. They also asserted that "ordinary Malians" are more touchy, proud and nationalistic about these things.

The unit had elaborated the third PRSP in late 2011 - that is, just before the crisis. The process has led to some interesting innovations aimed at better taking the country's changing context into account. As the document was drafted while tensions and combat between the army and Northern insurgent groups were intensifying, the unit insisted that it include some "pre-conditions" related to peace and security. Furthermore, to enhance ownership and sustainability (i.e., to incentivize the candidates running for presidents in the 2013 election and avoid the experience of duplication materialized with the Programme de développement économique et social), the unit insisted that the PRSP should be validated by the Council of Ministers before December 31, 2011, and shared with the country's main political parties before the election.

${ }^{11}$ For a detailed account of the events that occurred in Mali since the coup in March 2012, see Bergamaschi (2013). 
On the other hand, in the preparation of the third PRSP, several regional consultations were carried out by the unit countrywide, for which they had difficulties getting external funding (interview with Technical Assistant and unit employee, Bamako, 2013). The consultative process provided an opportunity for the unit staff to hear the aspirations of civil society representatives, religious and political leaders at the local level and to realize that 'they know what they want', and in particular: the efficient use of remittances from the diaspora in the Western region of Kayes; access to land and micro-finance in the central area around Segou; improvements in cotton production in the Southern region of Sikasso; cattle in Mopti along the Niger river; and finally, women's empowerment, the fight against desertification and water provision in the Northern regions of Timbuctu, Gao and Kidal (interview with head of the unit's Human Sustainable Development division, Bamako, 2013). However, for lack of time and incompatibilities with national planning tools, it was not possible to fully integrate these priorities in the PRSP nor translate it into regional operational schemes for implementation.

Initially, the unit agent felt confident and enthusiastic about drafting the third PRSP themselves; and they wanted to put the focus on agricultural production and equitable growth. But Danish insistence to hire an international consultant (from Senegal) to draft the PRSP once again demobilized the unit staff, which felt dispossessed of its principal mission. The consultant associated all sectors and actors in the PRSP (interview with the consultant, Paris, 2012), and was tempted to 'copy-paste' line policies, while mixing them with other existing frameworks and international requests (for example, Handicap International asked for a reference to the rights of disabled people to be added). This has led, once again, to a lack of prioritization. When the consultant left in late November 2011, the team - and especially its coordinator-amended the document, but had little time to do so since they wanted to comply with the political deadline (31 December 2011) that they had set themselves (interview with technical assistant, PRSP unit, Bamako, 2013).

The unit still found it hard to get access to some key policy documents like, for instance, the Government Financial Operations Table produced by the Ministry of Economy and Finance. However, in June 2013 it seemed better accepted by other actors. It is worth noting that like the rest of the administration, and despite the paralysis created by vacant political leadership and the suspension of international aid, the unit started to work again just a few days after the coup instigated by Captain Sanogo on March 22, 2012. The coordinator and most of his staff have kept their 
positions despite the coup and the several government shifts that occurred under transition governments. Since 2008, the team has also been successful in 'keeping' a young and competent national economist trained in Canada from working for aid agencies.

The unit is now part of Mali's normal institutional landscape. Staff continuity is ensured by the fact that the unit's coordinator is not affiliated to any party or political leader but 'has his entries' at the primature no matter who the prime minister is (interviews and informal discussions at the PRSP unit, 2013). He is recognized as a technocrat, for his professional background at the Ministry of Planning, his working ethos and ability to appeal to aid partners. As a result, he enjoys functional autonomy from the Ministry of Economy and Finance.

This process can best be accounted for as 'institutionalisation through adaptation', which describes how donor-sponsored entities are being absorbed and transformed by African states. Indeed, the unit's role differs from the one initially stated. It has never had the legitimacy to drive a national development strategy encompassing all sectors and actors, and has focused on managing aid relationships and translating international demands into national public policies and politics. But it has confirmed its role of entry point for donor support and of intermediary at the juncture between national politics and donor priorities. Resilience, translation and adaptation are key features of the unit's achievements and acceptance over time.

Some consider that, because of the accumulated experience, a betterdesigned technical assistance programme after $2010^{12}$ and the wake-up call created by the coup, the unit has gained autonomy and confidence, including in its relationships with other public administrations, foreign technical assistants and donors. For example, in the preparation of the Conférence des donateurs for the 'recovery' of Mali held in Brussels on May 15, 2013, some agencies like the UNDP and the World Bank were eager to sideline the PRSP and urged the government to produce a new document adjusted to the crisis - a Plan d'actions prioritaires d'urgence that would be seen as more 'political' by diplomats and donor headquarters, better articulated with the 'roadmap for the transition' adopted by

12 Four technical assistants are now funded by the UNDP and France. Only one permanent French TA works at the unit, while the others are based at the Malian Ministry of Health and the National Statistics Institute. Another TA only comes to Bamako three weeks every three months. Consequently, according to staff, he brings "new energy", new ideas and comes with a clear working agenda, while the risk of "substitution" is limited. 
the government in January 2013 (in particular, concerning actions to strengthen the Malian army and deal with refugees), more limited in scope (it would only be relevant for the years 2013-2014) and hence easier for them and the government to monitor. The unit and government (backed up by France) refused, arguing that it was more appropriate to promote the continuity of public administrations and policies-that is, to reactivate and rely on pre-existing frameworks such as the third PRSP adopted in late 2011. The PRSP was hence slightly adapted to include some elements of the roadmap for the transition, translated into English and renamed the Plan for the Sustainable Recovery of Mali 2013-2014 (PRED) for the Brussels conference.

During my visits in June 2013, the unit staff was working to establish a monitoring mechanism for the PRED that would combine previous policy tools with the demand for greater supervision of implementation by headquarters and European capitals. To a great extent, some continuity in personnel, policy tools and institutional processes was hence guaranteed within and by the unit in the midst of political crisis. The unit was also busy controlling that the disbursement promises made to Mali by donors in Brussels in May 2013 (over three billion euro) will flow into the country. The unit will be instrumental in the allocation and management of these funds. Its future partly depends on the outcome of the presidential elections to be held on the July 28 and early August 2013. Finally, its role in practice is likely to evolve as a result of the on-going shifts in priorities, modalities and actors of international intervention in Mali, from poverty reduction supported by traditional donors to military, humanitarian, security and transitional justice programmes sponsored by NGOs and emergency organizations, French and African troops and the staff of the United Nations Multidimensional Integrated Stabilization Mission in Mali (Minusma).

\section{REFERENCES}

Abrahamsen, Rita. 2004. The power of partnership in global governance. Third World Quarterly, 25 (8): 1462-1463.

Bayart, Jean-François. 2000. Africa in the world: a history of extraversion. African Affairs, 99 (395): 217-267.

Bergamaschi, Isaline. 2008. Mali: Patterns and limits of 'donor-driven ownership'. In Whitfield L., ed. The New Politics of Aid: African Strategies for Dealing with Donors. Oxford, Oxford University Press, 217-245.

- 2009. Assess and govern. Quantified data and poverty reduction politics in Mali: the matrix. Capital, Labour and Society, 42 (1-2): 116-139. 
- 2013. French military intervention in Mali: inevitable, consensual, and insufficient. Stability: International Journal of Security and Development, 2 (2): 20, 1-11, available at: http://www.stabilityjournal.org/article/view/sta.bb.

Berman, Bruce and John Londsale. 1992. Unhappy Valley: Conflict in Kenya and Africa. Book One: State and Class, London, James Currey/Nairobi, Heinemann \& Athens, Ohio University Press.

Bezes, Philippe. 2007. Construire des bureaucraties wébériennes à l'ère du New Public Management? Critique internationale, 35: 9-29.

Bierschenk, Thomas, Chauveau, Jean-Pierre and Jean-Pierre Olivier de Sardan, eds. 2000. Courtiers en développement. Les villages africains en quête de projets. Paris, Karthala/ Mayence, APAD.

Bierschenk, Thomas, Thioléron, Elisabeth and Nassirou Bako-Arifari. eds. 2002. Institutionalising the PRSP approach in Benin. Working Papers of the Department of Anthroplogy and African Studies of the Johannes Gutenberg University Mainz, 3a, available at: http:// www.ifeas.uni-mainz.de/workingpapers/PRSPf.pdf, accessed on: May 20, 2009.

— 2003. Benin. In Booth, David, ed. Fighting Poverty in Africa. Are PRSPs Making a Difference? London, ODI, 57-90.

Campbell, Bonnie. 1997. Débats actuels sur la reconceptualisation de l'Etat par les organismes de financement multilatéraux. In Groupement d'Intérêt Scientifique pour l'Etude de la Mondialisation et du développement (GEMDEV). Les avatars de l'Etat en Afrique. Paris, Karthala, 79-93.

Canut, Cécile and Étienne Smith. 2006. Pactes, alliances et plaisanteries. Cahiers d'études africaines, 184: 2-84, available at: http://etudesafricaines.revues.org/index6198.html.

Chang, Ha-Joon. 2006. Policy space in historical perspective-with special reference to trade and industrial Policies. Economic and Political Weekly, 41 (7): 1-26.

Cissoko Kama and Ramatou Touré. 2005. Participation des acteurs sociaux et gouvernance d'État: le cas du cadre stratégique de lutte contre la pauvreté au Mali. Politique africaine, 99: 142-153.

Darbon, Dominique. 2003. Réformer ou reformer les administrations projetées des Afriques: entre routine anti-politique et ingénierie politique contextuelle. Revue française d'administration publique, 105-106: 135-152.

Delpeuch, Thierry. 2008. L'analyse des transferts internationaux de politiques publiques: un état de l'art. Questions de recherche (CERI/Sciences-Po), 27: 1-69.

Dezalay, Yves and Bryant Garth. 2002a. La mondialisation des guerres de palais: La restructuration du pouvoir d'Etat en Amérique latine, entre notables du droit et Chicago boys. Paris, Broché/Seuil.

—, eds. 2002b. Global Prescriptions. The Production, Exportation, and Importation of a New Legal Orthodoxy. Ann Arbor, University of Michigan.

Escobar, Arturo. 1995. Encountering Development: The Making and Unmaking of the Third World. Princeton, Princeton University Press.

Ferguson, James. 1990. The Anti-Politics Machine: 'Development,' Depoliticization, and Bureaucratic Power in Lesotho. Cambridge, Cambridge University Press.

Fine, Ben, Costas Lapavistas and Jonathan Pincus, eds. 2001. Development Policy in the Twenty-first Century: Beyond the Post-Washington Consensus. London, Routledge.

Fichtner, Sarah. 2012. The NGOisation of Education. Case Studies from Benin (Mainz Contributions to African Studies. 31). Köln, Köppe.

Fraser, Alastair. 2008. Aid recipient sovereignty in historical context. In Whitfield Lindsay. ed. The Politics of Aid: African Strategies for Dealing with Donors. Oxford, Oxford University Press, $45^{-73}$.

Geschiere, Peter and Stephen Jackson. 20o6. Autochthony and the crisis of citizenship: democratization, decentralization and the politics of belonging. African Studies Review, 49 (2): $1-7$.

Gould, Jeremy, ed. 2005. The New Conditionality: the Politics of Poverty Reduction Strategies. London, New York, Zed books. 
2008. Thinking Outside Development: Epistemological Explorations 1994-2008, available at: http://blogs.helsinki.fi/gould/files/2008/o6/thinking-outside-96-dpi-17v08.pdf, accessed on: April 24, 2009.

Harrison, Graham. 2004. The World Bank and Africa: The Construction of Governance States. London, New York, Routledge.

Hatcher, Pascale. 2009. The Politics of Entrapment: The World Bank, the Integrated Development Model and Citizenship at a Crossroad. PhD dissertation presented at the International Institute of Social Studies of Erasmus University Rotterdam, The Hague.

Hibou, Béatrice. 1998. Banque mondiale: les méfaits du catéchisme économique. Esprit, 245: 98-140.

Johnson, John H. and Sulaiman S. Wasty. 1993. Borrower Ownership of Adjustment Programs and the Political Economy of Reform (World Bank Discussion Paper, 199). Washington, DC, World Bank.

Killick, Tony/Overseas Development Institute. 1998. Aid and the Political Economy of Policy Change. London, Routledge.

Lund, Christian. 2006a. Twilight institutions: an introduction. Development and Change, 37 (4): 673-684.

. 2006b. Twilight institutions: public authorities and local politics in Africa. Development and Change, 37 (4): 685-705.

Miller-Adams, Michelle. 1999. The World Bank: New Agendas in a Changing World. New York and London, Routledge.

Mosse, David. 2005. Cultivating Development: An Ethnography of Aid Policy and Practice. London, Pluto Press.

Mosse, David and David Lewis. eds. 2006. Development Brokers and Translators. The Ethnography of Aid and Agencies. Bloomfield, CT, Kumarian Press.

Organisation for Economic Cooperation and Development (OECD). 2005. Paris Declaration on Aid Effectiveness, Paris, OECD.

Peñafiel, Ricardo. 2008. L'Événement discursif paupériste, Lutte contre la pauvreté et redéfinition du politique en Amérique latine: Chili, Mexique, Venezuela (1910-2006). Doctoral dissertation, Université du Québec, Montréal.

République du Mali. 2008. Compte-rendu des travaux de la table-ronde des bailleurs de fonds au Mali sur le CSLP. Bamako.

Roberts, Richard. 1996. Two Worlds of Cotton: Colonialism and the Regional Economy in the French Soudan, 1800-1946. Stanford, Stanford University Press.

Scott, James C. 1985. Weapons of the Weak. Everyday Forms of Peasant Resistance. New Haven, Yale University Press.

Stewart, Frances and Michael Wang. 2003. Do PRSPs empower poor countries and disempower the World Bank, or is it the other way round? Queen Elizabeth House Working Paper Series, 108.

Stone, Diane and Christopher Wright. eds. 2007. The World Bank and Governance: A Decade of Reform and Reaction. London, Routledge.

Whitfield, Lindsay. ed. 2008. The New Politics of Aid: African Strategies for Dealing with Donors. Oxford, Oxford University Press.

Williams, David. 2006. 'Ownership', sovereignty and global governance. (Global Economic Governance Programme Working Paper, 22), Oxford, University College.

Wilson, Gordon. 2006. Beyond the technocrat? The professional expert in development practice. Development and Change, 37 (3): 501-523.

World Bank. 1997. World Development Report 1997: The State in a Changing World. Oxford, Oxford University Press. 
Thomas Bierschenk and Jean-Pierre Olivier de Sardan - 978-90-04-26496-0 Downloaded from Brill.com@4/26/2023 02:08:21PM via free access 


\title{
A BREEDING GROUND FOR REVENUE RELIABILITY? \\ CAMEROONIAN VETERINARY AGENTS AND TAX OFFICIALS \\ IN THE FACE OF REFORM
}

\author{
José-María Muñoz
}

On November 2004, over the course of an interview conducted in the city of Ngaoundéré, Adamaoua Province (Cameroon), a senior tax official shared his views about the difficulties involved in making those active in the cattle economy comply with recent innovations in tax law:

It's a sector that the state protects enormously. We would have liked to lay our hands on herders and traders to make them pay what they should but it's terribly difficult. We go about it gradually. We're trying to tax those who trade cattle in the south. We can control their railway shipments... It's certainly an undertaxed sector. On the one hand, there is [the] problem ... [that] herders, not only in Adamaoua but pretty much everywhere, distrust the authorities, specially the tax authorities. On the other hand, we lack the means to go after them. And the Ministry of Livestock, for the most part, does not make our task any easier... Truth be told, this sort of problem concerns our relations with all branches of public administration. They should help us because it is us who generate their budgets, who allow them to function. But we only get help from any of them in extremely rare cases.

These words serve as a reminder that effective reform does not only depend on the response of citizens or the overhaul of the structures and procedures of a given administrative department but also on the cooperation between different departments. My informant's straightforward point provides the impetus for the following pages, which explore how reforms affect public administrative action on the ground and how officials negotiate interdepartmental tensions. My focus is the Cameroonian tax administration, whose face began to change markedly in the 1990s. Since then, state officials and taxpayers have experienced this reform effort not so much as a package but rather as a succession of changes to law and administrative organization. Based on ethnographic research in Adamaoua, one of Cameroon's three northern provinces, this article examines the effects of a recent program aimed at improving the efficiency of the state's revenue-raising 
efforts. ${ }^{1}$ I set out both to analyze in detail the Program for Improved Revenue Reliability in the Animal Husbandry and Fisheries Sector (PSREP), one such relatively modest component of these reforms, and to place the scope of this program within a broader spectrum of administrative practice.

By looking into a Cameroonian case, in which the spheres of authority of different branches of public administration were reconfigured, I intend to contribute to two bodies of scholarship: a still sparse literature that approaches the workings of revenue authorities and their reform as ethnographic objects (Cantens 2009; Chalfin 2010; Abelin 2012; Boll 2012); and works that analyze the exercise of public authority in present-day sub-Saharan Africa. Despite its obvious implications for the questions of democracy and state building (Guyer 1992; Bräutigam 2009; Martin, Mehrotra and Prasad 2009), taxation has received only limited ethnographic attention in sub-Saharan Africa. The reform of tax administration has certainly been the object of intense debate and scrutiny, since tax authorities have long been held to be a strategic choice for attempts at reforming state bureaucracy (Kaldor 1963). This literature, however, has placed much of its emphasis on the assessment of state (in)effectiveness in mobilizing revenue (Stotsky and Wolde Mariam 1997; Chambas 2005; Gupta and Tareq 2008) and the potential for privatization in this domain (Kiser and Sacks 2009). Yet, as Ole Therkildsen (2001) has noted, the gap between revenue figures and the empirical research required to interpret them, in relation to policies, administrative action, and taxpayers' behavior, remains striking.

Recent studies have demonstrated how a transnational epistemic community of tax experts has played a major part in the design of strategies to improve tax administration in developing countries (Fjeldstad and Moore 2009a). Notwithstanding this strong international consensus on what the centerpieces of tax reform should be and the attested interest in understanding how this consensus is reconciled with national particularities and governmental priorities, the anthropology of policy in this domain is

1 These pages are based on fourteen months of fieldwork during several research trips between July 2003 and November 2004. They draw on participant observation and semistructured interviews with numerous state officials and cattle herders and traders working in Adamaoua Province. Research took place within the framework of a British Economic and Social Research Council-funded project. I am deeply indebted to the two other members of the research team, Philip Burnham (principal investigator) and Martial Massike (research assistant). I would also like to thank Thomas Bierschenk, Giorgio Blundo, Philip Burnham, Jane Guyer, Karen Hansen, Robert Launay, and Jean-Pierre Olivier de Sardan for their comments on earlier versions of this article. 
still in its infancy. "Tax administration is tax policy" is an often quoted dictum in the literature (see, for example, Bird and Casanegra de Jantscher 1992). In spite of the valuable invitation this maxim contains to go beyond programmatic policy formulations, from a heuristic point of view it is productive to make a distinction between general policy 'frameworks' and what is generally subsumed under 'policy implementation' (Shore and Wright 1997; Mosse 2004; Shore, Wright and Pero 2011). Accordingly, I will discuss the general contour of the administrative reforms in Cameroon before delving, through a specific example, into the nature of the transformations that they have triggered.

These pages, like the rest of this book, are also intended as a contribution to scholarship on the exercise of public authority in present-day subSaharan Africa. Here I follow in the footsteps of Bierschenk and Olivier de Sardan's $(1998,2003)$ dissection of the 'polycentric' political arenas in rural Benin during the era of democratization and decentralization. They propose to approach public authority in such a setting in terms of 'sedimentation' and empilement (superimposition). In a different vein, Achille Mbembe (2001: 66), in his seminal discussion on 'private indirect government,' referred to the 'fragmentation of public authority' as a major historical process in postcolonial contexts (see also Bierschenk in this volume). His ideas are particularly apposite for my purposes here, since he thinks such a fragmentation should be at the center of the analytical questions that he groups under the broad rubric of 'fiscality.' Mbembe also underscores the erosion of the mobilizing power of metaphors such as 'public interest' and 'common good,' a crucial development shaping Cameroon's political and economic landscape in the last two decades (for a somewhat different view, see Lentz's contribution on higher civil servants in Ghana, in this volume). An increasing number of works have taken heed of such lines of inquiry, combining an explicit focus on "the substantive activity of competing political organizations as they exercise public authority" with the belief that these matters are "not beyond detailed and vivid empirical analysis" (Lund 2006a: 675, 682). In this light, the "the practical form of public authority" appears as "composite and chimerical" (Lund 2006b: 689). My article finds its rationale in this larger endeavor to document how state officials and other power brokers - with varying degrees of selfawareness and for a broad range of ends-mediate between the state and its citizen-subjects.

Technologies of taxation and the exercise of public authority also occupy a prominent place in Janet Roitman's influential work on economic regulation in the Lake Chad Basin, an admittedly vague designation that 
includes Adamoua Province (2005: 5 n.7). For my purposes here, what she terms the 'pluralization of figures of regulatory authority' is of particular interest. Roitman (2005: 18) elaborates on this notion as follows:

Effective authority over [commercial and financial] exchanges [in the Chad Basin] and the surpluses they generate is exercised by an amalgam of personalities associated with state bureaucracy, the merchant elite, the military, and non-state militia groups... They manage to regulate local populations and define access to material resources and wealth, to tax the profits of economic relationships, and to establish preeminent authority over certain sectors of economic activity.

However, in Roitman's account, the 'personalities' whom we are told exercise authority seemingly dissolve in the alchemical image of the 'amalgam' — or in a 'military-commercial nexus,' as she prefers to designate it other times. In her work, such personalities often do not get past the status of faceless silhouettes. By drawing the readers' attention to the competition for authority between two branches of Cameroon's state bureaucracy, I want to recalibrate the debates that Roitman's book and numerous articles have inspired.

I present my argument in four sections. First, I offer an overview of two decades of reforms that targeted Cameroon's public administration as a whole and its tax administration in particular. Second, I introduce readers to the professional cultures of veterinary agents and tax officials in Adamaoua Province. The third section discusses how this program reorganized the collection of cattle-related taxes. The final section takes a look at cattle exports to Nigeria, which provide a vivid illustration of the uneven impact of this reform initiative on the practices of state officials.

\section{Reforming TAX Administration in CAMERoon}

Reforms in sub-Saharan Africa have placed many government employees in the dual position of agents and objects of reform, a Janus-faced role that has not failed to generate ambiguities and paradoxes. Cameroon has had its share of both, as will become apparent in the analysis of the Programme de Sécurisation des Recettes de l'Elevage et la Pêche (PSREP, Program for Improved Revenue Reliability in the Animal Husbandry and Fisheries Sector). The PSREP is a modest addition to an open-ended series of ambitious administrative reforms undertaken by the government since 1988, when it adopted its first International Monetary Fund-supported program. 
In the early years of structural adjustment, marked by the emphasis on the need to cut public spending in order to achieve macroeconomic stability, administrative reform was largely understood in terms of reducing the state payroll through layoffs and salary cuts. Even within these narrowly defined terms, a regime trying to navigate the troubled transition to multiparty politics showed itself unable and unwilling to implement such measures. Operation ANTILOPE, for example, was launched in 1987 but its main goal, to clean up the state payroll of 'ghost' civil servants, proved to lie beyond reach. The government has been grappling with this problem for more than two decades now. As late as November 2008, the minister of public service told national deputies that 5,324 new cases of fictive employees and pensioners had been detected. That the civil service, which Jean-François Bayart (1985: 216) in his groundbreaking analysis of the Cameroonian state, had singled out as the "main social force in the country," would resist these measures is anything but surprising. In the years of crisis and adjustment, the social and political position of government officials was significantly eroded. It was only in 1993 when, unable to cover the public wage bill, the government decided to take the drastic step of reducing the salaries of civil servants. ${ }^{2}$

The scope of reform was broadened in 1994 with the introduction of a legal framework aimed at improving civil service efficiency (Ngouo 1997). ${ }^{3}$ Despite its ostensible aims and although it listed the dedication to the service as fundamental obligation (article 15), the new statute for state employees explicitly accepted their parallel involvement in private activities (article 37). This unprecedented formal sanction of the widespread practice of 'straddling' did not pass unnoticed to critics (Sindjoun 1996: 64, Nanga 2000: 5). Indeed, far from disappearing, as some reformers had anticipated, straddling (the seeking of economic advantage by the simultaneous involvement in state employment and private business) continued

2 In January 1993, salaries were reduced by 15 percent on average, excluding police and military personnel. Later that year, in November, there was an additional reduction of 32 percent. The 1994 CFA franc devaluation further eroded their economic position. Senior civil servants, for example, saw their real wages fall by 75-80 percent from 1992 to 1995 (World Bank 2001: 4). In the last three decades, late payment of civil servants' salaries has also become commonplace.

3 Statut Général de la Fonction Publique de l'Etat, contained in decree 1994/117, of October 7, 1994. The decree was drafted with the United Nations Development Program's active participation (Bruneau and Abouem 2004: 7). In fulfilment of conditions imposed by the World Bank, the decree opened the door for an attempt to reduce the number of civil servants by 30,000 through voluntary departure and early retirement (Bayie Kamanda 1999). 
unabated and extended to the lower ranks of the civil service (Geschiere and Konings 1993).

From 1994, numerous governmental initiatives tackling different aspects of the state organizational structure have seen the light. Most of them have been placed under the mantle of the 'good governance' agenda and largely draw their inspiration from New Public Management ideas (Ngouo 2000; Tamekou 2008), (for similar reforms of Ghana's civil service in the mid-1990s, see Lentz in this volume; for the reforms in the Cameroonian education sector, see Charton in this volume).

These include an overarching National Governance Program (NGP, which has known two phases, 2000-2004 and 2006-2010) 4 and a myriad other programs and projects. ${ }^{5}$ These initiatives offer ample room for "the dramatization (théâtralisation) of technocratic and legal-rational discourse" (Sindjoun 1996: 65). Each new attempt acknowledges the contributions-and sometimes even the shortcomings-of previous ones. Often mandated by Cameroon's international 'partners,' each new effort contains the promise that things will be different thereafter. As the burden of acknowledged 'mitigated successes' and 'failures' increases, the leaps of faith required to keep the flame of reform alive are bigger. A recent Canada-sponsored program to introduce result-based management methods (PROMAGAR), for example, "has not aroused special enthusiasm," the ruling party's newsletter told its readers. The reason being that

4 The NGP was first announced by President Biya in his 1996 New Year's Eve speech but was not approved by him until 2000. A 2004 critical evaluation gave the impetus for a reformulation of the program in 2005. The UNDP participated in the program's conception at both stages. Progress in achieving the NGP's goals has been closely monitored by the World Bank and the IMF. It is also claimed to have played an important role in determining when Cameroon reached the Highly Indebted Poor Countries initiative's "completion point" that gives access to substantial foreign debt relief (Charlier and N'Cho-Oguie 2009). Cameroon finally reached the completion point on April 28, 2006.

5 SIGIPES, a computer system that manages state personnel and payroll, is probably the single initiative that has attracted most attention and controversy (Ngouo 2008). It was initially conceived in 1992 by then minister of public service, Garga Haman Adji, who was soon to resign. After several false starts, its pilot phase, which focused on four strategic ministries, began in 2002. In December 2005, the system's tortuous implementation made the headlines of the national press (for a sample, see La Nouvelle Expression, December 8, 2005; Le Messager, December 12, 2005). Alleged corruption in the provision of technical support by outside contractors motivated the suspension of two top officials within the Ministry of Public Service and Administrative Reform for "dishonesty and serious breach of trust." Ultimately, and largely on account of his parallel 'crusade' to expose irregularities in the admissions to ENAM, Benjamin Amana, the minister behind SIGIPES 'clean up' operation was replaced in September 2006. SIGIPES is now in the process of being extended to several other ministries. 
the "beautiful promises" contained in "similar projects, some still in place and others already buried," have been engulfed by "centrifugal forces" stemming from an "irréformable" civil service (RDPC 2009). As suggested by Béatrice Hibou (2006: 297) in her work on the Tunisian regime, we should be advised not to discard the possibility that these "reforms in perpetuity" are what constitutes the "success of reformism." Be it as it may, learning to coexist with reform has become part of the social condition of Cameroonian civil servants. ${ }^{6}$

Because of its critical role in revenue generation and its potential to showcase improved efficiency, the tax administration has figured prominently in the attempts to reorganize the civil service. It is often claimed that revenue offers a yardstick to assess administrative efficiency that is lacking in other areas of public administration-although the challenges of delivering on such claims can be daunting (Barbone et al. 1999 and Raffinot 2001). A senior official writes with a touch of pride that "Within the Cameroonian administration as a whole, the Direction Générale des Impôts (DGI, the national tax authority) is unique in having firmly and irreversibly embarked on the hazardous road to performance-based management" (Evina Obam 2005: 24). Changes introduced in the tax administration, however, cannot be understood in isolation from the overhaul of the tax and customs system more generally. Since 1994, the transformations of the customs regime and of personal and business taxation have been substantial and far-reaching. These transformations took place as the government gradually recovered from the 1991 Villes Mortes campaign, a wave of popular protests that contested its legitimacy and explicitly called for tax boycotts (Takougang and Krieger 1998; Roitman 2005). Revisions of the tax code included the suppression of the head tax and the creation of a specific tax for persons operating outside the regulatory framework (impôt libératoire) in 1995 and the introduction of a value-added tax (VAT) in 1999 .

These changes called for considerable additional efforts from disaffected state officials, whose salaries, which were not always paid on time, afforded a severely diminished standard of living after the 1994 CFA franc

6 Of course, this is far from being the exclusive trait of Cameroonian or African civil services. An illustrious specialist in the workings of the French administration, for example, talked about the "permanent failure of reform" in the former metropolis (Crozier 1995). These remarks, at a time when French public administration was in the midst of two waves of reform decided by Prime Ministers Rocard and Juppé (Guyomarch 1999), were made roughly when the above-mentioned succession of reforms was being tried out in Cameroon. 
devaluation. Their administrative services, as a result of the unevenly implemented austerity measures, lacked previously taken-for-granted resources. Moreover, not unlike the Nigerien court officials faced with an increase in the number and complexity of cases Oumarou Hamani (this volume) analyzes, tax officials confronted a considerably enlarged pool of taxpayers subject to a variety of new tax regimes. This represented, on the one hand, more files to be dealt with by each agent and, on the other, the urgent need to catch up with new law. Indeed, some transitional regulations were only in force for a few years. All these novelties, in turn, increased the possibilities for manipulation of the regulatory devices. Any official willing to get a supplemental income through collusive agreements with taxpayers and other extra-legal exactions could arbitrarily invoke new regulations to justify abuses.

As far as the reforms of the administration itself are concerned, a senior tax official in Adamaoua aptly summed up their presiding idea: "We are now compelled to deliver in terms of results, somewhat like the private [sector]." At the provincial and district levels, the system relied now on annual revenue targets. Under the new system, tax officials also receive a share in the improved tax payments as well as in the fines and penalties levied-although in Cameroon performance-based formulas have had more traction in customs than in tax administration (Libom Li Likeng et al. 2011; Cantens 2012). The managerial principles governing the operation of collection and audit services also entailed, at least rhetorically, turning taxpayers into clients. To that effect, a Taxpayer-Partner Program was adopted. Since 2002, taxpayers can address a single interlocutor at the district level in the figure of the chef de centre des impôts (CCI, head of the tax center), who takes on previously separate functions such as control, audit and dispute resolution.

The creation of the CCI also reflects a move from a system organized around different types of taxes to one organized around industries, localities and groups of taxpayers, which is consonant with widely followed prescriptions for tax reform in developing countries (Fjeldstad and Moore 2009a). Thus, with the involvement of foreign expertise, the government has created separate administrative units to deal with categories of taxpayers whose contribution could be 'optimized': one tailored to cater to a select group of the country's largest firms (DGE) in 2004 and others devoted to medium-sized enterprises (CIMEs) in 2008. In fact, it was this new approach that justified the initiative on which this article focuses. Indeed, the PSREP was one among several programs oriented toward improving 'revenue reliability' (sécurisation des recettes), that is, explicitly 
aimed at increasing the tax 'productivity' of certain sectors. With the active encouragement of its main donors, and in the face of the impending revenue shortages as oil production declined, the Cameroonian government attempted to raise revenue from economic sectors whose poor revenue yields could be blamed to a large extent on administrative deficiencies. Animal farming and fisheries, and, more important in quantitative terms, the forestry sector and the mining sector were obvious candidates for specific attention. ${ }^{7}$ These three programs for enhanced revenue reliability illustrate a critical feature of these reforms: they are premised on improved coordination among different agencies acting in the name of the state. At issue were relations between several specialized ministries and the Ministry of Economy and Finance (MINEFI). Other governmental efforts have sought improved coordination and data-sharing among tax, customs, and social security administration. ${ }^{8}$ To give a sense of the complexities involved in translating administrative reforms into effective measures in local contexts, I shall now turn to how the PSREP was implemented in Adamaoua Province.

\section{Veterinary Agents and Tax Officials in Adamoua Province}

The Prime Minister launched the PSREP in 2000 (décret no. 2000/980/ PM, of December 8,2000$)$. The program did not create any new taxes. It simply tried to involve MINEFI in the collection of certain duties (market, slaughterhouse, and laissez-passer veterinary fees, most importantly) that had been hitherto the exclusive responsibility of the Ministry of Livestock, Fisheries and Animal Industries (MINEPIA) veterinary agents. ${ }^{9}$ Therefore, to borrow Olivier de Sardan's terms (2001), at the core of the PSREP was the issue of the cooperation between two branches of the administration

7 Programme de Sécurisation des Recettes Forestières (PSRF, décret no. 99/370/PM, of March 19, 1999) and Programme de Sécurisation des Recettes des Mines, de l'Eau et de l'Énergie (PSRM, décret no. 2002/1722/PM of October 8, 2002).

8 The partnership between the tax authorities and the Caisse Nationale de Prévoyance Sociale, the governmental agency in charge of the social security system, was established in 2001 (Law no. 2001/017, of December 18, 2001). Setting up a Cellule Mixte Impôts/Douanes (customs/taxes joint unit) had to wait until 2005. In light of its failure to operate, the national commission for tax reform proposed its elimination two years later.

9 Because these duties are paid in exchange of services provided (a veterinary inspection, for example), they are not taxes in a technical sense. However, the services provided are often more nominal than actual. For example, the veterinary inspection is ordinarily either cursory or inexistent. This, added to their compulsory nature, justifies considering them under the rubric of taxation. 
that had different 'local professional cultures' but that were also invested in 'privatizing' their bureaucratic work. This call for cooperation took place in the context of long-standing tensions between the two ministries. Such tensions surfaced regularly during my fieldwork in Adamaoua.

Adamaoua is one of the country's main cattle herding and trading areas. Cattle focused a large part of German and French attempts to 'develop' this area. Colonial officials were acutely aware of the importance of cattle from a revenue perspective. As the chef de region wrote in a letter from 1950, "We cannot forget that Adamaoua shelters around 50,000 humans compared to the 300,000 head of cattle that form the tax base for the cattle tax."10 Although Adamaoua's economy has expanded and diversified in the last six decades as a result, among other factors, of becoming a major transport hub after the completion of the Transcamerounais railway in 1974, cattle remains its emblematic cornerstone.

As Jean Boutrais (2001: 55) reminds us, the protagonist role of veterinary officials in the cattle sector dates back to the colonial era. As was the case in other French-controlled territories and contrary to what happened in British colonies, veterinary officials were involved in spheres other than the control of animal health. Their tasks included not only the management and improvement of pastureland but also the selection of breeds and the regulation of markets and commercial flows. This colonial administrative legacy was consolidated after independence, when Ahmadou Ahidjo, the country's first president, created a strong national professional corps. Veterinary agents were an exception to the sous-administration (insufficient administrative presence) that characterized the northern part of the country (Marguerat 1984: 466). During this period the grid of veterinary services in the area was denser than that of healthcare for humans (Boutrais 1999: 6o9).

The first national veterinary doctors received training abroad. ${ }^{11}$ In 1966 , the inauguration of an Animal Health and Production Training Center in Maroua created the possibility of domestic training for veterinary

10 ANY (National Archives, Yaoundé) 3AC 6141 Taxe sur le bétail, Avis des chefs de régions sur l'augmentation, 1950. Unless otherwise stated, all translations from the French are mine.

11 This was the case of Maikano Abdoulaye, who after his studies in France, was to become the head the national veterinary services in 1966. Hamadjoda Adjouji, the longest serving minister of livestock, also studied in France. When the Dakar Inter-State School of Veterinary Science and Medicine was created in 1968, it became an attractive option for Francophone Cameroonians. Senegal remains to this day the most common source of degrees for Cameroonian veterinary doctors. 
assistants. However, until 2007 no national institution offered a veterinary doctor degree, which meant that those in the higher echelons of MINEPIA necessarily studied abroad..$^{2}$ At the time of my research veterinary doctors working in Adamaoua had been trained in France, Senegal, the former Soviet Union and Nigeria. These diverse educational itineraries are a source of internal distinctions and splits, not unlike those that Giorgio Blundo (this volume) describes among Senegalese and Nigerien foresters.

To this day, veterinarians rather than administrators, engineers or economists have retained control over MINEPIA. Nonetheless, the veterinary profession has seen considerable changes in recent decades, as Jean-Germain Gros $(1993,1994)$ has documented. From the mid 1980s, the state was unable to sustain its policy of automatic employment of veterinary professionals. In 1988, under pressure from the World Bank, the government accepted in principle the private practice of veterinarians. The formal end of state monopolies over the exercise of the veterinary profession and over sales of veterinary products, however, took a few more years. ${ }^{13}$ This gradual process of privatization has transformed the paternalistic 'assistance contract' that linked the administration to cattle herders and traders (Boutrais 1999: 622). In 1991, only 12 out of a total of 112 Cameroonian veterinarians had set up private practice (Gros 1994: 47). Despite the rhetorical commitment to do so, the state did not materially support the veterinary officials who decided to follow this course of action. Those who succeeded did so either on their own or with the help of international pharmaceutical companies. The numbers of private practitioners have increased considerably since. Adamaoua remains the province with highest concentration of veterinarians, boasting ten private importers of pharmaceutical products (Messomo Ndjana 2006). In 2004, the city of Ngaoundéré counted four private veterinarians, three of them operating as importers as well.

The career of most employees in the tax administration tends to be more uniform than that of MINEPIA veterinary officials. Since 1965, the immense majority have gone through the professional training and socialization that the École Nationale d'Administration et de la Magistrature

12 Based at the University of Ngaoundéré (Adamaoua), the École des Sciences et de Médecine Vétérinaire started functioning in September 2007.

13 See, respectively, Law no. 1990/033 of August 10, 1990; and Law no. 2000/018 of December 19, 2000. 
(ENAM) provides. ${ }^{14}$ Yet, even today, senior positions are generally occupied by those who have supplemented their studies abroad, often at the French École Nationale d'Administration, or in Washington D.C. under the supervision of international financial institutions. After independence, the presence of public administration generally and of tax administration in particular was extremely thin across the north. ${ }^{15}$ In Adamaoua, it was largely limited to the city of Ngaoundéré. The bulk of tax collection was undertaken by the administration territoriale, with sub-prefects in protagonist roles and 'traditional authorities' serving as key intermediaries. In 1983, when the status of Adamaoua changed from district to province, the grid of the tax administration became denser. From then on, tax officials took up most audit and collection tasks at the level of former sub-districts now upgraded to the district status. In the first half of the 1990s, in conjunction with the severe economic crisis, the Villes Mortes general strikes and tax boycott, which had massive followings in the province rendered the tax administration practically inoperative. Tax authorities have since attempted to recover the ground lost during those years. The informalization of economic activity, the limited administrative resources, and the disaffection of officials have marked the context in which this gradual redeployment of the tax administration has taken place.

A September 2004 meeting held in Ngaoundéré on the taxation of the cattle trade (Muñoz 2011) offers a recent example of the long-standing tensions between MINEFI and MINEPIA officials. The local prefect had conceived a conciliatory meeting with cattle merchants to overcome their defiance of newly imposed obligations but found that the representatives of the two ministries were in no disposition to present a united front against a set of notoriously elusive taxpayers. On the contrary, the meeting became an opportunity for settling scores between them. The grudges of the MINEPIA provincial delegate featured prominently. He reminded everyone how the tax authorities, as a matter of course, unfairly accused MINEPIA of stoking up incivisme - a label commonly used by the government to stigmatize those who fail to pay taxes as bad citizens (Roitman 2005; Muñoz 2010) — among herders and traders. To the embarrassed silence of the tax officials present, the MINEPIA delegate admitted that

14 There was a predecessor of the ENAM, the Ecole Camerounaise d'Administration, created by the French in 1959, on the eve of independence.

15 Marguerat (1984: 466) describes the whole north as self-administered and sous-encadré (under-supervised). In 1970, there was in the north a government official per every 430 people. The ratio of official per inhabitant in the rest of the country was much lower, 1/180. 
he was "perplexed to find out that the measures contained in [a recent] letter [from the DGI] were taken without [MINEPIA] being informed. I must say, however, that we are already used to this kind of practice on their part." Once more, he noted, the tax authorities had shown "a complete disregard for the role of MINEPIA, which, as you all know, is held responsible for anything involving cattle." With hindsight, it was perhaps not entirely surprising that this meeting dramatized the conflicts between MINEFI and MINEPIA officials. Such propitious occasions to air their reciprocal grievances are few and far between.

MINEPIA and MINEFI tend to have a markedly different rapport with the main actors of Adamaoua's cattle economy. For a long time, the upper echelons in the Ministry of Livestock have been monopolized by Adamaoua politicians. Foremost among them, Hamadjoda Adjoudji, the minister at the time of my stay in the field, had held this position for twenty years (1984-2004). Even by Cameroon's impressive standards of political longevity, this is a remarkable feat as well as an extreme example of the policy of ethnoregional dosage (proportioning) of government appointments. Adjouji's successor also hails from Adamaoua. Not only is the MINEPIA hierarchy identified with what is popularly referred to as the bloc IslamoPeul ('Muslim-Fulbe power block') but veterinary agents in charge of the bulk of the ministry's groundwork are almost without exception Fulfulde speakers. Even those who did not initially speak the language ended up learning it during their training or on the job. Not having minimal skills in Fulfulde would make communication with herders so difficult as to render their task almost impossible.

By contrast, the majority of the MINEFI staff in the province is from the south of the country, and therefore likely to feel estranged from participants in the cattle economy, who are largely Fulbe and Hausa Muslims. The overrepresentation of southerners in Adamaoua's tax administration dates back to early independence (Gondolo 1978: 94). As far as most political posts were concerned, however, President Ahidjo adopted the policy of appointing northerners - and only those who were Muslim or Islamized. After Biya became president in 1982, the pattern was reversed and southern governors, prefects, and sub-prefects received appointments in the newly created Adamaoua Province (Beauvilain 1989: 607-610; Takougang 1993: 95-96; Taguem Fah 1996: 247-248). As Philip Burnham (1996: 174 n.11) notes,

Given the substantially greater average educational level of southern Cameroonians, the Biya government has been able to appoint 'on merit' a much greater proportion of southerners to administrative posts in the Mbere and throughout the north. Such appointments are justified by their incumbents 
both as an ending of Ahidjo's policy of ethnic favoritism as well as a furtherance of [Biya's] RDPC policies of 'renouveau' and modernist socioeconomic development.

Even under Biya's predecessor Ahidjo, however, the small numbers of persons from the north with higher education meant that southerners occupied most of the technical jobs. Although the quantity of northerners in such positions has increased considerably in the last decade, their small numbers in elite training schools, such as the ENAM, and in technocratic governmental and parastatal jobs is still a commonly voiced grievance against Biya's regime in the north. That imbalance became there the focus of one of the most noticeable political opposition platforms in recent times, the 2002 Memorandum of the Great North's Problems.

MINEFI, in any case, has been singled out by the regime's critics as overwhelmingly Beti (Biya's ethnic affiliation). The senior tax official present in the above-mentioned September 2004 meeting, for instance, was one of only two people among more than thirty participants who did not speak Fulfulde. In fact, the MINEPIA provincial delegate, also from Adamaoua, hinted at this cultural distance in many of his remarks. Their respective cultural proximity and distance vis-à-vis cattle herders and traders translate into considerable differences between what MINEPIA representatives and what the tax authorities know about the cattle sector and its main actors.

\section{Enhanced 'Revenue Reliability’ of the Cattle Sector}

The PSREP impinged on the (largely tolerated but unofficial) privileges of MINEPIA's veterinary agents. For decades, one of the perks of being posted to a cattle area in Adamaoua was the significant income that could be obtained from siphoning off part of the revenue raised in their role as tax and fee collectors. These practices were widely known and colored stereotypes on the figure of the docta na'i (cattle doctor, a term used for both doctors and assistants). As a veterinary assistant who had worked in Ngaoui in the late 1970s summed up, "Life on the border with Central African Republic can be tough, but it was a fast money-saving job." Since the end of the 1980s, the late payment and the diminishing purchasing power of salaries gave these funds renewed importance. More than ever, MINEPIA officials needed to "prepare their retirement," as two of my informants put it. During this period, projects such as the fight against the tsetse fly (Boutrais 1999) or the promotion of the local dairy industry 
(Tsapi 2002), in which the state veterinary agents played key roles, were equally among those 'areas of suspicion' of which Olivier de Sardan (2009: 46) has written.

The PSREP acknowledged a preexisting situation of widespread misappropriation of public moneys at the level of MINEPIA régies de recettes (tax collection units). Neither one of the two parties whose cooperation the program required denied this state of affairs. For example, one of the top officials in Adamaoua's tax administration, while minimizing the financial import of the taxes concerned, explained the program's objectives as follows:

Since the chefs de secteur (heads of cattle grazing zones) work in rural areas for the most part, they behaved as loose cannons (en electron libre). They undertook the collection of these duties, only to put the money in their pockets. The state has decided to protect these funds [against such practices] and we have succeeded. We have multiplied revenue from this source by three or four $(. .$.$) Yet, it remains a pretty negligible sum. In any case, [to$ raise large sums] was not the [program's] goal. The goal was to make sure that the duties that a chef de secteur collected, ended where they should.

Similarly, in relation to the PSREP's targets, no one in the local ranks of the MINEPIA felt the need to beat about the bush. When I asked him whether there had been winners and losers in the program's implementation, an employee at the provincial office emphasized,

It is MINEPIA that the program has penalized! The aim was to steer (canaliser) funds that sometimes got lost [in the collection process], because there were many collectors involved. It was a matter of the state being able to reclaim (récupérer) its own revenue.

All the same, at first the implementation of the PSREP's new collection procedures was anything but straightforward. The program initially ran against the resistance of veterinary agents on the ground. In the 1990s these agents had seen their prerogative as sole suppliers of veterinary products and services vanish under the banner of liberalization. According to their testimony, some saw the initiative to subject their tax collection tasks to MINEFI's surveillance as a full-fledged attack on their profession. Their bosses and their nonveterinarian colleagues in MINEPIA tended to have a more circumspect view. "After all, the tax collecting side of their job, it is by accident that they have come upon it," one of them told me. In any case, resistance to the program made 2001 a remarkably disappointing year in terms of veterinary taxes. The vested interests of municipal agents in charge of collecting market and 
slaughterhouse fees, who were involved in similar irregular practices, posed additional difficulties.

In many respects, however, the veterinary agents' battle was lost from the start. The tax and customs administrations would not give up the new remunerative share in the cattle economy to which they were now entitled. Whereas before MINEPIA had kept the full amount of the revenue raised from these sources, the PSREP decree rewarded MINEFI's participation in the collection process by allocating 30 percent of that amount to the Treasury (MINEPIA receiving the remaining 70 percent). Moreover, the tax authorities soon abandoned a maximalist approach. According to my informants, they realized that pursuing every single instance of an individual pocketing state revenue would be too costly. Instead, they decided to concentrate their actions in the provincial markets that they thought were most promising, namely Ngaoundéré, Likok, Banyo, and Ngaoui. At the time, the example of Ngaoui (Mbéré District, next to the Central African Republic border) was presented to make a case for the need to unify the collection services of MINEPIA, customs and the tax administration. This more pragmatic approach yielded results. From July 2001 to the end of June 2002, taxes that came under the PSREP mandate generated the respectable sum of 1,800 million CFA francs (about 2,7 million $€$ ) at the national level, compared to a mere 200 million $(300,000 €)$ per trimester in the previous fiscal year (PRASAC 2003: 77).

To add some historical perspective, it is worth noting that such drastic improvements in veterinary tax figures are not unprecedented. In the second half of the 1980 s, for example, the tax collected by the MINEPIA provincial services rose significantly. Revenue raised from these sources went from around 42 million CFA francs $(64,000 €)$ in $1984-1985$ to over 145 million CFA francs $(220,000 €)$ in 1989-1990. Unlike the PSREP, this was an internal process that did not involve any other ministerial department. Indeed, at the time, MINEPIA's official explanation of this change emphasized tighter control of market transactions and not state agents' misappropriation of revenue. This was certainly the case in terms of recorded transactions. In 1988-1989 sales in the province markets had increased 28.2 percent and shipments to the south by 31.8 percent. Yet, MINEPIA's report for that year also hinted at other factors: "Adamaoua has not ceased to make progress in the collection and transfer (reversement) of taxes to the state coffers." ${ }^{16}$

16 MINEPIA's provincial archives, Rapport Annuel 1988/89, Délégation Provinciale de l'Elevage de l'Adamaoua, p. 91, emphasis added; see also Rapport Annuel 1990/91, p. 88. 
Despite the noticeable improvement that the PSREP had induced by mid-2002, important gaps in the collection of cattle-related taxes remained. Several incidents were aired in early 2003. With its distinctive reporting style, the state-owned Cameroon Tribune drew attention to the discrepancy between the taxes collected and the number of cattle traded and slaughtered in the Mbéré District. According to this report, in Meiganga, where estimated levels of activity in the cattle sector should have generated six million CFA francs $\left(9,15^{\circ} €\right)$ in veterinary taxes per year, the municipality had never collected more than 60o,ooo (915 €). In Dir, another municipality of this district where "cattle is the unrivalled backbone of the economy," things were "even more serious:"

On the occasion of a recent sub-prefect's visit, voices rose crying out against the harm that this situation is causing to the commune. Of five cattle markets in Dir, the tax-collecting officer noted that apart from the revenue coming from Dir-Centre, he has never received any money from the other veterinary centers. Who specifically profits from veterinary taxes? It is difficult, very difficult to tell with any certainty, since accusations are coming from all sides. Mayors accuse veterinary agents. These, in turn, retort that it is municipal officials in charge of collecting taxes, acting on mayors' behalf, who are to blame. In short, there is some sort of neglect on the part of the authorities and a set of collusive practices between butchers and their partners. ${ }^{17}$

By the time I arrived in Adamaoua in July 2003, the readjustment set in motion by the PSREP was by and large a closed matter. Customs and tax officials in MINEFI, who had more at stake in the program, found the increased productivity of veterinary taxes satisfactory. MINEPIA agents in the province's most important markets had seen their income diminish, although, as far as I could tell, they had resigned themselves to it. Following a trend that had already begun in the previous decade, many had found private economic activities on the side to make up for those losses. Veterinary agents who supervised lower-ranked markets, where PSREP control was weak, still enjoyed considerable flexibility. The main complaint MINEPIA representatives expressed about the program was that MINEFI, in its role as collector of funds from this source, failed to give MINEPIA its corresponding 70 percent in a full and timely manner.

The PSREP had strikingly little impact on the activities of cattle breeders, traders, and butchers. The program did not change much in their way of conducting business. They had, for the most part, always paid the taxes at issue (veterinary market and slaughterhouse fees and laissez-passer

17 Cameroon Tribune, April 3, 2003. 
certificates). These were difficult to avoid anyway. This is not to say that cattle transactions outside markets that violate existing regulations, but which are a long-term feature of the regional economy, came to a halt. Once collected, those tax funds were not their concern. Several told me they feared that disgruntled veterinary agents would now interfere in their business. Most, however, reacted more positively. Some explicitly welcomed the fact that the taxes they were paying financed public spending rather than the private whims of civil servants, some hoped that part of the proceeds were used in upgrading market and slaughterhouse facilities.

\section{The Unreformed TaXation of Cattle Trade to Nigeria}

The previous section has examined how the implementation of the PSREP in Adamaoua was a gradual and negotiated outcome. This section places the PSREP in a broader context of administrative practice. It analyzes a realm of administrative action that the law does not acknowledge and that has remained beyond the reach of reform.

One morning in the field, a group of cattle traders in Ngaoundéré were waiting for the military escort to leave for a rural market. A man approached them and introduced himself. He was a veterinary assistant in a village in the Faro-et-Déo District, located on the Nigerian border. What had brought him to Ngaoundéré, he said, were the irregularities surrounding cattle exports to Nigeria, which he wanted to report to his superiors at the provincial level. Traders did not hold export licenses nor did they file import-export forms when they sent new herds across the border. Instead, he informed us, they made payments to local authorities in the district's administrative center. He even quoted the stipulated sums per animal that the municipality and the local chief received. None of this money, he claimed, reached state coffers.

His alarm about the dimensions of this phenomenon did not impress the traders. As a matter of fact, some of them operated in Nigeria. The trader he had chosen to address was quick to put him in his place. Cattle exports to Nigeria were "a reality," in fact a very old one:

It has been going on for decades and it won't stop. Then, it is a question of government authorities agreeing on what forms it should take. You say traders are behaving irregularly, when it is the authorities that have encouraged them to proceed the way they do. Of course, the Treasury is missing 
revenue, but who is to blame for this? Is it the traders who are paying their dues, or the officials who are pocketing the money?

The veterinary agent was startled to learn that those in the upper echelons of MINEPIA were perfectly aware of the situation. He had heard that this illicit trade had received the Faro-et-Déo prefect's approval, but had never suspected that everyone else knew about it. "Everyone has given their laissez-passer!," retorted the trader, putting an end to the conversation. He called a couple of other traders who operated across the Nigerian border and asked them to exchange views with the veterinary assistant, which they did reluctantly.

When the veterinary assistant finally left, his visit prompted a series of observations. The trader who had dealt with him remarked that they must remain vigilant. The cross-border cattle trade was an extremely sensitive issue. Not only did it raise questions about Cameroon's relationship with Nigeria - a heated topic in the aftermath of the dispute over the sovereignty of the Bakassi peninsula-but also stirred up the specter of corruption by state officials. Others sounded more defiant. It was in the interest of local authorities not to meddle in this 'file.' If these facts were to be aired, they thought, traders would have little to fear. Only a naïve official who had not served long in his post, like that veterinary assistant, would think of trying to change the way things worked. Not so naïve, another trader countered. If he was acting like this, it was only because he had not yet found the way to obtain his own cut in the money being paid. Yet another trader, half-jokingly, went even further. In his opinion, "He has yet to realize he is just the last link [of the chain]. If he keeps bothering his superiors and other officials, he will be transferred to a remote post in the bush. If worse comes to worst, he could be thrown into the Faro [river]." Everyone burst into laughter.

This chance encounter illustrates how control over economic activities such as the cattle trade depends on the combined efforts of a series of individuals acting on behalf of the state. These range from the territorial representatives of the central government (prefects and sub-prefects), to delegates and other agents of the relevant governmental departments and agencies (MINEPIA, Ministry of Industrial Development and Commerce, MINEFI's tax and customs administrations), and elected local representatives (mayors), as well as other administrative 'assistants' (chiefs). ${ }^{18}$ As this

18 Decree no. 77-245 of July 15, 1977, which regulates the organization of chieftaincy, defines the role of chiefs as auxiliaires de l'Administration. The decision of some chiefs 
account shows, there is ample room for conflict and compromise among state officials in their exercise of authority.

The cross-border cattle trade from Adamaoua to Nigerian markets was banned during the colonial period. A 1946 arrêté (ordinance) forbade exports to both Nigeria and Afrique Equatorial Française. It did not, however, put an end to this trade. Like in other domains, the colonial state could not live up to its ambitions. The legal texts and administrative decisions that outlawed these commercial flows were ineffectual from their inception and trade continued unabated. Administrative records from 1947 to 1953 even report on its volume. The paradox of this illegal trade whose existence the authorities openly acknowledge has remained a fixture. The postcolonial state similarly held on to the notion that Adamaoua's cattle should be reserved to supply southern Cameroon and thus refused to grant export licenses to trade with Nigeria. All the same, it was not in any better position than its predecessor to implement such a prohibition (Boutrais, Herrera and Bopda 1992: 4). Routinely violated, regulations that subject this commerce to the possession of licenses that are not granted under any circumstances, are nonetheless productive. They create a whole sphere of illegal economic activity, which, as Karine Bennafla's (2002) exemplary research on cross-border trade in Central Africa has shown, does not preclude entanglements between traders and state officials. It only colors them differently.

A taste of this peculiar dynamic may be obtained by looking back on the aforementioned September 2004 meeting on the taxation of cattle trade. An experienced trader, particularly intent in explaining how traders were "on the losing side every single day," made passing reference to the fact that many of them had directed their efforts to the Nigerian market. His remarks elicited an immediate response from the MINEPIA provincial delegate, "But that trade is not authorized!" Disregarding the delegate's outburst, the trader continued his impassioned speech. Everyone, it seemed, found the interruption either irrelevant or too trivial. A month later, I interviewed the delegate at his office. He openly acknowledged that Adamaoua's traders regularly took part in "Nigeria's circuit of parallel sales" despite its illegality. Explaining this apparent incongruity, he said, "We

to openly get involved in party politics has led to cases of overlapping roles. The lamido cum mayor of Bibémi (North Province), whose controversial management of Adumri's cattle market in 1996 has been documented by Bennafla (2002: 336), is one instance among many. 
lack the means to prevent it (...) Frankly, once animals leave Ngaoundéré and go back into the bush, there is little we can do." He glossed over the fact that at border-crossing points the cattle convoys bound for Nigerian markets are highly conspicuous even for an occasional visitor like me. A recent report tells us: "As a result of the systematic failure to restrict cattle circulation to designated trails, as well as the porosity of the Nigerian border, customs cannot really control cattle flows towards this country. They have to resign themselves to the traders' verbal statements on the size of the herds being exported, without the possibility of verification" (PRASAC 2003: 77). This is by no means an exceptional situation in Africa, although cattle export bans are less common than import bans and restrictions or temporary border closures (Little 2003, 2010; Mahmoud 2003).

In Cameroon's Faro-et-Déo District, the impracticability of enforcing a cattle export ban, therefore, does not bar state officials on the ground from arriving at an understanding with those who take part in this trade. The lack of legal cover for these economic activities means that officials are constantly engaged in negotiating their share, if any, of the funds resulting from turning a blind eye on these exports. Agreements reached among them rest on fragile ground. They depend on a mutual understanding with traders. As the example of the newly-appointed veterinary assistant shows, changes in personnel can alter the existing balance. A story from Tignère (Faro-et-Déo District), which circulated widely while I was doing fieldwork, further illustrates this phenomenon. According to several testimonies, in the late 1990s a newly appointed Ministry of Industrial Development and Commerce (MINDIC) delegate for the Faro-et-Déo, who noticed that cross-border cattle exports went on with impunity, decided to take matters into his own hands. A former colleague of his, prone to embellish stories for dramatic effect, recounted the ensuing events to a group of friends as follows:

No sooner had [the MINDIC district delegate] seized several herds to prevent them from crossing the border, than did the prefect turn up and nearly slap him. The delegate tried in vain to make him see that, according to regulations in place, those exports were not legal. The prefect cut him short. He was not to be told what the law was in his district. The whole thing was settled there and then. The delegate sent a report to his superiors and kept silent thereafter.

Events unfolding outside Adamaoua can also upset the conduct of business at the Nigerian border. For example, a 2001 conflict over the presence of unauthorized Chadian and Central African traders in Yaoundé's 
cattle market was settled, among other things, with a circular note from the minister. In protest against the increased presence of foreign traders, Adamaoua's traders had decided on halting their supplies. The ministerial note, dated July 4, 2001, called MINEPIA officials' attention to "the massive presence of foreign traders," despite the fact that "no formal regulation [of their activities] exists." The minister further urged them "to take measures to put an end to [it]," to ensure that "the [beef] demand of the country's consumption centers is satisfied." It is instructive to compare the impact of this measure to that of the PSREP on cattle exports to Nigeria. It is ironic that a lowly ministerial circular proved in this regard more consequential than a Prime Minister's decree, particularly since the latter was more clearly applicable to those specific trade flows than the former. While the veterinary laissez-passer that cattle should receive on their way to Nigeria fell within the mandate of the PSREP, the circular did not mention the trade on Adamaoua's border with Nigeria. Nor do Nigerian traders operate in Adamaoua's markets in any significant number. And yet, whereas the PSREP did not concern itself with these exports, the circular note resulted in MINEPIA's officials taking a harsher approach to them. This translated into threats of cattle confiscation, and, presumably, bribes. The minister's instructions did not end the economic game that stood outside 'formal regulation' but instead led to a renegotiation of the norms that allowed for the game to go on, with the state agents taking a larger unofficial fee.

Adamaoua's cattle exports to Nigeria give us perspective on the scope of the PSREP. They bear out Blundo's point (this volume) on the need to take a closer look at the conditions that determine what 'the state sees'. These exports, which do not 'meet the eye of the state' (Muñoz 2010), show that economic invisibility is coproduced by state and nonstate actors alike, by citizens subject to regulations and a plethora of official or de facto state representatives.

\section{CONCLUSIONS}

The documents that spell out the tax administration reform tend to project an image of the state as a unitary organization in the legal-bureaucratic sense, driven by deliberate projects and strategies. Numerous critical studies of public administration reform in Cameroon and elsewhere have warned us against taking such an image at face value. The interest of initiatives like the PSREP is that their point of departure is 
an acknowledgement of the difficulties involved in bureaucratic coordination. They are symptomatic of an era in which, to use the evocative metaphor proposed by Thomas Bierschenk (this volume), decentralized governance and the increased autonomy of state agencies remain ongoing 'construction sites.' The PSREP pushed two sets of state officials to work together. The program is shown in this light as a multifaceted undertaking through which the inhabitants of two islands in the Cameroonian 'administrative archipelago' are forced out of the inertia of minding their own business. Veterinary officials were being told in no uncertain terms that what they had long held to be their business was not (exclusively) theirs anymore. This image of administrative archipelago surfaces in Jean Copans' (2001) critical reflection on the links between the historical junctures of African politics and the analytical models developed to make sense of them. In the present political context, Copans (2001: 14) argues, it is not entirely surprising that the state appears as a collection of islands "isolated from each other, where the multiplicity of local and intermediary dynamics ... bring into question both the centeredness of administrative management and the notion of national corps of civil servants." In this regard, the fragmentation of authority described by authors like Mbembe (2001) fits both a long durée trajectory and the recent historical conjuncture (cf. Hagmann and Péclard 2010: 555-557).

For all the nostalgia for 'a general administrative organization' that, as Copans intriguingly suggests, many would-be reformers and reform analysts may betray, the collaboration that programs like the PSREP called for had clear limits. After all, if integration and coordination had become 'dirty words' by the 1980 s as Parker Shipton (2010: 125) reminds us, they have not quite seen their sheen restored yet in most quarters. Consider how prosaic the aim of the PSREP was in its 'white paper' version. As one of the senior tax officials I have quoted reminded me, the program was simply a matter of ensuring that the moneys in question "ended where they should." This set the limits of the coordination efforts. And revenue-wise, it is worth reminding, the PSREP did well enough. Compare its results to those of its ailing later generation cousin, the PSRR, which targeted the revenue of road tolls. "Trying to perform balancing acts between the different departments", the tax officials working for the PSRR managed the 'feat' of reducing annual toll revenue almost in half within a two year period, a time in which both the number of tolls and registered vehicles increased. ${ }^{19}$

19 Cameroon Tribune, July 9, 2009; Mutations, January 18, 2008. 
Yet, in the case of the PSREP, the overriding effect of 'the revenue imperative' appears to be somewhat misleading. Undoubtedly, revenue weighs heavily on the outcome of reforms in the domain of taxation, the PSREP being no exception. The program, however, also entailed bridging the gap between two distinct professional repertoires. It is not simply that, to an extent compatible with its revenue targets, the program was pragmatically reformulated to reconcile veterinary and tax officials competing claims to 'privatize' their bureaucratic tasks. Rather, I have shown as well that there are nonrevenue dimensions to the PSREP-induced realignment of these two departments' respective spheres of influence.

In any case, an analysis of the PSREP on its own terms, with its focus on relationships between tax officials and veterinary agents, runs the risk of losing sight of a broader constellation of administrative practice. A look into the unofficial regulation of the cattle trade to Nigeria, where public authority results from a more complex dynamic in which authorities such as prefects, mayors, and chiefs, as well as a whole array of nonstate actors take part, elucidates the contour of that constellation. No matter how ambitious the reforms under way in Cameroon and other sub-Saharan African countries may be, the ebbing tide of state control over the economy depends on precarious, ambivalent and often reversible agreements among a variety of actors. Those processes involve varying degrees of avoidance, accommodation, cooperation, negotiation, resistance, and conflict.

\section{REFERENCES}

Abelin, Mireille. 2012. Entrenched in the BMW: Argentine elites and the terror of fiscal obligation. Public Culture forthcoming.

Barbone, Luca, Das-Gupta, Arindam, de Wulf, Luc and Anna Hansson. 1999. Reforming tax systems: the World Bank record in the 1990s. Tax Policy and Administration Thematic Group, World Bank.

Bayart, Jean-François. 1985 (2nd ed.). L'état au Cameroun. Paris, Presses de la fondation nationale des sciences politiques.

Bayie Kamanda, Cornelius. 1999. Cameroon: the retrenched workers of the civil service and parastatals, Le Bulletin de l'APAD 18, available at: www.apad.revues.org.

Beauvilain, Alain. 1989. Nord-Cameroun: crise et peuplement. Doctoral dissertation. Université de Rouen (France).

Bennafla, Karine. 2002. Le commerce frontalie en Afrique centrale: acteurs, espaces, pratiques. Paris, Karthala.

Bierschenk, Thomas and Jean-Pierre Olivier de Sardan. 1998. Les arènes politiques face à la décentralisation et à la démocratisation. In Bierschenk, T. \& J.-P. Olivier de Sardan, eds. Les pouvoirs au village: le Bénin rurale entre démocratisation et décentralisation. Paris, Karthala, 11-51. 
- 2003. Powers in the village: rural Benin between democratisation and decentralization. Africa: 73 (2): $145^{-173 .}$

Bird, Richard and Milka Casanegra de Jantscher, eds. 1992. Improving Tax Administration in Developing Countries. Washington DC, International Monetary Fund.

Boll, Karen. 2012. Representing and performing businesses: a segmentation model in action. Journal of Cultural Economy, forthcoming.

Boutrais, Jean. 1999. Zébus et mouches tsé-tsé: chronique de l'élevage en Adamaoua (Cameroun). In Baroin, C. \& J. Boutrais, eds. L'homme et l'animal dans le basin du lac Tchad. Paris, IRD, 599-626.

—. 2001. Du pasteur au boucher: Le commerce du bétail en Afrique de l'Ouest et du Centre. Autrepart, 19: 49-70.

Boutrais, Jean, Herrera, Javier and A. Bopda. 1992. Bétail, naira et franc CFA: un flux transfrontalier entre Nigeria et Cameroon, available at: http://www.documentation.ird.fr/hor/ fdi:010024622, accessed on: May 8, 2013.

Bräutigam, Deborah. 2009. Introduction: taxation and state building in developing countries. In Bräutigam, Deborah, Fjeldstad, Odd-Helge and Mick Moore, eds. Taxation and State Building in Developing Countries: Capacity and Consent. Cambridge, Cambridge University Press, $1-33$.

Bruneau, Juliette and David Abouem. 2004. Evaluation prospective du Programme National de Gouvernance du Cameroun. United Nations Development Programme, Yaoundé, available at: http://erc.undp.org/evaluationadmin/downloaddocument .html? docid=264.

Burnham, Philip. 1996. The Politics of Cultural Difference in Northern Cameroon. Edinburgh, Edinburgh University Press.

Cantens, Thomas. 2009. Être chef dans les douanes camerounaises, entre idéal type, titular chief et big katika. Afrique contemporaine 230: 83-100.

- 2012. The role of the customs elite on the reform process in Cameroon. In Amsden, Alice, DiCaprio, Alice and James Robinson, eds. The Role of Elites in Economic Development. Oxford, Oxford University Press, 281-306.

Chalfin, Brenda. 2010. Neoliberal Frontiers: An Ethnography of Sovereignty in West Africa. Chicago, University of Chicago Press.

Chambas, Gérard, ed. 2005. Afrique au Sud du Sahara: mobiliser des ressources fiscales pour le développement. Paris, Economica.

Charlier, Florence and Charles N'Cho-Oguie. 2009. Sustaining Reforms for Inclusive Growth in Cameroon: A Development Policy Review. Washington DC, World Bank.

Copans, Jean. 2001. Afrique noire: un État sans fonctionnaires? Autrepart 20: 11-26.

Crozier, Michel. 1995. La crise de l'intelligence: essai sur l'impuissance des élites à se réformer. Paris, Inter-Editions.

Evina Obam, Richard. 2005. L'intégration du pilotage des performances en finances publiques camerounaises. Master thesis. École Nationale d'Administration (France).

Fjeldstad, Odd-Helge and Mick Moore. 2009a. Tax reform and state-building in a globalized world. In Bräutigam, Deborah, Fjeldstad, Odd-Helge and Mick Moore, eds. Taxation and State Building in Developing Countries: Capacity and Consent. Cambridge, Cambridge University Press, $235^{-260}$.

Geschiere, Peter and Piet Konings. eds. 1993. Itineraires d'accumulation au Cameroun. Paris, Karthala.

Gondolo, André. 1978. Ngaoundéré: évolution d'une ville peule. Doctoral dissertation, University of Rouen (France).

Gros, Jean-Germain. 1993. The Privatization of Livestock Services in Cameroun: A Study in the Feasibility of State and Market Participation in Economic Restructuring. PhD thesis. University of California, Berkeley.

- 1994. Of cattle, farmers, veterinarians and the World Bank: the political economy of veterinary services privatization in Cameroon. Public Administration and Development, $14(1): 37-51$. 
Gupta, Sanjeev and Shamsuddin Tareq. 2008. Mobilizing revenue. Finance and Development, 45 (3): 44-47.

Guyer, Jane. 1992. Representation without taxation: an essay on democracy in rural Nigeria, 1952-1990. African Studies Review, 35 (1): 41-79.

Guyomarch, Alain. 1999. 'Public service,' 'public management' and the modernization of French public administration. Public Administration, 77 (1): 171-193.

Hagmann, Tobias and Didier Péclard. 2010. Negotiating statehood: dynamics of power and domination in Africa. Development and Change 41 (4): 539-562.

Hibou, Béatrice. 2006. Force de l'obéissance: économie politique de la répression en Tunisie. Paris, La Découverte.

Kaldor, Nicholas. 1963. Will underdeveloped countries learn to tax? Foreign Affairs, 41: 410-419.

Kiser, Edgar and Audrey Sacks. 2009. Improving tax administration in contemporary African states: lessons from history. In Martin, Isaac, Mehrotra, Ajay and Monica Prasad, eds. The New Fiscal Sociology. Cambridge, Cambridge University Press, 183-200.

Libom Li Likeng, Minette, Djeuwo, Marcellin and Samson Bilangna. 2011. Gazing into the Mirror II: Performance Contracts in Cameroon Customs. Washington, World Bank.

Little, Peter. 2003. Somalia: Economy without State. Oxford, James Currey.

- 2010. Unofficial cross-border trade in East Africa. In Sarris, Alexander and Jamie Morrison, eds. Food Security in Africa: Market and Trade Policy for Staple Foods in Eastern and Southern Africa. Rome, FAO, 158-181.

Lund, Christian. 2006a. Twilight institutions: an introduction. Development and Change 37 (4): 673-684.

- 2006b. Twilight institutions: public authority and local politics in Africa. Development and Change 37 (4): 685-705.

Mahmoud, Hussein A. 2003. The Dynamics of Cattle Trading in Northern Kenya and Southern Ethiopia: the Role of Trust and Social Relations in Market Networks. PhD thesis, University of Kentucky, Lexington.

Marguerat, Yves. 1984. Les faiblesses de la vie sociale et économie moderne. In Boutrais, Jean, ed. Le nord du Cameroun. Paris, ORSTOM, 459-477.

Martin, Isaac, Mehrotra, Ajay and Monica Prasad. eds. 2009. The New Fiscal Sociology. Cambridge, Cambridge University Press.

Mbembe, Achille. 2001. On the Postcolony. Berkeley, University of California Press.

Messomo Ndjana, Florent. 2006. Étude de la distribution et de la qualité des médicaments vétérinaires au Cameroun. PhD thesis, Université Cheikh Anta Diop.

Mosse, David. 2004. Is good policy unimplementable? Reflections on the ethnography of aid policy and practice. Development and Change, 35 (4): 639-671.

Muñoz, José-María. 2010. Business visibility and taxation in northern Cameroon. African Studies Review, 53 (2): 149-175.

- 2011. Talking law in times of reform: paradoxes of legal entitlement in Cameroon. Law \& Society Review, 45 (4): 893-922.

Nanga, Charles. 2000. La réforme de l'administration territoriale au Cameroun. Master thesis. École Nationale d'Administration (France).

Ngouo, Léon B. 1997. Responsibility and transparency in governmental organizations in Cameroon: a review of institutional arrangements. International Review of Administrative Sciences, 63: 475-492.

- 2000. Organizational development consulting in the context of structural adjustment in Sub-Saharan Africa: role and responsibility of consultants. International Review of Administrative Sciences, 66 (1): 105-118.

- 2008. Réforme administrative dans les services publics en Afrique: développement, performance et bonne gouvernance. Paris, L'Harmattan.

Olivier de Sardan, Jean-Pierre. 2001. La sage-femme et le douanier. Cultures professionnelles locales et culture bureaucratique privatisée en Afrique de l'Ouest. Autrepart, 20: 61-73. 
- 2009. State bureaucracy and governance in West Africa. In Blundo, Giorgio and Pierre-Yves Le Meur, eds. The Governance of Daily Life in Africa: Ethnographic Explorations of Public and Collective Services. Leiden, Brill, 39-71.

PRASAC (Pôle regional de recherche appliquée au développement des savanes d'Afrique Centrale). 2003. Etude sur la commercialisation des bovines et de la viande bovine dans la région CEMAC. N'jamena, Commision Economique du Bétail, de la Viande, et des Ressources Halieutiques.

RDPC. 2009. L'administration dans le bourbier de sa réforme. L'Action, available at: www .journal.rdpcpdm.cm.

Raffinot, Marc. 2001. 'Motiver' et 'chicoter': l'économie politique de la pression fiscale en Afrique subsaharienne. Autrepart, 20: 91-106.

Roitman, Janet. 2005. Fiscal Disobedience. An Anthropology of Economic Regulation in Central Africa. Princeton, Princeton University Press.

Shipton, Parker. 2010. Credit between Cultures: Farmers, Financiers, and Misunderstanding in Africa. New Haven, Yale University Press.

Shore, Cris and Susan Wright. 1997. Policy: A new field of anthropology. In Shore, Cris and Susan Wright, eds. Anthropology of Policy: Critical Perspectives on Governance and Power. London, Routledge, 3-42.

Shore, Cris, Wright, Susan and Davide Pero. 2011. Policy Worlds: Anthropology and the Analysis of Contemporary Power. Oxford, Berghahn.

Sindjoun, Luc. 1996. Le champ social camerounais: Désordre inventif, mythes simplificateurs et stabilité hégémonique de l'État. Politique africaine, 62: 57-67.

Stotsky, Janet. G. and Asegedech Woldemariam. 1997. Tax effort in sub-Saharan Africa. IMF Working Paper 97/107. Washington, International Monetary Fund.

Taguem Fah, Gilbert. 1997. Les élites musulmanes et la politique au Cameroun de la période française à nos jours. Doctoral dissertation, Université de Yaoundé (Cameroon).

Takougang, Josef. 1993. The demise of Biya's New Deal in Cameroon. Africa Insight, 23 (2): 91-101.

Takougang, Josef and Milton Krieger. 1998. African State and Society in the 199os: Cameroon's Political Crossroads. Boulder, Westview Press.

Tamekou, Raoul. 2008. The National Governance Programme (2006-2010) and the modernization of the administration: Cameroon and New Public Management. International Review of Administrative Sciences, 74 (2): 217-234.

Therkildsen, Ole. 2001. Understanding taxation in poor African countries: a critical review of selected perspectives. Forum for Development Studies, 28 (1): 99-123.

Tsapi, Victor. 2002. La vache, la viande et le lait dans l'Adamaoua: pour la redynamisation d'un industrie 'négligée'. Keynote address academic year 2002/2003, University of Ngaoundéré (Cameroon).

World Bank. 2001. Cameroon Country Assistance Evaluation. Washington: World Bank.

\section{LIST OF ACRONYMS}

ANTILOPE National Implementation of Computerized Management and Logistics of State Personnel

CCI Head of the Tax Center

CIME Tax Center for Medium-Sized Enterprises

DGI National Tax Bureau

DGE DGI's Unit for Large Taxpayers

ENAM École Nationale d'Administration et de la Magistrature

MINDIC Ministry of Industrial Development and Commerce

MINEFI Ministry of Economy and Finance

MINEPIA Ministry of Livestock, Fisheries and Animal Industries

NGP National Governance Program 
PROMAGAR Program for the Modernization of the Administration through Performancebased Management

PSREP Program for Improved Revenue Reliability in the Animal Husbandry and Fisheries Sector

PSRF Program for Improved Revenue Reliability in the Forestry Sector

PSRM Program for Improved Revenue Reliability in the Mining Sector

PSRR Program for Improved Revenue Reliability in the Road Sector

RDPC Cameroon Peoples' Democratic Movement

SIGIPES Computer System for the Integrated Management of State Personnel and Payroll

UNDP United Nations Development Programme

VAT Value-Added Tax 


\title{
OLD-SCHOOL BUREAUCRATS AND TECHNOCRATS IN MALAWI: CIVIL SERVICE REFORM IN PRACTICE
}

\author{
Gerhard Anders
}

\section{REFORMING 'DYSFUNCTIONAL' AFRICAN BUREAUCRACIES}

According to the World Bank and the International Monetary Fund (IMF), there is little doubt that African bureaucracies are inefficient and unsustainable. Corruption and mismanagement of public resources are identified as the main impediments to economic recovery. Since the 199os, Good Governance has been promoted by the international financial institutions (IFIs) as instrument to remove these obstacles to economic growth. The term Good Governance denotes a set of policy-measures intended to transform 'dysfunctional' public institutions into efficient and transparent service-providers accountable to the public and subject to the rule of law. One of the primary instruments to improve governance has been civil service reform, the reorganisation of the state bureaucracy according to the principles of New Public Management. Accordingly, World Bank and IMF have made the reorganisation of the civil service one of the primary conditions for their financial support. In sub-Saharan Africa, where most countries have been implementing Good Governance reforms in the past decade, the reorganisation of the civil service has had mixed results. In spite of the introduction of new management and accounting systems, outsourcing and privatization of non-core government functions and the dismissal of government employees made redundant the performance and efficiency of African bureaucracies is still found wanting by the 'donor community'.

This chapter argues that the implementation of the Good Governance agenda has failed to address the underlying dynamics of postcolonial bureaucracies in sub-Saharan Africa. The policies promoted by the IFIs are based on a technocratic conception of the state as homogenous and unified actor that needs to be repaired with a set of instruments or 'tools' provided by World Bank and IMF experts (see also Bergamaschi, Charton and Muñoz in this volume). This perspective is flawed since it does not account for the colonial legacy of African states and their historical trajectories since independence. Drawing on archival and ethnographic 
evidence $^{1}$ on the implementation of civil service reform in Malawi between 1994 and 2007 this chapter suggests that the implementation of civil service reform has deepened already existing fissures within the civil service rather than contributed to greater cohesion.

This is well exemplified by one of the central elements of civil service reform in Malawi, the retrenchment of government employees made redundant, deemed to be the first step toward creating a more efficient civil service by the consultants of the IFIs (World Bank 1989, 1993, 1994a, 1994b). The reduction of staff was one of the conditions for continued financial support from the IFIs and is usually considered to be one of the hallmarks of neo-liberal reform. The dismissal of employees also tends to be one of the most contested measures. It is, therefore, well suited for an analysis of the implementation of the Good Governance agenda. According to official figures the government of Malawi dismissed approximately 34,000 employees between 1994 and 2000, mainly support staff and junior civil servants. Staff reduction widened already existing fissures in the civil service that were the result of the creation of new agencies with support from the IFIs in the 1990s, on the one, and Malawi's colonial and postcolonial history, on the other hand.

The aim of this chapter, therefore, is not to establish the 'failure' or 'success' of civil service reform in Malawi but rather to transcend the contingent categories of development thinking defining 'success' or 'failure' and thereby to contribute to a better understanding of the dynamics of the postcolonial state in sub-Sahara Africa. In doing so it adopts a critical view of social engineering promoted by the IFIs and consciously disengages social scientific analysis from development practice. Such a perspective builds on a growing body of critical anthropological scholarship that investigates the practice of constructing or framing the very objects of development interventions (Escobar 1995; Ferguson 1994; Mitchell 2002; Mosse and Lewis 2005; Quarles van Ufford and Giri 2003; Marcussen and Arnfred 1998).

Transcending the instrumentalist vision of social engineering requires a much wider scope of inquiry, including 'factors' that seem to have no direct causal relationship with the policy intervention and unforeseen sideeffects. A number of studies investigate how unintended consequences

${ }^{1}$ Anthropological fieldwork in two urban areas, the capital Lilongwe and Zomba in the south, was carried out between November 1999 and November 2000, February and March 2002, and November 2007. 
may undermine the efficacy of policy measures (e.g. Long 2001; Moore 1973; Olivier de Sardan 2005; von Benda-Beckmann 1993). As early as 1967 the famous development economist Hirschman drew attention to the importance of influences outside the scope of the project design and unexpected side-effects:

[E] ach project turns out to represent a unique constellation of experiences and consequences of direct and indirect effects. This uniqueness in turn results from the varied interplay between structural characteristics of projects, on the one hand, and the social and political environment, on the other (Hirschman 1967: 186).

Since the mid 1990s, Malawi, a former British colony (until 1964) and one of the least developed countries according to the UNDP development index (UNDP 2006) has implemented a number of programmes designed and financed by the IFIs that target perceived problems in the civil service. Malawi has a long history of implementing World Bank and IMF policies prescriptions. It was among the first countries to implement the notorious Structural Adjustment programmes in 1979 and has implemented the usual set of reform programmes aimed at stimulating economic growth, generally with limited success (Harrigan 1997). Between independence and 1994 the country was ruled by Kamuzu Hastings Banda, President for Life since 1971. Under Kamuzu Banda's paternalistic rule all aspects of social and political life were closely monitored by the security services and the only legal political party, the Malawi Congress Party (MCP). The civil service did not remain unaffected. A culture of fear prevailed in the civil service and civil servants owed unconditional loyalty to Kamuzu Banda and the MCP. One-party rule ended in 1993 when the majority of the population voted for the introduction of multi-party democracy. The first free elections in 1994 were won by Bakili Muluzi and the United Democratic Front (UDF). Muluzi served as president for two terms, until 2004, when the incumbent, Bingu wa Mutharika, was elected. Especially in the first years after the introduction of multi-party democracy people enjoyed the new political liberties but soon disillusionment spread because successive governments have been unable to reverse the economic decline that has been affecting the economy since the 1980s. In an effort to reverse the economic crisis the democratically elected governments have implemented the policy prescriptions of the IFIs ranging from deregulation of the economy to civil service reform.

This sketch of the historical context provides the backdrop for a detailed account and analysis of the execution of the retrenchment exercise in 
three parts. The first part situates the civil service reform programme in the context of the Good Governance agenda promoted by the IFIs. The second part presents an account of the implementation of the retrenchment exercise, which shows that the framing of the object of civil service reform, i.e. the Malawian nation-state, by the IFIs failed to address the historical trajectory of the civil service in Malawi and, therefore, exacerbated already existing internal divisions. The third part, then, deals in more detail with these internal divisions and the ways how they shaped and were shaped by the implementation of the civil service reform programme.

\section{The InSTRUMENTAList Vision OF GoOD GOVERnANCE}

Good Governance emerged as the new paradigm of development assistance in the 1990s. It heralded an era of much bolder interference in the domestic affairs of governments of developing countries. The IFIs called for the radical overhaul of the state institutions according to the neo-liberal dogma in order to create favourable conditions for economic development. Good Governance would thus contribute to "sustainable economic and social development" (World Bank 1992: 5) and "macroeconomic stability, external viability, and orderly economic growth" (IMF 1997: 1; see also World Bank 1989, 1994b).

The booklet Governance and Development published in 1992 was the World Bank's first general statement of the new development agenda. It defined governance as "the manner in which power is exercised in the management of a country's economic and social resources for development" (1992: 3). According to the Bank the key dimensions of governance are "public sector management, accountability, the legal framework for development, and information and transparency" (1992: 6). Although this was the first publication to be exclusively devoted to issues of Good Governance, the Bank had addressed the problem of state bureaucracies in developing countries earlier. In 1989, a World Bank report on sub-Saharan Africa mentioned "deteriorating governance" as one of the main causes of the crisis in Africa. It attributed the economic crisis to the expansion of state services and the interference of the state in the economy after independence (World Bank 1989: 30). In line with this neo-liberal critique of the interventionist state, World Bank experts designed instruments to transform "dysfunctional" and "inefficient" government institutions in order to create the envisaged "enabling environment" by "defining and protecting property rights, providing effective legal, judicial and regulatory systems, improving the efficiency of the civil service" (World Bank 1991). 
In subsequent years World Bank staff and researchers developed the "governance approach" (Dia 1993: 1996) that provided an analytical framework for civil service reform in Africa. This approach attributed the failure of prior attempts to reform the civil service to the 'patrimonial character' of the state in sub-Saharan Africa. ${ }^{2}$ A variant of the 'governance approach' was applied in Malawi. Key functions such as revenue collection, customs and pre-shipment inspection were removed from the civil service and became the domain of new autonomous government agencies and private companies. These measures were supplemented with a civil service reform programme, the outsourcing of non-core functions such as gardening, security services and carpenter workshops and the privatisation of state-owned companies. The 'governance approach' embodied the Bank's vision of the state that would be limited to certain core functions the effective management of which would create the necessary room for private initiative to contribute to economic growth. The following part will discuss the consequences of the implementation of the 'governance approach' in Malawi focusing on the dismissal of staff made redundant.

\section{Right-Sizing the Civil Service}

One of the main objectives of civil service reform in Malawi has been the "right-sizing" of the bureaucracy. ${ }^{3}$ According to the experts of the IFIs a smaller, leaner and more efficient civil service is a necessary pre-condition for Good Governance. In 1996, the government of Malawi adopted an Action Plan in which it announced to outsource and privatize noncore functions, to reduce "overlap and duplication in the machinery of government", to improve performance and efficiency, and to "design and implement a retrenchment programme which will assist in the move to an affordable and sustainable civil service" (GoM 1996b: 2).

The dismissal of redundant employees was deemed necessary by the IFIs to correct the skewed staff composition and to render the civil service more cost-efficient. Many civil servants perceived civil service reform as threat to the status quo and attempted to manipulate, co-opt and appropriate it. The implementation of the retrenchment exercise met the silent resistance of many in the civil service since it affected the long-standing

\footnotetext{
2 The World Bank approach only bears a superficial resemblance to the neo-patrimonial approach developed by Eisenstadt (1972) and Médard (1982).

${ }^{3}$ Interview with the World Bank representative, Lilongwe, March 2000.
} 
practice of hiring large numbers of employees with little education or training to perform menial tasks.

The World Bank conducted two studies in 1991 and 1993 to assess problems in the civil service and make recommendations for the civil service reform (World Bank 1993; 1994a). These studies recommended reducing the number of support staff like watchmen, cleaners, workmen, messengers etc. occupying the lowest grades in the civil service, the Industrial Class (IC) and to a lesser degree the Subordinate Class (SC). The former were employed on a temporary basis and were, therefore, not part of the civil service establishment. The term civil service establishment denotes the established positions that are specified in the pay roll and controlled by the Public Service Commission, the body ultimately in charge of appointments and dismissals of civil servants. The SC, in turn, was part of the civil service establishment. ${ }^{4}$

Prior to the civil service reform the civil service provided employment and social security for thousands of manual labourers, gardeners, security guards, receptionists and messengers and each year more people found employment in the civil service. The expansion of staff was not the result of actual need but rather stemmed from a logic of allocating the state's resources, a well-documented characteristic of African bureaucracies. By 1995 more than 35 percent of all civil servants held lower ranks and had little or no formal education whereas only five percent of the civil servants occupied management and professional posts leaving many of these posts vacant due to the lack of suitable candidates (GoM 1996a: 27-31).

Although the IC posts were officially only temporary IC employees never had been threatened by dismissal. Prior to the 1990 government employment was a secure life-long position that entitled its holder not only to a regular - albeit small — salary but also to a whole range of benefits such as paid sick leave and terminal benefits upon retirement. Numbers of the IC and other subordinate staff grew because the superior officers in the ministries provided clients and kin with government jobs without effective control from the ministerial top or controlling agencies. The World Bank experts were the first who challenged this modus vivendi in the early 199os. They argued that the IC had to be abolished and that the staff numbers

4 Formally, civil servants proper are only those government employees holding established positions as opposed to temporary staff and IC staff holding non-established posts. Temporary staff and IC staff, however, were usually referred to as civil servants and counted as such in the civil service census (GoM 1996b). Hence, in this chapter all government employees are referred to as civil servants. 
in the lower grades had to be reduced while the top positions should be upgraded and salaries for senior management and professional functions ought to be increased in order to control the civil service wage bill and improve performance (World Bank 1994a). ${ }^{5}$

Employment of IC employees fell within the discretion of the individual departments compared to established posts, which had to be approved centrally by the Public Service Commission and the Department of Human Resource Management and Development. The World Bank missions had identified this practice as one of the main causes for the uncontrolled growth of the IC (World Bank 1994a). It was a well-known secret that most heads of departments and other high-ranking civil servants in the departments exploited their authority to employ IC employees to provide clients and kin with jobs and social security. Often they also hired people on the instigation of politicians who used their influence to provide their clients with employment. This authority to employ IC workers without interference from the Public Service Commission or the Department of Human Resource Management was also used to employ fictive employees, so-called ghost-workers. The salaries paid for the ghost-workers were pocketed by rackets of senior civil servants in the departments and accounting sections. Consequently, the World Bank recommended to abolish the IC and to make former IC employees redundant. Many of the tasks formerly performed by support staff such as gardening, manual labour and security were earmarked for privatisation. The remaining IC employees were supposed to be integrated in the establishment of the civil service (World Bank 1994a).

The actual implementation of this plan was of course much messier than the documents signed between the World Bank and the government suggest. Targets were not met, deadlines were not kept, and implementation was often subject to ad-hoc decision-making, particularistic interests and unanticipated events. Nevertheless, the World Bank and the IMF maintained just enough pressure to keep the government from reverting to the former practice of hiring large numbers of support staff who enjoyed the support of patrons in the higher echelons of the civil service or politicians. Due to the transition from one-party rule to multi-party democracy there was no real opposition among the politicians of the UDF

\footnotetext{
5 A notable exception constituted primary school teachers who were considered to be "juniors" but who were not threatened by retrenchment. The government had embarked on a programme to extend free primary school education and had hired thousands of primary school teachers in 1995 and 1996 thus providing employment for many dismissed civil servants.
} 
and the other political parties against civil service reform since civil servants were generally associated with Kamuzu Banda's regime. The cabinet neither opposed nor promoted civil service reform for fear of causing social unrest among the civil servants with the exception of the then vicepresident who promoted civil service, which fell in his portfolio. The civil service was deeply divided between those charged with the execution of the Action Plan and those resisting it as I will show.

The Secretary of Human Resource Management calculated that the IC had to be reduced to 16,00o employees. These 16,00o employees should be incorporated into the civil service establishment. According to estimates the civil service had employed about 50,00o IC employees in 1994. This is just a rough estimate since no reliable data on the IC existed prior to the civil service census conducted in 1995 (World Bank 1994a: 18). The Letter of Development Policy requesting US \$ 106.4 million for the first phase of civil service reform, the Fiscal Restructuring Development Program, included the implementation of the civil service reform as a condition for financial support of the World Bank. This letter, submitted by the government to the World Bank, stated that between February and September 1995 government had already laid off about 20,000 civil servants, mainly lower-ranking support staff of the IC, as a condition for disbursement of the loan. This meant that 14,000 more civil servants had to be laid off to reach the target of 16,000 posts. The next wave of dismissals occurred between 1997 and 1998: Thousands of government employees holding junior positions were dismissed. By 2000 the dismissal of staff made redundant was by and large concluded according to senior officials interviewed by the present author in 2002. ${ }^{6}$

In 1997, the government established a specialized agency, the Public Sector Change Management Agency (PSCMA), with the task to conduct functional reviews of each ministry. Establishment of the PSCMA was one of the conditions for the disbursement of the credit to finance the civil service reform programme. The functional reviews had to make recommendations on the improvement of performance, the internal command structure, the

6 The official numbers of retrenched civil servants should be treated with caution. There was no reliable data on the number of IC employees in 1994 and the number of 20,00o dismissed employees was not verifiable either. Considering that the government had an interest to report a high number of dismissed civil servants in the Letter of Policy since staff reduction constituted one of the conditions of the agreement with the World Bank it is at least possible that the government reported a high number of civil servants laid off prior to the disbursement of the credit to have a more favourable starting position for the civil service reform. 
"elimination of overlap and duplication" and the reduction of staff "to cut the wage bill", according to the director of the PSCMA. Most of the staff of the PSCMA was quite young, not older than 40, held university degrees in economics or human resource management and represented the professional elite of the civil service. Superior officers in the line ministries such as Health and Agriculture often refused to cooperate with PSCMA. Among the management of the ministries there was only little enthusiasm for the civil service reform that threatened to reduce their discretionary powers and the staff of PSCMA complained about delay tactics and other subversive forms of non-compliance from senior officers of the line ministries such as not keeping dead-lines and appointments or simply not following orders concerning the reorganisation of their departments.

By 2004, the functional reviews had been concluded and according to official figures all IC employees were either dismissed or incorporated into the civil service establishment on SC positions. Services such as security or gardening had been outsourced to private companies. With regard to the numbers of employees who were eventually incorporated into the civil service establishment it is quite possible that more than 16,000 employees were eventually incorporated into the civil service establishment. For example, the retrenchment exercise did not affect temporary staff working for externally funded projects executed by government departments and my evidence suggests that many people succeed to filter back into the civil service through these projects that fall outside the scope of the Department of Human Resource Management and the Public Service Commission. Due to the absence of statistics on this phenomenon it was impossible to establish how many dismissed civil servants actually succeeded in filtering back into the civil service but it is a fair guess to assume that it could be up to several thousand based on ethnographic evidence gathered during the author's fieldwork.

Even though a few thousand former employees might have succeeded in filtering back into the civil service the retrenchment exercise can be considered a success from the perspective of the IFIs since the majority of junior civil servants made redundant were dismissed thus freeing up resources for raising the salaries for scarce professionals. But 'success' is a contingent notion depending on the objectives and political context of a project rather than an analytical category. Hence, this article suggests that in spite of reaching the targets set by the experts of the World Bank and the IMF the retrenchment exercise was not an unequivocal success since it widened fissures and fault-lines within the civil service threatening its cohesion in the long run. 


\section{InCREASing Fragmentation of the Civil Service}

The account of the retrenchment exercise in the previous part warrants a closer look at the fault-lines within the civil service that were revealed and widened by its implementation. Two major fault-lines can be distinguished: The first one is the competition between new agencies with the task to promote the civil service reform and the classic line ministries and the second one is the growing gap between 'bosses' and 'juniors' that can be traced back to the colonial period under British rule. The fragmentation of state bureaucracies due to foreign interventions and the dynamics of postcolonial politics appears to be a widespread tendency in sub-Saharan Africa as a growing number of studies explicitly address this phenomenon. In a case study of the implementation of political reforms in rural Benin, Bierschenk and Olivier de Sardan (2003) use the term polycephaly to analyse the proliferation of agencies exercising political authority in the context of democratisation and decentralisation. More generally, a volume by Lund (2006) investigates the competition of multiple organizations in the local political arena. Anders' (2010) account of the implementation of civil service reform in Malawi presents a comprehensive ethnographic study of the everyday experiences of civil servants who are confronted with the fragmentation of the state bureaucracy in the context of the far-reaching interventions of the IFIs and other donor agencies at the turn of the 21st century.

\section{Enclaves vs. Line Ministries}

The 'governance approach' distinguishes countries with a high patrimonial, a medium and a low patrimonial character. For countries with a medium patrimonial character such as Malawi the World Bank prescribed the "enclave approach" "to build or reinforce the organizational, managerial and technical capacity to improve the performance and productivity of existing institutions" (Dia 1993: 3). In line with this approach the World Bank singled out government departments and agencies that would function as enclaves. These enclaves were expected to operate as centres from where the reform would spread throughout the whole civil service. Enclaves were either already existing ministries usually with crossministerial mandates such as the Ministry of Finance ${ }^{7}$ and the National

7 The Ministry of Finance usually has the "overall responsibility for managing the programme, and for monitoring and reporting responsibilities" (interview Ministry of 
Economic Council (NEC), formerly the Ministry of Economic Planning and Development, or newly established agencies such as PSCMA with the mandate to implement the various measures of the civil service reform. Of course, these ministries and agencies were not the only government agencies supported by the World Bank. The National Statistics Office, for example, received World Bank funding and assistance to improve data collection and the Department of Human Resource Management received assistance to implement the new computerised payroll system.

Due to the financial and logistical support of the World Bank the Ministry of Finance, NEC, the National Statistics Office and specialised units such as the PSCMA tended to have more resources and better qualified staff at their disposal. Generally, the cooperation of individual government departments or agencies with their respective donor agency was often better than between government departments. Considerable differences existed between bureaucratic routines and requirements of the various multilateral and bilateral donor agencies, which resulted in different bureaucratic practices between and even inside departments depending on the donor agency funding the projects (cf. Bierschenk and Therkildsen in this volume).

With regard to the implementation of the civil service reform conflicts arose between the 'enclave' agencies supported by the World Bank with the task to implement the various measures of the civil service reform and parts of the senior staff of the classic line ministries who tended to resist what they perceived as interference in their own affairs (cf. Botchwey et al. 1998: 81). These senior functionaries, having been socialised under Kamuzu Banda's autocratic rule and in fact owing their positions to him often were confronted with younger civil servants who were mainly employed in the new 'enclave' agencies.

This finding adds another dimension to the competition between the 'enclave' agencies and the classic line ministries. The 'enclave' agencies employed a high percentage of younger university-trained economists who are adept at using econometric theory. By contrast, many of the senior civil servants in the line ministries belonged to an older generation that made their career in the 1970s. I denote the former as technocrats and the latter as old-school officials. Most of the technocrats were in their thirties and joined the service in the late 1980 . They had enjoyed a better

Finance, March 200o) and functions as principal contact for World Bank staff and visiting missions. 
education than the older generation, either abroad or at the University of Malawi that had been established in the 1970s. They often identified with the emerging transnational class of consultants and bureaucrats working for international organisations such as the World Bank, the IMF and the UN. This class set the example for the technocrats in terms of remuneration and career opportunities.

The old-school bureaucrats had joined the service in the 1970s under the autocratic regime of Kamuzu Banda who ruled Malawi between 1964, when Malawi gained independence from Britain, and 1994, when the first multi-party elections were held. They had usually enjoyed less education due to the scarcity of educational facilities during the colonial era and had progressed slowly up the ranks by accumulating years of service. Their outlook was more national and they primarily perceived of themselves as being rooted in Malawian society. Owing their position to Kamuzu Banda, considered the father of the nation who secured independence from the British, they were brought up in a highly hierarchical culture where superiors' decisions were never questioned. Under Kamuzu Banda decisions were usually referred to the top, often to Banda himself, and people were often simply afraid to take decisions for fear of being accused of being a dissident. Moreover, most of them had served as junior officers in the colonial administration where Africans were required to follow the orders from their European superiors without questioning, a characteristic of the Malawian civil service addressed in more detail in the following section (for the Tanzanian civil service prior and immediately after independence, see Eckert in this volume).

These attitudes go a long way in explaining the absence of open protest by the old-school officials who resisted retrenchment. Furthermore, they were afraid of losing their positions after the transition to multi-party democracy and preferred to keep a low profile in order not to attract undue attention from their new political leaders who sought to replace many of those suspected of being closely associated with Kamuzu Banda and the MCP. In fact, this fear was unfounded since Malawi is hampered by a lack of trained professionals willing to work in government service and the new government was compelled to rely on the civil service it inherited it bears testimony to the attitude of avoiding decisions and keeping low acquired during the years of authoritarianism as a survival strategy.

The younger technocrats were usually more in favour of reform than the older generation, although not necessarily always along the lines of the World Bank's ideas. Having been brought up in the 1970s they were familiar with the oppressive atmosphere under Kamuzu Banda but 
many of them longed for change although they were very circumspect in expressing it openly for fear of unwanted attention from the security forces and party functionaries. Having been exposed to economics and being aware of the deepening economic crisis during the later days of Banda's rule in the 1980s many of them were more open to new ideas and many tacitly supported the reforms of the 1990s. Due to their age they had been less involved in the practice of hiring large numbers of support staff and, therefore, did not have the same sense of loyalty towards those threatened by retrenchment as the old-school bureaucrats in ministries such as Health, Agriculture or Labour. Being mainly employed in the 'enclave' agencies supported by the IFIs these younger economists often found themselves pitted against old-school officials in the line ministries who resisted any external interference in what they considered to be their affairs (Adamolekun et al. 1997: 215-217).

Dezalay and Garth (2002) describe a similar development for Latin America where economists trained in the elite universities of the United States formed bureaucratic and political elites in their countries of origin forming a transnational class of bureaucrats who "approach problems of economics and the state from precisely the same perspective" (Dezalay and Garth 2002: 28). In Malawi the influence of economists most of whom have worked either for the World Bank or the IMF is striking and it is noteworthy that the incumbent president Bingu wa Mutharika used to work for the World Bank and the minister of finance for the IMF. This generation gap, however, does not imply a complete rift between the old and the young generation. Like their cousins elsewhere the young technocrats are connected to the older elites by kinship ties and share many similarities with the generation of their uncles and parents although their outlook and style is different from earlier role models. The competition between technocrats and old-school officials, therefore, was not the consequence of a generation conflict but rather constituted one dimension of the multi-faceted competition between the newly created 'enclaves' and the classic line-ministries - a direct consequence of the implementation of measures to improve governance in Malawi.

\section{'Bosses'vs. 'juniors'}

The dismissal of employees made redundant revealed a widening gap between top officials or managers, on the one hand, and the rank and file of the civil service, on the other. In the Malawi civil service the former were casually referred to as 'bosses' and the latter as 'juniors'. When 
my informants referred to the 'bosses' they usually meant functionaries high up in the hierarchy occupying administrative and professional positions with the authority to issue orders and make decisions and other senior officers who supervise subordinate staff in a department. 'Bosses' constituted not more than five percent of all civil servants, i.e. about 5,00o persons (GoM 1996a: 29). The mass of civil servants was casually referred to as 'juniors' by my informants. Under this category fell all civil servants who were considered to be subordinate including lower-ranking civil servants such as support staff, unskilled workers and extension workers with no or little formal education and middle-ranking officers such as teachers and office clerks with no authority over other civil servants.

This rigid division between 'bosses' and 'juniors' is one of the characteristic elements of the postcolonial state in Africa that can be traced back to the notorious colour bar between European expatriate officers and African employees found in all African colonies. ${ }^{8}$ Under British colonial rule all senior positions in the civil service of what was then Nyasaland were held by Europeans whereas Africans were only found in junior positions such as teachers, clerks and labourers. According to Africans who served in the colonial civil service they were looked down upon by European officers who considered the African civil servants as inferior only emulating the manners of their colonial masters. Under colonial rule it was unthinkable for an African to challenge the decisions taken by Europeans and Africans were required to refer all decisions of importance to their white superiors.

The colonial division between superiors and subordinates was retained after independence in 1964 since Kamuzu Banda strongly discouraged any questioning of his authority, which he interpreted as critique of his regime. Juniors were not to challenge the orders of their superiors who, in turn, were not to challenge Kamuzu Banda's orders, who exercised absolute power between 1964 and 1993. In addition Kamuzu Banda-unlike Nyerere in Tanzania (Eckert, in this volume) - continued to rely on Europeans in running the civil service whom he considered no threat to his claim to absolute power. He only reluctantly embarked on a programme of 'Africanization' and until the early 1980s a number of Britons who had already served in the colonial administration held key positions in the civil service, the police force and the army. This continuity with the colo-

8 On Africans in the colonial civil service, see Bâ (1994), Eckert (2007) and Lawrance, Osborn and Roberts (2006). 
nial civil service did much to maintain colonial attitudes between 'bosses' and 'juniors' even after the retirement of the European officials.

It should also be noted that in spite of the ritualistic invocation of a shared African culture there is actually quite a considerable social distance between 'bosses', many of whom were trained abroad and enjoyed a formal western-style education, and 'juniors' who often hail from more humble origins. The 'bosses', either old-school officials or technocrats, belong to Malawi's tiny elite and consider themselves to be more 'modern' or 'civilised' than their cousins with less social status whereas many 'juniors' look with certain envy on the affluent life-style of 'those at the top', referred to as apamwamba in Chichewa, the country's main language. Although society at large in Malawi avoids the more ostentatious consumption observed in other African countries and people generally emphasise harmony and egalitarian values it is obvious that a considerable degree of alienation between 'bosses' and 'juniors' existed even prior to retrenchment. Because of that social distance the heirs of the colonial masters, the high-ranking functionaries, did not really go out of their way to protect people with whom they often had very little in common and whom they tended to look down upon in spite of the pervading logic of clientelism and solidarity. Instead, the 'bosses' preferred to keep a low profile in order not to jeopardize their own precarious position after the change in government after 1994 .

Since the implementation of the civil service reform constituted a condition for financial assistance of the IFIs the government did not really have a choice regarding the retrenchment of the redundant support staff. Of course, the president, the ministers and the top functionaries in the 'enclave' agencies knew that this decision would be extremely unpopular among the tens of thousands of 'juniors' who would be threatened with the loss of their jobs. Therefore, those responsible for the retrenchment exercise tried to put at least part of the blame for the unpopular measure on the World Bank and IMF, the institutions that had demanded staff reduction. Malawi's new democratic rulers feared the wrath of the civil servants who had become accustomed to go on strike to lend more weight to their demands. In fact no year passed between 1993 and 2004 without civil servants going on strike.

Considering the frequency of strikes in the civil service since 1994 the absence of large-scale or organized protests against retrenchment is striking. Several factors need to be considered in this regard. First, the level of organization among civil servants was very low during the second half of the 1990s, the time when most support staff was dismissed. Trade-unions 
had been prohibited during one-party rule and the new trade-unions, which were founded after 1994, remained weak with insecure funding and few members. Owing to their weakness trade-unions such as the Civil Servants Trade Union (CSTU) played a relatively minor role in the often-spontaneous strikes prior to 2000. This changed after 2000 when the CSTU was recognized by the government as the representative of civil servants' interests but it was too late to affect the retrenchment exercise, which had been largely concluded by that time. Second, many of those made redundant found employment elsewhere while their less fortunate peers still hoped to find employment although few of them eventually found their way back in the civil service, even after years of patience. This attitude derives from the clientelistic logic permeating the civil service, a well-known phenomenon in Africa, and the attitude inherited from the colonial era. Many dismissed 'juniors' thought it unwise to alienate their patrons by openly resisting retrenchment. They preferred to hover close to their patrons constantly reminding them of their obligations as patrons and some of them succeeded in finding other employment in the civil service or in the private sector due to the brokerage of patrons who succumbed to this subtle but strong social pressure.

The belief in the efficacy of clientelistic relationships, however, was thoroughly demystified when thousands realized that their patrons would not help them and many junior civil servants I worked with during my fieldwork expressed their alienation from the 'bosses' whom they accused of being selfish, an accusation not taken lightly in a society where the obligation to share one's wealth is a central moral principle. The alienation between 'bosses' and 'juniors' can be expected to undermine future efforts at transforming the civil service since trust in superiors is one of the preconditions for a functioning civil service. The frequent strikes by junior civil servants since the mid 1990s testify to the loss of confidence in clientelism although it is the subject of future research to investigate the impact of the growing alienation of the 'juniors'.

My interlocutors had a tendency to frame the conflicts triggered by the dismissal of staff made redundant and the introduction of the new housing allowance scheme in terms of ethnic and regional rivalries. Northerners and southerners accused people with a Chewa ethnic background from the central region for conspiring against them. People from the central region, in turn, would often point towards conspiracies of northerners against people from the centre.

To express conflicts in the idiom of ethnicity and regionalism has been a general characteristic of Malawian politics since the country's 
independence. President Banda, a Chewa from Kasungu in the central region, aggressively promoted Chewa tribal identity as the national identity at the expense of other ethnic groups in the north and south (Chirwa 1998; Kaspin 1995; Vail and White 1989). As Kaspin (1995) notes, ethnicity and regionalism provide distinct, although partly overlapping, registers in Malawi's cultural politics. The northern region is mainly associated with the Tumbuka and to a lesser extent Tonga and Ngonde. The central region is considered to be Chewa, although there are sizeable Ngoni populations. The south is primarily associated with Yao and Nyanja/Mang'anja, although there are also large numbers of Lomwe in the southeast who arrived in the early 2oth century from Mozambique to work on estates in the British protectorate. The Chewa and the Nyanja/Mang'anja speak the same language, which is referred to as Chinyanja in neighbouring Mozambique and Zambia, where there are sizable Chinyanja-speaking populations. In Malawi, Banda decreed this language to be Chichewa in order to strengthen his claim that Chewa tribal identity represented the nation.

Banda pursued a policy of discrimination and exclusion, in particular against northerners. Already in 1964, he dismissed several cabinet ministers, who had challenged his claim to absolute authority, during the Cabinet Crisis. All of them were from the north or the south and were forced into exile (Baker 2001). Many civil servants who were suspected of supporting the dissident ministers also left the country, among them Bingu Wa Mutharika, who returned in the early 1990s to Malawi and was elected president in 2004. The fear of dismissal or even imprisonment was ever-present during the 30 years of one-party rule. During the 1970s, when Banda consolidated his grip on power, thousands of civil servants, most of them from the north, were purged from the civil service. For example, my informants remembered that in 1977 several hundred employees of the National Statistic Office (NSO) in Zomba were suspended, some even dismissed and detained on sedition charges. Kaspin reports the forced transfer of northerners teaching in the central and southern regions to the north for allegedly "miseducating their students" in 1989 (1995: 6o9).

Banda's hostility towards northerners has to be considered in the context of colonial history. Northerners, in particular people with a Tumbuka and Tonga ethnic background, had dominated the colonial civil service because they had better and earlier access to missionary education. In the late 19th century, Scottish missionaries had established several mission stations in the north and Blantyre in the south, where they provided formal education to the surrounding areas, which afforded the graduates of these schools access to employment in government service, the 
missions and the settler economy throughout Central and Southern Africa (McCracken 2000; Ross 1996). As a consequence, the majority of African civil servants at the time of independence came from the northern region. Banda wanted to correct what he perceived as a distorted staff composition, inherited from the colonial administration, by replacing northerners with loyal Chewa and people from the central region. The civil service strike in 1963 in Zomba, which had mainly been carried by northerners, had already raised his doubts regarding their loyalty towards him. The thinking in ethnic and regional categories soon permeated society and the civil service, and influenced many a conflict in government departments.

Ethnicity and regionalism did not vanish after the end of Banda's rule. The power of ethnic and regional thinking was revealed during the referendum on the introduction of multi-party democracy in 1993 when the north and the south overwhelmingly voted in favour of multi-party democracy. The presidential and parliamentary elections the following year also showed the extent to which the country was split. The UDF and the other opposition parties received most votes in the north and the south whereas the MCP won the majority of votes in the central region (Kaspin 1995). Ethnic and regional stereotypes about Chewa, northerners and southerners continue to shape Malawi's political culture. In the civil service, ethnic and regional background often plays a role, for example, with regard to recruitment or promotion. Especially at the senior level, the origin of a civil servant can become an issue if he or she is from the 'wrong' region. Because of this it was still common practice to strive for a regional balance in senior government positions during my fieldwork.

\section{CoNCLUSIONS}

Retrenchment of government employees made redundant was a direct consequence of the programmes designed by the experts of the IFIs with the objective to reorganise the civil service according to the principles of New Public Management to make it more efficient and performancedriven, one of the preconditions for Good Governance à la World Bank and IMF. The implementation of the civil service reform, however, has not affected the underlying dynamics and structures of the civil service in Malawi. Instead the case presented in this article shows that civil service reform has widened existing fault-lines and exacerbated tensions within the bureaucracy. 
The analysis presented here warrants the question whether the instrumentalist vision of Good Governance promoted by the IFIs with its decontextualised and ahistorical concept of a 'dysfunctional' state that is in need of repair with the 'tools' offered by World Bank and IMF experts is suitable to bring about the transformation of the African bureaucracies deemed necessary by the 'donor community'. It rather appears that the reorganisation of the civil service in Malawi has not contributed to a more efficacious bureaucracy in spite of reaching the targets set by the IFIs in their stringent conditions such as laying off junior staff made redundant. The civil service is more fragmented than before, 'enclaves' and line ministries competing for scarce resources and 'juniors' being increasingly alienated from their 'bosses'.

\section{REFERENCES}

Adamolekun, Ladipo, Kulemeka, Noel and Mouftaou Laleye. 1997. Political transition, economic liberalisation and civil service reform in Malawi. Public Administration and Development 17 (2): 209-222.

Anders, Gerhard. 2010. In the Shadow of Good Governance: An Ethnography of Civil Service Reform in Africa. Leiden, Brill.

Bâ, Amadou Hampâté. 1994. Oui, Mon Commandant! Arles, Actes Sud.

Baker, Colin. 2001. Revolt of the Ministers: The Malawi Cabinet Crisis 1964-1965. London, I.B. Tauris.

Benda-Beckmann, Franz von. 1993. Scapegoat and magic charm: law in development, theory and practice. In Hobart, M., ed. An Anthropological Critique of Development: The Growth of Ignorance. New York, Routledge, 116-134.

Bierschenk, Thomas and Jean-Pierre Olivier de Sardan. 2003. Powers in the village: rural Benin between democratization and decentralisation. Africa, 73 (2): 145-173.

Botchwey, Kwesi, Collier, Paul, Gunning, Jan Willem and Koichi Hamada. 1998. Report of the Group of Independent Persons Appointed to Conduct an Evaluation of Certain Aspects of the Enhanced Structural Adjustment Facility. Washington, D.C., International Monetary Fund.

Chirwa, Wiseman. 1998. Democracy, ethnicity and regionalism: the Malawian experience. In Phiri, K. M. \& K. Ross. Eds. Democratization in Malawi: A Stocktaking. Christian Literature Association of Malawi (CLAIM) \& Verlag für Kultur \& Wissenschaft, Blantyre \& Bonn, 52-69.

Dezalay, Yves and Bryant Garth. 2002. The Internationalization of Palace Wars: Lawyers, Economists, and the Contest to Transform Latin American States. Chicago and London, The University of Chicago Press.

Dia, Mamadou. 1993. A Governance Approach to Civil Service Reform in Sub-Saharan Africa. Washington, D.C., The World Bank.

- 1996. Africa's Management in the 199os and Beyond: Reconciling Indigenous and Transplanted Institutions. Washingtonb, D.C., The World Bank.

Eckert, Andreas. 2007. Herrschen und Verwalten: Afrikanische Bürokratien, Staatliche Ordnung und Politik in Tanzania, 1920-197o. München, Oldenbourg.

Eisenstadt, Shmuel Noah. 1972. Traditional Patrimonialism and Modern Neo-Patrimonialism. Mimeo. Jerusalem, Hebrew University. 
Escobar, Arturo. 1995. Encountering Development: The Making and Unmaking of the Third World. Princeton, Princeton University Press.

Ferguson, James. 1994. The Anti-Politics Machine: 'Development', Depoliticization, and Bureaucratic Power in Lesotho. Minneapolis, University of Minnesota Press.

Government of Malawi. 1996a. Civil Service Census: Report on Census Results. March 1996. Lilongwe, Civil Service Census Executing Unit, Office of the President and Cabinet.

- 1996b. Action Plan for Civil Service Reform. Lilongwe, Government of Malawi.

Harrigan, Jane. 1997. Modelling the impact of World Bank policy-based lending: the case of Malawi's agricultural sector. Journal of Development Studies, 33 (6): 848-873.

Hirschman, Albert. 1967. Development Projects Observed. Washington, D.C., The Brookings Institution.

International Monetary Fund. 1997. Good Governance: The IMF's Role. Washington, D.C., International Monetary Fund.

Kaspin, Deborah. 1995. The politics of ethnicity in Malawi's democratic transition. Journal of Modern African Studies, 33(4): 595-620.

Lawrance, Benjamin, Osborn Emily Lynn \& Richard L. Roberts. 2006. Eds. Intermediaries, Interpreters and Clerks: African Employees in the Making of Colonial Africa. Madison, University of Wisconsin Press.

Long, Norman. 2001. Development Sociology: Actor Perspectives. London, Routledge.

Lund, Christian. 2006. ed. Twilight Institutions: Public Authority and Local Politics in Africa. Oxford, Blackwell.

Marcussen, Henrik Secher and Signe Arnfred. 1998. eds. Concepts and Metaphors: Ideologies, Narratives and Myths in Development Discourse. Roskilde, International Development Studies Roskilde University.

McCracken, John. 2000. Politics and Christianity in Malawi, 1875-1940: The Impact of the Livingstonia Mission in the Northern Province. Blantyre, Christian Literature Association of Malawi (CLAIM).

Médard, Jean-François. 1982. The underdeveloped state in tropical Africa. In Clapham C. ed. Private Patronage and Public Power: Political Clientelism in the Modern State. London, Frances Pinter, 162-192.

Mitchell, Timothy. 2002. Rule of Experts: Egypt, Techno-politics, Modernity. Berkeley, University of California Press.

Moore, Sally Falk. 1973. Law and social change: the semi-autonomous social field as an appropriate subject of study. Law \& Society Review 7(4): 719-746.

Mosse, David and David Lewis. 2005. eds. The Aid Effect: Giving and Governing in International Development. London, Pluto Press.

Olivier de Sardan, Jean-Pierre. 2005. Anthropology and Development: Understanding Contemporary Social Change. London, Zed Books.

Quarles van Ufford, Philip and Ananta Kumar Giri. 2003. eds. A Moral Critique of Development: In Search of Global Responsibilities. London \& New York, Routledge.

Ross, Andrew. 1996. Blantyre Mission and the Making of Modern Malawi. Blantyre, CLAIM.

UNDP. 2006. Human Development Report 2006: Beyond Scarcity: Power, Poverty, and the Global Water-crisis. Houndmills, Palgrave Macmillan.

Vail, Leroy and Landeg White. 1989 Tribalism in the political history of Malawi. In Vail L. ed. The Creation of Tribalism in Southern Africa. Berkeley, University of California Press, 151-192.

World Bank. 1989. Sub-Saharan Africa: From Crisis to Sustainable Growth. Washington, D.C., The World Bank.

- 1991. World Development Report: The Challenges of Poverty. Washington, D.C., The World Bank.

—. 1992. Governance and Development. Washington, D.C., The World Bank.

_ . 1993. Malawi Public Sector Management Review. World Bank, Southern Africa Department, Report No. 9643-MAI. 


\title{
TEACHERS' UNIONS AND THE SELECTIVE APPROPRIATION OF PUBLIC SERVICE REFORMS IN BENIN
}

\author{
Azizou Chabi Imorou ${ }^{1}$
}

\section{INTRODUCTION}

The aim of this chapter is to explore an avenue that has so far attracted little attention, namely the response of the teaching unions to educational reforms. Empirical observations of the challenges to reforms of the public service sector in Africa enable the identification of rationales of actors, and highlight the interaction between different interests and professional practices (cf. Chabi Imorou 2010b; Grindle and Thomas 1990 for comparative perspectives). They also render a re-reading of African civil services reforms necessary (Anders, Charton, Hamani, this volume; see also Olowu 1999). The focus in the case in hand is on the relationship between these challenges and the functions of the state in producing public service reforms. The analysis is based on the premise that these challenges are not so much obstacles (Brimelow 2003; Peterson 1995 and Trefon 2010) as the generators of socio-political dynamics.

Beginning with a close examination of the demands made by teachers throughout the implementation process of the 'New Study Programme' (Nouveaux programmes d'études, hereafter NPEs), an educational reform introduced in Benin during the 1993-1994 school year, I shall analyse how these demands, along with the practices to which they gave rise among teachers, helped shape the classroom delivery of public education and hence illustrate the complex nature of the reform process.

1 This chapter is a reviewed and revised version of a chapter of my Dr. phil. dissertation entitled: "Le Bénin à l'épreuve du syndicalisme enseignant. Les revendications des 'dévalorisés' et la construction de l'Etat (1945-2008)" (Department of Anthropology and African Studies, Johannes Gutenberg University, Mainz, 2011). Fieldwork was conducted between 2006 and 2008 in Parakou, Cotonou and Karimama, documentary research mainly in Cotonou and archive material and the colonial press were consulted in Porto-Novo (Benin) and Dakar (Senegal). This research was undertaken within the framework of the research programme States at Work (University of Mainz, Germany and LASDEL, Benin-Niger, see Bierschenk and Olivier de Sardan, Introduction, this volume). I am grateful to Thomas Bierschenk, Jean-Pierre Olivier de Sardan, Marcelle Yosson, Aziz Mossi, Nouratou Danko, Saï Sotima Tchantipo, Elieth Eyebiyi, Yacine Bio Tchané and Dominique Ahogbéhossou for their many suggestions. Special thanks to Susan Cox for translation into English. 
This chapter is organized around four key points. The first consists of a short history of educational reforms in Benin since 1945. The second briefly describes the content of the NPE reform and the context in which it was implemented. The third describes trade-union reactions to the reforms as well as the arguments underpinning the teachers' misgivings. Finally, on the basis of the first three points, I shall discuss a number of practices at work within the state apparatus.

\section{AN Overview of EduCATIONAL Reforms BETWEEN 1945 AND 1990}

The educational system in Benin has a long tradition of reforms, which it is important to remember here to facilitate a clearer understanding of the current debate on the NPEs. ${ }^{2}$ These reforms met with varying degrees of resistance.

\section{The Colonial Reform of 1945 and Its Continuity}

The first reform - and perhaps the most important to have been implemented in Dahomey (present-day Benin)—dates from 15 September 1945. It reorganized teaching in the territories of French West Africa and made provision for, among other things, the introduction of the syllabuses in force in France in schools that taught to secondary level and for the training of 'indigenous' teachers in the context of the extension of primary education desired by local populations. As Abdou Moumouni observes, this reform contained 'many of the features of the educational system as it is organized in France, as well as others that are quite specific: this organization will remain in place until the territories of the French colonies in Africa win their independence' (Moumouni 1964: 78). The aim of the reform was to 'train indigenous managers to become our assistants in every field, and to ensure the emergence of a carefully selected elite; it is also a matter of educating the masses, to make them more like ourselves and to transform their lifestyles" (Governor Bévié, quoted in Moumouni 1964: 54).

The nationalist movements which preceded independence and in which teachers played an active role were quick to criticize an education policy that created a division between Africans and their everyday environment. As a protest against this educational policy, teachers would demand the

2 A brief historical survey of education reforms in Benin can be found in Lanoue (2004: 121). 
Africanization of educational frameworks and syllabuses. However, the same overall policy would be pursued after independence as France continued to maintain a presence in the educational system through cooperation agreements. French was adopted as the official working language and as the medium of instruction in schools.

However, African history and geography was introduced into the syllabus and a form of mass education was put in place that would allow schools to cater for as many children as possible. The Conference of the African States on the Development of Education in Africa, which took place from 15 to 25 May 1961 in Addis Ababa, set universal primary education as its main goal. From 1965, and to adapt education to the natural (essentially rural) environment of the learner, the country opted for the 'ruralization' of primary schools.

\section{The 'Grosse Tête-Dossou Yovo' Reform}

In 1971, Dahomey, which continued to receive assistance for education from the French government, put in place a reform called the 'Grosse Tête-Dossou Yovo' reform, after its main initiators. The main aim of this reform was to train "individuals to take on responsibilities and to use their knowledge to improve the environment in which they live" (Ministère en charge de l'éducation and UNESCO 2007).

The reform would be fiercely criticized and challenged by teachingunion organizations of every persuasion (the SYNEPDA, ${ }^{3}$ the SYNEECAD, ${ }^{4}$ the CUESS, ${ }^{5}$ etc.), by pupil and student organizations (especially UGEED ${ }^{6}$ and FACEEN ${ }^{7}$ ), and by youth organizations $\left(\right.$ RAJEMO $^{8}$ and OJSD ${ }^{9}$ ). These organizations, most of which operated partly as trade-unions and partly as political parties, accused the government of, among other things, seeking to impose neo-colonial reforms which were alien to the basic aspirations of the Dahomey people. Consequently, in a motion calling for strike action, dated 4 November 1971, the UGEED “... urges vigilance and engagement on the part of all pupils, students, parents of pupils, workers in towns and in the countryside, patriotic soldiers, and policemen to

3 Syndicat national de l'école publique du Dahomey.

4 Syndicat national des enseignants des écoles catholiques du Dahomey.

5 Comité pour l'union des enseignants du secondaire et du supérieur.

${ }^{6}$ Union générale des élèves et étudiants du Dahomey.

7 Front d'action commun des élèves et étudiants du Dahomey.

8 Rassemblement de la jeunesse du Mono.

9 Organisation de la jeunesse de la sous-préfecture de Dassa. 
transform Dahomey into a vast battlefield against the 'Grosse Tête-Dossou Yovo' reform".

The Marxist-Leninist revolution of 26 October 1972 took place in this social climate that systematically rejected the 'Grosse Tête-Dossou Yovo' reform. As soon as the revolution was declared, the reform was called into question:

In public and private education, teachers at all levels, parents and pupils anxiously speculated about the future of our children, compromised by a reform that had been hastily conceived and inadequately thought through. Its promoters did not even have the courage and the honesty to apply it to the letter (Kérékou 1987).

\section{The National Programme of Edification of the 'New School'}

Following broad consultation with education stakeholders, on 10 September 1974, the National Council of the Revolution adopted a plan for educational reform dubbed the 'Programme national d'édification de l'école nouvelle' ('The National Programme for the Edification of the New School'). The 'New School' sought to align teaching, life outside the classroom and the social environment of pupils by introducing them to and involving them in production. The state's new law on education, which was adopted in 1975, was quite explicit: "All levels of education must be aligned with the demands of everyday life and with the social environment, so that pupils are introduced to production. Schools are production units". ${ }^{10}$ In real terms, the reform consisted in creating farm cooperatives in schools and in getting young people who had passed the baccalaureate to undertake teaching assignments.

The 'New School' reform, just like the 'Grosse Tête-Dossou Yovo' reform, soon faced social discontent, mainly because educational standards fell and the school fees paid by parents rose. However, the unions, which were subservient to the ruling power, had no other choice than to accept it. But that did not prevent sporadic protests, which were secretly orchestrated by Benin's Communist Party. In the face of this discontent, and after five years of general application, the 'New School' reform was the subject of a review in a seminar held in 1981. The seminar highlighted the reform's failures and, among other things, the fact that it had been hastily

10 For further information on this reform, see the research report by Salka Wetzig (2010). 
introduced and without proper planning of the school activities selected. At that point, Benin returned to the neo-colonial educational system.

\section{The Origin of the NPE Reform: The 'CRISIS', the NAtional Commission on EDUCATION AND THE Aid Donors}

A nuanced and detailed description of the context of the New Study programme reform can be found in Fichtner $(2010,2012)$. It will therefore suffice for our purposes to briefly refer to the meeting of the National Commission on Education (Etats généraux de l'éducation, EGE), prompted by the crisis in the educational system, and the intervention of the American donor, the United States Agency for International Development (USAID).

\section{The Crisis and the National Commission on Education}

The number one problem for education in our country is that the entire school system was set up to produce public servants and that, given the saturation of the public service, we must now establish, as a matter of extreme urgency and virtually without any transition, a system that educates people for other things. What are these other things? Of necessity, the private sector, and, since this sector is still in need of development, self-employment, job creation, the ability to start one's own business and to exploit new opportunities whenever these arise (Paulin Hountondji, Minister of National Education, RB/MEN 1990: 10).

These statements at the opening ceremony of the National Commission on Education (EGE) are testimony to the crisis in and incoherence of Benin's educational system in 1990. This was why the 'Conférence nationale des forces vives de la nation' (National Conference of Stakeholders), held in February 1990, decided to halt the reform in progress, i.e. the 'New School' reform, which had proved inappropriate to the new democratic context and the challenges of neo-liberalism. An intermediate programme was adopted and the conference recommended that the National Commission on Education should be convened to solve the 'crisis' at a national level. This high-profile event took place in Cotonou from 2 to 9 October 1990 and, like the National Conference a few months before, it brought together a large number of actors from the field of education: teachers and their unions, parents, government officials, pupils' representatives, students, and civil society representatives (NGOs and voluntary associations, in particular). 
Among the main conclusions to emerge from the conference were the need for a new educational system and the reform of the content of teaching programmes. This project for reform would subsequently materialize as the 'New Study Programme' (NPE) and was financed by donors who were becoming increasingly involved in the education sector. ${ }^{11}$

\section{USAID Support and the NPE Reform}

The United States Agency for International Development (USAID) agreed to provide significant financial and technical support for the reform. American aid was to cover all stages of the reform process from its design to its implementation.

In accordance with a new 'competency-based' approach, which was the main recommendation of the National Commission on Education, the programme was developed by teams of experts and consultants (both national and international) recruited from among school inspectors. Between the intermediate programmes that preceded it and the proposed new approach through the NPEs, substantial changes were introduced.

[Schools] must be capable of producing high achievers who will go on achieving, with entrepreneurial qualities, a passion for new ideas, the ability to run their own businesses and to create jobs, in short, citizens who can make an effective contribution to their country's development (Ministère en charge de l'éducation and UNESCO 2007: 7).

According to Labbé, a member of the team that developed the programmes, the new approach was different from the old one in that it prioritized 'social-constructivism' (the construction of knowledge) and 'cognitivism' (learning through processing information) over the 'mechanical rote-learning' that had been the mainstay of previous programmes. In several respects, this approach replicated Anglo-Saxon models, especially the Canadian model, which is considered by the programme developers as one of the most successful. At the educational level, in contrast to the old approach, in which the role of the teacher had been paramount, the reform was one that was centred on the learner, that is to say, the pupil's level of competence. The 30 or so subjects that had been offered previously were grouped into six subject areas: French, mathematics, life and earth sciences, social education, art education, and sports education. The

11 The study undertaken by Fichtner (2010, see also Fichtner 2012) shows how the search for funding created a real battleground with numerous international NGOs vying with one another. On the financing of reforms see Darbon (2003). 
emphasis was on concepts that were 'topical' in contemporary development discourse, notably the environment, the new technologies, democracy etc. These areas of knowledge were given prominence in the new textbooks, which are distributed to pupils free of charge.

The programme was implemented gradually. It began in 1994 with an experimental phase in 18 pilot schools, three from each of the six administrative departments, in order to study the 'feasibility' and 'applicability' of the new programmes before their general introduction, which was scheduled for the start of the school year in 2005. Training was initially targeted at the teachers responsible for the pilot classes, but it was later gradually extended to all teachers. However, the new reform was roundly condemned and met with various forms of resistance from both teachers and their unions.

\section{Trade-Union Reactions to and Arguments against the Reform}

Like the earlier reforms, the NPEs were contested. Protests were sometimes active but usually resistance was passive. The protests came to a head in 2002, with strikes organized, first, by the Syndicat national des enseignants du primaire, SYNAPRIM (The National Union of Primary Teachers) and, much later, by other trade-unions. There were various reasons for the trade-union reactions.

\section{Teachers Are "Disorientated by the New Approach"}

Adapting to the new teaching methods promoted by the NPEs proved difficult for the majority of teachers, who had to make the adjustment from the 'chalk and talk' approach - in which knowledge is invested with the teacher-to a style of teaching that puts the learner at the centre of the transmission of knowledge. This signalled a complete break with routine educational practices and demanded inventiveness from teachers and a considerable capacity for adaptation.

The difficulties encountered in implementing the new programmes were the result of a lack of training for teachers themselves, a lack of teaching materials and, above all, a failure to consult with the teaching unions. For, although the unions had been involved at the diagnostic stage when the National Commission on Education was convened, the design of the courses to be taught was essentially the work of teacher-consultants, both national (notably, retired or active school inspectors and education advisors) and international (western experts), who were not engaged in 
the day-to-day business of teaching. It should also be noted in passing that, since the Jomtien Conference in 1990 which had formulated the principle of "Education for All", union participation had become indispensable, not only in the decision-making process but also in the preparation of prognoses and strategies for action. All of this was essentially covered by the so-called 'partnership' principle (Petit 2010). In practice, however, participation in the field of education, as in other fields, was often a case of simply going through the motions (see Bierschenk, this volume) with the sole purpose of avoiding objections to the changes proposed by policy-makers. The fact remained that participation was no miracle antidote to objections, especially since the unions often refused to participate (Chabi Imorou 2010a).

Weakened and marginalized by these educational innovations, some teaching unions asked the authorities to halt the reform process since the majority of teachers, even among the most experienced, were "disorientated by the new approach" (in the words of one union member). Other unions, like the SNIA and the SNEC, were more flexible in their demands and asked for more training since the targeted training initially organized had involved only a small number of teachers, and since the others were unable to carry out their teaching duties adequately with only the newly published textbooks to rely on. The New Study Programme, of which so much had been expected, had adverse effects that could not be ignored. As for the parents, their own knowledge, the value of which tends to be exaggerated in the minds of the Beninese, was called into question.

\section{Avoiding the Lowering of Standards}

In their demands, the unions also berated falling standards of achievement. Although the new curricula were supported by the free distribution of new school textbooks, teachers were left with the impression that children were assimilating very little of what was being taught. Teachers and their unions were not the only ones to make this observation. Parents themselves noticed that their children, who had been taught by means of the competency-based approach, were under-achieving precisely in the areas of reading and writing, and hence developed alternative strategies, either resorting to additional lessons outside school hours or turning to the private education sector.

It should be pointed out that this finding was in stark contrast to the official school results, which recorded a continuous improvement in success rates. For example, despite the widely criticized shortcomings of 
the programme, in June 2005, the national success rate in the Certificat d'études primaires élémentaires (Primary School Certificate) was 98\%. This was due in part to examinations being tailored to pupils' abilities and to the adoption of a 'remedial' policy, under which extra classes were organized outside hours, especially at weekends (Chabi Imorou 2010b: 163-164).

Teachers obviously did not want to be blamed for these inadequacies and pressed for a return to the teaching methods of the old-style curriculum, such as the 'syllabic method' for reading and 'individual slates' (cadran opératoire) for arithmetical operations. Other issues were the need to restore the profession's social prestige and the need to address the concerns of parents.

\section{Denouncing the Contradictions between the Low Salaries of Teachers and the Demands for Professionalism}

The teaching unions also complained about the contradictions inherent in the reform process itself: while a certain amount of professionalism was required of teachers, their remuneration remained unchanged. The reform meant an increase in duties and responsibilities as well as the added imposition of having to master new teaching methods. Indeed, given that they did not receive any training, they were obliged to do their own research in order to adapt to the new ways of working. The reform focussed on pupils without taking the teachers into account. The living and working conditions of the latter were not deemed to be determining factors in the success of the reform. The training they were given was patchy and of very brief duration (one week, on average).

The unions criticized the actors involved in the reform process (designers, consultants and ministry officials) for profiteering from American funding via the claims they submitted for subsistence, bonuses and travel expenses. It was alleged that these allegedly 'astronomical' benefits enabled some members of the steering committee responsible for implementing the programme, including teachers (educational advisors and inspectors, in particular), to build luxury villas in Porto-Novo (the capital of Benin). A section of the city's Tokpota neighbourhood (which I visited) was dubbed the "New Study Programme District" (quartier NPE). The authorities in charge of the programme were seen by a large number of teachers as being out of touch with the situation 'on the ground' as those who actually applied the new programme were the teachers in the classroom. 


\section{Curbing Educational Extraversion}

The criticism directed by the unions at the NPEs also provided an opportunity for opposing American 'diktats' during the reform process, a reform inspired by the Anglo-Saxon educational model. The government was accused of not having an education policy that took account of national realities and of taking its cue from other countries, which were imposing inappropriate policies or policies that went against the 'national interest' through the allocation of funding. Educational extraversion was, therefore, condemned and the unions did not hesitate to include the demand that national languages be introduced into the classroom in their campaign for the revision of the new curricula.

This diversity of intermeshed arguments and rationales was based on a combination of a traditional form of industrial action generally focussed on pay and working conditions and demands that were increasingly focussed on educational policies, a tendency that pretty much became a universal phenomenon after the turning-point of post-Jomtien 'participation'.

\section{The Practices at Work in the State Apparatus}

Union reactions and motivations were the starting point for several initiatives taken by teachers as a way of 'supporting' the implementation of the reform. These informal practices essentially shaped the functions of the state in its ongoing quest for modernization. In other words, a set of factors existing alongside the official framework of the reform were making their presence felt within the state apparatus: 'adaptations' of the reform, the combination of educational practices originating from different historical times ('sedimentation', see Bierschenk in this volume), and difficulties and constraints generated by the reforming function of the state.

\section{The Various Adaptations of the Reform}

The absence of a response from the state to the demands of the teachers prompted them to seek other ways and means of exercising their profession. Hence, they focussed their attention on the settings over which they had most control, namely the classroom, where they themselves were in complete charge of the subject-matter which was taught in a context in which school inspections were a rarity. Consequently, they adapted the NPE reform in a number of ways in the actual classroom situation. Despite the highly innovative nature of the reform, a fact they readily 
acknowledged, and the training they had received during the brief training sessions, the educational practices of primary teachers would show little change and continue to replicate the old 'chalk and talk' methods acquired decades earlier. In practice, depending on the particular difficulties they faced, all teachers opted for educational practices that straddled the old and the new methods. The vast majority of teachers I encountered continued to teach their pupils to read using the 'syllabic method' (for French) and to do their sums on 'individual slates' (mathematics). They feel that these methods work, see them as irreplaceable and do not think that they should disappear along with the previous programme. There is no mistaking the fact that these are strategies for resisting the reform. Nevertheless, these adaptations are very informal and sometimes go undetected at the higher levels of authority.

However, there were times when the adaptation of teaching methods seemed the only option. In some schools, there were a substantial number of teachers recruited by the local community who simply had to do the best they could to ensure that teaching does at least take place. This was the experience of Rafiou, a community teacher in a village in the north of Benin who, on starting his job, was put in charge of a fifth-year primary school class, in which a competency-based approach was being used. Rafiou, however, had not received any professional training prior to being recruited and had to 'muddle through', thanks to the help he was given by the head teacher and by one of his friends, who was also a community teacher in the same school. Some teachers, therefore, (particularly community teachers, local contract staff and 'voluntary workers') sometimes began implementing the reform without the basic vocational training required, let alone the training needed to teach the NPEs. ${ }^{12}$

Consequently, disparities frequently appeared between the reform 'on paper', as conceived by the government and its consultants, and the reform as it was actually implemented by teachers in the schools. This obviously raises questions about the disparities observed in other contexts in Africa between theory and practice, between design and implementation, and, ultimately, between official and practical norms (Chauveau, et al. 2001; Olivier de Sardan 2004, 2009). In short, educational reform was the result of several adaptations. For NPEs to work, a few local 'ingredients' needed

12 A similar situation was observed by Mossi (2008: 67-69) in the case of the teaching of literacy whereby state actors were attempting to implement a reform for which they lacked the necessary skills. 
to be added for contextual reasons. At the same time, the reform was appropriated in various ways by the teachers, who have different aims from those underlying the reform. ${ }^{13}$

Although the adaptations affected by teachers differed from context to context, and even from school to school, they all had one thing in common: they ensured that teachers had more control over their professional activities. In general, the personal changes they introduced revolved around protecting their 'status' as teachers, as the repository of the knowledge that they are required to transmit to younger generations. From the teachers' point of view, at least, simply accepting the reform constituted something of a paradox since it is based on the principle that knowledge is 'constructed' by the pupil and the teacher is no more than a facilitator.

\section{The 'Sedimentation' Effect: The Erosion of the Link between Reform and Public Service Employees}

The sedimentation thesis developed by Bierschenk (in this volume) in his analysis of the functioning of African states and power structures can be redeployed here to interpret state practices generally, at least as carried out by state actors in implementing reforms. The outcomes of a reform, he observes, "do not supplant the outcomes of earlier reforms, at least not completely. Each institutional reform, each development project negotiated, leaves an institutional legacy which is incorporated into the existing body of institutional mechanisms". This is confirmed by empirical observation of the educational practices of teachers. It is certainly the case that the NPE reform did not eliminate earlier practices. Consequently, if the system worked, its success was far less due to the ingenuity of the reform package than to the initiatives taken at various times by the actors 'on the ground'. As a result, the reform eventually implemented can be seen as the superimposition of certain new educational practices, deemed to be effective, on earlier practices that have held firm under the weight of further reforms.

This superimposition of the different teaching methods was reinforced by the lack of training among teachers who entered the profession via a wide range of access routes (recruitment by the state or by the local community), which contributed to segmentation within the profession. Consequently, teachers who had been trained to use earlier teaching methods

13 This has also been noted by Blundo (2001) and Mossi (2008). 
('chalk and talk') were found working side-by-side with those who had been trained to use a competency-based approach (often over a relatively short period of time) and those who had received no training at all (the cohort of community teachers and local contract staff).

This selective sedimentation, which is typical of reform processes in Benin and maybe beyond, has a particular effect on the state apparatus: it weakens the link between the public service and public servants. In order to work properly, every state apparatus presupposes the existence of a link between the public service that it is supposed to deliver and the body of actors through which this service is delivered.

The "situational adjustments" (Blundo 2002) variously applied to educational practices point to a loosening of the link between teachers and the reform that they are responsible for implementing. First, educational practices are individualized on the part of teachers as they take particular advantage of the special nature of their profession; Since they each have the opportunity to shape and arrange their particular approach, they draw on the vast pedagogical universe of reforms deposited over the years. Second, the obligations which public servants are required to observe with regard to public reforms are extensively modified. Indeed, teachers only feel obliged to apply public decisions when these decisions coincide with their own professional interests or what they deem to be the 'national interest'.

This erosion of the relationship between the civil servant and a particular reform or public service in general is basically attributable to the state's weaknesses in the area of regulation and to the public servant's dual identity as both 'civil servant' and 'citizen': he is simultaneously 'outside' and 'inside' the state apparatus, leading both a 'public' and a 'private' life.

\section{CoNCLUSION}

The numerous reforms initiated within the public service often lack synergy with each one evolving along independent lines. In the case of the NPEs, there are significant discrepancies between the original intentions of those who designed the reform and the way in which the reform has actually been applied, as well as a lack of consistency and synergy between the reform and the measures taken to support it (especially training and equipment).

Moreover, public reforms nearly always appear unfinished or fragmented. New ones are forever being introduced, usually as the result 
of funding opportunities, before the earlier ones have been completely removed (see Charton in this volume). Up to now in Benin, educational reforms have been introduced every five years on average since independence: in 196o (first reform), in 1965 ('ruralization of education'), in 1971 ('Grosse Tête-Dossou Yovo' reform), in 1975 (reorganization of the 'New School'), in 1990 (General Assembly and the intermediate programmes), in 1994 ('New Study Programme'). Their duration is very short and barely corresponds to the duration of the primary cycle. This can also be seen as a sign of instability in curricula development.

From another perspective, the sectors affected by reforms will experience only few of the intended changes, or even witness the completion of any action that is undertaken. Reforms within the public sector in Africa are nevertheless appropriated by public actors to make them more workable (for a similar idea, see Hamani, in this volume). 'Internal' dynamics (from inside the system itself) operate rather than 'external' ones (international communities or donors), and the latter encounter all kinds of difficulties: resistance from the beneficiaries and the trade-unions, a lack of technical preparation on the part of the authorities, a lack of financial support to ensure the ownership and sustainability of reforms etc.

\section{REFERENCES}

Blundo, Giorgio. 2001. Négocier l'État au quotidien: agents d'affaires, courtiers et rabatteurs dans les interstices de l'administration sénégalaise. Autrepart, 20: 75-90

- 2002. La gouvernance, entre technique de gouvernement et outil d'exploration empirique. Bulletin de l'APAD, 23-24: 1-13.

Brimelow, Peter. 2003. The Worm in the Apple. How the Teacher Unions are Destroying American Education. New York, Perennial.

Chabi Imorou, Azizou. 2010a. L'action politico-syndicale des enseignants au Bénin (19452008). Approche socio-historique. Working Papers of the Department of Anthropology and African Studies of the Johannes Gutenberg University Mainz, 111, available at: http:// www.ifeas.uni-mainz.de/workingpapers/AP111.pdf.

- 2010b. Revendications syndicales et gouvernance du service public de l'éducation au Bénin. Discours et pratiques. In Petit, Pierre, ed. Société civile et éducation. Le partenariat à l'épreuve du terrain. Bruxelles, Académia Bruylant, 147-174.

Chauveau, Jean-Pierre, et al. 2001. La pluralité des normes et leurs dynamiques en Afrique. In Winter, Gérard, ed. Inégalités et politiques publiques en Afrique. Pluralité des normes et jeux d'acteurs. Paris, Karthala, 145-162.

Darbon, Dominique. 2003. Réformer ou reformer les administrations projetées des Afriques. Entre routine anti-politique et ingénierie politique contextuelle. Revue Française d'Administration Publique, 105-106: 135-152.

Fichtner, Sarah. 2010. A laboratory for education reform or a battlefield of donor intervention? Local debates on primary education and the New Study Programmes in Benin. International Journal of Educational Development, 30 (5): 518-524.

- 2012. The NGOisation of Education. Case Studies from Benin. Köln, Köppe. 
Grindle, Merilee and Thomas, John. 1990. After the decision: implementing policy reforms in developing countries. World Development, 18 (8): 1163-1181.

Kérékou, Mathieu. 1987. Dans la voie de l'édification du socialisme. Recueil des discours de notre Grand Camarade de Lutte le Président Kérékou. Cotonou, Direction de l'Information et de la Propagande and Société Yagoubi.

Lanoue, Eric. 2004. Réforme pédagogique, pratiques familiales de scolarisation et d'apprentissage professionnel en milieu cotonais. In Lanoue, E., ed. Politiques éducatives et dynamiques sociales d'éducation en Afrique subsaharienne. Enjeux, évolutions, déterminants. Paris, CNRS, 108-148.

Ministère en charge de l'éducation and UNESCO. 2007. Forum national sur le secteur de l'éducation. Thème $n^{\circ} 5$ : Le point des réformes éducatives de l'indépendance à nos jours. Document de travail du forum.

Mossi, Abdel Aziz. 2008. L'offre des services d'alphabétisation entre Etat et collectivités locales dans la commune de Nikki, au Nord-Bénin. Mémoire de DEA, UAC/FLASH/EDP.

Moumouni, Abdou. 1964. L'éducation en Afrique. Paris, F. Maspero.

Olivier de Sardan, Jean-Pierre. 2004. État, bureaucratie et gouvernance en Afrique de l'Ouest francophone. Politique africaine, 96: 139-162.

- 2009. Development, governance and reforms. Studying practical norms in the delivery of public goods and services. In Hagberg, Sten and Charlotta Widmark, eds. Ethnographic Practice and Public Aid: Methods and Meanings in Development Cooperation. Uppsala, Acta Universitatis Upsaliensis, 101-124.

Olowu, Bamidele. 1999. Redesigning African civil services reforms. The Journal of Modern African Studies, 37 (1): 1-23.

Peterson, Bob. 1995. Which side are you on? The role of teachers' union in school reform. In Levine, David, Lowe, Robert, Peterson, Bob and Rita Tenorio, eds. Rethinking Schools. An Agenda for Change. New York, The New Press, 253-263.

Petit, Pierre, ed. 2010. Société civile et éducation. Le partenariat à l'épreuve du terrain. Brussels, Académia Bruylant.

RB/MEN. 1990. Actes des Etats Généraux de l'Education. Cotonou, Ministère de l'Education Nationale.

Trefon, Théodore. 2010. Administrative obstacles to reform in the Democratic Republic of Congo. International Review of Administrative Sciences, 76: 702-722.

Wetzig, Salka. 2010. La réforme scolaire socialiste 'École Nouvelle’ au Bénin (1975-1990)— La mise en œuvre du programme scolaire et son évaluation par différents groupes d'acteurs. In Bierschenk, Thomas, ed. La justice et la police dans la République du Bénin. Un résumé de rapports de recherches étudiantes. Working Papers of the Department of Anthropology and African Studies of the Johannes Gutenberg University Mainz, 121b, available at: http://www.ifeas.uni-mainz.de/Dateien/AP_121b_(2013)_.pdf. 
Thomas Bierschenk and Jean-Pierre Olivier de Sardan - 978-90-04-26496-0 Downloaded from Brill.com@4/26/2023 02:08:21PM via free access 


\title{
THE STATE THAT WORKS: A 'POCKETS OF EFFECTIVENESS' PERSPECTIVE ON NIGERIA AND BEYOND
}

\author{
Michael Roll
}

\section{INTRODUCTION}

Given the highly contingent nature of historical processes of state formation, it is not the absence of effective states that demands explanation but their very existence. This opening statement turns the usual analytical perspective on states in developing countries on its head: from a deficiency-focused perspective (why is the state not working?) to a more unorthodox and constructive perspective (what is working, and why?), which this chapter will adopt. It looks at the frequent but largely unexplored phenomenon of 'pockets of effectiveness' (PoE) in weak governance states (see Roll, forthcoming). PoE are public organisations that deliver public services relatively effectively in contexts of largely ineffective government. Such pockets exist in most contexts, even in the most corrupt and ineffective countries; however, research and academic literature on this phenomenon is scarce and incoherent. Why do PoE exist at all in developing countries and how do they emerge? While this chapter touches on these questions, it focuses on what the answers teach us about the nature of the state, the 'stateness' in developing countries, particularly in sub-Saharan Africa. ${ }^{1}$

This discussion contradicts some commonly held assumptions about the nature of the state in these countries. While the state is often portrayed as weak, corrupt, particularistic and lacking a commitment to public service, our findings do not support such general judgements. Although the civil service in developing countries often constitutes a resource for politicians engaging in patrimonial politics, some crucial distinctions need to be made. Our findings show that, under certain circumstances, the very

1 This chapter is based on the research project "Pockets of Effectiveness in Nigeria", coordinated by the Friedrich-Ebert-Stiftung (FES), Nigeria Office, 2009-2010, when the author was the FES Resident Director in Nigeria. Seven PoE case studies were conducted by Nigerian researchers. The views expressed in this chapter are those of the author and should not be attributed to the FES. I thank the editors for comments on previous versions of this chapter. 
same factors that otherwise explain ineffectiveness, such as personalisation and politicisation, may also lead to exceptional public sector performance. Political interests and other motivations can lead politicians and top civil servants to find it more rational to make a public organisation work instead of exploiting it for individual gains. Furthermore, while overall effectiveness is unlikely to be found in current public administration systems in developing countries, individual civil servants generally respond to the same management techniques and incentives as their colleagues in the OECD world. It is not 'culture', narrowly defined, but the institutional context that explains the difference in performance. Another finding that contributes an important nuance to our understanding of stateness in developing countries is that a public service ethos does exist in their public administrations, albeit perhaps not very pervasively. These and other lessons about the nature of the state in developing countries will be discussed in greater detail in the final section of this chapter. They show that our understanding of stateness in weak governance countries remains flawed.

Section two presents PoE-related definitions and selected elements of a research framework for PoE. Following the introduction of two PoE case studies from Nigeria, the factors that best explain why and how they emerged as PoE are outlined in section three. Based on these findings, section four discusses what PoE teach us about stateness in developing countries.

\section{Pockets of EfFectiveness: Definitions AND RESEARCH FrameWORK ${ }^{2}$}

While PoE can be found in even the most ineffective of states, no research agenda has been developed to-date for their detailed investigation. A review of the scant literature that explicitly deals with this phenomenon shows that the research on what we call 'pockets of effectiveness' even lacks coherent terminology. Robert Daland (1981) and David Leonard (1991) use the term "pockets of productivity" while Barbara Geddes prefers "pockets of efficiency" (1990; 1994), a term further popularised by Peter Evans (1992; 1995). Moreover, other labels such as "islands of excellence" (Therkildsen 2008) and "islands of effectiveness" (Crook 2010) have been used. ${ }^{3}$ In light

\footnotetext{
2 For a more detailed discussion of the definitions and research framework, see Roll (forthcoming).

3 Through his involvement as an international peer reviewer in the FES Nigeria "Pockets of Effectiveness in Nigeria" project, David Leonard has also started to use the
} 
of this diversity, precise definitions and elements of a research framework are required before empirical findings can be presented.

\section{Definitions, Criteria, and Analytical Dimensions}

A pocket of effectiveness ( $\mathrm{PoE})$ is defined as a public organisation that provides public services relatively effectively despite operating in an environment, in which public service delivery is the exception rather than the norm. Most public organisations are ineffective, weak and involved in or affected by patronage and endemic corruption in this environment. In this context, 'effectiveness' refers to the actual provision of public services by the public organisation in question.

For our "Pockets of Effectiveness in Nigeria" research project we developed a set of criteria for identifying and selecting PoE, the most important criterion of which was the relative effectiveness of the organisation in providing the public service(s) the organisation was mandated to provide. This criterion is strongly context-dependent which means that the more hostile the context and the less effective other public organisations are, the less effective an organisation needs to be to fulfil it. However, the public organisation must still be successful in providing the corresponding services. When statistical data on this were scarce or of low quality, the results of perception polls, media reports and key informant assessments were used.

Other criteria included the organisation's mission to contribute to the public good, the capacity to contribute to the public good at national level and the organisation's persistence as a PoE for at least five years. Based on these criteria and the available data, a group of experts identified a sample of public organisations in Nigeria that qualified as PoE. Out of these, the seven most effective organisations were selected in a second round of criteria-led expert discussions. These seven organisations covered a broad spectrum of public and semi-public organisations and were agreed on as being among the most effective organisations in the overall sample. ${ }^{4}$

term 'pockets of effectiveness' (see Leonard 2010 and Prichard and Leonard 2010; personal communication).

4 The seven case studies included the Economic and Financial Crimes Commission (EFCC), the National Agency for Food and Drug Administration and Control (NAFDAC), the Federal Inland Revenue Service (FIRS), the National Agency for the Prohibition of Traffic in Persons and Other Related Matters (NAPTIP), the Ministry of Environment of the Lagos State Government (one state-based public organisation), the Punch newspaper (a quasi-public but privately owned organisation) and the Fahimta Microfinance Bank (another quasi-public organisation). 
Apart from the definitions and the list of criteria, we clarified and identified some key analytical dimensions for our PoE research framework. These were, in brief:

- Mixed performance and relative effectiveness: The performance of all PoE is usually mixed and their effectiveness is relative to the context, in which they operate and, particularly, in comparison to international performance standards. However, it is also relative with regard to their organisation units. While some units in an organisation might be effective, others might not. For our research project, this internal diversity served as a microscope for investigating the factors that led some units to perform better than others.

- Emergence and persistence of PoE: For analytical purposes, we distinguished between the 'emergence' and 'persistence' phases of a PoE as we assumed that the factors that explain why an organisation emerges as a PoE might differ from those that explain its persistence.

- Dynamic 'lifecycle' perspective and 'turning points': The effectiveness of $\mathrm{PoE}$ is also relative with regard to time. While organisations can emerge as PoE, they can also degenerate from PoE into ineffective organisations, or have upward and downward tendencies while struggling to persist. This led us to apply a dynamic analytical lifecycle perspective that pays attention to the temporal dimension. We also focussed on the 'turning points' as special analytical foci, which are the points or rather periods in time in which organisations either emerge as PoE or degenerate (on the concept, see Abbott 1997).

- Leadership: Leadership is a particularly tricky factor. While most management studies suggest that this is the decisive factor for explaining organisational performance, we were cautious on this point. We share these reservations with Judith Tendler who concluded that the achievements of the organisations in her case studies in Brazil were "not attributable to strongly intentional leadership" (Tendler 1997: 14). We wanted to establish, therefore, what the relative importance of leadership for PoE actually was within the context of other factors.

\section{The Political Sociology Perspective}

In our analysis, public administration is understood as a political process which is embedded in a specific social and political context. This political sociology perspective explicitly takes the political dimension into account, including the political nature of the delivery of public services. 
In developing countries, in particular, the delivery of public services has a wider significance far beyond the delivery of the service itself: it can be seen as a symbol for the acceptance by the state of its public responsibility for delivering services, at least in part. Hence, in our study we regarded even selective public service delivery as political action that is crucial for the process of establishing or rebuilding more or less effective states in developing countries.

Taxation and public service delivery are two sides of the same coin in this regard. 5 'State' and 'society' constitute each other in a contingent process of bargaining with each other for resources and power. The legitimacy of the state as well as some form of accountable relationship between the state and society have historically emerged through this process in many of today's OECD member countries. In largely discredited states, in which accountability relationships with citizens are rudimentary at best, the provision of essential public services "can lead citizens to re-engage with the state and can be a path towards a virtuous cycle of engagement and accountability in the broader political sphere" (Joshi 2006: 125). The political sociology perspective emphasises, therefore, that the relevance of $\mathrm{PoE}$ goes far beyond them being starting points for administrative reform, but rather elements for (re-)building states and more accountable and democratic state-society relations in weak governance states. While this point will be discussed in a forthcoming book (Roll, forthcoming), this chapter focuses more narrowly on what PoE can teach us about the nature of the state in developing countries. ${ }^{6}$ Moreover, not all of the analytical dimensions and distinctions presented here will be referred to in the following section.

\section{Why ANd How Do PoE Emerge?}

This section introduces two of our case studies and presents the explanatory factors for the emergence of PoE. Due to the small number of case studies involved, this analysis is preliminary and will require further qualification when additional case studies are available. The cases selected

\footnotetext{
${ }^{5}$ On taxation in developing countries from a political sociology perspective, see Bräutigam et al. (2008).

6 The forthcoming book (Roll, forthcoming) is a comparative study and includes case studies of PoE in China, Brazil, the Middle East, Suriname and Nigeria and across various historical and current periods of time.
} 
for this summary are two of the most outstanding success stories among Nigeria's public organisations in recent years: the National Agency for Food and Drug Administration and Control (NAFDAC) and the National Agency for the Prohibition of Traffic in Persons and Other Related Matters (NAPTIP). The analysis is based on extensive individual and group interviews with members of staff of the organisations at various management levels, interviews with the organisations' 'customers' or beneficiaries, and representatives of ministries, international organisations, embassies, private business and experts. Statistics, official documents, external reports and newspaper articles were also analysed.

\section{Case Studies}

\section{National Agency for Food and Drug Administration and} Control (NAFDAC) ${ }^{7}$

NAFDAC has a mandate to regulate and control quality standards for both imported and locally manufactured food, drugs, cosmetics, medical devices, chemicals, detergents and packaged water. It was set up by the National Agency for Food and Drug Administration and Control Decree No. 15 of 1993 as amended by Decree No. 20 of 1999 as a parastatal of the Ministry of Health. Gabriel Osunde was NAFDAC's pioneer director general and handed over to Dora N. Akunyili in 2001. She is usually credited with having transformed NAFDAC into an effective organisation. At the end of 2008 she was appointed Nigeria's Minister of Information and Communications, and Paul B. Orhii became NAFDAC's third director general in early 2009 .

Apart from its headquarters in Abuja, NAFDAC maintains offices in all 36 federal states of Nigeria along with six zonal offices for the geo-political zones of the country and three special inspectorate offices in big cities, in addition to Lagos (Aba, Onitsha, Kaduna), with strategic importance for the fight against counterfeit drugs and unregistered products. More than 3,00o pharmacists, technicians, enforcement and administrative staff work for NAFDAC. In terms of recruitment and promotions, financing and political control, NAFDAC became autonomous from its parent ministry, the Ministry of Health, shortly after Dora Akunyili's appointment in 2001. Following the adoption of a revised tariff structure for registrations,

7 This summary is based on the NAFDAC PoE case study by Irene Pogoson with Suraj Mudasiru and Azeez Olaniyan (2010). 
sanctions and penalties, NAFDAC has been able to raise more than two thirds of its annual income since 2003 .

One of Nigeria's greatest challenges in NAFDAC's area of responsibility is locally produced and imported counterfeit drugs. In 2001 about $80 \%$ of medications sold in Nigeria were considered deficient in one way or another, many of them dangerous for the patient's health and sometimes even life-threatening (Lemonick 2005). The situation was so serious that some West African countries banned drugs made in Nigeria all together. Before 2001, NAFDAC was considered an ineffective organisation, something that was also related to the constraints it faced under military rule. Since then, things have changed dramatically. In a representative national poll published in November 2007, NAFDAC emerged as the government agency that is considered to be the most effective (70 per cent), 12 per cent ahead of the organisation in second place (NOI Polls 2007: 4). This perception is supported by significant achievements. According to NAFDAC sources, the organisation destroyed substandard products valued at over USD 200 million between 2001 and 2009, achieved 45 convictions related to counterfeit drugs, had 60 more cases pending and a steadily increasing number of sanctions against manufacturers. The enforcement of NAFDAC's standards and mandate are reflected in the annually increasing, internally generated revenue. Both producers and consumers appear to have come to appreciate NAFDAC's work and value its seal of approval. This new-gained trust also led to a revival of the Nigerian pharmaceutical industry, both domestically and abroad and countries in the region that had imposed bans on Nigerian drugs lifted them. A 2006 survey report found that fake drugs had dropped from about 41 per cent of all drugs sold in Nigeria in 2001 to 16.7 per cent in 2006 (Barriaux 2007). The percentage of unregistered drugs was also reduced from 68 to 19 per cent during the same period (Nduwugwe 2008).

These impressive figures earned the organisation, and particularly its then-director general, national and international recognition. NAFDAC became a model for other African countries and Dora Akunyili probably became Nigeria's most decorated public sector executive. As early as 2003 she received Transparency International's Integrity Award and went on to win the Time Magazine Award in 2006- to mention just two of the hundreds of awards presented to her. Perhaps the best indicators of NAFDAC's effectiveness are the reactions of the fake drug producing and importing cartels. Several NAFDAC laboratories and offices were vandalised and set on fire, inspectors were threatened and there were several attempts to bribe and also assassinate Dora Akunyili. This can be the price 
of effectiveness when policing a sector dominated by criminal cartels that make huge profits.

\section{National Agency for the Prohibition of Traffic in Persons and Other Related Matters (NAPTIP) ${ }^{8}$}

NAPTIP was established with the enactment of the Trafficking in Persons (Prohibition) Law Enforcement and Administration Act of 2003. Carol Ndaguba was appointed in the same year as the pioneer executive secretary. She retired in early 2009 and was succeeded by Simon Chuzi Egede. The creation of the agency marked the fulfilment of Nigeria's obligations as a signatory to the United Nations Convention against Transnational Organised Crime (Palermo Protocols) and its Protocol to Prevent, Suppress and Punish Trafficking in Persons, especially Women and Children from 2000 (United Nations General Assembly 2001). The act gives NAPTIP a comprehensive mandate to fight trafficking, including the rescuing and rehabilitation of trafficked persons as well as the investigation of traffickers. The amendments that entered into force in December 2005 extended NAPTIP's powers beyond investigation to prosecution, and allowed NAPTIP cases to be prosecuted at state and federal high courts instead of only in the state high courts. The organisation, which employed a staff of around 250 in 2006, is under the office of the Attorney-General. Apart from its headquarters in Abuja, it has six zonal offices with rehabilitation centres attached to them in cities, in which trafficking is most prevalent. NAPTIP enjoys autonomy with regard to staff recruitment and promotion and has also benefited from almost consistently increasing budget allocations by government. In addition, the organisation received significant financial and technical support from international organisations and governments.

Trafficking is widespread, profitable and largely in the hands of established syndicates in Nigeria which makes NAPTIP's task a rather daunting one. Against this background, the organisation is widely praised as effective as confirmed by a European diplomat based in Nigeria:

There are many other things in this country which are not going very well but NAPTIP is not actually one of them. NAPTIP is one of those few state organisations that are functioning very well. (NAPTIP interview 18).

8 This summary is based on the NAPTIP PoE case study by Antonia T. Simbine with Franca C. Attoh and Abubakar Oladeji (2010). 
Up to mid-2009 more than 3,500 victims had been rescued, sheltered and rehabilitated, while 57 convictions had been achieved with more pending since the establishment of the organisation. Although this may not seem much, the fact that the annual number of trafficking convictions for the whole of Africa rose from a meagre 10 in 2003 to 90 in 2008 (U.S. Department of State 2009: 51) puts the figure into context. ${ }^{9}$ NAPTIP has been invited by various foreign law enforcement agencies to cooperate with them in cracking international human trafficking syndicates, something they have done successfully. This evidence is confirmed by the United States Department of State's "Trafficking in Persons Report" 2009 which upgraded Nigeria from tier two to tier one, which means that the government fully complies with the U.S. Trafficking Victims Protection Act's minimum standards for the elimination of trafficking (U.S. Department of State 2009: 225-227). ${ }^{10}$ Apart from the island state Mauritius, which has a population of little over one million, Nigeria is the only African country placed in tier one. As confirmed by the report, this major achievement is due to NAPTIP's exceptional effectiveness:

Nigeria's strengthened anti-trafficking record over the last year reflects the cumulative impact of progressively increasing efforts made by NAPTIP over the last several years. (U.S. Department of State 2009: 226).

\section{Explanatory Factors}

What are the most important factors that explain the emergence of these two organisations as 'pockets of effectiveness'? Since our focus is on the political dimension of PoE we neglect the contribution of technical equipment. Examples of such tools include the monitoring system and database on trafficking established by NAPTIP and NAFDAC's new registration procedures for producers and products. This technical side is relatively well covered in the literature and does not differ much from the OECD world. However, exactly how these organisations manage to overcome the political obstacles in a hostile developing country environment to be able to

9 Attaining convictions against human traffickers is very difficult. In most cases, the trafficked victims are required to give evidence before the traffickers can be convicted. Since these victims are often relatives or otherwise known to the trafficking networks, this is very dangerous for them.

10 Tier two includes countries "whose government do not fully comply with the Trafficking Victims Protection Act's minimum standards, but are making significant efforts to bring themselves into compliance with those standards" (U.S. Department of State 2009: 49). 
finally make use of these technical innovations is less well known. This is the dimension, on which we will focus.

Although literature explicitly dealing with the phenomenon we refer to as 'pockets of effectiveness' is scarce, three broad hypotheses can be identified that explain the existence of PoE (see Roll, forthcoming, partly based on Leonard 2008):

- Hypothesis 1-Internal factors: An organisation's effectiveness in a challenging context is determined by leadership and management-i.e. how it does its tasks.

- Hypothesis 2-External or political economy factors: The underlying political economy in which an organisation is placed will ultimately overcome and dominate all other causal factors and thus determine the level of effectiveness that is possible.

- Hypothesis 3-Function or task-related factors: The function an organisation performs determines the degree of specificity of the benefits it delivers, and also determines the incentives it provides to its staff and, therefore, an organisation's effectiveness.

None of these hypotheses can explain individually why PoE emerge. In contrast to previous studies (for an overview, see Roll, forthcoming), we explain the emergence of PoE as follows: In a given political context, a decisive political actor (or a group of actors) has an interest in the effective delivery of a particular public service. The public organisation in question is then provided with a high degree of autonomy, focussed powers and political protection. Moreover, a qualified and motivated pioneer leader with outstanding, inclusive leadership and management skills is appointed. This multifactorial explanation highlights that the key political mechanism for the emergence of PoE is the interaction of political interest and function. While the leadership and management factors are vital, they can only produce PoE if these political conditions are in place; on the other hand, the political factors alone are not sufficient. The factors that emerged in the analysis are presented individually in greater detail below with illustrations from the two case studies. Although the boundaries between them are sometimes blurred, they are clustered in three categories: political, institutional and managerial factors (see Figure 1). 


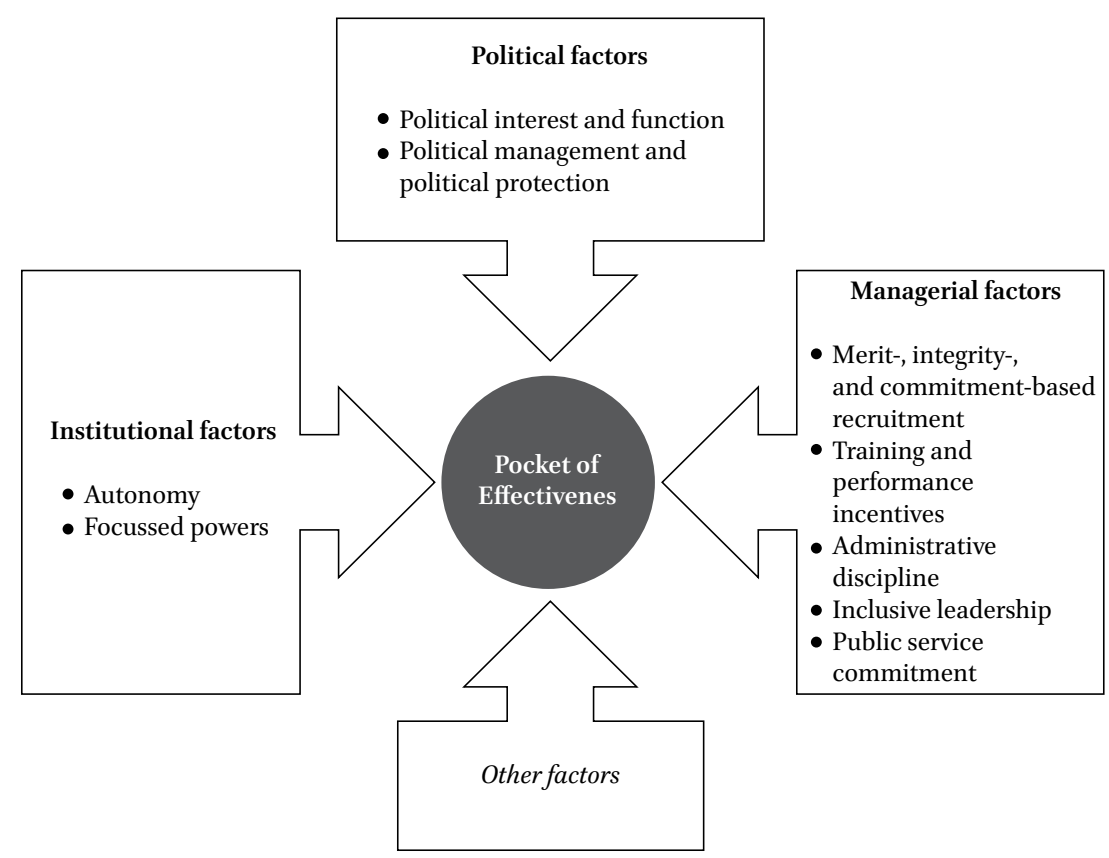

Figure 1: Explanatory factors for the emergence of Pockets of Effectiveness

\section{Political Factors}

\section{Political Interest and Function}

In both cases, the specific political context led then President Olusegun Obasanjo to develop an interest in the effective execution of the functions of fighting counterfeit and dangerous drugs and human trafficking. Obasanjo's particular sensitivity and attention to improving Nigeria's international image is key to understanding how he developed these interests. Obasanjo had some very tangible reasons for improving Nigeria's reputation, such as seeking a debt repayment and relief deal with the 'Paris Club', a group of 19 lenders, which was finally accepted in 2006. However, beyond such primarily instrumental motives, it is widely believed that he had a genuine interest in improving the country's reputation abroad with a view to boosting his own personal international prestige (see Gillies 2007).

Moreover, both phenomena, i.e. deaths from counterfeit drugs and the enormous scale of human trafficking, received increasing attention 
in both national and international media after Nigeria's return to democracy in 1999. They damaged the country's reputation which was already at an all-time low by the end of the Abacha regime. However, the development of this interest in a public service being provided more effectively is not a straightforward process. It takes shape in rather sporadic and unusual ways. In the case of NAPTIP for example, it was the wife of the then Vice-President Atiku Abubakar, who founded an anti-trafficking and child labour non-governmental organisation (NGO) in 1999, the Women Trafficking and Child Labour Eradication Foundation (WOTCLEF). Thanks to the strong position enjoyed by the wives of senior politicians in Nigeria, she succeeded in putting the topic on the political agenda. Supported by civil society organisations and international organisations, with her help the anti-trafficking act, which established NAPTIP, was enacted in 2003. This top-level political support ensured that the mandate of the organisation was strong and its powers far-reaching, while the continued support guaranteed increasing financial transfers to the organisation.

Dora Akunyili's case provides another example of how important the political context is, not only for understanding which public services are considered political priorities but also for understanding how people are selected to provide them effectively. While she was a trained and experienced pharmacist, this was not Obasanjo's only criterion for selecting her as NAFDAC's head. What made her stand out was proven integrity and incorruptibility. This factor was considered to be crucial by the president in the context of Nigeria at that time. The story that made President Obasanjo choose Mrs. Akunyili goes as follows: While still working at the Petroleum Trust Fund, she had to travel to London for medical treatment and had been given GBP 17,000 to pay her medical bills, including surgery. It turned out that she did not need the surgery and that the costs, therefore, were much lower than expected. On her return to Nigeria, Akunyili wrote a letter to Muhammadu Buhari, former Nigerian head of state and at that time chairman of the Petroleum Trust Fund, thanking him for the assistance and returned the remaining money. Buhari mentioned this unusual story of a member of staff of a public organisation returning money to her employer to Onaolapo Soloye, a former minister of finance and close friend and advisor of the then president. The latter was impressed, requested to see Akunyili's $\mathrm{CV}$ and recommended her to President Obasanjo. He then called her for an interview and subsequently appointed her as the new head of 
NAFDAC. ${ }^{11}$ Her appointment was met with strong political opposition since she was neither a member of the ruling party nor of the informal political elite networks through which such positions are usually assigned. Akunyili also lacked prior high-level political or administrative experience. Without the then president's special interest in appointing somebody with proven integrity, Akunyili would not have had a chance of being selected for this position.

\section{Political Management and Political Protection}

While the appreciation of and political support for the execution of a public organisation's function may be due to very situational motives, its continued protection and support requires the repeated renewal of the politicians' attention to it, which is why 'political management' is so important. 'Political management' refers to the lobbying for political support and influencing of decisions that strengthen an organisation's position by its leader. This continued lobbying can be carried out by various actors, such as the media, civil society, international organisations, political coalitions or the leaders of the very organisations themselves as in the cases of NAFDAC and NAPTIP. However, direct access to and the trust of top politicians and-above all-the president are essential. This is even more important if the process of arriving at policy priorities and preparing the budget is rather erratic as is often the case in Nigeria, for example. Apart from the inward-oriented aspects of management, these outwardoriented aspects of political management are of great significance in a fragile and hostile environment.

Two examples illustrate how crucial this 'political management' is. In the case of NAPTIP the pioneer executive secretary managed to get the act which established the organisation in the first place, in 2003, reviewed and amended in 2005. The most important change included assigning NAPTIP the powers to prosecute, allowing them access to the Federal High Court in addition to the state high courts, criminalising the trafficking of children as house helps, the regulation of the seizure of assets from traffickers and the establishment of the Victims Trust Fund. These very function-oriented amendments enhanced NAPTIP's effectiveness

11 Apart from several newspaper articles and interviews on this, see Akunyili (2010) for a personal account of this story (Akunyili 2010: xxxvii-xxxviii) and a copy of her letter of appreciation to the Petroleum Trust Fund's chairman and his response (Akunyili 2010: 320 ). 
tremendously. Even by global standards it is remarkable that an act that had just been passed is reviewed and amended within a period of only two years. This involved political management by the then executive secretary of NAPTIP Carol Ndaguba as well as strong political support.

At NAFDAC Dora Akunyili used her political management skills successfully to achieve the organisation's autonomy from the Ministry of Health in terms of funding, recruitment, promotion of staff, remuneration and political control. Before that, staff were transferred to NAFDAC from the ministry, its funding was included in the Ministry of Health's budget, remuneration was regulated by general public service guidelines and the ministry exercised political control over the organisation. Another example is the return of NAFDAC to Nigerian ports from where it had been banned by the military government in 1996. On the request of Dora Akunyili, the then president Olusegun Obasanjo granted approval and the clearance of imported goods by NAFDAC became compulsory again in 2001. This closed a huge inlet for imported counterfeit products and ended the Customs Service's monopoly on clearance.

Using these various political management measures, these leaders of public organisations actively shaped the immediate political environment in which their organisations operated. They did not just rely on existing legal provisions, but sometimes ignored, creatively reinterpreted or elegantly by-passed rules to be able to work more autonomously and effectively. As we saw in other case studies, political management often included creative and unorthodox measures which were not always in strict accordance with the law and, therefore, not without risk for the respective leaders. Apart from 'political management', 'creative interpretation and management' as well as 'taking risks' are therefore important elements of how leaders of PoE use the existing latitude, redefine and reshape it.

Leaders of public organisations can only carry out these activities over a sustained period of time if there is substantial political interest in the services their organisations provide. This interest must then translate into the political protection of the organisation and its leader. Refusing political interference, private interest-guided employment and complicity in diverting public funds are seen as an offence in a political context like Nigeria. Hence, organisations that operate relatively effectively rely on political protection for being able to persist as PoE. Political hostilities, strategically spread rumours and political or other coups against these organisation's leaders are frequent and difficult for them to survive without political protection. 


\section{Institutional Factors}

\section{Autonomy}

The various dimensions of autonomy include political, administrative and financial autonomy. More specifically, autonomy with regard to key procedures, such as staff recruitment and promotion, remuneration and welfare, are crucial. In an environment in which political interference in public organisations and their use for employing political clients and supporters is the rule rather than the exception, autonomy from this environment is essential. ${ }^{12}$ While organisation-specific acts were important in both case studies, political protection and continued enforcement of these acts and regulations were essential. It is only then that the executive leaders of these public organisations can establish a performance-based and performance-rewarding organisational culture that is necessary for the effective provision of the public services in question.

Apart from political autonomy, financial autonomy is also crucial. NAPTIP managed to obtain a secure and almost consistently increasing budget vote as well as support from international organisations. NAFDAC, on the other hand, reformed its tariff structure and from then on managed to generate at least two-thirds of its annual income through internal revenues. In a politically volatile context, the latter option is more sustainable in terms of autonomy although it is not completely safe from political interference either.

\section{Focussed Powers}

The term 'focussed powers' refers to the fact that organisations like NAFDAC and NAPTIP, which were established through task- and organisation-tailored acts, have comprehensive legal powers with regard to their mandate. In both case studies, these comprise of executive powers including prosecution. These organisations do not only have the legal authority to carry this out but also organisational means such as internal

12 In the context of administrative reform strategies in OECD countries, the model of the semi-autonomous executive agency has emerged in the last decades. Our case studies reflect some of the characteristics of such agencies. However, we could not establish whether or how their setting-up was informed by this model. The focus of the 'agencification' literature is still largely on OECD countries but case studies from developing countries are sometimes included. For more information, see OECD (2002), van Donge (2002), James (2003), Pollitt and Talbot (2004), Pollit et al. (2004), Larbi (2006: 31-33), Ayee (2008: 134-137) and critically Moynihan (2006) and Joshi and Ayee (2009). 
law enforcement units like investigation and prosecution departments, which refers again to their autonomy. They are closed systems in the sense that they can carry out almost all tasks related to their function except reaching and enforcing verdicts. Especially in a highly fragmented administrative system this reduces transaction costs and enhances effectiveness. Such costs would and do in other cases arise from communication and coordination problems, inter-organisational distrust and competition. Moreover, the fact that all necessary steps leading to prosecution are done in-house is a very powerful motivating factor for staff. If inspectors know that their cases end up in a judicial system where decisions and verdicts are often politically manipulated, this can frustrate them to an extent that they stop carrying out their own tasks professionally and instead look for private gains.

\section{Managerial Factors}

\section{Recruitment Based on Merit, Integrity, and Commitment}

Merit-based recruitment is one of the better-known explanatory factors for exceptional organisational performance (see Owusu 2006). This is confirmed by both case studies. For their directorial positions, sophisticated assessment centres were carried out, including written tests and oral examinations by a panel of interviewers, headed by independent professionals. At NAFDAC this procedure was unprecedented. In both cases qualifications and merit were not the only criteria, however. Commitment to the mission of the agency as well as proven integrity were equally important, particularly for those in leading positions. The pioneer NAPTIP executive secretary specifically selected experienced personnel from other ministries and law enforcement agencies whom she knew or had information about as a former Director of Public Prosecution. While a personal and not strictly merit-based element comes into play here, it was a complement to the professional standards and expectations and did not, therefore, compromise them. This elaborate process for the careful recruitment of senior managers nurtured their commitment to the organisation and their trust in its leader. Political considerations did not influence appointments as is often the case in Nigeria.

\section{Training and Performance Incentives}

The former group of factors is closely interrelated with training and performance incentives. Merit-based, integrity-based, and commitmentbased recruitment ensures that capable, honest and motivated staff come 
on board. Training provides further and more specialised qualifications through the tailor-made NAPTIP training programme on security and human rights for new staff. After this initial training, both organisations provide ongoing and often demand-driven training for staff in their respective areas of specialisation. NAPTIP also provides training for the staff of collaborating organisations, such as the police and immigration service.

Special international training courses and collaborative missions with international law enforcement agencies were applied in a focussed and strategic manner to reward good performance by both organisations. This was done in order to expose staff to international standards and best practices. In addition to international missions, greater responsibility, commendation by leadership and promotion were used as internal rewards and performance incentives.

Good remuneration is another factor that readily comes to mind when considering why organisations perform well. This is confirmed in the case studies since it allows organisations to attract the skilled and committed professionals they identify through their recruitment process. Staff of both organisations earn much higher salaries and enjoy better welfare packages than civil servants in most other departments and agencies.

As a basis for good performance, both organisations provide the necessary resources for staff to carry out their duties. This basic equipment includes, at the very least, functional offices and equipment, cars, generators, diesel for operating them, and computers and internet access, which is often in short supply or completely lacking in other public organisations, even in the capital city.

\section{Administrative Discipline}

Since the embezzlement of public funds and corruption are endemic in Nigeria's public sector, containing if not eliminating them is a major challenge for public organisations. However, to a certain extent at least, this is a precondition for the ability to provide public services relatively effectively. The sectors, in which both organisations work are highly susceptible to both phenomena as well as to attempts by those involved in these activities to bribe themselves out of prosecution. To respond to these challenges both organisations have established strict regimes of administrative discipline. At NAPTIP, corruption is discouraged by a combination of adequate compensation, the provision of the necessary resources for executing their tasks, teamwork when handling suspects and dismissal when found guilty. The last instrument has already been used 
in some cases. NAPTIP also has an internal anti-corruption unit. A similar system of zero tolerance for corruption and severe sanctions is in place at NAFDAC. Internal whistle blowing is explicitly encouraged and whistle blowers are rewarded if the case is confirmed by being promoted or sent on a training programme abroad, for example. On the other hand, integrity is advocated through 'leadership by example' and practised at the top executive level of the organisation.

\section{Inclusive Leadership}

A positive "organisational culture" or "organisational mystique" (Grindle 1997; Hilderbrand and Grindle 1997) is one of the more extensively researched factors that contribute to making organisations in hostile and other environments more effective. Our case studies provide evidence to support this result. Both heads of the agencies studied showed outstanding inclusive leadership and management skills. This does not necessarily mean that they worked in a particularly participatory manner in terms of decision-making, as they clearly had their own convictions and ideas and were very firm in executing them. However, at the same time, they encouraged staff to challenge them. They also invited external advice and collaboration when they deemed it necessary. Exchange, dialogue and initiative among staff were invited, and the principle of the 'power of the better argument' instead of the higher authority was promoted. Due to this communicative and inclusive leadership style, their professional qualifications and vision they enjoyed widespread authority in their respective organisations. This authority was further strengthened by the fact that they had partly handpicked their staff in leading management positions based on skills and demonstrated performance. As opposed to 'authority of the office', which is based on hierarchy, this is a kind of 'authority of personality', which is more comprehensive and powerful.

The fact of having been selected for a leading position in any of the organisations created a special and very personal loyalty and trust-based relationship with the respective leader. These trust-based relationships were further strengthened by the accessibility of the directors for their staff, even for consultation on private issues as the former NAPTIP executive secretary stated:

I listen to their personal problems and am sympathetic to their problems if there's a way I can help them, I help. You do these things, it motivates people. (NAPTIP interview 19).

The fact that she and the NAFDAC director cared for their staff was widely confirmed in the interviews. 
As a former Director of Public Prosecution, Carol Ndaguba was well qualified to head NAPTIP while Dora Akunyili was a trained pharmacist. Both had a vision of what kind of public services the respective organisation should provide and they communicated this vision internally while promoting it externally. 'Leading by example' in terms of discipline, integrity, hard work and commitment to the organisation's vision and mandate were characteristic, while public funds and internally generated revenue were managed transparently.

Responsibilities, expectations and feedback were clearly communicated. Possibly more important than this was their success in igniting and maintaining the commitment and even passion of their staff for working with the organisation and providing its public services as effectively as possible (see below).

Both directors practised, facilitated and sometimes even enforced collaboration both within the organisation and with external organisations at government, civil society and international levels. For a Nigerian governmental organisation, NAPTIP's extensive collaboration with civil society organisations working on human trafficking was rather unusual. This included but also went beyond the NGO of the former vice-president's wife who had lobbied for the establishment of NAPTIP. The organisation also liaises and collaborates with the anti-trafficking units of the police and immigration service. While NAPTIP had been set up as a new agency with Carol Ndaguba as the pioneer executive secretary, Dora Akunyili had to reform a previously existing organisation. One of the legacies of NAFDAC that she had to deal with when she took over was a strong intra agency inter-departmental rivalry. Therefore, apart from replacing selected members of staff and restructuring the organisation, she 'enforced' internal dialogue and collaboration. Inter- and intra-departmental meetings were established, at least two directorates had to be involved before any decision could be taken, and no problem could be brought to her attention before at least two directorates had discussed it. Externally, Dora Akunyili liaised with NGOs as well as donor agencies and ensured that they provided or sponsored training programmes when the organisation's own funds were not sufficient.

A particularly interesting issue that emerged from our research is the relevance of gender. Half of the PoE we investigated were led by women, which is a much higher proportion than that generally found in public or private executive positions. A senior NAPTIP official even explained Carol Ndaguba's outstanding performance with reference to gender by saying: 
She is a mother, I see her as that. You know when you are a woman and a mother, you push all other things aside and that passion of a mother in you will want you to do things that go beyond what you would have normally done assuming you didn't care. (NAPTIP interview 5).

While this comment reflects gender stereotypes of a female employee, at the same time it also opens up an interesting perspective on the potential that such stereotypes can provide. The former executive secretary herself also made reference to gender by referring to the fact that "because I am a woman, I wanted to prove that I can do it." (NAPTIP interview 19). In a male-dominated and patriarchal society, women in leadership positions can be strongly motivated to go to particularly great lengths and perform extraordinarily well. However, since there is no social automatism for this and many factors would need to be factored in for a substantiated analysis, these findings demonstrate first and foremost that more studies on this are needed.

\section{Public Service Commitment}

A commitment to public service can have many sources. Some of the most important ones that we discovered in the cases of NAPTIP and NAFDAC were personal encounters with the victims of human trafficking and the pride of working for a popular and exceptionally effective public sector organisation. Other reasons included positive responses from the media and citizens and the opportunity to contribute to the positive development of one's country. The more sources commitment comes from and reinforces other stimuli, the stronger it gets. One of the key criteria of the executive leaders for recruiting staff, particularly for leadership positions, was their commitment to the mission of the organisation. In our case studies both directors had personal reasons to be highly committed to the effective execution of the functions of the organisations they were heading. When NAPTIP's Carol Ndaguba was the Director of Public Prosecution, she occasionally also dealt with cases of trafficking of children to Italy, which she knew could only be the tip of the iceberg. Dora Akunyili's personal commitment to make NAFDAC work effectively partly stemmed from the death of her diabetic sister who died from an injection of false insulin in 1988:

Not only was it fake and did not contain the insulin she was supposed to take, but it was also contaminated and gave her abscesses. She did not respond to antibiotics, and we just watched helplessly until she died (Akunyili in Barriaux 2007). 
Such personal experiences appear to have had a particularly strong and lasting effect on personal and professional commitment to the respective public sector organisations.

In order to use commitment as a strong motivating factor for staff across the board, leadership at all levels must nurture and communicate it. Public service commitment can be ignited and maintained through inclusive and motivating leadership and management as outlined above. While this commitment existed at directorial level and was used by them in both cases, the lower ranks were also committed to the organisation's mission. A NAPTIP middle-level officer said that, irrespective of the financial aspects, it is only

when there is genuine interest, when there is passion for the victims of human trafficking, you will go any mile to make sure you track them [the traffickers; M.R.] down (NAPTIP interview 6).

According to the former NAPTIP executive secretary, their staff "got emotionally involved and quite bitter against the abuse that is meted out to Nigerian girls, children and women" (NAPTIP interview 19). This personal involvement and 'passion' for their job explain the strong commitment of the civil servants. It was even reported that in the case of NAPTIP private funds or resources such as cars were used for undertaking official assignments if other means were not available. While these may have been exceptional cases, they demonstrate that, by and large, the members of staff across the hierarchy saw their jobs with both organisations as both a personal and professional contribution to the provision of essential public services for their country.

Before continuing to discuss what these findings teach us about the nature of the state in developing countries, we shall return to the PoE research framework and some of the analytical foci outlined therein. With regard to internal variety or different degrees of effectiveness of the units of the respective organisations neither organisation showed significant variety in terms of performance. While NAPTIP was newly established and therefore did not have a 'turning point', NAFDAC's period of change began with the appointment of Dora Akunyili as the new head and the granting of more autonomous institutional status to the organisation. We were sceptical about the explanatory value of 'leadership', but inclusive, professional and dedicated leadership turned out to be a crucial factor for the emergence of a PoE, although far from sufficient on its own. While the leaders credited with transforming the two organisations into PoE have 
been replaced, their successors had not been in office long enough for us to detect any significant changes in the course of our research. Since the other case studies in our sample differ from the two organisations presented here, their inclusion may modify these results.

\section{What Do PoE Teach Us About Stateness in Developing Countries?}

Thomas Bierschenk's call for an "anthropology of statehood (or stateness)" (Bierschenk, this volume) is strongly supported by our research project and findings. Some studies which would fall into this category already exist. ${ }^{13}$ We prefer the concept 'stateness' (Staatlichkeit in German) over 'statehood'. While the latter is used to refer to sovereign states as distinct from other states, and has an external perspective on the state, the former has an internal perspective and looks at the nature, capability and quality of state institutions. What do the findings from the PoE case studies teach us about this stateness in developing countries and weak governance states more generally? We identified five important lessons that should be taken into consideration for future research and policy.

\section{Civil Servants Respond to the Same Management Techniques and Incentives - but Institutional Context Makes the Difference}

It may seem obvious to state that civil servants in developing countries respond to the same management techniques and incentives like their colleagues in the OECD world. However, a number of studies appear to suggest, implicitly at least, that civil servants in Africa and other parts of the developing world have a special and somehow culturally shaped 'mentality' and work ethic. According to these studies, the key problem lies, therefore, on the individual, group or even cultural level. Our study shows that this is not true. In both of the case studies from Nigeria staff responded positively to inclusive, collaborative, transparent and motivating management and to material as well as immaterial incentives.

13 Some of these sociological and anthropological studies that engage in a non-normative analysis of the empirical reality of stateness and public authority in developing countries include Anders (2010) on Malawi; Bierschenk and Olivier de Sardan (2003) on Benin; Christophe (2005) on Georgia; Gupta (1995) on India; Roll (2004) on Sri Lanka and on Africa in general Blundo and Olivier de Sardan (2006), Blundo and Le Meur (2009) and the "Africa Power and Politics" research programme (www.institutions-africa.org). More generally, Hansen and Stepputat (2001) are instructive. 
They did so because they operated in a context that allowed them to do so. The legal provisions were adequate, the staff was qualified and the necessary equipment and resources were available. The reason why the performance of public organisations is often low in developing countries is predominantly the institutional context and not 'mentality' or work ethic. Imagine what a German bureaucrat would achieve if he had to work under the same conditions as an average Nigerian civil servant in the rural north of the country: without reliable and punctual payment of the salary, being the only person with a more or less regular salary in his extended family, without funds for buying petrol for the official motorbike (if it works at all), without the forms and data that were supposed to have been sent by headquarters in the state capital months ago, without information about the latest changes in the departmental regulations etc. This diagnosis is key for de-essentialising the debate. Cultural explanations alone are of limited value while rigorous sociological, anthropological and political analyses that fulfil universal social science quality standards are needed.

Given an adequate institutional context, management techniques and incentives appear to have a degree of universal applicability. However, as Judith Tendler has shown in her landmark study Good Government in the Tropics (1997), they go far beyond material incentives or managerial approaches based on simplistic principle-agent models. The reverse conclusion is that without a relatively advanced institutional context for public organisations, even the use of modern management techniques and sophisticated incentive systems will not be able to improve public sector performance significantly-except for a few organisations as our case studies suggest. Hence, both external interventions and internal reform efforts must be simultaneously more selective and comprehensive than they usually are. Simply focussing on capacity building, internal monitoring and control or incentive systems is very unlikely to improve administrative performance in developing countries. ${ }^{14}$

14 The World Bank's scorecard on capacity building supports this conclusion. A 2005 evaluation report found that "[t]he Bank's traditional tools-technical assistance and training - have often proved ineffective in helping to build sustained public sector capacity" (World Bank 2005: viii) and concluded that despite "recent improvements, the Bank's support for capacity building in Africa remains less effective than it could be" (World Bank 2005: viii). 


\section{Effectiveness is Unlikely in the Existing Public Administration System}

By definition, PoE are unlikely to emerge. According to our findings, however, for PoE to emerge, a certain degree of autonomy from the public administration system is indispensable. This implies that, in principle, it is possible to avoid the usual practices which undermine effectiveness such as the hiring of political clients instead of qualified professionals. Hence, such organisations are 'pockets' or 'islands' in which other conditions exist and different rules apply from the rest of the public sector.

Bierschenk has pointed out that, due to the highly disintegrated bureaucratic system and inadequate resources available in developing countries, normative double-binds are developed and informal norms produced which do at best "enable the minimal functioning of the apparatus" (Bierschenk, this volume). In non-PoE organisations such informal rules have largely replaced official rules and norms that might exist but are not regarded as realistic and legitimate. One of the consequences of the autonomy of PoE from the existing public administration system is that such response strategies to inadequate conditions are no longer necessary. Under a function-oriented management, the more autonomy and powers the organisation gains, the less informal rules are required to compensate inadequate regulations. PoE organisations often have a detailed and integrated set of internal rules, norms and expectations. These are usually explicitly communicated, compliance is monitored and non-compliance sanctioned. However, effectiveness-enhancing informal rules such as working long hours also exist in PoE and are often established through 'leading by example'.

Apart from these largely positive aspects with regard to organisational performance, two more negative implications of the high degree of autonomy of PoE from the public administration system need to be mentioned. Bierschenk and Olivier de Sardan describe the sedimentation process in administrative systems in developing countries (Bierschenk and Olivier de Sardan 2003). Since PoE are often established as or become semiautonomous organisations, from a systemic point of view, they complicate the already disintegrated administrative systems even more. This leads us to the second negative or at least disappointing implication of PoE. Due to their isolation from the larger administrative system, their autonomy and the better remuneration and benefits, the average civil servant rather regards these 'alien' institutions which receive special treatment with envy and resentment. This rivalry and negative attitude make it unlikely that PoE will have a trigger effect and inspire the transformation of other 
public organisations into PoE, not to mention the administrative system at large. If PoE were to remain "small islands of functionality" (Olivier de Sardan 2009: 67) and isolated "enclaves" (Anders 2010: 60-69) without the potential to trigger broader change in the public sector of developing countries, their attractiveness for reformers would suffer. Research findings on non-donor initiated PoE as in the case of Nigeria are scarce to date. A discussion of their broader reform potential will be provided in Roll (forthcoming).

\section{The Command Mode of Governance Prevails: Personalisation and Top-Down Orientation}

Based in part on Georg Elwert's concept of the "command state" (2001), 'command mode of governance' refers to two characteristics of governance and stateness in developing countries which are confirmed by our case studies. ${ }^{15}$ These are a strong personalisation of political and administrative procedures and decisions and the corresponding dominance of these procedures by top leadership. The command of the person in power can overrule existing legal rules and regulations. He or she is, therefore, the final authority, a 'command authority'.

Due to the disintegrated bureaucratic system and the multitude of informal norms and rules, bureaucratic procedures in developing countries are not as strongly institutionalised as in most OECD countries. That is why uncertainties are not effectively absorbed in the administrations of developing countries and procedural predictability is limited. This lack of institutionalisation of law-based bureaucratic procedures is often substituted with the functional equivalent of personalisation: if I cannot get my public services based on my rights as a citizen, which are routinely recognised, I will try to get them by referring to my social status through my personal networks. This alternative mode of obtaining access to public services usually involves the capacity to offer something in return or the potential to threaten the official in question. Niklas Luhmann has argued that in social systems which are strongly personalised, people have

15 Georg Elwert defines the "command state" as "a system of politics and administration characterised by the primacy of present authority in daily life interaction and an ambiguous relation with legal norms, which however define the overall power sharing within the apparatus" (2001: 420). While we are not sure whether present authority in daily life interaction is always necessary, we agree that in a "command state" official laws and regulations can be overruled by powerful individuals at any time. The history of colonial rule in Africa explains how these modes of governance emerged (Young 1994). 
learned to attribute causality - understood as the social construction of cause-effect relationships-to personal networks and relationships and not to abstract institutions and procedures (1995: 7). According to him this may only change if other modes of delivery are established that are equally accessible, reliable and effective.

While personalisation does not mean that all procedures are necessarily personalised, it implies that in order to achieve something, the personal relationship mode is of overriding importance. That holds true for all kinds of transactions, irrespective of whether they aim at undermining or supporting the establishment of an abstract bureaucratic system. Some of our findings in the two PoE case studies support the latter aspect. To be able to provide public services effectively both leaders used their personal status and networks. They used their access to the president, which was strongly based on personal trust and appreciation, to create favourable working conditions for their respective organisations through political management. However, the need to use personal relations within these organisations and for their 'clients' was significantly reduced. This is due to the internal establishment and enforcement of rules and norms that differed from the rest of the public sector and offered more universal access.

The second point is even more evident in our findings: political initiatives usually originate from the top. It was then President Obasanjo's sensitivity to Nigeria's negative international reputation which, together with domestic and international pressure, led him to initiate reforms in the public sector during his second term in office (Olaopa 2008: chapter 5). In the PoE organisations themselves, the position of the leaders were exceptionally strong and they steered the organisations. In Nigeria, the strong position of the president in a presidential system, a de-facto one-party system with no need for coalitions or compromise and a strong material and symbolic social hierarchy ('oga culture'), ${ }^{16}$ further reinforce a top-down mode of governance. If we take this finding about the dominance of leaders at all levels a step further, it appears to imply that we should expect reforms towards more public sector effectiveness not as a result of media reports or civil society lobbying but the leader's

16 'Oga' is a Nigerian pidgin word for 'boss' and is frequently used for addressing a person, thereby acknowledging his higher social status and accepting his authority. Some elements of this 'oga culture' are reflected in the phenomenon of 'godfatherism' in Nigerian politics (see Albert 2005). 
own decisions. However, this would be taking things too far. Even powerful presidents in presidential systems do not operate and decide in a vacuum. As Obasanjo's special attention to Nigeria's international reputation shows, they are more likely to respond to some kinds of pressure and demands than others. Leaders of organisations are also influenced by personal experiences or strong civil society organisations that can support them in pushing for more powers or funds from the government, for example. Ultimately, however, those higher up in the respective hierarchies have to be at least favourably disposed towards the task or decision at hand to make it work. These principles apply at all levels of the political and administrative system.

While both characteristics of the command mode of governance usually undermine the access to and predictability of administrative procedures and decisions, our case studies provide evidence of the fact that they can also be used for strengthening them in exceptional cases. In weak governance contexts, therefore, personalisation and top-down orientation can facilitate more effective state performance if they are combined with an interest in a particular service being delivered and a minimum of meritocratic considerations.

\section{Public Service Ethos Does Exist in Developing Countries}

It is often argued that the public service concept is alien to many developing countries (for Africa, see Ekeh 1975). The very existence of a national 'public' is being questioned and hence also whether a public service ethos actually exists among politicians and civil servants. This ethos would morally oblige them to work for the benefit of the general public and do so with integrity and discipline. Authors often explain this lack of a national public with reference to colonialism. In most cases, colonial borders did not reflect existing social and political structures. It is argued, therefore, that they did not allow for a national public to emerge. The former prime minister of Nigeria's western region Chief Obafemi Awolowo expressed this concern as far back as 1947: "Nigeria is not a nation. It is a mere geographical expression." (Awolowo 1947: 47) he said referring to the amalgamation of three geo-political regions with different but also internally diverse ethnic, religious and social characteristics.

With regard to the lack of public service orientation and ethos, it is often argued that this is partly a legacy of the colonial past in which the state primarily served as an instrument of social control, political oppression and economic exploitation. The gap between state and society is said 
to have remained under African rule with the state as an alien apparatus that was used as a source of private enrichment by those who had access to it. Due to the superior loyalty to primordial groups and the lack of historical formation of a public sector including the corresponding norms, the argument continues, this could be done without running into moral contradictions. However, the public service concept is well known, is referred to in public debates and is instrumentalised as a motivating factor in exceptional cases. Our case studies show that the senior staff of both organisations were also selected on the basis of some degree of public sector commitment and motivation, whether task-specific or more general. They are apparently receptive to further motivation along these lines by the leaders of the organisation who themselves have been found to exemplify the public service concept in their day-to-day management. Bierschenk and others agree that "African officials see themselves as having a moral contractual relationship with the state" (Bierschenk, Lentz, this volume).

While the statement that public sector orientation does exist in developing countries where governance is weak is true, it requires further qualification. Due to a number of factors - the legacy of colonial rule certainly being one of them - the average civil servant probably feels less obliged to fulfil his public service mandate than his colleague in an OECD country. ${ }^{17}$ However, this difference is not one of substance but of degree. Furthermore, the enormous variety of public service orientation that exists in both developing and OECD countries is of great significance. There are those civil servants who practice and defend the public service ethos despite the odds, and despite often experiencing difficulties in these hostile environments. Others are not as strict with themselves but do not ignore the ethos altogether and hence do not damage the system as severely as others. These different categories call for serious attention to empirical detail instead of premature generalisation when researching these issues. Public service orientation is often limited, temporary and fragile in developing countries. However, if civil servants, who share this ethos or are susceptible to it, work together and can do so under some of the supporting structural conditions outlined above, these 'pockets of public service ethos' may eventually grow into PoE.

17 This might vary, depending on the level in the administrative hierarchy. Thomas Bierschenk (in this volume) argues that civil servants in the lower ranks tend to be more disappointed from the state than those further up. 


\section{Effectiveness in Developing Countries is Fragile but Real}

The governance and development debate is dominated by a deficiencyfocused perspective. ${ }^{18}$ Explanations for such 'bad' and ineffective governance are then often close at hand: indiscipline and corruption are two of the 'usual suspects'. While these factors have a role to play, it is grossly inadequate and irresponsible for academic studies not to go beyond them. Most problems of public administration in Africa can be explained by political interference, a lack of resources or their non-functional distribution, and a lack of adequately trained staff. Moreover, all of the other problems, with which OECD public administrations are also familiar, also exist: communication gaps, coordination problems and work overload. While the historical processes of state and civil service formation in developing countries are highly distinctive, they share the common features of massive institutional sedimentation, heavy fragmentation and, in response, normative double-binds (Bierschenk, this volume). The degrees of effectiveness may vary but public organisations exist in all of these countries which provide public services much more effectively than others. PoE are the result of a temporary and often precarious dynamic process of competing political powers, in which the interests of some political actors that favour the effective delivery of a particular service dominate. This is the essential precondition for the emergence of a PoE. As outlined above, once this is fulfilled, many other factors and their interaction are then necessary for its emergence.

These findings teach us that stateness in developing countries is much less well understood than it ought to be. Organisations, including but not exclusively public organisations, should no longer be treated as 'black' or even 'stuffed boxes'. The term 'stuffed boxes' refers to researchers opening the black box that the organisation represents and then instead of looking into it, stuffing it with his or her assumptions about how the internal structures look and how actors think and act. The researcher then closes the box again, paints it in a colour of his or her liking and presents the findings which are surprisingly often in line with what the assumptions have prompted the reader to expect. Such boxes must be discarded and assumptions, half-knowledge and stereotypes replaced with empirical data and analysis. These studies must observe social science research standards

18 However, a 'development success' literature is beginning to emerge, including the classic Tendler (1997), Bebbington and McCourt (2007), Manor (2007), Robinson (2007) and Grant et al. (2009), amongst others. 
and apply the same analytical rigorousness that would be applied for organisational research in the OECD world.

While the challenges involved in finding out more about the inner workings of state-related organisations are enormous, it is simply indispensable. Treating them as political micro-arenas and putting the organisations themselves into the political context in which they operate are two more lessons. Given the often limited understanding of the everyday life worlds and meaning systems of civil servants in developing countries, quantitative research has its limits. Anthropological and sociological studies of these varieties of stateness and their respective modes of reproduction and change promise to make us understand better what is already working in the developing world and why. PoE are a particularly interesting although, as this chapter shows, by no means exhaustive empirical and analytical perspective on stateness in this context. They enable us to gain a better understanding as to why, in light of the highly contingent and diverse historical processes of state formation, effective states or at least pockets of them actually do exist and will continue to emerge.

\section{REFERENCES}

Abbott, Andrew. 1997. On the concept of turning point. Comparative Social Research, 16: $85^{-105}$.

Akunyili, Dora Nkem. 2010. The War Against Counterfeit Medicine-My Story. Ibadan, Safari Books.

Albert, Isaac Olawale. 2005. Explaining 'godfatherism' in Nigerian politics. African Sociological Review, 9 (2): 79-105.

Anders, Gerhard. 2010. In the Shadow of Good Governance: An Ethnography of Civil Service Reform in Africa. Leiden, Brill.

Awolowo, Obafemi. 1947. Path to Nigerian Freedom. London, Faber \& Faber.

Ayee, Joseph R.A. 2008. Reforming the African Public Sector: Retrospect and Prospects. Dakar, CODESRIA.

Barriaux, Marianne. 2007. The Friday interview: Dora Akunyili. Indomitable woman in the front line of the other war on drugs. The Guardian, 9th November 2007, available at: http://www.guardian.co.uk/business/2007/nov/og/7, accessed on: April 29, 2010.

Bebbington, Anthony and Willy McCourt, eds. 2007. Development Success: Statecraft in the South. Basingstoke, Palgrave Macmillan.

Bierschenk, Thomas and Jean-Pierre Olivier de Sardan. 2003. Powers in the village: rural Benin between democratisation and decentralisation. Africa, 73 (2): 145-173.

Blundo, Giorgio and Jean-Pierre Olivier de Sardan. 2006. Everyday Corruption and the State: Citizens and Public Officials in Africa. London, Zed Books.

Blundo, Giorgio and Pierre-Yves Le Meur, eds. 2009. The Governance of Daily Life in Africa: Ethnographic Explorations of Public and Collective Service Services, Leiden, Brill.

Bräutigam, Deborah, Fjeldstad, Odd-Helge \& Mick Moore, eds. 2008. Taxation and StateBuilding in Developing Countries: Capacity and Consent, Cambridge, Cambridge University Press.

Christophe, Barbara. 2005. Metamorphosen des Leviathan in einer post-sozialistischen Gesellschaft: Georgiens Provinz zwischen Fassaden der Anarchie und regulativer Allmacht. Bielefeld, transcript. 
Crook, Richard C. 2010. Rethinking civil service reform in Africa: 'Islands of effectiveness' and organisational commitment. Commonwealth \& Comparative Politics, 48 (4): 479-504.

Daland, Robert. 1981. Exploring Brazilian Bureaucracy: Performance and Pathology, Washington D.C., University Press of America.

Ekeh, Peter P. 1975. Colonialism and the two publics in Africa: a theoretical statement. Comparative Studies in Society and History, 17 (1): 91-112.

Elwert, Georg. 2001. The command state in Africa: state deficiency, clientelism and powerlocked economies. In Wippel, Steffen \& Inse Cornelssen, eds. Entwicklungspolitische Perspektiven im Kontext wachsender Komplexität, Festschrift für Prof. Dr. Dieter Weiss. München, Weltforum Verlag, 419-452.

Evans, Peter B. 1992. The state as problem and solution: predation, embedded autonomy and structural change. In Haggard Steven, ed. The Politics of Economic Adjustment: International Constraints, Distributive Conflicts, and the State. Princeton, Princeton University Press, $140-181$.

— 1995. Embedded Autonomy: States and Industrial Transformation. Princeton, Princeton University Press.

Geddes, Barbara. 1990. Building 'state' autonomy in Brazil, 1930-1964. Comparative Politics, 22 (2): $217-35$.

—. 1994. Politician's Dilemma: Building State Capacity in Latin America. Berkeley, University of California Press.

Gillies, Alexandra. 2007. Obasanjo, the donor community and reform implementation in Nigeria. The Round Table, 96 (392): 569-586.

Grant, Ursula, Hudson, Alan and Bhavna Sharma. 2009. Exploring 'Development Success': Indicators, Stories and Contributing Factors. London, Overseas Development Institute.

Grindle, Merilee S. 1997. Divergent cultures? When public organizations perform well in developing countries. World Development, 25 (4): 481-95.

Gupta, Akhil. 1995. Blurred Boundaries: The discourse of corruption, the culture of politics, and the imagined state. American Ethnologist, 22 (2): 375-402.

Hansen, Thomas Blom and Finn Stepputat, eds. 2001. States of Imagination: Ethnographic Explorations of the Postcolonial State. Durham, NC, Duke University Press.

Hilderbrand, Mary E. and Merilee S. Grindle. 1997. Building sustainable capacity in the public sector: what can be done?. In Grindle, Merilee, S., ed. Getting Good Government: Capacity Building in the Public Sectors of Developing Countries, Cambridge, Mass., Harvard University Press, 31-62.

James, Oliver. 2003. The Executive Agency Revolution in Whitehall: Public Interest versus Bureau-Shaping Perspectives. Basingstoke, Palgrave Macmillan.

Joshi, Anuradha. 2006. Institutions and service delivery in Asia. IDS Bulletin, 37 (3): $115^{-126 .}$

Joshi, Anuradha and Joseph Ayee. 2009. Autonomy or organisation? Reforms in the Ghanaian internal revenue service. Public Administration and Development, 29: 289-302.

Larbi, George A. 2006. Applying the new public management in developing countries. In Bangura, Yusuf and George A. Larbi, eds. Public Sector Reform in Developing Countries: Capacity Challenges to Improve Services. Basingstoke, Palgrave Macmillan and UNRISD, 25-52.

Lemonick, Michael D. 2005. Drug Warrior. Time, 31st October 2005, available at: http://www .time.com/time/magazine/article/o,9171,1124289,0o.html, accessed on: April 29, 2010.

Leonard, David K. 1991. African Successes: Four Public Managers of Kenyan Rural Development. Berkeley, University of California Press.

— 2008. Where are 'pockets' of effective agencies likely in weak governance states and why? A propositional inventory. Working Paper of the Institute of Development Studies at the University of Sussex, Brighton, 306.

- 2010. 'Pockets' of effective agencies in weak governance states: Where are they likely and why does it matter?. Public Administration and Development, 30 (2): 91-101.

Luhmann, Niklas. 1995. Kausalität im Süden. Soziale Systeme, 1 (1): 7-28. 
Manor, James, ed. 2007. Aid that Works: Successful Development in Fragile States, Washington D.C., The World Bank.

Moynihan, Donald P. 2006. Ambiguity in policy lessons: the agencification experience. Public Administration, 84 (4): 1029-1050.

Nduwugwe, Justus. 2008. DFID, PATHS launch N13.2 Billion Health Support Programme, Leadership (Abuja), available at: http://allafrica.com/stories/20080616080o.html, accessed on: April 15, 2010.

NOI Polls. 2007. NOI-Gallup Poll, Second National Poll (November 2007). Results Summary, Power Point Presentation.

OECD (Organisation for Economic Co-operation and Development). 2002. Distributed Public Governance: Agencies, Authorities and Other Government Bodies. Paris, OECD Publishing.

Olaopa, Tunji. 2008. Theory and Practice of Public Administration and Civil Service Reforms in Nigeria. Ibadan, Spectrum Books.

Olivier de Sardan, Jean-Pierre. 2009. State bureaucracy and governance in francophone West Africa: an empirical diagnosis and historical perspective. In Giorgio Blundo and Pierre-Yves Le Meur, eds. The Governance of Daily Life in Africa: Ethnographic Explorations of Public and Collective Service Services. Leiden, Brill, 39-72.

Owusu, Francis. 2006. On public organisations in Ghana: what differentiates good performers from poor performers?. African Development Review, 18: 471-85.

Pogoson, Irene, with Mudasiru, Suraj and Azeez Olaniyan. 2010. National Agency for Food and Drug Administration and Control: Managing the Crisis in the Food and Drug Sector in Nigeria. mimeo.

Pollitt, Christopher and Colin Talbot, eds. 2004. Unbundled Government: A Critical Analysis of the Global Trend to Agencies, Quangos, and Contractualisation. London, Routledge.

Pollitt, Christopher, Talbot, Colin, Caulfield, Janice and Amanda Smullen. 2004. Agencies: How Governments Do Things through Semi-Autonomous Organizations. New York, Palgrave Macmillan.

Prichard, Wilson and David Leonard. 2010. Does reliance on tax revenue build state capacity in sub-Saharan Africa?. International Review of Administrative Sciences, 76 (4): $653-675$.

Robinson, Mark. 2007. The politics of successful governance reforms: lessons of design and implementation. Commonwealth and Comparative Politics, 45 (4): 521-548.

Roll, Michael. 2004. Autonomous politicians and the local state in Sri Lanka: on the social organisation of politics and administration. Internationales Asienforum, 35 (3-4): 263-293.

— - ed. (forthcoming): The Politics of Public Sector Performance: Pockets of Effectiveness in Developing Countries. London, Routledge.

Simbine, Antonia T., with Attoh, Franca C. and Abubakar Oladeji. 2010. Taming the Menace of Human Trafficking: NAPTIP as a Pocket of Effectiveness, mimeo.

Tendler, Judith. 1997. Good Government in the Tropics. Baltimore, John Hopkins University Press.

Therkildsen, Ole. 2008. Public Sector Reforms and the Development of Productive Capacities in the LDCs (UNCTAD, The Least Developed Countries Report 20og: The state and development governance, Background Paper No. 1).

United Nations General Assembly. 2001. United Nations Convention against Transnational Organized Crime, available at: http://www.unodc.org/pdf/crime/a_res_55/res5525e.pdf, accessed on: May 2, 2010.

U.S. Department of State. 2009. Trafficking in Persons Report 2009. Washington D.C., U.S. Department of State Publication.

van Donge, Jan Kees. 2002. Agencification. In Kirkpatrick, Colin, ed. Handbook on Development Policy and Management. Cheltenham, Edward Elgar, 315-322.

World Bank. 2005. Capacity Building in Africa: An OED Evaluation of World Bank Support. Washington D.C., The World Bank. 
Young, Crawford. 1994. The African Colonial State in Comparative Perspective. New Haven, Yale University Press.

\section{INTERVIEWS}

NAPTIP interview 5: NAPTIP senior official, Abuja, May 5, 2009.

NAPTIP interview 6: NAPTIP middle-level officers, Abuja, May 6, 2009

NAPTIP interview 18: Senior European diplomat based in Abuja, Abuja, June 8, 2009.

NAPTIP interview 19: Carol Ndaguba, NAPTIP pioneer executive secretary, June 8, 2009. 
Thomas Bierschenk and Jean-Pierre Olivier de Sardan - 978-90-04-26496-0 Downloaded from Brill.com@4/26/2023 02:08:21PM via free access 


\title{
THE DELIVERY STATE IN AFRICA. \\ INTERFACE BUREAUCRATS, PROFESSIONAL CULTURES \\ AND THE BUREAUCRATIC MODE OF GOVERNANCE
}

\author{
Jean-Pierre Olivier de Sardan ${ }^{1}$
}

In this chapter, we attempt to draw various comparative and theoretical conclusions from the empirical studies on state apparatuses and the public service professions in West Africa which are presented in this volume, but also from research which has been conducted in other contexts over the last ten years or so. ${ }^{2}$

To this end, we shall elaborate certain conceptualizations. Some of these concern the nature of the object itself: the Delivery state, the Local state, and Interface bureaucracies are all central to the topic of research in question. Other conceptualizations relate to the practices of state actors: they include the professional cultures and the practical norms on which these practices are largely based. Finally, to address issues of a more institutional and structural nature, we shall be looking at the bureaucratic mode of governance and at configurations of delivery, especially palliative delivery, in which this particular mode of governance is implicated alongside other modes of governance.

\section{The Delivery State, Interface Bureaucracies AND THE LOCAL STATE}

\section{The Delivery of Public or Collective Goods and Services}

By 'delivery state', we mean the function of the delivery of public or collective goods and services as performed by the state. The expression 'public

1 Researcher at LASDEL, Niamey, Niger.

${ }^{2}$ In particular by LASDEL scholars. LASDEL (Laboratoire d'Etudes et de Recherche sur les Dynamiques Sociales et le Développement Local), a social science research institute located in Niger and Benin, carries out research on the delivery of public or collective goods and services. For research results, see the series Etudes et Travaux du LASDEL, www.lasdel.net. Some of the analysis presented here was developed within the States at Work programme funded by the Volkswagen Foundation (www.ifeas.uni-mainz.de/277.php). It also has benefited from our involvement in the African Power and Politics programme, funded by the DFID and Irish Aid (www.institutions-africa.org/). On occasion, we have also drawn on previously published material (Olivier de Sardan 2001, 2003, 2009a, 2009b, 2010a, 2010b, 2011a, 2011a, 2011b).

C JEAN-PIERRE OLIVIER DE SARDAN, 2014 | DOI: 10.1163/9789004264960_017

This is an open access chapter distributed under the terms of the $\mathrm{GC}_{\mathrm{B}} \mathrm{BY}-\mathrm{N} \mathrm{C}_{2} 4.0$ license 
or collective goods and services' is deliberately wider than 'public goods' as used by economists and which corresponds to very specific criteria: it is applied to goods that have a double property, i.e. they are 'non-excludable' and 'non-rivalrous'. This definition is too deductive and restrictive, it paves the way for normative uses, and we do not subscribe to it.

Instead, we opt for a wider and empirical use of the concept. For us, public or collective goods and services are first and foremost goods and services that are perceived by the vast majority of users as a social necessity, and, either directly or indirectly, as coming under the state's duties towards these users. In other words, by general consensus, they are linked to the public interest, and are therefore matters of public concern, and thus public debate: for instance, access to drinking water, education and health, the fight against crime, an equitable legal system or an effective transport system are seen, in the African countries where we have conducted our research, as 'entitlements' or aspirations that are shared, whether they are articulated or not, by all users/citizens. It is, therefore, a concept: a concept which refers to emic, tied to specific historical and spatial contexts, and potentially including goods and services at an international, national or local level. Such a definition allows for the consideration of contingent factors that cause a good or service to be counted sometimes as public and sometimes not. The concept of a public good will therefore vary from place to place and over time. In other words, what constitutes a public good is an object of political struggle and public debate, depending on specific state trajectories which are different in, say, France from those in the United States, and different for, say, the 19th century to today (see Bierschenk and Olivier de Sardan, introduction to this volume).

It must be emphasized, however, that the conditions under which these goods are delivered are very largely local, even though they may involve non-local, national or international actors (the state, private companies, international organizations, development agencies etc.). It is, after all, at the local level that people drink, are protected from thieves, go to school and are medically cared for.

The delivery of some public or collective goods and services is a specific state function, which is performed regardless of the regime and the kind of power it wields. The state can never be reduced to either its purely repressive functions (which have already been roundly condemned by a whole body of literature inspired by Michel Foucault and James Scott) or the type of regime in charge (democratic/dictatorial/ patrimonial/populist, etc.). The state is also a complex organizational 
machine, whose actors/officials/bureaucrats provide clients/citizens with a variety of goods and services. Both representative democracies and military dictatorships construct, maintain and operate- -with greater or lesser degrees of efficiency-collective infrastructures, water and electricity supplies, schools and dispensaries. Both communist regimes and oil emirates deliver - with varying degrees of success - day-to-day security, aid when a disaster strikes, settling of justice, or economic regulations. The delivery state, therefore, is in no way synonymous with the welfare state: the latter is a special version of the delivery state, and is characterized by a greater range and volume of the goods and services delivered by the state. The neo-liberal state, too, is, in its own way, a delivery state because at least it delivers regulation (which is a vital component of public or collective goods and services) and also because it delivers a basic level of particular services (for instance, in the areas of security, law and education).

Admittedly, the state is never the sole deliverer of public or collective goods and services. Other actors and institutions may assume this role, sometimes in tandem with the state, sometimes in opposition to it, sometimes in its absence, and sometimes simultaneously and independently. Even under regimes in which the state uses force to exercise its monopoly of delivering certain public goods, as was the case in the former Soviet Union, various informal or clandestine procedures present a de facto challenge to this monopoly (Ledeneva 1998). The current prevalence of neo-liberal ideology has obviously meant a scaling down of the goods and services delivered by the state and made it easier for more non-state organizations to assume a delivery role (private operators in particular). In Africa, the importance of a community-based ideology within development organizations is, paradoxically, another factor contributing to this trend. Nevertheless, the delivery of goods and services by the state is still common in all parts of Africa, whatever imperfect or fractional, and the state is regarded everywhere as ultimately responsible for this delivery, in one form or another: i.e. as the main operator, a joint actor, regulator or guarantor.

Inasmuch as the delivery of goods and services is at the heart of what administrations routinely do on an everyday basis and of their relations with citizens/clients, to concern oneself with the delivery state is obviously to concern oneself with the state as a 'concrete entity' ("Etat au concret": cf. Padiolau 1982) or with "the governance of daily life" (Blundo and Le Meur 2009). It is also an opportunity to approach the state via some of its 'practices' rather than through the abstracting lens of discursive 
or symbolic representations, an approach taken by some anthropologists of the state. ${ }^{3}$

That being said, it is quite obviously the case that practices relating to delivery are also the object of representations, and that they too give rise to certain 'images of the state', certain 'conceptions of the state' and certain expectations of the state. ${ }^{4}$ Even in contexts in which the state is incapable of delivering by itself and in the proper manner the least onerous of services, it is still there in the background, an ever-present but shadowy figure, and its ineptitude is deplored (cf. Titeca and De Herdt 2011).

This kaleidoscope of popular expectations regarding the delivery state has been largely underestimated from a theoretical point of view, although the empirical results of much recent research give some indication of how they show up in real situations. When the delivery function is taken in account theoretically, it is mainly in terms of legitimization process (cf. Hibou 2011). Of course, analyzing the delivery state does not at all mean reducing it to this single function: there is no question of forgetting its despotic aspects, of circumventing the legitimization/domination processes that express themselves in it or of ignoring the methods used by political or economic elites in monopolizing power. But our perspective includes a further, often neglected dimension of the state, one that could be described as a semi-autonomous field, to borrow an often quoted phrase of Sally Falk Moore's (1973).

To produce a body of knowledge about state delivery of public goods and services through fieldwork is also to study the forms of bureaucracy connected with this delivery (which is the topic of this book). States deliver services through bureaucracies. Ethnographic investigation on bureaucracies implies ethnographic investigations on bureaucratic management: how bureaucracies manage the delivery as well as how this bureaucracy is managed. Here, too, contemporary anthropological research has too often considered that management is not a subject worthy of interest, or else that it is a disguised way of ignoring politics. But the analysis of management can perfectly well be combined with the analysis of power relationships, as work on New Public Management has shown (McCourt

${ }^{3}$ Cf. the introduction to this volume and Bierschenk's (2009) review of the book by Sharma and Gupta (2006).

4 Not only do 'ideas of the state' find more favour with social scientists than do practices, but, what is more, it is the images the state itself wishes to project or those expressed in public discourse that are studied, while ordinary people's perceptions of the state or those of public servants themselves (both types often being ambivalent and contradictory) are rarely investigated empirically. 
and Minogue 2001; see also Giovalucci and Olivier de Sardan 2009). In fact, management, like delivery, is also a semi-autonomous field, which social anthropology should investigate as such.

The same could be said of public policies. These are indeed largely devoted to the delivery of public or collective goods and services. In the case of Africa, however, there is an acute lack of such information. And yet, the lack of proper planning and the contradictions and inconsistencies of public policies are especially noteworthy in Africa and take on a distinct form. Empirical investigations into public policies are particularly interesting and allow us both "to study up" (Nader 1974) (looking at the decisions of those who promote and are responsible for those policies) and to 'study down' (looking at the ways in which they are implemented on the ground and at relations with clients), but also to study 'in the middle' (looking at the daily functioning of civil services). ${ }^{5}$

The latter level, to which socio-anthropological type fieldwork is particularly suited, is crucial to our understanding of delivery processes. It concerns a specific category of state actors who interact with clients/ users/citizen. ${ }^{6}$ For this reason, we have called them "interface bureaucrats" (Olivier de Sardan 2004). In 'northern' countries, the sociology of organizations and that of professions has yielded numerous studies on these public servants in their dealings with the general public, but, in the case of Africa, and, despite the recent spate referred to above, publications reporting results of empirical research on interface bureaucrats are still all too rare (cf. introduction).

\section{The Local State}

Among interface bureaucrats in Africa, those who work outside the capital and who make up what we might call the 'local state' or the 'state at local level' are even more of an unknown quantity. They are the state agents installed in the local arenas, ${ }^{7}$ scattered throughout the country's inland areas, in the secondary towns, the small towns and sometimes the villages,

\footnotetext{
5 In relation to education, cf. Chabi Imorou and Charton, in this volume, and Bierschenk 2007, Fichtner 2012; on the justice sector cf. Hamani, in this volume, and Bierschenk 2008; concerning policies on free healthcare in the Sahel, cf. Olivier de Sardan and Ridde 2013.

${ }^{6}$ Lipsky (1980) uses the term "street level bureaucracy" in the American context.

7 In a local arena, institutions and actors, bound by "multiplex" relationships (Gluckman 1955), confront one another almost 'physically'. On the notion of local arena, cf. Bierschenk 1988; Bierschenk and Olivier de Sardan 1997a. Cf., more generally, Swartz 1968, Bailey, 1969 .
} 
and hence in contact with users. They fall into two broad categories. On one hand, there are the actors of the so-called 'command' administration (prefectures or governorates), which took over from the colonial administrators (to this day, prefects and governors are called 'commanders' by the local people). On the other, a vast array of technical services represents the decentralized administration, far from the ministries. These are the main providers of goods and services on the state's behalf.

This 'local state' is subject to specific constraints. In local arenas, the delivery of public or collective goods and services by state actors follows particular patterns. Later on, we shall be using the concepts of the 'bureaucratic mode of local governance' and 'palliative delivery' in this context.

For hundreds of millions of farmers, livestock breeders, tradesmen and shopkeepers, interface bureaucrats are simply 'the' state. Whatever their 'ideas' of the state, for them the reality of the state is teachers, healthcare workers, police officers, livestock agents, water-supply technicians, registrars, customs officials, prefects, etc. Even development projects funded by international aid which play a central role nationwide hire former state actors as managers, and they routinely deal with current state actors, whom they consult locally or who serve as their 'points of contact (point focal)'.

It is true that, in many outlying areas, the state has only a token presence and in some areas virtually none at all. A statement like 'the state stops at PK 12' (in other words, $12 \mathrm{~km}$ from the capital; quoted in Bierschenk and Olivier de Sardan 1997b: 441) does not merely apply to the Central African Republic but is applicable to most of Congo, for instance. We do not, however, subscribe to the concept of a 'failed state', which is a hasty overgeneralization made about certain extreme local situations. ${ }^{8}$ There is no denying, however, that significant areas of 'failed delivery' do exist in African States, varying in degree from country to country, but more numerous and acute as one moves further away from the centre of power.

8 "Even in the context of a so-called 'failed state', public services are still being organized and provided", write Titeca and De Herdt (2011: 2), who demonstrate their point with the example of education in the DRC. Cf. also Thomas Bierschenk's review (2010) of the book by Englebert (2009), whom he criticizes for generalizing the situation in eastern Congo to the whole of Africa. On the notion of a 'failed state' being a 'failed paradigm', cf. Hameiri 2007. 


\section{The State's Presence in Francophone West Africa: The Reality, the Weakness and the Paradoxes}

In most African countries, for example Niger, Benin, Burkina Faso, Mali and Senegal which we shall take as our points of reference, the state is in any case visible from one end of the country to the other, and there are many 'external signs of state'. Its coverage of the whole country is an irrefutable fact. The state is officially represented everywhere, in its sovereign powers, by its appointed officials, the governors, prefects and subprefects, who are in charge of all the decentralized services (and who also have oversight of the communes); its presence is symbolically expressed through distinctive public buildings, each with its flag and vast square.

However, as soon as we focus on the delivery of public goods and services, the state's presence is actually seen to be very uneven:

Let us take the case of Niger. Health and education are two 'high density' sectors, in which the state's presence in rural areas is strongest and most visible by far. Both are public services characterized by a high degree of organization and hierarchy, and are relatively functional, manned by a large 'army' of public servants, forming a countrywide network and subjected to a host of complex and formal bureaucratic procedures. We could add to them the forces of law and order (the gendarmerie, the National Guard and the police), which also cover the whole of the country, albeit more sparsely and in smaller numbers. In contradiction to widely held beliefs about the 'retreat of the state', these three professional bodies have grown in size in recent years.

Other state sectors, on the other hand, are in decline or are seeing their activities scaled down or revamped. They are more or less 'disabled'. In some cases, their actors in the field are completely lacking resources and are therefore discouraged and unmotivated. In technical services such as sanitation, community development, livestock farming, agriculture or adult literacy, at both municipal and department level, there is generally only one actor (sometimes with a back-up, usually a civic service worker), who lacks the necessary means to carry out his mission (having neither a vehicle, nor petrol, nor professional expenses), and who hence has nothing to do except wait for the miraculous arrival of a possible 'project' (funded by a development agency) that will come to his aid.

The justice system falls somewhere in between. Coverage is still modest, although there has been considerable progress in the last 20 years (cf. Hamani in this volume) and its resources are very limited. However, through their rituals and organization, the magistrates' courts, which are concentrated in a few medium-sized cities, reproduce a measure of state solemnity, and the (admittedly unsatisfied) demand for impartial state justice remains strong. 
The local state does not only present these quite different faces, it is also a complex organisation that has undergone profound changes in recent times. Decentralization (and the deconcentration that came with it) is the latest of these in tandem with a policy encouraging privatization, which is driven by the development agencies. A typical example is afforded by the water supply services in Niger, which are supported by Swiss cooperation: they increasingly assume the role of service providers for local authorities, that they charge for their services.

The 'high density' sectors of the state (in which the state has a high profile) and the 'disabled' sectors (in which the state has a low profile) have, however, a few things in common.

First, the quality of the services they deliver is roundly condemned by clients, as is the behaviour of state actors, who are often criticized (with a few notable exceptions) for being arrogant, contemptuous, incompetent or corrupt.

Second, state services are often unable to deliver the services for which they are responsible through their own efforts alone. This gives rise to forms of co-delivery (involving both state and non-state actors) or nonstate delivery (outside the bureaucratic mode of governance) as a 'palliative' measure (cf. below).

Third, the management of human resources is haphazard in most areas, at both local and national levels. There is no guiding principle and countless problems repeatedly arise which are deplored by the workers themselves: e.g. absenteeism, patronage and clientelism, frequent interference, an absence of sanctions, chronic staff turnover, a lack of transparency, excessive centralization, a refusal to delegate, the failure of bonuses, inefficiency, the bending of rules, etc. Despite odd instances of things working as they should, there appear to be no permanent solutions to these problems (cf. Roll in this volume, Crook 2010, Tama 2012).

Fourth, development organizations are courted by state actors, who see in them bottomless resources (although to benefit from them, there are conditionalities to bear) in the face of which they devise a multitude of strategies: development brokering, financial handouts, brain drain, doublespeak, quests for daily expense allowances through the creation of ever more training courses and workshops, opportunities for local reform etc.

These four characteristics are the product of the professional cultures of state actors, which are of a very specific kind. They also are grounded in practical norms which differ from the official ones. 


\section{Professional Cultures and Practical Norms}

One of the most significant conclusions to emerge from the research conducted over the last 15 years or so by LASDEL_-in Niger and Benin, in particular, but also in some other countries in French-speaking Africa-is the considerable disparity, which is in evidence everywhere regardless of the sectors of activity, between public norms that are supposed to regulate the professional conduct of state actors and the actual conduct of these actors. This is the level at which we shall introduce the concepts of practical norms and professional culture.

\section{Practical Norms: The Gap Between Official Norms or Procedures and the Practices of State Actors}

How are the professional behaviours of state actors regulated, despite the fact that they often fail to conform to public norms and procedures? What are the forms that give a structure to the informal practices of the state actors in question? Although the behaviour of interface bureaucrats is frequently at odds with professional norms, nonetheless it is not entirely random or anarchical. Significant regularities can be identified. Of course, every social organization, in every country and in every period, experiences disparities between norms and practices. However, the extent and nature of these disparities vary considerably from sector to sector and from context to context. So how can we grasp the regulated informality that appear within African bureaucracies?

We shall call these informal regulations 'practical norms'. This is an exploratory concept. It is not analytical, it does not give a particular substantive content to the phenomena it describes and it does not define a specific interpretive model. It simply serves to bring to light, provided appropriate investigation is undertaken, a variety of methods of social regulation and of patterns of behaviour, without incorporating them prematurely into a single model (of the neo-'patrimonialism kind') ${ }^{9}$ and organizing them into a priori types. It serves a purely pragmatic purpose, i.e. that of investigating aspects of reality that would otherwise have remained 'invisible' because they are discreetly distanced from prescribed

${ }^{9}$ For a critical account of the concept of neo-patrimonialism, cf. Therkildsen, in this volume. 
behaviour. On the theoretical level, it can be used as a tool in an anthropology of practices, or an anthropology of 'gaps', in the sense of deviations from the official rules (cf. Bierschenk and Olivier de Sardan, Research paradigm, this volume).

The practical norms are the various informal rules, tacit or latent, that underpin those practices of public actors which do not conform to formal professional and bureaucratic norms. They describe the extent to which these practices converge, and they allow us to understand the divergences or 'play' (the 'slack', as it were) between formal norms and practices.

Such practical norms are not necessarily expressed as such by social actors; more often than not, they are automatic and routine, and exist at an unconscious rather than conscious level. To give a slightly different twist to Bourdieu's expression, one might say that they are incorporated into a 'habitus'. ${ }^{10}$ They are not directly 'observable'. Hence it falls to the researcher to uncover, identify and analyse them based on how actors act and how they speak.

Let us look at an example. In all the state services we have researched into in West Africa, the official regulations provide an entire battery of penalties for professional misconduct, ranging from a verbal warning to dismissal or to appearing before a disciplinary board. These official norms mostly replicate the French management practices and employment laws of the 196os. All public servants know they exist. Yet they are virtually never applied. All service heads complain about this, but most of the time none of them manage to discipline an offending subordinate. Colleagues argue that a sanction is cruel, would lead to too many complications, would be counter-productive or ineffective, would serve no useful purpose etc. Such a situation is only comprehensible when a widely operating practical norm exists: sanctioning is inappropriate! From hospitals to water and woodland services, from town halls to regional schools inspectorates, the practice is not hard to spot. Various arguments are invoked to justify this practical norm: compassion ('you can't discipline someone with a large family', or 'this worker is coming up to retirement' etc.), reputation (it will be seen as nasty or heartless to discipline someone...), pragmatism (a potential replacement wouldn't do any better), politics (the offender is a member of the party in power, he will be reinstated and the sanction overturned) etc. One can also try to interpret this practical norm using various sociological or anthropological lines of argument: pressure from the immediate social environment (making the case for leniency), the clientelist system (which means numerous

10 The concept of 'habitus' in Bourdieu's work suffers from two major weaknesses: (a) it has no real empirical foundation and remains a black box; (b) it is very domino-centric (Grignon and Passeron 1989); in other words, it is almost exclusively centred on the internalization of the process of domination. We believe that the concept of practical norms avoids these pitfalls. 
pressures on the punisher on behalf of the punished by the latter's 'protectors'), the moral values of charity and pity, a morality of 'shame', the corruption of public services by the system of sinecures and appointments through political patronage, and more general forms of corruption (so that everyone has a hold over everyone else), the absence of a managerial culture etc. Highlighting a practical norm does not mean abandoning interpretation altogether but constructing it on more solid, empirical foundations.

However, in concerning oneself with practical norms, it is important not go to the other extreme and neglect public norms. Certain disciplines in the social sciences could be criticized for having focussed exclusively and for too long on official or formal norms (law, for instance, in relation to legal and administrative norms, but also ethnology, in relation to social norms: kinship, power and rites). Hence, we must not fall into the opposite by forgetting about formal norms (something that interactionist sociologists or the new sociology of science have sometimes done). Our own aim is to explore the space that is opened up for state actors between the professional, bureaucratic norms they are always supposed to follow and the practical norms they often do follow. Formal bureaucratic norms and informal practical norms form the two end points of a continuum, within which social actors' strategies are played out.

One aspect of professional bureaucratic norms in African countries in which we have conducted our research must be underlined at this point: these public norms are particularly heterogeneous, often contradictory and sometimes outmoded (inherited from colonization) or incomplete (leaving important sectors outside official regulation) (cf. Bierschenk in this volume). The fact that they are frequently ill adapted to the local context obviously leaves more room for practical norms.

Within the public services, five main types of relationship between professional bureaucratic norms and practical norms can be distinguished. They are 'ideal types' and are hence frequently intertwined in the real world, and, in some cases, merge completely. Practical norms could be adaptative, semi-tolerated, transgressive, palliative or rebel.

(1) Sometimes, the practical norms remain close to professional ones and are no more than variations in the way they are applied or small 'adjustments' in the interests of the service or the client. Any 'application' of an official norm implies some room for manoeuvre and evaluation, and thus opens the door to practical norms. ${ }^{11}$ It may be a case of adding

11 We are thus reminded that "the meaning of a legal rule is never determinate and always remains subject to interpretation" (Nuijten and Anders 2008: 14). For Lipsky (1980), the tensions between institutional objectives, on the one hand, and the constraints in the 
a human touch to bureaucratic relationships, adapting to staff shortages or excessive workloads, taking account of certain requests by clients or certain constraints on public servants etc. These practical norms could therefore be described as adaptive.

(2) Sometimes, practical norms do not respect the rules, they are cheating with them. They evade official standards but in an innocuous register, with neither sanction nor stigmatization: in fact they are more or less tolerated. These are the "pragmatic rules" coined by Bailey (2001: 119): "how to break a normative rule without being penalized for it". They may be called semi-tolerated practical norms.

(3) Practical norms sometimes mark a radical departure from the formal norms, blatantly flouting them, as in cases in which the law condemns them as corruption: "The notion of corruption is theoretically inseparable from the transgression of a set of norms (juridical or ethical)" (Blundo 2008: 28). These practical norms are transgressive.

(4) Since the aim is to deliver the planned services, practical norms may sometimes actually transgress the letter of the public norms but obey their spirit. When funds have dried up, a disregard of certain regulatory requirements appears to be a coping strategy and a way of ensuring that the administration continues to function in spite of everything: in Senegal as in Niger, judges get shopkeepers to deliver official summonses and make defendants pay their own travel costs for attending court (cf. Hamani, this volume; Blundo 20o6). In such cases, the practical norms are palliative.

(5) Finally, practical norms can sometimes be directly opposed to professional norms, as 'counter-norms', and express a refusal-which can even be coordinated, though disguised — of the legitimacy of official norms, such as disruptions in industry. In this case, the practical norms are rebellious.

Empirical research alone will acquaint us with the subtle interconnections between official norms and practical norms, and allows us to describe actors' strategies in switching between these two levels. Social actors do not adhere to practical norms any more 'mechanically' than they do to public norms. One can also posit the existence of 'practical meta-norms', which would provide criteria for choosing between cases in which public norms need to be applied and those in which such or such

work environment and relations with clients, on the other, are the main explanatory factor of the "patterns of practices" of "street level bureaucrats". 
a practical norm would have to be followed. Contrary to the unifying and prescriptive interpretation of social norms that has pervaded much of the social sciences since Durkheim and Parsons, practical norms are not, any more than public norms, unavoidable, 'one-size-fits-all' rules. 'Practical norms' is therefore an 'agency-friendly' concept, which allows agency to be given a more empirical, more operational, more interactive and more collective content than the bald assertion that a margin for manoeuvre exists for every social actor.

\section{Professional Cultures}

The approach via practical norms provides an alternative solution to the explanation of the divergences between the public and practical norms of state actors via 'culture', or more exactly 'societal culture'. The fact is that a culturalist-traditionalist argument is often invoked, and it runs something like this: state agents depart from official professional norms because they are conforming to social norms in their traditional culture. The norms of 'African societies' are hence more or less smuggled into the delivery of public goods. The scant respect for formal, bureaucratic rules in Africa is due to the weight of 'community' pressures, local customs and traditional values. An entire set of stereotypes and preconceived ideas (Courade 2006), prevalent among scholars and the general public alike, is brought into play: i.e. ideas on 'African culture', 'socio-cultural traditions', 'the pre-colonial heritage', 'African conceptions of the world', 'cultural determinants', 'community values', 'the weight of magico-religious beliefs' and 'the precedence of the family over the individual'. 12

There is no shortage of empirical facts that should prevent one from systematically attributing to 'African cultures' customary practices of public actors that do not conform to professional norms, and from confusing practical norms with traditional social norms (even though there are occasions when social norms are transformed into practical norms, or at least legitimize them). For example, an entire range of practical norms within the public service were highlighted by our earlier investigations, such as the 'every man for himself' attitude, the 'perks', the 'widespread exchange' of favours, the principle of impunity, the use of doublespeak, contempt for the anonymous user, a systematic use of mediators and various forms of obligations resulting from clientelist practices. An analysis of the origin of

12 For a critical analysis of this 'Africanist traditionalist culturalism' cf. Olivier de Sardan (2010b). 
these norms shows that, far from stemming from a distant, pre-colonial past, they all point to a relatively recent past, colonial and post-colonial (cf. Cohen 1980; Olivier de Sardan, 2009a). The 'colonial situation', on the one hand, and development policies, on the other, have been decisive (but not exclusive) factors in the current pluralism of norms, and offer a reasonably comprehensive explanation of the origin of the considerable divergences between the professional and practical norms in evidence in interface bureaucracies in Africa. Many scholars have been emphasizing for a long time the extent to which laws introduced by the colonial state in Africa were 'adapted' or circumvented by local actors (Balandier 1963; Trotha 1994; Spittler 1981; Mamdani 1996; Bayart 1989).

However, the problem is to move to a higher level of generality, given the enormous diversity of practical norms, and produce theoretical interpretations that, while avoiding the convenient traditionalist-culturalist argument, will allow the theorization of both the shared aspects and the internal differences characterizing the complex world of the practical norms of state actors. Another use of the concept of culture, and one that is much more concrete and empirical, will allow us to do exactly that: the concept in question is that of the professional culture of state actors. It can be divided into two basic distinct components: on the one hand, a 'common bureaucratic culture', which cuts across the different state professions, and, on the other, 'specific professional cultures', peculiar to each one of them..$^{13} \mathrm{~A}$ third component may be added, 'sitespecific culture', insofar as the common bureaucratic culture as well as specific professional cultures are always localized, and partly regulated by context-specific practical norms. In any case, professional culture is a space regulated by widely shared practices and representations, which straddle a body of official norms and a body of practical norms. But it always allows room for strategies, rejections or conflicts.

\section{The Common Bureaucratic Culture}

A historical development of a special kind occurred in Africa that affected the very basis of classic interface bureaucracy, which posits a clean break between public and private. This was a legacy of colonization, a legacy that grew stronger in the post-colonial period. A 'colonial and post-colonial

13 The role played by the 'plurality of norms' in Africa has already been demonstrated (cf. Berry 1993; Lund 1998; Chauveau, Le Pape and Olivier de Sardan 2001). But the examples analyzed tend to come from specific domains, like land ownership, where different kinds of legitimacy and redress — clearly identified and 'visible'—clash. 
construction of contempt and privilege', was superimposed on the "social production of indifference" (Herzfeld 1992) typical of all modern bureaucracies. It encompassed the administration sector as well as the education sector or the health sector, inasmuch as nurses and midwives adopt towards their clients the same attitudes as customs officials, teachers, police officers and registry workers.

In fact, the bureaucracy that was imported wholesale into Africa by the colonial regime had a very specific character. The gulf between the administrators and the public, which is an integral part of the construction of any bureaucracy, widened another, deeper and more radical gulf, that between Europeans and the 'natives'. The highly exceptional and (even by the French administration's own standards) illegitimate indigénat regime, which granted inordinate powers to district officers ('commandants de cercle') and deprived those they commanded of their basic rights, did indeed produce a bureaucracy that was undeniably 'modern', but in a 'colonial' format that was something of a monster, mixing as it did a set of features deriving from the European classical model (organization charts, official procedures, written records, reports, etc...) and another set of features spawned by the colonial/despotic situation and often contradicting the first set (resulting in a kind of schizophrenia, traces of which still linger today) (for a fuller analysis, cf. Olivier de Sardan, 2009a).

Admittedly, not everything goes back to colonization, far from it, and various practical norms, such as the general absence of sanctions, the systematic 'every-man-for-himself' ethic, which undermines any teamwork, chronic absenteeism among staff and endemic corruption, are undoubtedly post-colonial. Others, however, which are just as recurrent in the behaviour of present-day African bureaucrats, can be traced back to the colonial administration (having been subsequently developed and incorporated). Contempt for the anonymous client, the role of mediators and the practice of conferring privileges are cases in point. Let us consider them.

Indeed, the enormity of the gulf between bureaucrats and their 'native' clients, embodied by the various provisions of the Code de l'indigénat and the prevailing colonial way of being (racism and paternalism, in varying proportions) introduced plenty of scope for arbitrariness, arrogance and even violence into the procedural rationality of traditional metropolitan bureaucracy, which was officially imported into the colonies for immediate application (cf. Bat and Courtin 2012). The long-term consequences have been significant: over and above the contempt many European public servants often expressed quite openly for those they governed, generations 
of African auxiliary and clerical staff learned from their colonizers how to erect barriers between themselves and the local population, signal their privileged status in as many ways as possible, construct their superiority by asserting the inferiority of others, maltreat 'natives', and behave arbitrarily. Hence the gulf was perpetuated in post-colonial administrations and at times became even wider.

Mediators were indispensable to the functioning of colonial bureaucracy, which was blighted by chronic under-government. Lacking human resources and a mastery of local codes and customs, colonial bureaucrats not only tolerated but even systematically exploited various forms of outsourcing — another marked departure from metropolitan rules-, relying on auxiliary workers, chiefs, brokers, interpreters, etc. and giving them room for manoeuvre (cf. Alexandre 1970; Lawrance, Osborn and Roberts 2006) After independence, the role of the intermediaries became more important to the point of now being one of the structural features of African administrations.

As for the system of privilege, it points straight to the innumerable 'perks' of colonial bureaucracy. The disparity was that much greater compared to public servants in mainland France because colonial managers were far less well educated. The mere fact of having a position in the colonial administration gave access to these privileges, regardless of competence or merit. Independence allowed former 'clerks' of the colonial regime to be promoted at lightning speed, catapulted overnight into all the senior 'colonial' posts of the new state, and hence to acquire the 'right' to operate a system of privilege in their turn. After that, the system reproduced itself automatically via the classic route of 'path dependency'.

More recently, the proliferation of enclaves constituted by development 'projects' have replaced the state in a number of its functions. A striking contrast has developed between the official public sector and the sector of international institutions or 'projects', with derisory national rates of pay and third-class privileges, in the case of the former, and rates in line with international standards and first-class privileges, in that of the latter. The upshot is that, today, after devastating structural adjustment policies and the new forms of development aid, the public service has seen many of its old privileges disappear and has lost out to development agencies. Privilege has been displaced at every level in the 'developmentalist configuration', from northern countries' experts to NGO outreach workers, and this goes a long way towards explaining the internal 'brain drain' inside Africa (the poaching of the best managers in the public service by the development agencies and international organizations). 
It should not be concluded from all this, however, that state mechanisms are governed wholly by rationales based on privilege, clientelism or corruption. Rationales based on competence or merit have not disappeared from administrations. Far from it, they, too, feature as components of bureaucratic culture, as part of a complex mix, or have a place within the practical norms (cf. Willott, Therkildsen, Lentz in this volume). The same is true of the finicky respect for bureaucratic procedures.

Furthermore, the switching between official and practical norms that characterizes the generic bureaucratic culture is obviously not enough on its own to account for the professional practices of the entire body of public service actors. These practices also vary, depending on the occupations and professions under consideration.

\section{The Profession-Specific Cultures of Public Actors}

Each type of job has its own officially recognized technical skills and professional norms, and a particular training system (a professional course, consisting of pre-service and in-service training). But jobs are also carried out in the real world, in a particular place, in ways that differ slightly from the official model, incorporating many of its elements, but mixed with habits, routines and 'tricks of the trade' that together correspond to the specific 'know how' of the job, to the requirements of a particular location, the way a particular department works, local management methods, the kind of hierarchy in place, relations between colleagues, contextual, material and financial constraints and so on. It is this patchwork of different elements, of which practical norms are a core feature, that makes up the 'specific professional culture'.

It serves our purpose here to take the example of health workers. One would be on fairly safe ground in arguing that there is a profession-specific culture among midwives in West Africa, given the number of empirical studies that have been undertaken, ${ }^{14}$ which have highlighted an entire range of convergent practical norms. These include the following: a sense of belonging to a social and professional elite, a certain contempt for the 'ignorance' of their patients, the opening up of the profession and the disappearance of the idea of a 'vocation' with its implied ethics, a feeling that the experience and instinct of midwives is more valuable than the knowledge of doctors, the appropriation of space and time in maternity hospitals for their own ends, a sense of impunity, the hunt for extra income at the expense of patients, the

14 Cf. Jaffré and Prual 1993; Moumouni and Souley 2004; Koné 2003; Vasseur 2004; Jaffré and Olivier de Sardan 2003; Jaffré 2009; Olivier de Sardan and Bako Arifari 2011; Diarra 2012. 
frequent delegation of tasks to birth attendants, cleaners or trainee nurses, the primacy of forms of female sociability over professional requirements, the search for per-diems attached to professional training sessions, regardless of their content etc...

This professional culture is often far removed from the official norms, but the latter are known nonetheless (and some of them are respected), and knowing them (and knowing when to apply them) is also a part of the professional culture. Midwifery practices are also different from the expectations of the local population, and have nothing to do with 'traditionalistculturalist' clichés: ethnic factors, witchcraft and kinship are not usually elements that have an explanatory relevance for the behaviour of midwives today (even though the latter, of course, in their private lives, have community ties, consult soothsayers and belong to family networks, just like anyone else). Pre-colonial traditions relating to childbirth (at home) are in complete contrast to this professional culture: in pre-colonial times, birth attendants, whose main task was to cut the umbilical cord, were old women socially close to the parturient, who were present chiefly to give support, encouragement and post-partum care (washing the baby and his mother and burying the placenta, as ritual required).

The professional culture of midwives is not, therefore, simply the product of formal training, where the official norms are taught. This formal training prepares them very insufficiently to the realities of their future professional life. Much more than that, the professional culture of midwives is made up by practical norms learned on the job. During their practical training, at the end of their formal education, trainees discover the 'real' job of being a midwife in a situation, in which there is a serious shortage of drugs and materials, a world away from the antiseptic and timeless depictions given in the lecture theatre, and without any guidance from their teachers: they suddenly have to do the bulk of the work themselves under the often lax supervision of the midwives on duty, who sometimes insult them if they are woken up 'for nothing'. These placements and their first two or three years in post are the main locus of their professional socialization, the privileged space for learning this professional culture (cf. Vasseur 2009). They discover how to cope when they have run out of a particular drug, how to fill in partograms at the end of a care session and not during labour, how to do one's job when there are no finger cots available, the blood pressure monitor doesn't work and the ambulance has been commandeered for the head of unit's shopping. They learn the tricks of the trade and the-more or less tolerated-'dodges' that bring in a bit of extra cash. They sort the tasks that really have to be performed from those they get used to neglecting. They gradually learn to inure themselves to suffering and death, to better resist the unreasonable demands of patients and their companions, to distinguish between 'good' and 'bad' patients and to live with hardship and injustice. They get over their initial (dis-)illusions and they begin to make ends meet.

Taken as a whole, the professional culture of midwives, no doubt like any other profession-specific culture, is a combination of at least three sets of 
elements: (a) direct 'traces' of the respective official norms and skills the midwives have assimilated during their initial training; (b) more indirect traces, in that they have been modified and 'tweaked', the various 'coping strategies' serving as a filter, in other words adaptive, semi-tolerated or palliative practical norms; and (c) a set of behaviour patterns external to the professional norms and learnt on the job, in other words a further set of practical norms that have a 'technical', 'relational'15 and economic' dimension, including corruption, and are frequently transgressive.

Furthermore, every professional culture includes various other bodies of workers on the fringes of the space it occupies, with a range of statuses, both formal and informal. For a professional culture 'localized', it is always associated with a typical space, which in the case of midwives, for instance, is a particular maternity unit.

Hence, the 'in-house' professional culture of a maternity groups revolves around the midwives, carers, cleaners, birth attendants and first-aid workers, with each of these 'bodies' being able, in certain respects, to perform the same therapeutic duties, establish similar relationships with clients, devise the same 'dodges', act in accordance with the same practical norms, but also, in other respects, to accept the distribution of roles and so maintain the hierarchy of relationships.

Paradoxically, it is these lower-grade workers-often volunteer workers, usually with a low turnover as they cannot be posted elsewhere-who ensure the stability of the localized professional culture (that is to say, a memory bank of the local habits, routines and 'dodges'), whereas, under the present system, administrations change at the drop of a hat, department heads rarely stay more than a year and the merry-go-round of transfers of doctors hardly ever stops (see Hamani in this volume, for the role of volunteers in the running of courts).

This localized professional culture, whether at service or clinic level, can be seen as one of the elements of an organizational culture peculiar to that department. An organizational culture, as well as a professional culture, is always a mix of formal and informal patterns, of official and practical norms. ${ }^{16}$

15 It should be remembered that midwives are usually the wives of - sometimes highranking - public servants and they exploit the protection they enjoy to avoid being posted in the provinces (cf. the pioneering article by Jaffré and Prual 1993; cf. also Diarra 2012).

16 'Deal and Kennedy (1982: 15) define organizational culture as the "system of informal rules that spell out how people are to behave most of the time"' (quoted in Grindle 1997: note 12). 
Similar processes can be observed in the legal system and education, as in all the profession-specific cultures involving jobs in the state sector.

\section{Combinations of a Common Bureaucratic Culture, a Profession-Specific Culture and a Site-Specific Culture}

It is obviously for analytical convenience that we have tried to distinguish between what belongs to a profession-specific culture, to a site-specific culture $_{s}$ and to a common bureaucratic culture. In real terms, they overlap, intermingle and even merge into each other.

For example, this triple influence could be read into the absence of compassion and patient care which can be observed on the part of healthcare personnel. On the one hand, a profession-specific culture has incorporated a range of 'defences' against unreasonable demands by patients, against the risks of patient management quickly becoming an all-consuming task and against helplessness in the face of suffering and death. ${ }^{17}$ On the other hand, a common bureaucratic culture has constructed the anonymous client as a nuisance, an inferior and a victim all rolled into one. Finally, the personality of the senior midwive and the degradation of the maternity house will add other site specific factors.

Similarly, it can be argued that the very special relationship to time that one finds among midwives is the product of the intertwining of three different times. The 'technical' time, on the one hand, is a form of time linked to the profession-specific culture (the rhythm of night duty, the deceptive time of false labour pains, the more experimentally standardized time of cervical dilation, the normalized time of partograms etc.). It frequently contrasts with the time that is 'lived through' by the parturients. The 'bureaucratic' time, on the other hand, is the time related to the common bureaucratic culture (where the illegitimate time of the client is always a disruption of the legitimate time of the bureaucratic actor). The local time of the health team is embedded in the precedent ones.

If we now extend the perspective beyond the example of the professionspecific culture of midwives, we can conclude that the delivery of goods and services by state actors is carried out according to modalities that always combine a common bureaucratic culture and a set of profession-specific cultures and site-specific cultures, or, to put it another way, combine related sets of practical norms in part shared by state actors irrespective

17 More generally, Lipsky (1980) had already noted that street level bureaucrats needed to "protect" themselves from clients. 
of their professions, and specific in part to the profession and to the local context. It can also be argued that it is this combination that constitutes 'the bureaucratic mode of governance', which is peculiar to state services when they deliver goods and services, compared to other suppliers.

\section{Local Modes of Governance}

The concept of 'mode of governance' should always be used in the plural and almost automatically implies a comparative perspective. The state is not the only provider of public or collective goods and services, other organizations also perform this role, in a way that is specific to them and, therefore, different from that of interface bureaucrats.

Development agencies, for instance, are not only providers of funding; they also deliver public services, sometimes in the same areas as the state as health or education (for example, through innumerable northern NGOs running or supporting clinics and schools $)^{18}$ and sometimes in areas abandoned by the state (such as micro-credit or sanitation). In some cases they do this directly, but increasingly they do it through outsourcing to local NGOs, or even through the mediation of village cooperatives or various local voluntary associations that they have fostered. Municipalities also deliver public services, such as the management of drinking water, the registry and community schools. And other actors also exist, both individual and collective, that perform a 'delivery' function, like 'big men' and sponsors originating from the locality (who finance a mosque, school or well), churches and brotherhoods (which open healthcare centres, distribute humanitarian aid or give help to the needy), and the 'neo-traditional' chiefs (who arbitrate in land disputes, ensure a degree of safety and welcome visitors). Most of these organizations have some involvement in education, the justice system (its arbitration function, at least), health, water supply and social welfare.

Furthermore, the approach adopted by these multiple social actors and organizations cuts across traditional boundaries. It blurs standard traditional distinctions like 'private/public', 'state/civil society', 'formal/ informal' and 'endogenous/exogenous'. The state's technical services now deliver commercial private expertise to communes and to individuals, NGOs and foreign aid agencies are staffed by the nation's former

18 Cf. Fichtner (2012) on the "NGOisation of education". 
best public servants, the transfer of public sector habits into the private sector is now just as rife as the better known converse (so that one now hears of forms of corruption internal to the private sector and the existence of 'private bureaucracies'), associations are mushrooming in the hope of benefiting from 'projects', and many organizations exist in unclassifiable grey areas, in which they perform state functions without actually belonging to the state. These organisations are "twilight institutions" (Lund 2006).

Each organization has its own forms of legitimacy and authority, its own actors, its own well-publicized operational rules (i.e. its system of official norms), its own way of applying these rules 'on the ground' (i.e. its configuration of practical norms). The coordination between these various types of actors and the degree of manoeuvrability regarding the rules thus become important issues.

We shall refer to these different modalities, each with its distinctive character, through which organizations deliver public or collective goods or services, as 'modes of governance'. In doing this, we use the concept of governance in a non-normative way, stripped of both the ideological visions peculiar to some development organizations and the oversimplified, reductive critiques typical of certain academic deconstructions. This perspective simultaneously takes into account the delivery dimensions and the political dimensions of public or collective actions, and allows us see the state and development organizations in Africa in a new light (cf. Blundo and Le Meur 2009).

To be more specific, a mode of governance is an institutional mechanism ('dispositif') for the delivery of public or collective goods and services, in accordance with specific official norms and specific practical norms, incorporated into specific professional cultures and bringing into play specific forms of authority.

The notion of local governance is one variant of this definition, which seems to us particularly fruitful at the empirical level. The local level is certainly the level at which the best insight is gained not only into how a particular mode of delivery works (at the interface with clients/users), but also into how different modes of governance can co-exist; it is at this level, too, that the concrete forms of action by the various powers that occupy the same local arena can be simultaneously observed. Each mode of local governance has its own particular forms of authority and legitimacy, which are accepted or contested to a greater or lesser extent and which are more or less effective in delivering goods and services. 
Our research in Niger identified, ideal-typically, eight modes of governance. ${ }^{19}$ Among them, four are public ones. They are omnipresent and are also found in other African countries: the bureaucratic mode of governance (state services), the development project-based mode of governance (development projects and aid interventions), the associational mode of governance (associations, cooperatives, farmers' groups, etc.) and the municipal mode of governance (arising from recent decentralization, and the implementation of elected local governments). These four modes can be defined as 'public' modes of governance, in that they all are supposed to serve the public interest (or the general interest), they all concern the public domain, and they are all related to public spaces. Four other modes of governance, that are sometimes less prominent, often less central, more individualized, but also more disparate, could be added to them, inasmuch as they, too, deliver public or collective goods and services, either on an occasional or a permanent basis: the chiefly mode of governance (exercised either by administrative-i.e. colonial-stylechiefs, or by 'customary', 'traditional' chiefs, or else by neo-traditional chiefs), the sponsorship-based mode of governance (involving sponsors and big men), the merchant mode of governance (private operators sometimes deliver public services), and the religious mode of governance (similar in some ways to the associational mode, but with its own specificity nonetheless).

Each of these modes is officially regulated by specific normative and formal rules. But each of them also has its own informal regulation mechanisms. Each has its own forms of accountabilities, including formal ones, linked to public norms, and informal ones, linked to practical norms (cf. Blundo in this volume). And each calls on a panoply of specific practical norms.

Each mode of governance is first of all describable and analysable at the local level, the level of its interface. This does not mean, however, that it is confined to a locality, or that it is idiosyncratic. Quite remarkably, the same forms of local delivery are replicated throughout French-speaking West Africa, even crossing national borders.

The common bureaucratic culture is, therefore, largely the same in Niger, Mali, Burkina Faso, Benin and Senegal, and the profession-specific

19 For a more detailed description of these eight modes, cf. Olivier de Sardan 2009c, 2011a. 
cultures of state actors also extend beyond borders (which is not to say that significant differences do not exist, despite this common identity, depending on the sectors, countries and regimes-differences that can only be unearthed by empirical research).

The same applies to the other modes of governance. Development projects are uncannily similar everywhere in West Africa, village associations and farmers' groups operate along the same lines everywhere in West Africa, patrons make the same investments and introduce the same kind of patronage everywhere in West Africa, and municipalities are faced with more or less the same difficulties everywhere in West Africa.

Although these various modes of local governance exist side by side, it does not follow that each of them always delivers goods and services promoting the general interest in parallel, independently and on a more or less specialized basis.

\section{Configurations of Delivery and Palliative Delivery}

What actually happens is quite the opposite. The delivery of these goods is often effected through complex forms of coordination between different modes of local governance, in other words between various sections of local authorities or other legitimate bodies, each with its own operating methods that have a presence in the local arena: state services, administrative chieftaincies, communes, associations, development projects etc. In other words, state bureaucracies, more often than not, do have to cooperate volens nolens with actors and organizations belonging to other modes of governance.

Let us take the example of personal safety in Niger (see also Bierschenk in this volume). Disputes between farmers and nomadic herders are common in the country's interior, and sometimes lead to fatalities. It is the job of the police (gendarmerie) to prevent these (by patrolling) or to settle them (through written reports or arrests). To do either of these, a $4 \times 4$ vehicle is needed to get around. However, the car is often out of order, and the fuel allowance is woefully inadequate, hence patrols are few and far between. It is, in fact, the chief's 'knights' who alert the police whenever there is trouble. The car is fixed or the fuel is bought with dues paid by the local population and collected by the village chiefs and a contribution from the mayor. As for the 'livestock routes' ('couloirs de passage') created especially for the herders, which should allow conflicts to be avoided, these are defined and mapped out by NGOs and funded by aid agencies.

This situation is one of co-production of the public good 'safety', which, in addition to the bureaucratic mode of governance (represented by the 
police), also brings into play the chiefly mode of governance, the municipal mode of governance and the developmental mode of governance. It also includes the clients themselves since they contribute to delivery through the dues they pay. This is a specific 'configuration of delivery'. By this term-'configuration of delivery'-I understand the various combinations of actors, organizations and means - both state and non-statewhich enable a good to be delivered.

In the above-cited example, co-delivery is a consequence of the state's inability, in one of its statutory functions, which is also a delivery function, to ensure this delivery by itself. It is therefore 'rescued' locally by other actors and organizations. Sometimes, when faced with the inability of their own administrations to fulfil their obligations, the state actors themselves 'cobble together' local solutions (bricolage or inventive practices, see Blundo and Hamani in this volume, and Cleaver 2002).

We refer to these practices as 'palliative' delivery or co-delivery. This has become widespread, and it allows goods and services that serve the general interest to be delivered even when the state is found wanting.

Palliative delivery relies very much on 'arrangements', which frequently take a monetary form, involving a payment by the client. He is the one who must somehow 'dig deep into his pocket' to fund expenditure that used to be undertaken the state, or which came under the state's official responsibilities.

These practices are sometimes quasi-official, and even institutionalized, in other words they obey public (or quasi-public) regulations recently laid down by the state (or its appendages and partners) for dealing with its own inadequacies: the clearest case is education in the Democratic Republic of the Congo where the education system is funded largely by parents, whose contributions sustain the entire system, from the bottom up and in accordance with formal criteria, and where the Churches are the main providers of public education (cf. Titeca and De Herdt 2011). However, one could also argue that the introduction of health costs recovery in West Africa as a result of the Bamako Initiative is a form of palliative delivery: faced with the state's inability to supply healthcare centres with drugs, patients have to pay a fixed sum for treatment and the money collected in this way is used by the centres to buy more drugs. In this case, the institutional form of palliative delivery remains internal to the bureaucratic mode of governance. The generalized practice of selling water by the bucket in areas that have boreholes or pumps, to guarantee repairs that the state can no longer ensure, is the same kind of process. Hence, it emerges that when palliative delivery relies on the client and is also institutionalized, it is close to being a form of privatization. 
However, palliative delivery can also take place in an informal context while remaining within the bureaucratic mode de governance, and require palliative norms. Various unofficial charges levied on clients by public actors (in other words, various forms of petty corruption) serve not only to line the pockets of these actors but also to keep the service afloat so that it can continue its work: the actors of the Water and Woodlands Service (Eaux et Forêts) pay for their petrol and office equipment out of the 'income' generated by the 'racketeering' to which the farmers are subjected (Blundo 2011). This amounts to a kind of informal privatization, which is internal to the public services (Blundo and Olivier de Sardan 2006).

However, very often palliative delivery takes a co-delivery form that is sometimes institutional in nature but, generally, informal. In fact, the kind of 'informal tinkering' that occurs at the local level is the most common response. It brings into play personal relationships between actors from different modes of governance. It depends on the goodwill of individuals and a commitment to reform on the part of local actors. It is therefore vulnerable and an easy prey for critics.

\section{CONCLUSION: REFORMS AND REFORMERS}

Generally speaking, clients/users/citizens everywhere are deeply dissatisfied with the bureaucratic mode of governance, as our, and others', research has shown in various fields. The general feeling is that public services in Africa are blighted by inadequate delivery and poor quality. Although all four public modes of governance habitually appear as incapable of translating their professed aims into realities, it is the bureaucratic mode of governance that most often comes under fire. The need for reform is stressed everywhere: and so the demand for reform is not just a demand from the outside world, from international organizations, but also (no doubt for other reasons and, obviously, in other forms) a demand from the grassroots level-the people themselves-for better-quality goods and services. The opportunistic behaviour of state actors, which shows up in a number of practical norms, reflects a widespread malaise among themselves, made up of discouragement, bitterness and cynicism.

Nevertheless, we met, in the course of our researches, state actors from all sectors who stood out as exceptions and who departed, to a degree, from the practical norms prevalent in their professional milieu, by following certain alternative practical norms (often closer to the official norms, but without merging with them), in order to deliver better-quality services 
(see Lentz and Roll in this volume). One can describe these exceptions as 'admirable' in the sense that an actor's nonconformist attitude often has a high personal cost, since it subjects him to the criticisms of family, friends and colleagues.

These reformers 'from the inside' (actors in the bureaucratic mode of governance) are, of course, in a very different position vis-à-vis the reforms proposed and implemented by the reformers 'from the outside' (actors in the developmental mode of governance). They operate within local professional cultures (even if they do not adhere to them in every respect), they have a command of the practical norms (even if they modify or criticize some of them) and they organize delivery or palliative co-delivery. In contrast, 'outside' reformers focus on official norms, either by permanently producing new official norms - hence the endless reform of public policies (cf. Chabi Imorou, Charton and Muñoz in this volume). Or they try to improve the compliance to norms in place by introducing planning, control or management systems (as with the 'new public management' techniques). Or else they propose more training. As things stand at present, these various measures appear to have little effect. At best they may serve as 'windows of opportunity' for 'inside' reformers, who sometimes exploit them to act in their own way in the specific area of practical norms and professional cultures.

Let us take the example of multiple accountabilities to illustrate the gap between reformers from the inside and reformers from the outside. While the latter work with a ready-made definition of accountability as a unique principle, the everyday reality we have studied is one where each mode of governance has its own forms of accountability, not only formal but also informal. Bureaucrats are submitted to an officially hierarchicalbureaucratic accountability. But most of them are also de facto accountable to a 'boss' or an 'elder' somewhere in the public service, who intervenes for them in order for them to get their position, and/or to a patron or sponsor outside the public service, with whom they do deals and have "arrangements". Moreover, when bureaucrats co-deliver a public service, they interact with actors belonging to other modes of governance, and are submitted to other types of formal and informal accountability. Any local reformer must take in account such constraints, most of them unknown or not taken in account by international experts.

Here is another example. In the face of the difficulties of public administration in Africa, development agencies have always been switching desperately from one mode of governance to another, in search of the key that will open all doors. It is tempting to believe that such and such a 
mode of governance will provide, in and of itself, a miracle solution. After the great defeat of the bureaucratic mode of governance in post-independence Africa, which occurred under both dictatorial and democratic regimes, and whose effects have persisted to this day, the preference was for the associational mode of governance, espoused in the name of community participation. Then it was the municipal mode of governance and democratic decentralization that embodied everyone's hopes. The 'merchant' mode of governance also has had its fierce supporters since the advent of the era of neo-liberalism and is still en vogue. Finally, disappointed by all of the foregoing, some people have even turned to chiefly governance as the alternative.

But contrary to the expectations of many development experts, no mode of governance has intrinsic virtues that guarantee better performance in public goods provision. 'Within' each mode of governance, there exist 'reformers' who are concerned to improve delivery performance and 'conservatives' who are content with the current situation and the rents they derive from it. We use the opposition between 'reformers' and 'conservatives' here not in its usual ideological or macro-political sense, but only in relation to the issue of better access to public services and goods and improvement of their quality.

In other words, the different concepts we have used in this paper-delivery state, mode of governance, practical norms, delivery configuration-are all linked one to each other. And they all belong to the grounded theory type: they are issued from empirical research 'on the ground'. Maybe for this reason, they may not only help to better grasp complex situations without falling in ready-made theories, simplistic dichotomies, or ideological judgments, but they may also open fresh perspective on reform issues.

\section{REFERENCES}

Alexandre, Pierre. 1970. Chiefs, commandants and clerks: their relationship from conquest to decolonization in French West Africa. In Crowder, A. and O. Ikime, eds. West African Chiefs: Their Changing Status under Colonial Rule and Independence. Ile-Ife, University of Ife Press, 2-13.

Bailey, Frederick. 1969. Stratagems and Spoils. London, Basil Blackwell.

- 2001. Treasons, Stratagems, and Spoils: How Leaders Make Practical Use of Values and Beliefs. Boulder, Westview.

Balandier, Georges. 1963. Sociologie actuelle de l'Afrique noire: dynamique sociale en Afrique centrale. Paris, PUF.

Bat, Jean-Pierre and Nicolas Courtin. eds. 2012. Maintenir l'ordre colonial, Afrique et Madagascar XIX ${ }^{e}-X X^{e}$ siècles. Rennes, Presses Universitaires de Rennes.

Bayart, Jean-François. 1989. L'Etat en Afrique. La politique du ventre. Paris, Fayart. 
Berry, Sara. 1993. No Condition Is Permanent. The Social Dynamics of Agrarian Change in Sub-Saharan Africa. Madison, University of Wiconsin Press.

Bierschenk, Thomas. 1988. Development projects as an arena of negotiation for strategic groups. A case study from Bénin. Sociologia Ruralis 28 (2-3): 146-16o.

. 2007. L'éducation de base en Afrique de l'Ouest francophone. Bien privé, bien public, bien global. In Bierschenk, Thomas, Blundo, Giorgio, Jaffré, Yannick and Mahaman Tidjani Alou, eds. Une anthropologie entre rigueur et engagement. Essais autour de l'ouvre de Jean-Pierre Olivier de Sardan. Paris, Karthala, 251-276.

- 2008. The everyday functioning of an African public service: informalization, privatization and corruption in Benin's legal system. Journal of Legal Pluralism and Unofficial Law 57: 101-139.

- 2009. Review of: Sharma, Aradhana, and Akhil Gupta. 2006, eds. The anthropology of the state: a reader. Oxford, Blackwell. Zeitschrift für Ethnologie 134 (1): 154-158.

- 2010. Review of: Englebert, Pierre. 2009. Africa. Unity, sovereignty and sorrow. Boulder: Lynne Rienner. Africa Spectrum 45 (3): 161-165, available at: http://hup.sub.unihamburg.de/giga/afsp/article/view/382/380.

Bierschenk, Thomas and Jean-Pierre Olivier de Sardan. 1997a. ECRIS: Rapid collective inquiry for the identification of conflicts and strategic groups. Human Organization 56 (2): $238-244$.

- 1997b. Local powers and a distant state in rural Central African Republic. The Journal of Modern African Studies 35 (3): 441-468.

Blundo, Giorgio. 2006. Dealing with the local state: the informal privatization of streetlevel bureaucracies in Senegal. Development and Change 37 (4): 799-819.

- 2008. Hidden acts, open talks. How anthropology can 'observe' and describe corruption. In Nuijten, Monique and Gerhard Anders, eds. Corruption and the Secret of Law. A Legal Anthropological Perspective. Aldershot, Ashgate, 27-52.

- 2011. Une administration à deux vitesses. Projets de développement et construction de l'État au Sahel. Cahiers d'Etudes Africaines 202-203: 427-452.

Blundo, Giorgio and Pierre-Yves Le Meur. eds. 2009 The Governance of Daily Life in Africa. Ethnographic Explorations of Public and Collective Service. Leiden, Brill.

Blundo, Giorgio and Jean-Pierre Olivier de Sardan, with N. Bako Arifari and M. Tidjani Alou. 2006. Everyday Corruption and the State. Citizens and Public Officials in Africa. London, Zed.

Chauveau, Jean-Pierre, Le Pape, Marc and Jean-Pierre Olivier de Sardan. 2001. La pluralité des normes et leurs dynamiques en Afrique. In Winter, Gérard, ed. Inégalités et politiques publiques en Afrique. Pluralité des normes et jeux d'acteurs. Paris, Karthala, 145-162.

Cleaver, Frances. 2002. Reinventing institutions: bricolage and the social embeddedness of natural ressources management. European Journal of Development Research 14 (2): 11-30.

Cohen, Ronald. 1980. The blessed job in Nigeria. In Britan, Gerald M. and Ronald Cohen. eds. Hierarchy and Society: Anthropological Perspectives on Bureaucracy. Philadelphia, Institute for the Study of Human Issue, 73-88.

Courade, Georges. 2006. L'Afrique des idées reçues. Paris, Belin.

Crook, Richard. 2010. Rethinking civil service reform in Africa: 'Islands of effectiveness' and organisational commitment. Commonwealth and Comparative Politics 48 (4): 479-504.

Deal, Terrence and Allan Kennedy. 1982. Corporate Cultures: The Rites and Rituals of Corporate Life. Reading, PA, Addison-Wesley.

Diarra, Aïssa. 2012. La prise en charge de l'accouchement dans trois communes au Niger: Say, Balleyara et Guidan Roumji (Etudes et Travaux du LASDEL. 101), Niamey, LASDEL.

Englebert, Pierre. 2009. Africa. Unity, Sovereignty and Sorrow. Boulder, Co., Lynne Rienner. Fichtner, Sarah. 2012. The NGOisation of Education. Case Studies from Benin. Köln, Köppe. Giovalucci, François and Jean-Pierre Olivier de Sardan. 2009. Planification, gestion et politique dans l'aide au développement: le cadre logique, outil et miroir des développeurs. Revue Tiers Monde 198: 383-406. 
Gluckman, Max. 1955. The Judicial Process among the Barotse of Northern Rhodesia. Manchester, Manchester University Press.

Grignon, Claude and Jean-Claude Passeron. 1989. Le savant et le populaire. Misérabilisme et populisme en sociologie et en littérature. Paris, Seuil.

Grindle, Merilee S. 1997. Divergent cultures? When public organizations perform well in developing countries. World Development 25 (4): 481-495.

Hameiri, Shahar. 2007. Failed states or a failed paradigm? State capacity and the limits of institutionalism. Journal of International Relations and Development 10 (2): 122-49.

Herzfeld, Michael. 1992. The Social Production of Indifference. Exploring the Symbolic Roots of Western Bureaucracy. Chicago, The University of Chicago Press.

Hibou, Béatrice. 2011. Anatomie politique de la domination. Paris, La Découverte.

Jaffré, Yannick and Jean-Pierre Olivier de Sardan. eds. 2003. Une médecine inhospitalière. Les difficiles relations entre soignants et soignés dans cinq capitales d'Afrique de l'Ouest. Paris, Karthala.

Jaffré, Yannick and Alain Prual. 1993. Le corps des sages femmes, entre identités professionnelle et sociale. Sciences Sociales et Santé 11 (2): 63-80.

Jaffré, Yannick, Diallo, Yveline, Vasseur, Patricia and Chrystelle Grenier-Torrès. 2009. La bataille des femmes. Analyse anthropologique de la mortalité maternelle dans quelques services d'obstétrique d'Afrique de l'Ouest. Descartes, Faustroll.

Koné, M. 2003. 'Contexte' et 'gombo' dans les formations sanitaires. In Jaffré, Yannick and Jean-Pierre Olivier de Sardan, eds. Une médecine inhospitalière. Les difficiles relations entre soignants et soignés dans cinq capitales d'Afrique de l'Ouest, Paris, Karthala, 237-261.

Lawrance, Benjamin, Osborn, Emily Lynn and Richard Roberts. eds. 2006. Intermediaries, Interpreters and clerks. African Employees in the Making of Colonial Africa. Madison, Wi., The University of Madison Press.

Ledeneva, Alena. 1998. Russia's Economy of Favours: Blat, Networking, and Informal Exchange. Cambridge, Cambridge University Press.

Lipsky, Michael. 1980. Street-level Bureaucracy: Dilemma of the Individual in Public Services. New York, Russel-Sage Foundation.

Lund, Christian. 1998. Law, Power and Politics in Niger. Hamburg, Lit Verlag.

- - ed. 2006, repr. 2007. Twilight Institutions. Public authority and local politics in Africa (Development and Change vol. 37, no. 4). Oxford, Blackwell.

Mamdani, Mahmood. 1996. Citizen and Subject: Contemporary Africa and the Legacy of Late Colonialism. Princeton, Princeton University Press.

McCourt, Willy and Martin Minogue. eds. 2001. The Internationalization of Public Management: Reinventing the Third World. Northampton, Edward Elgar.

Moore, Sally Falk. 1973. Law and social change: the semi-autonomous social field as an appropriate subject of study. Law and Society Review 7 (4): 719-774.

Moumouni, A. and A. Souley. 2004. La Maternité Issaka Gazoby et l'Hopital National de Niamey (Etudes et Travaux du LASDEL. 19), Niamey, LASDEL.

Nader, Laura. 1974. Up the anthropologist. Perspectives gained from studying up. In Hymes, Dell H. ed. Reinventing Anthropology. New York, Vintage ( ${ }^{\circ}$ ed. 1969, Pantheon), 284-311.

Nuijten, Monique and Gerhard Anders, eds. Corruption and the Secret of Law. A Legal Anthropological Perspective. Aldershot, Ashgate.

Olivier de Sardan, Jean-Pierre. 2001. La sage-femme et le douanier. Cultures professionnelles locales et culture bureaucratique privatisée en Afrique de l'Ouest. Autrepart 20: 61-73.

- 2003. Pourquoi le malade anonyme est-il si mal traité? Culture bureaucratique commune et culture professionnelle de la santé. In Jaffré Yannick and Jean-Pierre Olivier de Sardan, eds. Une médecine inhospitalière. Les difficiles relations entre soignants et soignés dans cinq capitales d'Afrique de l'Ouest. Paris, Karthala, 265-294.

- 2004. Etat, bureaucratie et gouvernance en Afrique de l'Ouest francophone. Un diagnostic empirique, une perspective historique. Politique Africaine (96): 139-162. 
- 2009a. State bureaucracy and governance in West francophone Africa. Empirical diagnosis, historical perspective. In Blundo, Giorgio and Pierre-Yves Le Meur, eds. The Governance of Daily Life in Africa. Ethnographic Explorations of Public and Collective Service. Leiden, Brill, 39-71.

- $200 \mathrm{gb}$. Development, governance and reforms. Studying practical norms in the delivery of public goods and services. In Hagberg Sten and Charlotta Widmark, eds. Ethnographic Practice and Public Aid: Methods and Meanings in Development Cooperation (Uppsala Studies in Cultural Anthropology. 45), Uppsala, Acta Universitatis Upsaliensis, 101-123.

- 2009c. Les huit modes de gouvernance locale en Afrique de l'Ouest (Etudes et Travaux du LASDEL. 79), Niamey, LASDEL

- 2010a. Développement, modes de gouvernance et normes pratiques (une approche socio-anthropologique). Revue Canadienne d'Etudes du Développement, $3^{1}$ (1-2): 5-20.

- 2010b. Le culturalisme traditionnaliste africaniste. Analyse d'une idéologie scientifique. Cahiers d'Etudes Africaines (198-199-200): 419-453.

- 2011a. The eight modes of local governance in West Africa. IDS Bulletin 42 (2): 22-31.

- 2011b. Local powers and the co-delivery of public goods in Niger. IDS Bulletin $42(2)$ : $32-42$.

Olivier de Sardan, Jean-Pierre and Nassirou Bako Arifari. 2011. La référence obstétricale au Bénin, Etude socio-anthropologique (Etudes et Travaux du LASDEL. 79), Niamey, LASDEL.

Olivier de Sardan, Jean-Pierre and Valéry Ridde. 2013. L'exemption de paiement des soins au Burkina Faso, Mali et Niger. Les contradictions des politiques publiques. Afrique Contemporaine 243: 11-32.

Padioleau, Jean. 1982. L'Etat au concret. Paris, PUF.

Sharma Aradhana and Akhil Gupta. eds. 2006. The Anthropology of the State. A Reader. Malden, Blackwell.

Spittler, Gerd. 1981. Verwaltung in einen afrikanischen Bauernstaat. Das koloniale Französisch-Westafrika 1919-1939. Wiesbaden, Steiner.

Swartz, Marc, ed. 1968. Local-Level Politics. Social and cultural perspectives. Chicago, Aldine.

Tama, Clarisse. 2012. Les enseignants de l'école primaire au Bénin. Transformations d'un groupe professionnel. Dr. phil. dissertation, Department of Anthropology and African Studies, Johannes Gutenberg-Universität Mainz.

Titeca, Kristof and Tom De Herdt. 2011. Real governance beyond the 'failed state': negotiating education in the Democratic Republic of the Congo. African Affairs 110 (439): $213-231$.

Trotha, Trutz von. 1994. Koloniale Herrschaft. Zur soziologischen Theorie der Staatsentstehung am Beispiel des "Schutzgebietes Togo". Tübingen, Mohr.

Vasseur, Patricia. 2004. Socialisation des sages-femmes jeunes diplômées dans la vie active au Sénégal. Mémoire de l'EHESS, EHESS Marseille.

. 2009. Le travail des sages-femmes, entre savoir technique et normes pratiques. In Jaffré Yannick et al. La bataille des femmes. Analyse anthropologique de la mortalité maternelle dans quelques services d'obstétrique d'Afrique de l'Ouest. Descartes, Faustroll, $225^{-263 .}$ 
Thomas Bierschenk and Jean-Pierre Olivier de Sardan - 978-90-04-26496-0 Downloaded from Brill.com@4/26/2023 02:08:21PM via free access 


\section{INDEX OF NAMES AND PLACES}

Aba 370

Abacha, Sani $\quad 376$

Abbott, Andrew 368

Abdoulaye, Maikano 310n2

Abélès, Marc 51n

Abelin, Mireille 302

Abouem, David 305n2

Abrahamsen, Rita 274

Abrams, Philip 14, 72

Abubakar, Atiku 376

Abuja 370, 372

Accra 22n, 175-176n1, 187n-19on, 192n-194n, 196n-199n, 201

Adamaoua Province 28, 301-302n, 304, $308-318,320-322$

Adamolekun, Ladipo 341

Addis Ababa $\quad 35^{1}$

Adji, Garga Haman 306n2

Adjouji, Hamadjoda 310n2, 313

Adu, Amishadai L. 42

Adumri 320n

Afrique Equatorial Française 320

Agamben, Giorgio 54

Ahidjo, Ahmadou 310, 313-314

Ahogbéhossou, Dominique $349 \mathrm{n}$

Akunyili, Dora Nkem 370-371, 376-378, $383-385$

Albert, Isaac Olawale 39on

Alexandre, Pierre 414

Almond, Gabriel 5 in

Althusser, Louis 4

Amana, Benjamin 306n2

Aminzade, Ronald 208

Anand, Dibyesh 910

Anders, Gerhard 3, 25-26, 28, 46, 5on2, $86,226,233,236,272,329,338,349$, 386n, 389, 409n

Anderson, Jock R. 262

Andreski, Stanislav 103

Ansprenger, Franz 213

Anugwom, Edlyne E. $\quad 95,104$

Arce, Alberto 49n

Arlit 165

Arnfred, Signe 330

Arusha 205, 212-213

Asad, Talal 47, 54

Ashanti 179

Attoh, Franca C. $372 n$
Austen, Gareth 21

Avineri, Shlomo 9n

Awolowo, Obafemi 391

Ayee, Joseph $\quad$ 178, 180-181, 379n

Ayeni, Victor 44

Azande 21

Bâ, Amadou Hampâté $342 n$

Badara Fall, Alioune 146

Badie, Bertrand $\quad 18,39 n 3$

Badou, Agnes O. 5on1, 223n1

Bailey, Frederick 403 n, 410

Bakassi 319

Baker, Bruce 147

Baker, Colin 345

Bako-Arifari, Nassirou $18,23,41,5001$, 223n1, 236, 415n

Bala 76

Balandier, George $\quad 47,412$

Bamako 22n, 271, 271n1, 275, 277-285, 287-290, 292-295, 296n, 423

Bana, Benson 116

Banda, Kamuzu Hastings 331, 336, 339-346

Banganda $\quad 116$

Banyo 315

Barbone, Luca 307

Bargny 74

Barkan, Joel D. $\quad 116$

Baron, Catherine 5onı

Barriaux, Marianne 371,384

Bartelson, Jens 8

Bastide, Roger 48

Bat, Jean-Pierre 413

Bate, S.P. $\quad 38$

Bates, Robert H. $\quad 43,124 n, 225$

Baxter, Michael 262

Bayart, Jean-François $19,39 n 3,41-42$, 93-94n1, 275n2, 305, 412

Bayie Kamanda, Cornelius 305n2

Beauvilain, Alain 313

Bebbington, Anthony 393n

Beckedorf, Anne-Sophie 5onı

Beek, Jan 3, 5on1, 223n1, 236

Behr, Rafael 37n2

Behrends, Andrea 16, 41, 182n

Bellagamba, Alice 16, $5^{2}$

Benda-Beckmann, Franz von 16, 331 
Benda-Beckmann, Keebet von $\quad 16$ Bénéï, Véronique 39n2, 5on1

Benin 22-25, 29, 44n, 152, 166, 168, 222-223n1, 227, 230-241, 284n, 286-287, 303, 338, 349-363, 386n, 399n2, 405, 407,421

Bennafla, Karine 320,320 n

Bennet, John W. $3^{8}$

Benor, Daniel 262

Bergamaschi, Isaline $3,25,28,49,226$, 236, 271, 271n2, 274, 281, 292, 294n, 329

Berger, Louis $\quad 285,289$

Berman, Bruce 291

Berry, Sara 412n

Beti 314

Bezès, Philippe 45, 271-272, 291-292

Bibémi 320n

Bienen, Henry 207, 209

Bierschenk, Thomas 3-4, 7n2, 16, 19-20, 22, 25, 27, 29, 35, 37n1, 40, 43n2, 46, 48- 5on1, 52-53, 55, 82, 103, 105, 147, 152, 168, 170-171, 175n1, 196, 221, 223-224n, 226-228, 230, 230n, 232, 235, 240, 242, 250, 259n, 263, 265, 271n1, 279, 284n, 293, 302-303, 323, 338-339, 349n, 356, $35^{8}$, 36o, 386, 386n, 388, 392-393, 400, 402-404n, 408-409, 422

Bio Tchané, Yacine $349 n$

Bird, Richard 303

Biya, Paul 252, 306nı, 313-314

Blankenburg, Erhard $37,37 \mathrm{n} 3$

Blantyre 345

Blundo, Giorgio $\quad 4,16,18,23,25,28-29$, 41, 49-5on, 55, 69, 71, 73-75n, 78, 109, 147-148n, 170, 230, 232, 236, 241, 250, 302n, 311, 322, 36o-361, 386n, 401, 410, 420-421, 423-424

Blunt, Peter 42

Boas, Franz 46

Boesen, Nils 113

Boll, Karen 302

Bolland, Patrick 206

Bonn-Meckenheim $\quad 175 \mathrm{n} 2$

Boone, Catherine $39 n 3$

Booth, David 43n2

Bopda, Alain 320

Bosetzky, Horst 238-239

Botchwey, Kwesi 339

Botswana 25, 202, 262

Bouillon, Florence $37 \mathrm{n}_{3}$

Bourdieu, Pierre 408, 408n

Boutinot, Laurence 78,84

Boutrais, Jean $\quad 310-311,314,320$

Bouza 164

Brandecker, Nora $\quad 3,223 n 1$
Bratton, Michael 39n3, 113, 120-121, 123, 123n2, 128, 131, 137n

Bräutigam, Deborah 302, 369n1

Brazil 369n2

Brennan, James 208, 214

Brimelow, Peter 349

Bruhns, Hinnerk 11

Brumfiel, Elizabeth M. 93

Bruneau, Juliette $305 \mathrm{n} 2$

Brunsson, Nils 138, 241

Brussels 296, 297

Budniok, Jan 42, 50n1, 223n1

Buganda 40

Buhari, Muhammadu 376

Bujra, Janet M. 98

Burawoy, Michael 39

Burkina Faso 286, 405, 421

Burma 46

Burnham, Philip 302n, 313

Burton, Andrew 208

Bush, George W. 122

Butler, Judith 54

Byaruhanga, Charles 118

Callon, Michel 39

Cambridge $103,175 \mathrm{n} 1$

Cameroon $\quad 25^{-26}, 28,228-229,232$, 249-269, 286, 288, 302-328

Campbell, Bonnie $\quad 273,292$

Canada 75, 179, 271n2, 296, 306, 354

Cantens, Thomas $73,302,308$

Canut, Cécile 290

Carneiro, Robert L. $\quad 47 \mathrm{n}$

Carrier, James G. 20

Casanegra de Jantscher, Milka 303

Central African Republic 314, 316, 320, 322, 404

Chabal, Patrick $\quad 92,113,120-121,123-124$, 131, 134, 141

Chabi Imorou, Azizou $\quad 24-25,29,46$, 5on1, 223n1, 230, 236, 349, 356-357, 403n1, 425

Chad 161-162, 322

Chalfin, Brenda $\quad 15,15 \mathrm{n}, 50 \mathrm{n} 1,302$

Chambas, Gérard 302

Chang, Ha-Joon 273

Chapple, Eliot 38

Charlier, Florence $306 \mathrm{n} 1$

Charton, Hélène $\quad 3,25^{-26}, 28,46,86$, 226, 229, 249, 271n1-272, 306, 349, 362, 403n1, 425

Chauveau, Jean-Pierre 49n, 146, 232, 237, 329, 359, 412n

Chazan, Naomi $39 n 3$

Chesshyre, Robert $37 \mathrm{n} 3$ 
Chewa 344-346

Chibber, Vivek 250

Chicago 17

China 10, 208, 369n2

Chirwa, Wiseman 345

Christophe, Barbara $386 n$

Cicourel, Aaron V. 39

Cissoko, Kama 282

Clapham, Christopher 119

Clarke, Jeremy $\quad 117$

Cleaver, Frances 423

Clignet, Rémi 184

Cohen, Abner 42

Cohen, Jere 53

Cohen, John M. 133

Cohen, Michael D. $3^{6}$

Cohen, Ronald $\quad 39,48,101,412$

Cohen, William B. 41

Collier, Paul 124n

Comaroff, Jean 15

Comaroff, John L. 15

Commaille, Jacques 160

Congo, Democratic Republic 25, 404, $404 n, 423$

Conkling, Robert $39 \mathrm{n} 2$

Cooper, Frederick 41n, 225

Copans, Jean $39,46,81,177,230,323$

Côte d'Ivoire 283,286

Cotonou 349n, 353

Coulson, Andrew 208, 212-214

Courade, Georges 411

Court, Julius 117, 126

Courtin, Nicolas 413

Cox, Susan 349

Crook, Richard 366, 406

Crozier, Michel 36, 307n

Dafinger, Andreas 16

Dagara 175n1, 189, 191n, 201-202

Dahomey (see also Benin and Danxome) $231,350-35^{2}$

Dakar 69, 84, 253, 310n2, 349n

Daland, Robert 366

Daloz, Jean-Pascal $\quad 92,120-121,123-124$, 131, 134, 141

Damien, Francis $\quad 216$

Daniel, G.F. 179

Danko, Nouratou 349n

Danxome (see also Benin and Dahomey) 40

Dar es Salaam 213

Darbon, Dominique $39 n_{3}, 46,170,250$, 254, 257, 265, 274, 292-293, 354n

Das, Veena $52,70,146$

Dassa $351 n 7$
De Herdt, Tom $\quad 146-147,230,402,404 n$, 423

Deal, Terrence $\quad 417 \mathrm{n} 2$

Deininger, Klaus 116

Deleuze, Gilles 54

Delpeuch, Thierry 279

Denmark 295

Derlien, Hans-Ulrich 10n2, 15

Dezalay, Yves 291-292n, 341

Dia, Mamadou 333, 338

Diallo, Yveline 5onı

Diarra, Aïssa 415n, 417n1

Diourbel 80

Dir 317

Djibélor 76, 76n

Djigo, Alpha Seybatou $\quad 83^{-84}$

Dobler, Gregor 3

Downing, Theodore 49n

Du Bois de Gaudusson, Jean 146-147, 154

Durkheim, Emile 411

Eames, Elizabeth 48

Eckert, Andreas 41n-42, 177n, 205-206, 208, 212-213, 225, 340, 342, 342n

Eckert, Julia 3n, 16, 27, 39n2

Egypt 10

Eisenstadt, Shmuel 48, 119, 333n1

Ekeh, Peter P. 101, 391

Elguezabal, Eleonora $37 \mathrm{n} 3$

Ellis, Stephen $39 n_{3}$

Elwert, Georg 43n2, 48, 227, 250, 259n, 389, 389n

Emmert, Isabel 38

Engel, Ulf $114,121 n 1,123-124,131,137$

Englebert, Pierre $\quad 25,404 \mathrm{n}$

Erdmann, Gero 114, 121n1, 123-124, 131, 137

Escobar, Arturo 290, 330

Espagne, Michel 21

Europe 4n2, 7-10, 15, 17-18, 20-21, 24, $39-40,44,46,50,53,53 \mathrm{n}, 55,84,175$, $207,224,234-235,242,276,279,281-282$, $285^{-287}, 289-290,297,340,342,413$

Evans, Anne 5, 45

Evans, Peter 126, 366

Evans-Pritchard, Edward E. 21, 46, 145n, 223n2

Evens, Terry M.S. 47

Evers, Hans-Dieter 19

Evina Obam, Richard 307

Eyebiyi, Elieth $349 n$

Fall, Abdou Salam 83

Fallers, Lloyd A. 47, 51n

Fardon, Richard 7

Faro-et-Déo District $\quad 318-319,321$ 
Fatton, Robert $\quad 39 n_{3}$

Fay, Claude 49n

Feest, Johannes 37n3

Feierman, Steven $\quad$ 206-207

Feldman, Gregory 72

Ferguson, James 52, 249-250, 254, 290-291, 330

Fichtner, Sarah $\quad$ 5on1, 223n1, 236, 279, 353-354n, 403n1, 419n

Fine, Ben 273

Fjeldstad, Odd-Helge $\quad 302,308$

Flanders, Laura $122 \mathrm{nI}$

Fortes, Meyer 46

Foster, Philip 179, 184

Foucault, Michel $7 \mathrm{n} 2,53-54,400$

France 5, 8, 37, 40, 222, 227, 231, 235, 254, 271n2, 276, 279, 283, 285-288, 293-294, 296n-297, 307n, 310-312n1, 350, 400, 413-414

Fraser, Alastair 273

French West Africa 350

Freud, Sigmund $53 \mathrm{n}$

Friedberg, Erhard $\quad 36$

Fulbe 313

Fuller, Chris J. 39n2

Gabon 251n

Gao 295

Garth, Bryant $\quad$ 291-292n, 341

Gauthier, Nicole $37 \mathrm{n} 4$

Gayakoye, Sabi A. $\quad 166$

Geddes, Barbara 366

Geertz, Clifford $5^{\text {in }}$

Gellner, David N. 39

Georgia 386n

Germany $\quad 5,8-9,22-23 \mathrm{nl}, 37,69,222$, 227, 233, 238-239, 271n2, 283, 310, 349n

Geschiere, Peter 280, 306

Ghana 22-25, 27, 41n, 174-204, 205, 222, 231, 240, 303, 306

Gillies, Alexandra 375

Giovalucci, François 403

Giri, Ananta Kumar 330

Gladwell, Malcolm 191n

Glasman, Joël 71

Gluckman, Max 47, 403n 3

Gobatto, Isabelle $\quad 50 \mathrm{on}, 147 \mathrm{n}$

Godin, Francine 44n

Gold Coast (see also Ghana) 179

Goldsmith, Arthur A. 227

Gondolo, André 313

Goody, Jack 47n

Göpfert, Mirco 3, 5on1, 223nı

Gould, Jeremy $\quad 271 \mathrm{n} 1,273-274,281,292$
Gouloumbou 74

Gouré 149

Gramsci, Antonio 7n2, 53-54

Grant, Ursula 393n

Great Britain (see also United Kingdom) 39, 103, 179, 206, 211, 231, 235, 237, 302n, $310,331,338,340,342,345$

Greece 39n1

Greenstreet, D.K. 179

Grignon, Claude 408n

Grindle, Merilee S. 121, 126-127, 349, 382, $417 \mathrm{n} 2$

Gros, Jean-Germain 311

Guest, David E. 114, 122, 126

Guignon, Catherine $\quad 37 \mathrm{n} 4$

Guillot, Maurice-Antoine $\quad 37 \mathrm{n} 4$

Gumpert, Hans Ulrich 8

Gupta, Akhil $7 \mathrm{n} 2,52,70,302,386 \mathrm{n}, 402 \mathrm{nl}$

Guyer, Jane 302, 302n

Guyomarch, Alain 307n

Gyimah-Boadi, Emmanuel $\quad 128,137 \mathrm{n}$

Hagmann, Tobias $\quad 16,50 n 2,323$

Hahonou, Eric K. 5on1, 223n1

Haines, David W. 39

Halle/Saale $113 n$

Hällmeyer, Heide 223nı

Hamani, Oumarou $\quad$ 24-26, 29, 46, 5on1, $87,145,223 n, 238,241,308,349,362$, 403n1, 405, 410, 417, 423

Hameiri, Shahar 404n

Hammar, Amanda 3n

Handelman, Don 47

Hansen, Karen 302n

Hansen, Thomas $\quad 52,70,386 n$

Harrigan, Jane 331

Harris, Richard L. 42

Harrison, Elizabeth 49n

Harrison, Graham 274, 277

Harriss, John 39n2

Harrisson, James 262

Haruna, Peter Fuseini $\quad$ 177n

Harvard $175^{\mathrm{n}} 1$

Hatch, John 213

Hatcher, Pascale 273

Hausa 313

Hayes, David 259

Hazelrigg, Lawrence E. 53

Hegel, Georg Friedrich $\quad$ 9-11

Heilman, Bruce 217

Herrera, Javier 320

Herskovits, Melville J. 48

Herzfeld, Michael 39n1, 413

Heyman, Josiah McC. 39 
Hibou, Béatrice $16,19,39 n 3,285 n, 307$, 402

Hilbert, Richard A. 13

Hilderbrand, Mary E. 382

Hilgers, Mathieu 15n, 5on1

Hirsch, Eric 39

Hirschman, Albert 331

Hobbes, Thomas 8

Hopkins, Raymond F. 211, 215

Hountondji, Paulin 353

Houtzager, Peter 113

Hull, Matthew S. 39n2

Hydén, Göran $\quad 39 n 3,43,117,205^{-206}$

Igbo 100, 222

Iliffe, John 207

India $5,194,237,386 \mathrm{n}$

Ireland 7on, 399n2

Italy 384

Ivaska, Andrea 208

Jackson, Stephen $\quad 280$

Jacob, Jean-Pierre 49n

Jaffré, Yannic $\quad 23$, 50n1, 415n, 417nı

Jaglin, Sylvy 5on1

James, Oliver 379n

Japan $271 \mathrm{n} 2$

Jega, Attahiru 104

Jennings, Michael 205, 207-208

Jézéquel, Jean-Hervé 4on

Jirapa District 181, 201n

Johnson, John H. $\quad$ 273-274

Jomtien 253, 356

Joseph, Richard A. 92, 107

Joshi, Anuradha $369,379 n$

Jourde, Cédric 39n3

Juppé, Alain 307n

Jütting, Johannes 146

Kaduna $\quad 370$

Kaffrine 74

Kalanga 202

Kaldor, Nicholas 302

Kaluszynski, Martine $\quad 160$

Kampala 47, 134

Kappel, Rolf 9

Karimama 349n

Kasfir, Nelson 43

Kaspin, Deborah $345^{-346}$

Kasungu 344

Kaufmann, Daniel 141

Kaunda, Kenneth 123

Kawawa, Rachidi $\quad$ 208, 210, 212

Kayes 295
Keating, Michael 23n2

Kedougou 76

Keïta, Modibo 283

Keller, Edmond J. 23

Kelsall, Tim 43n2, 242

Kennedy, Allan 417n1

Kérékou, Mathieu $35^{2}$

Kidal 295

Killick, Tony 272

Kiragu, Kithinji 118

Kiser, Edgar 302

Kluckhohn, Clyde 53

Klute, Georg 16, $5^{2}$

Koehn, Peter H. 42

Koerling, Gabriella 5onı

Kolda 74

Koné, Félix Y. 49n, 236, 415n

Konings, Piet 306

Kouandé 221-222

Kountché, Seyni $\quad$ 156-157

Kouthiary $\quad 76$

Krader, Lawrence $\quad 47 \mathrm{n}$

Krieger, Milton 307

Kristen, Petra 126

Kroeber, Alfred L. 53

Kroeker, Lena 5on1

Krohn-Hansen, Christian $\quad 5^{2}$

Kruyt, P. Dirk 49n

Lackner, Helen 41

Lafaye, Françoise $\quad 147 n$

Lagos 370

Lake Chad Basin 303-304

Lama Kara 221

Lambussie District $\quad 181$

Lamont, Michèle $\quad 176$

Lane, Jan-Erik 37

Lanoue, Eric 35on

Larbi, George A. 379n

Lathrop, Stacy 72

Latin America 292n, 341

Latour, Bruno 21, 39

Launay, Robert 302n

Laurent, Pierre-Joseph 49n

Lautmann, Rüdiger 37

Lavigne Delville, Philippe 49n

Lawra District $\quad 181-183,185$

Lawrance, Benjamin N. 41, 177n, 342n, 414

Le Meur, Pierre-Yves 16, 23, 5on2, 386n, 401, 420

Le Pape, Marc $\quad 146,232,237,412 n$

Leach, Edmund 46

Leavy, Jennifer 113,121 
Ledeneva, Alena 401

Leibfried, Stephan $\quad 15$

Leiden 3

Leimdorfer, François $\quad 7 \mathrm{n} 1$

Leipzig 3, 27inı

Lemonick, Michael D. 371

Lentz, Carola $3,23-25,27,41 \mathrm{n}-42,146$, $175,175 \mathrm{n} 1,179 \mathrm{n}, 182 \mathrm{n}-183 \mathrm{n} 1,185 \mathrm{n} 1,191 \mathrm{n}$, 201, 201n, 205n1, 228, 233, 238-239, 303, $306,392,415,425$

Leonard, David $\quad 42-43 \mathrm{n} 2,113,366-367 \mathrm{n}$, 374

Lesotho 249, 291

Lewis, David 49n, 279, 330

Libom Li Likeng, Minette 308

Liedtke, Max $\quad 37 \mathrm{n} 4$

Likok 315

Lilongwe 33on, 333n2

Lindberg, Staffan I. 80

Lipsky, Michael $36,125,195,250,260$, 403n2, 409n, 418n

Little, Peter 321

Locke, John 8

Lomwe 345

Long, Norman 48-49n, 331

Lonsdale, John $39 n 3,291$

Lühe, Nico von der 262

Luhmann, Niklas 389-39o

Lund, Christian $\quad 16,147,152,278,280,284$, $291-293,303,338,412 \mathrm{n}, 420$

Lusaka 124

Lynn Jr., Laurence 37n2

Magaria 149

Mahmoud, Hussein A. 321

Mainz 22n, 175n1, 221n, 223nı, 349n

Mair, Lucy P. 47

Malanville 165

Malawi $25-26,28,329-348,386 n$

Mali $22-25,28,222,231,236,25 \mathrm{ln}$, 271-299, 405, 421

Malinowski, Bronislaw 21, 46-48

Mamdani, Mahmood 412

Manchester $38,47-48$

Mann, Brenda 39

Mannheim, Karls $181 \mathrm{n}$

Manor, James 393n

March, James $\quad 36,122,136-137$

Marcussen, Henrik Secher 330

Marguerat, Yves 310, 312n2

Marie, Alain 7n1, 49n

Maroua 310

Martin, Denis-Constant $\quad 5^{2}$

Martin, Isaac 302
Marx, Karl 53n, 55

Masquelier, Adeline $\quad 52,70$

Massike, Martial 302n

Matamey 149

Mattes, Robert 128, 137n

Mauritius 373

Mbaché 79

Mbembe, Achille $\quad$ 303, 323

Mbéré District 313, 316-317

McCourt, Willy 45, 116, 393n, 402

McCracken, John 345

McDevitt, Damien 262

McGowan, Patrick J. 206

Mead, Margaret 38

Meagher, Kate $\quad 5^{1}$

Mease, Kenneth 117

Mecca 84

Médard, Jean-François $\quad 39 n 3,42,48,119$, $333 n 1$

Mehrotra, Ajay 302

Meiganga 317

Messomo Ndjana, Florent 311

Middle East 369n2

Middleton, David 46

Miescher, Stephan F. $\quad 182 n 2$

Migdal, Joel S. 14, 69

Miller-Adams, Michelle 272

Minogue, Martin 45, 403

Mirriah 149

Mitchell, Timothy 330

Mkandawire, Thandika 114, 205n2

Mongbo, Roch L. 49n

Monjardet, Dominique $\quad 37 \mathrm{n} 3$

Mono 351n6

Monson, Jamie 208

Moore, Mick 113, 121, 302, 308

Moore, Sally Falk 331, 402

Mopti 295

Morgan, David 38

Morin, Denyse 118

Mosse, David 37n1, 49n, 279, 291, 303, 330

Mossi, Aziz 349n, 359n-36on

Moumouni, Abdou $35^{\circ}$

Moumouni, Abdoulaye $\quad 415 n$

Moynihan, Donald P. 379n

Mozambique 345

Mpuga, Paul 116

Mudasiru, Suraj 37on

Mukandala, R.S. $\quad 118$

Muluzi, Bakili 331

Muñoz, José-María $\quad 25^{-26}$, 28, 46, 86, $226,229,232,236,272,301,312,322$, 329, 425 
Museveni, Yoweri Katuga $\quad$ 117, 130n, 135

Mutahaba, Gelasa 117

Mutharika, Bingu wa 331, 341, 345

N'Cho-Oguie, Charles 306nı

N'Guigmi $\quad \mathbf{1 6 1}_{1}$

Nadel, Siegfried F. $\quad 47 \mathrm{n}$

Nader, Laura 72,403

Namata, Joseph A. $\quad 215^{-216}$

Nandom District 181,185

Nanga, Charles 305

Nash, June 39

Natitingou 221-222

Naudet, Jean-David $\quad 45,226$

Ndumbara, Laurean 217

Nduwugwe, Justus 371

Neboisa, Marianne $37 \mathrm{n}_{4}$

Netherlands 9, 271n2

Nganang, Patrice 226

Ngaoui 314,316

Ngaoundéré $\quad 301,311-312,316,318,321$

Ngonde 345

Ngoni 345

Ngouo, Léon B. 305, 306, 306n2

Niamey 3 , 7on, 145-169, 221n, 399nı

Nicholas, Ralph W. $93,95,98$

Niger 22-26, 70-71, 87, 145-173, 222, 231, 308, 349n, 399n, 405-407, 410, 421-422

Nigeria $\quad 25^{-26}, 29,44,48,91-112,165,192$, 304, 311, 318-322, 324, 365-397

Nkrumah, Kwame 179,185

Nugent, Paul 39n3, 225

Nuijten, Monique 39n2, 409n

Nustadt, Knut $5^{2}$

Nwabughuogu, Anthony I. 100

Nyang'oro, Julius E. 117

Nyanja/Mang'anja 345

Nyasaland (see also Malawi) 342

Nye, Joseph S. 206

Nyerere, Julius $\quad 205^{-214}, 217,342$

Obasanjo, Olusegun $\quad 375^{-376}, 378$, 390-391

Oladeji, Abubakar 372n

Olaniyan, Azeez 37on

Olaopa, Tunji 390

Olivier de Sardan, Jean-Pierre $3-4,13$, 15n-20, 22-24, 27, 29, 35, 37n1, 40-41, $48-53,55,71,73,86,92-93,145^{-147}$, 170-171, 178, 223-224, 228, 230, 23on, 232, 235-240, 242, 250, 259n, 271n1, 293, 302n-303, 309, 315, 331, 338, 349n, 359, 386n, 388-389, 399-400, 403, 403n, 408, 411-413, 415n, 421n, 424
Olowu, Bamidele 349

Olsen, Johan P. $\quad 36,122$

Olukoju, Ayodeji 106

Onitsha 370

Oppen, Achim von 5on2

Osborne, Emily Lynn 5 , 12, 41, 237, 342n, 414

Ouagadougou 286

Owusu, Francis 126,380

Oxford 103

Oyugi, Walter Ouma 43, 43n1

Ozouf, Jacques 37n 4

Ozouf, Mona 37n4

Padiolau, Jean 401

Palermo 372

Paquot, Elisabeth 49n

Parakou 221, 349n

Paris 49, 253, 279, 282, 284, 292, 295, 375

Parkin, David 47

Parsons, Talcott 53, 411

Passeron, Jean-Claude 408n

Pauli, Julia 41

Péclard, Didier $\quad 16,50 \mathrm{n} 2,323$

Peñafiel, Ricardo 272-273

Pero, Davide 303

Peters, B. Guy 15, 122n2, 124, 129, 141

Peterson, Bob 349

Petit, Pierre 356

Peyroux, Élisabeth 50n1

Pogoson, Irene 370n

Pollitt, Christopher 379n

Pont Noirot 80

Poole, Deborah $\quad 52,70,146$

Pope, Whitney 53

Porto-Novo 221, 349n, 357

Prasad, Monica 302

Pratt, Cranford 212-213

Pressman, Jeffrey L. 37

Price, Robert $\quad 43,177 n, 181,186-187,202$

Prichard, Wilson $367 \mathrm{n} 1$

Prinz von Hohenzollern, Johann Georg $37 n 4$

Prual, Alain 415n, 417nı

Prussia 5, 8, 10, 13, 40

Quarles van Ufford, Philip 49n, 330

Quiminal, Catherine 49n

Raadschelder, Jos C.N. $\quad 5^{\mathrm{n}}$

Raffinot, Marc 307

Randeria, Shalini $\quad 16$

Rauch, James E. 126 
Rawlings, Jerry $\quad 176,180$

Raynal, Maryse 148,158

Rehbinder, Manfred 37

Reichertz, Jo 37n3

Reinhard, Wolfgang 8

Reno, William 39n3

Rhodesia, Nothern (see also Zambia) 47

Ribot, Jesse 78

Richman, Joel 38

Ridde, Valéry 403nı

Riggs, Fred W. 43, 138n

Riles, Annelise 39

Risse, Thomas 25

Roberts, Richard 41, 291n, 342n, 414

Robichau, Robbie 37n2

Robinson, Mark 116, 393n

Rocard, Michel $307 \mathrm{n}$

Roitman, Janet $\quad 303-304,307,312$

Roll, Michael $24-26,29,44,227,233,276$, 365-366n1, 369, 369n2, 374, 386n, 389, 406, 425

Roman Empire 10

Ropé, Françoise 254

Rösel, Jakob 16

Ross, Andrew 345

Rothchild, Donald $39 n 3$

Rottenburg, Richard 39, 49n-5on2

Roubaud, François 46

Rugumyamheto, Joseph 117

Rutgers, Marc $5 \mathrm{n}$

Rwanda 25

Rzafindrakoto, Mireille $\quad 46$

Sabatier, Peggy R. 4on

Sabot, Richard H. 209n

Sacks, Audrey 302

Sadleir, Randal 212

Saetren, Harald $37 \mathrm{n} 2$

Sahel 80

Saint, William 104

Saint-Louis 84

Sandbrook, Richard 94

Sanogo, Amadou 295

Schareika, Nikolaus 3

Schefer, Gerwin $37 \mathrm{n} 4$

Schiavo-Campo, Salvatore $\quad 118$

Schiel, Tilman 19

Schlichte, Klaus 3, 14, 69

Schmitter, Philippe C. 231

Schneider, Leander 214

Schröer, Norbert $\quad 37 \mathrm{n} 3$

Schupper, Gunnar Folke 15

Schwartzman, Helen 38
Scotland 345

Scott, James 8, 55, 70, 214, 278, 291n, 400

Segou 295

Seibel, Wolfgang $10 n 2$

Senegal $25^{-26}, 69-89,170,251 \mathrm{n}, 275$, $275 n 3,295$, 310n2-311, 349n, 405, 421

Service, Elman $47 \mathrm{n}$

Sharma, Aradhana $\quad 7 \mathrm{n} 2,5^{2}, 402 \mathrm{n} 1,410$

Shils, Edward 5in

Shipton, Parker 323

Shore, Cris 72, 303

Sikasso 295

Simbine, Antonia T. $372 \mathrm{n}$

Simon, Herbert A. 36

Sindjoun, Luc 252, 305-306

Skoog, Gun Eriksson 206

Smith, Daniel J. $\quad$ 50, 5on2, 94, 229, 266n

Smith, Étienne 290

Soeffner, Hans-Georg $\quad 37 \mathrm{n} 3$

Sokoto 165

Somalia 25

Souley, A. $415 \mathrm{n}$

South Africa 25

Southall, Aidan $47 \mathrm{n}$

Southwold, Martin 47

Soviet Union 311, 401

Spain 8

Spalding, Nancy 214

Spies, Eva 224n

Spittler, Gerd 40, 40n, 224, 412

Spradley, James 39

Sri Lanka 386n

Stepputat, Finn $\quad 52,70,386 n$

Stewart, Frances 282

Stöger-Eising, Viktoria 214

Stone, Diane 273

Stotsky, Janet G. 302

Straus, Scott 113

Sudan, Southern 46

Suriname $369 n 2$

Swartz, Marc $403 \mathrm{n}_{3}$

Switzerland 9, 406

Tabora 207

Taguem Fah, Gilbert 313

Tahoua 164

Tait, David 46

Takougang, Josef $\quad 307,313$

Talbot, Colin 379n

Tama, Clarisse 5on1, 223n1, 406

Tamba 76

Tambacounda $74,76,87$ 
Tamekou, Raoul 306

Tanganyika (see also Tanzania) 207-209, 211

Tanguy, Lucie 254

Tanout 149

Tanzania $\quad 25^{-27}, 113^{-144}, 205^{-219}, 274$, 340,342

Tareq, Shamsuddin 302

Tax, Sol 38

Tchantipo, Saï Sotima 5on1, 223n1, 349n

Tendler, Judith $16,126-127,368,387$, $393 n$

Terhart, Ewald $37 \mathrm{n}_{4}$

Terray, Emmanuel $47 \mathrm{n}$

Theobald, Robin 122, 141

Therkildsen, Ole $\quad 3,24-26,48,83,102,113$, $113 \mathrm{n}, 117,117 \mathrm{n}, 120,122,125,127 \mathrm{n}, 129,134$, $217,228,232-234,239,242,302,339,366$, 407n, 415

Thioléron, Elisabeth 223nı

Thomas, John 349

Tidemand, Per 113n, 117n, 122, 125, 127n, 129

Tidjani Alou, Mahaman 18, 22n-23, 41, 5on1, 147, 236

Tignère 321

Tignor, Robert L. 101

Timbuctu 295

Titeca, Kristof $146-147,230,402,404 n$, 423

Tobler, Hans Werner 9

Togo 221

Tokpota 357

Tonga 345

Tordoff, William 207

Touba 80,84

Touré, Amadou Toumani $\quad 281,289$

Touré, Ramatou 282

Trefon, Théodore 147,349

Treiber, Hubert 10

Trotha, Trutz von $16,40,412$

Trouillot, Michel-Rolph 52

Tsapi, Victor 315

Tuareg 293

Tumbuka 345

Tunisia 251n, 307

Tzermias, Nico 7

Uganda $\quad 25^{-26}, 113^{-144}, 217,233^{-234}$, 266n, 274

United Kingdom (see also Great Britain) 70n, 110
United States of America $5,103,110$, 121-122n1, 179, 271n2, 292n, 341, 353-354, $357-358,400,403 n 2$

Uppsala 3

Vail, Leroy 345

Valentine, Ted 119

van de Walle, Nicolas $113,120-121,123$, 123n2, 130-131, 133, 226, 229

Van Donge, Jan Kees 379n

Van Maanen, John 38

Vasseur, Patricia 5on1, 415n-416

Veneman, Ann 122, 122n1

Verba, Sidney $5 \mathrm{in}$

Von Stein, Lorenz $\quad 7-10,13,35,55$

Voss, Katja 223nı

Wa 193n, 195n, 200

Wacquant, Loic $15 \mathrm{n}$

Waldmann, Peter 8-9

Wang, Michael 282

Warner, William L. 38

Washington D.C. $\quad 43-44,286,288,291$, 312

Wasty, Sulaiman S. $\quad 273-274$

Weber, Max $\quad 6-8,10-14,18,40,51 \mathrm{n}, 53$, 53n, 55, 91, 119, 141, 176, 190, 224, 228, 237-238, 293

Wedel, Janine 72

Wedell, Martin 262

Weder, Beatrice 126

Weick, Karl E. 230

Werbner, Richard 42, 202

Wetzig, Salka-Lena 223n1, 352n

Wheeler, John R. 133

White, Howard 113,121

White, Landeg 345

Whitfield, Lindsay $\quad 272-273,275,277,292$

Wildavsky, Aaron 37

Williams, David 273

Willott, Chris $\quad 3,25^{-26,48,50 n 1, ~ 75, ~ 91, ~}$ $96 \mathrm{n}, 101,192,239,240,415$

Wilson, Fiona 5on1

Wilson, Gordon 280, 291

Wittgenstein, Ludwig 54

Wolde Mariam, Asegedech 302

Wolf, Eric R. 46

Wolof 80, 81

Wood, David 117

Woodall, Brian 121

Wright, Christopher 273

Wright, Henry T. $\quad 47 \mathrm{n}$

Wright, Susan 303 
Yao 345

Yaoundé 310n1, 322

Yessoufou, Akimi 223nı

Yosson, Marcelle 349n

Young, Crawford 40, 102-103, 110, 225, 389n

Young, Malcolm 37n3
Zaire (see also Congo, Democratic Republic of) 102

Zambia $47,123,208,345$

Ziguinchor $76,76 \mathrm{n}$

Zinder $\quad 145^{-169}$

Zomba 33on, 345-346

Zürn, Michael 15 